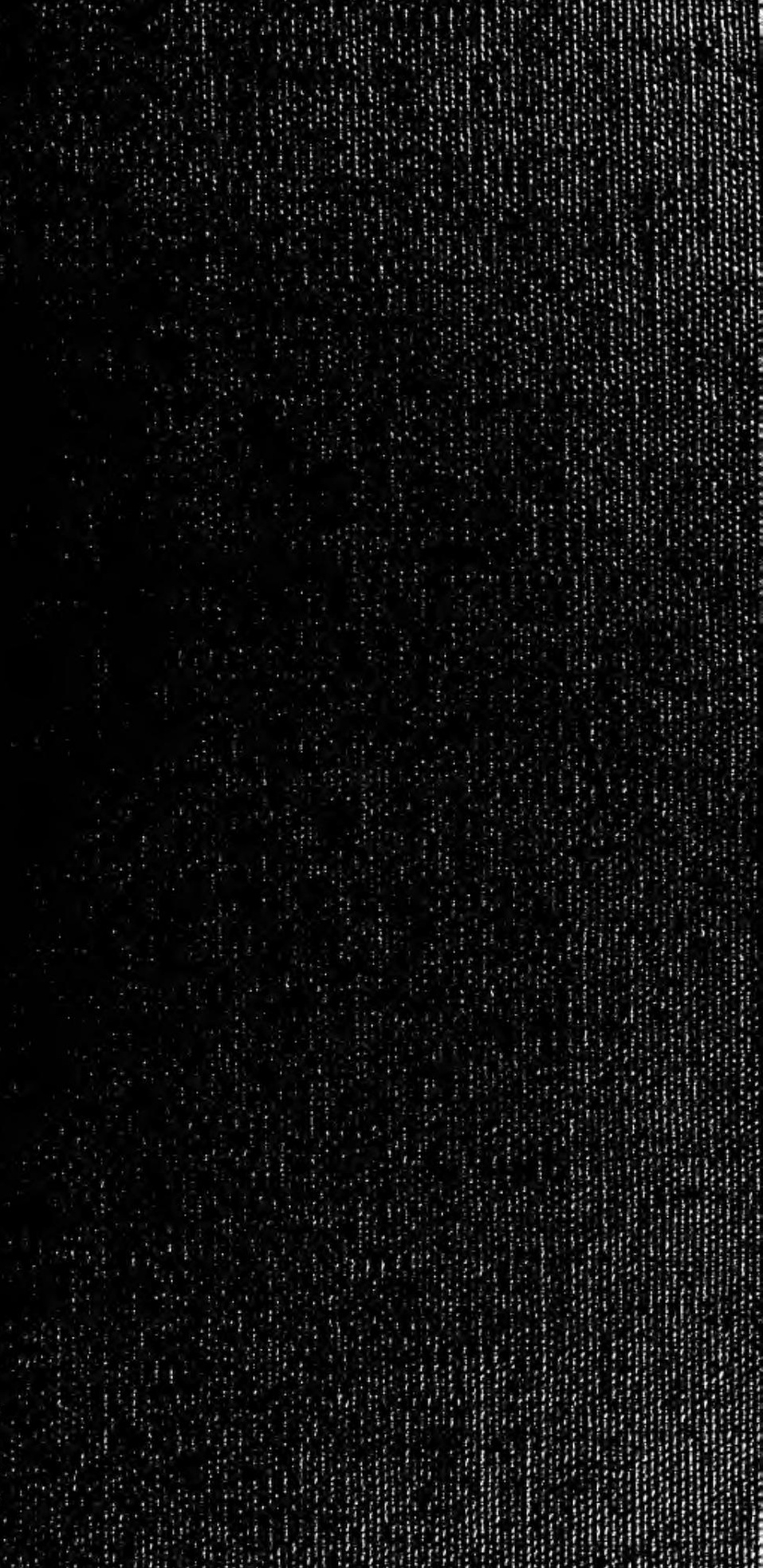



E
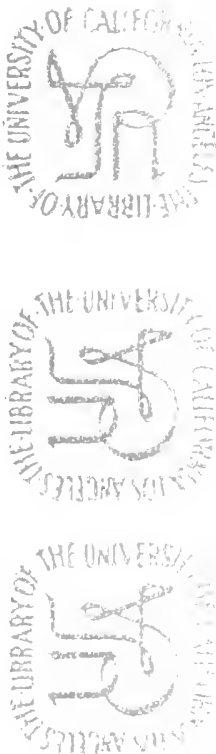

AHE UBSALY

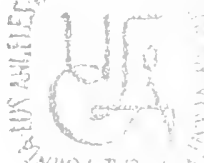

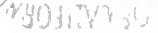
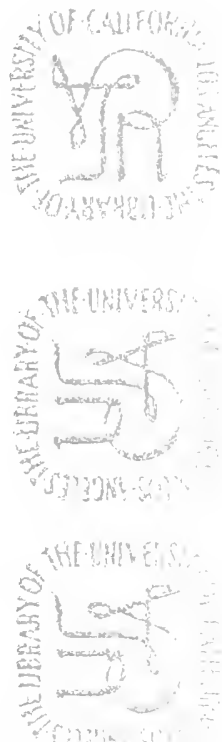
8894210 


\section{FASTI EBORACENSES.}





\title{
FASTI EBORACENSES.
}

\section{LIVES}

OF THE

\section{ARCHBISHOPS OF YORK.}

BY

THE REV. W. II. DIXON, M.A.,

CANON RESIDENTIARY OF YORK, ETC.

EDITED AND ENLARGED

$\mathrm{BY}$

'I'HE REV. JAMES RAINE, M.A.,

SE'RETARY OF THE SURTEES SOCIETY.

\author{
IOLUME 1.
}

LONDON :

LONGMAN, GREEN, LONGMAN, AND ROBERTS. 1863. 
IONDON :

IITCHELL IND SON, PRINTERS, WAROUR STREET, W. 


\section{PREFACE.}

When a work like the present emerges from the press, a work long-promised and long-delayed, on which the toil of many years has been lavished, the reader may naturally wish to know somewhat of its origin and progress, and it is only right, in this instance, that his emiosity should be gratified. These explanations may be appropriately prefaced by a short accomit of the begimner of these biographical annals, to whose industry and judgment the present volme is intended to be a memorial.

William Henry Dixon was the son of Henry Dixon, vicar of Wadworth, in the deanery of Doncaster, and was born at that place in the month of November, 1783. His mother was the half-sister of the poet Mason, who basked for many ycars in the favour of the family of Darcy at the neighbouring rectory of Aston, which he has immortalized in his verse. 'The estates of that well-known writer came into Mr. Dixon's possession, together with some literary treasures of much interest and value, including several volumes in the beantiful handwriting of Gray. These have now found a resting-place in the minsterlibrary at York.

Mr. Dixon received his education at the grammar-schools at Worsbrough and Houghton-le-Spring. In 1801 he was matriculated at Pembroke college, Cambridge, and in January, 1805, he graduated in arts. In 1807 he entered into orders, and with the curacy of the pleasant village of Ticklitl he began his clerical career in the diocese of lork, with which he was con- 
nected during the remainder of his life. Throughout the whole of Yorkshire there were few elergymen more useful than Mr. Dixon, and none, perhaps, more gencrally beloved. He passed throngh all the grades of elerieal life, and did his duty in cach, whether he was acting as a parish-priest or a canon, or in the wrightice and more delicate position of adviser to the prinate, for he was domestic chaplain to two archbishops. For many years he was a prebendary of Ripon, but he gave that office up in 1852, and he held also, in suceession, the perpetual curaey of Mappleton, the vicarage of Wistow and curacy of Cawood, the vicarage of Topcliffe and the rectory of Sutton-onthe-Forest. At the time of his decease he was prebendary of Weighton and a canon residentiary at York, rector of Etton, and ricar of Bishopthorpe. In the last-mentioned position he was brought frequently into daily contact with the primate, who had the greatest confidence at all times in his wisdom and diseretion.

In his private life no one merited or won more universal respect and regard than Mr. Dixon. Gifted with ample means, and with a heart as open as his purse was large, he was never appealed to in vain, and he rejoiced to do good. In almost every parish in which he laboured he left behind him some substantial token of his munifiecnec, and in everything that he did he exhibited the considerate kindness and the courteous demeanour of a Christian gentleman. His mobtrusiveness made these points in his eharacter more observed and valued, for he was singularly modest and retiring, and yet when from the necessities of station he was brought prominently before the public eye, he never slurank from doing his duty in a position to which he was naturally arcrse. The refinement of his manners threw a charm orer everything that he said and did. Nearly ten ycars have passed away since his decease, but even now there is no one in York who does not speak of Mr. Dixon with an honest warmth of feeling which is beyond the suspicion of affectation. An almost universal homage is still paid to his 
courtesy and goodness. In this brief tribute to his character the writer can only give the echo of the popular roice. It is a matter of deep regret to him that he never even saw the gentleman of whom he is now speaking, and whose literary labours it has been his privilege to take mp and enlarge.

In the glorious choir at lork, surrounded by carring and colours such as no other Christian temple can exhibit, a pions hand has erected a memorial of brass, enriched with the cunning workmanship of the graver, to an mele and a nephew. Upon it the names of William Mason and William Dixon are inscribed, although neither of them is sleeping in that sacred dust over which you walk. One is resting in a neighbonring graveyard, the other is lying in "Aston's seeret shade," which he loved so well. Yet in the noble fane at York, in which they were both sometime dignitaries, how appropriately are these two kinsmen commemorated and eonneeted! 'That shrine in which they worshipped gave to each of them of its inspiration. It evoked Mason's verse, and the choir of the eathedral and its musie were almost his ehief care: it induced Dixon to recount and recall the great deeds of those who had ruled and ministered in that sanctuary of which he was so proud.

The worthies and the annals of the ehureh of York have at all times exeited an unusual amount of attention. Putting aside many historical works of a general interest and bearing in which the capital of the North and its ecelesiastical superiors are mentioned very frequently and fully, there are many pices which are specially devoted to the Fasti of that eathedral. From the writings of Beda and Aleuin we may learn the history of Panlinus and Chadd, of Egbert, Albert, and the Eanbalds, but we have separate and distinct lives of as many as five of the carly primates, Wilfrid, St. John of Beverley, Oswald, Thurstan, and St. William. In the twelfth century the famons chronicler, Symeon of Durham, addressed a bricf but interesting letter to Hugh, the dean of York, in which he gare him a short acconnt of the arehbishops up to his day, and about the same time, or 
at little later, the poet, Ilugh de Sotevagina, wrote down the lise of the first fomr primates after the Conquest, and his work is as yet mupuhlished. The historians of the chureh of Hexham mend many interenting particulars relating to the archbishops ancl the attherlial of York, with which they were officially (onnerted. In the fourtenth century, 'Thomas Stubbs, a Dominic'an fritr, compiled his well-known chronicle containing the bionriplyy of the heads of the Northern provinee from its foumdation to the end of the reign of Edward III., and this was subseruently eontimed by an unknown hand to the period of the Reformation. In addition to this there is more than onc prem in which the glorics of the chureh of York are described in lively rerse, ascending from the middle of the fifteenth century until the mists of antiquity eonceal all historical information but that which snggests itsclf to the imagination of the enthusiastic bard. After the Reformation there is a long pause in the annals of lork, broken only by the biographies of the Northern arehbishops which occur in the great work of Godwin, hy Ilacket's delightful life of archbishop Williams, and a work by anestler hand on the same theme. Towards the close of the -renternth cintury we come to a man of whom no Yorkshireman olloht to speak witlout respect and admiration, James Tinere, the rork antiquary.

Ihe wats a scion of a good Yorkshire family, and in his zeal fir antipuity he was not moworthy of the county which was the mother of lioger bodsworth and many other scholars of repute atul fante. Mlis powers of application must have been proliwims, for althomgh he was but a middle-aged man when he dind, he had filler seores of folio volumes with materials for lintory, hiography, and genealogy, all written in that curiously minute hand which was one of the eharacteristies of the literary min of that age. The nerves and the heads of those who are nuw living shrink from the very thought of what persons like l'ryure, londale, 1)odsworth and 'Torre conld effect and endure. I de not think that fannes Torre of York was inferior in appli- 
cation to any of the scholars that have been mentioned. If we form our estimate of lim merely from the three or four volumes of his manuscripts which are preserved at lork in the registry of the dean and chapter, we ean see that lie was a mam of extraordinary powers. In the space of three or four years he literally made an abstract of most of the official documents in the registers of the archbishops and the chapter. 'The succession of elergy in every living in the diocese, up to the time in which he lived, is given as far as he could ascertain it. The testamentary burial of every person of importance, all instruments and deeds commected with endowments of livings and ehantries are mentioned, and in many instances church notes are added besides. These are some of the contents of these wonderful rolumes.

The most extraordinary, however, of them all, is that which is specially devoted to the minster at York. There is in it a listory of the church from the carliest times; there is a perfect survey of the fabric, all the glass is described, every monment is measured and drawn, and its inscription and decorations are given in the most minute way, by which many things are preserved which have long since disappeared. The endowments of the church are all given: there is even an abstract of the leases. There are full lists of the parsons, vicars, and ehantry-priests. But the greatest wonder in the rolume is that part which may appropriately be called the Fasti of the Cathedral. It is a list of all the archbishops, deans, dignitaries and canons of the church to the time in which Torre lived; all their preferments in the diocese are spccified; the exact dates are giren, with references for each statcment, but here, as a gencral rule, the compiler ends. These things are merely the dry bones of a skeleton, but each is in its proper place, and Torre has left to others the more difficult and laborions task of clothing them with flesh and blood. He lias made the framework of the Fasti himself, and in doing that he has accomplished a great deal.

Torre died at a comparatively carly age, and little has becu 
sine dome to illustrate the biography of the dignitaries of the mimster. Ilis lists appeared with a few additions in the works

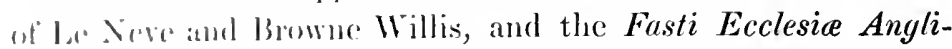
ramer latre bern still more improved in the recent edition by Mr. T' I. Ilady. The antiquary, Francis Drake, wrote the lises of the arrhlishops and published them in his Eboracum, but they rentain little information of any novelty or value, and thy atre disfigured in screral places by those caustic remarks of "hich that historian was too fond. There are memoirs also of atrhlsi-lep shlarpe and of several of the later primates, but the Fasti of the industrious Torre still oceupy the first position in inipulance. They are not free of course from errors of omission and commision,-the character of the work precludes the possibility of that-lut on the whole these unrivalled collections arre marrollomsly cxact.

Mr. Bixon's connection with the ehurch of York, the taste for latters which he inherited, and the natural bent of his own mind, induced him many years ago to turn his attention to the mammseripts of 'forre, and the history of the minster and its oflicers. As he was mable to decipher the medieval hands, he twek the greater interest in the more modern period, and with mucl industry and persererance he drew up a volume which he intitlel, "Fasti Eboracenses; or, A catalorue of the Members of the ('atlicdral of York from the Great Rebellion to the present time." These are written in a stout folio of five hundred and fifty pares, drawn up with much care, and illustrated with infirmation derived from many persons and somrces. The work in by no moms a dull and dry catalogne of names, but it contailus muncerns extriacts from printed books, and many facts "hich conlul muly have been aseertaincd by personal enquiry, and with murle trouble and research.

For many years Mr. Dixon confined himself to the limits which hase just loren montioned, but at the suggestion of the lite lramed and aniable Arehdeacon Todd, he subsequently determined to take a willer range, and to attempt the biographies 
of the worthies of the minster from the rery carliest times. This exteusion of his subject seems to have suggested to Mr. Dixon another method of arranging his materials. In the first portion of his work he had marshalled the dignitaries in regular succession under the offiees which they oceupied; in the latter he adopted a purely chronological order, with no regard to offices at all, and at the head of each century he placed a short essay on the general history of the chureh during that period. This plan was an intelligible and a good one, but the great length to which the lives of the primates alone have extended, has rendered its rejection necessary. Between the first and the second portion of Mr. Dixon's work there is no comparison in value and importance. The latter part (in point of time the earlicr) was commeneed far too late in life to present any appearance of the industry and research which are apparent in the other, and which would have been evident to a great extent in this if a longer eareer had been rouchsafed to $M[r$. Dixon. As it was, through the aid of the mannscripts of Torre, he had laid down a pretty substantial framework for his book. From the same invaluable collection he had derived many notices of the livings and offices which each dignitary enjoycd, and he had added, besides, some extracts of his own from other sources. There was no attempt, however, at composition, and for the most part Mr. Dixon's collections for the mediaral portion of the Fasti are little more than a bare catalogne of names and dates.

Soon after Mr. Dixon's lamented decease, which oceurred in the month of February, 185t, his widow, acting muder the advice of Mr. Canon Harcourt and the late Dr. Rainc, resolved to prepare for publication the Fusti Eboracenses as a memorial to her husband. In compliance with his father's wishes, the charge of the work was undertaken by the editor, who was at that time a mere stripling as well in years as in literary experience. Neither he nor any one else who was interested in the book had at that time any idea of the real extent and weight of 
the burken which he was fastening to his shoulders. It was unious, in whaterer light the undertaking was regarded, that much toil and researeh wonld be required from the editor. In what form his labours were to be eomeeted with those of his predecessor was not so evident. Dr. Raine, in the first instance, was of ofinion that Mr. Dixon's manuscript should be made use of as a text, and that the additions of the editor should appear in the form of notes, but he soon discovered that this arrangement was impossible, as it would be mere folly to have ten and of ten twenty or thirty hines in note-type to illustrate only one of trxt. Mr. IIareomrt, by whose advice, together with that of 1)r. Raine, the editor has been guided in any ease of difficulty, at IIr. Dixom's request, stated from the rery first that Mr. l)ixon's manuscript shonld merely be used as a foundation on which the work should be construeter. At all events the general understanding was that what was wrong should be struck out, and what was wanting added. To do all this was a very weighty and scrious office. No one, I belicre, was at that time conscious of the toil that it wonld entail, least of all the writer of these works.

Ton years have almost passed away since this resolution was arrived at, and the present rohme at least will shew that the editor has tried in all honesty and honour to adhere to it. These ten years have bronght great changes to him as well as to others. They have remored from his sight one in particular, whose memory he can never dwell upon with aught but love and rererence, who before his decease had begun to look with some regret and fear upon the labour cntailed by the work which he hard comiselled the editor to undertake. Those fears, however, have been happily belied, and the hopes and aspirations that ever aecompanied them, as the writer humbly trusts, would not have been entirely disappointed, had his sire been spared to look upou this volume. The old words, Spartam nactus es, have bern contimnilly in the editor's mind, and he has been animated thronghout his work by a wish, and why should he be ashamed 
to own it? that he might do some little honour to the name of a father of whom his ehildren have so much reason to be proud. But the editor has been upheld throughout his lathour by a higher motive still. He was requested to add to and eorreet $\mathrm{Mr}$. Dixon's manuscript, supplying as far as he could whatever was defieient; a commission as unlimited as the labour which it necessitated. He accepted it roluntarily and eleerfully in its fullest and widest sense, and in its fullest and widest sense, as a matter of duty, he has endearoured to fulfil it. Ile felt at all times that he could not conscientionsly do otherwise, and in spite of labour which, in one word, has been tremendous, in spite of sacrifices as severe as they lave been varions, in spite of several very heavy discouragements, under which many would have shrunk and fainted, he has perserered in doing his duty by his work. He could never have done so if he had not been strong in body and stout in heart, and he cammot be too grateful to One who orders and sustains both, that his health has been uninjured, and his resolution, although sometimes sorely tried, still buoyant and molaunted.

The whole of the present rolume has been witten by the editor, and nineteen-twentietlis of the materials lave been colleeted by him. It was his wish to have issued the two volumes, in which the lives of the arehbishops are to be comprised, at one and the same time, that the second, in which Mr. Dixon's work will be more apparent, should appear contemporancously with the first, which the editor, owing to the paneity of the materials collected for it, has been obliged to write himself; but, at the request of Mrs. Dixon, the first rolume has been issued withont its intended eompanion. The editor has also been desired by the same lady to write or re-write the whole of the second rolume. It will not be necessary, howerer, for him to do that entirely. Mr. Dixon's own eollections for the later portion of his work will save the editor much trouble and researeh, and the public before long will have an opportunity of fully estimating the merits of an undertaking which, but for 
Mr. Dixon, would never have been begun, and which is offered up as a memorial to his industry and judgment, not less sincere and lasting, it is to be hoped, beeause so much of it has been construeted by an alien, although a friendly, hand.

The perusal of this rolume will shew the reader that this is not a work that has been hastily or carelessly constructed, and will at once explain the delay in its appearing, although it contains the lives of only forty primates. Many, however, will be surjurised when they are told that the editor has made contemporanconsly, in behalf of the Fasti, collections, on the same scale, for the biography of some seventeen hundred other persons, extending over a period of twelve centuries, and comprising, among the very greatest men in the Church and State, three hundred English and foreign bishops, three popes, and at least sixty cardinals. It is not too much to say that almost the whole range of the history, biography, and topography of England, and, in part, of other comitries, has been ransacked for these lasti. This, as every student knows, conld not be done without great labour. He is aware, also, that for mediæval biography medixal documents and annals must neeessarily be examined, and that few have the inclination, still fewer the ability, to have recourse to them. Some may, perhaps, smile when the editor tells them that he has given up nearly a whole year to daily toil among original evidenees in the publie offices to make his work as complete as possible. New matter is what is wanted in these days, and that ean only be derived from repositories like these. We wish also to hear of new men-not of persons like Wolsey ant Cranmer, to whose biography there are perhaps few additions of any importance to be made; but of bishops like Thurstan and Thoreslyy, Bek, Skirlaugh, Hatfield and Langley. We want to know what they did and how they worked, who were the officers and clergy that were under them, what was the discipline of the church in their day, the state of the monasteries, the private and public life of the parish priests and canons. At present we know alnost nothing about our early chureh history and bio- 
graphy, and for the simple reason, that men will not take the trouble to seek for information where alone it can be found. In preparing the Fasti the editor has made an honest, although very imperfect, attempt to fill up and supply a manifest defect, and he has not shrunk from the drudgery which the nature of his work required. He may venture to say with bishop Hacket, "I drew the knowledge of those things of most moment which I shall deliver from the spring-head, and I trust in God that I have incorporated them into this frame with integrity." In these days of book-making, one work with a loud-sounding title suceeds another, repeating the old errors and the old conclusions, which the absenee of new evidenee prevents the writers from discarding. All that they can do is to put the old materials in a new and a more pleasing setting, althongh this is not often the case. The book is the old dish served up again, the "crambe repetita," against which the great Roman satirist shot his arrow.

No one is more sensible of the great defects of this work than the writer. What exertions can be worthy of so noble and so grand a subject! 'The editor's sensations are like those of the scholar who comes into a vast library, or of a person who finds himself suddenly introduced into the presence of a great multitude of men. The one regards himself as a dot or an mit in such a concourse, the other sees what a pigmy he is in genius when he gazes on those ponderons tomes which express the thoughts and the feelings and the deeds of the almost forgotten dead. The editor is well aware of the grandeur of his theme, although he has not risen to the high level on which it onght to have been placed. He does not believe that he has gathered together a third of the information which may be discovered about many of the primates whose lives he has been bold enough to attempt, and of this volume one third, perhaps, will be found to be incorrect. The very nature of the work precludes the possibility of complete accuraey and exactness, and if the writer had waited for them, his labours would never have been 
ready for the press. It is a great thing to lay a fomdation for future reseinch, and to gire people something to correct. It is a natter of deep regret to the editor that so few of the national documents, especially the Close and Patent Rolls, are in the hands of the public. He is well aware that they may destroy many of his conclusions, and supply facts of which he is completely ignorant; but he must throw himself in this respect on the consirleration of others. All will allow that he has not shrunk from toil, and he has been equally anxious to aroid harsh eriticism and controversy. Of course he has not refrained from expressing his opinion about men and things, but he has endearoured to make his way by stating what he believes to be the truth, and not by shewing where others are in the wrong. lle is so well aware of the hidden fires that are smouldering under his own feet, that he has no wish to evoke them by censuring or attacking others.

One great difficulty that the writer has been obliged to contend with is this, that this work is restricted to a certain limited spaec, and he has thus been unable to do full justice either to lis subject or himself. The strong hand of compression will be apparent in every page of this work. The life of more than one primate, were it fully entered into, would form a volume of itself. On account of this want of room many things have necessarily been omitted; facts have been stated, but the conclusions to be drawn from them have been left to others, and many critical remarks upon difficult and disputed points have been abbreviated or abandoned. But with all this compression the lives of the archbishops alone will occupy the space which was intended at one time to be filled by the whole Fasti of the cathedral; and with these lives, to be completed, it is expected, in another rolume, this work will come to a termination. The reader will not be introduced to those many hundreds of other dignitaries, about whom such a mass of information has been collected. It would recpure ten or twelve volumes like the present to do justiec to thcir biography, and the ammals of the arehiepiscopate 
must not be ruthlessly eurtailed. It is with no little regret that the editor is obliged to throw aside five-sixths of the materials which he has gathered together, especially as a third volume, comprising the lives of the deans, sub-deans, chancellors, precentors, treasurers and arehdeacons of York, would not only constitute the history of the cathedral to which the biography of its remaining members could easily be appended, but it would also disclose a vast body of information about many good and great, although hitherto muknown, dignitaries, which would be of greater novelty and interest than that which is now laid before the public. It would be a matter of much concern to the editor to see the subject contimued on a scale less extensive than the present, but flesh and blood, somehow or other, camnot but shrink from the thought of the labour which such an undertaking would require, although in this ease it wonld be merely the construction of an edifice ont of the materials that have already been collected. It is certain, however, whatever people may say or think, that until the Fasti of one eathedral or diocese are exhausted in the way that has been suggested, we can know but little of the true history of the English Chureh. At present we are only catching at straws and pursuing shadows. We want to see what the ecelesiastics of other days believed and did, how they lived and wrote and died. At the present time we scarcely know their names.

This book professes to be nothing more than biography. It is not the history of the English Church or of any part of it. It has nothing to do with what are called "the times" of the archbishops or of any of them,- - that rague and unsatisfactory term which is almost invariably the title of a bad book. It has simply to do with the men themselves with whom the work professes to deal, and collateral information is brought in only with the intention of setting off their eharacters and history. This book is addressed ad clerum rather than ad populum, to the bees and not the butterflies. It is written to bring out truth, and not to please fancy or prejudice, or merely to attract 
the popular eye. 'Too many sacrifices have been made to these already, and scholars who are worthy of better things have been frightened by the hugbear of popularity. Popularity of course must have its due weight in the mind of every one, reader or student, and it is but folly for the scholar to kick against the pricks by professing to despise it, but it must not be everything. If this is to be a book of reference,-and it ean scarcely expect to rise to that dignity, - why shonld it be made a bad one, merely to gratify the taste that shrinks from dry details. This is an enquiring age, and what it wants are new facts from which new conchusions may be drawn. The true gold of literature and learning is far below that surface on which too many in these days are content to work. In quest of that gold the editor has not been ashamed to dig, and he has tried to do so in an honest and a kindly spirit. He is well aware that the main reason why people shrink from early biography and history is, that they camnot realize those times, they camot think and feel as the men of those days thought and felt, of whom they know so little. You may see their portraits, if you wish, in the memorials that they have left to us. Yon may trace ont the fincr features of their character in their works, and rise up a better man than you sat down. 'The cditor' would fain hope that he has sojourned not altogether in rain among those great and holy men with whom he has cndeavoured to surround himself, that he has drawn their true portraiture, and ascribed to them thoughts and words and deeds that are not unworthy of them. His labour has shewn to him, and he trusts to others also, that in those ages which many pass by as umenlightened and uninteresting, there were learning and true greatness, and a spirit of devotion and self-sacrifice of which few in these days can fully and properly conceive. Men like these belong not to one party, but to all, and they are Lngland's noblest and greatest sons. Their rery presence scems to act as an inspiration in the places which they once hauntel. Who can enter the glorious fane of York withont fecling this, although he is a stranger to its history and 
its fortunes? A kind of saered influence secms to hang around you there, a legaey to the present from the past. Associations throng around you, for great things have been done within those walls. Roman emperors walked over this ground when as yet this temple was not. It was here, in the dayspring of Christianity, that the Northumbrian monarch stood with Paulinus at the font, and made rows and promises which he was not long spared to keep. On this sacred site was the church of which Wilfrid was the founder, lovingly enshrining in its heart the little chapel which had witnessed the baptism of the ling. Recollect that Bede was in it twelre centuries ago, and that in this place were the home and the school of Alcuin, of which he spoke with true filial gratitude and enthusiasm among the Paladins of Charlemagne. Kings and nobles have stood where you now stand, and many of the princes of Northumbria, Norsemen, and mighty men of renown, are sleeping beneath your feet. What sights and scencs have these time-honoured walls beheld! They have seen, speaking only of more recent events, and what I may eall ouly modern days, they have seen the great king surrounded by his court when St. William's bones were placed in a new tomb. They have looked upon the minions and the reprovers of his unwarlike son, Lancaster and Bohun, Clare, Argentine, Gaveston and Despenser. They have seen the marriage of Edward III. to Philippa of Hainanlt. They have witnessed the trimmphant progress into the North of the victor at Agincourt, that he might pay his orisons at the shrine of the great saint at Beverlcy who had given him, as he thought, his victory. They have seen the mutilated remains of Harry Hotspur laid at last in the cold earth, and the presence of Richard III. and his youthful son, on a day of short-lived triumph, among his rejoicing Northmen. This is the transept which Walter Gray erected, and there in it he is reposing moler that high-towering tomb. That is the monument in which Serope's bleeding eorpse was laid, and there on the screen is the image of the cruel king who slew him, still bearing upon its 
face a puerile token of the disgust which his injustice aroused, and almost by his side is his mhappy grandson's statue, to which the foolish and impassioned Lancastrian in after days paid a fruitless worship. No one ean look on that nave and on that glorious window, the finest perhaps in the whole world, without thinking of the great primate who filled it with those glowing colours which, aftcr the lapse of fire centuries, look down upon you with a softer and a more solemu light, and then go into the choir, and forget Thoreshy if you can. Stone and marble and glass are voiceful there, and they tell you with one tone of the good deeds of him who, with no memorial but themselves to prescre his name, is sleeping in front of that eastern window before the old altar of St. Mary, which he once reared, and which he loved so well.

In conclusion, the editor must acknowledge, and he does so with pleasure and gratitude, the aid which he has received from others during the progress of his work. Many a helping hand las been held out to him, and he has met with much sympathy which he eamnot easily forget. To the Dean and Chapter of York he is under the decpest obligations: he has had unrestrained access to all the muniments they possess, as well as to their choice library; and from the elapter-clerk, C. A. Thiselton, Esq., he has receired far more than merely formal courtesy, the unvarying attention and kindness which have extended over many years. To Nessrs. Hudson and Buckle he is equally grateful for the readiness and the pleasure with which they have allowed him at all times to consult the records in. the archbishop's registry, withont which permission this volume would have becn comparatively worthless.

The erlitor's most sincere thanks are due to Mr. Canon Ilarcourt, one of the grcatest promoters of literature and science that York has ever known. If it had not been for him, this work would never, perhaps, have appeared in its present form, and he has been at all times most desirons, not only to smooth away any difficulties which may have arisen in the writer's path, 
but to give, what has been still more valued, many a kind word of eneouragement and adviee. The editor is also wishful to express his acknowledgments to Archdeacon Churton for his assistance, which few are as competent and none more willing to bestow. He camnot but feel that the lives of the archbishops of York would have proceeded from Arehdeacon Churton's pen more appropriately than from his own, and that no one could do greater justice to the worthies of a cathedral among whom he himself oceupies so high a plaee.

It would be impossible for the editor to enmmerate and thank, as he could wish, all those who have helped him in his work. He cannot, however, pass over the Rev. William Stubbs, J. R. Walbran, Esq., and W. H. D. Longstaffe, Esq., who have afforded valuable assistanee in securing the aceuracy of this volume; nor must he omit two tried and always kind friends, Robert Davies, Esq., and the Rev. John Lees, who have been good enough to examine every sheet as it issued from the press, and to render aid and comsel with a readiness and a pleasure whieh he cannot prize too highly.

It is painful to speak of those who are not, but it would be unjust to pass those by who took no little interest in the progress of a work, the eompletion of which they have not been permitted to behold. To none would the sight of this rolume have afforded more sincere gratifieation than to two beloved kinsmen, seholars themselves of repute and fame, who have gone into the new country, and the writer's fondest reeollections are centred in a father and an uncle. But there are others, also, now no more, whom the editor camnot forget. From Joseph Hunter, Esq., the historian of South Yorkshire, he received at all times an almost parental kindness, and the aid which a master of his art is so pleased to render to the son of an old fellow-labourer in the great eause of letters, when he adopts his father's tastes and manifests a desire to make them hereditary. Of the Rev. Charles Wellbeloved the writer ean only speak and think with affectionate regard, and he will always remember one who at 
ill :120, which fow are permitted to reach, retained unimpaired the wistom of the comstuns elus, together with the warm zeal and hunyancy of youth. Nor must the editor pass by the late Armbishop Muserave. Ile will always be decply sensible of the comsiderate symprathy of the late primate, and of his overflomine kindness, of which he was frequently the recipient.

'The writer must also express the great obligations he is muler to the printer, Mr. Mitchell. He does not think that any house in Lomdon could prepare more creditable proofs than those which Mr. Mitehell hats submitted to him.

J. R.

Yonk, April 25, 1863. 


\section{REFERENCES AND AUTHORITIES.}

The editor, for sereral reasons, has not placed his references at the end of each life, but has appended them to the fact to which they especially refer. 'Their number may perhaps be reprehended, but the writer has wished to put in each note an exhaustive list of the anthors who have mentioned the particular cireumstance to which it refer's. The reader may not, perhaps, have aceess to every work that is referred to, but when many authorities are given, it will he in his power, if he wishes to do so, to test the accuracy of the narrative by examining at least one of them.

Exact references have been given to everything but the manuscripts at York. Any fact ean be found without diffieulty in the registers of the arehlishops, which are arranged chronologieally, and divided into arehdeaconries, ete. Into the Aetbooks of the Dean and Chapter it is not so easy to enquire. 'Torre's fanciful titles, if given here, would only bewilder the enquirer, and a new system of lettering must be adopted when they pass, as they soon will, through the binder's hands.

Where there is a variety of editions of the same work, it will be necessary to mention those which the editor has made use of. This will assist the reader and facilitate investigation.

Alcuini Opera. 2 vols. Fol., 1777. 1678 .

Baronii Annales. 11 vols. Fol., 1589, and the Continuation, 3 vols. Lyons,

Beda, ed. Smith, Fol., Cambridge, 1722.

Dugdale's Monasticon. The new edition.

Foedera. The new edition.

Florence of Worcester. 4to, London, 1592. The continuation from the new edition by the Engl. Historical Society.

Peter Langtoft. Ed. Hearne. The reprint.

Chron. de Mailros. Ed. Bamatyne Club. 4to, Edinb., 1835.

William of Newburgh. Ed. Ilearne. 22 vols. Svo, Oxon., 1719.

Matthew Paris. Ed. Wats. Fol., London, 1681.

Chron. Petrib. Ed. Giles.

Polydore Vergil, Historia Anglice. Fol., Basilex, 1556.

Savile's Scriptores post Bedan. Fol. London, 1596.

Saxon Chronicle. Ed. Ingram, 1to. London, 1823.

Triveti Annales. 8vo, Oxon., 1719.

Wendover. Ed. Giles, 2 vols. 12 mo. 
A LIST OF THE LIVES CONTAINED IN THE PRESENT VOLUME.

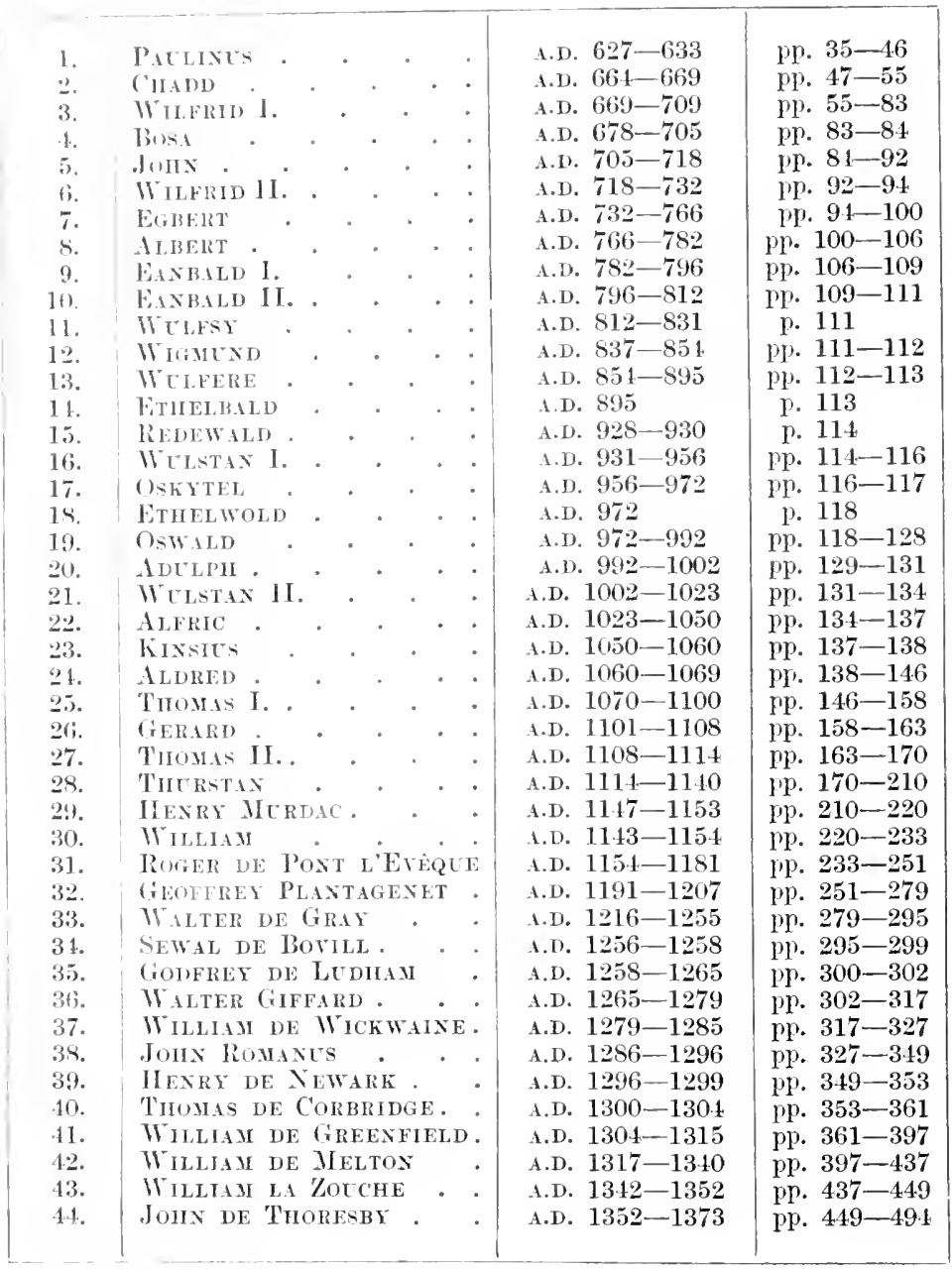




\section{FASTI EBORACENSES.}

\section{INTRODUCTORY CHAPTER.}

The history of the archiepiscopate of York commenees with the mission of Paulinus. The lamp of truth loegins at that time to shed abroad its full light, although several centuries had passed away sinee it was first kindled. An enquiry into the origin and progress of the Northern Chureh will be a necessary and appropriate introduction to the biography of its leaders. This, however, must be made in the briefest and the most summary manner, and I shall not pursue it after the arrival of the Norman conqueror.

It is not easy to say to whom we are indebted for the first preaching of Christianity in Britain. No one has as yet given any satisfactory solution of this doubtful point, and the bigotry of contending partizans has enveloped it in additional obseurity. It seems evident that there was in the British chureh an Eastern as well as a Western element; indeed it is quite possible that Judaic traditions had been brought to England before the birth of the Redeemer. The Eastern origin of the inhabitants of these islands, the frequent visits which they reeeived from Asiatic merchants, eould not fail to make the Britons more or less aequainted, at a very early period, with the trutlis of Christianity, and there are traditions whieh such a supposition can alone explain. We must either take it for granted that Greek forms and opinions, the Græeanitas of which Mabillon speaks, were at one time the tenets of the universal ehureh, a point which will not be readily conceded, or that there was some direct communieation at a very early period between $A$ sia and Britain, which originated those peenliar valiations from Roman discipline and ceremonial that werc once rife in England. Howerer this question may be settled, it is equally certain that Christianity would flow into this comtry from the Eternal City. It is very probable that our little group of islands, which were so 
well knewn at Rome for their fertility, their mineral wealth, and the valour and independenee of their inhabitants, would be homenred witla a sperial sisit from sone of the carly propagators of the firith; hut, eren if they had merel reached our shores, "I may lo sure that the truths which they ineuleated everywhere, with such rusery and suceess, wonld come to Britain seroner or liter from the cmperinm of the world. The early Christians shmmed neither the (amp nor the formo ; erery place and profession was thenged with comserts to the true faith, and we nay be certain that there would be many of them in this comtry, in attendance upon the imperial conrt, or in the ranks of the Roman armies. Wherever there were Christians they would have their atsemblies and eomeregations, and they would probably imitate, as far as possible, the example of their brethren at Jerusal(nt, where "all that believed were together, and had all things common."

From little begimuings a chureh would gradually be estahlished. I do not mean to say that Christianity would at once become the national faith; very far from it ; but still it is remarkable that we find no trace of any opposition being made to the new ereed by the professors of the native religion. Into no (omintry could ('hristianity be introduced with greater chances of success. It would soon cneounter Druidism, and it does not appear that the meeting produced any angry collision. The Eastem origin of both creceds, the sacred mystery that enveloped then, the retiond lives of their teachers, would disarm the suspreions of eren the erifted critic. A kind of allianee seems to latre beren mate between ('hristianity and 1) luidism, and, as is encomally the case, the new and more astive religion stepped beline lime inte the place of the old. It became, in this way, more or lese the national faith. Sicenring the favour of the native princes, and cncombering little opposition, if any, from the Druich themselves, the ('hristian roligion got possession of the is holy plares and ronsecerated them to a more exalted wor-

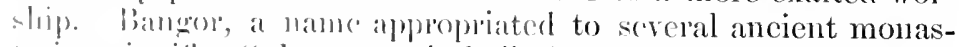

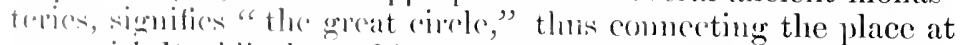
mece with lmidical worship and bruidieal remains, and shewing how ('hristianity had oceupied or stuperseded them. And on otheresensms the Christians in Britain have displayed a similar achoitures. As soom as they gained the good opinion of the ruling prowers, they have quietly taken prossession of the holy Janes of the lately recognized ereed, keeping a firm loold of their

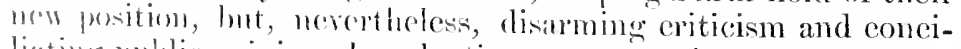
liating pulblic opinion, by ardopting, to a certain extent, all that was sonel and politic in the preceding system. It was one of the pirees of advice which Gregory gave to Angnstine, that he 
should use the temples of the Roman deitics, and in this respect that sagacions prelate only followed the example of arealins and Honorius. A little purification was enjomed, and then these heathen shrines might be dedieated to God. 'The eathedral church at Canterbury occupied the site of a Roman temple, so did old St. Panl's and Westminster Abbey. The crypt of the monastery at Ilexham exhibits rorkmanship of rery great antiquity. ${ }^{a}$

It must have been a great boon to the Saxous to have citics ready built for them, as the Britons had too great a r'card for the Romans to destroy their works. Bcda speaks with admiration of the memorials of their skill and energy that were standing in his time, temples, aquedncts, and bridges; but how grand they must have been nearly three centuries before his day, whon the Saxons first amived. They had all their public buildings ready, a mighty step towards civilization for a nation that was ignorant of everything but war. They were sheltered from their foes by Roman bulwarks; they could sleep, if they chose, in Roman houses $;^{b}$ they could pray, when they had learned the value and the need of prayer, in a Roman temple. It was from these edifices that the Saxons themselves learnch how to build. What is now called Saxon architecture is only a rude imitation of the work of Roman masons. Nor were the Saxons indebted to Italian art merely for the shrines in which they worshipperl -it gave them also the sacred ressels for the sanctuary. In the ancient Ritual of the church of Durham, and in the Pontifical of Egbert, archbishop of York, there are spccial forms of prayer for the consecration of resscls that were found in heathen places. This tends to shew that every nook and cranny in the Roman cities and camps has been ransacked long ago for hid treasure. And that the Saxons carried off everything of valuc, the pancity of the Roman remains discovered at the present day is a sufficient proof. No one who examines the seals that

a There are no remains of this antiquity in Tork. The minster stands within the old Roman camp, but there is nothing to shew that it either occnpied the site, or was constructed ont of the remains, of any heathen temple. The old name of Christ's Church, was the church of the IIoly Trinity in the king's court. What king? Did it stand within the precinets of the palace of the monarchs of Northumbria ? The recent restorations of the two ehurches upon Bishophill, disclosed some very early fragments of masonry and senlpture, and the two buildings, as they stand at present, exhibit soveral frat ures of remarkable interest. They oceupy the highest gronnd within the eity. is this the hill on which the earticst bislop that risited Eburacm set ul his tent, and which, after the fishion of ont spiritual ancestors, wats cromed at once with a Christian temple? 'There are precedents for such astch, and the surpfoxition will explain a name abont which there has been some douth.

b The Sixom remains which lave been oceasionally discovered in limun camps in the North of Enychand, secm to shew that these places were inhabited after the denat me of their buthers. 
inc appeuded to the carlicst charters can fail to see how many of them ane impressions of Roman gems. The seal of the great momatery of l)mbam is a remarkable instance. On the one bat is the woll-known consis of St. Cuthluert, but on the other, now lost, tho monks wisher to represent the head of their benefiutor, line ()wale, so they eravel upon a rim of brass the

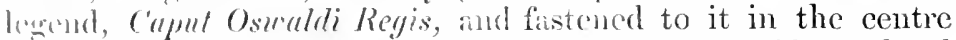
at fine arem, the spoil of sone lioman camp, a magnifieent hear of Jupiter 'l'onans!

IIr ammot aceept umreserved!y the statement of Beda, that Boitain was first comverted to Christianity by missionaries who were sent from Rome by Elentherius at the request of the British chicftain Lucius, about the year A.D. 180. It is plain that glimpses of the truth must have previously reached these inturls, howerer vague and nuccrtain they might be. It was probahly the wish for some more definite and accurate teaching,

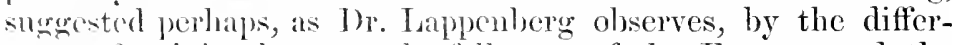
(nines of opinion between the followers of the Fastem and the Mratem ceremonials, that tempted Lucius to send to the bishop of home for his assistance and advice. With the adrent of this mission the British episcopate is said to have commenced. Ilow it was distributed and arranged it is impossible to say. Whe traditionary accomt asserts that there were twenty-eight prolates, one for carly of the greater British cities, who occupied the position of the Poman flamines. Orer them were three prosiclents.

The cities which were governed by an archbishop were Lomdon, Vork, and Cacrleon-mpon-Usk, or the City of the Legions. What the duties or the exact rank of these high oflirials were we are not informed, only we are told by IVilliam of' Newhurgh that there was no arehbishop, that is in the sense of a later age, in the carly British church. York is the only ('ity of the three that has preserved its ancient honours, and one of its merliceral chromiclers has proudly recorded-

\section{"Deficiunt reliqua, primo frustrantur honore,} Ast Eboraceusis sola manet stabilis !"

The origin of Ehuracmm is concealed in the mists of antiquity. Fa be it from me to dwell mpon the fables of which the chronirlors of the past ages were so fond. I shall leave to them the glnics of king Ebrane, and the prestige of a city which was the scat of a monareh at least twelve conturies before the advent of ('hristianity! Eburacum may be satisfied with a humbler' and yet a mobler origin. It is from the pages of the Roman ambalist that we mist learn the story of its grandeur. It is not probable that the Roman amies were well acquainted with 
Eburacum before the expedition of Agricola into the North, which took place towards the close of the first ccutury after Christ's birth. 'There the great eaptain would discover, what the name imports, an ancicnt Celtic city. Conld we sec the place as the intrepid Italian then belield it, we shonld be loth to dignify it with such a title. There would be before us a eollection of dirty hovels crowded together within an cnelosed space, and a population of half-naked and painted harbarians living among their flocks and herds, and surronnded on all sides by wild-wood and water. But wretehed as Eburacum must then have been, it could nerer have been so great under the Roman rule had it been of little consequence before. The Romans knew well how wise it was, in a strange and savage country, to take possession of a place of antiquity and note; where, probably, there was the only market in the district, and towards which all the forest pathis converged. Here they eould have a rendezvous for their armies in the North, and a dircet communication with the ocean by the waters of the Ouse. It is scarecly possible to exaggerate the importance of Eburacum during the greater part of the first three centuries after Christ's birth. It was one of the most important places, if not the capital, of Roman Britain, and as Britain became more potent in the councils of the Empire, so did Eburacum become one of the greatest eities in the great Roman world. It is probable that every emperor who visited this island took up lis abode in that city, and when he was absent the legate was the occupant of the imperial palace. Two emperors, Severns and Constantins Chlorus, died within its walls. 'Two claimants of the purple, Carausins and Allectus, were comnected with the district, and the former is said to have been nominated Imperator at Elburaeum. How magnifiecnt must have been the city which was thus connected with stirring incidents and men of cnterprize and energy! Thronged it would be with that noble soldiery which was as yet invincible, and filled with all the luxury and pomp that nestle about a palace or a court. Fortifications of the most massive character were around it, and within were public buildings, as fair and as grand as those which Italian architects had reared beneath the softer skies of their own delightful country. The historian, in a later age, when he gazed upon their rums, accustomed thongh he was to more striking outlines and more delieate forms of beanty, conld rebuild in fancy the shattered fabries of Eburacum, and say proudly to himself that the nolle eity must indecel have been anotler Rome. ${ }^{\circ}$ With what amazemout would the Briton look upon

e Richard of Cirencester tclls us that Verulanium and Eburacum were the two Roman municipia in Britain.

Aleuin, in his poem De Sanctis et 
the magnifiecere that Alenin admired. The very sight of such crandrur would aptivate the simple-nimded sarage, and in the fascinating huxury that encireled and ensmared him, Eburacum would ha" to him, as his conquerors desired, a second Capua.

It may be saffely aswmed that there was a Christian congresation at liburacim presided over by a bishop, if indeed the cpiscopate were cstablisherl at that time in Britain, which there is no reason to doulst. How the good seed that was brought from linne ripened to the harvest it is impossible to say. Among the Romans themselies it is not probable that the new rrecd crperieneed less success than it met with at their hands in other countries; nay, it is likely enough that they would look 1 unon it with greater favour, as they were here removed from all those dangerous fascinations of place and form that attracted them in other lands to their idol-worship. Among the Britons it would be the more readily aecepted, as it chimed in with their traditions from the East, which must have been cherished even by those who had no intercourse with the merchants from Asia of from (iaul. Ilowerer this may have been, it is evident that ('hristianity obtained a sure footing in this country whilst it was in the possession of the Romans. We know, also, that its profescors were for a long time immolested." The persecutions that desolated the adjacent continent, and gave to the church of lyoms many a noble martyr, never reached these shores. There is 110 recond of Severus, an apostate from Christianity and an active opponent clsewhere of the true faith, raising his hand arainst my believer in Britain, althongh he was for some time a resident in the island. The Romans were more tolerant here than they were in Italy and Gaul. They were less secure, and omsequently had lesime to spend in religious controversies. l'erhity the Britons were so attached to the Christian faith that the liomans alid not dare to ruftle them. Perhaps the British chnreh was so insignificant that it was entirely overlooked.

In the great persecution of Dioeletian which began in the year 29) , the British Christions were not spared, and the cmperor wonld not be disposed to faron the island on account of its recent revolt. The care of this country was at that time

Printificibus ercl. Eibor., says that the liomins built the eity.

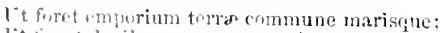
lit fient ducilus secura putential regni,

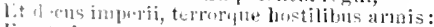
Fisst ab fertromo venientibus huspita purtu Aavibus receano, cte.

IIarrion, in his Description of Britrin, speakine of Ronnan treisures, wherve, "What sure hat h beene seene of them in the ritie of Lomelon, - and likewise in Yorke, named also Victrix, of the lenion Victoria, or altera Roma (becanse of the beantie and fine buildins of the same), I myselfe can partlie witnesse, that have seene and often had of them; if better testimonie were wanting."

d "Suseeptam fidem Brittani usque in tempera Diocletiani principis inviolatam interramque quieta in pace servakant." Beda. 
entrusted to Constantius Chlorus, one of Diocletian's associates in the empire. When the order for the persecution was communicated to him, Constantius was probably at lork. Eusclins in his laboured panegyrie upon his son, Constantine the (ircat, would lead us to believe that the wishes of Diocletian were disregarded, and that Constantins was most liberal and tolerant in his views and conduct. Beda, howerer, a more trustworthy anthority, gives us a very different account. He tells us of thic number of the martyrs and confessors that there were at that time in Britain-how the churches were thrown down, and the trembling believers were obliged to flee for refinge to the deserts and the momtains. And yet, in spite of all this cruelty and intolerance, the great Saxon historian speaks of Constantius as "vir summa mansuetudinis et civilitatis," and Theophanes

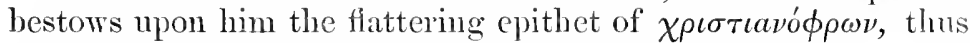
justifying, to a certain extent, the praises of Ensebius. He was, in all probability, the unwilling execntor of the wishes of Diocletian, and, like Obadiah, conkl spare when he was ordered to destroy. And this is the more probalble from the fact, that when he became a free agent he embraced that faith against which, in bygone years, he had been compelled to set his face. When Dioeletian put off the purple in 305, Constantius divided the empire with Galerius. He then professed himself a Christian. 'The desolated churches were rebuilt, the sacred eeremonial was restored, and the joyous worshippers emeroed at length from their hiding-places in the forests and the mountains.e There was peace at last for the scattered and affrighted flock, but after reigning for a few month the peace-maker was remored from it, and his ashes were laid to rest in the city of Eburacum. 'The first of his two consorts is still remembered for her virtues and her sufferings. She is said, on rery slight anthority, to have been a British lady, and it was this belief, together with the memory of her excellence, that eansed three churches in ancient York to be dedicated to the sainted lady whose husband died within its walls, the good cmpress Helena.

The fame of the mother and the sire pales before the merits of the son, for to whom does the Christian church owe a decper debt of gratitude than to Constantine the Great? The statement that he was born in Eburacm rests upon no better anthority than the assertion of the English ambassador's at the councils of Basle and Constance in the beginning of the fifteenth

- "At ubi turbo persecutionis quievit, progressi in publicum fideles Clnisti qui se tempore discriminis silvis ac dosertis abditisve speluncis ocenlerant, renovant ecclesias ad solum usque de- structas, basilicas sanctorum marty'um fundant, "onstrunnt, perficiunt, ac veluti, victricia signa pasin jorolnant, dies festus celebrant, sacra munclo rorde atque ore conficinnt." Beda, i., 8. 
rentury ; but it was in Eburacum that some period of his early life must have been spent, and it was in Eburacum that he was silnterl as imperator. It that time he was not a Christian, but soon afterwards he deliberately adopted his father's faith. Enschins tells us that he was influeneed by the good example of his sire, and any Englishman may be proud to think that the faith of one of the great regenerators of the heathen world may have been strengthened, if not kindled, by the sight of the piety and fervour of the imperial household, and the Christian congrearations in Eburacum.

IVe should naturally expect that Constantine through his comncetion with our island would take some notice of its church, and, accordingly, we find that three British bishops, including one from the city of York, were present at the couneil of Arles in A.1. 314. The same episcopate was also represented at the councils of Nicea, Sardica, and Ariminium. And from the accomits that are preserved of the deliberations at these sacred meetings we may gather that the British bishops were thoroughly eatholic and orthodox. They were not afraid, also, of standing uy for the faith when it was imperilled by the machinations of hereties. Against the Arians they took so decided a part that they are mentioned with honour by Athanasius; and Hilary, writing from his place of banishment to the bishops of Germany and Britain, says of them, "Gratulatus sum in Domine incontaminatos ros et illiesos ab omni contagio detestandx heresios lerstitisse."

Tradition has handed down to us the names of several of the carly bishops of York, for, as Weever observes, "I finde a sucression of British archbishops long before the time of Paulinus." The evidence on this point is rery seanty and unsatisfactory, and there is no possibility of aecuiring any aceurate information.

A person of the name of Taminus is said to have been bislop of York in the begimning, alparently, of the seeond "rutury, and to lave suffered martyrdom. A elerical error is the origin of this statement. Taurinus was not "episcopus Eboracensis," but "Ebroicensis," i.e., of Evreux in France, with which place his name is still honourably comnected. He must be expmenged therefore from the Fasti of the English Chureh, as with fuller, we must be "conscientiously serupulous not to take or tonclis a thread which is none of our own."

Archbishop Lssher mentions an assertion made by a chronicle of lork in 1160 , to the effect that Fagan was the first bishop of liburam. Fagun is said to have been one of the Christian miscionaries who were sent from hone by Elentherius. If fagm really presided orer the chureh of lork, Lueius must 
have been king of the same eity, an honour which the metrical chronicle of Eburacum ascribes to him when it says,

\footnotetext{
"Sanctus Faganus, collega suts Damianus

Regem cum populo mundificant la vacro.

Templo mundato, consecrato, reparato, Metropolis sacra conditur ecelesia."
}

The temple which was thus purified is stated by the poct to be the shrine in which king Ebraue and his descendants had observed their pagan rites for twelve hundred years, and which, on the arrival of the Roman missionaries, had been given up to Christ. The whole statement is probably fabulous, and the assertion that Lucius appointed Theodosins to the see of York rests only upon the authority of Harrison's description of Britain which is prefixed to the well-known chronicle of Ifolinshed.

For the name of Eborius, who is stated to have been present at the council of Arles, in A.D. 314, as "cpiscopus de civitate Eboracensi, provincia Brittamia," there is somewhat stronger evidence. Arles was one of Constantine's councils, and we must remember that we may expeet to find British bishops associated with an emperor who was almost a Briton himself, and that of all those prelates he would, we should think, be most of all disposed to invite a bishop of Eburacum. The presence of Ehorius is mentioned in an ancient catalogne of those prescut of rery fair authority. The name is so eloscly akin to that of the city over which he presided that we eamot consider it to be the same that he usually bore. He had, in all probability, some uncouth British name which was ehanged by the Roman officcrs at the council for one more euphonious which bore a special reference to the eity which he represented; so that Eborius Episcopus may be considered to be the same as Eboracensis Episcopus. A grave doubt, however, is thrown upon the connection of Eborius with York, as in another list of those who were at Arles he is said to have presided over a different city in the province of Byzantium.

The next name that we find in connection with the sec of York is Sampson, or St. Sampson as he is gencrally called, and it scems probable that he was actually the bishop of that place. He is said to have lived in the fifth ecutury. The metrical chronicle of York asserts that Sampson was brought to Eburacum by king Aurelins, who rebuilt the ehmeh which the Angles had destroyed, and made Sampson its ruler. It is by no means easy to discern the track of real history among the mists of fable; but it is probable that before the saxous olutained full possession of Ehuracum they had phundered and injured the eity in some of their flying excursions, and that the British 
chieftains recovered it for a time, and restored what had been destroyed or chaned. The life of St. Sampson has been more than one written $i^{f}$ but the areoment that is given of the saint is by no means clear and satisfactory. We are told that he was a nittive of (ilamorumshire, and a student in the monastery of the colebrated lltutus. Here he made such progress that in eourse of tinc he hecame the president of the house, and as years parecil on, after varions changes, he was induced by king Aurelins, or Ambrose, to become bishop of Eburacum. It is not probable that he hold that office long. We are told that he was driven ont of the eity by the Pagans, and that he fled to St. David's and beeame the bishop of that see. But even here there was no rest for him. A dreadful plague that was ravaging Wales obliged him, much against his will, to cross the seas into Brittany, where he became arehlbishop of Dol. At that place Sampsoin died and was interred. This is the sum and substance of the accomints of St. Sampson. They abound, however, with conflicting statements into which there is no necessity to enter. It is probable that he was at York, and, singularly enough, there is a church in that eity dedieated to him; the only one, I believe, in England of which he is the patron.

'The old chronicles of York, relying upon the fabulous account of Geofficy of Monmonth and Wendover, mentions another bishop of the riame of Prramus or Pyramms. The legend about him rums as follows. The famons king Arthur, the last tower' of British strength, risited look one Christ-tide after the departure of st. Sampsom and his eleroy, and grieved at finding the holy places desolated and the ehmehes half consumed by the fires which the Pagan invaders had kindled, he ordered them to be restored, and made Pyramus, his chaplain, bishop of the city. Athongh the whole of this story is probably fabulons, we can we!l imagine what a struggle there would be in the North between the Britoms and the Saxons. The latter were heathens, and wond studionsly desecrate the holy places of their enemies, in many of which, for centuries, worship of some kind or other must have been pairl. The sacrilegions invasion of a timehomomed shrine would make the Briton solvow over the injury as decply as the paran lioman would bemoan the loss of the tutchary deitios of his homsehold. There are probably the germs of truth in the traditions that have been mentioned. They give us a vague and indistinct picture of eonfusion and change. lonk minst lare been lost and reeorered several times before

$f$ one life, by an anonymons anthor, lias been mublished by IIabillon in his Bendicline Acts. There is ansther in the Biblislleca Floriacensis. A third was written by Balderic, archbishop of Dol, in the twelfth century. I have thousht it unnecessary to go minutely into the subject. 
the Saxons won it, and we may be sure that as often as the Britons regained their lost position they would re-establish the religion which their enemies had despised. At last the torrent of invaders became so strong that it swept them out of York for ever. The last British bishop is said to have becn Tadiocus, and when he saw the hostile armies pouring in he joined Theonus, bishop of London, and fled for his life to $\mathrm{IV}^{\circ}$ ales.g After this time the names Wclsh and British arc irlentical. Thenceforward for a gloomy century there is deep night hanging over the North, and it lasted until Paulinus dispelled the darkness by rekindling the old light in the new kingdom of Northumbria.

Of the condition and extent of the British church it is impossible to speak with eertainty. Some are disposed to think that the absence of any carly memorials of Christianity is a token of its insignificance or nonentity. The argument, lowerer, proves too much. By the same course of reasoning you might shew that the neighbouring establishments in Gaul, and the seven Asiatic churches themselves, had no existence. Erery relic of the faith that illumined these in the earliest ages has disappeared, but who ean say that the sacred light had not once shone? The accordant testimony of the fathers chimes in with the narratives of our own chronielers and the voice of tradition, when they assert the zeal, the sufferings, and the picty of the old British church. It is painful and yet eheering to be obliged to trace the progress of Christianity by heresies and persccutions. Melancholy although they are, they can still purify and ennoble. Diocletian was, in one sense, as great a bencfactor to England as Constantine the Great. The British Church had its bishops, who were stalwart champions of the faith; it had its eonfessors and its martyrs. Chrysostom tells us that there were British versions of the Bible. We know that heretical teachers found their way to this island; their very presence shews that there was something to corrode. But what real and satisfactory progress conld any church make when change and violence were on every side of it? Its bishops could only be missionary bishops, and we know from the records of the eouncil of Ariminium that they had no regular endowment. Its clergy could only work ineffectively, if they worked at all, when their lives were cudangered by the inroads of foreign maranders and the petty warfare of the native chieftains. Organization would be impos-

8 The following passage is a fair sample of the metrical chronicle of York, from which it is taken.

"Turbatis rebus A rchipresul Tadiacus,

Ecclesiæ sedem deserit et patriam
Archipontificum Tadiacus sedis Eborum, Cltimus ex lBritomm gentibus ille fuit. Corporasanctorum, simul omnia vasa sacrorum, Cunctas res reliquas transtulit ille sacras. Expulsi liritomes nomen pat riamque reliuqunt, bisti Wallonses nomine bablorio." 
sible, and we cannot be surprised therefore at the existence of that detcrioration of morals and manners among the clergy which Gillas so strongly reprehends. Discipline alone could prevent this, and how was it to be enforced? Life was to be first protected and secured. As the wave of Pagan violence broke slowly over Britain, the ministers of Christ fled as it drew neall them; they rested not till they were behind a barrier which the water's could not penetrate or overthrow-the secluded valleys and the momtain fastuesses of Wales.

In Wales the trembling fugitives were secure: there was an asylum for them in that noble provinee which has so frequently becu the home of freedom and independence. The cradle of Christianity in Britain was destined to be its sanctuary. The (arliest glimmerings of the saered light illumined the country of St. 1)avid. 'The Asiatic merchan ${ }^{\star}$, who braved in his little bark the perils of the seas, found in that land the descendants of those Cimmerians who, restless like himself, had sought for a new home bencath another sun, and he would boast himself of the same lincage, and recognize a kinsman in the host that entertained him. Between the Welsh and the Asiatic churches there was a marked similarity, and time did not obliterate the resemblance but increased it. When Constantine had aseended the inperial throne, and after his decease, the news was brought out of the far East to Britain, how the pious Helena and her ilhustrions son had decorated the holy places in Palestine, and areeted shrine after shrine to commemorate Him whose divine presence lad consecrated that land, and from every comer of the West there were pilgrims setting forth to visit those hallowed abodes of which such great things were spoken. There were holy men in the East already, whose love and labours had added to its renown, if any supplement were necded. The sight of the pillar on which simeon had wateled and died was enough to tempt thi' deront Briton across the storm-swept seas. With what delight woukd he listen to the fervid cloquence of Chrysostom! With what reverence would he gaze on Jerome in his coll at lisethlehem! Every city and hamlet had its associations and its memories. Some hol presence that had cmobled it secmerl to linerer in it still. "There was another lesson, also, which the Brition pilgrims would learn dhring their sojourn in the East. All along their route they would observe the retreats fin pious and self-denying men that were springing up around them. Here was a carem in which some impassioned zealot was striving to obliterate, by solitary penance, the offences of the pist. If ere a band of derotees liad crowned some frowning procipios with their tabcruacle, where their only companions were the raven and seagull, croaking and screaming as they 
swooped through the clear bluc air above the foaming breakers. They could sec the fearless immates of these awe-inspiring slupines as they desecuded from their home among the elonds down the face of that insulated peak which raised them ont of the world beneath, and then their thoughts would pass away to their own wild fatherland, and they would long for such sanctuarics there which the spoiler could nerer reach, where the worldworn sinner could strive to forget the past, and the pions enthnsiast could muse in lowly pride mpon the perfections of Ilim who is the God of the hills as weil as of the valleys, and seenrely devise some great seheme of love and labour to culanee, if possible, His glory. They came home and erected in their own land the great monastery of Bangor, which was onee the residence of abore 2000 monks. There is no trace of it remaining now :

"Tantum avi longinqua valet mutare retustas."

Bht shortly before the Reformation you could mark the decaying walls looking down upon the "sacred Dee."

It was this great sanctuary that fed the streams of Christianity which watered Wales and Ireland. In the beginning of the seventh century it was divided into seven portions, each of them containing at least 300 monks who supported themselves by manual labour. In this and in other points there was a striking similarity between the British monks and those in the Thebais of Egypt and other parts of the East. The positions chosen for the monasteries and the habits of their inmates were identical. The learned Selden, no mean authority, speaks of the Alexandrine rule being introduced into Britain at a rery carly period, and Rudburn says that in the sceond century Fagan and Dervan filled the church of Winchester with monks professing the rule of St. Mark. William of Malmesbury asserts that the monastery of Glastonbury, the origin of which is encircled with Eastern traditions, was goremed after the Agyptian fashion. The Culdees of Iona always looked up to St. John as their founder. These, assuredly, are signs and tokens of a very early connection with the East.

Between Wales and Trcland, the British and the Scottish tribes, there would at all times be a direct commmnication. Ireland is said to have been converted by St. Patrick who was sent from Rome. It is most probable, howerer, that the Christian faith had reached that country before the tine of that saint, and Mabillon himself confesses that the peculiaritics of the British church, in spite of better teaching, were dominant in early times in Treland. My readers must not be led away by the ingenious and fallacious argmments of modern partizams, and imagine that these peculiarities involved any material diflerenee 
in doctrinc. 'There was nothing of the kind. In faith they were as fimly mited as they were in the great comneils in the fompth contury; the only discrepancies were in comparatively triviat points of discipline and form, and the persistence of the Britons and sicots was mainly nourished and kept up by their old foeling of national independence. It would be idle, however, to dem that between the Roman and the old Welsh, Irish, and suestish churehes there were many differences in form and discipline. St. Bernard, in his life of Malachy, bishop of Comnor, grives strong evidence on this point. The monasteries which he lescribes as existing in Ireland followed the same rule that was o) selred in Wales. The peculiarities which that rigid disciplinarian censured may be briefly enumerated. In the first plice, as a gencral lule, there serms to have been a secular and a marricd clerey resulting in the evils of worldly-mindedness; and, as at Almagl and St. Indrew's, in an hereditary sacerdotage, the greatest bane by which any church can be afflicted. Anotlicr, and a famons, point of difference was in the manner of observing Waster, to which alhusions will be subsequently made. In the mode of administering baptism, in the form of the tonsure, in the colebration of matrimony and episcopal ordination, ${ }^{h}$ there were also variations. The Seottish people, also, wave no tithes or firstfruits, and they negleeted or despised confession and the rite of confirmation. Several of these pecmliarities may be traced to other countries than our own, and there is no one point that has bcen alluded to which would make the Briton or the Scot either a heretic or a schismatic in the full sense of those terms.

The name generally ascribed to the early derotees in these islands was Colidei or Culdees, the origin of which is involved in some little obsemity. It is probably equivalent to Cultores Dei. By them Wales, Ireland, and Scotland, were in the earliest times, to a great extent, oversmead. In their observances and rubries they were guided ly the traditions of their spiritual forefuthers, and it was the fecling of ancestral and national pride that tompted them to despise the invitations to full conformity with the chuch catholic which were so frequently held out to them. 'To the Culdees the carly Christian memorials in Ireland ancl Scotland are, in all probabitity, to be ascribed. We owe to them that a lelicate interlacing work, itself of Eastem origin, by which the eallicst crosses and mameeripts are adomed. In working with their own hands they shewed to others the utility of labour; they became the patrons of industry and agriculture.

h The culdens have actually becon held forwate by molom siontish writers, as the originators of Presing- terianism! It is umnecessary to allude further to such absurd and infounded statements. 
In this manner they were the promoters of civilization as well as of religion. 'That the system of the Culdees was a popmlar one is shewn by the sneeess that attended it. Its professors were, socially, but little different from those around them. There was nothing in it that baflled imitation; it so nearly resembled Druidism that it seems to have supplanted it. it tanght the people uscful and necessary arts, whilst, at the same time, it raised their thonghts to higher and better things. It did its work. It was just the system to attract the attention and the sympathy of a rude and ignorant people; but something more decisive and more refined would be neeessary for the social and religious advancement of a more civilized nation. A body of seenlar elergy like the Culdees would have but little inflnence there.

It was in the middle of the sixth century after Christ's birth that the Culdee Columba passed over from Ireland to Iona, and planted there a little colony of holy men, which growing in influence and numbers, exercised in after years such a mighty influence over the kingdom of Northumbria. This was not the first visit that Christian missionaries had paid to Seotland. I shall say nothing of the journey of the abbot Regulus from Greece with a few of the relies of St. Andrew. We are told that some of those who eseaped firom the perseention of Diocletian fled for safety to Mona and Albania-the Isle of Man and the sonthern part of Seotland; and at the close of the same century, the fourth, Ninias or Ninian, as he is ealled, preached the Gospel in that district, and ereeted a chureh of stone, the first that had been seen in that country, at Candida Casa, or Whithern, in Galloway. Thus there were believers in Sentland, and thirty or forty years after this, Pope Celestiuns scut Palladius to be their first bishop. But it is to St. Columba and his followers that the eredit of evangelizing Scotland is to be especially aseribed; and the home that they selected for themselves, with the leave of king Connal, was the island of IIii or Icolmkill, better known in these days by its more modern name of Iona, or the Island of the Waves.

Close to the westem shores of Seotland lies that solitary island, hallowed still by the noblest assoeiations that any Christian sanctuary ean boast of. A thousand years have passed away since the Culdees were there, but their great leader and his followers are not yet forgotten. The ruins that yon see around you are the remmants of the shrine which a forcign order of monks erected, and not of that in which Colnmba prayed. But still at Iona you never think of the Cluniac but of the Culdee! You are treading upon holy ground. This is the eradle of the Christianity of the North; and bere, bencath 
your feet, are the sea-kings stepping! Rob it of its assoeiations, and there is nothing to attract you to that island. It could be no selfish motive that drew Columba over the stormswept ehannel to a place like that. A nobler impulse led him there than the quest of pleasure or the promptings of waywardness or caprice. It wats the love of God that guided the bark of that apostolic brotherlood to their sanctuary in the sea. "The memolies of the happy past, the thoughts of others who were loving and praying for them in the home that they had deserted, could not wean them from their high resolve. The winds might howl around the frail tabcrnacle that they had set up, the spray might drench them through and through, but they remembered that they had devoted themselves to Him "whose way is in the sea," and they cared not for the tempest or the waves. Here they conld pass away in peace, withont a drear of that dissolution for which they had made a lifelong preparation! Here they could train themselves in deep seclusion for a higher reach in holiness, or meditate upon new victolics orer the unculightened hearts that were beating with no love for them upon the adjacent continent! If the Pagan held ont to them a friendly hand, they could reach him in a few minutes in their little boat. If that hand were threatening destruction, the timid evangelists could fice again to their old lome across the protecting water.

Jow peaceful and how happy must have been the life of that deroted brotherhood in their sanctuary at Iona! Every day had its raried oceupations, and in each there was a charm. Without, there were their nets and boats, for the sea was their meatow and their tillage. Within, there were the voices of supplication and praise, rising hearenwards even in the watches of the night-the sacred page rich with some divine story-the class room with the little knot of pupils to listen and to learn. Brighter and brighter shone the holy flame that was kindled at Iona, and to distant shores was its radiance diffused. There wcre not wanting intrepid evangelists to earry it with them among the rock-bound Hebrides; they were not afraid of encomtcring even the iceberes of the Baltie and the seas that rolled around the shores of Iecland. A halo of sanctity hung around Columba and his isle. The abbats who succeeded him were the greatest ceclesiastics in the North.

Whilst the lamp of truth was thus burning in the North, as well as in Ireland and in Wales, there was thiek darkness hanging orer Northumbria and the other provinces of England. The Saxons did not eren tolerate Christianity, and its professors flol in terror as they drew near. It was to convert them that the pions Gregory sent forth Augustine, enconraged by the fair 
youthful faces of some natires of Deira or Yorkshire that he saw in the slave-market at Rome. The history of that mission and its success need not be dwelt upon here. A few years after the arrival of Augustine, Gregory addressed to him a letter in which he recommended him to make Jork a metropolitan see, with twelve suffragans under it. This is quite enough to shew the importance of that city more than twelve centuries ago. As a personal compliment to Angustine he was to have control over the new see and its prelates during his life; but his successors were to inherit no snch anthority, and the question of precedence was to be determined by priority of elcetion. And to shew that the new episcopate was to be invested with the power of a metropolitan, it was to receive a pall fiom Rome without which no one could have suffragans under him.

Some time elapsed before any opportmity oceurred of attempting to carry this scheme into effect, as Northumbria was dark with pagan idolatry, which the Culdees of Iona, strange to say, seem not to have endeavoured to remove. The cuterprize was undertaken in the begiming of the seventh century by the missionary Paulinus, who was made the first primate of Northumbria. Of his labours and their fruits I have elsewhere giren an account. But the question may be asked, and it is a rery interesting one, how is the great success of Paulinus to be accounted for? Even under the teaching of an apostle, converts did not rush into the arms of the chureh by tens of thousands. It may be said, and plausibly too, that the people did but follow the example of their monareh; but it is observable in the conversion of king Edwin and Coifi, the high priest, that they were guided to a great extent by the popularis aura. Why, let me ask, should the people be favourably disposed towards Christianity? I can scarcely belicre that an intolerant rule, ereu though it lasted for eighty year's, conld have obliterated every trace of a religion which seems to have had a strong hold on the North before the Saxons reached it. Wilfrid, at a later day, strove to recover as many of the holy plaees of the Britons as he could trace, and if there were traditions then, would they not be much stronger when Panlinus was at his work? Christianity had been the religion, it may be eonecived, of the defeated party, and would it be forgotten by the remnant? It is a most curious circumstance also that the Pseudo-Nennius ascribes the conversion of Edwin and his subjects, not to Paulinus, but to Rum the son of Urien. Urien was a well-known British chicftain who had struggled long and stoutly against the Saxom usurpation. Can his son, after his father's fall, have gone to Rome and become a priest, assuming on that occasion the Latin name of Paulinus, by which we know him? What person 
nore likely to be sent by Gregory from Rome to the comntry of his birth? What person more likely to be ordered by Honorius into the North to erangelize a people that had suffered and bled with his sire?: If these suppositions are correct the suecess of Paulims is a matter of no surprise. His eareer, however, as a missionary was a short one, for it ended with the leath of Edwin in 6:33. The land was searcely ready for the seed when the sower was taken away.

With what euriosity must the Culdees in the North have watched the progress and the fortunes of Paulinus! The novelty of the enterprize and the zcal of the missionary eould not fail to interest them. There is no record of any meeting, or of any intcreourse between them. The interriew between Augustine and the Welsh Christians had been anrthing but satisfactory. The Britons regarder the Saxons with the bitterest animosity. Charity was forgotten in the memory of national wrongs. Before there eould be any cordiality there were many injuries to be wiped ont. Even after their eonversion, Beda boldly says that the Britons set the Saxons at nonght, and treated them like Pagans. It is sad to think that Cadwalla, the Cumbrian prince, who drove Paulinus out of his diocese and slew Edwin, was a C'hristian in name. The Irish prelate, Dagan, refused to eat bread or to eome under the same roof with arehbishop Laurence, and we ean casily imagine that a little of the same feeling would aetuate the Culdees of Iona, when, whilst they were artive in erery other direction, they made no attempt to convert the Saxons in Northumbria. A more farourable opportunity for misionary exertion was soon offered to them, and under difierent ancpiees. The rear after Paulinus left the North, Oswald atcended the Northimbrian throne, and he had been eonrerted to Christianity whilst he souglit protection aeross the 'T'weed. Aceordingly, when lie beeame king, he longed to proparate his recently acquired creed, and he sought for that purprese the assistance, not of Panlinus, who was in Kent, but of the culdees from lona. A missionary of the name of Corman was the first person who was sent into Bernieia, but he could make no progress with the rude inhabitants of the distriet, and he returned to Iona to give a pitcous aceomnt of his mission, and to discourage the efforts of any future erangelist. He 'cemed to be quite maware that the fault had been in himself rather than in the natives, and that a little more taet and patience might have effected a conversion which he now considered to be impossible. Another inmate of the same monastery, of the name of Aidan, was listening whilst Corman told to his

' This has been pointed out for the first time by Mr. Hodgson Hinde. 
brethren the story of his own failure, and he eriticized the method and the plan that Corman had adopted with so much wisdom and judgment, that he was himself prevailed upon to take up the holy cause that had been abandomed, and to go forth as a missionary into Northumbria.

The place on which, with the king's permision, lie set up his tabernacle was a characteristic one. It still bears the name which the piety of its inmates won for it, the Holy Isle. liock and sea and sky there were on all sides, enhanced by that dlead charm of solitude whieh captivates the saint. As the crangelist looked towards the south he could see before him king Ida's towrer, the Joyeuse Garde of story, crowning the grey cliff' of Bambrough, in which his patron was residing, and near them across the angry waters of the frith were the bleak rocks of Farne, which St. Cuthbert has immortalized. Reared he harl been himself on another island amid the western seas, and now, mindful of his old home, he chose for his abode in the strange land that he was to convert, a scene that would daily remind him of a place with which he harl been long familiar, yea, another Salamis in the bosom of the deep, that was to be consecrated for ever by grander and holier memories than any earthly victory ean evoke. Twice a day did a belt of living water encircle that little sanctuary; and when it was ungirt, there were the quicksand and the shoal, the scream of the seagull and the curlew. Here there was a safe retreat; for what spoiler could venture to approach? Here there was that solitude without which no great work for God can be conceived or matured. And in the evening, when the sea mists were away, the devoted bishop could see in the distance the lights in king Oswald's castle, and pray that they might long be fellow-workers in the path of Christian duty. Thankful he might indeed be for such patrons as Oswald and his brother Oswin, and his spiritual children inherited the gratitude of their sire. When the news was bronght to Bambrough of that disastrous field in which Oswin had been slain, the saintly Aidan laid himself down to die, and expired with his head resting upon one of the buttresses of that little church of wood in whieh they had worshipped God together, and when the monks of Durham enshrined in after ycars the body of St. Cuthbert, they placed reverently upon his breast, as one of their most precions treasures, the mutilated hear of Oswald.

On the career of Aidan in Northumbria, Becla, who had no partiality for the Scottish school, is eloquently minute. The life of the brethren at Iona was imitated at Lindisfarne. Humble, patient, intrepid, Aidan was the rery man to win his way with such a monarch and such a people." II is whole time nits 
yirm up to his great work, instruction, prayer, and preaching. Two cutire lays in each weck did he pass in abstinence and penance. Ile visited his diocese on foot, and all his worldy substure was sulpendeled to the poor. How pleasing it must have luen to see him culcaromping to explain to the rustics, as well as af forrinel comld, the promises and the claims of Christianity, muromtlily it may be, but still with words and gestures that -howed the calnestness of the speaker, whilst, whenever there Was any obscurity in what he said, the good king Oswald, who was a listencr also, was the interpreter and explainer.

"Tis a picture for remembrance."

It was not forgotten by the Northmbrians who gazed on it. The simple piety of Aidan, his love and labours, were copied implicitly by his sucessors in his sce and the holy brotherhood that obryed them. They acted like a spell upon the warm and minmejudiced hearts of the people of the North.

'The influcnee that these men exereised in Northumbria was rerreat indece. For thirty ycars they were paramount within that rast district. The large tracts of land that were given to Iidan and his successurs by the kings stood in need of cultivatim, the monasteries that they crected required inmates, and, therefore, at the instigation of the bishops of Linclisfarne, the Seottish Cullecs cane pouring daily into Northumbria, preaching and teaching, building churches and occupying religious lumses. They penctrated, also, into the southern provinces of Britain. We can traes them in leeland and in the Baltic. We find them in Fance and on the Rhine, at Cologne, Würsburgh, liatishom and Viemma. Those who assert that the Culdees were deyisers of miscionary exertion are egregionsly misinformed.

With the churehes and ministers of the Culdees there spread at the sance time their diseipline and ritnal, which after the aldrut of Angustine were suljected to much hostile eriticism. 'The Inalian monks conld not but dislike those differences in form which separated the natise clergy from themselves. All attrmpts to bling abont an amicable arrangement were unsuccesful. In ram did Angustine and his snccessors speak of the rast bencfits that would result from unity, how undesirable it was that the eommon voice of Christendiom should be set at molit by a little party in an obscure island, but they spoke to draf' "ars. Dislike of the Saxoms, with whom the foreign missionarios were alliod, embittered the opposition of the Culdees; thry chung to theis permliarities with an obstinacy worthy of a better eaure. The bitterest controverses in religion are generated by little things.

As the influence of the Italian missionaries increased, a 
collision between the two religious partics became maroidable. Finan, the successor of Aidan, had a sharp dispute with a Northumbrian of the name of Ronan, who denounced the views of his superior in no measured terms. Soon after this an erent occurred which brought prominently before the people of the North the necessity of mion or compromise. Oswy, the Northumbrian monarch, took for his wife a prineess who observed the Roman mode of keeping Easter. Thus, in point of fact, the festival was observed twiee in one year in the same court; whilst the king was celebrating the feast with merriment and joy, the queen was still busy with the fasts and the prayers of Lent. Taking new courage at this obvious inconsistency, and aided by the active co-operation of prinee Alefrid and the queen, the Italian party prepared to strike a heary blow at the system that thwarted them. Oswy summoned a great council at Streonshal at which the question was to be decided. 'Tho result of that meeting is well known. It ended in the trimph of the Roman party, which was completed by a hasty and inconsiderate step which bishop Colman then took; he gathered his Culdees together, and found a refuge eventually in Ireland. Some attempts were subsequently marle to recover for them their lost position, and they were temporarily sucessful. When Wilfrid, at Alcfrid's request, had aceepted the bishopric of Deira, and had crossed the seas to receive there the rite of consecration, Oswy, disliking that step, advanced Charld to the see of York. The racancy had been made by the decease of Tuda, who had succeeded Colman. After a brief tenure of office, Chadd roluntarily resigned it, and thenceforward no $\mathrm{Cnl}$ dee was ever the president of the see of York. All the intellect and the energy of the North were, for the future, on the side of Rome. Wilfrid, Benedict Biscop, and Cuthbert, introduced the Benedictine a'ule, or some modification of it, which scems to have worked efficiently for a time. Theodore and Egbert refused to recomize the ordination of the Scottish or British prelates without some proper confirmation of it. Eghert wrote, for the benefit of his clergy, several works on discipline and ceremonials. Eambald probably introdneed into his diocese the Roman service books. In spite of all this oroanized and continuous opposition, the system of the Culdees was for a very long time not entirely obliterated in Northumbria. The bretluren in the monastery at lork retained the name of Colidici, or Culdees, until the time of Henry I. The spiritual descendants of the old Scottish monks flourished for a long while after this beyond the Tweed, in spite of the war that was being constantly waged against them by the regular orders. The archbishops of York could do but little against then there, athough on one 
occasion Thurstan was bold enough to send the prior of Nostell to be bishop of St. Andrew's. He wished, no doubt, to obliterate all traces of the Culdces, but the destroyer found himself in a nest of hornets.

The ancient title of the prelates, upon whose biography I shall soon enter, was merely that of bishop of York, an appellation borne by all the presillents of that see between Paulinus and Eghert. The possession of the pall gave them the power of having suffragans moler them, and they were then called archbishops of the Northumbrians. The two titles were subsequently combined. The right of electing the prelate seems to have rested, according to Alcuin, in the brethren of the monastery of York; and that distinguished scholar congratulates them upon the possession of that right, and the honest and excellent use that they had made of it up to his time. In the eleventh century the canous rejected Egelric of Peterborough, who had been nominated to the see. The Northumbrian monarch seems to have had the power of approval, and, on one occasion at least, there was a popular element in the election. It is curious also to observe that Wilfrid II. and Eanbald I. were marked out for the primacy by their predecessors, to whom they seem to have acted for some time as coadjutors. This step was in all probability taken with the consent of the brethren of the house. For sereral generations the archbishops were school-masters, having been exalted to the see from the class-rooms in the monastery: after the Conquest, when the power of the state became paramount, they were generally the chaplains of the king.

Many of the Saxon primates of York were courtiers and statesmen, and their biography is intimately connected not only with the amnals of the church, but with the history of England. Paulinus was a royal chaplain, and left the North in the same suite to which he was first attached. The great Wilfrid basked in the smiles of a court before he suffered from its scorn, and luring his whole life he was the farourite or the foot-ball of kings. Eghert was son and brother to a monarch of Northumbria. Wulstan was an intrigning politician, and played, with varying success, a very conspicuous part in the perils of his time. Oswald shared with Dunstan the responsibility of adrising Edgar, and pushing the scheme of ecclesiastical reform. Adulph was chancellor to the same prince, and Alfric was either the prompter of some of the wicked deeds of Hardicanute or his tool. Aldred, with the exception of earl Godwin, was probably the greatest man in England in his day, and his influence with Edward the Confessor camot be exaggerated. He steered the Saxom ehurch successfully throngh the perils of the Norman 
conquest, and it was only after his decease that William conld obtain his full ends. The archbishops of York held a rery high position among the great men of England. They had a diocese extending from the gates of Lincoh far into the Nortlı, and to which another see in the South was temporarily united. They had a mint and other privileges of their own. 'Tliey were the lords of many a broad acre, and moved about with an almost royal retinue. The number of regal grants which they witnessed shews how frequently they were in the presence of the sovereign.

It must not however be imagined that, although they were thus occasionally oceupied, the northern prelates were oblivious of the high calling to which they were especially devoted. It was a duty as well as a necessity for them to conciliate the favour of the great, but public offices and employments did not interfere with the urgent claims of the flock, or the studies and devotions of the shepherd. The lives of the northern bishops present to us many a noble trait of piety and zeal. The missionary work of Paulinus and Wilfrid is not yet forgotten. We remember the patience and loyalty of the one, and the selfsacrificing toil of the other. W'e can see the humble-minded Aidan, unkind to no one but himself, descrting the table of the monarch, and hastening to the crowd that was waiting for the good news from God. Chadd is before us, wandcring through his diocese on foot, or prostrating himself in lowliest obeisance amid the roaring of the thunder. We hear St. John observing, "It is more suitable for" a bishop to be at his monastery, in attendance upon the poor, than revelling at the tables of the wealthy !" How noble were the fruits of the labour's of the scholar-prelates, Egbert and his three successors: the first, a prince in birth and energy, toiling with his pen as well as with his lips, and all glorious advancers of the cause of Christian education! A sacred light still encircles the memory of Oswald. In the holy time of Lent, Kinsius went from village to village, preaching and bestowing alms, very frequently with bared fcet. But in the midst of all this active employment hours were still found for solitary devotions and solitary penance. Of all the characteristics of our early Christian prelates this is perhaps the most remarkable. Each of them seems to have had an oratory, or some sechuded spot, the predecessor of the private chapels of our bishops, to which he could resort.

"Wisdom's self

Oft seeks to sweet retired solitude."

Aiclan devoted two days in each week to solitary prayer. Cuthbert ended his life upon that barren iskand which he had been so muvilling to desert. Chadd was in his oratory when the hea- 
moly meseneres arived to tell him that he was soon to leave it. Hohn, who in his earlier years had been a hermit on the 'lync, wase up lis bishopric at lork to wateh for his end at Borelcy, and two of his snecessors, Wilfuid and Albert, following lis example, devoted the latter portion of their lives to se"lusiom and prayer. In a later age, when the light of holiness was less bright, there were to be found some good men who in their solitary alevotions had not forgotten the practice of Christian antipuity. Arehbishop Sharpe is said to have walked very firepurntly from Bishopthorpe to Acaster Malbis in the early morning, and to have knelt down and said his prayers to God in the poreh of that little ehureh. In the grounds of his own palace at Bishopthorpe he eaused a labyrinth, as he ealled it, to be constructed, and that was his oratory. 'Thither would he resort many times a day. The book was elosed, the friends were left behind, the cabinct of coins was locked, and the derout prelate sought the privacy of his cell, to banish the eares of cantl and to meditate upon heaven.

The most infhential of all the means by whieh the North of Enoland was crangelized was lindonbtedly the establishment of monasterics, $j$ and the arehbishop of Tork could wicld no more rillective wayon for the orepthrow of paganism and vice. People in these days are too apt to depreciate the debt of gratitude which we owe to the early monks. The best interests of ehureh and state were by them nurtured and advaneed. The pions derotec eonld in the monastery pray and meditate; the selolar rould think and learn; the world-worn pilgrim eould at length repose. Two monarehs of Northumbria, Coenwulf and Eadbert, crided their days in a convent. Within those walls there was a smotuary from the world and the rengeance of the pursuer. The rescied fugitive wonld there gaze upon a seene as faseinating as it was new. He would witness the devotions of the inmates in their never-pansing but never-wearying round. He would see the labours of the school-room, shared in by the children of the ncighbouring nobles and the instruetors of anothereseneration. I Ie would visit the library and the seriptorium, and olscreve the are with which cach precious tome was treastured mpand copicd; and how masic, architceture, painting, and colimplipy had their initators and admirces. If there had been no momasteries we should have had no books, and we should have lost the Latin language, the noblest legacy that antiquity lias bequeathed to us. And if we rearard monasticism in its cflerts mom the onter world, we shall soon see how it softened and cumbled it. I pass by the humanizing intuenee of a life

; It is my intention to enter at greator ledr:th into this subjert in the intro- durtion to the lives of the Deans of lork. 
devoted to worship and literary pursuits, and turn to other points in which the monks advanced, if they did not orieninate, the cause of civilization. When they were not engaged in the services of the chureh or cloister they were generally husy with some manual employment. There was a saying among the Egyptian derotees that a labouring mouk was only tempted by one devil, and in the English monasteries there were nome to depreciate the usefulness of labour. 'The inmates were remularly trained to it, and even the bishops were obliged to be acquainted with some handieraft. And what they professed and puactised themselves they tanght to others. One of the reasons for the selection of the descrt or the wild-wood as the site of the earliest retreats was undoubtedly the desire to bring the country into cultivation. The founder usually endowed the house with a portion of land sufficient to maintain a certain number of families. Upon it the monks were regularly employed. They tilled and sowed it with their own hands, reclaiming the moor from the heather, and clearing away the wook and water. 'They ehased and killed the wolves, which were then abundant. 'They hunted and snared their own game, they canght their own fish. Before Wilfrid arrived in Sussex, the inhabitants were ignorant of the gentle art. They won their own hay, and reaped and gromul their own coln. Agriculture was thus advanced and commerec followed in its wake. 'The progress of the carly civilization of the North is coincident with the growth and influcnee of the monasteries. How many of these retreats there were in Nortlumbria prior to the Danish invasion it is scarcely possible to say. Mr. Hodgson Hinde makes out a list of twenty-one. The rery site of some of them is forgotten. They were orerthrown by the savage men whom they tried in vain to soften. 'The situations which the earlicst houses of religion occupied are a sufficient index of the perils of the times. Many of them were on the banks of some stream on which the inmates could lannch their little barges and escape from the invader, or in some patlless desert that no stranger could approach. Wren in the days of Henry VIII. the royal commissioners were unable to discover the abbey of Blanchland, in the county of Durliam, till they were recalled to the scarch which they had given up by the tones of the convent-bell which the monks were ringing, too prematurely, for joy at their escape! 'The sea was the defence of such wild and lonely retreats as Lindisfime, 'Yynemonth, Hartlepool and Whitby. It was in a later age, when peace and law were at last paramonit, that the ecelesiastical orders were able, in the sites and construction of their aborles, to blend together in one sweet union the beanty of nature and of art. 'Then it was that they deserted the sea-beaten clill and the little strip 
of green turf among the moors for a fairer resting-place, the charmingly sepuestered valleys and the wood-embosomed haughs which are washed by the Coquet and the Wharfe, the Swale and the Rie.

It is difficult to say at what time the earliest churches in the North of England were erected. Wilfrid, in his oration at the dedication of Ripon minster, speaks of the holy places which the British Christians had deserted, and that he succeeded in his attempts to recorel some of them seems to be partly evident from the filct, that under the walls of one or two Saxon churehes in the North Rilling of lorkshire, hnman remains, belonging to a very carly period, have been disinterred. The ehurch of Whithern in Calloway, a building of stone, is said to have been crected by Ninian in the sixth century. Alcuin, whilst speaking of king Edwin, tells us that he began the minster of York.

"Eeclesiasque suis fundarit in urbibus amplas."

The first temple between the Tees and Tweed was that at Lindisfarne, and to the energy of Aidan and his successors is due the crection of most of the carly churches in Bernicia. Their dedications are rery suggestive. Several of the houses of God in Cumberland and Westmerland shew the names of Irish and Scottish saints, which were brought into the country by their founders. Brancepeth, in the county of Durham, owes its name not to an idle legend, but to St. Brendan, to whom the church is dedieated. St. Columba presides orer Warcop and Topeliffe. At Whitlsy, the aneient Streonshal, St. Ninian had once a shrine. The name of Patrington in Holdemess is derired, not, as Mr. Kemble suggests, from the Patringas, but from the patron sint of Ireland who presides over the church; whilst the neighhouring shrine of IInestear, as well as the abbey of Selby, the creation of a later age, are dedieated to St. Patrick's friend, Cremanus, the sainted bishop of Auxerre. All these names seem to point to a rery early Christianizing of the country, in all probability by the Culdees. The churches themselves were of the rudest possible deseription. They were made of planks of wood, and were thatched with reeds or turf. Stone, if attainable, seems to have been very rarely used. The perils of the times were a bar to anything like expense or ornament. It is 'ulious also to observe how many of the early ehurches are on the margin of some stream. Onc great reason for this propinquity was that which induced St. John to take up his abode upon the banks of the Jordan. When the word had been delivered and received, the meacher and his audience went into the water, and the convert was there admitted a member of that church to which he was eager to belong. As the popula- 
tion migrated or some enemy approached, the little church of wood could easily be deserted or removed, and the minister could retire to some monastery or fastness. His usual abod(", in the earliest times, was within the walls of some convent, where he was under the eye of the superior, and subject to the control of the bishop, and he left it at their bidding to risit his flock in the wilderness, and to officiate in his little feld-kirk. In course of time, as peace and order became more firmly established, parochial arrangements began to be made, and the country was gradually divided into properly-endowed ecelesiastical distriets. The present state of the ehureh in sereral of the English colonies will throw some light upon their progress and formation. In New Zealand and Australia one clergyman has frequently a tract of land thirty or fifty miles in eircumference under his charge. So it must have been in Saxon England. Those large parishes which are gradually disappearing from Laneashire and Yorkshire owe their size originally to a scanty population and a paueity of teachers.

In many other ways, also, did the Saxon primates of Northumbria endeavour to advanee the spiritual welfare of their charge. The school, the teacher, and the chureh were not allowed to languish for want of eneouragement and support. Proper endowments for them all were gradually made by the wealthy and devout, in addition to the regular contributions of the faithful. The aiding of the ministry, the maintenance of the fabrie and services, and the feeding of the poor, were the objects for whieh these offerings were made. Over their appropriation and use the archbishop exereised a salutary supervision. Any defect in discipline or ritual was remedied by his own independent authority, or by the ageney of a couneil. Synods also were oecasionally convoked. The personal character of many of the archbishops added strength and poteney to their official acts. They were men of piety and learning, of splendid tastes, and courtly influence. Their mumificent gifts to the monasteries must have been eopied and admired. The commons would gaze with wonder and yet pleasure upon the introduction of new arts and treasures, at the glazing, seulpture, painting, and embroidery which they saw before them. The train of masons and artizans by which Wilfrid was aceompanied would surely have some good fruits. The Italian music that James and Benediet introduced was not formotten. The sight of such temples as Hexham and Ripon, Bererley and York, conld not fail to produce a marrellous effect and derotion: eivilization and taste wonld necessarily be fostered by it. Each familiar shrine would evole the memory of some onee potent name. A holy influence seemed to linger around it still. 
Bontuty there was there, and between the ereative and the sympatheric mind there is a strong bond of union. Great men long since gence down into siloner, who had been reverenced by

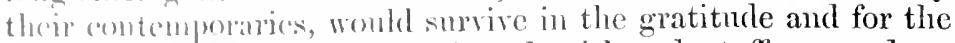
"lal of posterity. The aged and withered staff seemed to hlosem and bear froit again.

In prite of all this attention and actirity on the part of the Northern primates, it is impossible to say that the ehureh made any marked and efficiont progress in Northumbria prior to the C'omgucst. 'Their labours were practieally as fruitless as those of the Manaides. I car scarcely think that the eause of these shortemines is to be ascribed to the listlessness or opposition of the propile. 'There must have been among them many Pagan usages and traditions such as were reprobated in the time of Eimbala, but the presence of those relies of heathenism did not mar the progress of the chmch in other districts where they were cynally pifs. I thoughtful mind will deteet several more prohable reasons for the fallue. One is, without doubt, the size of the district which the arehbishops professed to moderate. Gresury's recommendation about the appointment of twelve suffrasalls had nerer been sarried out, and the primate, therefore, had a dinerse which the intellect and the energies of the strongest man were unable to direct. Good work indeed was begun, but there wre mome to foster and encourage it. Monasteries sprung: up in which, as Beda says, worldliness and viee dressed themsctres in the garb of religion. The archbishop, with his many arocations and his frequent presence at the eourt, was unable to check this. 'There were many parts of his diocese which he comld rancly, if crer', risit. Ilow could any newly-introdueed fith advanee when there was such a want of supervision and direstions: This state of things would not be improved by the fout which was loner maintained between the Culdees and their ruigins opponcuts. Wilfrid and his party carried the day, and introdued a stricter rule, but his subsequent misfortunes imperded it: murture and its growth. He pulled down the honse of his memies, lut contd erect little in its room. One system nentralized the other. Christianity, if it is to prosper, cimmot bong dwoll in tabernactes in the wilderness. It must lave fised places, discipline, and rulers. All these were more or les wanting in Northumbria. The chureh, therefore, kept Warcring to and firo like a storm-tossed ship. Practices crept in which ('atholicity rejected, and there were none to eheck them. It the time of the Conquest the canons of Durham, with the example of St. Cuthbert before them, retained but one print of the bencelictinc rule which they once observed. They sally the homs in a peculiar mamner. At Hexham, Whalley, 


\section{OLD LFFDS CHANTRIFS}

R. V. T. sends the following additional information pecting the above, in reply to "B. D." (see Nos. $(76-7):-$

Che chantry at Beeston was founded by Will. de ferton, 19th May, 1256. It is stated that a great contion took place between William de Beeston and Holy inity, York, concerning this chapel, in 1258 (42 Hen. [.).-See Harl. MSS., 797, fo. 8, Brit. Mus.. \&c.

If the chantry at Farnley, no foundation is shown in Henry VIYI. Imrd Mounteagle was the patron." witl cm the incumbont, (Yabriel Croft, rcmaineth, and weth the same, by 'Thos. Gibson, his deputy." 'Tho ome was deriver, from lands in Holbeck, \&e.

$r$ St. Mary-on-the-Bridge little is known. except that "tood "super pontem de Leedes." A similar chapel $y$ still be seen at Wakefield, \&c. Thoreshy states that his time there was a school at Leeds Bridge on its

it. Helen's, Holbeck, mentioned in Pope Alexander's firmation of Palph Paganell's grant to the Convent Holy Trinity, Y ork, was not the only chantry in that inship. There was St. Helen's Chapel, to the site of ch access was gained by St. Helen's bridge. aresby believed that the medicinal well at that place ; one of those which in different parts of the country dedicated to St. Helen, and that the chapel had been It in consequence.

is to the chantries of our Iady, that in which the wn was placed was founded by the parishjoners, July $\mathrm{h}, 1500$. The bandlets on the crown are not found ore the time of Henry VII. Robert Fell was the est at this altar, 27th Henry VIII. The other ntry is supposed to have been situated at the cast I of the aisle immediately north from the high choir, was founded by the parishioners at the same time, 1 John Mathew was its priest. The measurements the chantries were 20ft. by 20ft. and $17 \mathrm{ft}$. by $20 \mathrm{it}$. pectively. With respect to the former, see Harleian \$., 802, Brit. Mus.. \&e.

iegarding tlie chantry-donative in the chapel of $\mathrm{Hol}$ $k$, no foundation is shown in 27 th Henry VIII., but in Dyneley was the incumbent, and " useth daily to Mass therein," and is taken from a stipendiary priest, ing oo tithes, and receiving a yearly rent of $£ 4$, d by Sir Arthur Darcy, out of the lands of Holy nitv. York-Adam Alan, chaplain of Holbeck; will Je 9th November, 1434, proved 10th March, 1434-5, at rk. To be buried in church at Leeds. Sir Thos. liell. of Holbeck. priest; will made 233rd January, , proved 14th April, 1535, at Xork.

\section{YORKSHIRE WORTHIES.}

R. V. T." continues his Yorkshire sketches and arkable incidents (resumed in 1.139):ARCHBISHOP LONGLEY.

ongley Right Rev. Charles Thomas. J).D., Bishop of on, and eighty-fifth Archbishop of York, was born Iuly, 1790 , being the fifth son of .John Iongley. time Recorder of Rochester. He was educated at iminaters shol apd Chrigt Church Oxfords viere

lotage obtained. ('onfesreded. Many of the elerey followerl theil (xamplis. astical reform. And ('vill i smaller, and less suljoert d state of public aflairs provement. Ithat romlel watust clicef, and lace il and more gentle airs. le, and Nomman cansed Can we wonder, then, he, and its influmene so $n$ the spiritual provinee ow so carnestly. Mally ;h he was, weles spent in fld robled Nonthumbria recked the usefulness of id Aldred are too well mollimful to tum fiom o the sufferings of their sword. The Danes dejorthumbria. The wanare full of thrilling and with the body of their and poct. A talisman it $3 y$ bore aloug with them. ireli depended upon their hace ras loug denied to beyond the scas. They nd green glades of Yorkof trial that they fommd ed crag which they have English Sion. "A fair t binding charm attaches we within thy walls, oh my till loving eliild, bids thece

rians had in the carlicst thumbria, cxtending from de, and from the Humber to the Frith of Forth on the other. The power of the prolates kept pace with the growth or curtailing of the kingelom, although they oceasionally asserted and maintained a still widel spiritual empine. These clams, as will be seen hereafter, were frequently the causc of much controversy and bitterness.

It was the wish of Gegory that Emgland should be divided 
teams in the Iancashire Smior Competstion-swnto Widnes, Wigan. Stockpnrt, St. Ielen's, Altriucham, Jamow, Radeliffe, Millom. Birkenhead, Rochdne I Inncts I anraster, and Morecambe-they will do much letter than they would have done had they remaine. in the Yorkhire Senicr Competition. They are no without hopeg of winning the competition, and being plarerl in the Ireague in the exason of 1802.

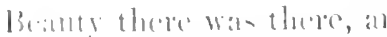

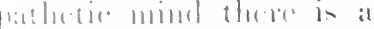

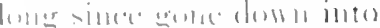

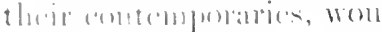

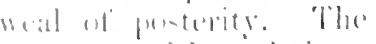

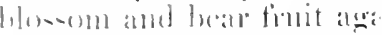
In sples of all this atte Dentluen primbers, it is int

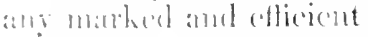

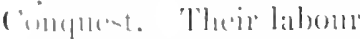

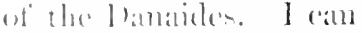
Inorenomines is to be ase

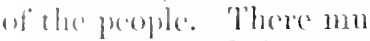
nsiluce and tratitions su latulnalel, hut tho poxeme mail the promess of the cl

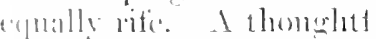
hatble ratsoms for the fail

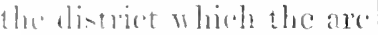
wory rerommendation al

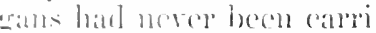
a dionese which the intell mants wein anals to direct there were'mome to funter: lup in wlich, ar Boclat say sho in the wath of relie atroutions and his fircourel (-heck 1his. There were

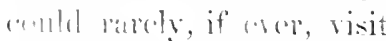
linth arliande whom there lijeretion, 'Plibs state of firlul allich was losug main

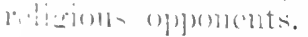

$11 \mathrm{i}$

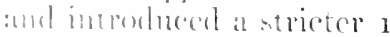
impureled its molture and

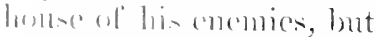

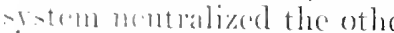

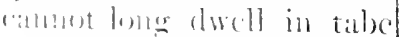
hate fisel phaters, discipline

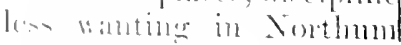

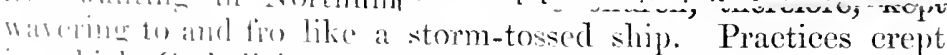
in which ('atholinity rejected, and there were none to check 1hren. It the time of the ('omquest the canons of Dumam,

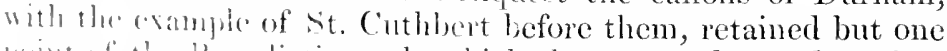

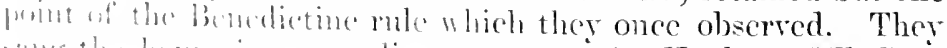

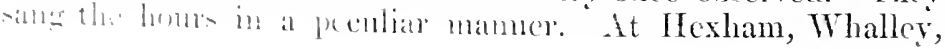

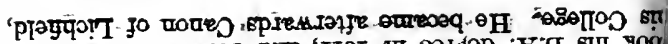

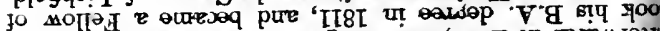

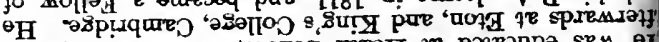
purs "xej!c

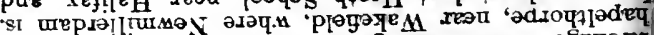

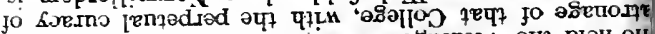

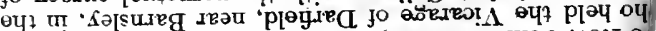

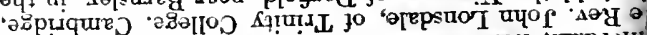

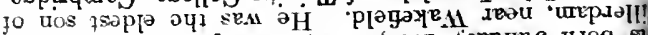

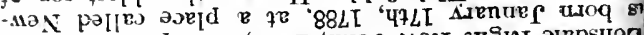

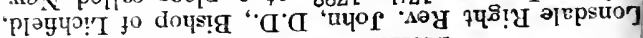
'ITASNOT dOHSIG

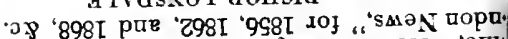

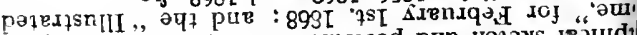

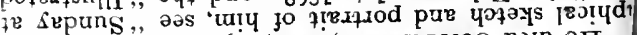

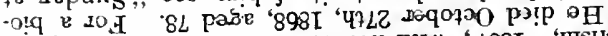

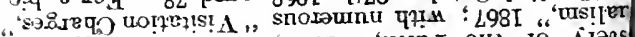
pue sint?i

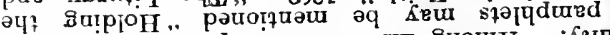
strouxos paysigqnd snosounu stq Buour - Sqtut

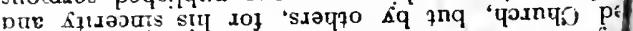
-qeisa

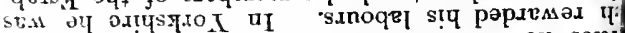

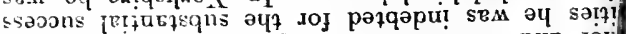
asolit of pur uoip!sodsip to ssautipa! pue sav jo iftaens .

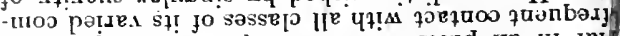
II! sy

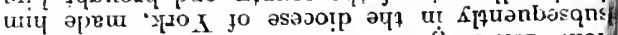

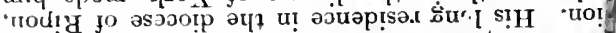

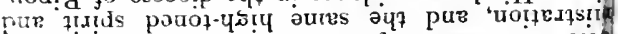

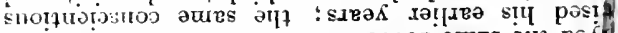

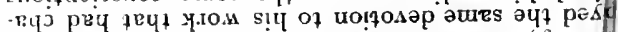

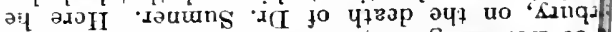
jo doys!y

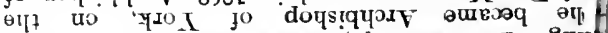

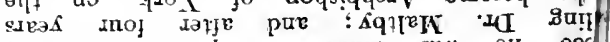
"ureysina jo doys!g әpeu sex ay 998

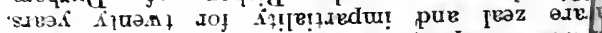

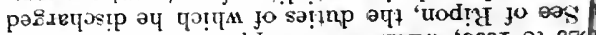

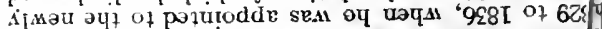

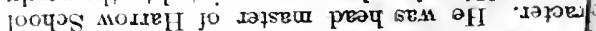

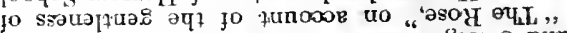

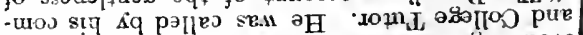

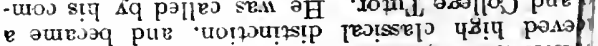


and Bedlington an hereditary sacerdotage obtained. Confession seems to have been much disregarded. Nany of the clering were married men, and sereral bishops followed their cxample. There was great need indeed of ecelesiastical reform. And even if the diocese of Northumbria had been smaller, and less subject to religious contentions, the troubled state of public aftairs would have precluded or retarded improrement. What could Christianity do when ehief was warring against ehief, and raco against race? It required a kindlier soil and more gentle airs. The troubles which Briton, Saxon, Dane, and Norman cansed in Northumbria are matters of history. Can we wonder, then, that the light of religion was so feeble, and its influence so partial? Paulinus fted for his life from the spiritual provinee which he had begun to plough and sow so carnestly. Many years of Wulstan's life, fearless although he was, were spent in exile. The dangers which beset Eanbald robbed Northmubria of Alcuin. The Danish incursions checked the uscfulness of Oswald. The troubles of Wilfrid and Aldred are too well known to be repeated. It is still more mournful to turn from the disasters which befell the pastors to the sufferings of their flocks, and the ravages of the fire and sword. The Danes destroyed almost every monastery in Nortlumbria. The wanderings of the monks of Lindisfarne are full of thrilling and romantic incidents. Their pilgrimage with the body of their saint has been deseribed by historian and poet. A talisman it was dearer far than life itself which they bore along with them. The very existence of the Northeri chureh depended upon their safety, and they knew it. A resting-place was long denied to them. They sought for it in rain beyond the seas. They sought for it in vain among the hills and green glades of Yorkshire, and it was rery late in their day of trial that they found a sanetuary at last, the wood-embosomed erag which they have erowned with the grey towers of the English Sion. "A fair" place" indeed it is, and memory's most binding charm attaches me to that "holy hill." May peace be within thy walls, oh my nursing mother! A wandering, but still loving elild, bids thee prosper and be blessed.

The archbishop of the Northumbrians had in the earliest times the control of the whole of Northumbria, extending from the Mersey to the Clyde on the one side, and from the Humber to the Frith of Forth on the other. 'The power of the prolates kept pace with the growth or eurtailing of the kingdom, although they occasionally asserted and maintained a still wider spiritual empire. These claims, as will be seen hereafter, were frequently the cause of much controressy and bitterness.

It was the wish of Gregory that lingland shoukd be divided 
into two large provinees; the Northern to be under the rule of an archbishop, who was to aet as metropolitan over twelve sulfragans. This arrangement was subsequently confirmed by leo III., but for rarjous reasons it was never carricd into effect. The following sees were in existence in Northumbria, or were under the control of the Northern primate anterior to the Conquest.

Livimsarese. The seat of sixteen bishops, beginning with Lidan in 635, and ending with Eardulph. It was then transferred to Chester-le-Street. The first four bishops of Lindisfarne had the sole charge of Northumbria after the flight of Panlinus.

Hexunn. This see was founded in $6 \% 8$, when the diocese of Tork was divided by Theodore. It had a succession of thirteen bishops, the last of whom was Tydfrith, who died in 821 .

Linvisey. Established by Theodore in 678. The seat of the episcoprate was probably at Sidnacester or Stow, and Eadhead was the first and the last bishop. Lindsey, although a part of Mereia, was at that time under the rule of the Northumbrian monarch by right of conquest; it was soon recovered by the Mercians, and Eadhead retired to Ripon. The claim, however, to Lindsey was not surrendered. When the see of Lincoln was established soon after the Conquest, archbishop Thomas asserted that Lineoln, Stow, and a great part of Lindsey belonged to the province of Lork, and resisted the appointment and the arts of Remigins and his snecessor, Rohert de Bloet, in the most determined way. The primate seems to have been in the right. The dispute was arranged, much against the will of Thomas, by pope Paschalis and William Rufus. Lindsey was to be henceforward a part of the diocese of Lineoln, and the ser of lork, in the place of it, was to have the abbey of Selby and the momastery of St. Oswald at Gloncester. The bishop of Inncoln became thenecforward a suffragan of Canterbury.

Rupox. Fomded in 6z9 (\%). Eadhead went there when he retired from Lindsey. IIe was the first and the last bishop.

(iALL)WY. A sec established in 681, the district having been arded to Northumbria by Eegfrith. Trumwin was the first preclate, and he was called the bishop of the Picts. The seat of the cpiscopate was at IThithern or Candida Casa, where there was a succession of six bishops. Shortly before the year 800 (ialloway came again into the possession of the Picts, and several renturies elapse before we hear again of Christianity at Whithern.

('nister-LE-STREeT. The bishopric at Lindisfarne was remored to this place about 880 , and continued here for nearly a 
century, when it was taken to Durlam. There was a snceession of nine bishops at Chester.

Durnas. The scries of bishops began here in 990, and is still going on. There has been much eontroversy and wrangling between the sees of Durham and York on the question of subjection. The bishops of Durham were men of too great influence and spirit to be suffragans to any one, but they ought undoubtedly to have paid ecclesiastieal obedience to York. 'The contest was carried on for a long time with varying success, and even at the present day the power of York over Durham is not altogether admitted. The temporal power of the bishops of Durham was greater than that of the arehbishops of York, and their appeals to the sovereign were frequently listened to, on that account, with the greater farour.

Glasgow. Magseu and John, bishops of this see, were consecrated by archbishop Kinsins shortly before the Conquest, and acknowledged themselves the suffragans of York. 'Their profession was disowned by their suecessor's, nay, their very names are excluded from the fasti of the church of Glasgow by Scottish writers.

It will be seen that at no period anterior to the Conquest were there more than five prelates within Northumbria. On the arrival of the Normans the archbishop of York Inad only two suffragans, the bishops of Durham and Glasgow. In 1132, Henry I. established a bishopric at Carlisle, and subjected it to York. Cumberland, Westmerland, and Lancashire, with the adjacent islands, had been a part of Northumbria from the time of Ecgfrith in the seventh century, and were probably visited by the chorepiscopi, or the Scottish and Irish missionary bishops. The see of Sodor and Man was not formally subjected to York until the year 1458, although it had formed a portion of the old kingdom of Northumbria, and had on sereral occasions been connected with York. The see of Chester was founded by Henry VIII., and since that period only two bishoprics have been erected in the North. The suffragans of the archbishop of York at the present day are the bishops of Durham, Carlisle, Sodor and Man, Chester, Ripon, and Manchester.

With regard to the Scottish bishops and their subjection to York there has been much angry contention. It was undoubtedly designed in the first instance that the Scottish prelates should be suffragans of York, and before the Conquest such of them as were canonically appointed rendered their obedience to that see. The rest that we hear of were, probably, merely the chorepiscopi. After the arrival of the Normans there secms to have been for some time a desire for mity, and we find the bishops of St. Andrews, Glasgow, Whithern, Orkney, and the 
Isles, recognizing the supremacy of the archbishop of York. A (dange, howerer, soon sprang up. The influence of the Culdees and the chorepisenpi, and their inceasing dislike of the English, soon made the Seottish bishops loreak off their comnection with an ecclesiatical head whom they never saw in their own comntry, and from whom their own national feelings more and more alienated them. They began to receive consecration at the hands of their lrethren at home, and the bishops of St. Andrews began gradually to take the lead. At the commencement of the twelfth century pope Calixtus urged upon the Scottish king and his nobles the duty and the propriety of having their bishops properly consecrated by the metropolitan of York to whom they were subjeeted. In 1175 the question was again monted at the council at Northampton, and the result of the delate was that the bishops and abbats of Scotland rendered their submission to the arelıbishop. The practice was soon given up, and in the reign of Ldward I. pope Alexander took the Scottish bishops under his protection during the strugghle with England. 'The wars which now ensued were an effectual har to the elaims of York, and in the fifteenth century the pope formally exempted the Scottish ehureh fiom any obedience to an English metropolitan, and made the bishop of St. Andrews primate. The deeree was rigorously resisted by the archbishop of ' York, but the pope told him that no enemy ought to be metropolitan of Scotland. In the following century it was the intention of arehbishop Lee to have revived the claim, and to have submitted it to a general conncil, but the ecelesiastical trombles of the age were an effectual bar to any legislation. The chureh of Sicotland is altogether exempt fiom any English jurisdiction, but that frecdom has been the greatest curse which has betitlen it.

'The last proint to be remarked upon is the relation that has existed between fork and Canterbury, which has not alway becu of the most amicalble kind. The original intention was that the two metropolitans should be cutirely independent of eachother. When one died the survivor was to eonsecrate lis new brother, and mitil that erent took place he was to conscrrate all lishops, crom the sorcreign were it neeessary, and sing high mass before him on the three great festivals. It was intended that the Northern primate shonld have twelve suffragans muder lim, and the pall, which he was to receive from Rome, was to be the title-decel as it were of his anthority. In position and power the two anchlishops were to be exactly equal.

It was not -o). Fir a rentury after the departure of Paulinus from the North mo bishop of lonk either songht for or obtained the pall. Withont this he enuld have no sulfirang, and he was 
himself in point of fact under the authority of ('anterlumy. It was the absence of the pall from York that accounts for the surcessful interference of Theodore with Wilfrid. Eschert, however, at Beda's suggestion obtained that privilege which was continued to his sucecssors. The position of the two primates was now equal, although the influcnce of York cren then must. have been less than that of Canterbury, on accomt of the few suffragans that it had, and the disasters that fell npon Northumbria. Soon after the Conquest Lanfranc made a suceessfin] attempt to subject York to Canterbury. He refused to consccrate 'Thomas of Bayenx muless he made his profession of obedience. Thomas, mfortunately, made his submission at the request of the king whose chaplain he was, but the controrersy was immediately resmmed. The result was unfaroumable to York, as the Northern provinee was formally subjected to Canterbury at a great synod hetd in 1072. This decision, however, was as formally reversed by pope Honorius, fifty year's afterwards, at the request of archibishop Thurstan, and the two metropolitans were henceforward independent of each other. Peace and amity were not so speedily restored. I shall mention, in their chronological order, the scenes and animositics which this want of friendly feeling oecasionally produced.

These prefatory remarks are merely introductory to the biography with which I profess especially to deal; and many of the points which have been already bricfly alluded to will ocem again to my readers in their proper sequence and position. 



\section{TIIE ARCHBISHOPS.}

\section{'THE ARCHBISHOPS OF' YORK.}

@aulinus was the first missionary from Rome that preached the Gospel in the Saxon kingdom of Northumbria. We are told that he was a Roman by birth, ${ }^{a}$ and this statement is strongly eorroborated by Beda's deseription of his personal appearance. ${ }^{b}$ The words of the famous historian are thus rendered by a Christian poet :-

"Who comes with functions apostolical?

Mark him of shonlders curved and stature tall, Black hair and vivid eye and meagre check,

His prominent feature like an eagle's beak,A man whose stature does at once appal,

And strike with reverence."

On the other hand, however, we have the assertion of the Pseudo-Nennius that it was not Paulimus who baptized king Edwin and the many eonverts in Bernicia and Deira, but Rum, the son of Urien, who was the well-known opponent of the Saxons in the North. ${ }^{c}$ Can we identify him with Paulinus, and regard the latter name merely as the Latin title which the missionary assumed when his patronymie was discarded? If this were the ease, Paulinus was a Briton. An able historical writer" observes that "the following sequence of events is far from improbable :- that on the death of Urien of Reged, and the expulsion of his family from the throne, his son Rum retired to Rome, and there entered into holy orders; that when Gregory was looking about for missionaries to send to Britain, he should gladly avail himself of the serviees of a British priest highly connected, more especially when we know how anxionsly

- Alcuin de SS., etc., Ebor., apur Gale, i., 709.

b Beda, ii., 16: "Vir longre staturax, paululum incurvus, nigro eapillo, facie macilenta, naso adunco pertenui, venerabilis simul et terribilis aspect $n . "$

- Gale, i., 117. Lel. Coll., iii., 49, who salys, "Run mapur Beglen., i. e., Pinlinus."

"Mr. Hodgson Hinde, in the first volume of the llistory of Northmmberlaud, 77. It may be asked, Wly shonld the son of a british chieftain sol to Rome? 
Augustine strove, though without suceess, to obtain the cooperation of the British clerery in the work of eonverting the Anglo-Saxons; lastly, that when the Kentish king had to select from the ecclesiasties about him a chaplain to aceompany his daughter into Northumberland, he should make choice of a native of the district."

Panlinus left Italy in 601, ${ }^{e}$ at the bidding of Gregory, whose disciple he is said to have been, $f^{\prime}$ to labour in the harvest-field of England, where there was a great lack of reapers. ${ }^{g}$ His companions were persons of repute, and the names of the members of the party make up, singularly enongh, an hexameter line $\mathrm{e}^{h}-$

\section{Mellitus, Justus, Paulinus, Rufinianus.}

They bore with them a missive to Angustine, in which Gregory ammonneed his desire that York should be a metropolitan see, ${ }^{i}$ with twelve suffragans. Little, perhaps, did Paulimus at that time think that his own shoulders would be decorated with the patl.

Many years elapsed before the intentions of the chief pontiff conld be carried into effect, and during this period Paulinus was, probably, one of the coadjutors of Augustine and Justus in the erangelization of Kent. A wider field of duty was before lim-the great Saxon province of Northumbria.

The monarch of Northmmbria between 593 and 617 was Ethelfrith, the slaughterer of the monks of Bangor. He succeeded his father Ethelrie on the throne, which properly belonged to Edwin, his wife's brother. The reign of Ethelfrith was a very prosperons one, and yet he was by no means free from care. Is the brother-in-law, whom his father had wronged in his infancy, grew up to manhood, the "destrietus ensis" seremed to hang over lithelfrith by a more slender thread, and his anxicty anoused the fears of "Erwin, who, trembling for his life, fled at last to the court of Redwald, ling of the East Angles, after he harl sought for protection in other lingdoms and other hiding places. Thither, also, do the hate and fears of Ethelfith pursuc him. Bribes alle freely offered for the fugitive, but withont efleet, and then comes the more potent threat of war, which induces the timid Redwald to pledge his word to

'Saxon thron., 28. Aswer, apurl Grale, i., 113. Stubbs, col. 16ist. Fl. Wizorn. (232) makes the date 626. Vit: S. Gregrorii, apur Mabillon, Acta SS. wrel. S. B., sac. i., 122. Vitia S. Allg. aprert Angl. Sacram., ii., 62.

'live of Hexhan, col. 2so. Acta ss. mense Oct., ex Laur. Strio. The life of Paulimus in the Acta $5 \mathrm{~S}$. is an uninteresting compilation.

5 Berla, i., 29.

h Dedil, i., 29. Hist. Mon. S. Ansust. Cautuar, 96. Anglia Sacra, i, 1, 65. Baronii Annales, viii., 147.

Beda, ut supra. Vita S. Augustini, atud Mabillon, Acta SS. ord. S. B., rice. i., 515. Labbe, Concilia, r., col. 1558. Spelmanni Conc., 90. 
the monareh of Northumbria that he would either put to death or surrender the unfortmate refugee. The news of this derision was brought to the unhappy lidwin by a friend, who promised to shew him a safer place of retreat, but he wonld not arail himself of his offer. Fortume had been so unkind to him that he eared not now whether she smiled or frowned. Redwald had weleomed him to his halls-why should he question his good faith by fleeing from them? He would stay where he was and await the end. ${ }^{j}$

It was night, and the homeless wanderer was seated on a stone bench before the royal palaec, musing on his unhappy lot, and very sad at heart. Suddenly there stands before him in the gloom a wondrous visitor; his features were unknown, and his attire, like his face, was strange. Who eonld he be?

\section{"Frigidus horror}

Membra quatit, gelihusque coit formidiue sanguis."

The stranger was the first to speak: "All men are now asleep; why art thon awake and sitting sorrowfully in this place?" Edwin gave a hasty answer, deprecating the intrusion upon his privacy; but the questioner heeded not the angry words, and told him that he knew well the cause of his anxicty. "But what," he said, "would be the reward of him who should banish all thy sorrow, and persuade Redwald neither to injure thee himself, nor to give thee up to thy foes?" "Any good that I could do him," was the reply ; and the speaker again resumed, "What reward should be lis were he to plerge his word that thon shouldest be restored to thy lost throne, and that thon shouldest become a greater monareh than England has yet seen ?" "Anything that I could gire and do for him to shew my gratitude," was Edwin's bolder and more grateful answer. "If all this is granted to thee," said the mysterious stranger, "and he who now speaks to thee has proved himself a trine prophet, wilt thon listen to his words and his advice when he shews to thee a better rule of life than any of thy sires have known before thee?" "Yea, that I will, in all things," was the reply of Edwin; and then the stranger's hand was laid upon his hear, - an aet of authority not likely to be forgotten by the speaker or the promiser, ${ }^{k}$ - and the striking words fell upon the exile's ear, "When this sign shall come again to ther, reeolleet then this hour and these words, and delay not to do as thou hast promised." The injunction was scircely nittered

$j$ The whole story is in Beda, ii., 12. Alcuin de SS. Ebor., apud Gale, i., 704, 5. Bromton, col. 781. Roger of Wendorer, ed. Giles, i., 76. Mabillon,
Ann. Ben., i.. 332, 3.

$k$ "Tatis signmm," as Mabillen calls it. Cf. Win., ix., 300. Jux. Nat., vi., 17. Orid, 'Trist., v., 4, 15. 
before the speaker hat ramished like a spirit through the gloom, and bolwin, trembling and astonished, found himself alone in the friendly darkness.

P'anlinus, in all probability, was the stranger who thus spoke and acted, and the whole scene is just such a one as an Italian monk woukl derise to inflnence an impressible mind. Redwald was at that time half a Christian, and the missionary would, perhaps, be flitting about the court in the hope of subjugating him entirely to the true faith. The event surpassed Edwin's most sanguine expectations. The friend who had connselled him to flee had acquainted the queen with his determination, and she, in pity for lis sufferings, had moved her husband, who had probally been influeneed by the mysterious stranger, to take up the exile's cause. Not only did Redwald protect the distressed fugitive, but he restored him to his lost inheritanee, slaying the intruder Ethelfrith in a battle near the sluggish waters of the Idle.

Thus, in $61 \%$, Edwin became the monarch of Nortlumbria. The words of the mysterious stranger were accomplished, but no one asked him to fulfil his promise, and he thought, no doubt, that it was a spirit that he had seen. The end had not yet come. In 625, Edwin, still a pagan, wooed for his second consort Ethelburga, a daughter of Ethelbert, king of Kent, who had been converted by Augustine. Her brother, who was the king, rejected the proposals of the Northumbrian monareh with the seornful answer that a Christian virgin could not take to herself a pagan husband. This difficulty was soon met by Edwin. He not only promised to allow the lady, if she became his wife, to worship Grod with all her suite, but lie professed his readiness to listen to the aremments of Christianity, and to adopt them, if they were deemed irresistible by men of prudence and discretion.'

The marriage takes place, and Panlinus accompanies the princess as her chaplain, having been consecrated bishop of the Northumbrians by arehbishop Justus on the 21st of July, 625, , $^{\text {m }}$ to preside orer the mission. No one conld go into the North with greater chances of snceess. He knew a token that would

' Beda, ii., 9. Stubbs, col. 1687. Mabillon, Amu. Ben., i., 332.

" Berla, ii., 9. Saxon Clicon., 32.

Flor. Wisorm., 232. Iinger of $W^{T} \mathrm{en}-$ dover, erl. Criles, i., 7t. Cliron. S. Crucis, a]mi Wharton, i., 153. Hist. Mon. s. Dus. ('antuar, 153. Rad. de biceto, (ol. 137. Bromton, enl. 7to, 80. Stubbs, *). Mfsi. Mabillon, Wun. Ben., i., 332. Baronit Lmiales, viii., 268. In
Gosceline's life of Augustine in the Anglia Sacra, ii., 66, 7, it appears that Augustine paid a visit to York after the massacre at Bangor! Two of his miracles are recorded. At the same time he is said to have baptized an extraordinary number of converts in the Swale! Cf. Smith's Beda for the explanation of this story. 
soften the king's heart when everything clse liad failed, but that was a resource not to be lightly or incantiously made use of. The most potent argument was to be the last. ln the meantime he could make but little progress. He gained no converts. All that he did was to preserve the queen's suite by his daily teachings and celebrations from the pagan smperstitionis of the country. ${ }^{n}$

Neither the arguments of the preacher nor the entreatics of the queen could induce Edwin to adopt the Christian faith. But Paulinus was patient and obserrant. IIe conld read the king's feelings, and he saw that time alone conld change them; when once converted, he knew that Edwin wonld act boldly and consistently, and the missionary, griered and yet hopeful, was waiting for the event. It was precipitated by one or two remarkable circumstances. An unsuecessful attempt was made upon the king's life by a minion of a king of Wessex, and, on the same evening, Edwin's queen gave birth to a daughter. 'The king thanked his gods, but Paulimus poured forth his praises to his Creator, to whose agency he ascribed these two signal favours, with such fervour, that Edwin, struck by his earnestness, promised that if the God whom Paulinus worshipped would enable him to vanquish the king of Wessex, he would renounce his creed, and, as a pledge of his sincerity, he allowed his new-born daughter to be baptized. Eleven members of the royal houschold accompanied her to the font. ${ }^{\circ}$

The victory was Edwin's, but still the conqueror believed not. He talked about the new faith to Paulinus and his nobles, but he did nothing. A letter arrived from pope Boniface at this juncture, exhorting him to embrace the creed of his wife, but it was ineffectual. $p$ Ethelburga spoke to no purpose. The worts of Paulinus were listened to, but rejeeted. 'The king was dissatisfied with himself, for he had made a promise, and he hat not kept it. The fear of giving offence deterred lim from revealing what were the convictions of his mind. "He durst not entertain truth, a lawfull king, for feare to displease custome, a eruell tyrant." 4 He was moody and careworn, sitting by himself and musing over what was uppermost in his thoughts." The crisis had at length come, and the preacher knew it. Well might he say with Ulysses,-

${ }^{n}$ Beda, ii., 12. Stubbs, col. 1687. Malmesbury, apud Sarile, 9, a. Baronii Ann., viii., 269.

- Beda, ii., 9. Flor. Wigorn., 232. Chron. S. Crucis, anud Wharton, i. 153. Bromton, col. 781. Nemins, apur Gale, i., 114, 15. Roger of Trendover, i., 76 , who says that thirty were bap- tized with the princess. Baronii $A m$, viii., 275 .

$p$ Beda, ii, 10. Hist. Mon. S. Ang. Cant., 155, 162-3. Bromton, col. 7S1. Labbe, ('oncilia, v., col. 1659). Sipelmanni Concilia, 135. Baronii S Sm., viii., :69. " F Fuller's ('hureh llist., book ii., 72. $\quad r$ Bexk, ii., 12. 


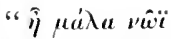

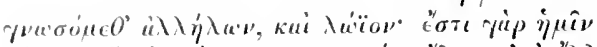

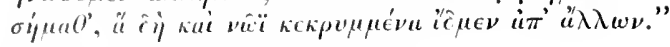

Home the monarch was when Panlimus passed into his presence, and the well-known sign was again made; the hand was laid upon the head which it had tonched twelve years before amid the darkmess of the night. "Rememberest thou this?" said the miscionaty to the king: Edwin would have cast himself at his feet had he not been presented; and then, at last, there somnded in his eas the tones of a roiee no longer unfamiliar to him, "Bchold, thine encmies have fallen in the battle; that is the Lord's gift to thee; behold, the kingdom that thou didst covet is thine, that hath the Lord given thee likewise; remember thy third promise, and weleome the faith and the rule of Him who hath done for thee such great things: an earthly throne He hatl given to thee already, hearken to His will that I declare to thee, and thon shalt share with Him His kingdom in the heavens."s

There was no lesisting an appeal like this. The king gave way, and toll Panlinus that his wishes coincided with his duty, and that he shonld become a Christian. He desired, however, to confer with his eouncil before he made any public amnouncement of his conversion. To this Panlims would willingly assent, for the subjeet was not a new one to many members of that assenbly. The hias of Edwin wonkl now be known and would have its due weight. The opinions of the councillors were taken individually ; and although the king cautiously spoke of the new faith as a "doetrima eatemus inandita," the answers that were clicited, if they alid not prove that the speakers believed in Christianity, still tended to shew that they had no confidence in their own 'reed. 'The speceh of Coifi, the pagan high priest, was a very striking one. If said plainly, that in his own religion thele was neither nerit nor use. "Ile, he observed, had served his gods more faithfully than others, and what had they donc for hin! Coifi took a very ntilitarian view of religion in wencal, but it was the popular one, and the comcil assented to his wish to hear more of the new doctrine, and to adopt it if it were approved of.

'?hen it was that Paulinus had the opportunity for which he waited so many years. "Exspectate venis!" Right in front of him, perhaps, was the great idlol-temple of Northumbria;" around

$$
\text { i., } 77 \text {. }
$$

bilwin would brome aefuainted with 'hristianity al the compt of Rerlwakl. !ienla, ii., 13 .
" Dr. Ilook imagines that the Council was held at York, and describes the ride of Coifi to Gormmindham,-the whole scene being a pleasing invention. Coifi rirl not mount the king's horse because 
him were the great men of the province eager at length to hear the good tidings which they had so long rejected; there was the monareh, deaf no longer to his entreaties, but at listene' and a believer. Well might Panlinus speak with eloquenere and fervonr, before an andienee like that. There is no record of what he said, but he must liave spoken with the dignity and the power of an apostle. The resnlt was a most marvellous one.' Coifi was the first to renomee his idolatry, and willly cagcer to atone for his past blindness, he vanlted, by permission, on the king's steed, and ginding on his sword, rode, lance in hand, to desecrate the idols and the shrime that he had so long revered. When the people saw him on horseback and in arms, as no priest had ever been before him, they thought that he was mad. But soon, more vulgi, they were carried away by his impetuosity ; they burst into the temple and its enclosines, profaning and destroying what they could. All this was done at Godmundham near Market Weighton, a place which in after years came into the possession of the church of York by the rift of the famous Ulphus.

This important event ocenred, I believe, in the spring of 627, and upon Easter day (April 1:2) in this same year a most striking ceremony was witnessed at York." This was the baptism of Edwin. A little ehureh or chapel of rood was hastily construeted at the bidding of the king, ${ }^{x}$ and dedicated to St. Peter, and in it did the monareh become a member of the true faith. Two of his children were baptized at the same time, together with Iffi the son of Osfrid, and many other persons of distinction and royal birth. ${ }^{y}$ Around that little oratory, which he had so much reason to remember, the grateful monarch, at

there was any journey to make to the temple, but simply to shew his contenupt for the pagan rule that a priest should only ride upon a mare!

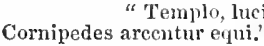

"Beda, ii., 13. IIist. Mon. S. Aug. Cant., 163-4. Hemry of Huntinsdon, apud Savile, 187-9. Bromton, col. 782. Alcuin de SS. etc., Eccl. Ebor., annd Gale, i., 706.

"Chron. S. Crucis, apud Wharton, i., 153. Roger of Wiendorer, i., 77. Chron. Cantuar., col. 2230 . Flor. Wigorn. places the baptism in 628 .

x Saxon Chron., 33. IIist. Mon. S. Aug. Cant., 165. Auglia Sacra, i., 153, The altar at which Edwin was baptized was afterwards dedicated to St.Panl. Ct. Aleuin de SS. Ecel. Ebor , and Symeon, col. 113. $y$ The Ps. Nennius (Gale, i., 115) says that 12000 persoms were baptized with Edwin in one day, and that for forty dass Paulinus " non cessavit baptizans ome genus Ambronum, i.e. Ald.-Saxonum." Roger of Wendover, i., 78. goes farther, and says that soom after there was not one unbeliever left. Beda, ii., 1t. Angl. Sticra, i., 153. Rarl. de Diceto, col., 438. Bromton, col., 782. Stubbs, col., 1685. Lel. Coll., ir,, 69. Gainmar, Yestorie des Lingles, apmd Ilon. Hist. Brit. 777, 9, says :

\footnotetext{
"Li reis Edwine estreit done reis; Si prist les cristiene leis: be lierwic ent: jeo savon, Kil estorat religiom, E แก muster restorat, lis a sint l'ere la domat. Icist reis fu del linate lille, Ki a seint lere fist sacelle. l'ns evoskes lo laptizat, k'atlins ont non, Deus mult l'amat."
} 
the instigation of Panlims, began to ereet a ehurch of stone which he never lived to eomplete.

"Euborica solidis suffulta columnis

Nobilis illa manet relio speciosa decore,

Qua statione sacra fuit ille lavatus in unda."

It was in the form of a square with the shrine in the middle. Howrer unsightly the latter may have been, we cannot but arlmire the fecling which prompted its preservation. Amid the temples and the gorgeons buildings on the Capitoline hill the Romans lovingly preserved the straw-thatehed eottage of their founder; in the ancient ehurch of York you could see the oratory of wood in which the sacred water had been poured for the first time upon a monarch of Northumbria.

$\Lambda$ glorions field was now opened to Paulinus, and every one was ready to listen and assist. Edwin fixed the seat of his episcopate at York, ${ }^{a}$ and, at the request of that monarch, pope Honorins rewarded the zeal of the good bishop by the welcome gift of a pallinm. ${ }^{b}$ The labours of the great missionary during his residence in the North must have been prodigious. ${ }^{c}$ The kingdom of Edwin stretehed from beyond Lineohn and Sonthwell far into the lowlands of Seotland, and the whole of this immense distriet seems to have been traversed by Paulinus. 'Tradition has preserved some traces of his footsteps. In Northumberland there is a Panlin's well, and Pallinsburn in the northern part of the same county is the burn or rivulet of Panlinms. There are still ancient crosses with which his name is connected at Dewsbury and Whalley, and there was another near Easingwold in the time of Edward ${ }^{d} .^{d}$ They were memorials, in all probability, of a visit of the arehbishop whom the people of Bernicia and Deira had good eanse to remember. $\mathrm{He}$ mored abont with the court, for he was the royal chaplain, and wherever it halted there was work for him to do. Rarely has any missionary had so successful a career. There were no oratories or haptisteries when he begun his work, ${ }^{e}$ and he needed them not; for wherever there was water he conld baptize, and he could find a pulpit anywhere. At Adgebrin or Yeavering near the Cheviots he is said to have spent thirty-six days in catechizing the converts and baptizing them in the waters of

= Alcuin de ss. etc. Eccl. Ebor., appud riale, i., $706 . \quad$ "Saxon Chron., 33. Ansl. Sacra, i., 153.

"Sixom C'hron., 31. Beda, ii., 16, 17. Hist. Hon. S. Aug. Cantuar., 170 . Bromton, col. 783 . Stubhs, col. lfiss. Isaber concilia, Y., col. 1683 . SpelmanniConc. 138, 9. Barmii Aun., viii., 326. Mabillon, Ainn, Ben, i., 336. c "Per sex annos continuos verbum Dei in Northanimbrorum provincia predicabat." Symeonis Ep. de A rch. Ebor., col. 77.

d Archæol. Eliana, n. s., i., 154. Nichols' Collect. 'Topogr., i., 149-54. Walbran or the Saxon church of Ripon, 70. Whitaker's Whalley, 50. Loidis and Elmete, 299. c Beda, ii., 14. 
the Glen. ${ }^{f}$ In the province of Deira, where a great portion of his time was passed, he would generally be baptizing at Catteriek or 'Tanfield (Donatield) in the Swale and Yore.g It was, doubtless, at the instigation of Paulinus, that Edwin prevailed upon Eorpwald, king of the East Angles, the son of his old protector Redwald, to become a Christian $;^{h}$ and hence it is that he is traditionally comnected with the infant-miversity of Cambridge. ${ }^{i}$ Hilda first heard of Christianity from Paulinns. ${ }^{j}$ We hear, also, of the missionary in Lindsey and Nottinghamshire. In Lindse $y^{k}$ he was the earliest propagator of Christianity, and Blecea, the prefect or reeve of Lincoln, was his first conrert: he erected a church, the predecessor of that glorious temple with which that "sovereign hill" is erowned, and in it, in 627 , did he consecrate archbishop Honorius.' He is said to have founded the church of Sonthwell about the year $630,{ }^{m}$ and, nearly a century after this, Beda heard from a Lincohnshire abbat a description of the personal appearance of the great evangelist as it was given to him by one who had been baptized by him, with many others, in the presence of king Edwin, in the waters of the Trent."

The support and countenance of Edwin must have been a great aid to Paulinus, but, mnfortumately he did not long enjoy them. Cadwal, a British sovereign, aided by the fiery and savage Penda, broke into Northmmbria and slew its king in a great battle at Haethfelth or IIatfield Chase in $633 .^{\circ}$ The loss of her protector was a sad blow to the Northern church. Ilis bloodstained head was bronght to York, and was interred in the porch or ehapel of St. Gregory ${ }^{p}$ within the minster that he was building. $q$ His sufferings and his zeal have enshrined his name

$f$ Beda, ii., 14. Bromton, col. 782 ; Stubbs, col. 1688.

$g$ Beda, ii., 14. Archdeacon Churton (Hist. of Early Englislı Church, 53) thinks that Donafield was near Doncaster. I agree with Mr. Hodyson Hinde in placing it at Tanfield on the Yore.

$h$ Beda, ii., 15. Wm. Malmesbury, apud Savile, $14 a$.

i Sprotti Chron., 271, ex Cantelipi Antiq. Univ. Cant. Fuller's Ch. Hist., bk. ii., 74 .

$j$ Beda, iv., 23.

k Beda, ii. 16. Saxon Chron., 3 t. Roger of Wendover, i., 78, Bromton, col. 782; Stubbs, col. 1688. Archdeacon Churton and Dr. Hook speak of IBlecea being the founder of the church of Lincoln, but Beda's words may bear a different construction. Cf. Hist. Mon. S. Aur. Cant., 169, and Henr. Iluntingdon, apud Savile, 188. Lel. Coll., iv., 69.
'Beda, ii., 16. Sax. Chron., 34. Roger of Wendover, i., 78. Anglia Sacra, i, 151. Hist. Mon. S. Aug. Cantuar., 170. Rad. de Diceto, col. 438, Bromton, col. 782. Stubbs, col. 1688.

n Dugdale's Monast., vi.. 1312.

"Beda, ii., 16, ed. Smith ant Mon. Hist. Brit., 168. n. Lel. Coll., iv., 100. - Berla, ii., 20. Bromton, col. 781; Stublss, col. 1685. Harpsfeld, 89. Lyfo of Saynt Werburge, ed. Chetham soc. 16.

p Beda, ii., 20. Bromton, ut supra. Roger of Wendover, i., si.

q It was finished by king Oswald. Beda's deseription of this ehurch is an interesting one (ii. 11). "Curavit majorem ipso in loco \& augustionen de lapide fabricare basilican, in cujus medio ilsum quod prius fecerat, oratorimm includeretur. Pregnatis ergo fundamentis in gyo prioris oratorii fer quatrum conpit adificare basilican. Sed 
in the calendar, ${ }^{r}$ and fow prople are perhaps aware that the capital of Seotland is the buroh of Edwin, who shewed his taste by laving the foundations of a rity amid the finest scenery in Europie.

After the death of Edwin it was unsafe for his widow to remain in Nortlumbria, and as Panlinus had been in her suite crer since she came into the North, it was clearly his duty now to take measures for her protection. He found a ship on which he placed the gneen and her family, and with the assistance of Bassus, one of Edwin's warrior's, the party r'eached the shores of Kent. Here there was a hearty welcome for them from archbishop Honorius and king Eadbald, the brother of Ethelburga.s

The fingitives earried away with them the treasures of king Edwin, and among them were a cross and chalice of gold which had been nsed at the celebrations on the altar. Beda tells us that they were preserved in his day in the church of Canterbury. ${ }^{t}$ Panlinus also took with him his pall; and more than a century clapsed beforc York was again an arehiepiscopal see." One missionary there was who remained behind in the deserted kinglom at the bidding of his lcader, and that was James the deacon, who had been the companion of Panlinus during his residence in the North. He resided for some time at Akebargh, James' town, near Catterick in Deira, and was rery diligent in teaching and baptizing. But he was especially famous for his great skill in singing and his fondness for the Gregorian tones, which he targht as well as chanted. He is supposed to be buried in the churchyard of Hanxwell, and to be commemorated by an ancient "loss."

Such was the termination of the mission of Paulinus into Northmm! ria. I failure it undoubtedly was, but a failure for which the misionary cannot well be ecnsured. The system that he pursued, or rather his want of system, has been severely (riticized. Possibly in the ontset he might appeal too strongly to the temporal adrantages that would accompany Christianity;

prins quam altitudo parietis exset con. sumntata, rex ipse impia nece occisus (o) his idem successori suo Oswaldo perficiendum relignnit." Alcuin (Gale, i., $7(07,8)$ sives the following aceount of O) wrald's church building.

"Extruit ecclesias donisque exnrnat opimis, Vasa ministeris juastans pretiosa sacratis A reento gernmis aras vestisit of atro.

Serica parictibus tendens velamina sacris,

Auriblaterolis pulcre distineta coronis,

Sanctarle suspendit varias per tecta lucernas."

'llhele is an account of st. Edwin, king and martyr, in Caperare's Nova Legemta, $116-20$.

i\}edil, ii., 20. Saxon Cluron., 35.
Roger of Wendover, i., 81. Hist. Mon. S. Aug. Cantuar., 173. Angl. Sacra, i., 155. ILigden, apud Gale, i., 207. Rad. de Diceto, col. 438. Bromton, col. 784. S1ubbs, col. 168s. Baronii Annales, viii., 328. Mabillon, Ann. Ben., i., 360.

$t$ Beda, ii., 20. Bromton, col. 784 . Roger of Tiendover, i., 81.

"Beda, ii., 20. IIist. Mon. S. Aug. Cant., 182. Hisden, apnd Gale, i., 207.

"Beda, ii., 16, 20 ; iii., 26 ; iv., 2. Bronton, col. 785. Arch. Al., n. s., i., 185. Possibly the word Hawkswell is Jake's-well, just as Akebairch is Jake'sbargh. W. II. D. I. 
but was it wrong to make use of an argument which was innocent in itself, and would have great weight with the people of the North? The power to discorer this approach to their licarts, and to avail himself of it, tends to shew that Panlimms possessed discernment as well as tact. When royal favour at last smiled upon him, and a kingdom more than $300^{\circ}$ miles in lenoth became his ficld of labour, did he negleet lis work? 'The eridenee of history and the whisper of tradition still tell us that he was not "an unprofitable servant." It is idle to suppose that a man, with few fellow-labourers and an immense diocese filled with heathen, could in six years mature what we call "organization." That comes after the rougher work has been done. Before there is any arrangement there must be something to arrange. 'The word must be first heard and the listener's received into the fold, and then "organization" follows. Pauliuns was no sluggard in preaching and baptizing. But when the network of a great religious system might have been advantageously woren, he was, unfortunately, removed. He was no recreant to his duty in following his widowed mistress. Had it not been for her he never would hare reached Northumbria at all, and now he was bound to protect her by the most solemn obligations that loyalty and gratitude could suggest. But why did he not return, it may be asked, when Oswald became king? It must be remembered that it was some time before the influence of Oswald extended into Deira. Panlinus was becoming an old man, and would he be wise in returning to a district where security, perhaps, was not firmly re-established? IIe would be less able to work than before, and in addition to this, was not the necessity for his return removed to a great extent by the exertions of Aidan and the monks of Lindisfarne? We must remember, also, that James the deacon was still his deputy in Northumbria. Paulinus, however, was not idle after lie left the North, and he never shrank from the hard path of duty. Hlis position in the South was, indeed, a humbler one, but, as fuller charmingly observes, "he minded not whether he went np) or" down hill, whilest he went on strait in his calling to erlorific God and edifie others; sensible of no disgrace, whein degrading himself from a great arehbishop to become a poor bishop. Such betray much pride and peerishness, who, outed of cmincut places, will rather be nothing in the church, then any thing lesse then what they have heen before."

The bishoprie to which the quaint historian alludes was that of Rochester, which Panlinus aceppted at the request of Ilonorius and Eadbald. ${ }^{x}$ We know little, hencefon'ward, of his mis-

w Fuller's Ch. Hist, book ii., 77. Cf.

Wm. of Malmesbury, apud Sarile, 132; and JIarpefeld, Hist. Angl., (it.

x Berla, ii., 20. Saxon ('luon.. 35. 
sionary work. He was a great bencfactor to the monastery of (ilastonbury, rebuilding the church and covering it with lead, and we are told that he lived some time within the walls of that ancient house." He died on the 10th of Oetober, 64t,z and was interred in the secretarium or chapter house of the church of St. Andrew at Roehester which king Ethelbert had built. ${ }^{a} \mathrm{He}$ was commemorated by the following epitaph.

\footnotetext{
"Siste gradum, clama, "Ini perlegis hoc epigramma, Paulium plora quem subtraxit brevis hora Noljis per fumns: de presulibus fuit unus, Prudens, veredicus, constans et firmus amicus. Anni sunt rati Domini super astra regentis Quadraginta dati quatuor cum sex quoque centis."'
}

The name of Panlinus was placed in the calendar after his decease, and he beeame the great patron saint of Rochester. ${ }^{c}$ Arehbishop Lanfrane translated his remains, and deposited them in a silver shrine which he presented to the ehureh, giving at the same time a cross to hang over the feretory. ${ }^{l}$ Among the relies in the minster of York were a few of his bones and two teetlı.e The monks of Durham wrote his name in golden letters in their Liber Vita. $f$ He had never been a benefactor of theirs, for in Beda's day and long after it, there was " nulla cognitio Dunehmi,"g but they gratefully commended him to God as one of the earliest Christianizers of the North.

Rioger of Wendover, i., 81. Hist. Mon. S. Ang. Cantuar., 173. Rild. de Diceto, col. 138. Stubls, rol. 1688. Reg. Rotfonse, 1. Ined. Mon., i., 152. Weever's Fumerall Mon ts., 310. Mabillon, Ann. Ben., i., 360. Giamar, l'estorie des Engles, apul Mon. Hist. Brit., 779, says,

'Eadhald li reis bien les recuilli, Mult honora l'aulins e joi.

Guant arecivesque ne poit estre, livesilue en fit a lioncestre."

y Wun. of Malmesbury, apud Giale, i., 300. Hugd. Mon., i., 3.

z Saxon Chron., 38. Flor. Migom., 237. Anglia Sacra, i., 15., 3\%1. Asserii Inn., apud Gale, i., 114 . Hist. s. Alsust. Cant, 182. Roger of $W^{r}$ en- dover, i., 87, gives the date 616. Hermanni Contrati Chrou., apud Canisii Leet. Ant., iii., 23\%. Baronii Amn., viii., 365. Mabillon Ann. Ben., i. 388.

"Angl. Sacra, i., 154. Lell. Coll., iv., 81. Reg. Roffense, 22.

$b$ Weever's Funerall Monts., 310,11; and I)ugd. Mon.,i., 152, from a metrical (hron. Archiej. Ebor. inter MSS. Cotton. Chron. S. Aug. Cantuar., 182.

c Malmeshury, apud Savile, 132. Reg. Roffense, 33. Acta SS, sub. Oct. 10.

Capgrave's Nova Legenda SS., 264-5.

d Reg. Roflense, 126.

" Fabric rolls of York minster, ed. Surtecs Soc., 151.

$f$ Publ. by Surtees Soc., p. 7.

g Flor. IVigroru., 368. 
Ga्adra, or Chand, for I shall give him the name by which he is generally known, was one of those holy and apostolie men of whom the early chureh had so much reason to be proud. 11 . was, probably, a native of Northumbria, ${ }^{h}$ and was the yomgest of four brothers, ${ }^{i}$ Cedd, Cynibill and Calin, all of whom were priests, ${ }^{j}$ the first of them being the bishop of the East Saxons whom he converted to the Christian faith.

Chadd first beeame acquainted with the monastic life m Ireland. ${ }^{k}$ He was, subsequently, an inmate of the monastery at Lindisfarne, and was one of the twelve pupils under the guidance and instruction of the venerable Aidan.? He was educated, therefore, in the tenets of the Scottish school which had been brought to that place from Iona.

About the middle of the seventh century, bishop Cedd, by the permission of Ethelward, king of Deira, founded the monastery of Lastingham near Kirkbymoorside, in aceordance with the Scottish rule. ${ }^{m}$ The remains of that little sanctuary may still be seen. They are standing on the slopes of a long hill that looks towards the North, and the heather ereeps up towards its foot as if it were envious of the bright green turf that lies in the hollow below the chureh. Solitary is the village now, and solitary it must have been at all times. In that little shrine are resting the bones of the evangelizer of the East Saxons, and to the cell which once stood near it came the venerable Beda to learn from the brethren of the louse how their two first abbats, Cedd and his brother Chadd, had lived and died."

In the year $66+\mathrm{Cedd}^{\circ}$ went to his rest at Lastingham, having previously commended his infant monastery to the charge of his brother Chadd, who sneceeded him as abbat.p Of Chadd's rule at Lastingham there is very little known. Beda tells us

${ }^{h}$ Beda, iii., 23, speaks of Cedd's custom "suam, id est Nordanhymbrorum, provinciam revisere," from which Dr. Smith infers, and reasonably enough, that it was his patria.

i Bollandists, Acta SS., March 2, where there is a short account of Chadd compiled principally from Beda. Cf. Lel. de Script. Brit., i., 78.

j Beda, iii., 23.

${ }^{k}$ Beda, iv., 4. Eddii vita S. Wilfr., apud Gale i., 58. Flor. Wigorn., 246. Higden, apud Gale, i., 186.

i Beda, iii., 28. Symeonis Hist. Ecel. Dunelm., 29. Bromton, col. 788. Mabillon, Ann. Ben., i., 557.

n Beda, iii., 23. Flor. Wigorn., 239.

$n$ Beda, pref. to history. Cf. ibid., iii., 23.

The names of the two brothers are frequently confused, especially by Hen. of Huntingdon and Bromton. Fuller (Ch. Hist., bk. ii., 83) quaintly observes "though it be pleasant for brethren to live together in mity ; yet it is not fit by errour that they should be jumbled together in confusion."

p Beda, iii., 23. Flor. Wigorn., 241, Bromton (col. 789) says, that Cedd died "tempore mortalitatis," and probably, therefore, of the great plague, and Henry of Huntingdon (Savile $190 \mathrm{a}$ ) in addition to this makes the incorrect statement "eni successit in episcopatu frater ejus Ceadda." Durd. Mon., i., 312. 
how a party of thirty brethren became the inmates of that house, whilst he was there, ont of love to their old master, crdd, who hatd placed them in a monastery in his diocese. The period of their sojoum at Lastingham was but short, as the whole pinty, with the execption of a little boy, was cut off by a pestilence.?

The rear (6) wituessed the great struggle between the Roman ind the Scottish partics, and Chadd, donbtless, would be deeply interested in the controversy and its result. He would little think, howerer, that it would effect so great a change in his own life and fortunes. The decision of the royal president of the comcil of Streonshal gave snch oflence to bishop Colman and the Scottish monks, that that prelate, accompanied by a number of his adherents, retired from Northumbria. This was probably an nmexpected trimmph to the Roman party, which were strong cnough, soon afterwards, to advance their leader, Wilfrid, to the northem primacy. Wilfrid refused to be consecrated by the British bishops, and on that account, by the permission of Alchfrid, the prinec-regent of Deira, he went abroad to receive that rite in France. During his absence the Seottish party were not idle. They gained the car of Oswy, the king of Northumbria. They could not forget the injury that Wilfrid had done to them at Streonshal, and the insult that he was now offering to the native prelacy by sceking consecration in France. They would endearour to aronse suspicions in Oswy's mind against his son, Alehfrid, who was only his deputy in Deira. They commented sererely upon the injury that Northumbria was sustainimg by Wilfrid's prolonged and maccountable absence.r Oswy, who, in all probability, had nerer expected that Colman would desert his sce, was influenced by them. He prevailed upon the humble-minded Chadd to leare his cell at Lastingham and to become bishop of his province. With great adroitness he placed the seat of Chadd's episcopate, not at Lindisfarne or IIexham, but at York. Thus there was no room for Wilfrid. Alchfrid conld not introduce a second bishof, into Deira, and with Bernicia he had nothing to do.t

Chadd was thus placed in a position for which, however alicu to his disposition, his piety and humility peeuliarly fitted him. His appointment would be regarded as a party trimmph; for although cedd, betore he died, renomeed the Scottish

"Beda, iii., 23.

- Eadmer, Tita Wilfridi, apud Acta Ss. ord. S. B. sice tert., i., 203. Ric. of Hexham, col. 294. Fuller's Cl. Hist., bk. ii., 86. Wright (Mios. Lit., i., 173) says that Wilfrid was abroad for three years.

- Stubbs, col. 1689. Fridegodus, Titas. Wrilfr., alud Acta SS. ord. S. B. ser. tert., i., 179. t Beda, iii. 25, 27. 
mode of observing Easter," we are told that Chadd did not relinquish it. ${ }^{r}$ At the request of Oswy, the bishop-eleet went to seek for consecration at the hands of Deusdedit, but on his arrival in Kent he found that that prelate was in the tomb. What was to be done? Wina bishop of Winchester was at that time the only prelate in England who had been consecrated aecording to the Roman ritual, and to him Chadd went." Wina ealled in to his assistance two of the British bishops who still adhered to their old method of observing Easter, and the ceremony took place. This was the first oceasion on which British and Roman bishops were associated together. I cannot think that there would have been any union eren at this period, if the Welsh bishops had not thought that by their assistance they were cheeking the dreaded and impetrous Wilfrid. In Chadd they knew that they had a brother, and their presence at his consecration was at the same time a tribute of respect to the simplicity of his eharacter and the purity of his life.

Chadd was now bishop of York, and the spiritual ruler of Northumbria, and he was not unequal to the requirements of that high office. He had none of the restless energy and fiery zeal of Wilfrid, but he surpassed him in all those gentler virtues which should bud and blossom in the true Christian's heart. More congenial to his quiet and retiring disposition would have been the purple heaths and the silent woods of Lastingham, but his was a spirit capable of adapting itself to any position, busy or secluded, to which the path of duty guided it. Every ancient writer speaks of Chadd with reverence and affection. Gentle he was, and amiable, illustrating by his blameless life the holy rule that he taught others to abide by. The Scriptures were his constant study and his guide. In his management of his diocese, the lives of his old master Aidan and his brother Cedd were his exemplar. There was no place that lie did not visit on his missionary journeys. If he passed through the gateway of the hall he did not despise the hovel of the serf,

"Beda, iii., 26. Flor. Wigorn., 212.

v Beda, iii., 28. Eddius, Tita S. Wilfr., apnd Gale, i., 58. Mabillon, Ann. Ben., i., 478, says, that Oswy summoned Chadd out of Ireland, and Colgan, on that account I suppose, makes Chadd an Irish saint. Trithemins calls Chadd a Benedictine! (Acta, SS., Bollandists, Mar. 2).

w Asser (Gale i. 146) says that Chadd was consecrated in 654 . The nsual date is 664 , and it is assigned by the following anthorities, Beda, iii., 28 ; Saxon Chron., 48; Roger of Wendover, i.,
98; Flor. Wigorn., 211; Hene. of II minting apud Savile, 191, $b$; Ric. of Hexham, col. 293; Bronton, ibid., 789 ; Gerrase, col. 1636 ; Stubbs, ibid., 1689; Chron.S. Crucis, ajurl Ausl. Sar., i., 155. Rad. de Viceto (col. 1391) places the ronsecration in 665 , and it must be remembered that $A$ silbert, by whom Wilfrid was made a hishop, wis not promoted to the see of P'aris mutil 665 (Mabillon, Ann. Ben., i., 178). ('f. Hist. Mon. S. Ane. Cantuar., I97: and Eadmer, Vita S. Wilf., apud Acta SS. ord. S. B., sac. tert., i., 203. 
travelling always on foot from place to place like the holy men of old..$^{x}$

It must liave been rery galling to Wilfrid on his return from liance to find himself deprived of his expected see, and one of the Scottish party in his room. It was useless to make any opposition, and he shewed his discretion by remaining quiet in his monastery at lipon, excreising his episcopal functions in the pastorkess distriet of Kent, and elsewhere, whenever his serviecs were required." In 669 'Theodore came to England as metropolitin, and was soon actively engaged in measures of reform. Ile paid espccial attention to the episcopate, and he would soon come into contact with Chadd. ${ }^{z}$ Chadd, it must be remembered, had no pall, he was only bishop of York; so that the rule laid down by Gregory abont the independence of the two metropolitan sees was not now in force, and Theodore knew that w ell. Indecl, from the power that he seems to have exercised in the North I have actually found him invested with the title of archbishop of York, ${ }^{a}$ an honour to which he had no claim. Chadd and Theodore, the Briton and the Greek, meet face to face, and the contrast is a striking one. Both were men of piety and goodness, but the respect of Theodore for Chadd would be lessened by the idea that he had taken possession of Wilfrid's see, and that he had been consecrated in an irregular manner. ${ }^{b}$ He hesitated not to tell Chadd what he thought, and possibly, with some asperity. The reply that Chadd made, "humillima voce," was characteristic of the man. "If," said he, "I have not been consecrated in due form, I willingly resign my office; I never at any time deemed myself worthy of it, but at my monarch's bidding I accepted it, inworthy as I was, for it was my duty to obey him." Any latent pique that there was against the speaker in 'Theodore's mind, must have been driven away by this reply. "The soft answer turneth away wrath." He answered, that he ought not to resign lis see, ${ }^{d}$ but Chadd's determination was made. leace and quict had been the object of his life, and he would seck them now. Ile voluntarily gave up his hishopric in favour of Wilfrid, ${ }^{c}$ and returned with pleasure to his old home at Lastingham ${ }^{f}$

It has been said that Chadd was removed from his see, ${ }^{g}$ but

" Berla, iii., 28. Hist. Mon. S. Ang. Cantuar., 197. Gervase, col. 1637. Mabillon, Am. Ben., i., 557.

y Berla, iv., 2. Eddius, ajud Gale, i., 58. Biromton, col. 789.

z Beda, iv., 2. Eldius, 58, 59.

"Vita S. Cuthberti, apud X Ser., $67,70$.

b Beda,iv.,2. Fddius, apud Gale, i.,59. c Beda, iv., 2. Rad. de Diceto, col. 439 ; Bronton, col. 789.

d Beda, iv., 2.

- Eddius, ajud Gale, i., 59.

$f$ Beda, iv., 3. Flor. Wigorn., 244. Eadmer, apud Acta SS. ord. S. B. sæe. tert., i., 205. Hic. of Hexham, col. 293; Stubbs, col. 1689. Anglia Sacra, i., 426. g Some writers say that Theodore 
the whole of Theodore's conduct towards him seems to contradict this assertion, and he had not the power to displaee him withont the consent of Oswy, even if he had had the wish. It would be equally unfair to eharge Wilfrid with intrigue beeanse he stepped into Chadd's place. It was only proper that he shonld sueceed him. A man to whom a bishopric had been pronised, and who, when he had lost it, had laboured patiently for three years in another and a humbler vineyard, deserved to be thus rewarded. The meekness of Chadd indueed him to give way, and is he to be blamed for it?

This change took place in $669,{ }^{k}$ and Chadd returned to Lastingham. His days, howerer, were not to end in that secluded monastery. Jarumman, the bishop of Mereia, died about this time, and Wulfhere, the king of the provinee, requested Theodore, to whom he was greatly attached, to fill up the vacant sec. Theodore, unwilling to conseerate a new bishop, named Chadd, ${ }^{i}$ whom he had never forgotten, to the king, and he with the assistance of Oswy and the arehbishop induced the humble-minded recluse to accept the proffered honour. ${ }^{j}$ It was then, in all probability, that yielding to the solicitations of 'Theodore, Chadd was re-ordained "per omnes gradus ceclesiasticos." ${ }^{\prime}$ The propriety of the step may be questioned, but it shews how anxious Chadd was for peace and mity.

If the old traditions of the abbey of Peterbrongh are true, there was a comnection between Wulfhere and Chadd, or his brother Cedd, which easily aceounts for Wulfhere's wish to make Chadd the bishop of the Mercians. The legend says that he was converted by him.' The king had two sons, II ulfade and Rufine. Wulfade was a mighty hunter, and was pursuing

removed Chadd, i.e., Eddius, 59. Fridegodus, apud Acta SS. ord. S. B. sxe. tert., i., 180. Roger of Wendover, i., 99. Wm. of Malmesbury, apud Savile, 147, $b$; Ric. of Hexham, col. 293, and Anglia Sacra, i., 65. Eddius, however, in another place, says that Wilfrid's appointment was made with Chadd's consent. Cf. Mabillon, Ann. Ben., i., 495.

${ }^{h}$ Chadd is said to have been bishop of York for three years. Symeon de Arch. Ebor., col. 78. Stubbs, col. 1689. Rites of Durham, publ. by Surtees Soc., 43 .

$i$ Beda, iv., 3. Eddius, 59. Inen. of Huntingdon, apud Sarile, 191, $b$. Bromton, col. 789-90. Eddlins says that Wulfhere promoted Chadd to Lichfield at the request of $W$ ilfrid. Malmesbury (Savile, $148, b$ ) says that Wilfrid aided Chadd to Lichfield, "suffragio suo," alluding probably to some council. j Beda, iv., 3. Eddius, 59. Eadmer, ut silpra, 205. Bromton, col. 789-90. Gervasius, col. 1638. Lyfe of Saynt Werburge, 21.

"To graunt them a bysshep of holy lyvynge, To governe the people by spyrytuall techynge, To shewe to his subjectes the ensample of vertu, And to preche and teche the fayth of Chryst Jhesu."

${ }^{k}$ Cladd's re-ordination, or perhaps, the completion of his previous conseeration, is alluded to in Beda, iv., 2. Eddins, apud Gale, i., 59. Flor. Wigrorn., 215. Gervase, eol. 1638.

'Appendix to Smitl's Beda, 7.15. Gunton's Church of P'eterbro', 10\%, etc. I.el. Coll., i., 1, 2. Fuller's Ch. Hist, book ii., 81. Gunton $(2,3)$ salys that II ulfhere was converted by Finau. Lyfe of Saynt Werburge, 10-6. I say notling of the story of Chadd lianging his carment on a sumbeam ! 
a stag one day when it led him past the cell in which Chadd was living the life of a hermit. The story is a heautiful one, and it was told in nine of the old windows in the west cloister at Peterbrough."

"The hart brought Wulfade to a well

That was besyde Seynt Chaddy's cell.

"Wulfade askyd of Seynt Chad,

Where is the hart that me hath lad?

" The hart that hither thee hath brought Is sent by Clirist that thee hath bought.

"Wulfade prayd Chad that ghostly leech The faith of Christ him for to teach.

"Seynt Chad teacheth Wulfade the feyth And words of baptism over him seyth.

"Seynt Chad devoutly to mass him dight, And hoseled Wulfade Cliristy's knight."

Wulfade induces his brother Rufine to be baptized, and the end is that the brothers were surprised by their father in Chadd's eell and were killed by him. Remorse, however, followed, and the penitent sire adopted the faith of his murdered children, at the instance of Ermenilda his queen.

"Wulfere contrite hyed him to Chad

As Ermenyld him counselled had.

"Chad bade Wulfere for his sin

Abbeys to build his realm within.

"Wulfere endued with high devotion

The abbey of Brough with great possession."

I mention this story merely as a legend, but it is too pieturesque to be disearded. It is quite possible that there are in it some shadows of the truth. It is not known at what period of his life $W$ ulfhere became a Christian. Chadd may, perhaps, have lived a solitary life in Mercia, and may have converted its monareh. At all events, when he became bishop at Lichfield, he had a fast friend in Wulfhere, who gave him a pieee of ground, large enough to maintain fifty families, on which he was to ereet a monastery at a place ealled Ad Barue. ${ }^{n}$

The seat of the bishoprie of Mereia was at Liehfield, and Chadd had an immense diocese extending over a great portion of

mestroyed in 1603. Cf. Gunton, $337-8$

" Beda, iv., 3. Flor. Wigorn., 246. Bromton, apud X., Scr. col. 790, Ma- billon Ann. Ben., i., 557. Dr. Smith, the learned editor of Beda, thinks that All Barue may be Barton on Humber. It is, rather, Barrow. 
the Midland counties. ${ }^{\circ}$ He ruled over it for two years and a half, ${ }^{p}$ and illuminated it with those virtues which distinguished him in the North. ${ }^{q}$ His good deeds and his holy life are not yet forgotten. His journeyings in his dioeese were all made on foot, and it was with difficulty that arehbishop Theodore, who was struck by his simple piety, prevailed upon him to ride, and helped him to mount his horse with his own hands." He might well be proud of such a suffragan as Chadd.

The story of Chadd's end is given by Beda ${ }^{s}$ with all that power of description for which he is so remarkable. He lived, the historian tells us, near his chmreh at Lichfield, and there were with him seven brethren, with whom, when their labours were over, he would read and pray. In addition to these seven there was a monk of the name of Ouini. ${ }^{t}$ He had been in old days one of the suite of the queen in the court of East Anglia, and having given up all for Gor when his fortunes were at their height, had gone in the dress of a humble labourer to live with Chadd at Lastingham. Thenceforward there was between him and his master a bond of mion that was knit together by common feeling and mutual regard. One day at the end of February, whilst the brethren were at their devotions in the chureh, and Chadd was in his cell at prayer, Ouini was away from them. Suddenly he heard the sweet roices of a celestial choir "descending as from heaven," and singing as they came. Jubilee there was there, and not a note of sadness. His eye could discern nothing whilst his ear was drinking in the melorly. The band seemed to hover around the little oratory in which Chadd was praying; it entered in, and, after a while, pouring forth a still more glorious burst of music, it passed away as it came, and the strain

"Then seemed to go right up to heaven and die among the stars."

As Ouini was musing anxiously on what he had heard, the window of the little cell was opened, and his master summonerl him with his accustomed signal. "Haste," he said, "to the church, and call to me my seven brethren, and come with them

o The title given to him was, "Merciorum et Lindisfarorum episcopus ;" Lindisfarorum referring to Lindsey. Beda, iv., 3. Flor. Wigorn., 216. Gervase, col. 1638.

" Beda, iv., 3. Anglia Sacra, i., 425-6. Stubbs, col. 1690 .

$q$ Beda, iv., 3 .

r Beda, iv., 3. Gervase, col. 1638.

$s$ Beda, iv., 3. Beda's affection and veneration for Chadd's memory seem to have been very great. Ite records several traits in the life of the saint which are onitted here.

- In Ely cathedral is a portion of a eross which was found in the adjacent village of Ifadenham, bearing the following inscription, " + . Lacem turm Ovino da, Deus, et requiem. Amen." It is supposed that this was the friend of Chadd. Ouini was commemorated in the Benedictine Martyrology on March 11. Cf. Bentham's Ely, 50, 51. 
thyself." And when they came, he bade them live together in love and holiness, and told them that he should soon leave them. "The sweet stranger that has visited our brethren has come to me to-day, and I have had my summons. Go, bid the bretluren in the ehurel commend me to the Lord, and let them never forget that they must die themselves." Hallowed by his blessing and sad at heart they went upon their errand, but Onimi returned, and prostrating himself' at his master's feet, begged of hm imploringly, "Tell me, father, tell me, if I may ask, what melody that was which I heard." "Heardest thou that?" said Chadd to him. "I eharge thee in the Lord's name to speak of that to no one before I die. Thou didst hear the voices of the angels bidding me to those joys of heaven that I have loved and longed for always. In seven days they shall be mine, for they shall then come for me."

"So now I think my time is near. I trust it is. I know

The blessed music went that way my soul will have to go."

Seven days after this prophetic amouncement, on the 2nd of March, 672," he was taken to his rest; and was it a wonder, says Beda, "si diem mortis, vel potius diem Domini lætus aspexit, quem semper nsque dum veniret, sollicitus curavit." $A$ life like his, hallowed by the praetice of every virtue, humble, prayerful, and self-denying, had generated that perfect love of God by which fear is driven out.

"With as much zeal, devotion, pietie.

He always liv'd, as other saints do die."

And when his summons came, as Eddius beantifully observes, "tempore opportuno in riam patrum exegit, expectans diem Domini in judieio rentmo, ut eredidimus sibi mitissimum, sicut dignum est."'w"

They inuried him at Liehfield, near the church of St. Mary, ${ }^{x}$ by the waterside; and when a fairer temple, dedicated to St. Peter, was erected, they enshrined his remains within it in a feretory of wood. Miraculous powers are said to have belonged to them eren in Beda's days, ${ }^{z}$ and in after ages the renown of Lichfield and its wonder-working shrine was very widely spread. ${ }^{a}$ A place was fomnd for Chadd in the calendar, and his day is the 2nd of March. ${ }^{b}$ In the Sarm and Aberdeen breviaries there was an office appropriated to him, ${ }^{c}$ and his life was

"Beda, iv., 3. Flor. Wigorn., 216. Peterbro' Chron., 2.

" Beda, iv., 3.

* Eddius, apud Gale, i., 59.

$x$ Beda, iv., 3.

y ILickesii Dissert. Ep., 118. Lel. Coll., iv., 80.

$=$ Beda, iv., 3 .

"Hen. Huntingdon, apud Savile, 191, b. Bromton, col. 790 .

${ }^{b}$ Acta SS., Bollandists, Mar. 2, where there is a short life of Chadd compiled principally from Beda.

"Acta SS. 
inserted in the Nova Legenda. ${ }^{\text {Prond }}$ of his having been brought up at Lindisfarne, the monks of Durham inscribed his name in golden letters in the Liber Vite of their ehurch ${ }^{e}$ and in one of the windows in the Gahilee of their cathedral was Charld's portraiture "in fyne coulored glass, as he was acenstomed to say masse, with his myter on his head, and his erosier stafle in his lefte hand exquisitelie shewed."'f At Lichfield a text or evangelistarium, said to have been Chadd's, is still preserved."

WI ilfrio, a very great name in the ceclesiastieal annals of the North of England. He was, I belicre, a native of Northumbria, and his parents are said to liave been persons of some consequence and position. ${ }^{h}$ I pass by the marvels that are said to have attended his birth, which occurred, according to Eadmer, in 634, but probably, a little earlier. When he was thirteen years of age he was precocious enough to wish to desert his home, and to devote himself to God's service. The mainspring of this desire was probably the harshness of his step-mother, who was not slow to encourage him in his design. She gave him and his companions everything with which boys would be delighted, arms, horses, and brave attire, all that would set ofl a comely youtl, and produce a favourable impression at the court, for thither would each aspirant after a name bend his steps. Eanfleda was then the queen of Northumbria, and to her notice was Wilfrid introduced. He soon won her favour, for even at that early period of his life Wilfrid seems to have been a courtier. Cudda, an aged and faithful member of the royal household, retired to Lindisfarme to spend the remainder of his days, and with him the youth was sent. In that secluded monastery the boy became a favourite

\section{"Ineensa pietatis ardor Prodidit sese, mieuitque primo Flore juventr."}

He was a zealons and an attentive student. He committed to memory the whole of the Psalms aceording to Jerome's ver-

d Capgrave, 58, 59.

- Publ. by Surtees Society, p. 7.

$f$ The Rites of Durham, publ. by Surtees Soeiety, p. 43.

8 Nichol's Literary Anecdotes, i., 86. Among the MSS. of Fr. Jumius in the Bodleian library, 5136, is a Sixom
Homily, "In natale S. Ceadde Episc." (Smitli's Cat.)

${ }_{h}$ Eddii Vita S. Wilfr., apud Gale, i., 4. Wm, of Malmesbury, apud Savile, $117, b$. Eatdmer, Vita š. Willir., apud Acta ord. S. B., iii., seec. i., 198. 
sion, together with sevcral other books, and he won the hearts of all by his docility and gentleness. ${ }^{i}$

Year's passed away, and Wilfid was still at Lindisfarne, but a comminding spirit such as he possessed conld not brook the idea of a life-long exchusion in that solitary island. Ambition wats a stranger to those simple hearts that beat around him, but Wilfrid was longing to see more of that world which the holy brotherhood had renomineed. He had mastered himself, and now he would finin master others. Far away across the angry seas that surrounded him, and beneath softer skies, there was at rity of which he would often hear, and a mind like his would never be wearied with the recital of its present and departed ghlorics.

\section{"The city, that by temperance, fortitude, And love of glory, towered above the clouds, Then fell-but, falling, kept the highest seat, And in her loneliness, her pomp of woe, Still o'er the mind maintains, from age to age, Her empire undiminished."}

Everywhere the young scholar would hear with rapturc of the light that had radiated in all ages from the eternal city. Oh! that he could, visit the limina Apostolorum, and behold the hallowed shrines of which such great things were spoken! To Rome, therefore, he resolved, if possible, to go.j

His royal patroness, Eanfleda, encouraged him in his design, glad, perliaps, to rescue her favourite from the hands of the Scottish monks. She sent him to her kinsman, Erconbert, king of Kent, who gave the yonth a kindly welcome, and recommended him to tarry at his court till he eould find companions for lis jommey. During lis stay in Kent he neutralized the effeet of what he had been tanght at Lindisfarne by learning the Psalms after the fifth edition of the Roman use. Wearied at length with the delay, he set sail from England in 652. He went with a single companion, Benedict Baducing, who is better known by the name of Benediet Biscop. ${ }^{k}$

Lyons was the first place at which the pilgrims halted. A prelate of the name of Dalfinms is said to have oceupied at that time the chair of Ireneus, and in him Wilfrid found a most sincere fricnd. Dalfinus did all he could to induce his guest to

- My anthorities for this paragraph are Eddius, nt supra, and $1 T \mathrm{~m}$. of Milmesbury, Stubbs. col. 1690, Eadmer, ut supu, 198; and Fridecodus, Vita S. Wilfr., annd Aeta SS. ord. S. B., iii., siec., i., 172.

j Edlin: 11. Bella, v., 19. Eadmer, 198. Fridegodus, 172. William of Vianesbury, alud savile, 148.

s Beda, v., 19. Eddlins, 41-5. Fri- degodus, 173, who says that he was in Kent "triquadro anno." Ladmer, 199. Stubbs, 1690, Malmesbury, 148.

$l$ Mabillon observes that no such prelate as Dalfinus occurs in the Fasti of Lyons, and he conjectures, probably enongh, that the bishop here mentioned was Annemundus. Dalfinus' comes was the brother of Annemundus, and henee the error. Act. Ben. i., 443. 
remain with him; he offered to adopt him as his son-to marry him to his niece ${ }^{m}$ - to make him gorernor over a part of (i ianlbut it was all in vain. Wilfrid's face was set towards liome; and to Rome, after a long but necessary delay, did he make his way. ${ }^{n}$

We can well imagine the enthusiasm with which the pilgrims would gaze upon the eternal eity. An ardent mind, such as Wilfrid possessed, might indeed think with the poet,

\footnotetext{
"I am in Rome! Oft as the morning ray

Visits these eyes, waking at once I cry,

Whence this excess of joy? What has befallen me?

And from within a thrilling voice replies,

Thou art in Rome! A thonsand busy thonghts

Rush on my mind, a thousand images;

And I spring up as girt to run a race."
}

The piety and earnestness of Wilfrid soon attracted the attention of an archdeacon, of the name of Boniface, who fom in the youthful Saxon a ready and intelligent scholar. Ile taught him the rules and customs of the Roman ritual, and shewed him the correct mode of observing Easter. ${ }^{o}$ He explained thoroughly to him the four gospels, and, pleased with his pupil, he introduced him to the pope, who laid his land upon the young scholar's head and blessed him. Wilfrid's attachment to the Scottish system wonld be on the wane when he left Rome for Lyons, and on his arrival in that city he reccived the tonsure, after the Roman fashion, from Dalfinus, who completed the conrersion which Boniface had begun.? Wilfrid remained with the good prelate for three years, ${ }^{r}$ and would in all probability have been his heir, had not his patron lost his life in a persecution raised by Baldhild, the widow of Clovis II.s The church of Lyons may well glory in its martyrs. Dalfinus was added to the noble list, and Wilfrid was all but suffcring with him. "Who is that fair youth that is making himself rcaly for death?" was the question of the murderers. "A Saxon from Britain," was the reply, and then came the unexpected rejoinder, "Let him go, and touch him not."'t There was still a great work for the youthful confessor to perform!

In 658 , after an absence of five ycars, Wilfrid returned to

"' A son of Wilfrid is mentioned by Eddins and Frithegode, but he was only an adopted child $(61,85$.)

$n$ Beda, v., 19. Eddius, 45. Eadmer, 199. Fridegodus, 173. Malmesbury, 148.

- Beda, v., 19. Eddins, 45. Eadmer, 200. Stubbs, col.1690. Malmesbury, 148.

$p$ Eddius, 45-6. Firdegodus, 171.
Eadmer, 200. Malmesbury, 148.

2 Berla, iii., 25. Eddius, 46.

r Edlius, 46. Stubbs, col. 1690.

- There is a difliculty here, as Bathildis was a good Cliristian; other MSS. rearl lirunichildis. Cf. Mabillon, Amm. Ben. i., 413.

${ }^{t}$ Bedli, v., 19. Eddius, 46. Eadmer, 200. Fridegrodus, 175 . 
Fingland. Great changes had taken place whilst he was abroad. In Northumbria Alcfirid was now, under his father Oswy, the ruler of Deira. II is friend, Coenwal, king of the West Saxons, latd persmaded him to adopt the riews of the Roman party, ${ }^{u}$ and it was with no little joy, therefore, that Alcfrid heard of the return of Wilfrid. What an opportunity for the dissemination of the opinions which he had adopted! He begged Wilfrid to come to him, and the missionary was ready enough to obey. Alcfrid did everything to induce him to reside permanently within his kingdom. He became, as it were, his scholar. ${ }^{v}$ He wave him lands in East Stanford, ${ }^{w}$ and, soon after, the monastery of Ripon. Over this house Wilfrid was abbat, and introduced within its walls the Benedictine rule, ${ }^{x}$ the Scottish monks retiring at the accession of their new superior, rather than give up their views. ${ }^{y}$ Wilfrid directed the establishment for at least five year's, at the close of which period he was ordained a priest by Agilbert the French bishop of the West Saxons, at the request of Alefrid, in the monastery of Ripon. ${ }^{z}$

This event seems to have occurred in 664 , a year in which great changes took place in the Northumbrian church. The painful contrast between the Scottish and the Roman party was becoming every day more discernible, especially in the observance of Easter. In the Northumbrian court there was, on this point, a most ammoying discord. King Oswy, who had been brought up and baptized by the Scottish monks, whose language he also spoke, observed their method of keeping the great festival, but Eanfleda his queen, with her suite and Romanus her chaplain, followed the Roman rule. Thus, in point of fact, the festival might be celebrated twice in the same year in the same court, and whilst the one party was full of joy at the arrival of the amniversary of the resurrection, the other might be still observing the fasting and the humiliation of the solemn period that preceded it. Something elearly ought to be done to remedy the seandal and the discrepancy. The Italian party was gaining strength, and resolved to suppress the eril against which it contended. It had among its supporters the queen and Alcfrid, the regent of Deira, who was under the influence of Wilfrid. A gilbert was ready to give his assistance, for he had been dis-

4 Eddins, 46.

"Beda, iii., 25.

Eddius, 46. Eadmer and Fr., nt supra, limger of Tendover, i., 96.

w Beda, v., 19, who gives the date 661. Eddius, 47. Wright, Biog. Lit., i., 170. Dr. Ifaigh thinks that the place is Stamfori, co. lincoln. Cf. Arch. El. n. s., i., 161 .

* Beda, iii., 28; ir., 11. Ilist. Mon.
S. Ang. Cant., 198-9. Preface to Fridegode'slife of Wilfrid, apud Acta SS. ord. S. B., iii. ssec, i., 170 .

$y$ Beda, iii., 25. Gervasius, apud X Scr., col. 1636. Roger of Wendover, i., 96 , gives a rather different acconnt.

Beda, iii., 25. Eadmer, 201. Fridegodus, 176. Wendover, i., 97. Stubbs, col. $\mathrm{j} 690$. 
placed for a while from his see by a Scottish bishop. King Oswy is induced to summon together a council at Streonshal to settle, if possible, the points in dispute, and to come to some unity in practice.

On the one side was Colman the Northmmbrian bishop, with his Scottish clergy, the abbess Hilda and bishop Cedd; on the other, were Agilbert and his priest Agatho, Wilfricl, James the deacon, the fellow-worker of Panlinus, and Romanus. Cedd acted as interpreter between the two parties, as they spoke different languages.

The arguments made use of and their result are so well known that it is unnecessary to repeat them here. Colman grounded the practice of his party in keeping Easter, on the anthority of St. John the Divine and Columba. Wilfrid, the spokesman of the other sicle, elaimed the countenance of St. Peter. Peter, as Wilfrid asserterl, was the rock upon which Christ had built his ehurel, and to him had been given the keys of heaven. The argument was a fallacious one, but Oswy was unable or unwilling to see its defects. "Is it true," he said to Colman, "that our Lord said that to Peter?" Colman could but assent: and then the monarch resumed, "Can you shew that any such authority was given to Columba?" "He could not say that. "Do you then both agree that Peter received the keys from our Lord?" They assented. "If it be so," said Oswy, "I cannot gainsay the power of him that keeps the keys, 'for' fear (as he said) lest coming to heaven-gate, St. Peter should deny him a cast of his office, and refuse to let him into happiness." "' The reply, seemingly given half in earnest half in jest, pleased the bystanders, and Colman, to his great disappointment, found himself the loser, it having been arranged at the commencement of the sitting, that the defeated party should alter its practice. The tone of levity which the king had assumed would be more galling, perhaps, to Colman than the adverse decision, and he took a step which in more sober moments he would, probably, regret. He practically contemned the decision of the monarch by which he had promised to abide, and, deserting his diocese, retired erentually with his monks to Ireland. ${ }^{b}$

Wilfrid's victory was thus complete; indecd, it would be far greater than either he or Alcfrid could have possibly anticipated. The field was now their own. A person of the name of Tuda was appointed to succeed Colman, but he oecupied the 85 .

a Fuller's Church History, book ii.,

${ }^{b}$ An aecount of the whole conference is given in Beda, iii., 25. Eeldius,
56. Farmer, 201, 2. Fridegodus, 176, 7. Flor. Wisorn., 212. Spelmanni Conc., 145, etc. Stubbs, 1690. Wendover, i., 97,8 . 
see for a rery short time, and his death cansed another vacancy. 'l'hese changes were diungrons, and the Roman party would feel the necessity of vigorous and instantaneons action. They must have a bishope who would press forward their views with promptitule and energy. Wilfid had won for them the victory at Streonshal ; who was more worthy to be the new bishop? It was Wilfid that they chose. ${ }^{c}$ Eddius tells us that he was unwilling to acecpt the office; but his seruples, which are perhaps magnified, were overeome. He objected, however, to be consecrated by any of the native bishops, whom he regarded as schismatics; and he requested permission to receive that rite in France. The roval assent was obtained, and Alcfid sent his favourite across the seas to his old friend Agilbert, who was then at Paris.d Tilfid was consecrated at Compiegne. There was at the ceremony all that pomp and show of which he was so fond. Twelve hishops were present on that occasion, and they carried their new brother, with hymns and joyous music, in a golden chair.

'These things were done in $665,{ }^{e}$ when Wilfrid was about thirty years of age. Everything that he had hitherto taken in hand had prospered. His most ardent aspirations were being realized. Ilis party was victorious, and he was at its head. If streugth of intelleet and strength of hand could stamp the Benedictine rule on England, he was the man to do it. Little, lowever, did he think, when he set sail for England, that the clond was even then gathering orer his head which was to darken the remainder of his life.

IIis disasters began as soon as he left France. He was canght by a tempest in the Chamnel, and was dashed upon the roast of Sussex. The savage wreckers rushed to the stranded vessel. A struggle took place in which the priest of the pagan plunderers was slain. Exasperated at this, they assailed the royagers, who, after four contests in which they sustained some losis, made good their retreat to the ship, which was set afloat by the lotuming tide. A fair wind carried them, at length, into the port of Sandwich ${ }^{f}$ After he had landed, Wilfrid would soon learn that he had suffered a worse shipwreck than that from which he had just escapcd. The see of York was lost to

Eddius, 56. Fridegodus, 178. Ric. of Hexham, col. 293.

¿ Berla, iii., 27 ; v., 19. Eddins, 57. Fadmer, 202-3. Fridegodus, 178. Wentorer, i., 98. Flor. Wirorn., 213. Ric. Hexham, col. 293. Rad. Diceto, col. 139. Bromton, col. 789. Gervase, rol. 1636. Stubbs, col. 1690 . IIen. IIuntiuedon, apud Savile, 191, a.b. IIist. Mon. S. Aug. Cantuar., 193. e Asser (Gale i., 146) makes the date 651, a manifest error. The Saxon Chron. (18) places it in 664. Rad. de Diceto (439) in 665, and the event could not have occurred earlier, as Agilbert became bishop of Paris in that year. Cf. Mabillon, Ann. Ben., i., 478. 'The Peterbro' Cliron. (2) puts it in 66.4. $f$ Eddius, 58. Eadmer, 203. Fridegodus, 178-9. 
him. His long absence ${ }^{g}$ had aroused the Scottish party, and it had gained the ear of Oswy. Alefrid was either dead" or nuable to assist his old favonite; the Culdees were again paramount, and the holy Chadd was now the bishop of Northmubria.

Wilfrid must have been deeply mortified when he heard of this news, but he shewed his good sense by shaping limsclf, with all resignation, to his altered fortmes. The character of Wilfrid was always most noble in adversity. He is said to have retired to his monastery at Ripon, of which he was still the abbat.

\section{"Spe meliore manet latebris contectus in illis"i}

is the assertion of his poetical biographer, but I can scarcely believe that he would seek a permanent abode in the provinee of his successful rival. The greater part of his time secms to have been spent in Kent and Mereia, where he exercised his episcopal functions without let or hindrance, ${ }^{j}$ and won the good opinion of all by his piety and zeal. ${ }^{k}$

Thus was Wilfrid employed till Theodore arrived in England, in 669, and through his means, as has been previonsly shewn, that active prelate was reinstated in the see of York. He was now in the position which he had so long coveted, and who could have a nobler or a more responsible eharge? Oswy had extended his kingdom far into Scotland, and the whole of his vast realm was under Wilfrid's spiritual superintendence." He was not unequal to the duties of his high office. Earnest and energetic he seems to have been at all times, and his efforts were crowned with signal success. Firmly and boldly did he moderate his churches, introducing, wherever he could, the Benedictine rule, or something like it, and multiplying in every direction the elergy and the shrines. He journeyed through his diocese, preaching and baptizing. It was a common thing for the presidents of religious houses to make him their heir. Many were the gifts that he received for sacred purposes, and the nobles generally shewed their confidence by entrusting to

g Fridegodus, 179. Ric. of Hexham, col. 294 .

${ }^{k}$ Cf. Arch. Al., $n . s$., vol. i., a paper by Dr. Haigh, who consiclers the cross at Bewcastle to be the monument of Alcfrid, and that he died in 664 . He says that the words "Wilfrid preaster" oucur on the stone, shewing, as Dr. Haigh thinks, that Alefrid died before Wilfrid was a bishop. I am inclined to doubt all this.

i Fridegodus, 179. Eddius, 58.

j Beda, iv., 2. Eddius, 58. Eadmer,
201. Fridegrodus, 179-So. Stubbs, col. 1690.

${ }^{k}$ Beda, iii., 28. Eddius, 58. Ric. of Hexham, col. 293. Gerrasius, col. 1636. Henr. Huntingdon, apnd Savile, 191, b. Hist. Moul. S. Mus. Cant., 198.

$' C f$. Chadd. Flor. Wigorn., 204. Eldius, 59. Simeon, col. 78. Bromton, col. 790. Gervasins, 1636. Stubbs, 1690. Fividegodus, 180.

"Bedin, iv., 3. Symeon, Ilist. Errl. Dunelm., 41. Gervase, col. 1638. Stublss, col. 1690 . 
him the chlucation of their children." The influence of the seottish party began quickly to disappear. Many gave in their allhesion to the new rule, and those who saw that there was no chance of their own retum to power, retired to those distriets where ('olumba was not yet forgotten."

T'mperate and sparing as Wilfrid secms to have been in his personal expenditure, he was well aware of the importance of mitward forms and beantiful sights and sounds in religious worship. lle was wise enough to know what a powerful auxiliary to deep fervour and holiness is to be found in a highly ornamented temple. It was not for nothing that he had visited the ctcmal rity, and gazed with rapture upon those glorious shrines that were even then there! What a contrast to the humble adifice of wool and reeds in which he had prayed at Lindisfanc! Now, happily, he was in i position to raise the religious tone of his diocese by improving and decorating its churches. With the assistance of Eddius and Eona he taught the Christim worshipper that simple and yet exalting musie with which the name of Gregory is immortally counceted. The temples, also, in which were heard the roices of the sweet singers, were marke more worthy of the chants with which they now resomnded. Masons, glaziers, and limners, the ministers of civilization as well as art, were always in the train of Wilfrid.q At Iexham, on "the silver Tyne,"r arose at his bidding that beantiful shrine, which the Scot afterwards despoiled,s the "pulcherrime habitationes" of which even Alcuin could speak, and which justified the boast of Eddius and Hexham's learned prior, that their peer did not exist on this side of the Alps." At lork, also, the great renovator was not idle. The church that Edwin and Oswald had erected was greatly in decay, and it grieved the energetic Wilfrid to sce the Lord's house thus desolate and forlorn. A new roof of lead was put upon the minster. (ilass was placed in the windows, for the first time, so that the birds conld no longer fly in and out, and defile the sanctuary within. The walls were covered with plaster, the altar was decorated with appropriate furniture, and means were found to keep the temple contimually in repair, and to maintain its ministers. But it was on Ripon that Wilfrid's choicest gifts

"Edrius, 62. Eadmer, 207.

Beda, iii., 28. "Fildius, 62.

8 Bedk, iv., 2. Eddins, 58.

r Were cowley living now, he would alter lis epithet.

- Chron. de Lanereost, 171-5.

'Almini Opera, i., 196. Caniaii L.et Int., ii., 105 .

'flue site was given by Etholdreta
(Lel. Coll., iv., 108). The author of the Mirac. S. Wilfr., apud Acta SS. ord. s. B., sscc. tert., i., 230, says that Wilfrid merely restored an old church, "ab antiquissimis fundata regibus." Cf. Eddlins, 62 ; Eadmer, 208 ; Fridegodus, 183 ; Ric. of Hexham, col. 289-94.

" Eddius, 59. "Basilice oratorii Doi, oflicia semirnta lapidea eminebant. 
were showered, for no plaee was dearer to his heart than that little monastery which he had ruled in prosperity and adversity. Eddius speaks with rapture of the shrine that Ripon now beheld, and with which he limself was so intimately comnected." Of polished stone, it was with its pillars and its porches, a copr, no doubt, of some temple in that famous city that Wilfrid had longed to visit amid the solitude of Lindisfarne. Wonld that we could see the precions text that, among other splendid gifts, he bestowed upon his favourite church, written in golden letter's upon purple vellum, and enclosed in a jewelled case ! ${ }^{x}$ And when all things were completed, the founder resolved that the new shrine should be solemuly set apart for God, and that the feast of the dedication shonld be observed as in the days of old. You might see at that time all the pomp and circumstance that befitted so high a ceremony, and which Wilfrid was so fond of manifesting and educing. 'King Ecgfrid and his brotler' Alwin eame, with the princes and nobles of Northumbria, the abbats and the varions officers who bare rule both in church and state. In the presence of that great concourse did Wilfrid dedicate the church and the altar, resting ity with precions coverings of purple and of gold. And then, after the celcbration of the eucharist, the consecrator turned limself to the worshippers, and, like the great Eastern potentate, declared what great things had been done for God. All the gifts that princes and holy men had made on that day to the ehureh did he recite; and then, purposely no doubt, he enumerated, as far as he could, the possessions of the British priesthood which had passed into other hands when the Saxons had come in. The lesson which he meant to teach would be obvious to all. "Follow the example that has been this day set you. Give back to us the rightinl

Nam culmina antiquata tecti distillantia, fenestræeque apertæ, avibus nidificantibus intro et foras volitantibus, et parietes incultæ, omni spureitia imbrium et avium, horribiles manebant-Primum culmina corrupta tecti renovans, artificiose plumbo puro tegens, per fenestras introitum avium et imbrium vitro prohibuit, per quod tamen intro lumen radiebat. Parietes quoque lavans, super nivem dealbavit." Cf. Eadmer, 205. Lel. Coll., iii., 258. The description of Fridegodus is new (180)-

"Ecelesiæ vero fundamina eassa retuste. Culmina dissuto violabant trabe paluabes.

Iumida contrito stillabant assere tecta:

Livida nudato suggrundia pariete passa

Imbrieibus uullis: pluviæ quacumyut vagantur.

Pendula disseissis fuitant laquraria tirnis,
Fornice marcebant eataracte dilapidato.

11 is ita eontuitis, exhorruit ilicet alti

Viribus ingenii reparare peribula templi,

Incumbunt fessi vasto sudore latomi,

Nee minus approperant opicizi emblemata proni

Areus ineultos byalino clandere velo.

Pondus et informes atlantes ferre priores

Jussitetexpletum: lymphis perfunditurabis,

Albauturque suis lustrata altaria freplis."

$u$ Eddius, 59, 60. Alenin, apm Gale, i., 714. Lel. Coll., i., 51. Mabillon, Ann. Ben., i., 495.

$r$ Eddius, 60. Lel. Coll., iv., 110-11, where there is an extract from a life of Wilfrid by peter de libis, once in the vestry at Ripon.

$y$ "Altare cum basibus suis Domino dedicantes." 'The word brsibus lats oceasioned some little diflieulty. It is clearly an error for vasibus. 
poscessions of our church, and thus we will employ them." The striking eeremony was orer, and it was followed by a banquet for all comer's which lasted for three days and three nights. ${ }^{z}$

Wilfrid was now at the height of his prosperity. By the commonalty he was regarcled with a kind of adoration. The simple natives would gaze with astonislment upon the tokens, crerywhere evident, of his wealth and popularity, the numerous monasteries that he had ereeted and endowed, the splendour and lenerth of his train when lie rode abroad, dressed and armed as if it larl heen the escort of a king. ${ }^{a}$ But there was a Nemesis amid all this prosperity which a little discretion on the part of Wilfrid might easily have appeased. Shrewd and mischievous obsersers were not wanting who would point out to the monarch of Northumbria the increasing influence of the prelate, greater than any subject ought to possess; they would whisper in his car that Wilfrid's pomp and magnificence was alien altogether from that humility which was the true master-chord of the religion he professed, and alien, also, from the simple lives of men like Lidan and Chadd, whom he apparently despised. Those who affect greatness are liable to the evils that attend it.

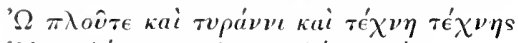

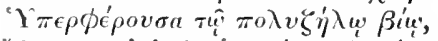

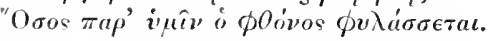

The arrow was shot against Wilfrid, and there were many that watched its flight.

Ecgfrid was the son of Wilfuid's old patron Oswy, and he seems to have inherited for a while the affection of his father and brother for their farourite prelate. This kindly feeling, howerer, only lasted for a time. The first consort of Eegfrid was the princess Etheldreda, the great patron-saint of Ely, and she made and obscrved a foolish vow of perpetual virginity. Wilfricl had over her, as he had over every one, a very great influence, and Eegfrid songht his aid in endeavouring to alter the resolution of his wife, promising him almost anything if he conld streceed. It was to no purpose. If Wilfrid tried to dissuarle her from her resolve he was unsuceessful; but from the record of the ciremstanees which Beda gives I cannot but think that he applauded her resolution, and, in the end, after a twelve ycars' union with Eegfrid, he permitted her to take the veil in the numery of Coldingham. ${ }^{c}$ The king could not fail to regard

Edrius, 60. Fridegodus, 180-1. Lol. Coll., iv., 109, 49. Cf. a raluable laper by Mr. Walbran for the Yorkshire Arrhitentural Society. "Eddius, 63.

$b$ Wilfrid robtaned a great influence over oxwy before his deatl. The monarch made a vow to go with him to Rome to end his days, if he recovered from the illuess that killed him. Beda, iv., 5 .

$r$ The anthorities of this paragraph are Beda, iv., 19. Eadmer, 208. Wen- 
Wilfrid as Balak did Balaam, "I called thee to curse mine enemies, and behold, thou hast altogether blessed them. I thought to promote thee to great honour, but the Lord hath kept thee back from honour.'”

The ill-matehed couple were diroreed, and Eegfrid took for his second wife a daughter of the king of Wessex. She is said to have been a woman of a hasty and impetuons disposition, and there soon sprang up an implacable feud between her and Wilfrid. ${ }^{d}$

Causa latet-"

"Qure tantum accenderit ignem

What the cause of that eumity was it is impossible to say, but bitter rords must have been spoken, and bitter feelings generated, if we may judge from the result. A little of Chadd's gentleness might hare prevented all this acrimony and contention, but Wilf iid had a very different disposition. Nine yeas's had clapserl since he had stepped into Chadd's place; now the same hand that placed him in it was to make him a wanderer and an exile, seeking for justice at the hands of a foreign potentate, and finding lis decree, after all his trouble, to be but a brutum fulmen.

When this quarrel was at its height in the Northumbrian court, archbishop Theodore was busily engaged with his measures of reform. Much there was for him to do, and, aged though he was, he did not shrink from the nudertaking. One point to which he especially directed his attention was the subdivision of the English dioceses, for, undoubterlly, they were far too large to be managed efficiently by any one man. Ile began with the province of Mereia, and then he would look, naturilly enough, to Northumbria. How to proceed in this case was a matter of some difficulty. It was uindoubtedly to the interest of the southern metropolitan to have as many suftragans as possible, and it was equally desirable to kecp the bishop or bishops of Northumbria subject to the same anthority ; but how was this to be effected ?e lo make several bishopries in Northumbria would add nuaterially to his own power. Ile

dover, i., 106. Hist. Eliensis, apud Gale, i., 510-apud Angl. Sac., i., 598. Ric. of Hexham, col. 291. Caperave's Nova Legenda, fol. cxli. Wilfrid made her abbess of Ely, and was of great nise in aiding her in arranging her convent and securing its privileges. Cr. Vita S. Ftheldredse, apud Acta SS. ord. S. B., sxe. ii., 747-57. Bronton, col. 791, and Bentham's Ely, 21, 57. In the "Iyfe of Saynt Werbure" (72) it is said that Etloldreda

\footnotetext{
"Was reverently receyred into relygyon, And alter the yere of her" probacyn

l'rofessed there was by bysshop wylfryde; Where all worldy honours she set on sycle."

"Edrlim, 63. Eadmer, 208. Frirlegodus, 183-1. ITist. Eliensis, apud 1 ngr. Sacr., i., 598. Simeon, col. 78 . Ric. of Hexham, col. 291. Stubbs, col. Ifoll.

- Erdelius, 63. Ourlinus de Suript. Forel, i. 16fi-2.
} 
michlit smbdivide that kingdom in virtue of the legantine anthority, but this was rather a hold step to take. He might presume upon the absence of the pall at lork, for Wilfrid had never received it, and eonsider Wilfid as a suffragan of his own, but to do as he wished, and to intrude within Northumbria, he wouk require the consent of the king. And just at the time when that consent was needed it was voluntarily offered. The queen had mate her husband Wilfrid's enemy, and the feud was then raging, and 'Theodore, who was watehing his opportunity, rejoiced to find himself invited into Northumbria by its sovereign.

He went, and the king and he, without consulting Wilfrid, mocerded to subdivide the diocese of Northumbria. The plan, as it was funally arranged, in addition to York, placed a bishop at Lindisfame, Hexham, and Whitherne. ${ }^{f}$ There is nothing to be siid against the poliey of extending the episcopate, indeed there is nothing to shew that Wilfrid was in this instance averse to it, but the change was effeeted in a manner which is liable to grave censure. Decency, to say nothing of law and justice, ought to have suggested to Theodore and Ecgfrid the propriety of consulting IVilfrid on a step in which he was especially concerned. It was not to be expected that Wilfrid would submit to such treatment. He went to the two dividers, and demanded of them what he had done to be thus plundered. "We have no fault to fincl with thee," was the reply, "but we cannot alter what we have done." Disappointed in this mamer of the justice that he had demanded, the indignant prelate turned to his last resource; lie made an appeal, which was then for the first time heard before an English sorereign- "appellatus est ad Crasarem" - he referred his canse to the decision of the pope. ${ }^{g}$

There is a fascinating account of his adventures on the way. It rominds us, strikingly, of the Odyssey, and of the varied fortmes of one, who, like IVilfrid, was a risitor at strange

$f$ In the first instance, Eata was flacel at Itexham and Eadlaed in Linley, which was annexed to Northmulria by Eecfrid. (Saxon Chron., 51 , says that bosa and Eata were first a]pointed.) After Wilfrid went abroad Eata seems to have had the charge, for a while, of the whole of Northumbria, cxcept Lindsey, aud on that accoint I find him called archbishop of Tork (Vita s. Eate, Biogr. Mive, Surtees Sow. 125. Walbran on the Saxan ('hureh of Ripon, 96 r.) bosa was sors made bishop of Tork, and in 680 or 681 Lata was translated to Linulisfurne, Trumbert succeding him at IJ exhan. Trmmwin, also, was placed orer the Picts, and Eadhaed, Lindsey being lost to Northumbria, became bishop of Ripon. Cf. Beda, iv., 12. Fridegodus, 184. Wendover, i., 104. IIist. Mon. S. Ang. Cant., 275. Symeon, ITist. Eccl. Dumelm., 44. Ric. of IIexham, col. 294.

s Beda, v., 19. Saxon Chron., 61. Eddins, 63. Eadmer, 209. Fridegodus, 184. Simeon, col. 78. Ric. of Hexham, cul. 294. Diceto, col. 440. Bromton, col. 792-3. Gervasius, 1638. Stubbs, 1691. Iahmesbury, apnd Savile, 10, $b$. IIen. Iuntingdon, ib., 191, $b$. Symeon, IIitt. Eeel. Dunehn, 44. Chron. S. Crncis, ajud Angl. Sacr., i., 155. 
courts, and could adapt himself, with equal readiness, to the inhabitants of the wild lands on which he was driven with his companions by the stormy waters. Both possessed unto the end

"One equal temper of heroic hearts,

Made weak by time and fate, but strong in will

To strive, to seek, to find, and not to yield."

Wilfrid left the shores of England in $6 r 8,{ }^{h}$ witlı a large train, regretted deeply by the thousands of monks whom he had left behind him in Northumbria. But, even now, the latred of his enemies, changing, perhaps, into that fear which is more diabolieal than hatred, concerted measures for his orerthrow. A message had been sent to Theodorie, ling of Nenstria, desiring him to detain Wilfrid on his jouney, and he, with the assistance of Ebruin, his chicf minister, prepared to arrest the exile. He eseaped from them in a very singular manner. $B y$ a most extraordinary coincidence Wilfrid or "Winfrid, bishop of Liehfield, was wandering at that time in Neustria. Deceived by the remarkable similarity of name, Ebruin seized upon him and his companions, and most eruelly were they used. Wilfrid, however, escaped from one peril to fall into another. A contrary wind drove him out of his course, and he landed among the savage tribes upon the shores of Friesland. ${ }^{i}$ And here, with that noble and energetic spirit of devotion, to which his own interests were at all times subordinated, he remained till he had taught the heathen natives and their monarch, Adalgisus, the rudiments of the true faith. It was the first time that the saving word had been preached upon the shores of the northern seas. Fuller has beautifully remarked that "as nightingales sing the sweetest when farthest from their nests, so this Wilfride was most diligent in God's service when at the greatest distance from his own home."'j There was nothing in such a country to tempt ambition or elicit pride. The love of self could never have induced a man like W'ilfrid to sojoun in a distriet like that, and, to his credit be it spoken, at every period of his life when he was required to surrender personal considerations to the eause of God that sacrifice was willingly made. The prinees and the people were baptized by thousands, and they shewed

h Saxon Chron., 54. Asser, apud Gale, i., 146. Flor. Wigorn. (251) makes the date 677 .

i Beda, v., 9. Eddius, 61. Eadmer, 210. Fridegodus, 185. Alcuin, de Pont. Ebor., apud Gale, i., 713. Wendover, i., 105. Flor. Wigorn., 25:. Diceto, col. 440. Stubbs, col. 1691 . Chron. Petrob., 3. Mabillon, Acta SS. ord. S. B. seec. iii., i., 603, prolos. in vitam S. Willibrodi. Mabillon, Ann. Ben., i., 510, who says that Wilfrid, knowing the designs of his enemies, sailed voluntarily to Friesland. Willib. Bosschaert de primis reteris Frisix Ayrostolis, ed. 1650, and Batavia Sacra, ed. 1714, p. 21, where there is a short life of Wilfrid drawn up from the Acta ss., ete.

i c'luurch Iristory, book ii., 88. 
their gratitude to their converter by rejecting with scorn the profiered bribes of Ebruin, ${ }^{k}$ who was striving to remedy his criner which he had at length discovered.

In the begiming of the spring Wilfrid proceeded on his journer, finding friends at every halting-place. Dagobert, a French prince, had not forgotten the hospitable reception that Wilfrid had once given him in England, when he was an exile, and, recollecting that kindness, he gave the wanderer a most hearty welcome? Having failed to induce Wilfrid to take up his abode in France by ofiering him the see of Strasburg, he sent him on, with rich presents and bishop Deodatus for his guide, to Berchtar the monarch of the Lombards, who had refised to be a party to the evil designs of Ebruin and Theodorie. From that court the pilgrims passed onwards to the eternal city. ${ }^{n}$

Five and twenty years had elapsed since the humble scholar from Lindisfarne journeyed into that city of which such great things were told him. At that time he was nnknown to every one when he entered it, but now he was escorted on his way by kings and princes, and the father of the Christian faithful was expecting the arrival of one of the greatest of the bishops. "Quas ego te terras et quanta per aquora vectum
Accipio, quantis jactatum, nate, periclis!"

The story of Wilfrid's sufferings and labours was known in Rome long before he was there to tell it. Cöenwald, the messenger of 'Theodore, had arriver before him, but Agatho and his bishops har tumed a deaf ear to his tale. An appeal, the first appeal, from an English bishop to the court of Rome was an event of no slight importance. It gave the pope an opportunity of setting the seal of his anthority upon the British chureh in what appeared to be a just eause. The decision of the synod was manimously in favour of Wilfricl. IIc sat among the bishops who were deliberating against the Monothelites as the representative of his church, ${ }^{n}$ and, flattered and honoured by all, he crossed the seas in triumpl, bearing with him the papal mandate which authorized the restitution of his see, and hurled against the gainsaycrs of that bull all the terrors that the court of Rome conld wicld. ${ }^{\circ}$

Wilfrid reached Northumbria, little dreaming, perhaps, of the reception that awaited him. His respect for the anthority of Rome was so great that he imagined, no doubt, that every

${ }^{4}$ Eddins, 61. Eadmer, 210. Fridegodus, 185.

Eildius, 65. Eadner, 211. Fr., 186.

${ }^{2}$ Eddius, 65. Wadmer, 211. Fr., 186. Ciamar, l'Estorie des Engles, a) ad Mon. Hist. Brit., 7S2.
"Beda, v., 19. Wendover, i., 105.

- Eddius, 66-8. Eadmer, 212. Trid., 187. Flor. Wigorn., 252. Diceto, col.111. Bromton, 793. Stubbs, 1691 . Labbe, Concilia vi., col. 582. Spelmanui Cone., 160. 
one would give way to it. In this he committed an curregions mistake. The independenee of the Saxon chnreh was at that time very strongly marked, and Theodore, himself an enissary from Rome, was most active in maintaining it. But among the native princes the idea of submitting to any foreign jurisdietion had never once been mooted. Wilfrid's bulls and letters were treated with derision by the Northmmbrian conrt. Eegfrid regarded him merely as a rebellions subject. He was cust immediately into prison. His bulls were taken away from him. The reliquary that he had brought from Rome became the plaything of the queen. Nine months elapsed before the prisoner regained his liberty at the intercession of the abbess Ebba, the king's aunt, and then he was banished from that kingdom with which his name will be immortally comnected. Wherever he went the hate of Eegfrid pursued him. He paused for a while in Mercia with prince Berthwald, but king Ethelred, to serve Eegfrid, compelled him to depart. The queen of Wessex was the sister of Ermenburga of Northumbria, so there was no sanctuary for him there. It was at length the high privilege of a heathen province to give an asylum to a bishop whom every Christian kingdom liad rejected. ${ }^{p}$

It was in Sussex, in 681, that Wrilfrid found a sanctury at last. $q$ He little thought, when on his return fiom his fir'st journey he escaped with difficulty from the wild wreekers on that coast, that in after years he would find in that country a peaceful resting-place. Ethelwalch, the sovereign, and his quecen had been baptized at the instigation of Wulfhere king of Mereia, and there was a little monastery at Bosham which Dicul, a Scot, had foumded. It had but five or six inmates, and neither they, nor the king and queen, harl made any converts to the faith which they professed. The adjacent kingdom of Kent had been the first to welcome the message of Augustine, and the light that shone there lad radiated to the farthest extremities of England. How strange that Sussex should have been still in darkness! As Fuller truly observes, "herein it was rerified, 'Many that are first shall be last, and the last first.' Yea the Spirit ' which bloweth where it listeth,' observes no visible rules of motion; but sometimes taking no notice of those in the middle, reacheth to them that are farthest ofl.",

The more difficult the task was, the more cagrer was the great heart of Wilfirid to accomplish it. Ile threw himself into

s Eddius, 71-2. Eadmer, 213-15. Fridegodus, 189. Lel. Coll., iv.. 109.

7 Eddius, 72. Earlmer, 216-17. Fridegodus, 191. Beda, iv., 13; v., 19. Alcuin de Pont. Eccl. Ebor.; arnd Gale, i., 713. Wendover, i., 105. Flor. Wigorn., 252. Diceto, col. 411. Stubbs, col. 1691. Huntinglou, apul sivile, $191, b$. Spelmanni ('omeilia, 178.

('hureh History, l,k. ii., st. 
the evangelization of Sus-ex with the energy of an apostle. The inhabitants of the district were not only heathens, but it seems that they were ignorant of all those arts in which sarage tribes are rencrally adepts. When Wilfrid came among them the land wa- being desolated by a famine. It was by no means an mmonal thing to see the emaciated natives assemble in parties of forty or fifty, and, hopeless for the future, grasp hold of each other"s hand, and throw themselves from the cliffs to end their miscries in the sea. It this conjuncture Wilfrid happils arrived. He taught the half-starved sufferers how to fish and provide for themselves, endearouring

"Br Aow frurlence io make mild

A rucced peorle, and thro' soft degrees

Subdue them to the useful and the good."

Civilization was thus the herald as well as the companion of religion. Gratitude to their benefactor minged his words to the hearts of the natives, and they adopted the faith which he preached to them. On the day of their baptism the windows of haten were again opened, and the rain descended upon the long barren ground."

Grateful for the services that Wilfrid had rendered to himsolf and his subjects, Ethelwalch give him a piece of land at Selsea. This was the beginning of an ecelesiastical foundation which was afterwards removed to Chichester. At Selsca Wilfrid immediately erected a monastery, over which he presided for five rears, exereising at the same time his episcopal functions in the adjacent country, and giring the natives a practical lesson on the vice of slarery." In 686 he arain reaped the benefit of the courtes whieh he had at all times shewn to fugitives and exiles. When Cadwalla, a scion of the roval house of Wessex, was in banisliment, Wilfrid had been his friend, and now, when the tide harl at lenerth turued in his fortmose, Cadwalla was not forsetful of his former benefactor. Br force of arms he took proserion of Wesex, Kent and Sussex. He then gave to Wilfrid the hishoprie of Wesses and a fourth part of the Isle of Wight, which the energetic prelate bronglit over to the Christian faith. But the greatest victory of all was the conversion of Cadwalla. 'The eonquerol' was a pagan till he beeame firmly seated on his throme, and then, through policy as well as conviction, he re-

- Berla, iv. 3. Earlmer, 217. Brom-

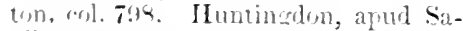
vilu. 191, b.

- Bodli, ir., 13. Edlius, 72. Ear. mer, 217. Hist. Mon. S. Mlue. Cant. l:k. situbbe, col. lfigl. T.al. coll., ir.. 7\%. "Bula, iv., 13.
The credit of erangelizing the island is, perhass, to be shared with Wilfrid, bishop of the Merciars, and Eoppa. rf. Beda, ir., 13, 16; r. 19. Saxon Chiron., 17. Earmer, 217. Wendorer, i., 105. Flor. Wieorn., 256. Hen. lluntiniton, 192. Stubbs, col. 1691. 
solved to embrace that faith which the majority of his subjects professed, and of which Wilfrid was the preacher. He determined that the pope should baptize him. And to shew that he was impelled by no sordid or common impulse, the routhiful monareh, in the very flush of greatness, had the eourage to throw aside his seeptre, and to prepare himself in the scehision of a monastery for that solemn rite of which he was so soon to be the recipient. ${ }^{\circ}$

There was one person who woutd observe the progress of Wilfrid with the greatest interest, and that was Theodore. lle could not but be struck by the eneroy and suceess of his exiled brother. He was too good a man himself to allow any personal feelings to prevent him from admiring so much industry and self-denial. And then, doubtless, a self-accusing thought would flit across his mind that it was throngh his means that Wilfirid had been excluded from a larger sphere of duty, where he might have done, if that were possible, a still greater work for God. There had been, in all probability, no intercourse between the two since that memorable scene in the halls of Ecofrid. Were they to "go down to the grave in silence," withont an attempt at reconciliation, or a single word of kindness and forgireness? Theodore was approaching the patriarchal age of ninety, and Wilfrid's climacteric year was rapidly coming on,

"Lenit albescens arimos capillus."

A reconciliation was happily effected, ${ }^{x}$ Theodore making the first adrances. He was not deterred by the peevishmess of age from acknowledging his error, and Wilfrid, with his heart softened by adversity, was able to forgive. Theodore now shewed the sincerity of his regret by many acts of kindness. He would fain have nominated his old foe to be his successor in his see, but Wilfrid's thoughts were centred in his own kingdom in the North, and, courteously deelining the proffered gift, he begged to be reeonciled with the sovereigns who ought to have been his friends. None ean better value the blessings of peace than those who hare been scathed and seared by discord. 'Theodore's good offices were immediately at Wilfrid's serrices. He restored him to the favour of Ethelred, king of Mereia, whose kingdom, through Eegfrid's interests, had been elosed to him, and that monareh gave him lands and monasterics, and permitted him to act as a bishop within his province. But Theodore did still more for him. He wrote in his behalf to Aldfrid, an ille-

w Beda, v., 7. Eddius, 72-3. Fadmer, 217. Fridesodus, 191-2. Wendover, i., 115. Bromton, col. 799. Hen. Huntingdon, 193. Baronii, Ann., viii.,
594. Smith's Flores Eecl. Hist., 126, a very badly arranged and badly written work.

$x$ Erldius, 73. Eadmer, 218. 
witimate son of Osuy, who harl recently succeeded his brother Finfind on the Northmmbrian throue. Aldfrid invited Wilfrid to return into the North. 'The sees of Lindisfame and Hexham were at that time racant, and they were given to Wilfrid, who loft them soon afterwarls for his old bishopric of York, Bosa, mobably, surrendering the charge to which he subsequently retempoil."

111 these things were done in 686 , and Wilfrid was thus restoren to his dignities and lomours, and for fire years did he enjoy thent..$^{*}$ But there was to be no rest for him even now. Afiliction, alas! hast tanght him only a temporary lesson. An insane love of change lumel him, a second time, to his fall. What injury has been rloue to the progress of true religion by men who have been thus minded. The eonduct of Wilfrid on this occasion was incxensable. He ought to have been well acquainted by this time with the fechings of the native princes of Northunbria, and yet he adopted a course of conduct which would be sure to ontrage them. The highest spiritual victories have been won by men of a gentler and a more forbearing temperament. Ile harl been but five vears in his old dioeese when he kindlod, for the second time, the flame of contention. He was again shipwrecked by making an attempt to undo everything that had been effected during his absence. He wished to recorer for the church of York its mivileges and possessions, of which it is obscurely said by Eddius it had been deprived. He was desirous of obliterating the sce of Ripon, which he would look 1 you with a jealous eye from its vicinity to York. He was rager, also, to abrogate the constitutions and decrees of his old rival Theodore, made whilst the two prelates were encmies, by which the Northmmbrian province liad been moderated for some years. King Mldficl, who was a man of leaming and diseretion, would inot assent to the wishes of Wilfid, and the disaprointed prolate, who wanted the paticnt endurance of Paulinus airl the gentleness of Chadd, determined to have his own way or unting. He retired to the Mercian cont, where he acted as a hishop, and consecrated Etha and Suilbert of Friesland. ${ }^{a}$

Artuated by a sincere wish to make peace among his divided churehes, Aldfind, with Berthwald, who was now the Southern primate, and the greater part of the English bishops, met in a

y Bela, ix, 29. Eddins, 71. Eadmex, 219. Fridegolus, 193. Flor.

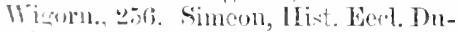
wohtu, 6o. Ric. of Hexham, col. 295.

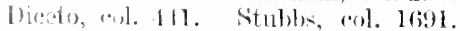

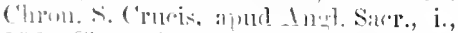

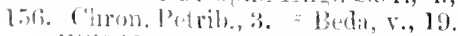
Milliri berame bisho "Mediter- raneorum Anslorum," and Leicester was, probably, the place at which he reviled. Bedla, v. 11. Eddius, 75. Fudmer, 220. Fridegodus, 193. Flor. Wigoril, 258. Ric of Hexham, col. 2yfi. Direto, ecl.t11. Chron.S. Crucis, aprid Ined. Sact., i., 157. Acta SS, ord. s. B., sece tort., i., 212. 
great synod at Edwine's path. Wilfrid, also, was there by the desire of the comncil, and after a long debate it was resolved to perpetuate the regulations of Theodore. Wilfiril professed his readiness to obey the decrees of the synod so loner as they were in consonance with the canons; but he boldly, and most injudiciously, asked the deliberators how they eould renture to prefer the judgment of Theodore to that of Agatho, Benedict and Sergius. After consulting for a while in private, they endearoured to persuade him to resign all his offices into the hands of Berthwald, in the hope, as they seemed to imply, of having some compromise effected, but perhaps, as Eddius asserts, to deprive him of everything, and to say that he had given it up. This was a strong step to take, and one which shewed how little confidence they had in Wilfid. $\Lambda$ friend, however, had warmed him of their design, and he met thcir request with the reply that he wonld bow to the decisien of the archbishop, so long as it was not opposed to the rules of the holy fathers. Annoyed at Wilfrid's pertinacity, they began to threaten him, saving, in the end, that he shonld be deprived of everything save the monastery of Ripon, and that he should not be allowed to go beyond its precincts without the permission of the king. Wilfrid, upon this, broke out into an indignant expostulation, which would have come with better taste from other lips. "Was it for this that he had laboured as a bishop for" nearly forty years? Was it for this that he had torn the Scottish system up by the roots, teaching the Northumbrians the correet mode of ealeulating Easter, and giving them the proper tonsure, the Benedictine rule, and the knowledge of ehanting? And, after all this, forsooth, he was to be entrapped into putting his name to a decree which was meant to be his ruin!" Full of indignation he made his appeal, for the second time, to the court of Rome. The archbishop and the king were disposed to throw him into prison for this, but the other members of the synod reminded them that as Wilfrid had come among them with a safe conduct he could not honourably be detained. IIe was permitted, therefore, to depart, and he returned to the court of Mercia, and Ethelred kindly promised to do nothing to his prejudice till the question in dispute had been arranged at Rome. ${ }^{b}$

To Rome, therefore, did Wilfid journer when he was above threescore years old. Age, however, conild not tame that intrepid spirit. The church, which he had done so much to serve, drove him out of her communion, but he looked for justice at other hands. There were still some at Rome who recollected

"Eddius, 75-7. Earmer, 220-1. Labbe, Concilia, vi., col. 138z-t;. Śpelmanni Concilia, 200. Fridegordus, 195.
Wendorer, i., 117. Stubbs, col. 1691. Chron. Petrib., \& (in 691). 
him when lie came there with a splendid retinue and backed by the support of kings. Now, he was in a far humbler guise, but the lapal cont could not but shew their gratitude to so valuable a servant. Il is aceusers had anticipated his arrival, but their tale was disrecrarded. Wilfrid was absolved from all blame, and the pope, Joln VI., wrote an admonitory letter in his behalf to Etholred and Aldfrid. At Rome Wilfrid must have spent many ycals. Fain would the aged prelate lave ended his days in the holy city which he had visited in joy and sorrow. Christian heross had consecrated it for crer; men of spiritual prowess who had passed through the firc of persccution before they had won the victory. Glorious shrines were covering the places which had been watered with their blood; and there would Wilfril, who had passed under the share himself, have been a watcher and a suppliant, willing to copy their death as he had initated their life, and to pass away, like them, into the presence of the Ineffable One. His bones, however, were to rest in the country of his fathers. The pope and his council desired him to retrim to England to claim that justice to which he was entitled. Ile sct his face once more towards England in 703 or 7) 1 , when he was serenty years of age. The journey was a terlions one, for the old man could not travel rapidly. A very dimuerous illness, a shadow of the end, assailed him by the way at Meanx, and his life was with difficulty saved. Acca, one of lis companions, who in after ycars became bishop of Hexham, had a marvellons tale how the archangel Michael shewed himsciff to his siek master, and told him that the same mercy should be rouchsafed to him that was granted to Hezekiah, and that four reat's should be added to his life. ${ }^{c}$

IThen Wilfrid arrived in England he had an interview with archbishop, Berthwald. He was a gentle and a conciliatory prelate, and there was soon peace and amity between them. 'The letter that Wilfrid had bronght to him from the pope conld not fail to influence him, and he promised to exert his influence to ahrogate the decision of the synod. From Berthwald Wilfrid passed on to the Mercian conte, where he found that his old fatron lithelred had become a monk at Bardney. At the sugenstion of the new sorereign, Wilfrid sent two messengers to Allfrid to request permission to visit his kingdom, and to bring with him the letters from the pope. The monarch of Northumbria was obdurate. Not one word in any decree would he alter in obedience to a papal mandate, and he refused, henceforward, to listen to the repuest of Wilfrid. Aldfrid died shortly

Bula, Y., 19, 20. Eddits, 79-83. Liulurer, 2-23. Ric. of llexham, cul.
297. Fridegodus, 195 . 
afterwards, and the partizans of Wilfrid assert that he shewed his penitence on his death-bed. The throne of Northumbria was now oceupied by Eadulf, and to him, also, did Willind, still longing for his old charge, send his messengers. His hope's, however, were dashed to the ground by the harsh response that if he and his friends tarried for six days within his kingdom, they should lose their lives for their disobedience. With this answer Wilfrid would be sorely disappointed, for', expecting a kindly weleome, he had visited his old monastery at Ripon. Two months after this everything was reversed. Eadulf was banished, and Osred, the youthful son of Aldfrid, was on the throne of Northumbria, with Wilfrid for his friend. ${ }^{d}$

The case of Wilfrid would soon foree itself upon the consideration of the young monarch and his comcil, and a great synod was assembled on the banks of the river Nidde to adjudicate upon it. Osred was there aecompanied by the three bishops of the province (Bosa, John, and Eadfrith) and the abhess Elfleda. Arehbishop Berthwald was also present with the thanes and princes of Northumbria, and Wilfrid was by his side. Berthwald began by reading over the letters of the pope. Very few of the auditors would be acquainted with the language in which they were written, and the archbishop was requested to interpret them. In reply, he said how difficult it would be to do that with exactness, and professed his readiness to give a brief summary of their contents. He had thus an opportmity of softening down, or omitting, all the harsher portions of the letters, which, if properly understood, would have frustrated altogether his sincere wishes for peace. The epistles, as he said, desired that all the eeclesiasties of the prorince should be reconciled with Wilfrid. The bishops were either to restore to him his churehes, or to shew eause to the contrary in the Roman court, and excommunication was to be the punishment of their disobedience. The voices of the three interested prelates were at once raised against this deeree. They brought forward, on the other side, the solemn decisions of Eegfrid and Nldfirid, alleging that they conld not be altered: they quoted, also, against the arehbishop, not only the example of 'Tlicodore, a prelate sent from Rome, but his own words on a previous occasion. This was the erisis of the conference, for not only did the law seem to be against Wilfrid, but Berthwald was, as it were, convieted of ineonsisteney. The abbess Elffeda now asserted that Aldfrid, on his death-bed, had regretted his treatment of Wilfrid, and that he had promised, if lis life were spared, to rescind his decree against him and the papal an-

\footnotetext{
${ }^{d}$ Beda, v., 19. Eddius, 81-5. Fad- Wendover, i., 118. Labbe, Concili:1,
} mer, 223 .

vi., eol. 1389. Spelmanni Cone, 203. 
thurity; and Berehtfrid, the confidential minister of Aldfrid and his son, mentioned a row that his late naster had made at babmumber when that fortress was besieged, by which he pledend himself to restore Wilfrid, shonld he be vietorious; and he said, anthoritatively, "It is the will of the king and his mmmeil that the wishes of Allfird shonld, in every respect, be adlucred to." It was evidently the desire of the powers that be that Wiltivid should return. The bishops conld not fail to sec this, and they retired to hold a consultation by themselves. After" a long deliberation, in which Berthwald and Elfleda took a part, a compromise was effected. Wilfrid was not, indeed, restored to lork, but Ripon and Hexham were given up to him, and the prelates, glad, no doulst, that there was concord and anity at last, gave each other the kiss of peace. $f$

For the second time did Wiffid become bishop of Hexham. Miny years had passed away sinee the sainted Etheldreda gave him that little portion of gromend by the waters of the 'Tyne, on which he raised the fair shrine which Eddius deseribes, and to that trmple did the aged prelate at length return. Once he would nerel have sulmitted to the compromise that gave Hexham to him again, but age and trouble had robbed him of his old fire. l'eace he would now seck, for he had had enough of the storms of life. That place of rest was to be his soon, where he would never hear their somd. The shadows of death were already datkening aromol him. He was attacked by the same complaint which had nearly carried him off as he returned from lime, but the prayers that the faithful put up for him were heard, and the end was not yet. The sickness, however, was not withont its admonitory lesson. The aged prelate in the presence of sereral of the bretluen of the monastery of Ripon, which was a private powsession of his own, appointed his kinsman, 'Tathbereht, the ruler' of that house, and made the following disposition of his worlly estate. He livided it into four portions. One share was bestowed upon the churehes of the Viroin and St. Panl at Rome, the eity to which he had never appealed in vain. Another was given to the poor. A third was begueathed to the muler's of his two religious houses at Ripon and Ilexham, for the bencfit of their monasteries. With the remaining share he rewarded the companions of his sufferings and trimmphis,

\section{"Fortes pejoraque passi}

And then, when this neecssary duty was dispatehed, did he tell

$f$ Bedil, r., 19. Eldins, 8.5-6. Fad-

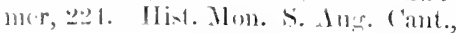
280. Hiceto, col. 1.2. Hice of Hex- ham, col. 296. Stubbs, col. 1691. Mabillon, Am. Ben., ii., 11-15. Baronii Amn, viii., 652-3. 
his admiring andience that he had another journey yet to make before he traversed the ralley of the shadow. 'Two ablats had arrived to bid him to the II ereian court, for Coelred, the suecessor of the faithful Ethehed, begred him to inspect and put in order the monasteries within his kingrtom. And he wonld go. Even when the hand of death was ehilling him, that undeearing spirit was still ardent when there was any good work to be done for God. The scene among the monks of Ripon reminds us strongly of St. Panl's last interview with the Ephesian elders. Wilfrid spoke, indeed, of the possibility of his return, but conld they expeet that? He told them also of another more probable contingeney to which their hearts would sorrowfully assent. They threw themselves at his feet, and anid their prayers and tears he commended them to the Lord. They never looked upon that face again. ${ }^{g}$

To Mercia he journeyed, and set ererything in order as the monareh wished. 'The exertion was too great for his aged frame. He fell sick in the monastery of Oundle, which he hatd himself established, and there, on the 12th of October, ${ }^{h} 709$, did he pass into his rest. His "life was like an April-day, often interchangeably fair and fonl; and after many alterations, he set fair in full lustre at last.'” For serenty-six rear's had Wilfrid been a Christian soldier, but he was at length released. The final struggle is orer; the rictory eomplete; and as the monrners were gazing upon that face now so motionless and still, they fancied that there was around them the sound of rustling wings. Could it have been the spirits who were bearing away their new brother on his homeward journey? Do they now come for him, and, as Danicl Heinsius beautifully says :-

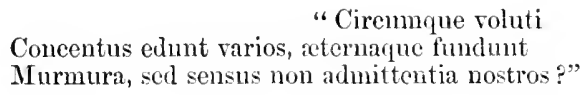

A very great man passed away that day, for, in many respects, we may eonsider Wilfrid as the star of the AngloSaxon church. It is not often that we meet with sueh a conbination of intellect and energy. He lived in an age when a master-hand was needed, when church reform was especially required. The system of the Culdees was not calculaterl to make any permanent impression. It wanted diseipline and

$g$ Eddius, 87. Eadmer, 221-5.

${ }^{h}$ Mabillon, Ann. Ben., ii., 24, makes 8th kal. May the day of his death. Wendover is in error as to the dite. Cf. i., 118, 130.

i Beda, v., 19. Eddlins, 78. Saxom Chron., 61. Eadmer, 225. Wendover, i., 118. Ric. of Hexham, col. 296. Bromiton, col. 79 t. Stubbs, col. 1692. IIen. Iluntingdon, 193, b. Chron. Petrib., 5. 1List. Caenob. Burgensis, apus Siarke, 13.

j Fuller's Clureh History, bk. ii., ol. 
authority to direet it. The vigrorons intellect of Wilfrid at once deterted its deferets, and, with the landable ambition of a man who is conscions of his own powers, he strove to remedy them. It repuired no little bolducss and skill to influence the mind of () w $y$, and to pull down the supremaey of Colman and his monkis. But Wilfidd did all this, and effected a reform without which 'lheodore could have done little, and to which Dunstan :mll ()wald, in after ycars, were greatly indebted for their suceren. But Wilfid had not only a destructive genius, but he ("inced at the sane time great coistructive and administrative aldility. II built up the Benedietine rule upon the ruins of the sstrin of ('olmulba. Ile bronght it in in all its comprehensivenim, and set every part of its delicate and varied machinery in motion-its discipline-its ritual-its accompanying graces of anchiterture and music were all of them attended to. Hexham iml Ripon are two only of the many monasteries of which he wiss himsiff the fomnder. It is no slight honour to have aided the (establishment of such abhers as Ely, ${ }^{k}$ as Evesham ${ }^{l}$ and Mrdhamsteal." In doing all this, howerer, he had no little opposition to contend with. The reformer has always troubles in his path, and Wilfrid, also, experienced them. And in meeting them he exhibited the defeets in his character. He wanted tomper and he wanted judgment. I camnot blame him, as many do, for appealing to the court of Rome, for it was natural enongh that he should regard Rome as the head of that mission to Lingland which she had herself so recently established. Romo had, at that time, as mueh right to moderate the ecclesiantir's in Lngland, as we have in these days to give our own ritnal and discipline and bishops to heathen territories abroad. And when juatice was denied to him at home, to what other arthtratur could he refer his cause? Wilfrid's error was not so much in making these appeals as in the manner in which he make them. II would make no allowance for the feelings and opinimus of his opponcuts. His quick mind conld detect what others could not see, and he had not the patience to wait till their powers of vision and apprehension became stronger. $\mathrm{He}$ thus stumbled where others, with half his intellect, would have sucereded. Iom may he conscions of your inferiority yourself, hut it is by mo means pleasant to be taunted with it by another. llilfrid was in this way eontinually offending national pride,

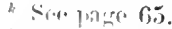

Malbilno, Aeta Ss. ord. S. B., Vita $\therefore$ Hewini El. Wirorn., 170 .

It in ferible that austlee Wilfrid whe chorermed with Merllamstead or

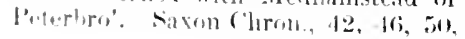

53. IList. Cænobii Burgensis, apud Sparke, 12. Labbe, Concilia, vi., col. 576. Spehmanni Concilia, 181. Lel. Coll., i., 5. Gunton's Peterbro', 128. Wright's Biogr. Lit., i., 170. Arehæol. Fl.. n.s., i., 163. 
and provoking contention and dislike. And there is the less excuse for him when we consider the extraordinaty influcnce that he could exert, his winning demeanour and address, and his marvellous power's of fascination. Any one thus highly endowed onght to manifest a little forbearance and consideration for his less gifted brethren. Glorions indeed is the picture of Wilfrid in his prosperity, hasking in the smiles of courts, and scattering his treasures with no sparing hand, but, if he had thus lived and thus died, we should never have known lim as the evangelizer of Sussex and the apostle of the Frisians. 'The landseape that is garish beneath the meridian smo, is fairer far beneath the shadows of the elond, and lorelier still under the cool soft lights of evening. When Wilfirid was in exile, and advanced in years, we may all admire him. We never think of the hasty temper and the imperfeet judgment, when we see how his prond spirit conld humble itself to suit his altered fortumes, and how, when age and sorrow lay heavily upon him, he could derote himself with uneonquerable ardour to the great canse of God. That must have been an honest and a noble leart that could thus forget the troubles that afflieted it, and burn, at such times, oblivious altogether of its own sufferings, with greater love and sympathy for others. These, surely, are some of the sigus and the tokens of a Christian hero.

The aged prelate was not laid in the grare in his monastery at Oundle. His heart, amid its feeble throbljings, still trembled, like the magnet, towards its beloved North, and they carricd his remains, at his own request, to his old home at Ripon." He was entomber, by the south side of the altar, ${ }^{o}$ with all the honours of the dead.

Forty years had passed away sinee Wilfrid stood before that holy place and consecrated it to God. Little thought he at that solemn festival that his own name would be conneeted with that work for perpetual generations. That abbey became one of the three great churehes in Yorkshire, and it was famous throughont England. The privilege of sanctuary and the right of using the ordeal were among the honours conferred upon it by Athelstan. $p$ The power of working miracles, which is said to have belonged

n Beda, v., 19. Saxon Chron., 61. Eddius, 88. Eadmer, 225. Flor. Wigorn., 264. Chron. S. Crueis, apud Angl. Sacr., i., 157. Ric. of Hexham, col. 296. Hickesii, Dissert. Epist., 118. Mabillon, Ann. Ben., ii., 2t.

- Beda, v., 19. Wendover, i., 118. The remains were afterwards translated by archbishop Grey (Walbran's Church of Ripon, 96). "After the extension of the old presbytery," says Mr. Walbran, "the slurine of St. Wilfrid was removed to the eastern extremity of the north side of the choir, where Leland saw it shortly before the Reformation under the areh by the high altar." Cf. Lel. Itin., viii., 21.”. "reliquice ejus sub areu prope magnum altare nume sulhate." p Lel. Coll., iv., 10, ex libro l'etri Blesensis. 
to Nilfid in his life-time, added in after years to the glories of his shrine. Ilis seal was a sorercign specific for the murain. lii, banner W'nt ont frequently, as a talisman, to the wars. Villy rhurehes wore dedieated to God in his name, and there irc fin eathedrals that dicl not possess an altar and a chantry of it. Wilfind. It Dumbam, in the beantiful Galilee that bishop P'nlsiy" crected, there was a figure of the saint in a window "in finc (ouloned ulasse, as he was acenstomed to say masse, with lis mytr' on his hoad, and his crosier stafie in his lefte hand." Inder his feet was an inseription whieh reeorded his titles, anmomer which the monks of Durham would read with no little pricl. "mono anmo rexit episeopatum Lindisfarnensem."r Among the relies in the minster of Torn, there was one of Wilfrid's alms, set in silver, and two texts, or evangelisteria, which had bromerel to him. In the side of one of them there was a (lucifix inscrted, and both were riehly decorated with gold and silscr."

There used to be some little controversy with referenee to the final resting-place of the remains of Wilfrid. Fuller of sispes "as he luad becn a great traveller, when living, so his hours took one jompuey after his death." It is said that they wreremored to ('antephny. One chronicler gives to Dunstan the crentit of tramslating them," but Frithegode asserts that Odo remored them, having fomnd the shrine most grievonsly negleeted whon he visited the chumeh." Lanfranc, in after years, deposited throm in a splendid shrine. The Noltherns, however, allege that the remains of Wilfid II., and not those of his predecessor, were removel into the South. ${ }^{x}$ Several passages ${ }^{y}$ are brought forwarl to shrw that the homes of the saint were preserved at Ripon, esperially an indngence of arehbishop Grey, in whieh it is statrd that they wore then perfect, and that they were (xhibited to the worshipping beholders. It may be said with truth that another skcleton might easily be substituted for that of Wilfirl, and that the passages which speak of the bones and

$?$ IIist. Dnnelm. Sor. Tres, publ. Surters bice., Aljux., 110.

" litas of Durliam, publ. by Surtees seriety, 12. Wilfrid's nime was in. aribed in colden letters in the Durham Liler Vitie (7).

- labric linlls of York Minster, mull. ly surtecs Societ y, 221-3. IIst. Jon. Je Abinedon, ii., 17.

"humbh lJistory, book ii., 91.

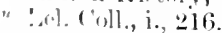

limbluer, 2zi. Direto, enl. 45.5. balluer lalls a similar story of arch-

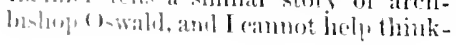

ing that Oswald and Odo have been confused. Fadmer says that Oswald earried to Woreester the bones of Wilfrid junior, whom, however, he calls a saint!

* Eadmer, 227.

$r$ A point of some importance in the constest for yrecedence between York and Canterbury, ef. Eadmer, 226-7. Anglia Sacra, i., 66, ii., 50, 206. Gerrasius, col. 1291 and 1301. Bromton, col. 863. ILigden, apud Gale, i., 266. Mahmesbury, apud Savile, 153.

y Lel. Crill., i., 10, iv., 80 . John of llexham, col. 273 . 
body of the Saint do not prove that they were really his. One of his arms, it must be remembered, was in the treasury of York at the dissolution.

The epitaph that was written for Wilfrid, and which was set up over his shrine at Ripon, is recorded by Beda. $z$ It consists of twenty hexameter lines mentioning his good works, and setting them forth for the imitation of posterity.

\footnotetext{
"Wilfridus hic magnus requiescit corpore presul, Hanc Domino qui aulam ductus pielatis amore Fecit, et eximio sacravit nomine Petri, Cui claves celi Christus dedit arbiter orbis; Atque auro ac Tyrio devotus vestiit ostro. Quin etiam sublime crucis radiante metallo, Hic posuit tropheum, necnon et quittuor auro Scribi Evangelii procepit in ordine libros; Ac thecam e rutilo his condignam condilit auro: Paschalis qui etiam sollemnia tempora cursus Catholici ad justum correxit dogma canonis, Quem statuere patres, dubioque errore remoto Certa suæ genti ostendit moderamina ritus: Inque locis istis monachorum examina crebra Colligit, ac monitis cavit que regula patrum Sedulus instituit: multisque domique forisque Jactatus nimium per tempora longa periclis, Quindecies ternos postguam egit episcopus annos, Transiit, et gaudens celestia regna petivit.

Dona, Jesu, ut grex pastoris calle sequatur."
}

The name of Wilfrid was duly entered on the calendar. His feast was appointed to be observed on the 12th of Fehruary, and that of his translation on the 24th of April. His depositio or burial was commemorated on October 12 th. ${ }^{a}$

Several works have been ascribed to the pen of Wilfrid, but, apparently, on very questionable authority. Amongst them were the following:- "De Celebratione Paschæ, lib. i. Pro Clerieorum Tonsura, lib. i. Edicta Pharensis Synodi, lib. i. Epistolæ, ad Diversos, lib. i."

Few persons have had more biographers than Wilfrid, but hardly any of these secm to have taken a fair and impartial view of his life. Beda, who could have thrown a great deal of light upon his eharacter, is so sparing of information and praise, that I cannot but think that Wilfrid was no farourite of his. In Beda's account of the treatment of Chadd there are one or two most remarkable omissions. We are obliged, therefore, to seek for information in the laudatory and highly-coloured works of Wilfrid's friends or partizans. Modern writers, for the most

z v., 19. Falmer, 228. Flor. Wigorn., 26\%. Higden, apud Gale, i., 245. Diceto, col.44\%. Lel. Coll., ii., 592, ex Ann. Eliens., with some variations. a The obituary of the church of Durham fixes it on 3rd Oct. Cf. Lil). Ti1x, publ. by Surtees Society, 146.

b Balieus de Scrijt. Brit., cent., i., 86. 
part, have treated the subject with so much ignorance and partyspirit, that no reliance can be placed upon what they say.

'Ple first hiormpler, in time and reputation, is Edde, or Eddins steplamms, as ho is called, the chaplain of Wilfrid, and the weat tracher of the Gregolian music. II (riaw $\|$ ) at the repuest of Aeca and Tathbereht. It abounds with valuable information, and it is one of the most curious finese of biograply that we possess. It is, of course, very hinhly colomed, but there are nuany minute tonehes which bear "1pon them the impress of truth and affection. The work has becm twies printed: by Mabillon, in his great work on the saints of the Bcnclictine order, and by Dean Gale, in his valualsk collection of English historians. ${ }^{c}$

'The next in order' is Fidegodus, a monk of Dover, who wrote a life of St. Wilfid, at the request of Odo, archbishop of Canterhury, in hexameter verse. Odo carried Wilfrid's remains to Caniterbury, and Fridegodus became his bard. Ilis poem is a metrical version of the work of Eddius, given in striking but meoutl language, and full of Graecisms. It is minted by Mabillon." Ondinms thinks that Fridegodus was the anthor of the poem, De Sanctis et Pontificibus ecelesiae Ebor., which serms to be properly ascribed to Aleuin by Dean Gale. Mabillom, howerer, resarded the question as an open one.

Odo, arelibishop of Canterbury, is said to have written a life of IVilfid in heroic rerse? Some suppose that it is to be identified with the poem of Fridegodus, but Mabillon observes that thr surecimen of it cited by Earhmer belongs to a different work. Ocho's poem is not knowin to be in existence. A letter of lis reforme to it is printerl in the Anglia Saera.f

Printed by Malillon, in Acta SS. crl.s. b., sace iv., i., 670-72.2, from a IIS. in the Cottonian library, which was copicel for him loy Dean ciale. ciale gives it himself in lis $\mathrm{XV}$. Ser., mol. i., w - 90, with alditions, ete., from a Ms. at Salisbury. The Ms. which both anthors marle nse of is in the Cottouian Library, Vespasian, I). vi., lut the learned Dean had one of his own (Snith's (ate). In the sance pellection, in 'lins, $\mathrm{A}$. 19, there is : - luort treation of two folios, "le Ortu "t Vita S. Wilfridi." See Berla, iv., 2.

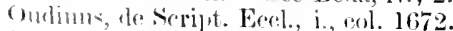
lissus de llist. Latinis, 278. Cave, IIist. Lit, 150. 'Tamer, Mibl. Angl., 77 l. litsens, 119-21. Wricht, Bibl. 1.14., 2.29. La., Scrijt., 103. There was a "oly of the life, by Eddins, in the library at Glastonbury (Lel. Coll., iv., 15.1). There was another among the MSS. of Henry Jones, rector of Sunningwell, Berks (Smitlr's Cat ${ }^{\mathrm{e}}$ ).

${ }^{d}$ Acta SS. ord. S. B., tert. sæe., i., 171-96; sxe. iv., i., 722-6. Ex. MS. corlice bibl. Corleiensis in Gallia. There is an interesting aceount of Fridegode in Ondimus, ii., eol. 467. See Wm. Malmesbury, apud Savile, 200. Bale, de Seript. Brit., cent. ii., 32. Vossius, 316. Mabillon, Ann. Ben., ii., 24. Wright, 433.

$e$ There was a copy of it in the library at Glastonbury (Lel. Coll., jv., 154). Cf. Mabillon, Aeta SS. ord. S. B., sxe. tert., i., 169.

$f$ ii., 50. A most pompons and affected piece of Latinity. Wharton regards it as the jreface to the life by Fridegode, but, apparently, without just eause. 
Earmer, the chaplain of archbishop Ansehm, drew ир another life of Wilfrid, founded upon the narratives of preceding writers, and giving only some new miracles. Ansclm translated the remains of Wilfrid, and, probably, desired his chaplain to record the merits of a Saint who was now commected with his church. Eadmer's work has been printed by Mabillon, and by the Bollandists in their Acta Sanctorum. ${ }^{g}$

Leland gires extracts from a life of Wilfrid, by Peter de Blois, archdeacon of Bath, which he found in the vestry at Ripon. This was dedicated to Geoffrey, archbishop of York." Gerald Cambrensis, also, wrote verses "in porticu eccl. S. Marix ab Wilfrido episcopo constructa." $i$ There is some account of Wilfrid, and much novel information about Hexham, which is unknown to our Northern historians, in the treatise on the Saints of the church of Hexham, and their miracks, which was drawn up in the middle of the twelfth century by a canon of that house. ${ }^{j}$

Soja was one of the five bishops who were edncated at Streonshal under the abbess Hilka. ${ }^{k}$ Of his history there is very little known. When Wilfrid lost his sce in 678, Bosa was one of the persons among whom his rast diocese was divided, and he received for his share the provinee of Deira, the seat of his episcopate being placed at York. ${ }^{l}$ He was consecrated by Theodore. $^{n}$ In 685 we find him witnessing a grant of king Ecofrid, There is some doubt as to the Iength of Bosa's tenure of the

5 Acta SS. ord. S. B., sæe. tert, i., 196-228. Acta SS., 24 Apr. From a MS. in the Cottonian library. See Oudinus, ii., 1072, and seqq.

h Lel. Coll., iv. 109.

i Ibid., iii., 114.

$j$ Printed from a MS. in the Bodleian library, by Mabillon, Acta. Ss. ord. S. B., swec. tert., i., 228-46. Other notices of Wilfrid may be found in Cangrave's Legenda Nova, 300-7. Harpsfeld, 94-6, etc. Bp. Smitl's Flores Hist. Eccl., 117-18. Lel. de Script Brit., i., 103. In Benet Coll., Cambr., is a "Vita Wilfredi" (Smitll's Cat $^{e}$ ). At Winchester there is a MS. intituled, "Revelatio Wilfedi, arch. Ebor." (Ibid.)

${ }_{k}^{k}$ Berda, iv., 23. Flor. Wigorn., 251. Wendover, i., 107. Vita S. Berre, 57.
Leland (De Script. Brit., i., 92) says that Hilda procured his elevation to the see of York.

1 Beda, iv., 12. Saxon Chron., 5 t. Wendover, i., 10\%. Flor. Wigorm., 252. Symeon, Hist. Eccl. Dunelm., 46-7. Asser, apud Gale, i., 146 . Huntingron, apud Savile, $191 b$. 1)iceto, col. 410. Bromton, ibid., 792.

${ }^{n}$ Beda, iv., 12. Flor. Wigroln., 252. Vita S. Eata inter Biogr., Miscell., publ. by Surtecs Soe, 12?. ILuntingdon, ajud Savile, $191 \mathrm{~b}$. 1)iceto, col. 410. Bromton, ibid., 793. Gervasits, ibit., 1638.

$n$ Lel. Coll., ii., 517. Trithenins de Viris illustr, ord. S. B., lib. iv., call. 61. $\Lambda_{p p^{\mathrm{x}}}$ to Smith's Beda, 782. Busa witnesses a charter of Eegfril in 685 (Codex I)ijt., i., 29). 
ser of liok. It secms probable that he lost his position on

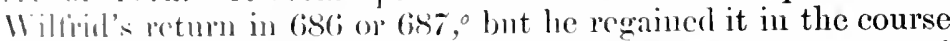
of two of threc ycats, and hold it mutil his death, which oceurred in $7(1)$. The mandate of pope Jolm which required him to meret IVilfid, and conne to some arrangement about the see of lom, was therefore uscless.q The little that we know of Bosa is rory mols to his credit. He was the instruetor of Acea, who bermine lishop of IIcxham.r In the life of Eata, Bosa is spoken of "1. "sinctus et l)co amabilis vir."s Symeon calls him "sanetisinms ot 1)eo dilectus;" and Florence of Woreester tells us that he was a person "multa sanetitatis et humilitatis." Mlenin also bestows upon him no ordinary praise. A short crtract fiom his panegyrie will suffice:-

"Prafuit ecclesib renerandus Bo:a sacerdos,

Condignu- sradui meritis mune temporis alto,

Vir monachus, prasul, doctor moderatus honestus,

Qnem divina saris virtutum gratia sertis

Comlerat, et multis feeit fukencere donis."

bosa oceurs in the calendar as a bishop and confessor. The li! set apart for him is Jan. 13.

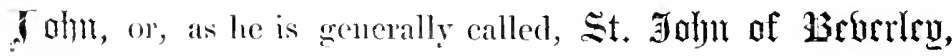
is said to have been the son of noble parents, ${ }^{x}$ and to have been born at 11 arpham" in the East Riding of Yorkshire. In his youth he was entrusted to the care of archbishop Theodore, who educated him, and gave to him his name of John. ${ }^{a}$ Subscuncinty he beame one of the pupils of Hilda, the abbess of

" Eidlins apul Gale, i., S5-6. Eadmer,

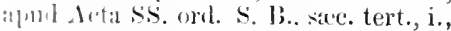

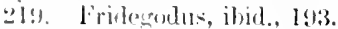

" [n. Simill, the leirued editor of lindit, lines the date of his death in GS7, hatine been misterl by 11 harton in the Anet. sianat, i., 6i9.5. The eroror is correntent in the alp ${ }^{x}$ (p. 759), by the ulitur's alcomplished son. The editor of licali, in the Mon. Ilist. Bril., 233. makis a similir bhumler. Florence (20.5) says that lo died in 7os. The mandate of fope Joln shews that he was alive in 703 or 4." Siubbs, Rer. S:trom Anel., 1.

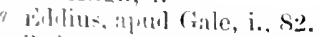

Bulli, צ., 20. Mirize. S. Wilfr.,

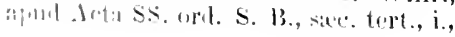

211. Symeon, col. 102. Ric. of Hexham, ibirl., col. 297 .

s Misc. Biogr., publ. by surtees Soc., 123.

t X. Ser., col. 102, quoting Beda, v., 20.

"Chron., 255.

${ }^{r}$ De SS. et Pont. Eecl. Ebor., apud Gale, i., 718.

${ }^{*}$ Acta SS., Bollandists, where there is an minteresting life of Bosa compiled from Bela, etc. Another day is assisned to him. Harpsfeld, 147.

$x$ Stubbs, col. 1692 .

y Lel. Coll., iv., 100. Acta SS., mense Maio.

z Stuble, ut sulıra. Bromton, ibid., col. $7 ! 4$.

a stublss, col. 1692. 
Streonshal, " a circumstance," as Fuller observes, "which soundeth something to her honour and nothing to his disgraec, secing eloquent Apollos himself learned the primar of his C'hristianity partly from Priscilla." IIe is claimed, also, by the university of Oxford as her first master of arts." We may conclude, therefore, that he was a person of more than ordinary learning.

"His light," as his biographer Foleard observes, " was not hid under a bushel." He soon began to preach the Gospel to the people. He arrested their attention by his eloquence and learning; and his holy life winged his words to their hearts. At the same time he did not neglect his own scholastic studies. Like every person of consequence and ability, he was the eentre of a circle of pupils who came to him for instruction. He was an excellent expounder of the Scriptures, and was well versed in history and otlier subjects. ${ }^{e}$ Among those who profited by lis teaching was the vencrable Beda, whom he afterwards ordained. $f$ It was no slight honour to have been the master of such a scholar, and it was, probably, from John that Beda derived that taste for historical pursuits which has won for him an molying reputation.

The zeal and learning of Jolm could not fail to attract the attention of the Northumbrian court, and his comection with Theodore would be sure to contribute to his advancement. King Aldfrid was his patron, ${ }^{g}$ and through his means, in all probability, John succeeded Eata in the see of Hexham. 'This appointment is enveloped in some mystery, which may, perhaps, be cleared away in the following manner. Eata died, $T$ beliere, in the autumn of $686,{ }^{h}$ and abont the same time Wilfrid returned into Northumbria, and was allowed to take possession of the sces of Hexham and Lindisfarne, which were then vacant. We know that Wilfrid was only bishop of Lindisfarne for a ycar, ${ }^{i}$ and we are told that John was consecrated bishop of Hexham on the

b Beda, iv., 23. Wendover, i., 107. Vita S. Begre, 57. Folcard (Acta SS.) calls him the pupil of Elfleda, at Whitby. Stubbs (col. 1692) is also wrong in calling John's inctructress Eifrida. Mabillon, Ann. Ben., i., 471, commits an error when he sijeaks of John as "Wicciorum Episeofus."

c Fuller's Worthies, n.e., ii., 497.

¿Cains de Antiq. Univ., Cant. i., 106. Acta SS., ut supra. pref. IIarrison's description of Britain, 158. 'Twyni Antiq., Acad. Oxon, 169. Wood's Liti. Univ. Oxol1, i., 28, and IList. Iniv. Oxon., iv., 37-8. His figure, as a fellow, was in one of the windows of the rhileel at Univ. Coll. Smith's Annals of UTiv.
Coll., 129. Fuller (Worthies, ii, 497) says of him, "I remember his picture in a window in the library at Salisbury, with an inscription under it, atlirming lim the first master of arts at (Ixforl." It has still to be proved that there was an miversity at Oxford at flat time.

e Folcard, apud dchat SS. Stubbs, col. 1692 .

$f$ Folcard, ut supra. Triveti Imnales, 262. Nabillon, Jota ss., Ord. S.ls., saxc. tert., i., 536, ex tita Bede, per('eolfridum. I,cl. le Script. lBrit., i., 116-18. $g$ led. Col., iv. 100. havon Chron, 63. lieg. Siternm $\ln m$ l., 1.

i Berk, iv., 29. Flor. Wizorn., 256. Symeon, Hist. Eecl. Dumelm., 60. 
2itl Ingust, 68r.' It may be inferred, therefore, that Wilfrid touk prisession at that time of the see of York, which was eeded (1) him, voluntarily or involuntarily, by Bosa, and that he left the northern portion of the great diocese of Northumbria to John and badbert. With IIexham John was very well acquatinted. For some time before he was raised to the see he had lived in an hemitage at II arneshalg or Hameshow, otherwise called liaylesmomnt, on the 'Tyme, ${ }^{k}$ so that the field of labour to "hich he was now introrheed was by no means unfamiliar to him. IIe presided orer the see for abont eighteen years, but we kmu very little of his labours and his life. At a little village called carnesbroc, distant a mile and a half from Hexham, on the opposite bank of the Tyne, he consecrated a church which was dedicated to St. Miclacl.! 'To it, especially m Lent, John was accistomed to retire to watch and pray in secret. Thither did the needy and the sick resort, and their benefactor did not neweret then. We have an aceount of a miracle that John is sitil to hawe worked at Carnesbroe."

() 11 the drath of Bosit in 705, , Jolm was translated from Il'sham wo lork, and Alenin, when speaking of the new prelate and lis approintment, is by no means sparing of his praise.

\footnotetext{
"Intrrea los:a felicia regna petente,

Acripit ecelesio regimen clarisimus ille

Vir fietate, fide, meritis et mente, Johannes, lontificalis apex, priscorum formula patrum, Fluminat doctrina fundens e pectore puro."o
}

The sixom Chronicte (6.3) is the anthroity for this datr. (to ibis., 56. 1)r. Sulith, in his edition of Bedli, v, 2, :ant Rirliard of Hexhan (X Ser., col, 2:15), saly that John heeame bishop of

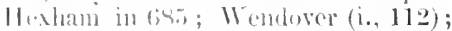

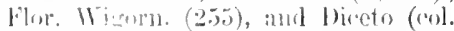
111) fut the aldeintment a vear later.

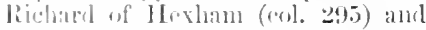
followal (Arlal SS.) sily that Jolnu hold

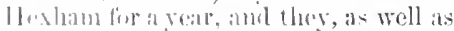

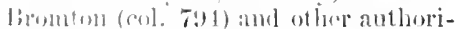
liwe, sily that he went to lork in 686 or 7. lion bring then deat, whereas he was alive in 705 (cf. liver. Sacr. Ane., t.

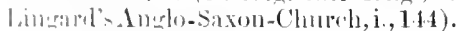

$11 \mathrm{~m}$. of Malme Imry (Savilo, 153); Andia silura, (i., (bis); and IList. Mlon. s. Aus. (ant., (279-80) sity that John wis Triven ont ol Hexham to make

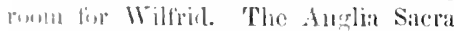
aty that bus was expelled from rork

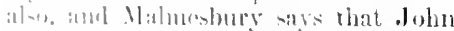
wont from Jlexham to York, i.e, from

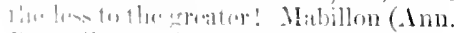
bon., ii., 20) is quile at famb in the chronology

$k$ Lel. Coll, iv., 100. Stubbs (col. 1692) calls the place Arneshange. Richard of Hexham (col. 291) calls it Ernëshou, and Higden (apud Gale, i., 217), the oratory of St. Michael or IIarneshow. Higden and Richard identify the oratory and the hermitage.

' Beila, v., 2. Folcard, ut supra. Lel. ('rull., iv., 100. Rich. of Hexham, (col. 292) silys that the church of St. Micliael was beinn by Wilfrid and finished by Acea. 'The only' church at present dedicated to St. Michael in the neighbonrhood of ILexham is that of Warden. 'There is a village bearing the name of St. Joln's Lee, on the opposite bank of the Tyne.

m Beda, v., 2. Folcard, ut supra.

$n$ Sixon Cliron., 56. Fl. Wigorn., 268. Symeon, col. 76. Ric. of Hexham, ilid., col. 296, who says that he was bishop of York thirty-three years.

"Alcuin de SS., etc., ecel. Ebor., ajm Giale, i., 722, where there is an interenting life of St. John in verse. 
Of the good work that John did in Yorkshire we hare sereral pleasing memorials. I say nothing of the miraculous powers which he is said to have possessed. It is enough to wateh his good example in the ordinary path of duty. With king Osied ${ }^{p}$ he seems to have been a favourite. He joined with that monareh and his nobles, and in synod assembled they made many wise enaetments for the management of the Northumbrian chureh. $q$ John saw, also, that they were earried into effect, for he was very diligent in visiting his monasteries and attending to the poor. When he was asked to a banquet after the consecration of Burton ehurch, he uttered the noble sentiment, "Magis episcopum deeere ad monasterium redire, et Deo in suis pauperibus servire, quam per domos divitum convivari.". In the midst of his labours he did not negleet the solitary watehes and the prayers of the reeluse. His own residence in York was adjacent to the ehureh of St. Miehael the arehangel, and thither he retired at stated periods to humble himself before (rod.s There would be a eharm to him in that familiar name. It would remind him of the little oratory in which he had once prayed by the waters of the Tyne.

Amid the many duties that waited upon his high offiee John never forgot the lessons and the example of Theodore. He had always around him a little company of pupils to whom he was the Gamaliel. Beda indeed had left him, and was preparing in his solitary eell the works that we still admire, but there were others now at the feet of his old master. St. Sigga was there, and Herebald, the abbat of 'Tynemouth in after' years, and at this time the eompanion as well as the pupil of Johm. Berethune, another of his scholars, became abbat of Beverley, and narrated to Beda those miracles of the good bishop which the great historian has reeorded. Of Wilfrid, the pupil who sueceeded him in the see, I shall elsewhere speak. ${ }^{t}$

Bale asserts that John was the author of the following works. "Pro Luea Exponendo lib. i. IIomeliae Evangeliorum, lib. i. Ad Hyldam Abbatissam, lib. i. Ad Herebaldum Diseipulum, Epist. i. Ad Andoenum et Bertinum, Epist. ii., et alia." "

It is with Beverley and the East Riding of Yorkshire that the name of John is espeeially conneeted.

\section{"_- Natale solum dulcedine capitos \\ Dncit, et immemores nou sinit esse sui."}

$p$ Folcard, nt supra. Lel.Coll. iv., 100.

$?$ and ${ }^{r}$ Folcard, ut supra. I believe that this is the symor which is said to have been lield at Alne in 709, and about which there is some mystery and doubt. Labbe, Concilia, vi., 1 101 . Spelmanni Conc., 215.
- Folcard. Bromiton, col. 791.

t Folcard. Bromton, ut supra. Stubbs, col. 1693. Lel, Coll., iv., 100.

"Script. Brit., cent. i., 89. Bale is probably drawing, as usual, upon his inaggination. 
'This was the charm that bound hin to that district. Among the wooks and lakes with which it then abounded he found a village of the name of Inderawood, which a later generation rhancel to Bercrley, from the beaver's that then sported in the "rater's of the Hull." It that time, no doubt, it was an oasis amone the wild woods in which it was embosomed. A little rhur.', was there, dedicated to the beloved disciple, ${ }^{n}$ the namesike of the holy prelate who now gazed in rapture upon the scenery around him. Finscinated by what he saw, and a mighty impulse noving him, John became the owncr of the place. He added a (hoir to the existing chureh, and converted it into a monastery. Seren priests were placed in it with as many clerks. On the sonth side of the church Jolm erected an oratory, which he dedicated to St. Martin, and made into a nummery. Neither was there any want of permanent endowments. The founder boumht and ippropriated to his monastery lands in Ridings, Wririck, Bilton and Patrington, and stimulated by so good an cximule, the nobles in the neighbourhood most generously assisted him. One gave to him North Burton, and another the mancm of Walkington. Churehes were erected, and the foundations of a great ecelesiastical settlement were laid, of which John had much reason to be proud. ${ }^{x}$

This noble work was the great effort of Joln's life, and it is natmal enough that he should be attached to that place which he hard honoured and arlorned. The affections always nestle around the labour of the head and hand. Dear to John, without doulst, would be the temples that Vilfrid had erected; lastingham woukd remind him of the toil and the lore of Chadd, and at Streonshal he would muse with affection upon his old instructress,

"He gathers round him, and revives at will

Srenes in his life - that breathe enchantment still."

But nome of these places or scenes would possess the charm thit attracted him to Inderawood. It was his own offering to (iod in the eoming of his birth. There the aged prelate could sily with (icere, but in a far higher sense, "hic sacra, hic gemus, hic majorm multa restigia,-Qnare incst nescio quid, et latet in animo et scusu meo, (quo me plus hic locus fortasse delectet." "lhere he could meet with that solitude which the court and the renced city rould never give him. There he could watch over the infant society of which he was the founder, and, at the same

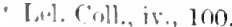

* I. el. (ill., iv. 100. Sinctuar. Dn$11 \mathrm{~lm}$ and Beverlar., pmbl. by Surtees $\rightarrow, 1, \ldots, 6$.
- Folcarr, apud Acta SS. Gaimar, l'kstorie des Engles, a und Mon. Hist. Brit., 783. Lel. Coll., iv., 100-101. Dugdale's Mon., ii., 127. 
time, endeavour to reach a ligher step on the great ladder of perfection. As each succeding winter left its mark npon his brow, he would long more and more for the quict that lie haid found in his hermitage on the Tyne, and coret that rest which the busy world denied him.

"For there the soul, released from human strife,

Smiles at the little ills and cares of life."

The desire was irresistil)le. In 718 he deserted the sce of' York, which he had occupied sinee the death of Bosa, and, nominating as his successor his old pupil Wilfrid, he retired to spend his days among the solitude of Inderawood. $y^{y}$ Berethune, a beloved scholar, was the abbat of the monastery, and by him he was affectionately welcomed. $z$ For four year's was the aged prelate an inmate within those walls, and then his prayers and his watchings were conchuded. On the seventh day of Mİay, $7: 21$, he was called away to his rest."

He was buried in St. Peter's porch, ${ }^{b}$ within the church that he loved so well, ${ }^{c}$ and from which he is called to this day St. $\mathrm{J}_{\mathrm{ohn}}$ of Beverley. His remains, like those of St. Chadd, were deposited in a feretory of wood, which was beautifully carved. ${ }^{d}$ In 1037 he was solemnly canonized at Rome by Benediet 1X., and in that year archbishop Alfrie remored his bones, and deposited them in a precions shrine which was radiant with gold, and silver, and jewels.e 'The care of the pions archbishop was fruitless, for the shrine was, probably, destroyed or lost in the fire by which the church of Beverley was consumed in September, 1187. Five years after this John's remains were discovered, and deposited in another place. In 1664, whilst a grave was being dug, the ashes of the Saint were found in a case of

y Saxon Chron., 56. Flor. Wigorn., 272. Beda, v., 6. Aleuin de SS., etc., apud Gale, 1., 724. Folcard, apud Acta sS. Symeon, col. 76. Ric. of Hexham, ibid., 296.

z Bromton, col. 794 .

"Beda, v., 6. Saxon Chron., 63, having been a bishop thirty-three years, eight months, and thirteen days. WTendover, i., 135. Folcard, apud Leta SS. Liber Vitx Dunelm., ed. Surtees Soc., 143 , in which St. John's mame is entered in golden letters (7). Hirrlen, apud Gale, i., 247. Stubbs, col. 1693. Bromton, col. 794, who says that he was bishop of York twenty-three years. Chron. Petrib (5) says he died in 722. Lel. Coll., iv., 101. Gaimar, l'Litorie des Engles, apud Mon. Hist. Brit., 785, says of him,

"Li bons Johans idlone transi,
Celui ki gist a Beverli."

b Folcard, apuld Leta SS., says that he was buried "in porticu s. Joh. Evang."

c Beda, v., 6. Saxon Chron., 63. Foleard, ut supra. IIigden, alud Gale, i., 217. Ric. of Il(xham, col. 296. TLickesii Dissert. Ep., IIs. Stubbs, col. 1693. Lel. Coll., iv., 31, 80. Dusclale's Mon., ii., I66. Cilporave and othors are wrong when they sily that John was buried at Sarum. (f. 'Twy Antiq. Acad. Oxon., I69.

d Stubbs, ut supra, col. 1700.

- Stubbs, nt supra. Lel. Coll., iv., 102. 
lead, and were re-interred by the order of the archbishop of the diyl 'They were anain hromght to light in 1736.9

liry creat was the sanctity of that shrine in the days of old: miny pilgrimages were mide to it, and many miracles are siald to have been wronght through the ageney of St. John. ${ }^{h}$ With the exeeption of Cuthbert of Durham, no Northern Saint wite reginded with more vencration than St. Joln of Beverley. Mrsterions virtues are said to have proceeded from his shrine, anil a holy oil to have flowed from his tomb. ${ }^{i}$ The fame of beverley and its Saint attracted the attention of king Athelstan, who, like 1)arid of Scotland, was "ane soir sanet for the crown." When he was on his way to Scotland he is said to have gone to Burroley to obtain the assistance of St. John, promising his church many privileges and gifts if he were successful, and laviun behind him his "cultellum" as a pledge that he would rederm.

\section{"IIe went to Beverlay}

Anl praied to the bishop Jon in fertre wher he lay, That he wild bede lis bone, untille the Trinite, Ant he suld grve his kirke framchise and fe, 'To haf and to holde als he was kyng leall."'k

The monareh carried with him into Scotland the banner of St. John, and success attended him. I pass over the marvellous story of the sword, which reminds us of the adrenture of king Arthur. On his return to England the vietor did not forget his promise. He founded at Bererley a college of secular eanons, adding to the old endowment divers lands in Lockington and Brandesburton.? He ware it, also, among other rights, the priviluge of sanctuary, which the eluurch of Beverley enjoyed until

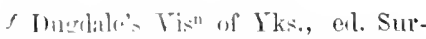
leves Sor. 20, where a lomer alecount of the diwery is given. Thoresby's lialr, ii., 13i. Ninth. a Wrod's Life, al. Bliz., J10. Camden's Britamnia, n. e, iii., 32\%. Poul-ou's Beverlae, 666.

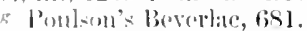

h Berlin, v., a-f. Mlenin de SS. Elwor, apurd Galc, i., 723-4. Wenfluser, i., 135. Folrard, Liber Vitx, al. Surters Sne, 113. IIist. Mon. S. Aliz. (aut., zso. Scala Chronica, 6, 211. Rir. of Herham, col, 291-2. liprinton, enl. 791. Stuble, col. 1692-3. 1.r. roll., ive, 100, ete. Caprewe's Xisa lorecondia SS., 189-91.

- on June 11, l113. Archbishop Kimpuranted an indulgence of 100 dass to those who visit the tomb, "which is mow very faments, experitlly for the very healthiful suldily of aweet oil which is now observed to gush from the tomb more largely and abundantly than 11:ual, for the healing of all faithful worshipmers." The monks of Meatux had some of this oil in an ampul. (Ponlson's Ilolderness, ii., 313). Capgrave's Nova Legenda. Harpsfeld, Hist. Angl., 117-8, where there is a short account of St. John. Twyni Antiq. Acad. Oxon., 170.

$j$ Foleard, apud Acta SS. Sanctuar. Dnnelm. et Beverlac., ed. Surtees Suc., 98. Triveti Annales, 321. Ailrerl, col. 356-7. Bromton, col. 838. Cart. Domns S. Leon. Ebor., MS., Cotton., Nero D., iii., 5 a. Higrden, apud Gale, i., 262. Lel. Coll., iv., 100-101. Rymer's Fxdera, i., 771-2.

${ }^{k}$ Peler Lanstoft's Chron.,29. Chron. Pelrib., 28. Jn 938.

'Acta SS. Lel. Coll., iv., 101-2. 
the Reformation." 'The words in which these grants were made have been handed down by tradition :-

\section{"Als fro make I thee As hert may thenk Or eghe may see."}

I find them mentioned in a confirmation of the privileges of the chureh which was made by Heury IV., and you may still see them on a tablet in Beverley minster under a portrait of Athelstan, which it is unnecessary to describe. The canons would be glad to preserve a memorial of the monarch who regarded St. John "as his tutelar Saint," and the piety of Athelstan was duly recited in the legend. ${ }^{p}$

The example of Athelstan was copied by other kings who were glad to honom the Saint, and to eonfirm the chartered privileges of his town. Edward the Confessor was a benefactor to the minster. William the Conqueror and Stephen were prevented, it is said, by miraculous interference, from plundering its lands, and William became its patron. ${ }^{4}$ John visited the town and added to its privileges, but not without a befitting consideration for his generosity. ${ }^{r}$ Edward I. carried with him the banner of the Saint, as a talisman, to the wars in Seotland, and made his offerings at the tomb at Beverley on more occasions than one. ${ }^{s}$ Henry IV. eame to Beverley and confirmed its privileges, ${ }^{t}$ but it was his son, Henry V., who paid the greatest honour to St. John. The victory of Agincourt was won on the 25th of Oetober, the day on which the translation of the remains of the Saint was commemorated, and the monareh attributed his success to St. John's intercession." He shewed his gratitude by making a pilgrimage to the shrine with his queen. $^{v}$ But he did more than this. It was probably at the desire of Henry that archbishop Chicheley wrote, on Dee. 16, 1416, to the bishop of London, reqnesting that in consequence of the great victory, the day of St. John's burial, i. e., the 7 th of May, should be observed with due state and eeremony, "ecm "regimine chori, ad modum festi unius confessoris et pointificis."

n Foleard. Lel. Coll., iv., 101. The register of the sanctuary has been published by the Surtees Society.

n Frdera, viii., 369. Codex Dipl., ii., 186.

- Weever's Funerall

Monuments, 181. Sanctuar Bev., ed. Surtees Soc., 98.

p Triveti, Ann., 321. Lel. Coll., iii.,

4. Capgrave's Nova Legenda.

7 Acta SS. Lel. Coll., iv., 102-3.

$r$ Poulson's Beverlac, 63, 537. s Liber Garderoba, 27. The king made his offerings at the tomb, "ubi S. Joh. primo sepeliebatur." 'Triveti, Ann., 321. Langt oft, ii., 303.

"Befor Saynt Jon he woke a nyght or he the in nam."

- Fredera, viii., 369.

" Federa, ix., 121. Sir IIarris Nicolas' ace of A gincourt, 176. Lugd., Mon., ii., 166.

"Ponlson's Beverlae, 595. 
The homomes of Oet. 2.5 were shared witl SS. Crispin and ('ispinimin."

1 life of St. Jolu has been written more than once. His principal hiomplater was Folcard, a monk of Canterbury, who wote his work in the clerenth contury at the request of Aldred, anhlinlup of lork, to whom he dedicated his book. ${ }^{x}$ It is printed in entenso by the Bollandists in their Aeta SS., under the ith of 11 ay ; and it may also be found, in an abridged form, with another short life by a namcless anthor, in the great work of Mabillon.y 'The nariative of Folcard is meagre and unintresting, and is evidently the production of a person who knew little of his subject. Subjoince to Folcard's life is a collection of the minales ascribed to St. Jom, some of which were written (row by 1 illiam Kocel, a cled of Beverley. I believe him to be idcritical witl Iskctyll, who is said to have compiled a life of st. John: Loland, in his Collectanea, gives extracts from two hives of St. John. 'The first is that by Foleard. The latter, which is by an anomymons anthor, is divided into three palts, and contains much interesting information. There is a bricf accomnt of him in C'alygrave's Nova Legenda SS.

MVilfrio EE, on Jutior, as he is called, to distinguish him from his illustroms namesake. He was a favourite pupil of Jolne, who mesigned the bishoprie of lork in his favour, when old arre had remered him mequal to the duties of the office.

" Fim]era, ix, 121. Dnenl., M[on., ii.,

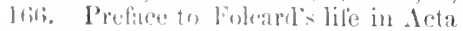

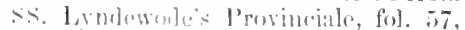

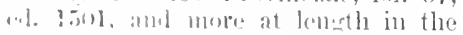

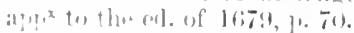

Whe tranerilu which the Bullin-

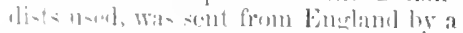

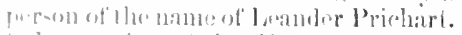

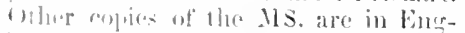
land, riz.. inter Mes. (uttont., Fimstina

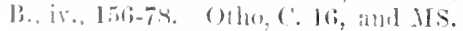

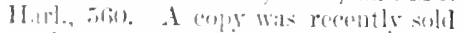
at Ho dispersion of the savile USS. fir tonl, al very laree sum when we remomber the imintopetine character of th. WS., and that it is alpedy in print. 1. hand aw a copes in the library of st. Mary sork (cill., ir, 37). phere is ansilior amone the larker Mss., 1 . 11 (

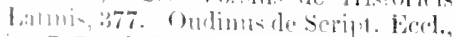
i1., 747. Laland. de soriph. Brit., i.,

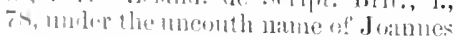

Fibrolegamms. Wright's Biogr. Lit., i., 231.

= Tosils de 1Tist. Latinis, 51.4.

y Actr S.'. ord. S. Ben., ed. 1731, seec. iii., i., $110-13$.

a Lel. Coll., iv., 99-101.

b Fol, 189- 1 , ed. 1516. A short aret in Smiłl's Flores Hist. Ecol., 118. Pitsens, 122. My friend, Mr. stubbs, informs me that there are some critacts from an unjublished life of St. Joln amons the Wharton MSS., in the library at Lambeth.

Bedir, v., 6. Aleuin de Pont. Ebor., ap!ul Cale, i., 721. Saxon Chron., 56. I'hr. Wigorn., 272. Foleardi, Vitas. Joh., ajpld Acta s., mense Maio. Symeon, col. 78. Stubls, col. 1694, Who calls him St. Joln's chaplain. Ifigden, ajnd Giale, i., 217. Mabillon. Am. Ben., i., 47t, where he is sairl to have been one of Ifilda's pupils. Ibid., ii., 50. IIarysfeld, 148. 
Before this Wilfrid had been the rice-dominus, or abbas, of the monastery at York, the bishop himself being the dominus or ruler. Wilfrid gave to the church of ' York sereral noble gifts, furnishing the altar with sacred ressels, and covering it and the crosses with plates of silver gilt. He was munificent, also, to other churches, and he seems to have attended diligently to his episcopal duties." Wilfrid is said to have sanetioned the accusation that was brought against Beda, of promulgating heretical opinions in his treatise, De sex cetatibus mundi, and the historian made against him the counter-eharge of indulging to excess in the luxuries of the table. ${ }^{e}$ The words of Alcuin are probably corroborative of the testimony of Beda, when he says,

\section{"Hos mentes dapibus, illos sed carnis alebat: \\ Hos fovet retheriis, illos carualibus auget." $f$}

The poet, howerer, speaks in laudatory terms of Wilfrid's energy and goodness. There is some difference of opinion among the historians as to the vear in which he vacated the see, but the difficulty is removed by the following passage, which some modern writers have overlooked.

\footnotetext{
"At sua facta bonus postquam compleverat ille

Pastor in ecelesiis, specialia septa petivit,

Quo servire Deo tota jam mente vacaret:

Contemplativa seseque per omnia vita

Dans, mundi varias curasque reliquit inaues." $g$
}

It thus appears that Wilfrid followed the example of his old master, John, and devoted the last portion of his life to solitude and prayer. He took this step in $732,^{h}$ the year in which he is said to have died, but the closing seene was deferred until the 29th of A pril, 744. or 745.j What the "specialia septa" were to which he retired it is impossible to say. The dignitaries of York, in after times, asserted that he was interred at Ripon, and that arehbishop Odo carried away his remains, and not those of his more illustrious namesake, from that church to Canterbury. ${ }^{k}$

d Aleuin, apud Gale, i., 721.

e Beda Epist. ad Eegbertum, ed. Smith, 306. Vita S. Bedre, inter Acta SS. ord. S. B., sae. tert., i., 518. ApY ${ }^{x}$ to Smith's Beda, 802 .

$f$ Alcuin, apud Gale, i., 725.

$g$ Ibid. Smith's Beda, 315.

$h$ The year in which Egbert came to the see. Hoveden (Savile, 231) says that Wilfrid died in that year, and he is followed by Mr. Stubbs in his Reg. Sacr. Angl. Symeon (col. 78) says that Wilfrid was bishop for fifteen year: Hen. of Huntingdon (Savile, ig5 $b$ ) says for ten. Cf. Promem. ad op. Alcuini, ed. 1777, vol. i., xvi.

i Saxon Chron., 67, he having been bishop of York thirty winters. Flor. Wigorn., 272. Higden, apud Giale, i., 249. Mabillon (Ann. Ben., ii., 21.) putts the depositio of S. Wilfr. (i.e., jum.) on 8 kal. Jume. Wendover, i., 145 , makes Wilfrid die in $7+3$.

j Symeon, col. 104. Chron. de Mailrus, 4. Addit. ad Bedam, ed. Snitl, ,221.

* Auglia Sacra, i., 66. Hist. Mon. S. Allg. Caut., 2S1. Malmesbury de Pont., aprut Savile, 153. 
liulmer, howerer, maintains that his bones were carried away frem lipon to Woreester by the eclebrated Oswald.'

I Gbert was the son of Lata, and a member of the royal family of Jorthmbria. He was first consin to king Ceolwulf, the "mont glorions roolwulf," to whom Beda dedicates his history. ${ }^{m}$

"Regali stirpe creatus,

Nobilinm coran seclo radice parentum." ",

The routhful noble was sent by his father to a monastery to receive his colucation. After awhile he went to Rome, with his brother legred, to extend and complete his studies, and there he was adluitted into deacon's orders. His brother having died at Rome. Eghert returned into Northmmbria."

In 3 ; : Wilfrid resigned the bishopric of York, and Egbert was appointed by Coohwulf to suceed him. ${ }^{p}$ The selection was an excellent onc. By his learning Egbert was peculiarly fitted fine that high ofliee, and his noble blood would add greatly to his influchere with the court and people. Soon after he was raiscel to the see of York, Beda, who was now drawing towards the (') ofe of his pilgrimage, wrote a long letter to him filled with sonsible advice as to the management of his diocese. It gives us an armirable pieture of what, in the opinion of the writer, were the duties of a ('hristian bishop, and sets vividly before us the condition of the Northern chmrel.

In the first place, the great listorian recommends Egbert to illustrate fucrsonal teaching by personal holiness ; to give to study and contemplation the hour's that many waste in idle comversatim, and to cschew the socicty of useless and worldly compantons. He then advises lim to ordain a larger number of fricsts to teach and administer the sacraments in the rillages,

1 Anelia Sacra, ii., 206. The inseription stated that they were the bones of st. Wilfricl. Wilfrid II. was never camonizerl. The evidence is most contlieting, and "adhue sub judice lis "xt."

on Sixm Chrom., 66. Symeon, Ilist. Eorl. 1)meln., 83, 81 .

"Alouin de Ss. Ecel. Elor., apul Giale, i, 725.

"Srmern, Ilist. Ecel. Dunetm., 83. " 1 jatre bata in monasterium traditu-..t." 1r. Sunith, in a note to his whtim of lida, 312, commits an error, with regard to this passage. He makes Eata the bishop and not the prince. Mabillon (Ann. Ben., ii., 94) falls into the same mistake, and so does Mr. Wright (Biogr. Brit. Lit., i., 297).

$p$ See Milfird's life. The Saxon Clron. makes the date 734(66). Flor. Wigorn. puts it in 744, "arehiepiscopatus insigni snblimatus" (272). Cf. Baronii fmll, ix., 110. Wendover (i., 14t) makes the date 743. Addit. ad Bedam (Smith, 223) make the date 732. 
and also to translate the Creed and the Lord's Prayer ont of the - Latin into the Saxon tongue, as well for the use of the listeners as for those who officiate in the ehmrehes. Beda, in the next place, expresses his wish that the episcopate should be extended. 'There are many places, he says, among the woods and hills of Northumbria, that a bishop has never visited for years, although all are regularly tased for his support. This disinelination for subdivision was to be aseribed to the pride and avarice of the prelates themselves. Against the evils which neeessarily resnlted from such a system, there was an adequate remedy in the injunction of the pious and foreeasting Gregory that there should be twelve bishops in the Northern province, and Beda beess his friend to secure for himself the pall, and to obtain the permission of king Ceonwulf to carry this recommendation into effect. Several of the larger monasteries could be eonverted with advantage into the residenee of a bishop. From this point Beda passes on to the corruptions with which these religious institntions were filled, and the urgent necessity for reform. They were hotbeds of the grossest rice; no rule or diseipline was observed in them, and luxury and exeess, of every kind, were rife within their walls. Ever since the days of Allfrid it had been the common practice, not only of persons of distinetion, but of officers of the conrt, to obtain grants of land for the purpose of founding a monastery; and, when it was established, and freed, in this way, from secular jurissliction, it was merely converted into the residence of the founder with his family and friends, who had nothing of religion but the cloak. The whole dioeese, as Beda said, was full of disorder and corruption, and it would require all the determination and skill of a bold reformer to suppress them.q The existence of several of these evils in the Northern provinee is mentioned with regret in a letter that was addressed to Egbert by the pions and energetic Boniface. ${ }^{r}$

These warnings and suggestions were not lost upon Eghert. His first endeavour was to obtain the pall, which was given to him by Gregory III. at Rome, in 735. He thus beeame the second archbishop of York. More than a century had elapsed since Paulinus fled into Kent, earrying lis pall with him, and no one since that time had sought for the lost honour, a neglect which was made, in after years, a strong argument for the pre-

$q$ Bedx, Epist ad Ecgberctum antistitem., ed. Smith, 305-12. Mabillon, Ann. Ben., ii., 97-8. Acta SS, ord. S. B., sæc. tert., i., 548-9.

$r$ Bonifacii Epist., apud Bibl. Max. Patrum, xiii., 73, 106. Baronii Ann., ix., 110. Mabillon, Ann. Ben,, ii., 101.
Spelmanni Conc., 232, 237. In MS. Cotton., Vesp. A., xiv., among many of Alcuin's letters, is said to be one from Pant the First, " ad Ethberktum Archiepiscopum ot Eadberhtum filium regis." Cf. Wilkins' Concilia, i., 141. 
crelence of canterbury, when the famous controversy arose lutweru the two metropolitan sees." When Eghert thus became archlishop he stepperl at once into a commanding position, and crery bishop in the Nortliern province was made his suffiagan. In i3s his hands wore still farther strengthened. In that year his brother Vadbert nounted the Northmmbrian throne, and the protretion of the state was thereby assured to the arehbishop. He could now act with anthority and decision. It is impossible (1) say to what extent he carried ont the reforms which Beda and Boniface recommended, but, at all events, it is eertain that he was diligent in his duties. ${ }^{t}$ The books that he wrote shew that he had the interests of his dioeese at heart, and if he took so) much pains to commit to writing a system of diseipline and reclesiantieal rule, we may safely infer that he would do his best to see that they were properly observed. All the works of Righert secu to presuppose the existenee of a regular clerical orenaization, and as he ocenpied the throne of Paulinus, with such commanding influenee, for above thirty years, he wonld have time cmongh to see the system in full play. Aleuin aequaints us with his pisty and cricrgy." He is said to have been the first prelate who possessed a mint at York." He paid great attention to the services and music of his chnreh, introdueing the obscrvance of the hours. He was, also, a benefactor to the fabric of the minster, bestowing upon his eatherlial the eloice work of the jewcll's and the goldsmith, and giving to it figured "urtains of silk of foreign workmanship." He was, in all prohability, the first introducer of the paroehial system into the North. Ilis worlsis were of great repute in the Anglo-Saxon rhureh. 'They comprise a l'ontifical, $x^{x}$ or' a series of special offiees for the use of a bishop, a volume of Excerptiones, or extracts from the father's and canoms on matter's of discipline, ${ }^{y}$ a Dialogue

Saxm rhron., 66. Adilit. ad Btodan, ml. Suntll, 2.2. Chron. de Mailes, 3. Wenlower, i., 115 (iu 715) Siment, col. 100. Stubbs, col. 160\%. C'hron., J. Wallingford, and risle, i., 529. Ilinden, ilbid., i., 219. Inveden, apul Savile, 230, b. “Cuteri rpposoni inter Paulinum et Eghertum nirhil altius fuam simplicis episcopi verabule anhelarunt." Auglia Sacra, i. lit. IIjet. Mon. S. Aug. C'mut., 28I.

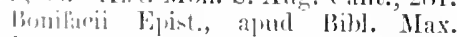
Patrum, xiii, 73. Nalmesbury, apud Sasvilu, 12b, 153.

Mronin, iplul riale, i., 723. Addit. ar l'suntmitiale lisherti, in Laws, etc., of Ellatiml, ii., 233-5.

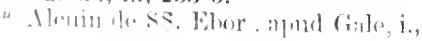

725. IList. Mom. S. Aug. Cant., 281.

"Daries on the York Mint, 3.

"Alcuin, apud Gale, i., 725.

* Published for the first time by the Surtees Society, from a MS. in the Imperial Library at Paris, which formerly belonged to the chureh of Evrenx. It has been reprinted by the monks of Solesmes (Sarthe) in their Spicilegium. There are some extracts from it in Mitrtene de Ant. Eccl. Rit., t. ii., lib. ii., c. xiii. The peculiarities of the Pontifical are pointed out in $\mathbf{M r}$. Maskell's Mommenta Ritualia.

" Printed entire in Thorpe's Ancient Laws and Institutes of England, ii., 326-42, and, partially, in Wilkins' Conilia, i., 101-12. Tabbe, Conc, vi., 
de Ecelesiastica Institutione ; a Confessionale" and a l'anitentiale, ${ }^{b}$ the two latter works being in the native as woll as in the Latin tongue, and for an obvious reason. Other treatioss arr also ascribed to him. Egbert secms to have studied decply, and to have borrowed much from the witings of his predecessors, especially from those of 'Theodore. Everything that he has done shews that he was a rigid disciplinarian. Some of his rules are severe to an excess, some of his penances are frightful. His ideal of a faithful Christian must have been something far too high to be attained by frail cring man. And yet we camot doubt his sincerity and carnestuess. A person who would commit to writing such minute dircections for moral conduct and montal control was a man of more than ordinary powers. That heart must indecd have been erucificd itself before it could thus tcach other's how to crucify the world. The enemy of all must have becn battered down by long vigils and tear's in the closet and in the desert. And having won the victory at length, that heart conld shew others, yea, all, how to strive and conquer. An emnobled purity secms to envelop it; it reposes in the still light of holiness, but it is the brightness that surromids an angel.

There are other reasons, besides his literary labours, which entitle Egbert to the gratitude of posterity. He is said to have been the founder of the celebrated school of York and of the library connected with it. ${ }^{d}$ There was no nobler place of cducation at that time in England. The renown of the scholars and their master was nentioned with delight among the Paladins

col. 1586-1604. Sprelman's Conc., 258-80. There is a manuscript in MSS. Harl., 438; another, once belonging to the church of Worcester, in the library of C. C. C., Cambridge. Cf. Wanley, ii., 109. Mabillon, Ann. Ben., ii., 210-11. Ondinus, i., 1796.

$z$ Ancient Laws and lustitutes of England, ii., 87-96. liede, L1. Labbe, Concilia, vi., eol. 1604-11. Wikins, i., 82-6. Leland found a copy in MIS. in the library at Sarum (1tin., iii., 92). There is one in MS. in MSS. Cotton., Vitellius, A, xii. See Ondinus, i., 1736. Lel. de Script. Brit., i., 11 \%.

a Ancient Laws and Institutes of lingland, ii., 128-69. 'There is a coly in MS. in MSS. Harl., 13S. See Ondinus.

${ }_{b}$ Ancient Laws and Institutes of England, ii., 170-239. Extractis from it, sub nomine Beda, in Labhe, vi., col. 1611-19, and Sprelman, 2s1-8. Wilkins, i., 113-11. 'There is a $11 \mathrm{~s}$. of it in the library of C. C. C., C'ans- bridge. Cf. Wanley, ii., 109. Leland foumd another in the library at Sarum (1tin, iii. 92). Sce Ondinus, ut supra, and lekmd, 1) Serint. Brit., i., 11., and Wright, 305. Fuller (Ch. Ilist., l)k. ii., 101) is anything but complimentary about the terileney of these works.

c Sc. "Iruditiones Discipulorum, lib. i. Homelia ef Lectiones, lib. i. Ad Erclesiarum lastores, lib. i. Ad Zathariam jro Pallio, elist. i. Ad lindbertum fratrem, reucm, epist. i. All Atinimn diaconmm, efist. plunces. etc. (Bale, Scrint. Brit., cent. ii., 109.) 1'itsem, 153-1; a most inarenrate writr.

d Ilimden, ayml Gale, i., 219. Lel. (oll., fii., 259. Alcuini Op., ed., 1777 , pocem. to rol. i., xvi. Lamonin, ix., 336. Sinithi Flores II ist. Eecl., 153. There is a lome account of Eerbert's liturary labours in Oudinns, i.,

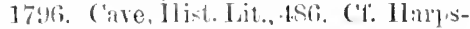
tild, 1 IS. Ial. Script. Tirit., i., \$1\%. 
of' C'harlemagne.e Beda, in his cell of Jarrow, rejoiced to hear of the rrood work which was being done at York, and longed to throw aside the infirmities of age, that he might pay another visit to his illustrions diocesan from all parts of Europe vouths of noble birth found their way to the seat of the Northern jurimacy to be tanght by the prince-bishop. $g$ Egbert himself was the moderator of the school, and Albert was the vicedominus or abbas, the former giving lessons in divinity, the latter in crammar and in the arts and sciences. ${ }^{h}$ The reputation of one of Egheri's scholars is enongh to resene his name from oblivion. It was no slight honour to have cultivated the tastes and fostered the genius of Aleuin. ${ }^{i}$

In the life of Alenin there is an interesting description of the daily work of his master in the monastery of York whenever his attention was not distracted by weightier and more important matters. 'The cares of his diocese would occupy of course the first place. "As soon as he was at leisure in the morning he sent for some of the young elerks, and sitting on his conch taught them sucessively till noon, at which time he retired to his private elapel and celebrated mass. After dinner, at which he ate sparingly, he amused himself with hearing his pupils discuss literary questions in his presence. In the evening he recited with them the service of complin, and then calling them in order, he gave his blessing to each as they knelt in sucsession at his feet." $j$

The pen of Alenin was not dipped in gall when he spoke of his instructor. The verse may haply be meonth, but it cannot conceal the affection of the writer. ${ }^{k}$ IIe tells us of the learning of Eghert, of the suavity of his manner, of his gentleness and goodness. Stern he eould be where a rebuke was merited, and yet who was more loving or beloved? Alenin could deseend from the height to which his own suprassing genins had raised him, and speak of his old teacher with the affectionate humility of a child. That is no slight tie which binds the scholar to his master. It will be long before I forget mine, although those once observant eyes are elosed, and that well-remembered voice is still.

'Towards the elose of his life Egbert seems to have resigned

- Ilist. Mon. S. Aug. Contuar., 281. Malmesburs, apud Savile, 12, b. Higden, a]ur (iale, i., 250. Lel. Coll., iii., 259.

$f$ liedie Epist. ad Egbertum, ed. Sinitl, 305 .

s Vita Alcuini, procm. ad Op., ed., 1777, i., Ixi.

"Lureuz, Life of Alenin, 9.

i Vita Alcuini, proom. ad Op., el.,
1777, i., lxi.-iii. Mabillon, Acta SS. Ord. S. B., sxe. iv., 148. Lel. Coll., iii., 259. Baronii Ann., ix., 338. Lel. de Script. Brit., i., 121.

$j$ Lingard, i., 98. Vita Alcuini, apud Acta SS, ord S. B. sece. iv., i., 149.

${ }^{k}$ Alcuin, ap. Gale, i., 725. Malmesbury, apur savile, 12, $b$. Mabillon, Ann. Ben., ii., 9.1. 
the management of his sehool to Albert and Alenin.' It could be in no better hands. He himself had weightier matters to attend to now. Tranquil must have been his life within the walls of his monastery at York, happier far than if he harl tarried in his father's court. And now, when the heat of the day was over, there was the contemplation of the future left to him; there was also the remembrance of the past, and to him in his declining year's there would be pleasure in the retrospect. " List enim quiete, et pure, et eleganter acta aetatis placida ac lenis senectus." Whilst the aged prelate was watehing in his cloister, his brother Eadbert was on the Northumbrian throne, and anid the cares of royalty he would enry the peacefulness of that life which the archbishop had adopted. He would see him resigning his scholastic duties to prepare himself for a very different scene; and then the monarch would muse upon those startling thoughts which a later poet so beautifully moulded into rerse.

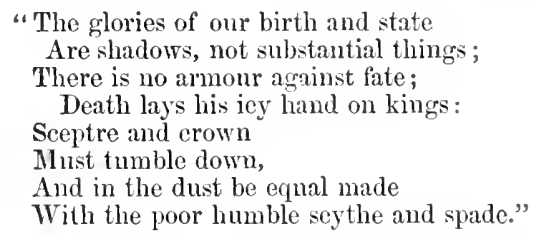

Was he ready for the ehange which even he was to expect? Ife voluntarily laid aside his honours, and, taking the tonsure like his uncle Ceonwulf, entered his brother's monastery in $75 \%$. to spend with him in quietude and prayer the remainder of his days." It was a sight worthy of an exalted age. The remnant of their earthly lives was devoted to Him "who seeth in secret," and ere long they passed into His presence. 'The archloishop' was summoned first, on the 19th November, r66, having been the ruler over his see for thirty-four winters." ${ }^{n}$ His brother followed him on the 19th August, 768. ${ }^{\circ}$ They were laid side by side in one of the porches or chapels in the cathedral of York. ${ }^{p}$

2 Alcuini opera, ed., 1777., prowem. to vol. i., xxii. Lorenz, Life of $\mathrm{Al}$ cuin, 10. Malmesbury de Pont., apud Savile, $153, b$.

"Saxon Chron., 72, Wendover, i., 149. Wallingford's Chron., apud Gale, i., 529. Chron. Petrib., 7. Baronii Ann., ix., 119.

"Some writers say that he was bishop thirty-six winters. Sax. Chron., 74. Flor. Wigorn. (276) gives the 1 t. Cal. as the day of his death. Symeon, col. 106. Chron. de Mailros, 7. Len. of Ifuntingdon, apud Sarile, 196, $b$. IIoveden, ibid., 231, b. Chron. Petrib., 8. Symeon, IIist. Eecl. Dumelm., \& 1 , where he is said to have been bishop thirty-two years. Nabillon, Amn. Ben., ii., 210-11. Wendover, i., 151, says that Eubert died in 767 , and that Eanbald sueceeded him. Addit. ad Bedam, ed. Smith, 224, make the date 766 .

- Sixon Chron., 7.1.

${ }^{p}$ Alenin, apnd Gale, i., 725. Saxon Chron., 66. Mahnesbury, apud Savile, 153. Symeon, Hist. Ecel. Wumelm., 83. 
Fuller, thercfore, is slightly incorrect when he says, "In that are the greatent priners and prelates their corpses came no

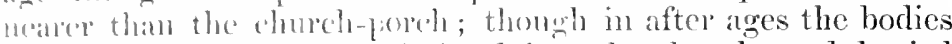
of 1 mance persous were adnitted into the church, and buried therem." I cammot hut call to mind the directions which good hishel, Hall wave in his last will to his execntors, "My body," lar says, "I leave to be intered without any funeral pomp, with thic inly monition, that I do not hold God's house a meet reperitory" for the dead bodies of the greatest saints."

Tluert, who suceceded Fubert in the arehbishopric, was the sul of parente of infuence and rank.s He was edueated in the monastery of lork, where he was soon regarded as a yonth of no mlinary ability. linbert the prinec-bishop was his kinsman, and the tics of hood, which at that time were valued and resurked, would link the two together; but they had another hond of miom, a far mobler one than the aceident of birth, -in the fiscrinating tastes wheh they both enltivaterl and enjoved. With whit pleatsure and affection wonkl the prekate look down upon the youthenl seloliar! How delightfinl to wateh the sprearling of those radiant fires of genius which he had himself enkindled !t He mallied Hhert ont for a earecer of usefnlness and distinetion. He raised him in eomrese of time to the priesthood. He associated hin with himself in the charge of his pupils, making him the manter of the shools, and also the defensor cleri. It is not cratety known what were the duties of this officer. In all probability he was the abbas or rice-domimns, who has been already mentioned, and, thereisere, the superintendent of the elergy within the walls of the monastery, if not beyond them.

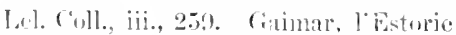

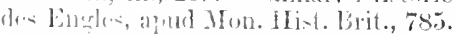

liclurith latine ant mun son fiere;

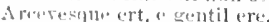

Aubeders gisint, pres a pres,

A liverwich, a pretices."

C"lunele Histore, Jonk ii., 101.

II iustanley's Vorthios, 35s.

For this menoir the pocm of Alenin

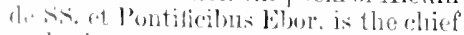
:Hllority (ciale, i., 7:7, ete.)

dlbert's nome is varionsty spelt. I

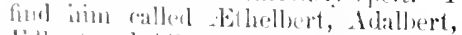

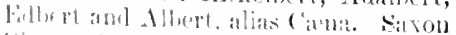

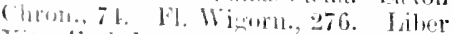
Vitio Eect. Dumehn., 7 . Iluntinglom, apurl Savile, 196 b. Symeon, De Arch. litur., लn. 78. Stubbs, ibid., 1697. Míbillon, Ann. Ben., ii., 211, 212.

Albert s name is not inserted among the arehbishogs of Tork by MalmesImry, $1101^{\circ}$ is it in the Hist. Mon. S. Ans. Cantuar. Hen. Huntingdon inserts hjs mame and then contradicts limiself:

Albert comsermated Frithwald bp. of Hexham at Iork, and Ethelbert to the sume see in 776 . Saxon Chron., 73, 76. I1mtingdon, apud Savile, 191 .

$t$ "Pontifieique comes Eegbert conjunctus adhiesit,

c'ui quolue sanguineo fuerat jam jure propinuluts." 
The renown of the school of York was spread at this time through the greater part of Europe. Egbert had built it up, and it was a trimmph to the genius of Albert to be able to increase it. It was a noble work that these two illnstrious scholin's were then doing. Egbert, indecl, when Albert becamc his assistant, merely gave iustruction in the New Testament, but Albert explained the Old Testament, and gave lessons grenerally in the arts and sciences. He led his mumerons scholars into a wide field of learning-grammar, rhetoric, law, poctry, astronomy and natural philosophy. And not only was he the master of such stores of erudition, but he had the happy power of imparting them to others. He was able at the same time to communicate and croke. Wherever there was the slightest ray of genins, however tremulous and feeble, he conld detect and strengthen it. His pupils, also, conld love their instructor whilst they admired his learning. Fascinating he was and affectionate, with a wimning kindliness of manner that entwined itself around the hearts of all. There hare been many like him since who have sacrificed their very lives for others, and for the sacred cause that they have striven to advance. The busy world has too often markerl them only to censure the modest tastes that shrunk from its follies, and to snecr at a disposition which it could neither appreciate nor understand. Neglected or unobserved, those teachers of the young, the thinker and the scholar, have gone down to their graves in silence, living only in the hearts of those who have drumk in from their lips the lesson of their lives. There is a day coming on which men of genius and learning shall emerge from the darkness in which posterity has buried them, to witness a strange cancelling of opinions and rerersing of degrees. How often in this world has the fame of a great man been rescued from oblivion by an accident or a chance! If there had been no Alcuin, we should have known, perhaps, nothing of the toil and work of Albert!

Alcuin was without doubt the greatest scholar of his age, and one of the brightest stars in the Anglo-Saxon church. IIe was a native of York, and a pupil in the school of Egbert. $\mathrm{II}^{+} \mathrm{e}$ have already seen how he loved and renerated his master. To Albert he was bound hy the closest ties of affectionate regard. He was his companion and his friend as woll as his pupil. Nenin became an assistant in the school, "and subsequently, when elevated to the see, Albert appointed him one of the canons of the minster, and raised him to the homouralsle and arduons office of magister scholarum. In that position Alcuin won for himself an undying name. The learning and the character of such men

"Appointed by Egbert. Alenini Op., 1777, rol. i., lroam., xxii. 
ats Signlf, Eanubald, St. Lindger and Fridugisus confer immortal honour on Alevin and York.

Not only did Albert derote his energics to the school-room, but it was his ambition to leare behind him a splendid collection of books for the benefit of his college. There were some there already which Eighert had collected, but Albert may be called the foinder of that library, although his predecessor had begun it." II was anxious that the fruits of his zeal should survirc to cencrations yet umborn, long after his own lips were silent. Books, as he well knew, were

"The only men that speak aloud for future times to hear."

And he resolved to leare behind him a noble library for the benefit of posterity. 'This wonld ensure to the North of England a continuance of the school for which York was now so famous, for wherever there was a library there would be students, and wherever there was learuing the light of religion would never be extinguished. To gather books together in that illiterate age was a nolble enterprize, but Albert was not appalled by the difficulty of the undertaking. He threw himself into it with all the ardour of a bibliomaniac. The English collections could not atlay his thirst for litcrature. Nore than once did he cross the scas with Alenin for his companion, ${ }^{x}$ nerer caring for the perils with which the trareller was besct, if only he could secure some of the precions tomes that he saw for his library at home. Italy was one of the comntries that he risited, and he wandered among its monasteries and shrines on the same ground which, in a later age, tempted the author of the Philobiblon to desert his monarch and his see. The treasures which fascinated Poggio and Petrarch were as get unknown, and there were no Medici to patronizc and comnicud. Albert had a welcome everywhere, for his reputation had preceded lim. Fain would they have detained him in Italy to seatter there the rich seeds of learning which were springing up in England, but he would not desert his scholars and his scliool. IIe came back to York bringing with him the treasures that he had collected. Alenin speaks with rapture of these precions volumes in a well-known passage which, although often quoted, must not be omitted here. It deseribes the contents of the library at lork, which he calls in another place the

Alenini Op., i., procem., xxii. Ibid., laiii., siculf is called " enstos Heborice civitatis ecolesie." II sres to Rome "at encles. ordinom discendum-et rau-ia cantus." rita S. lindgeri, apud Molillon, Arta SS. ord. S. B. sac. iv., i., 37 , anl lita 13. Alsmini, ibir., 150, 2. Jun. Ben., ii., 186, etc. Alcuin, et son
Influence Litteraire, etc., par Fr. Monnicr, 10.

* On the table of benefactors in the minster Albert is called "Quartus fundator. Primus bibliothecam condidit." Gent, 61 .

- Alcuini Op., i., procem., xvi., 287. Lorenz' Life of Alcuin, 9,10 . 
flowers of Britain.y It will be seen that the authors of the ancient world were very fairly represented in that collection.

" Illic invenies veterum vestigia Patrum,

Quidquid habet pro se Latio Romanus in orbe,

Gracia vel quidquid transmisit clara Latinis :

Hebraicus vel quod populus bibit imbre superno,

Afriea lucifluo vel quidquid lumine sparsit.

Quod pater Hieronymus, quod sensit Hilarius, atque

Ambrosius presul, simul Augustinus, et ipso

Sanetus Athanasius, quod Orosius edit avitus :

Quidquid Gregorius summus docet, et Leo paja;

Basilius quidquid, Fulgentius, atque coruscant

Cassiodorus item, Chrysostomus atque Johannes.

Quidquid et Althelmus docuit, quid Beda magister,

Quæ Victorinus scripsere, Boetius, atque

Historiei veteres, Pompeins, Plinius, ipse

Acer Aristoteles, rhetor quoque Tullius ingens.

* Quid quoque Sedulius, vel quid canit ipse Juveneus,

Aleuinus et Clemens, Prosper, Paulinus, Arator,

Quid Fortunatus, vel quid Lactantius edunt.

Quæ Maro Virgilius, Statius, Lncanus et anctor

Artis Grammatica, vel quid scripsere magistri.

Quid Probus atque Focas, Donatus, Priscianusve,

Servius, Enticius, Pompeius, Comminianus.

Invenies alios perplures."

We may picture to ourselves the life of Albert and his pupils in the monastery of York when these heroes of past ages were their companions. Horace was not there, nor the lighter writers of antiquity. They listened not to the melodions numbers and the glorions poetry of Grece, but they conld open the pages of the historian, and read for themselves the thrilling legend, and the exploits of the warriors and statesmen of that mighty city, which, rising even when it fell, had become the abode of the greatest bishop in the West. Here they conkd drink in the persuasive arguments and the glowing eloquenec of the standardbearers of their own church, men of prowess and renown, who, whilst they lived on earth, were fit already for the society of angels. Here, before them, was the story of their sufferings and their victories, the sighings and the vigils of the recluse, the fiery trials which the martyrs met and scomed, the ecstasies of the enraptured devotee, the heaven-born words that had flowed from the lips of the departing saint, when the light of another world was already beaming upon his face. The licart of the youthful Saxon would burn within him when his master told him of the trimmphs of faith that had been achieved, and of the glorics that he could himsclf sccure. With delight he would hear how many of these holy men had lired and died in

y Malmesbury, De Gestis Pont., apłul Savile, 153. Alcuini Op., i., 53. 
the scchsion of a momastery, working as he worked, and he would study to be like them. The remembrance of this would be with tlee pupil in the class-room and the dormitory ; it would make his ere grow brighter when it rested upon the saered page; it womld sinde his hand when it wote klown the words by which he was cuthralled; it would neve him for his daily oecupations, and sanctify them all. What a happy life was his when the silenee of the study was broken only by the summons to the honse of (iod, where the voiee of prayer and praise chimed in with those seceret aspirations which it strengthened and emolsed! Monotonous it may seem, but it was not wearisome. A holy light illmined it, molunging and serene as that heaven from which it eame.

'The lighest honour in the North awaited Albert. At the death of ardhbishop Exbert in 766 Albert was appointed his sucerssor, in eompliance with the wishes of the people. ${ }^{*}$ He was romsecrated, together with Alehmund, bishop of Hexham, on the 21th of April, $76 \sigma^{z}$ In $7 \%$ g pope Adrian sent to him the pall." 'The great scholar was an execllent archbishop. He was a strict disciplinarian, as we might expect, and a terror to evildreps, but at true follower of the Good Shepherd in his affection for his flock. It is such a learler that the sheep love to follow to the still waters and the pleasant fickls. And they who had known him in the lowlier position which he had previonsly adorned were conscions of no alteration in his manner or disposition. The pomps and luxuries of the comt could not ensnare or dazzle him; the old simplicity of his habits and his kindliness of licart weere still muchanged.

To his ehmoly at lork Mhert was a great benefactor, for he was at mat with splendid tastes, and personal frugality had not led him to broglect the deeoration of Goll's house. lin 741 the minster had been ereatly injured by a fire, ${ }^{b}$ and it was

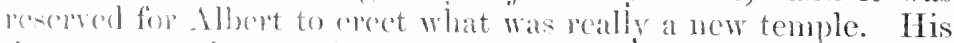

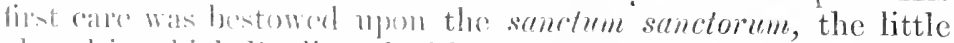

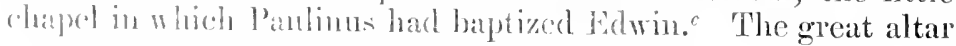

Sirment, (m) 107. ('liren. de Miri]-

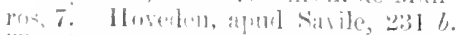

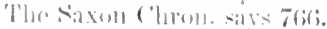

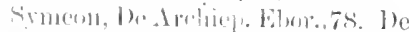

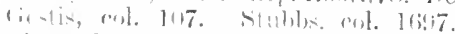

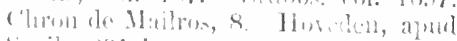
situik, 231 b.

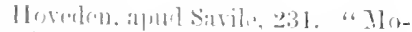

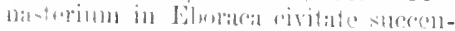

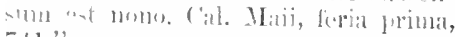
$711 .$,

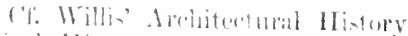

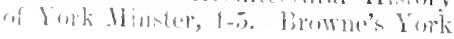

Minster, i., 3, 1. Tabric Rolls, ed. Surtexs Sice, furef., ix. Gent's York, 61. Bentham 's Ely, 25-6. Mr. Willis is of Ginimo that dibert brilt two churches, the one, with the altar at which Edwin wat haptizerl, was the minster, the other with the thirty altars, a different building. It reems to me that they wore the same (pref. ix.), and Edwin's chapet was fobably rebovated, in the first instrance, that it might be used for service whilst the minster was being erentuds 
in it he renovated and dedieated to St. Paul, and he madc another near it. All the sacred ressels and crucifixes were of silver or gold, and were inlaid with precious stones. Aromerd this little shrine Albert began and completed a new elurreh, a good work that won for him the title of one of the founders of the minster.d Aleuin and Eanbald were the superintendents of the work, which remained minjured mitil the Norman Conquest. It contained as many as thinty altars, and was probably of that Byzantine style of architecture which was then so prevalent abroad.

The lamp of life was now flickering ont; the days of Lllbert were drawing towards their close. Kich in good works and active piety as they lad been, the aged prelate, when he looked back upon the past, could only see that it was full of opportumities neglected or misused, of numberless shorteomings. lle would sigh to himsclf,-

\section{"O quid solutis est beatius euris Quum mens onus reponit!'”}

And lie resolved to tear himself from that world by which he had been enthralled. He would follow the example of Joln and Wilfrid, and the remainder of his days should be dedicated to God. Like the aged Jacob, he called aronnd him his spiritual children. Eanbald, a belored pupil, he nominated his coadjutor in the see, and consecrated him to that high office. ${ }^{e}$ To the faithful Alenin he gave up the school on which so much of his cnergies had been sjent, and the care of the library that they had collected, and then he entered upon his solitary wateh, to atone, as far as he could, for the oftences of the past.

Two years and two months were spent in this retirement. $f$ Ten days before his eyes were elosed in death, he was permitted to witness the completion of the elmueh that he had begmu, and to join Eanbald in dedieating it to God. IIe retired to his cell to die. The affectionate Alenin was a witness of his end, and among the last words that Mbert nttered was a desire that his friend should cross the scas, and pay a visit to France and

d This title is given to Albert on the board preserved in the minster, which is of the age of Dean Gale, who was thoroughly conversint with the history of the catherlal. Gent (1) 6il) gives it copy of it in his account of York.

Alcuin's deseription of Allort's church is too curious and viluable to be omitted:-

"Ast nora basilicie mira structura dicbus

Priesulis hujus erat jam cepta, peracta, sacrata.
Irec nimis alta domus solidis suffulta columnis, Supprosite rule stant curratis areuhns, intus

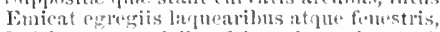
Pulch ranue port icibus fulget ciremmlata mult is, l'lubina diversis retinens solaria tectis, Que triginta temet varis ormatilus aras."

- Cliron. de Mailros, 8. ILoveden, arud siavile, $232 a$.

$f$ șmon, De Archim. Eloor., col. 78. Stubbs. eol. 1697. Mabillon, Ann. Ben., ii., 255. 
liome.g Alloert was taken to his rest at York $^{h}$ on the 8th of Norember, 781 or $78 \%,{ }^{i}$ at the sixth hour of the day. A noble Hocesion of laymen and ceclesiastics accompanied him to his horial, all full of grief for the patron whom they had lost, yet with that sorrow there would be the conviction in erery mind that the great scholar was at rest, and each would share in the thought which Aleuin has thus expressed :-

"Jam cui Christus, amor, potus, cibus, omnia Christus ;

Vita, fides, sensus, spes, lux, via, gloria, virtus."

Gambald E. was the pupil and the successor of Albert. The greater part of his life liad, in all probability, been spent in the monastery of York, and there he had made himself acquainted with the stores of learning that Eghert and Albert conld impart. From a student he became a teacher, and, with the famous Aleuin, le shared the affeetions of Albert. Eanbald was probably the vice-dlominus of the monastery, and when the good bishop in his declining years threw aside the cares of his high office, he made Fanbald his coadjutor, thereby nominating him as his suecessor. Eanbald had already erinced his aptitude for business by taking the charge, with Alcuin, of the rebuilding of the minster. It was his high privilege to join his aged benefactor, Albert, in dedieating it anew to God. He was then in a more exalted position than he had occupied when the work began. The mitre was upon the brows of the architect. ${ }^{j}$

Eanbalk took the place of Albert in 782, and the first care of Alfwold, king of Northumbria, was to provide him with the pall. ${ }^{k}$ Aleuin himself, at the request of his friend, went to Rome to bring it. ${ }^{l}$

"I tamen, pro me, tu, cui licet, aspice Romam,"

and on his return Eambald was solemnly confirmed in his office. lxiii.

8 Alcuini Op., i. Vita in procem.,

${ }^{h}$ Saxon Chron., 77. Huntingdon (196b) and Hoveden (235), by a mistake, say that he died at Chester.

- Saxom Chron., 77. Chron. de Mailros, 8, and Symeon, De Gestis, col. 1118, make the date 780 . Fl. Wigorn., 278 , and Chron. Petrib., 9, say 781. Mabillon, Acta SS. ord. S. B., sece. iv., i., 152. Alcuini, OP., i., Vita Alc., frorm. Ixiii.

jAleuin, be Pont. Fecl. Ebor., apud
Gale, i., 730. Symeon, De Gestis, col. 107. Malmesbury (Savile, 153a) makes one Earibald and not two, missing out Albert; so does Wendover, i., 151 .

${ }^{k}$ Saxon Chron., 77. Chron. Mailros, 9. Iluntingdon, apud Savile, 197. Horeden, ibid., 235b. Symeon, De Gestis, col. 108. Bromton, col. 797. Stubbs, col. 1697. Labbe,Bibl., i., 323. $l$ IIabillon, Acta SS. ord. S. B., sæe. iv., i., 152. Vita Alc., procem., Op. i., lxiv. Recueil des Historiens des Gaules, v., 445 . 
Between the two seholars there existed the elosest intimacy and regard. They worked and tanght together. Eanbald, like his master and his namesake, lives for us in the light of Alcuin!

The state of Northumbria during the archiepiscopate of Eanbald was anything but farourable to the progress of Christian teaching. The country was full of violence and bloodshed. Alfwold ascended the throne at the expulsion of king Ethelred, and was murdered after a short but useful reign by one of his own captains. Within a twelvemonth his successor and nephew, Osred, died a violent death. Tempted by the chances of success, amid the general confusion, the exile Ethelred seized his old kingdom, and, after wreaking a futile rengeance upon his enemies, fell a rictim soon after to a conspiracy among his own nobles. To add to the general dismay, the Danes broke in upon the divided and unhappy country. They desolated that sacred shrine which Aidan reared at Lindisfarne, and in which Wilfrid and Cuthbert had watehed and prayed. Those looly men would think in their day that no foeman would ever reach that little temple which cliff and wave had made into a sanctuary, but the sea-kings eared neither for rock nor storm. The startled inmates were slaughtered at their altars. In the succeeding century they deserted their insecure abode, and, after many wanderings, found a resting-place at last, yea, another Salcm with its holy hill, beside the waters of the Wear.

All this trouble and confusion must have materially crippled the Northumbrian church. What satisfactory progress would it now make? The labours of the school of York went on, although there were, probably, fewer pupils. The great library was used and treasured, and there would always be scholars when Alcuin was the master. That illustrious teacher, however, was at this time very frequently abroad. The royal court of France had for him far greater charms than the devastated kingdom of Northumbria. Peace he found there and security, a noble patron, the most accomplished eourt in Europe, and the society of men of letters and intelligence. Can we wonder that in 790 , troubled by the confusion around him, he deserted York for France? Six years after this, in a letter to king Ofla, he says that it had been his wish to return, had the violence of the pagans not deterred him from making the attempt." But although he was thus absent, he was still present in heart and spirit with Eanbald and his old associates at York. He corresponded with them, and strove to mitigate the disasters that appalled them. He rebuked Ethelred and his nobles, and gare them good advice which they forgot. ${ }^{n}$ IIe reminded the brethren

$"$ Ale., Op., i., 57.

n Ibid, i., 17, 20. 
at IIcxham and their bishop of the light of Christian exeellence that had illumined their beautiful shrine, and bade them recolleet and rherish it. ${ }^{\circ}$ He begged the inmates of the monasteries of Wearmontl and Jarrow to eall to mind the spiritual renown of licrla, Benedict and Ccolfrid, and exhorted them to patienee and ('mlunance $p$ He consoled the monks of Lindisfarne for their sufferings and affliction.q 'To the brethren at York he speaks in terms of the most affectionate regard. ${ }^{r}$ He praises them for their constancy and zeal in a manner which shews that they had not yet fallen, in spite of all their tronbles, from their first estate. Ic irives them advice in a tone that expresses his firm eonviction that they would adopt it. He yearns towards them with sympathy and kinduess: "You," he says, "are ever in my heart. I pray for rou first of all. Oh, for the lore of God, eherish with heart and tongue your son Alcuin! Oh, remember me, fathers and brothers mine, who are all most dear to me. I am yours in life or death. And haply it may be mcreifully allowed that my bodr, in its old age, may repose with you who nurtured it in its vonith. But if another resting-place shall be mine, yet, if God will, there shall be rest for my soul, wherever it may be, through your holy prayers. I trust in you. For-we believe that the sonls of our brotherlood are to be gathered into the same abode of bliss. Although a difference in merit shall neessitate a difference in reward, still the nature of eternity is sueh, that all must be happy who enjoy it. And like as there is one sun that shines on all, a sun that all see alike, whether they are near or distant, so a never-ending hliss shall be given to all the righteons in Cod's kingtom, although the height of their exeellence may crown some with a greater glory, Oh, most beloved brethren, make yourselves ready to attain to that glory with the fullest intention both of will and deed."s These are indeed the aspirations of a poet and a saint! His bones were not laid where he wished, in the city of his birth. They are resting in the comitry of his arlopition.

There is little more to be said about Eanbald. His lot was cast in troublous times. He would look, however, upon the last public act of his life as a sign and promise of peace to his distracted diocese. 'This was the coronation of Eardulf, on whose hatnd he placed the Northmmbrian crown on the 25th of June,

"Alc., Op., i., 196.

Ibirl., i., 21,80 , etc.

3 Ibirl., i., 11.

In a letter to Ethelred (i., 20) Al. cuin mositions a singular purtent that ocenred in the chureh of York shertly before the arrival of the lanes. "(2uid significat phuvia sanguinis quan in ruadragesimali tempore in Ireboraca civitate, qux est caput totius regni, in ecclesia Beati Petri principis Apostolorum, vidimus, de borealibus domus, sereno aere, de summo tecti minaciter cardcre? Nonne potest putari a borealibus partibus venire super terram sansuinem?" s Alc., Op., i., 8, 9. 
796, the bishops of Whithern, Lindisfarme and Hexham assisting him. ${ }^{t}$ On the 10th of August Eaubald died at the monastery of Etlete or Elete." They bore his remains to York with a noble procession, and interred them in St. Peter's minster. ${ }^{r}$

Tantraliy HE. was consecrated hishop of York in a monastery called Sochasburg, on Sunday, the 14th or 15th of August, A.1). 796. Ethelbert, Higbald and Badulf were the officiating prelates. ${ }^{20}$ On the 8th of September in the following year, being the festival of the nativity of the Virgin, Eanbald was solemnly confirmed in the archbishopric, having received the pall from Rome $^{x}$ which qualified him for that high position.

Eanbald was one of the presbyters of his predecessor, ${ }^{y}$ and a very favourite pupil of Alenin. That illustrions scholar was in France when Eanbald I. died, and he was summoned thence to York, as one of the fratres of that church, to proceed to the election of a new president. The choice, in all probability, would have fallen upon himself. Unwilling to desert the French court and schools, and to renture into a divided and unhappy comntry, Alenin gave up all idea of journeying again to England, and he had the satisfaction of hearing that his pupil Eanbald had been raised to an honour which had been within his own reach. $z$

Between Eanbald and his old master there was maintained the most affectionate intercourse. Alcuin addressed him under the friendly title of Symeon. ${ }^{a}$ He held him up as a pattern to the recreant Osulf. ${ }^{b}$ He spoke in his praise to Charlemagne, and the "prafulgidus" David honoured him with an epistle. He sent him a ship's load of metal to be used in the bell-tower of

t Saxon Chron., 81-the clate made 795. Huntingdon, apud Savile, $197 a$. Hoveden, 23.

u Stubbs, 1697 , calls this place Aclete. Where is it? It may be Yokeflect, in Yorkshire. May it not rather be $\mathrm{Ay}$ cliffe, in the county of Durlam, where there are some early Saxon crosics? There were ecclesiastical meetings at Acle, whilst Eanbald was archbishop (Saxon Clron., 79; Ric. Hexham, col. 298. Ifuntingdon, 196 b). Symeon (De Gestis, col. 138) speaks of a place called Aclea in the South, ant calls it "campus quereus."

"Saxon Chron., 82. Chron. de Mail- ros, 12. Symeon, De Gestis, col. 114. Hoveden, 233.

w Saxon Chron., 82. Chron. de Mailros, 12. Symeon, De Gestis, col. 11t. Stulbbs, col. 1697. IIoreden, apud Savile, 233 .

s Saxon Chron., 83. Symeon, etc, ut supra. 323. Stulbs, col. 1697 .

= Alcuini Op., i., 62-3. Malmesbury, apud Savile, 153. "J)ignité rúscrée à Alcuin, s'il cût voulee rester danss sa patrie." Monnier, Vie d'Aleuin, 11.

"Ale. Op., i., 230-1, ete.

$\checkmark$ Tita Ale., prow'm. ad Op., i., xaiv., and Op., i., 217. 
his church.c When the lawlessness of the times had originated a gencral declension in mamners and morals in Northumbria, especially in the monasteries, Alcuin wrote to Eanbald one of his most useful and remarkable letters of advice. It is easy to scr from the tone of the epistle that the prelate had been the writer's pupil. It recommends the arehbishop to be a rigid disciplinarian, to attend to the rules and customs of the Roman ehurch, to bestow especial eare upon the management of his school. It lays down many rules for Eanbald's instruction as to his own dejortment, and the governing of his churches and cleroy," and contains many somd and practical suggestions. There is, unfortunately, an absence of any specific information as to the state of the Northem arehiepiscopate. The writer speaks of what onght to be done, and not of what had been done, and he leaves the general impression that there was great room for improrement in the management and discipline of the vast diocesc of Northumbria.e

As far as can be ascertained, Eanbald appears to have been an active prelate. He did his best to recover for Ethelard of Canterlumy, at the request of Aleuin, the portion of his diocese which had been taken away from it by Offa. $f$ He presided in A.D. 798 over a synod at Pinchenheale, at which, according to Symeon, some wise and judicious enactments were made relating to the ecclesiastical courts and the observance of Easter. $g$ There is no evidence to shew that he was the author of a book of synodical decrees. ${ }^{h}$ If he was, the fact is a slight proof of the assertion that he introdnced into the ehureh of York the Roman ritual. Eambald enjoyed the privilege of coining money. ${ }^{i}$

There is one portion of Eanbald's life which is involved in some mystery, - his comnection with Eardulf, the Northumbrian king. Before the elose of Alenin's life we find the arehbishop reprehended by his old instructor for placing himself in opposition to his sorereign. IIe protected the lands and persons of the enemies of Eardulf, adding to his own territories, and maintaining a greater number of military retainers than any of his predlecessors, to the discredit of his office and the overburdening of the monasteries at which he chanced to be a guest. With regard to the first charge, Eanbald pleaded the dictates of Chris-

Ale. Op., i., 231. "Ut domusculat clocearum stagno tegatur."

d One of the offences of the Northumbrian elergy at this time was foxluturting !

- Canisii Lect. Antiqux, ii., 450. Alc. Op., i., 63, ete.

Ale., Op.,i., 80, 233-1, ete. Malmes. bury l)e l'ont., apud Savile, 153 b. IFist.
Mon. S. Aug. Cantuar., 281. Wendover, i., 167.

g Chron. de Mailros, 13. Symeon, De Gestis, col. 114. Stubbs, col. 1697. Labbe, Conc., vii., col. 1148. Spelmanni Cone., 316. 218.

$h$ Pitseus, 164-5. Tanner, Bibl. Brit.,

i Davies on the York mint, 7 . 
tian charity as his excuse, and it was not a bad onc. With regard to the number of his followers, he might have said with justice that it was neeessitated by the turbulence of the times. But we hear of the archbishop again in comnection with the same matter. ${ }^{j}$ In A.D. 808, when Lardulf was deposed, Eanbald was concerned in the negotiations that preceded his restoration by Charlemagne, and we are told that the archbishop and king Kenulf were suspected by pope Leo of unfair dealing in that affair. $^{k}$ It was probably his past regard for the city of York in the time of Alcuin that induced Charlemagne to become a peacemaker in Northumbria.

Eanbald is said to have died in 812 , in the reign of Eamred ; there is, however, some uncertainty about the exact date.

XTIIlfsy was the suceessor of Eambald. The date that has been generally fixed for his consecration is 812. Symeon tells us that he became archbishop in the reign of Eanred, who came to the throne of Northumbria in 810. Of the official acts of Wulfsy there is little known, and the history of the North at that period is involved in equal obscurity. In the Cottonian library there is a letter adkressed to Wulfsy, by Egred, bishop of Lindisfarne, about an alleged miraele." Wendorer says that Wulfsy died in 831."

XXY innuñ became arehbishop whilst Eanred was king of Northumbria, about the ycar 837 . This may be inferred from the statement of Symeon, who says that Wulfere died in 900, having been bishop forty-seven years, and that Wigmmond, his predecessor, held the see for sixteen years. Some coins of this prelate, issued from the York mint, are in existenec. ${ }^{\circ}$

There are one or two interesting allusions to the church of York at this period among the letters of Lupus, the well-known abbat of Ferrieres, which have been printed by Baluz. ${ }^{p}$

j Ale., Op. i.- Cf. Lingard, AngloSaxon Church, i., 126.

${ }_{k}$ Mabillon, Ann. Ben., ii., 383. Recueil des Historiens des Gaules, v., 602.

l Symeon, De Gestis, col. 78.

"' Lel. Coll., ii., 298. MIS. Cotton, Tib. A., 15.

$n$ Labbe, Bibl., i., 323. Stubbs, col. 1698. Wendover, i., 176. Liber Vite Dunelm., 7 , where he is called Uulfsige. Malmesbury, De Pont. (Savile,
$153 b)$ calls him Wilfrid.

- Symeon, De Areh. Ebor., col. 78. Stubbs, col. 1698. Wendover, i., 183. Liber Vita Dunelm., 7, where he is called Wimund. Davies on the York mint, 7. On the stycas the arclibishop's name is Vigmund.

${ }^{p}$ Lupi Epist., ed. Baluz, ed. 1710, 103-1. Mabillon, Ann. Ben., ii., 68.. He makes the date of the letters 819 . 
One epistle is addressed to Guigmund, bishop of York, and to the congregation under lim. It informs them that the writer hald recorered a cell that he had lost, and expresses a wish for the renewal of fricndly intercourse between the two houses.

T'here is another letter addressed by the same dignitary to Altsing the abhas (or viec-dominus) of the church of York, repeating the request that he had marle to Guigmund.

'These letters are valuable in several respects. They shew that there was a friendly feeling at that time between the monastery of lork and the society of Lupus, and that the communication between Northern and foreign houses, which existed to so great an extent in the precerling century, was still kept up. 'Ther tell ws, moreorer, that the monastery of York was under the same gorerument that was described, sixty year's before, in the writings of Aleuin, and that the famous library was still in existcuce, inasmuch as Lupus solicits the loan of a manuscript of Quintilian, one of the Questions of St. Jerome on the Old and New 'Testament, with a similar work by Beda.

WT ulfere is said to have suceceded Wigmmod in 85t, in which year he received the pall, and thereby became arehbishop of the Northumbrians?

The kingrom of Northmmbria during the latter half of this century was in the most lamentable conclition. It was torn in pirese by internal dissensions, and the ineursions of the Danes were rery ummerous and appalling. The sufferings of the famons licgnar Lodbrog on his ber of snakes were bitterly avenged. The sca-kings corcred the ocean with their fleets, and fire and hood marked their track through the desolated country. Nearly all the Northern monasteries were destroyed by them. What progress conld Christianity make? The preacher could scarcely save his own life.q

In 872 the Northumbrians expelled Eghert their king, who had been appointed by the Danes, and Wulfere is said to have gone into exile at the same time. ${ }^{r}$ They are said to have gone to the court of Burhed, the monarch of the Mercians.s The

" C'liron. de Mailros, 18. Symeor, Te (istis col. 121, 139. Stubles, col. 1698. bilue lita loundme, 7. Hoveden, apud savile, 232a. Wemlover, i., 183. Labbe, liilil., i., 3*3.'

3 Mribillon, Amn. Ben., iii., 169. Iurenlen, zaz $b$. Asser, ajud (Gale, i.,
159 , where it is said of the city of York, "Non tume adluc illa civitas firmos et stalilitos muros illis temporibus habelat."

$r$ Sineon, De Gestis, col. 145. Hoveden, 233 b. Symeon, Hist. Eccl. Duseh, 95. In 870. s Wendover, i., 206. 
following year witnessed the death of Egbert, and the restoration of the archbishop. ${ }^{t}$ But this was not the only trouble that Wulfere is said to have cxperieneed. At mother period of his life, probably in 86\%, when York was eaptured by the Danes, Wulfere made his escape and got himself away to Addingham in Wharfdale. He is said to have stayed there for seren years." If this was the case, we are involved in a chronological difficulty. Possibly the year that Wrulfere spent in exile in 87.2 may form a part of the seren? In the chronicle of Metrose it is asserted that that prelate retmined to York at the death of Egbert, by whom he was driven ont." Egbert, it will be remembered, was supported by Danish influence, which Trulfere wonld, in all probability, despise. It is reasonable enongh to conjectmre that Wulfere fled from the Danes in 867, and that he retmined at the decease of Eghert in 873 "when he heard that Herod was dead." This will do away with the chronological diffienlties which this paragraph presents.

There is much uncertainty as to the perigd of Wulfere's death. Symeon says in one place that he died in 892; in another, that he lived eight years longer, thus making him preside over the Northmmbrian arehiepiscopate for the long period of forty-seven years. ${ }^{*}$ Hoveden places his death in $890 .{ }^{x}$

Thythald snceeded Wulfere. He witnessed a charter which was made in the year 895 . It has been gencrally said that he was consecrated in 900 , receiving the pall four ycars afterwards. There is nothing whatever known of lim. y $^{\prime}$

- Wendover, i., 207. Symeon, De Gestis, col. 14.5.

« Symeon, De Arch. Ebor., col. 78. Stubbs, col. 1698. Asser, (Gale, i., J72) under the year 893, says, "Wodem annocapta est civitas Ebroacensis a Nordmannis, sed episcopus, Sebar lomine, Deo anctore, evasit." This is Evrenx, not York.

"Chron. de Mailros, 20. Stubbs, vol. 1698, seems to countenance this view.

* Symeon, De Gestis, col. 133 and 150, and Cliron. de Mailros, 21, make
Wulfere die in 892. Symeon, De Arch. Eljor., col. 78, says in 900, "anno xlvii. episcopatus." Stubls, col. 1698.

* Apmir Savile, $2: 1 b$.

y Codex Diplom., iı., 126. Chron, de Mailros, 25. Symeon, De Arch. Ebor., col. 79;-1)e Gestis, col. 133, 151. Labbe, Bibl., i., 323. Libel Vita Dunelm., 7. Stubbs, col. 1698, says that Ethelbald received the pall four years after" his conserration, "regnante Ldwardo seniore, Elfredi regis filio." Hoveden (Savile, 241 b) dates his consecration in 848. Malmesbury, Savile, 1536 . 
IBrorwald, Lionerwald, or aldotheward, followed after Ethelfald, but the year of his consceration has not been ascertained. I find him witnessing charters between 928 and 930, but there is nothing to throw any light upon his acts and deeds.

XV ulstan ocems as arehbishop of York as early as 931 ; in which rear we find him witnessing a charter which has been printed by Mr. Kemble. ${ }^{2}$

Winlstan is said to have been raised to the see by the famons Athelstan." That monarel was the first of the English kings who reduced Northumbria to subjection, and a considerable portion of his reign seems to have been spent in the North of England. Athelstan's affection for Christianity was very strongly marked. To the chmeh of Beverley, at the instigation of Wulstan, and in gratitude to St. John, he granted several noble privileges and possessions. To the minsters of York and Ripon he was equally mmificent. His generosity would, to a certain ('xtent, be prompted by the wish to conciliate the good opinion of his new subjects, and, in the dispensing of it, he would, in all probability, be guided by the advice and suggestions of IVulstan.

After the death of Athelstan Wulstan appears in a new character. IIe comes before us as a diplomatist and a soldier. Gratitude to his benefactor. Ithelstan onght to have strengthened his loyalty to his sueessor, but we find the arehbishop intriguing with the Danes, and joining the Northumbrians in renouncing their allegiance to Eimmur. In the first instance, indeed, he lard shew himself a pearemaker, as, in conjmetion with Odo of Canterbury, he interposed his anthority, and prevented a

= Sinneor, Te Arels. Ebor., eol. 79. Stubls, col. 1698. Malnesbury, apud Savile, 153 b. Codex Dij,lonı, ii., 163-4.

a fodex Diplom., ii., 16s. In the same collection there are other deeds to which llulstan was a wituess. There are some in the Hist. Mon. de Abinglon, i., 66, etc. One of the titles assumed by the archbishop was, " W $\mathrm{nlf}$ sanus archons servitutis oflicio mancipals, Eborace civitatis archiepiscoptis."

$b$ sinctuar. Dunchu. et Beverlac., ed. surtees Soc., 98. Stubbs, col. 1698, where it is said that the king gave at that time the whole of Amomnderness to York. Sinneon, de Aroh. Ebor., col. 79. Polydore Vergil, 114. Smithi Flores IIist. Ecel. Angl., 191. Leland (Coll., iii., 3) mentions the following story :--

"In the time of king Athelstan, when the king lay in his tentes beside York, the king of Scottes faynid himself to be a myustrelle, and harped before king Athelstane, only to espy his ordinannce and his people. The same night lie cam to the host and slew Targe, archebishop of York, and al the people in his ward." 
combat between Edmund and the Northumbrians near Lincoln. This was in 941, but, soon afterwards, Wulstan allied limsolf' with Anlaf the Dane, forgetting how the father of his youthfiul patron had but a year or two before swept away or desolated more than one Christian establishment in his diocese. d Anlaf was subsequently baptized,-a fact which seems to account for the conduct of the archbishop; but the ministers of the church ought to pause, under any cireumstances, before they throw their influence into the scale of violence and bloodshed.

The sympathies of Wulstan seem to have been henceforward on the side of the Danes. In 943 he was with Anlaf when he stormed Leicester, and when that city was hesieged by Edmuud, the prelate and the prince with difficulty made their escape by night.e A treaty was soon after made, and there was a hollow peace, which lasted for a few years. In 916 Ldmund was assassinated, and was suceeeded by his brother Erlyed. Wulstan, with the Northumbrian magnates, took the oath of allegiance to him at a place called Taddenscliffe $; f$ this concession having been brought about, according to Ingulph, by the good offices of Turketyl, the archbishop's cousin, who was at that time the king's chancellor, and afterwards the abbat of Croyland. $g$ As a thank-offering, in all probability, for this reconciliation, Edred is said to have given two silver images to the church of York. ${ }^{h}$ The gift, to say the least, was a premature one. The sympathies of the Northmmbrians in favour of a Danish line of monarchs soon overpowered their loyalty. In 917 the archbishop and his compatriots broke ont into open rebellion, and made Eric, a Northman, the son of Harold Harfager, their king. ${ }^{i}$ This treachery neeessitated a hostile invasion of Northumbria by Edred, in which, among other disastcrs, the monastery of Ripon was destroyed. ${ }^{j}$ The wayward people then sought and obtained a reconciliation with Edred, and made specions promises that were speedily to be broken. The homage of the Northumbrians for the next few year's was given alternately to

c Chron. de Mailros, 29. Symeon, De Gestis, col. 134. Hoveden, apud Savile, $242 b$. Wendover, i., 251 .

¿Symeon, De Gestis, col. 134. Trendover, i., 251. Hoveden, apud Savile, $242 \mathrm{~b}$. e Saxon Cliron., 147.

$f$ Saxon Chron., 148, in 917. Fl. IVigorn., 352. Symeon, De Gestis, col. 156, in 949. Wendover, i., 253. Hoveden, apud Savile, 243.

$g$ Ingulph, apud Gale, iii., 31. Маbillon, Acta SS. Ord. S. B., sxe. v., 496. Turketyl was the son of Cilward, Wulstan's mole. He is said to have held witl the chancellorship, "pingnissimam prabendam in ecel. Ebor ;" a statement which throws discredit mon the anthenticity of Ingulph's Chronicle, as there weie no prebenda at Jork at this time. 'There were but seven canons, who seem to have lived upon a common fund. Ingulph is not to be relied nuon.

${ }^{h}$ Symeon, De Gestis, col. 156.

i Saxon Chron., 148. Symeon, ut supra. Ethelwardi Chron., ayud Mon. Hist. Brit., 520. Ahredus Beverlac., 111.
; Wendover, i., 255 . 
Eric and Anlaf. In all these convulsions Wulstan must have played a comspienous part, and it was the fear of his influenee and his treachery that induced Edred, in 952, to throw him into prison at bediburoh. ${ }^{k}$ The nominal reason for his incarceration, alcording to Wendorer, was his putting to death many of the citizens of 'Thetford in revenge for their having unjustly killed the abbat Aldelm.' Wnlstan was in restraint for a short time," and then the king, ont of respeet to his office, allowed him to resume his episcopal functions at Dorchester. ${ }^{n}$ Malmesbury, however, informs us that the prelate scornfully rejected the proffered pardon, and died soon afterwards, probably of disappointment and baffled pricis. ${ }^{\circ}$ We hear nothing more of Wulstan, as the hopes of the Danish party were destroyed by the death of Eric and the hanishment of Anlaf. He died at Oundle on the 26th of December, 955, and he was there interred. ${ }^{p}$ At the same plaee the light of life had deserted his fumons predecessor Wilfid, but the greatness of the apostle of the Frisians demanded a nohler sepulchre than was accorded to his spiritual descendant. Both had been tossed about by the waters of afliction, hut they exalted the one whilst they overwhelmed the other. 'The one was only a seheming politician, the other was a confessor and a Saint.

Pskutrl, the suceessor of Wulstan, was a kinsman of Turketyl, the eclebrated abbat of Croyland, $q$ and a friend and coadjutor of St. Dnistan. In 950 he was made bishop of Dorehester, ${ }^{r}$

* Withahnry or Juthanbury. Saxon Chron., 119, makes the date 952. Fl. Wigorn., 353. ('hron. de Mailros, 31. Symeon, De Gestis, col. 156. Malmesbury, Je Gestis, apud Sarile, $153 \mathrm{~b}$. lloveden, ibid., 2243. Ingulph (Gale, iii., 41). Chron. Petrib., 29, riving the date 919.

i Vendover, i., 256.

" The chronology is much confused. Ingulph, Gale, iii., 4l, says that Wul. stan was released in 9.18. In Mist. Won. de Abingrlon, he apjears as a witness to clurters granted in 951, 2, 3. He could only have been in prison for a short time.

n sixun (hron., 119. Fl. Wigorn., 3.33. Clhron. de Mailmos, 31. Symeon, [no Cintis, col. 15t. Wendover, i., 25f. Hoverlen, 213. Wulstan was not made blshop of lorchecter, as some say, but mercly resumed his efiscopal functions at that place.

- De Pont., apud Savile, $153 b$. The passage is obsctre, "Datam veniam indignatus vitam e vestigio exierit."

"Saxon Chron., 150. Fl. Wigorn., 354. Chron. de Mailros, 31. Symeon, De Gestis, col. 157. Stubbs, col. 1699 . Hoveden, apud Savile, 244. Wulstan witnessed a charter in 956. Codex 1)iplom., ii., 331.

q Saxon Chron., 158. Ingulph, apud Gale, iii., 4.1. Turketyl is said to have been a canon of York. Oskytel is probally the person mentioned in the Hist. Eliensis, apmd Gale, i., 482. Ord. Vitalis, apud Duchesne, 541.

$r$ Saxon Chron., 158. Vita S. Oswaldi, apud Angl. Sacr.,ii., 197. Stubbs' Episcopal Succession, 15. 
from which post, in 956, he was translated to the see of York, with the consent of king Edward and his council. ${ }^{t}$ II e made a joumey to Rome to procure the pall, his kinsman and successor, the well-known Oswald, being his companion across the channel. ${ }^{u}$

There is but little known of Oskytel's career at York or elsewhere. He was a man of piety and learning." To Oswald he was extremely kind. He aided him in his distress after the decease of his uncle Odo, and, subsequently, he sent for him to Flcury to request his aid in making reforms in his diocese,-a good work which Oswald was ready enongh to assist in.w Oskytel was, therefore, a coadjutor of Dumstan in his endearours to introdnce the Benedictine rule. How far he was successful it is impossible to say, but the number of charters to which he appears as a wituess shews that he was frequently absent firom his see. ${ }^{x}$ In 968 he consecrated Elfsig to the bishopric of Chester. ${ }^{y}$ He joined with arehbishop Dunstan in confirming the privileges of Croyland, $z$ and his intimacy with 'Turketyl led him to shew much kindness to that monastery.

Oskytel died at Thame on Allhallow-mass night (Nor. 1), 972. ${ }^{b}$ The erent eroked much sorrow and regret. ${ }^{c}$ 'Turketyl, his friend and kinsman, carried his remams to Bedford, where he was the abbat, and there the arehbishop was interred. ${ }^{d}$

Sir Simonds D'Ewes had in his library an account of the lands that belonged to Oskytel, in right of his archbishopric, written in Saxon.e

s Fl. Wigorn., 35\%. Chron. de Mailros, 31. Symeon, De Gestis, col. 157. De Archiep. Ebor., col. 79. Stubbs (1699) says that he was sixteen years at York, and Wendover (i., 256), asserts that he became archbishop in 951 .

${ }^{t}$ Saxon Chron., 158. Symeon, De Gestis, col. 157.

" Eadmer, Vita S. Oswaldi, apud Angl. Sacr., ii., 197. Hist. Rames., apud Gale, i., 392.

"Wendover, i., 256. Smithi Flores Hist. Eccl., 202.

"Ang. Sacr., ii., 197. Servatus, prior of Wreester, speaks of Oskytel in a way that seems to imply that he was only a learner, "Erat enim rudis adhuc in castris Domini, novitas ei ex- tranen, novorum traditio aliena" (MS. at Iurbam, fol. 10).

"Oskytel subscribes himself as " Oscytel Eloracensis basiliex primas insegnis." Hist. Hon. Abing don, vol. i., 261, and many otler plices. Codex Diplom., ii., 374, ete.

$y$ symeon, IIist. Ecel. Dunclm., 138.

z lingul, apud Gale, iii., 14. Dugd. Mon., ii., 116.

a Savile, 501. Mabillon, Acta SS. ord. S. 13., sxec. v., 505.

b Saxon Clyron., 1Es. Iligden, apud Gale, i., 267. Fl. Wigorn., 351. Chrou. Mailpos, 33, and Symeon, De Gestis, (col. 15!). 'A In!l. Sacr., ii., 203. d saxon Chron., 158.

- llimley, 306. 
I thrlwold is said by two ehroniclers to have succeeded Oskytel, and his name appears on the old lists at York. We are told that he resigned his see, preferriug a quiet life. $f$ This is all that we know abont him. He must not be eonfused with "the father of monks," Ethelwold, the benevolent bishop of IVinchester.

Sswald was the son of Danish parents of high rank and conseynence. His father was a great favourite of king Athelstan. His nucle, Odo, presided over the see of Canterbury, and to another archbishop, Oskytel of York, he was related by the ties of blood. g

The youth was gifted by nature with a noble bearing. His manners were fascinating and attractive, and there was every prospect of snceess in the path to greatuess. But even in those early rears, from which holy thonghts and aspirations are too frequently exchuded, the boy was musing a high and a determined spirit. The sports of other children had for him no char'm. The honour of his family should suffer nothing in his hands, but conld it not be enhanced, he thomght, if he became the servant of the King of heaven? Frithegode, the poetical biographer of Wilfrid, ${ }^{h}$ was his instructor, and placed before the ronth the authors of antiquity, but it was upon the page of the Divine story that Oswald loved especially to dwell. His ardent spinit burned within him at the glorious recital. Dane although he was, he could there observe a wisdom deeper and more sublime than the greatest Northmen conld have imagined. There were poctry and adventure grander and more vivid than those of the most impassioned sagas. And then Frithegode would tell him what great men, in lates days, had learned out of that book the lesson of their lives. He wonld hear of Benediet and his noble rule- of Augustine and his spiritual trinmphs-how Beda

$f$ Symeon, De Arch. Ebor., col. 79. Stublis, col. 1699. Mir. Stubbs omits his name altogether.

5 Eadmer, Vita S. Osw., apud Anel. Sarr., ii., 192-3, compared with IIs. Colton, Nero, E. i., and the life by Servatus, prior of Worcester, in the library of the dean and chatpter of Durham, B. iv., 39, B. Chron. de Mailros, 33. Hist. Ramesiensis, apud Gale, i., 391 .

h.walk had two hrothers, Osulf and
Athelstan, and a nephew, Elfwin. (Cf. 'Thomas' Worcester, 41-7.) Oswald, another nephew, was a monk at Ramsey (Hist. Rames., 430), and an anthor (Pitseus, 181. Bale, cent. ii., 150). A grammarian of the name of Constantine, according to Leland, wrote a yoem in Latin Elegiacs, which he addressed to archbishop Oswald in commendation of his learned nephew.

${ }^{h}$ Eadmer, 193. Hist. Rames., 391. Mabillon, Amn. Ben., iii., 541. 
toiled and died-how Wilfrid worked and suffered for the cause of God. There was his uncle Odo with the pall of primacy upon his shoulders. Why should not he follow in the steps of those who had done great things for God? The die was east, and the boy's resolution was firmly taken.

He was sent by his uncle to Winchester, and there he became, in the first instance, an ordinary canon, and, afterwards, the superior or dean. ${ }^{i}$ The glories of $W$ inchester had not yet arisen. The eeclesiastics there were merely secular canons. They were married men, and their lives were anything but what they ought to have been. ${ }^{j}$ The evil was too firmly seated to be remedied by a youthful superior, and Oswald was too conscientious to be a silent spectator of "what he could not cure. He went in sorrow to archbishop $\mathrm{Odo}^{k}$ and aequainted him with his difficulties and scruples. He told him how umprofitable to himself and others had been his life at $1 \mathrm{H}$ inchester. He was disgusted with the pride and avarice of his brethren. Their praises sickened him. He was resolved to attach himself to a religions order and become a monk. He would scek for the repose, which he had not yet foumd, within the walls of Fleury, and learn the rule of Benedict at the resting-place of its holy founder by the waters of the Loire.

Odo was overjoyed at his nephew's detemination, and sent him on his way with commendatory letters, and blessings, and advice. He liad passed some time at Fleury himself, and the toilsome honours of age had not banished from his recollection that sacred shrine. The youtluful scholar was received within the same walls, and professed himself a monk. The same ardent longing that led Wilfrid to the eternal city from the solitudes of Lindisfarne, direeted the steps of Oswald to the "Queen of Monasteries." The noble stranger was received with open arms by the abbat and his bretlren. They watched with affectionate admiration the zeal of the youthful derotee. They had grown grey themselves in the path of duty, but when they looked at Oswald they were not ashamed to confess that they conld still take a lesson from one so much younger than themselves.

i Elected dean "coneanonicormm conciliante suffragio." MS. Dumelm., fol. 7 .

$j$ The following aceomit of Oswald's life at Winchester is taken from the MS. in the Cottonian library. "Nrat enim valde inclitus in omnibus operibus suis, amabilis et affabilis omnibus anicis suis. Fulsebat cotudie in sericis vestibus, et epulabatur per singulos soles splendide, eni smppeditabant gaze terrestres, nee vero honores quos servavit Cluristo non sibi, sicut fostea rei probavit eventus. In diebus illis non monastiei viri ijsius sanctse institutionis regulceermt in reurone Luglortum, sed erant religiosi et dignissini cleriei, gui tamen thesauros snos quos arilis adyuirebant cordibus non ad ecelesio honorem sed suis dare solebant uxoribul."

k Fadmer, 193-1. Hist. Rames., 391 
Docility there was in him, and a gentle manner far beyond his rails. Ho would watch and pray in secret over the requireimonts of his high ealling. The mastered all that the brethren could teach him, noving quietly among them with a happy comintmance. Sereral ycars passed away, and he was still at Flen'y. Ile had taken upon himself all the orders of the chureh. Ho was now a priest, and his highest aspiration was that he might pass away to his rest within those walls where he had leamed the lesson, that there is joy and pleasure even in the chistered cell.

Odo was delighted when he heard what his nephew had done at flemy, how he had answered, and more than answered, his warmest wishes and desires. This own day of life was elosing, and, before it ended, he was eager to see again his kinsman, of whom he was so prond. He besonght him to return to England, to aid hin in his dioesse, to rivit him once more. The summons was not one that an affectionate heart conld refuse. The brethen would fain have detained Oswald, and wept at his departure, lont he lastoned across the channel. With all his sperel he was too late. The primacy was vacant before he reatehed the shores of England. The death of his mele eaused him the most poignant aflliction. He went to Canterbury, but the sight of the place awakencel many hitter memories. His patron, his dearest kinsman, was lost to him. Whither should he now turn trm

Oskytel, another rekation, had just beeme the head of the Northern province. Ire weleomes Oswald with open arms. The prelate sets ont tor liome to secme for himself the pall, and his kinsmin acompanies him. Oswald, howerer, was unable to patse by the wallo of lilury. He left the train of Oskytel, and turned axile to his faromite abode. The inmates welcomed him with jo: ; and he returied with a happer heart to his old path of duty.

Whilst lie was at Floury the arehbishop returned to England, but in the managenent of his rast dioesse he soon missed the cucery and experione of his kinsman. He entreated him to desert the Lure for the Onse, and to revive within his province a stricter form of discipline; and Oswald, nothing loth, acepted his invitation." "The English monasteries were at that time in

I Mahillon, Anu. Bon., iii., 5!1, anys

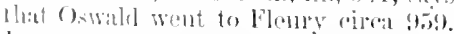

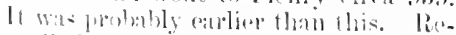

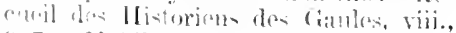

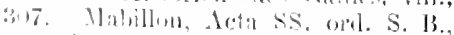
$\approx 1$ ri., i., sis.

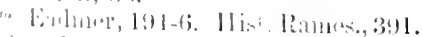

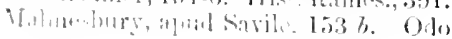

died in 961.

" Ladmer, 197. Hist. Rames., 392. "valut Jnseph uterinum Benjamin, cepit emm amplexibus fovere; quem secum petinuit fiturimis diebus, comment:ms ipsem omnilus amicis suis, menertim Juntano" (MSS. Cotton, Nero L., i., 6, a. b.) "In omni man- 
great need of a reformer. They were filled, principally, with secular canons who observed no discipline, and were guided, for the most part, by no religions rule. Time and necrlect had all but obliterated the lessons of 'Theodore and Wilfird. A mastcrspirit, however, was now arising, who was bold enough to colrect the evil and to enforce, as far as he could, the great srstcm of which Benedict was the anthor. Dunstan was now sitting in the chair of Odo. That encrgetic man had hoard of the fame of the monk of Fleury. Who would be more able to assist him in his projects of reform? They met, and the most affectionate intercourse ensued. As a proof of his estcem, and that Oswald might have a larger sphere of uscfulness, Dunstan prevailed upon king Edgar to advance his friend in the year $96 \mathrm{il}$ to the bishopric of Worcester, which he had himself recently vacated. ${ }^{\circ}$

Oswald was a most energetic prelate. The main object of his endeavours was the revival of the ancient order and discipline of the chmeh, which had been too long neglected, and he saw no other method of bringing this about except by the re-introduction of the Benedictine rule and the suppression of the houses of secular canons. In these designs he had two able coadjutors in the arehbishop and Ethelwold of Winchester, the triple light, as the historian ealls them, which scattered the darkness from off' the face of England.p The position of Dunstan gave him the greatest amount of influence, especially with the king, but Oswald was in reality the designer and chief mover in the reformation. The sovereign was induced to pass a decree at a comneil of the church, ordering the exprntsion of the married clergy, and the name of 'Oswald's law' which was given to it, points to the bishop of Worcester as its originator.q That prelate had already established a little colony of twelve monks from Fleury at a place ealled Westbury, under the charge of Germanus, and the sight of that house was so gratifying to the king that he directed more than forty monasterics to be constructed after the same model." As soon as the "law" was passed, Oswald expelled the secular canons from seven churches

suetudine susceptus, mansitabat a latere ejus in magnificentia dies non paucos" (Servatus., 10).

- Eadmer, 198. Flor. Wigorn., 356. Hist. Rames., 392-3. Chron, de Mrailros, 32. Wendover, i., 260. S5meon, De Gestis, col. 158. Hoveden, aund Savile, 214. Chron. Petrib., 30, where the date 960 is given. Dunstun was the consecrator.

$p$ Malmesbury, apud Savile, $31 b$.
Eadmer, Hist. Novorum, apur Anselmi Op., 2S. 'Turketyl of croyland was a great friend of the three (Ord. Vitalis, apul Dochesne, 511). Polydore Vergil, 119.

4 Eadiner, 200. Hist. Rimnes., 393. Lable (Cone., ix., 696-9. Sprelman, 476. Wilkins, i., 239, 216-9. The circumstance was recorded in the windows at IVorcester. (Thomas, 16, 31.)

- IISS. Cottun, Nero E. i., 7 b. 
in his diosesc, putting monks in their room, Pershore and Wincheombe being, probably, two of the places in which the chature was madde. But the carcer of the reformer was beset with many difficulties. Hle was powerful enough to remodel the monasterics of Ely and St. Albans ; nay, one ehronieler goes so far as to sat that he had a controlling power over all the religious houses in England," but he was foiled within his own diocese, where the secular canons had great influenee. $\mathrm{He}$ could do little with his own ehmel at Worcester. He endearoured to lessen the anthority of the canons, and granted leases of their property." He built, also, by Dunstan's adviee, a rival chumeh wn the cemetery of that belonging to his opponents. In it he was acenstomed to officiate himself, and by his personal demeanor' and holy life, aceompanied by a little justifiable adroitness, the new sanctuary became gradually thronged with worshipucrs, and was regarded as the principal temple in the diocese. The secular canons were slowly but surely pushed out of their places."

The year 9): witnessed the end of Oskytel of York, and Dunstan secms to have been exceedingly desirous that the Northern primary should fall into the hands of some one who would uphold the Benedictine rule. The struggle between the two religions parties was at its heiwht, and York, as Dunstan felt, could not be safely giren up. Who was so well qualified to moderate the racant see as Oswald, who had worked in the province muler his kinsman Oskytel? He indueed Edgar to offer it for his acceptanee, and, after some hesitation, Oswald was prevailed upon to take it. ${ }^{x}$ But that the good work which was going on in the diocese of Worcester shonld neither be preventer nor retarded, the new oceupant of the ehair of P'anlinus was allowed, at Dumstan's suggestion, to retain in commendam the ecclesiastical superintendence of his bishoprie in the South.y It was quite impossible, as was proved by the

s Earmer, 200. Baronii Ann., x., 937.

t Fiadmer, 201.

"Ord. Vitalis, ajud Duchene, 517 . "Oria multiplis"i tam sagacitate quam honitate pollebat, ommibus Anglia eanohilis prapowitus erat."

"Thomas's Bishops of Worcester, 40, etc. Oswald justified this practice whe king. Corlex, Diplom., i., pref. xxxi. In that valuable work, vol. iii., the o are many of these grants.

w " Non vi pulsis ser arte eireumrentis" (Malmesbury, ayud Savile, 153 b). Firlmer, 202-3. Fl. Wigrorn., 359. ('hrom. Itiliros, 33. Other writers seem to say that more or less force was used. Wendover, i., 262. Hoveden, 241 $b$. Symeon, De Gestis, col. 155. Chron. Petrib., 31. Higden, apud Gale, i., 267. 'This seems to have taken place in 969.

${ }^{r}$ Symeon, De Gestis, col. 159. Labbe, Bibl., i., 323. Chron. de Mailros, 33. Hoveden, apud Savile, 244 $b$. Higden, apud Gale, i., 217. Several writers make the year 971. Fl. Wigorn., 359. Salmer, 203. Wendover, i., 268. symeon and Hoveden. Stubbs, col. 1699. Servatus, fol. 14.

y Gadmer, 201. Rad. de Diceto, col. 
result, for any one to do justice to such a charge, and nothing but a very eogent reason ought to have snggested eren the temporary mion of two dioceses which were so far apart.

Immediately after his aceeptance of the Northern see, Oswald set ont for Rome and obtained the pall at the hands of John the pope. ${ }^{z}$ On his return to England he was solemnly installed at lork. A biographer of the arehbishop gives us an interesting account of the city at that early period. ${ }^{a}$ The walls and the magnificent buildings were greatly in decay, which had been accelerated no doubt by the neglect of its inhabitants and the assaults of invaders. From a strong military position it was being gradually changed into the mart for commerce, which was its glory in the middle ages. The wealth of the eity, even then, was in its shops and warehouses. It was thronged with Danish merchants. The adult population was at least thirty thousand. All this seems to shew that the accomnts of the great mischief which the Danes did to York has been exaggerated. They seem to have ocenpied the eity and not to have spoiled or destroyed it. Oswald, who was a Dane limself, would be welcomed by the inhabitants. The eeremonial at his installation was a magnificent one. When his devotions in the church were over, he went to his own hall which was sprinkled with holy water. He then distributed the panis benedictus with his hands in the shape of a cross, aceording to aneient enstom. The banquet then began. ${ }^{b}$ After this the ehroniclers are silent, and we know next to nothing of what Oswald did at York, althongh he presided over that see for twenty rears. There was no Northern writer to speak of what he effected in Northumbria. One biographer records a risit which the arehbishop paid to Ripon, where he diseovered the remains of Wilfrid and the early abbats of that place. He placed the bones of that great prelate in a feretory and earried them, as Eadmer says, to Worcester. 'The same writer, in another work, has told us that Odo had previously removed the bones of the Northern worthy

456, says that the two sees were held together beeause the Danes had wasted Northumbria.

= Some writers say pope Stephen. Eadmer, 201. Chron. de Mailros, 33. Symeon, De Arch. Ebor., col. 79. Stubbs, col. 1699. Fl. Wigorn., 359. The pope was Joln XIII. Cf. L'art de vérifier les Dates, i., 272, ed. 1783 .

a This new and most valuable information is taken from MSS. Cotton, Nero, E. i., 15 b. "Est civitas Eboraea metropolis totius gentis Northanimbrorum, quæe quondam erat nobiliter edificata et firmiter muris constructa, qua nune dimissa retustate; quat tamen gaudet de multitudine populorum, non minus virorum ac mulierum, except is parvulis et pubetinis, quam $\times x \times$ milia in eadem eiritate numerati suut, qua inediciabiliter repleta et mercatorum gazis locupleta q'i undique adveniunt, maxime ex lanorum gente."

${ }^{b}$ IIS. Cotton, Nero, E. i., 16.

c Eadiner, 205-6. He sass that the resting-place of these good men was revealed to Oswald in a drean. The Cottonian MS. onits this. 
to ("antellury, and he speaks of this Wilfid as if he were the scomd hishoj of thit name, forgetting entirely that that prelate was never canonized. The whole story must be looked upon with smspicion.

II' hear a good deal of Oswald's reforms in the South, but there is little to slicw us thist he made any change in the Northern monasteries. From this want of evidence it has been inferred by some that the Benedictine rule was already in existence in the North, and that there was nothing for him to reform. With this opinion I camnot agree. I I do not believe that the Benedictine mle was erer firmly established in the North till after the Concuest. The minster at York was never oecupied by monks. 'The olscervance of orler and diseipline may have been pressed upon the ranons, and it may, perhaps, have been partially attended to under a diligent arehbishop, but they never beeame monks, in the proper sense of that word. They lived upon a common fund and had a common dormitory and refectory, from which it may be inferred that they were immarried, but they were nerer Benedietines. Ilad they been so, the minute instructions which Alenin wrote to the brethren at York would have been mmecessary; and within thirty years after the death of Oswald the canons rejected a strict arehbishop, and they were thence called "osores monachorum." If the Benedictine influence had been strong in Northumbria the bones of Wilfid wonld never have been removed into the South, assuming that they were actnally taken away. I believe that Oswald accepted the sec of York, not with the certainty of lyeing able to carry ont his reforms in that provinee, but to keep some religious oppoment ont of the position. To attend adequately to the two dioceses was imposible. The whole of the North was seaned and scarred by the sanguinary warfare of the native prinese in years gone by, and the ineursions of the Danes. How conld Oswald work there? There were troubles enough in his old diocese of Woreester. The duke of Mercia was talking the part of the secular canons, and he was to be withstood. He womld carry the day if the archlishop remained in

a In the Cotfonian MS. is the following rmarkable pasage, "1)e loco in yur cojus jontificalis eathedra posita est, quilt reforim, quidifue dicam? Nome in eo in fluo quondim mansitalam diaromes et struriones(sic) fecit Deo servirr monachos? Eilifiravit nove llieroonlinsu purtar, const ruxit ipsins cemobii

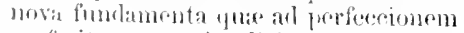
lerfureit, ct cum simplicitate condis beo of 1 ulit.

This comes inmediately after the acconnt of the visit to Ripon, and probably refers to that chureh or to that of "Worcester. The writer, it will be obsered, speaks with doubt and mecrtainty, and knew little or nothing about Northern affairs. Ripon had been, in the first instance, a Benedictine homse, and had been recently destroyed by the Danes.

"This title is given to them by Leland. See the beginning of the life of Alfie, \% 134. 
Northmmbria. It was wiser to strengthen the house which he had erected in the South, than to try to ereet another in the North with its fomdations on the sand.

The number of charters in existence which were granted by Oswald in connection with the see of Worcester, shews how permament was his continnance in that diocese. $f$ But he had many other avocations, and during the reign of Edgar he seens to have oecupied a very important position in the state. $\mathrm{He}$ was a witness to the charter of privileges granted to the abbey of Peterborongh by king Edgar; he was present when the same monareh re-founded the ancient monastery at Gilastonbury. ${ }^{g}$ He took an active part in the coronation of Edgar, Edward, and Ethehred. ${ }^{h}$ But when the sceptre fell from the grasp of Edgar, a series of troubles began which embittered the remainder of Oswald's life. The power of the secular canons l'crired under the influence of Elifhere of Mercia; his farourite monks were neglected or expelled, and the plans mpon which the best of his energies and intellect had been spent were seattercel to the winds. ${ }^{i}$ This was a crucl issue for a life full of honest purposes and self-sacrificing derotion.

There was one place, howerer, where Oswald was not forgotten, and which he watehed and tended in prosperity and adversity, and that was the monastery of Ramsey. There it was that he had prevailed upon the pions Alwine to ereet a shrine to God, and he had himself assisted him. Lonely that place was before that temple was erected, girt with stagnant pools, and covered with reeds and brushwood that love the water; but even there three holy men had fixed their abode, and the roice of praise was heard among the mushes as they trembled in the wind and startled the bittem from its resting-place. 'The walls of a chureh were raised upon that island, for such it then was; a colony of monks soon nestled within them, fostered and endowed by the offerings of the faithful. As years passed on there was a shrinking in the treacherous fen; two towers foll to the ground; the pillars and arches cracked and terrificd the trembling inmates. A nobler shrine was now reared upon the old foundations, and one of the last aets of Oswald's life was its

$f$ Codex Diplom., ii., 383, etc. Hist. Mon. de Abingdon, i., var. loc. There are also charters granted ol witnessed by Oswald in Wanley, 199, 200, ete. MSS. Cotton, Tesp. A. v. Appendix to Smith's edition of Beda, 773-1, 8. Hickes' Dissert. Ep., 70 . Wilkins, i., 258.

g Saxon Chron., 156. Malmesbury, apud Gale, i., 321. IIist. Canobii Burg. (Sparke), 19. Lable, Coric., ix., 70t. Sprelman, Conc., 183. Duerl. Mon., i., 51.

h Chron. de Mailros, 33, 35. Wl. Wigorn., 359, 362. Ingnl]h, afud Gale, iii., 5\%. Wendover, i., 2 tion- 7 . Hovelen, 21.t-5. Symeon, De Gestis, col. 159-60. Diccto, col. 457-9. Giervase, col. 1617. Stubbs, col. 1699.

i Mss. Cotton, Nero, E. i., 12b. Mabillon, Amn. Ben., iii., 638. 
conseration. 'This was in Norember, 991. It must have been a tonching and a melancholy sight. The archbishop and his fricul Slwine met there for the last time. The aged prelate was bowed down with years, and sorrow had sets its mark upon his brow; and all folt within themselves, as they gazed upon his filce, that the light of this earthly sum would not long illumine it. "I Im going hence," he said, in that strangely prophetic tone which the world-monn saint can use, "I must leave you all soon; may Christ make us all one in paradise."

'Phose were his last words; and with tears and blessings he returned to IIorcester to prepare himself for the end. The smmmons, however, was not given for awhile. 'The winter came and was jassing away with its snows and showers. It was now the holy scason of Lent. In addition to his many acts of piety and derotion it was the enstom of the aged prelate at that sacred time to wash day liy day the fect of twelve poor persons, kissing and wiping them with a towel after the example of the Magdalene and her Lord. One day the brethren found him standing bencath the opcn canopy of heaven and gazing, with silent prayer upon his lips, on the skies above him. "I am looking," was his answer to an enquiry, "on the way that I am to take. Ol, my children, let me have a little foretaste of the joys that are to he mine. 'The morrow shall not pass before I see that rterual rest for which I have laboured until now." He spoke and re-entered the little oratory that he had left, but his eye was still bright, and there was no symptom nor shadow of the end that was so near.

'The morrow came with its customary work, and the holy cucharist was given to him, for he desired it. The twelve poor jeople cance to him according to their wont. He tottered as he stooped to them, but he would stoop. He washed their feet and kissed them as of old. It was done, and the verses of the psaln__ "Oculi mei semper ad Domimun" - mine eyes are ever waiting 11 ron the Lord-were over, and he was in the midst of them. When he came to the doxology they bowed in suppliant obeisance. "Ciloria Patri et Fitio et Spiritui Sancto"k was what he said. There was a pause. He spoke no longer to carthly ear's, and yet, perchance, that sentence was completed in anothir state and in a more exalted presence.

'The day of his departure was the 28th of February, 992."

j Earmer, 207-8. Hist. Rames., apud (iale, i., 395. Chron. de Mailros, 38. Fl. Wigorn., 365. Chron. Petrib., 31, 5. Hoveden, col. 245 b. Symeon, De (imatis, mol. 162. Stubbs, col. 1699 .

${ }^{k}$ The venerable Beda departed with the salue words uron his lips.
' Eadmer, 208-9. Chron. de Mailros, 38. Hoveden, apud Savile, $245 \mathrm{~b}$. Higden, apud Gale, i., 267. Mabillon, Ann. Ben., iv., 81. Baronii Ann., x., 1024 -5 .

m Saxon Chron., 168. Eadmer, 210. Hist. Rames., 426. Wendover, i., 271. 
They laid his bones in his own church at Worcester," and his successor, Adulph, placed them honourably in a scrinium or feretory. ${ }^{\circ}$ Miracles are said to have been wrought there, and a halo of sanctity hung around the memory of Oswald. $p$ lle was entered on the calendar. 'Two of that name were enshrincel in that sacred page. The one was the holy prelate of whom we are now speaking; the other was the good king of Northmubria who carned for himself a crown of martyrdom on the battlefield. The former sleeps in the church that he erected; the mutilated head of the latter was laid, where it still reposes, on the breast of St. Cuthbert in his tomb at Durliam.

The portiphor of St. Oswald is still preserved in the library at C. C. C. Cambridge. $q$ His infula or stole of purple and gold, set with gems and of radiant beauty, was treasured in the minster at Beverley in the time of Stublss. This was probably the stole which Adulph found in his tomb at Woreester. ${ }^{r}$

Oswald is said to have been the autlor of several works which are now lost. They were, a Collection of Letters to his uncle Odo; a work inscribed to his friend Abbo, commencing with the words Prescientia Dei monachus; a treatise, Ad Sanctos, composed whilst he was at Fleury, and begimning Oswaldus, supplex monachus; and Statuta Synorlatia, in one book."

Oswald, himself, has had several biographers. The first in age and importance, is an unknown monk of Ramsey, whose work is now in the British Mnsem. It is a MS. of the noblest kind, written certainly within twenty or thinty years

Symeon, Higden, Fl., Stubbs, Hoveden, Chron. Petrib., and Mailros, ut supra.

"Symeon, Higden, Flor., W'endover and Eadmer, ut supra. Lel. Coll., iv., 81, 160. Hickes, Dissert. Ep., 120. Mabillon, Ann. Ben., iv., 81.

- Servatus, fol. 21. Cliron. de Mailros, 40. Diceto, col. 461. Dr. Thomas, in his history of Worester (61), gives an engraving of a tomb attributed to Oswald, the work of a later age. I have, unfortunately, been unable to examine a copy of Hemming's Chronicle of Worcester. Dr. Thomas, however, lias made great use of it.

${ }^{p}$ Eadmer, 209.

$q$ Among the Parker MSS., K. 10 (Catalogue, pr. in 1722. Wanley, 110. Smith's Cat. of MSS). The book formerly belonged to the church of Worcester.

$r$ Stubbs, col. 1699. Servatus, fol. 21. Mabillon, Ann. Ben., iv., 81 .

s Bale, cent. ii., 141. Pitsens, 180. Tanner, Bibl. Brit., 560. Wright,
Biogr. Lit., i., 467.

t One of the finest MSS. that I ever saw. It is entituled, "Vitre et Passiones Sanctorum," and is written, in varions hands, by a very bold scribe mon the finest vellim. It is of the folio size, and the caligraphy is excellent. The class mark is Nero, E. i. The life of Oswald is written in donble colmmu, and occupies twenty-one folios. On the first leaf is a note in the hand of the celebrated archbishop $T$ ssher, suggesting that Elfric was the antlor. The writer, however, dismoves this by saying $(15 a)$ whilst speaking of a miracle, "Esi hujus rei testis Elfricus archiepiscolus eivitatis Cantix. Sunt alii guam plurini consingeni viri (qui dicant) quod vera sunt que dicimus."

The following pasage shews that the anthor was a monk at Ramsey or Worcester, "Nobis autem preposiit Ethelnothum, et illis, qui sub eo erant in civitate, anteposuit $W^{\text {ynsinum, qui crat }}$ nostri cenobii gimnasio eruditus." 
after the decease of Oswald, and finl justice has not yet been done to it. The style is oreasionally inflated and diffuse, but the life contains some norel and raluable information.

'There is another life of the archbishop by Eadmer, the bionrapher of Wilfrid, which is printed in the Anglia Sacra." This is merely an abstract, at times carelessly and elumsily done, of the carlicr account by the monk of Ramsey. There is an abrilgment of the life by Eadmer among the Lansdowne MSS. in the british Miscum, which forms the text, I believe, that is adopted by Mabillon."

Servatis, who was prior of Worcester in the twelfth eentury, de'w up an aceount of Oswald. There is a copy of this MS., which is generally believed to be lost, in the valuable library of the dean and ehajter of Durham. It is founded upon the earlier biographies, especially upon that of Eadmer, and makes use rery fieguently of the same sentenees and words. It is evidently a compilation for the use of the ehurch of Worcester, with ardlitions to the previonsly received aecounts; one, in particular, describes the translation of Oswald's remains by Adulph. ${ }^{x}$

Alfrie of Canterbury and Folcard, the biographer of St. John of Bererley, are said to have described the acts and deeds of Oswald, bit their works are not known to be in existence.y There is much interesting information about Oswald in the history of Ramsey abbey, which has been published by dean Galc. The chroniclers of that house had good reason to remember and commenorate him.

"Anglia Sircrn, ii., 191. Cf. purefat. ad candem, xis.

No. recexxivi., 76-81. Among "ther lives of the saints written in the fificenth century. The book once belonged to Ramser abber.

- Actat SS. ord. S. B., Nier. v., 728.

s A most beautilit Ms. of the twelfth crutury, in suall folio. The clas-s nisrt is 13. ix., 39 B. The rolume, aloo, contains the life of St. Wubtan, and pobably belomged at one time to the church of Wroce-ter. It has been at Ihulham for many renturies, as is evikent by the following inscription 17\%) a fly-leaf", "Iste liber assingnatur commut ahuariolo Dunelm. (x promuratione domini Johamis de Rypon monarhi et medici.'

y Ord. Vilalis, lib. ii. Oudims ii., 107f. Tlue ale lives and notices of (bwnlt in dreta Ss. Fob., vol. iii., 7536h. (Tiken from Eidmer). Mabillon, 10la ss. ort.s. B., war. v. where there are three lives, one abridged from Eadmer, another extracted from the Ramsey chronicle, and the third, a compilation from Capgrave and the Bollandists. There is a life in Capgrave's Nova Legenda, ccli., etc.

= Other works relating to Oswald are in existence which I have not seen, but it is not probable that they contain anything new, e.g. "Vita S. Oswaldi archiepiscopi, ejusdemque miracula" (IISS. Bodl. F. 6, 2130, 15) and "Miracula S. Oswaldi Ebor. archiepiscopi" (Benét Coll. Cimbr.)

In the old library of the monks of Peterbro' were "Tersus magistri Henrici de vita S. Oswaldi" (Gunton's Peterbro, 205). In MSS. Bodl., 3856, is a tract "De Vita et miraculis S. Oswalli," given by 'Thomas Lord Fairfax ; and there is a similar life in the library of St. John's Coll. Oxford (Smith's (at.) 'These may, perhaps, refer to king Oswald, and not to the arehbishop. 
F Doulph, the abbat of the monastery of St. Peter at Burgh, was the successor of Oswald. The retreat, of which lie was the president, was founded three centuries before his time by WTufere of Mercia. It was then known by the name of Medeshamstead, and had a munifieent endowment. The Danes at length laid it in the dust, and it was the privilege of lithelwold of Winehester, in the latter part of the tenth ccutury, to prevail upon his royal master, Edgar', to restore it. 'The inmates were henceforward to observe a new rule, and the plaee received at the same time a new name. It was called the burgh or town of St. Peter, a title that still survives to us in the modern Peterborough.

The history of Adulph and his eonneetion with Burgh is a remarkable one. Like others of his day, he held a liggh position at court, and was ehaneellor to king Edgar. A domestic affliction is said to have opened his eyes to the vanity of earthly honours, and to have changed the whole current of his life. He had an only son who was unhappily overlaid by liis parents as he slept between them. The distressed father was appalled at this involuntary erime, and was about to cross the seas to seek for absolution at Rome, when bishop Ethelwold told him that he could best atone for what liad occurred by deeds of mercy and eharity at home. The old abbey of Medeshamstead was in ruins: Croyland had already arisen in beauty through the care of Turketyl; there was an example for him to eopy and a field to work upon. The resolution of the nobleman was soon taken. He went to Medeshamstead, and there, in the presenee of the monarch and his court, devoted his worldly substance to the restoration of that ruined temple. He resigned his office, and assuming the dress of a Benedietine, gave up the remainder of his days to unlearn the ways of the world tliat he had renounced. ${ }^{a}$

Adulph could not have been long at Burgh before he was raised by Ethelwold to the post of abbat of that monastery. ${ }^{b}$ Who was more worthy of that homour? 'To his munificenee and energy was due the restoration of that shrine, and he had set an example which the monareh and his nobles had been glad to follow. ${ }^{c}$ A church of rare beauty had arisen in that

a Hist. Coenobii Burg., apud Sparke, 18. Chron. Petrib., 35. Lel. Coll., i., 6, 7. Gunton's Peterluro', 10-11. The metrical hist. of Peterbro' in Sparke, 217 , which begins thus:-

"Un chaunceler avoit le rei, Adnlf lapell;

Cil en out un petir fiz, "qu'il tant amat."

${ }_{b}^{b}$ Ingulph, apud Savile, $502 b$. Vita
S. Ethelwoldi, apud Mabillon, Acta SS. ord. S. B., sire. v., 616. IIist. Mon. de Abingdon, ii., $26 \%$.

c Hist. Cornob. Burg., 18. Adulph's gift to the chmrel when he beeame a monk was a remarkable one, "plenam hastan armillis extra argentum ot variis ornamentis." 
will comontry. The brakes and formests were eleared away, the fins were drancl, and moss and moor at length owned the smpremacy of man." Good work like this camnot be too highly praiced, and, mulomtunately, we know too little of its anthor. II0 ane told that Adulph was present at the consecration of litulsey abbere and, in the year 975, he and the abbat of 'Thomery committed their fricind Turketyl to the tomb. $f$ For the noxit seventecu years his encrgies secm to have been quietly and mostentationsly deroted to the interests of his monastery.

In 99:3 the death of Oswald racated the sees of York and Morcester, and the abbat of Burgl was appointed his suceessor he the common voice." He held both these arduous and homonrable posts for the same reason, in all probability, that harl mited them in the person of his predeeessor. We know litile of his cpiscopal carcer. He did not, as it is said, make his obedience to Canterbury. ${ }^{h}$ The prelate who did so was Adulph a bishop of Lindsey. Like Oswald, he was a great firind and bencfactor to Flenry. WTe find him making and witucsing a few grants; and we hear nothing more of him. lint who can say that that life was fruitless and those years mixpont about which the chroniclers are mute? Ont of that silenver there secms to come the sound of a far more approving roice which whispers to us of the good deeds of one "whose juitic is not of man but of God."

'Tliere was, howerer', onc great seene at Woreester in which Adulph took a part, the translation of the remains of Oswald to a more befitting resting-place. This was done on the $15 \mathrm{th}$ of April, 100:. King Ethohel was there with a long array of bishos and loly men, and the ceremonial must have been a mannificent one. ${ }^{k}$ Six weeks after this, on the 5th of June, ${ }^{l}$

d Cixon Chron., 156. Lel. Coll., i. fi, 7. Ciuntom, 9-10, $218-9$.

(inintron, 11.

$f$ lumulph, inum Savile, 505.

\& Sixull ("loron., l6i). ('hron. Mail. ros, 34. Anelia tinera, i., 173. Symon, De ficstis, eol. l6iz. "Ommium conselisil, wel volumtate regis of eprixco-

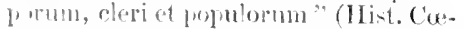
atobii bure. 33). In 995 lie signs a rhaptur is "reetus in epise. Ebor." (IIir. Mon. de Alumenten, i., 391) Was loe at that time withrmt the jall :

s Inelia Sarra, i., 78. 'Textus lioffrnsis, 215 .

Malme-bury, apud Savile, 1.51.

j ('xlex l)iflom., iii., 286, 295, rte. lli-t. Mron. do Mhinglem, i., 365 , ete. Thomas 11 ureester, j6.
${ }^{\star}$ Fl. Wigorn., 370. Chron. de Maillos, 40. Chron. Petrib., 38. Wenlover, i., 276. Hoveden, apud Savile, 2.16. Symeron, col. 164. Diceto, col. 161. Stubbs, col. 1699. There is a rather long account of the ceremony in the life of Oswald by Servatus (MISS. 1)unelm., B. iv., 39, B., 21). The author spreaks of Adulph as "vir habitu monachns et mandatorum Domini eximius executor."

"Ann. Wicorn. (apud Angl. Sacr., i., 173) make him die on May 6th; so do Fl. Wigorn. (370) and Symeon (col. 165.) A Worcester obituary says that he diest on Jume \& (Wharton i., 473.) 'The Peterbro' Obituary, on June 5 (ilditl.), the day on which his depositio was commeniorated in that church 
Adulph's own body was laid in the grave in the same church in which his predecessor was sleeping, whose holy life he harl madc the model for his own.

WW Ulstan HE. was raised to the arehiepiseopate of York and the see of Worcester on the death of Arhuph. ${ }^{\text {m }}$ Of his previous history there is little known. IIe is said to have been a monk and an abbat." His family was an hononrable one; many of his kinsmen were persons of consequence, and his sister's son Brihteage beeame bishop of Worcester. ${ }^{\circ}$

Like most of the prelates of his time Wulstan was a courtier, and he is said to have been an especial favourite of Ethelred, Edmund, and Canute. I find him witnessing at York the gift of Darlington which Ethelred made to St Cuthbert, ${ }^{p}$ and he was present in 1004 when the same monarch confirmed the foundation of Burton abbey." About 1006 he was at the council at Eynsham in Oxfordshire, when thirty-two canons were enacted for the direetion of the cluurch and state, with a special referenee to the ravages of the Danes. ${ }^{r}$ In 1018 he witnessed king Canute's grant of privileges to Canterbury. In 1020 he was with the same sorereign at the dedieation of his chureh at Assington. ${ }^{t}$ In the same ycar he consecrated archbishop' Ethehoth, and one of his own suflragans, Edmund, bishop of Durham. " He was a kind benefactor to the chureh of Ely, and was a man of coirsequence and repute both in the church and the court.

The character of Wulstan has been rery severely assailed. William of Malmesbury attacks him for holding two sees at one

(Dugd., Mon. i., 362.) A Lambeth Calendar makes the date June 5 (Gunton, 248, 9.) 'The Peterbro' Chron. says, wrongly, that he died in 1003 (38). Cf. Saxon Chron., 176. Chrou. Mailros, 40. Hoveden, 246. Symeon, col. 165. Stubbs, col. 1699.

n In 1002 or $1003, \mathrm{Fl}$. Wigorn., 370. Chron. de Mailros, 40. Symeon, le Gestis, col. 165. Wendover, i., 276.

$r$ Fl. and Symeon, ut supra. Diceto, col. 461. Hoveden, apud Savile, $216 z$. Ann. Wigorn., apnd Angl. Sacr., i., 473. Hist. Eliens., apud Gale, i., 506, whero it is said that lie was a monk.

o Fl. Wigorn., 397. Hoveden, 251. Hist. Eliens., 506. Symeon, col. 178. In the Hist. Eliens. (Gale, i., 506) it is said of Wulstan, "Secto matris ntero in hane lucem productus fuerat et vacue nberibus proximorum industria edncatıs." The same thing was said of archbishops Kinsius and Frewen!

$p$ Symeon, Hist. Dnnchn., 1-19.

q Ann. Burton, apud Gale, iii., 246.

r Spelmanni Conc., 510.

- Ibid. There are other grants witnessed or made by him in Colex Diplom., iii., 330, etc.; iv., l, etc. ('hrom. de Abingron, i., 380 , ete. Snith's $A p^{1}{ }^{x}$ to Beda, 778-9. Hist. Eliensis, apud Giale, i., 522-3. Dugd., Mon., i., 51. Iranley, 300, cte.

'Saxon ('hroz., 202. Fl. Wigorn., 392. Hoveden, 250, $\overrightarrow{3}$. Symeon, cal. 177. 1)iceto, col. 467. Stubbs, col. 1700. Hist. Elicns., apnd Gale, i., 506 .

"Saxon Chrom., 202. Symeon, II ist. D)111.m., 156. 
time," whilst he never censures Oswald and Adulph who did the same thing. "Bimamy of bishops," says Fuller, "goes by forour, and it is condemmable in one what is commendable in anotlere." "The Worcenter historians are more severe than IIalmesbury thuse is recklessly showered upon Wulstan. He is called a plunderer and a robber. ${ }^{x}$ They eharged him with taking away some of the lands of the see of Worcester and appropriating them to that of York. Dr. Thomas, however, a more recent chronicler of the church of Worcester,y takes a juster view. II says that, in all probability, the estates of the two bishopries had become so mixed together that it was cxtremely difficult to separate them, and that, therefore, it is unfin to attribute to design what may merely have been the result of accilent. It was intended also, I believe, at this time that the two sees should be always mited. This seheme secms to have had its origin, as I have already stated, in the policy of Dumstan and Oswala; but afterwards when Northumbiria was ravaged by the Danes, the possession of the Sonthem bishoprie was fomd to be necessary for the maintenance of the Northem primate. It was on this ground that Edward the ('mfersor subsequently decided in farour of their union. ${ }^{z}$ The archlishops of C'anterbury would not be likely to oppose it, as the primate of the North would the be placed in the position of is suffrigan to the successors of Augustine.

Wulstan is very holiourably comnected with Anglo-Saxon literature. It is gencrally believed that he was the author of the Homilics, to which the name of Lupus Episcopns is affixed." III of them are still nupublished, with the exception of one which is a striking address to his comntrymen on the Danish inrasiom. It was written in the year 1012 , and exhibits a fearful picture of the vice and lawlessuess of the age. Wulstan was also the author of an Encyclical Letter to the inhabitants of his

" Te Gestis Pont., apud Savile, 151. IIe says that II ilstan onght not to liale bidil Worcester, beconise he difforend form lis two predecessurs, "sanefitatr " h habitu." He mas, lowerer, a monk, and we ran form anopinion now, ae woll as Mahmesbry, as to his sanctitas.

ts Church Ilistrory, book ii., 130.

- Lmprobus was the epithet generally applimel to him. 'Tluomas' Worcester, 57 .

" Hist. Woresster, 57.

= 'Tlumas' Morcoster, alp', i.

" Mankey (1:0) mado this disenery. These IIrnilies are anonor the Prarker Viss. at C. C. C., Cambridge (Smith's ('at) There are some of them in Mss's.
Cotton, Nero, A. i.; and others, called "comeiomuncule," in 'Tiberins, A. iii. There is a transcript of tive made by $\mathbf{F r}$. Junius, with collations, in MSS. Bodl., 5213 (Smith's Cat.) Sce Ondinus, ii., 501. There is a list of these Homilies and much interesting information about then in Wanley, 27-30, 140-3.

${ }^{6}$ This is in US. in C. C. C., Cambr. (Sunith's Cat.), and a copy by Junius in MSS. Bodl., 5213. It is printed in Hickes' Dissert. EY., 99-106, edited by $\mathrm{W}$. Elstoh. A separate edition in folio was published at Oxford in 1701, "Sermo Lmi Eliscopi, Saxonice. Latinam intcrpretationem notasque adjecit Gulielmus Elstol)." 
diocese, ${ }^{c}$ and he is said to have becn the promulgator of a cole of rules which are called the Taws of the Northmmbrian priests. ${ }^{d}$ We are indebted to him, besides, for two Pastoral Letter's which Alfric Bata translated, at his sugestion, into Anglo-Saxon fiom the Latin in which they were originally composed." Wulstan, therefore, in spite of what has been sairl against him, was a man of piety and learning. He dared to be a censor at a time when it was dangerous to rebuke. He was not ashamed of literature when there were few to cultivate or appreciate it. IIaymo studied under his care at York; $f$ Alfric Bata assisted him in his literary labours; and Alfric of Canterbury, another scholar, remembered him affectionately in his will.g

There is a curious story comnceted with Wulstan's cnd. IIe had come to the monastery of Ely, a place to which he was much attached, and the brethren welcomed him to their abode with a reverent procession. The archbishop placed himself at its head, and as he was moving up the church the staff', on which he was leaning, sank deep into the ground. "Here shall be my resting-place," ${ }^{\prime}$ he said; and so it was. ${ }^{i}$ He died at York on the 28th of May, 1023, ${ }^{j}$ desiring again, before his eyes were elosed, that his bones shonld be renoved to Ely. They laid him in the ground at the appointed place, and miracles are said to have borne witness to the sanetity of the archbishop. When the monks of Ely restored their eathedral they were obliged to disturb his remains, and they were laid for a while in the cemetery of the brotherhood before they found a resting-place in the renovated choir. The body had returned to its kindred

c In MS. at Corpus, Cambridge. There is a copy of it by Jumins in MSS. Bodl., 5150, collated with MSS. Cotton, Tiberius, A. iii. (Smith's Cat.) Cf. Wanley, 85, 137.

$d$ There is a copy of this in MS. at Corpus. The Laws have been minted in Labbe, Cone., ix., col. 495 ; in Laws and Institutes of England, ii., 290 303, and in Wilkins, i., 218-21, where they are put among locuments of the tenth century. Wilkins' Angho-Saxon Laws, 98-10\%.

e Oudinus, ii., col. 49t. In MS. at Corpus, and in MISS. Harl., 438, and elsewhere. Published in Laws and In. stitutes of England, ii., $361-89$, and in Wilkins' Anglo-Saxon Law', 161-17'.

$f$ Tauner, Bibl. Brit. Pitseus, 181.

$g$ "And he beeroeth Unifstane xreebiseope ane sweor-rode (a crosic for the neck), and anne ring and anne psaltere" (Hist. Mon. de Abingrlon, i,, 416). IIiches, Dissert. Eprot., 62. (o- dex Diplom., iii., 352.

$h$ Hist. Eliens., apud Gale, i., 606. Diceto, eol. 467. The legend of St. Wulstan thrusting his stafl into the stone will be remembered.

${ }^{i}$ Leland (Coll., i., 13) says that he died at Ely, and expressed a wish to be interred at Peterbro'. lle was buried at Ely. Fl. Wigorn., 393. Hoveden, 250, b. Amu. Wigorn., apmel Angl. Sacr., i., 473. Symeon, col.177. I)iceto, col. 167. Stubbs, col. 1700. lin the II ist. Canob. Burse. (15), it is sail that Wulstan had siven to Peterb"r" "se et ommia sua. Sed emm isset ad risifanda Sanctorum loca, et renisect al $\mathrm{El}$, ihi infirmatus est et mortuns of sormitus."

$j$ Saxon Chroll, 208. Fl. Wigolrl., 3!3. Ann. Wigorn., apum Angr. Sacr., i., 173. Chrontede Mailoes, 15. Symeon, col. 177. Stubse, col. 1700. lloweden (Sivile, 250, b), say's that he dien on the wenll. C'hron. of Wincliester, ed. Stevensull, 390. 
dist when the grave was opened, but the vestments were undecared. 'The dress of the prelate was complete, and the wonlcring monks beheld the pall with its golden pins. ${ }^{k}$

FIfirir, sumamed Putta or Puttoc, was the next arehbishop of York? At the time of his appointment he was provost of the church of Winchester, one of the most important positions in England. Ile was consecrated at Canterbury by arehbishop Eovelnoth in 10:3, ${ }^{m}$ and received the pall at the hands of pope Johm at Rome on the 12th of November, 1026." The see of Worcester, in this instanee, did not accompany the Northem primacy, as Leofsi seems to have occupied it since about 1016, acting probably as a suffragan to Wulstan during his life. ${ }^{\circ}$

Alfic was closely comected with the court, and for many years took a prominent part in public affairs. In 1026 or $10: 2 \%$, when Camnte, eager to atone for the offences which had raised him to the throne, went as a pilgrim to Rome for absolution, he wrote a letter to the two archbishops acquainting them and his subjects with his design, and he addressed another to them on his return. In all probability the two prelates had recommended that jouney, and speaking to the monarch of the crimes of his earlier years had said to him,

"For, sare alone

The hand of Clurist's high vicar upon earth, A lurt so heinous what may heal :"

Not long after lie came back the king was called away from the kingrloms that he hark won before a higher Sovereign, and Alfric assisted his brother of C'anterbury in plaeing the erown njon the head of IIarold Harefoot.q In 1039 the throne was again racant, and IIardicante took up the sceptre to which he

s Hist. Eliens, 507. Bentham's Ely, 86. 91.

¿ P'uttoe (1'1. Wigorn., 393). Putta (c'liron. Mailpos, 15). Puttoe signifies a kite, and the nane, probably, is an mplowant allusion to some of Alfric's rruel acts. I am indebted to archdearon Churton for this surgestion.

It ra-at this vacaney, probably, that Eiselrie (afterwarls bishol ol Durlam) was rhosen arehbishop, but was rejerdul by the canoms, "quia pone naplirale est eis semprea invirlere monachis ; ynia monach!n erat, noluerunt pati eum archiepiscopum esse" (Hist. Canob. Burg., apud Sparke, 45).

"saxon Chron., 203. Fl. Wigorn., 393. Chron. de Mailros, 46. Hoveden, ajud Savile, $250 \mathrm{~b}$. Symeon, col. 177 . Diceto, col. 468 .

"Sason Chron., 205. Stubbs, col. 1700. Flor., etc., ut supra.

"Lel. Col., iii. 259. 'Thomas' Worcester, 60 .

$p$ Wendover, i., 298. Flor. Wigorn., 394. Ingulpl, apud Gale, ii. 59. Malmesbury, De Gestis Regum, apud Savile, $41 \mathrm{~b}$. " Gervase, col. 1651. 
had been previously entitled. One of the first public acts of the new king was the manifestation of a miscrable and unfecling spite against his predecessor, which Alfric, mufortmately for his own character, is said to have suggested als well as to have earried out. The body of Harold was torn from its grave, and was cast, without its head, into the Thames, to shew that he had been monarch by a false title. ${ }^{r}$ In 1040 the archbishop appears as an informer. He aceused earl Godwin, and Living, bishop of Worcester, of being implicated in the murder of Alfred, the half-brother of the king. 'The earl was too powerful to be assailed, but the prelate was driven away from his see, which became the prize of the archbishop. Whilst he was in possession of Worcester he had an opportunity of giving a blow to the people of that eity which they would long remember, and which was prompted, it is said, by the angry disappointment that he felt at their not choosing him originally as their bishop. One of the umpopular taxes of the day was being collected, and the people arose against the king's servants who were gathering it in, and two of them were slain. Upon that the archbishop is said to have advised his master to plunder and burn the eity as a punishment for the offence. ${ }^{s}$ His advice was adopted, and Alfric is said to have been the chief agent in perpetrating the crime. In the following year Alfric gave up the bishopric, and permitted Living to return. ${ }^{t}$ All this does not place the archbishop before us in a farourable light. The example of his old master, Cannte, might have tanght him a very different lesson, to say nothing of the words of a still greater Sovereign which he professer especially to follow. In 1043, Alfric assisted at the coronation of Edward the Confessor." We find his name appended to numerous deeds, especially to one which Canute made to the monks of Croyland."

There is some good to be set against the evil. I camnot indeed attribute to Alfric the works that were composed by a writer of that name. $\quad$ The head and the hand which prompted

r Malmesbury, De Gestis Pont. (Savile, 154), brings this accusation against Alfric. Other writers do not allude to it,e.g., Fl. Wigorn., 401. Malmeshury, De Reg., 43. Hoveden, 251 b. Symeon, col. 180. Diceto, col. 474 . Bromton, col. 933. Higden, apud Giale, i., 276. Lel. Col., iii., 259. The chief argmment bronght forward to shew that this Alfric was not the writer, is his political character, and he is condemmed on the sole testimony of Malmesbury. The point seems to be yet an open one, but I leave it as I fomnd it. s Fl. Tigorn., 402. Wendover, i., 303. Hoveden, Symeon, and Lcland, ut supre.

' Symeon, col. 180.

"Fl. Wigorn., 10 1. Chron. Mailros, 48. Cliron., Petrib.,46. Alured Ber., 119. Wendover, i, 306. Symeon, col. 181. Diceto, col. 474. Bromton, col. 936. Stubbr, col. 1700. Ailred, col. 366 and 375 . Gervase, col. 1651.

" Ditgd. Mon., ii., 118. Hist. Mon. de Abinirlon, i., 54, tis, ete. Codex 1)ijlom., iv., 22, ete.

w As there were several persuns of 
thrn were animated by a nobler and a more Christian spirit. But there are still some acts of charity and generosity which will buoy up the archbishop's memory. He was a noble benefinctor to Beverley and Peterborough. On the 25th of Oetober, 1037 , he took up the remains of his predecessor, St. John, and trimslated them to a new shrine with a gorgeous eeremonial. Jolm hart been canonized in the same year, probably at Alfrie's request. The bones were placed in a rich ease, bright with gold and silver and precious stones, which was deposited in a feretory of cumning workmanship and marrellous design. In the same church he established a sacrist, a chancellor and a precentor, and added to the endowments by purchasing and presenting linds. in Middleton, Fridaythorpe, and Holm. He also obtained from Edward the Confessor a grant of three anmual fairs to be held in Beverley. ${ }^{x}$ To the abbey of Peterborongh he was also most munifieent. He bestowed upon it some precious restments and plate. Their end was an unfortmate one. Aloont the rear 1100 some Flemish and Freneh thieves broke into that famous monastery and stole a large cross, which stood upon the altar, set with gems, two chalices with their patens, and two candlesticks, all of pure gold, which had been given by archbishop Alfric. The robbers were subsequently eaptured, but their booty eame into the possession of the king. ${ }^{y}$

Alfrie died at Southwell on the $22 \mathrm{nd}$ of Jamuary, 1050, $z$ and was interred at Peterborough, " that nursery and resting-place of Saints and prelates to which York owes so much. Gunton, the historian of Peterborough, who wrote in the seventeenth contury, mentions a discovery which revealed the tomb of the archbishop. "On the north side of the choir in the cathedral, in two hollow places in the wall, were found two chests of about three foot long a piece, in each of which were the bones of a man, and of whom appeared by a plate of lead in each chest,

the name of Alfric living about the same time, it is not ease to discover which of them was the rammarian. The learued II enry Wharton wished to shers that he was onr archbishop, and wrote a dissertution to prove it (Dissetatio utrm Elfricus Grammaticus:) whith he printed in his Anglia sacra, i., 125. The other sile, on behalf of Alfric of (anterbury, wis taken m, apprarently with suceses, in the followins work," Edwardi-Rowei Moresi de Eifrioc, borobemensi archicpiscopo, whnumbarins: edidit (irimus Johannes "Throkelin. Ho. London. 1789." ('f. IVrizht, 1so. Oudinus, ii., cul. 189, 4 re. ('ave, $588-9$. 102.

r Stubbs, col. 1700. Lel. Coll., iv.,

y "Dedit cum corpore suo alban de purpura cmm optimis aurifriciis paratam et duas cappias optimas, et stolas, et dalmaticam albam, et altare cum reliquiis optime com auro paratum, tria frallia et baculum suum," etc. (Hist. C'(molb. Burg., 45). Lel. Coll., i., 12, 15.

z Saxon Chron., 224, "A very venerable man, alid wise."

a Thid. Fl. Wigom., 410. Chron. Mailros, 49. Chron. Petrib., 48. Hoveden, 251, b. Ingulph, apud Gale, iii., 6\%. Srmeon, col. 18\%. Jiceto, col. 175. Stubles, col. 1700 . 
whereon the name of the person was engraven. In the one was Elfrieus, on the other Kynsius, both which hat been arehbishops of York, and, being dead, their bodies were interred in the monastery of Peterborough, where formerly they had locen monks." c

K insius, the next arehbishop, ${ }^{d}$ began his religious eareer ats a monk at Peterborough. ${ }^{e}$ In course of time he became the chaplain of Edward the Confessor, and when the see of York was vacant by the death of Alfrie, Kinsins was adraneed to that honourable post, ${ }^{f}$ after it had been retained for some time in the king's hands..$^{g}$ In 1055 he journeyed to Rome, and obtained the pall from pope Vietor. ${ }^{h}$ Kinsins was at York for a very short period. His name is appended to a few eharters. ${ }^{i}$ In 1059 I find him witnessing a grant which his royal master made to the abbey of St. Denys, near Paris, ${ }^{j}$ and, in the same year, he was acting the part of a peacemaker together with Egelwin, bishop of Durham, and Earl Tosti, in prerenting a war with Scotland, by prevailing upon king Malcolm to make some timely concessions. ${ }^{k}$ On the 22nd of December, 1060, the archbishop ended his days at York, having in the earlier part of that ycar eonsecrated the abbey at Waltham. ${ }^{l}$ They carricel him to Peterborough, and laid him honourably in the monastery in which his earlier years had been spent, and where he wished to be interred." His resting-place was in the ehoir, close to the high altar, on the north side. ${ }^{n}$

The historian of Peterborough speaks in high terms of the

c Gunton's Peterbro', 98.

${ }^{d}$ 'The $\mathrm{S}^{-}$, on name of this prelate is Kynesice. Stubbs (col. 1700) mention... the ing "lar circumstance, "quod :.on natu: sed ?e ventre matris caesus fuit."

e Ingulph, apud Gale, iii., 66. Chron. Petrib., 48. Hist. Cœnob. Burg., apud Sparke, 45.

$f$ Fl. Wigorn., 410. Chron. de Maillos, 49. Wendover, i., 308. Symeon, De Gestis, col. 18. Hoveden, apud Savile, 253.

b Bromton, col. $943 . \quad h$ Ibid., 213.

i Codex Diplom., iv., 1 to, ete.

j Histoire de l'Abbaye de St. Ienys, 126, \& l'appendix, 85.

$k$ Symeon, De Gestis, col. 190.

l Chron. de Waltham, cd. Stubbs, is. "n Saxon Chron., 250. Fl. Wisorn. 421. Chron. de Mailros, 5 t. Symeon, De Gestis, col. 190. Ingulph, apud Gale, iii., 66. Hoverlen, apud Savile, 255. 'The Peterbro' Chron. (32), says that he died at Peterbro', and Dugdile (Mon. i., 363), says that his deprositio was observed in that monastery, on Dec. 20.

" "Jacet tumulatus in serinio juxta mo "nnm altare in parte boriali" (Chiron. Petrib., 52. Gunton (History of Peterbro', 98), says, "For Ky'lsius, I have heard my father, who was well reat in the antiquities of this church, say, that the marble nonument, now lying on the north silte of the quire, was his. It bears the port raicture of a shaven monk lying on the ton.". 
picty of the archbishop's life. Whilst there was a lavish expenditure among his clerks and household, Kinsius himself was as abstincut as a hermit. He lived upon the coarsest fare. During Lent it was his wont to journey from village to village, preaching and hestowing alms, frequently with bared feet, and making no 1 se of a litter or a hor'se. 'lo aroid ostentation and vain wory, he travelled generally by night. ${ }^{\circ}$ Such, doubtless, were the traditions in the monastery at Peterborongh, and they are pleasing reminisconces.

Kinsins was a great benefactor to the Chureh. He built a large tower of stone at Beverle, and hung in it two bells, bestowing also upon the minster divers books and ornaments. He gare other bells to the churches of Sonthwell and Stow.p To the athbey of Peterborough he gave, with his body, the vill of Tinwell, a text or copy of the Gospels decorated with gold, and jewcls and treasures to the value of $€ 300$. These were lost adterwards to the house throngh the cupidity of queen Edgith."

Mlorrd, the last of the Saxon archbishops of York, was a person of extraordinary energy and influence. He was brought 11) in the fimous monastery of Winchester, which had so recently furnished a primate to the Northern prorince in the person of Alfric. After a while lie was appointed abbat of Tavistock. ${ }^{r}$ That housc had been recently endowed and renovated by bishop Living of "Worecster, and, in 1046, after a life remarkable for its strange vicissitndes of fortune, that prelate was laid in the tomb by the monks of 'Tavistock, who had great reason to remember lim. 'Their' abbat, Aldred, becane his successor in his bishopries

In this position Aldred had a wide scope for the exercise of his raried and extraordinary powers. There was in him much restless mergy and rersatility of talent. He could take up arms, were it reguired, and attack the maranders on the Welsh marches; he conld toil at another time for the rule of Benedict, and establish new houses of monks to observe it, but he was more at lome in the palace than in the convent. He was pro-

" Ifist. Comobii Burgensis, apud Sparke, 15.

${ }_{p}$ S Stubbs, col. 7 700. Lel.Coll., iv., 102.

7 Ilist. C'anobii Burg. 6. Lel. Coll., i., 12-13. 'Tinwell was "de patrimenios =nce."

"Ifreden, aput savile, 252. Stubbs, col. 1700. Rudborne, apud Angl. Sacr., i., 240.

- Saxon Chron., 216. Symeon, col. 182. Wiceto, col. 475. Aldred, however, makes his subseription as a bishop before this. Possibly he had acted as coarljutor to living. 
bably indebted to bishop Living, a friend of Edward the Confessor, for his introduction to state affairs, in which he played so conspicuons a part. With that monarel,, who was casily subjected to ecelesiastieal influence, Aldred was a great favourite, and he served him loyally and well. His first achierement as a statesman was the effecting a reconciliation between the king and Sweyn, the son of Godwin, who had recently murdered his consin Biom. ${ }^{t}$ In 1049 he and Herman bishop of Sherburn went as the royal ambassadors to Rome, and they prevailed upon the pope to absolve their master from the row which he had formerly made of going on a pilgrimage to that eity." To the circumstance of Edward's staying in his own kingdom we owe the re-foundation of the stately abbey of Westminster, in which he sleeps." Soon after this we hear of Aldred as the commander of an expeditionary force which the ling sent forth to seeure earl Godwin and his restless sons, but they had escaped before it arrived. ${ }^{*}$ Shortly afterwards Aldred was very roughly handled by Griffin, a Welsh prinee, when he was leading his men against a band of Irish pirates in the neighbourhood of the Wye. ${ }^{x}$ In 105t he was honoured by the king with a commission of great national importanee. This was an embassy to Germany, to the emperor Heury III., who was then residing at Cologne. Aldred, who was treated with the utmost courtesy, was in that famous city for a whole year as the guest of the arehbishop, and, with his assistance, he prevailed upon the emperor to allow his nephew by marriage, the son of Edmund Ironside, to returu to England with his family.y 'The English monarch was wishful that he should snceced him on the throne. The hand of death, however, was laid upon the futnre monareh, and the erown of his unele, which was intended for him, was afterwards placed by Aldred npon the brows of Harold. $\tilde{*}$ To Edward the bishop seems to have attached himself with the pliant readiness of a courtier. In 1058 he erossed the scas

' Fl. Wigorn., 409. Hoveden, 252 b. Symeon, col. 184. Stubbs, col. 1701. Knyghton, col. 2331.

"Saxon Chron., 223. Chron. de Mailros, 49, where the date 1050 is given. Symeon and Stubbs, ut supra. Lives of Edw. the Confessor, ed. Luard, 70, where Aldred is prematurely called archbp. of York.

" Ailredus, Vita Edw. Conf., col. 385. Spelm. Conc., 635. Wilkins, Conc., i., 316. Iabillon, Ann. Ben., iv., 610, $672 . \quad$ "Saxon Cliron., 229.

$x$ Flor. Wigorn. Tliomas' Worcester, 67 .

y Saxon Chron., 213. Fl. Wigorn.,
4.16. Clıron. Mailros, 51. IIigden, apud Gale, i., 280. Symeon, col. 185. Ailred, col. 366, 3si. liromton, col. 945. Stubbs, col. 1701. Knyenton, col. 2333. Wendover (i., 311) nukes the date of this mission 1057. Anglia Sacra, ii., 219. The emperof wave him a Sacramentarium and a l'salter, abrut which there is a curioms story.

"Fl. Wigrm., 427. Synieon, col. 193. Diceto, col. 479. Bromiton, col. 958. Stubbs, col. 1702. Knyghton, erl. 2339. Higden, ajud Gale, i., 2st. Hist. Eliens, ibid., 515. Hoveden, apud savile, 256. Ingulph, ibir., 511. IIist. Mon, de Abingdon, i., 489. 
again on a very different progress-a pilgrimage to Jerusalem. ${ }^{a}$ The enterprize itself, and the way in which it was carried ont, are indicative of the character of the man. The Bedonins of the desert had never gazed upon an English bishop before. The pomp and dignity on which they looked ill beseemed a disciple of the poor earpenter of Nazareth. The illustrious pilgrim stood upon those holy hills, on which, in after years, the noblehearted Godfrey was content to watch and weep. He offered a precions chalice at the sacred tomb in which there was once laid, for a few memorable hours, the corpse of one who stinted not to any the riches of His grace, whilst He knew not Himself where to lay His head.

Whilst Aldred was actively engaged in the service of the state, he was not oblivious of his higher calling. In 1055 the charge of the see of Wilton was entrusted to him, which Herman had resigned, and he held it mntil 1058, when he restored it to that prelate, who was at length willing to receive it. ${ }^{b}$ In 1056 prince Griffin, the restless leader of the Welsh, broke into the English territory, and slew the bishop of Hereford and his clerks at Glastbrig. The vacant sce was eommitted to the charge of Aldred, who held it, in commendam, with that of Woreester, and his first business was to effect a reconciliation between Griffin and the king. ${ }^{c}$ About the same time he had a mmifieent benefactress to Worcester in Godiva, ${ }^{d}$ the fair lady of Corentry, - the same who

\section{And built herself an everlasting name."}

In 1058 Aldred dedicated the abbey church of Gloncester, which he had himself erected, and made the holy Wulstan the abbat.e The rnle of Benediet was observed there, for Aldred, although a conticr, was a disciplinarian, and came back from Germany with larger vicws on ecclesiastical matters, and a strong resolution to enforce them, which he did also in the North. $f$

At Christmas, 1060, the death of Kinsius vacated the see of York, and Aldred succeeded him, ${ }^{g}$ resigning the bishopric of

"Saxon Chron., 219. Chron. de Maitros, 53, Cliron. Petrib., 52. Anglia Sacra, i., 174. Symeon, col.190. Stubbs, col. 1701 .

b Symeon, col. 189 . Bromton, col. 916. Stubbs, col. 1701. Knyghton, col. 2335. Ilirrlen, ajud Gale, i., 281.

c Saxon Chron., 247. Fl. Wigorn., 418. Symeon, col. 189. Stubbs, col. 1701. Hoveden, apud Savile, $25 \mathrm{k}, b$.

d Wendover, i., 315 . Symeon, col.
189. Ailred, col. 389. Knyghton, col. 2334.

- Saxon Chron., 249. Symeon, col. 189. Diceto, col. 477. Stubbs, col. 1701. Horeden, 255. Lel. Coll., i., 28 ; iii., 262. Dngd. Mon., i., 531. Mabillon, Ann. Ben., iv., 583.

$f$ Stubls, col. 1701 .

s Wendover, i., 318. Symeon, col. 190. Diceto, col. 478. Malmesbury (Savile, 15k), says that Aldred bought 
Hereford, ${ }^{h}$ but retaining that of Worcester. In the following year he went to Rome for the pall. Earl Tosti, one of the most illustrious subjects in England, was his companion. The honour was not obtained, for the pope was indignant at the proposed tenure of the two sces by one person, and that his licence had not been solicited for Aldred's promotion. He also charged the petitioner with simony and want of learning. He deprived him of all his honours, and the degraded prelate quitted the eternal city in disgrace. Other misfortumes were awaiting him. The bishop and his friends had gone abont a day's journey from Rome on their way homewards when they fell into the clutehes of a party of brigands, who maltreated the travellers, and stripped them of ererything they possessed. In a happy moment the thonght oecurred to the despoiled prelate that he would return to Rome as he was, and make a last appeal, in forma peuperis, to the merey of Christ's vicar. It was snecessfinl. After Aldred had promised to resign the see of Worcester, the archbishopric was confirmed to him, together with the honour of the pall. The conversion of the pope was caused, in all probability, by what earl Tosti said to him. The rage of the stalwart Saxon was excessive at the insult and the robbery. It boiled orer in langrage seldom heard at the papal eourt. "What distant nation," he said, "would hecd the excommunication of the pope, if villains at home despised it? Why should he trample on suppliants, and leave the bandits to themselves? If the goods whieh they had lost were not restored by him who should have taken care that no one tonehed them, the king of England would repay them out of the Peter-pence when they erossed the scas." The words are worthy of a son of the patriotic Godwin. ${ }^{i}$

As soon as Aldred arrived in England he vacated the sce of Worcester, and Wulstan was his successor, whom he eonsecrated at York, Stigand of Canterbury being under snspension. ${ }^{j}$ The king, however, subsequently made Wulstan of Woreester a suffragan of York, ${ }^{k}$ and Aldred, in eonsequence of the porerty of

his way to the archbishopric. Malmesbury lias scarcely one good word for Aldred.

" Wendover and Symeon, ut supra. Bromiton, col. 952. Stubbs, col. 1701. Hoveden, 255. Ingulph, apud Gale, iii., 66 .

i Saxon Chron., 250. Fl. Wigoru., 421. Symeon, col. 190. Uiceto, col. 478. Bromton, col. 952. Stubbs, col. 1701. Knyghton, col. 2336. Malmesbury, apud Savile, 154. IIoveden, ibid, 255. IIigden, apud Giale, i., 282. Wendover, i., 318. Tita S. Wulstani, apud Angl. Sacr., ii., 251. MSS. Tansl., ceccii., 29. Baronii $\Lambda$ m., xi., 337.

$j$ Vita S. Wulstani, apmd Angl. Sacr., ii., 250-1. Chron. de Mailros, 50. Symeols, col. 191. Diceto, col. 478. Bronton, col. 952. Knyghton, col. 2336. Hoveden, 255, b. Wendover, i., 318. Anglia Sacra, 17 1, 511. Fl. Wigorn. (121) says that at the time of enusecration Alibed ronfessed before the king to clain no subjection from Itulstim. Kuyghton, col. 2267.

"In 1062, Edward the Confessor made a grant to Aldred of the church 
the Northern province, which had not set recovered from the incursions of the Danes, appropriated to it twelve of the manors belomging to lis late bishoprie in the South. ${ }^{l}$ For this act, which may be justified, the Worcester historians have not been sparing of their ecinsure, but they seem to forget that, even after his departure into the North, Aldred was a noble benefactor to the church of which he had been deprived." Meamness was not an element in his eharacter. He scattered abroad his treasures with the liberahity of a prince. The York historian is trumpettongued in his praise, and well he might be. Aldred was a great builder and endower. Ho established stalls at Southwell, now for the first time rising into importance, ${ }^{n}$ and at York, according to Leland, he finished a refectory and a dormitory in the Bcderu. He eompleted, also, a similar suite of rooms at Bererley which his predeeessors had begun. ${ }^{\circ}$ 'To the minster in that place he was an especial benefactor. He added to it a presbytery, and rebuilt the whole of the old church towards the west as far as the great tower of Kinsins. He decorated the roof with glowing colours, till it looked like another heaven. He made a pulpit of 'Teutonic work of marvellous construction, and rich in costly metals and ingenions devices. ${ }^{p}$ He direeted the pen of Folcind to describe the virtues of St. John.q The privileges of the sanctuary were extended by him, and he procured for the town the grant of an annual fair. He prevailed upon king Edward to gis to the church the lordship of Leven, and lie converted the seven canomries into prebends, adding an eighth to the number, and giring them fixed endowments and subsidiary vicars.r

Whilit Aldred was thus generous and active, he was not without his share of troubles. The state of the North was anything but satisfactory. The intrigues of his old friend, earl 'Tosti, filled that part of England with tumult and dismay. In 1066 , after II arold had been crowned by Aldred, these disorders were multiplied. Tosti broke into Yorkshire to win for himself

of Wircester on acconnt of the desolate condition of the see of York. The bishop was to be his ricar or deputy. This was evidently a personal fawour to Alfred, and not a grant in perpetnity to his church. 'The deed is in Thomats' Worcester, $A_{1} \mathrm{w}^{\mathrm{x}}$, i.

I Simneon, col. 190-1, 202. Bromton, col. 952. Stubbs, 1702. They were restored by 'Thonds. The Woreester lisiorians, on this acoount, are extremely violent argainst Aldred.

"Thiomas's Worcester, 7:2. Anglia Sacra, i., 474.
"Stubbs, col. 1704, 13. The History of Southwell (276) seems to take it for granted that Aldred was buried there.

- Iel. Coll., iv., 102-3. Stubbs speaks only of a refectory at York.

${ }^{p}$ Stubbs, 1704. Lel. Col., iv., 102-3.

$\checkmark$ Folcard de Vita S. Joan. Bev., apud Acta SS., mense Maio. In the dedication to the archbishop Folcard speaks of Aldred as " Lucerna ardens et lucens in caliginoso loco, Anglorum archipresul."

r Stubbs and Lel., uf supro. 
a kingdon, and bronght with him the king of Norway, the famons Harold Hardrada, with a rast lost of follower's. 'They were met in the fields of $1 \mathrm{~W}$ ater-Fulford, in front of the present palace of the arehbishops of York at Bishopthorpe, by the carls Edwin and Morkere, but the invaders earried the day, and there was a rast slaughter of ecelesiastics as well as soldicrs, for the feelings of the elergy and their spiritual head were with Harold and the Saxons. Harold himself arrived a few days after this, and the rebels were completely ranquished in a battle near Stamford-bridge. Tosti, the brother of the rictor, was slain in spite of his great personal bravery. Hardrada never returned to his home in the wild North. The treasmres which he had won in the far Last were lost to him. The famous Lauderda was taken on the field, and the eonqueror Harold, overjored at his snceess, went to celebrate his trimmph in high state at York.

There soon eame to him in that eity the tidings of another adrent which sileneed at once the revel and the song. William the Norman had anived in England. The spoils of the Norsemen were left behind in the charge of archbishop Aldred, and Harold hastened into the Sonth with all the strength that he could gather together to oppose the new invader. The results of that disastrons field are too well known to be repented. The independenee of the Saxon chmeh, the freedon of a noble people, the glories of the honse of Godwin, were obliterated, when the bravest of the Anglo-Saxon prinees died at IIastings.s

The position of Aldred was now a perilous one, but he was fully equal to the emergency. His eonnection with Ilarold was well known. He was still holding the spoils which had been won at Stamford-bridge. Would the Saxon primate throw limself and the ehurch into the arms of the victorions invaders? He could not surrender his patriotism at onee, however neeessity might demand the sacrifice. We are told that it was the wish of the archbishop and the chief men of London to place the crown upon the head of Edgar Atheling, the grandson of Edmund Ironside, for whose family he had toiled and laboured in the days of Edward the Confessor. But the seheme was impracticable, and the temper of the Norman conqueror would brook no doubt or delay. Aldred's opposition nirght destroy the Anglo-Saxon ehureh, of which he was the spokesman and the chief ornament. He was not ready to precipitate such an end as that. With the good judgment which seems to have

s Saxon Chron., 260-3. Symeon, col. 194. Ailred, col. 40\%. Íiceto, col. 479. Bromton, col. 958. Kuyshton, col, 2339. Wendover, i., 327. Hoveden, 257. Master Wace, his Chronicle,
134-5. Giaimar, ed. Petrie, 87.

t Saxon Chron., 263. Fl. $1 \mathrm{~T}$ igorn., 430. Srmeon, col. 195. Diecto, col. 480. Bromton, col. 961. Knyghton, col, 23.13. Hoveden, apud Savile, 257 b. 
enicled him at every crisis the archbishop gave way." He met the confueror at Berkhamstead, on his way to London, and took the oaths of allegiance. ${ }^{v}$ But he did more than this. On niid-winter day, 1066, in the absenee of Stigand of Canterbury, who was not permitted to officiate, Aldred erowned the new monarch in the abbey church at Westminster. ${ }^{w}$

"This noble due Wy ylam hym let crownyng kyng,

At London, a uyde wynter day, noblyche thorw alle thyng,

Of crelrebyssop, of Euerwyk, Aldred was hys name.",x

Fut before the prekate would eelebrate that rite he made the conqueror pledge his word, in the most solemn manner, that he wonli reverence the laws, and pay due respect to the rights and liberties of the eluurch. ${ }^{y}$ Vain liope! In a few years the old Saxon fabrie was rent in pices, and a new race of bishops occupicd the ehurches which had been reared by the picty of the native princes and the now despised nobles.

William kept his word to Allred as far as he was able to observe a promise. He was wise cnough to conciliate the favour of so influential a prelate; and Aldred, also, saw the necessity of being a conrtier. He was frequently with the king. $z$ In 1008 he consecrated the comntess Matilda, queen. ${ }^{a}$ Aldred was treated by the monareh with uniform respect, and, in the end, lie and the bishops of Worcester and Rochester were the only native prelates who were allowed to retain their sees. ${ }^{b}$ The archbishop, however, was indehted for the respect which was shewn him to his own firmmess and independence. He was a fearless champion of the rights of the ehureh. On one oceasion when Urse, the sheriff of Worcester, had infringed upon the sanetuary of the ranons by building a eastle or residence on the south side of their church, Aldred excommunicated him, and laid his pos-

"IIemingford, anmel Gale, ii., 437. Wim. Neubrig., i., 15. Bromton, col. 962 .

"Saxon Chron., 26 \%. IIoveden, 258. Symeon, col. 195. Diceto, col. 450 .

"Saxom Chrom., 261. Fl. Wirorn., 131. Chrm. Mailros, 55. Chrou. Potrib., 5. Ord. Vitalis, apud Du(hesne, 503. Alured. Bev., 127. Symeon, exl. 195. Iniceto, col. 480. Bromton, col. 962. Stubls, col. 1702. kingshton, col. 23 13. Malnesbury, apud Savile, 58. IHuntingdon, ibid., 211. lloverten, ibiel., 258. Hist. filiens., alut Gale, i., 515. Wrendover", i., 333. Mattlew l'aris, t. Rudborne, ilnul ITlarton, i., 218.

s lishert of Ciloncester, ii., 367 .

y Joreden, simmon, Stubjs, Alured.
Bev., ut supra. Malmesbury, $154 b$. Huntingdon, $210 \mathrm{~b}$. Gesta Willelmi ducis, apud Recueil des Historiens des Ganles et de la Franee, xi., 100.

" Maseres, 166. I find him witnessing royal charters. Gunton's Peterbro', 111-2. Mistoire de l'abbaye de St. Denys, appendix, p. 88. Smith's Beda, ay $\mathrm{y}^{\mathrm{x}}$, 782. Hist. Mon. de Abingdon, i., 451 , etc. Wanley, 299 , etc. There are many deeds witnessed by him in Kemble's Codex Diplom., vol. iv.

a Saxon Chron., 268. Maseres, 212. Hoveden, 258. Symeon, col. 197. Diceto, col. 482. Bromton, col. 953. Stubbs, col. 1702. Knyghton, col. 2314.

${ }^{b}$ Hist. Mon. de Aloingdon, i., 490. Hapes, De Nugis Curialium, 224. 
terity under a eurse which is said to have been marrellously fintfilled. ${ }^{c}$ On another occasion, at lork, some of his own carts, whilst on their way to his farms, were seized by the king's officers, and all compensation and justice were contemptnously refused. The indignant archbishop hastened up to London wit $\mathrm{l}_{1}$ that decision and encrgy which he conld always exhibit. The king was in the abbey of Westminster when he foumd him. Aldred refused him the customary salutation, and stood fearIessly before him with his pastoral staff" in his hand. "Did not I give thee the crown and bless thee," he said, "when thon eamest from another country, and didst win this kingrom which the just vengeance of the Lord surrendered to the destroyer? Now thon hast broken the oath that thon didst take, and thon shalt have a curse, and not a blessing." Stricken with a terror which he rarely felt, the monareh threw himself at Aldred's feet, deprecating the expected malediction. It canne not. The story of the wrong was told; justice was at once done; and the benediction flowed from the lips of the intrepid prelate which had been opened to condenm. ${ }^{d}$

The lesson, however, was only partially remembered, and Aldred must have watched with sorrow and dismay the progress of the king. A conqueror is too frequently the servant of his followers, and so it was with William. He, as Fuller says, soon began to make "the Normans his darlings, and the English his drudges."e From church and state old faces gradually disappeared. Discontent increased to be repressed by force. "There was soon an iron domination. In 1069, the two sons of Sweyn king of Denmark, Harold and Cannte, landed in the Humber to make an attempt on England. $f$ The whole North welcomed them with open arms. Aldred had striven to make peace, and there was no peace. All his endeavours had been fruitless. His labours were unrequited, and those for whom he had toiled - the comntry and the church which he had lover so well-were on the brink of ruin. The heart of the afflicted patriot was broken, and his last prayer was that he might be spared the sight of the misery which he anticipated. IIe died on the 11 th of September, 1069, the day of SS. Protus and Hyacinthus, and his remains were interred in the minster at York.g

- Malmeshury, apud Savile, $\mathbf{1 5 4 b .}$ Thomas' Worcester, 72. The curse took the form of a rhyme.

\section{"Hightest thon Urse?} Have thou God's curse!"

d Stubbs, col. 1703-4. Malmesbury, $154 b$, tells the story in a slightly different form. Wm. Neubrig, i., 16. Baronii, Ann., xi., 492.
- Church Ilistory, book iii., 2.

$f$ symeon, col. 198. Hovedell, $258 b$.

g Saxon Chron., 270. Wl. Wigorn., 433. ('hron. rle Mailros, 55. Alured. Bev., 128. Hoveden, apud Savile, $258 b$. Thos. Wikes, apud Gale, ii., 22. Symeon, col. 198 . I Iiceto, col. 482. Bromton, col. 965. Stubbs, col. 1708. Kuyghton, col. 2344. 
Aldred was indeed removed "from the evil to come." In a later age, the ruin that he saw around him and the desecration of Ciod's honse hastened the end of bishop Hall, and, as his pancervist Duport observes,

"Pati hae nescins hine abivit nltro."

Aldeed was happily delivered from that sight. Within a little while after his decease the eity of lork, eaptured and re-captured, was in ashes; the minster with its treasures-its mumiments, and the glorious library which had been the pride of Saxon England-all were surrendered to the flames. The archiepiscopal lands were wasted. ${ }^{h}$ Beverley was the only place in lorkshipe that escaped. ${ }^{i}$ The rengeance of the conqueror suffered scarecly a simgle homestead to remain between the Humber and the 'Tees. The last of the Saxom primates of York was seancely haid in the tomb before the church in which he rested was sacked and bumed.j

Thamas of Baurux, ${ }^{k}$ was the suceessor of Aldred, and with him there commences a new dynasty of archbishops. He was born at Bayeux, a little town in Normandy. The names of his parents weje Osbert and Muriel.' His father was a priest, "in and simlpson, afterwards bishop of Worcester, was his brother." From his carliest years Thomas was distinguished for the rlegance of his taste and his ardour in the pursuit of literary distinction. The schools in his own comtry were insufficient to satisty his eravings after knowledge, and he sought for additional simplies in Germany and Spain. When he returned to Bayeux, his learniug attracted the attention and gained for him the intimary of Odo the bishop of that place, who was a brother of the Congueror of England and a person of commanding influence. Odo is said to have taken Thomas and Sampson under his protection, and to have sent them to study at Liege and other places. Thomas became the favourite of the

\footnotetext{
i Ellik' Introduction to Domesday, i., 319 .

Miracles of St. Jolm of Beverley, a) Ald Acta ss., mense Mrio, 17 .

;A vivid accomnt in Symeon, col. 199. Saxon Chron., 271. Bromton, col. 966. Kinyhton, col. 2341. Wendroser, i., 337. Symeon, Hist. Ecel. 1)umelm., 183. Hoveden, apud Savile, g5sb. Malmesbury, ilinl., 15tb. Ord.
}

Vitalis, ajud Duchesne, 515.

${ }^{k}$ He is also called 'Thomas Major, and Thomas the Norman.

$l$ Liber Vita Dunelm., ed. Surtees Soc., 139-40.

"n Bromton, col. 969.

$n$ Ric. of Ilexham, col. 303, says that 'Thomas was "ex nobilissima prosapia oriurdus, vir magnificus." 
prelate, and was made the treasurer of the church of Bayeux. When Odo crossed the chamnel to visit his royal brother Thomas accompanied him, and had soon the honour of becoming one of the king's chaplains. ${ }^{\circ}$

In the year 1070 William shewed his regard for Thomas by raising him to the see of York. This was done at Windsor it the feast of Pentecost.p $A$ difficulty at onee arose about his consecration. In the ordinary course of things that ceremony ought to have been performed by the archbishop of Canterbury, but at this time there was no Southern primate, and, in the North, the see of York, by an accident, had not a sufficient number of suffragans to officiate." Thomas therefore, most provokingly, was obliged to wait until Lanfranc was made archbishop in the month of August. He then went to him to be consecrated. This Lanfrauc refused to do mless he would first profess obedience and subjection to Canterbury. Thomas at once refused, and stated his case to the king, who sent him back to Lanfranc with an order that the rite should be performed without the condition. That prelate then went to William, and defended the course which he had adopted. He said that it was necessary for the safety of the comntry that England should have one primate as well as one sovercign. An archbishop of York might easily side with some of the foreigners who visited his dioeese, and set up a new monarch, thus splitting the lingdom into two. ${ }^{r}$ The argument was a plausible one, and had its due weight with the Norman courtiers, who forgot that Thomas was one of their own countrymen, and that there was no reason to doubt his loyalty. It convinced the king, who tried in vain to alter the determination of Thomas. What soft words were unable to produce, threats at last effected. William told him that if he persisted he would bring down upon himself his heaviest displeasure, and that all his kindred should be banished from Normandy and England. After this, Thomas went to

- Stubbs, col. 1705. Ord. Titalis, apud Duchesne, 516,665. Dugd., Bar., i., 24. 'Thomas' Worcester, 103.

p Fl. Wigorn, 435. Chron. Petrib., 55. Hoveden, 259 b. Symeon, col. 202. Diceto, col. 483. Bromton, col. 968. Stubbs, col. 1706. Knygliton, col. 2345.

$q$ Stubbs, 1706. The information which this writer gives is derived from the life of Thomas by Hugh Sotevagina, the precentor and archdeacon of York, which is preserved in the Registrnm Magnum Album in the office of the dean and chapter of York. Full use has been made of it, especially in this account of the controversy with Lanfranc.

r "Porro utile esse ad resni interritatem et firmitatem conservandam, ni Britannia tota mi guasi primati subderctur. Alioquin contingere posse vel suovel successorum tempore ut de lacis seu Norensibus siviscotis qui liboracum navisio venientes rosnmm infestare solebant, unus ab Eboracensi arelicpiscopo et a povincice illius indigenis mobilibus et perfidis rex rearetur, et sic regnum turbatum seinderetur' (Hugh). Möhler, in his Life of Anselm (ed. 181:, pp. 112-13) commends this policy. 
Canterbury prepared to submit. "Wilt thon be subject to the chmeh of ('anterbury, to mo and ny successors?" was launfinuc's question. "Wo thee," was the reply, "but not to thy surecssors." The tears rushed from the eyes of the petitimer when he thus spoke, and no farther would he go. Lanfrane was not too exacting, and the wished-for consecration took placer.

This occurred in 10\%0, and in the following year Thomas and Lanfianc went to Rome together to obtain the pall. Remigius, the bishop of Dorehester, accompanied them." The three predates excited the admiration of the Romans by their ready wit, their munificence and their learning." Whilst they were in that great city 'Thomas mooted before the pope the question of the subjection of his chureh to Canterbury. He raised at the same time another point of interest. He claimed for his strecessors the supremaey orer the sees of Dorchester (Lincoln), Worcester, and Lichficld. The comnection between York and Worcester has been already mentioned. The other two places were in the old prorince of Mercia, and had, therefore, been occasionally dependent upon Northumbria. Lanfranc was taken by simprise, but he soon recovered himself. He met the first part of 'Thomas's claim by the somewhat unfair assertion that (iregory wished lork to be the equal of London, but not of Cantcrbury, which had become the seat of the primacy. Lanfranc then made a terrible comnterstroke, and turned the tables most completely upon Thomas and Remigius. $\mathrm{He}$ charged them with being uncanonically elected; Thomas, because he was the son of a priest, and Remigins, for having been guilty of simony. Nlexander, who was a great admirer of Lamfine, flecided atgainst them, and took from each his pastoral staff' and ring. These he subsequently restored at the request of Lanfiane, who had no wish to injure his companions. Upon the main point in the dispute, the question of subjection, Alexandcrery cautiously refrainch from explessing an opinion, but he referred the settlement of it to a national synod in England. The controrersy about Woreester was to be terminated by the decision of Lanfranc himself." The three

- Ianfranci Opp., ed. 16.18, 11-12. Bromton, col. 969. Stublss, col. 1706.

t Fl. Vigorn., 435. Chron. Mailros, 56. Malmesbrury, ajud Savile, 117. Symeon, col. 203. Jiceto, col. 483. Bromton, col. 969. (iervase, col. 1653. Fnyphton, col. 2343. Baronii Arn., ix. 512. The Saxon Chron. (273), says that he was consecrated on his return from Rome after making the profession. There is a long accoint of the controversy between York and Canterbury, on the question of the profession, in the Anglia Sacra, i., 65-77.

"Chron. Mailros, 56. Fl. Wigorn., 437. Horedeu, 260. Symeon, col. 203. Diceto, col. 483. Knyghton, 2348. MSS. Lansdowne, 402, col. 29.

v Ord. Vitalis, apud Duchesne, 248.

* Eadmer, IIist. Nov., apud Anselmi Opp., 30. Diceto, col. 484. Bromton, col. 970 . 
prelates now returned to England, liaving halted for a while at Evrenx, where they were the guests of Gislebert, the bishop of that place..$^{x}$

When they arrived in England, a synod was held in the presence of the king, at which the controversy between Canterbury and York was thoroughly considered. 'The result was favourable to Lanfiane and his church. That prelate, who harl far more eloquenee and ready wit than his opponent, drew up his case in the most elaborate manner, and the listeners took his part. The Humber was made the Southem boundary of the diocese of York. The Northern archbishops were to swear allegiance to Canterbury, and to appear with their suffragans at all the councils, ete., within that provinee to which they should be bidden. By a subsequent order, made in 1075, they were to sit at the right hand of the primate.y 'The archbishops of Canterbury were to be consecrated at home by their brethren from the North, who were to come to the same place to receive the same rite. All this was against Thomas and his see; indeed, he seems to have made but little opposition. IIe was spared, however, at the king's request, the shame of taking the oath of obedience. He simply made his profession in writing, and nothing farther seems to have been required of him.z Lanfiane was overjoyed at his success. He announced it to the pope in a lengthy and jubilant epistle. ${ }^{n}$ It was communicated, also, to a friend of his at Rome who was rapidly rising into importance, the energetic and fearless Hildebrand. ${ }^{b}$

The controversy between York and Worcester must next be considered. 'The relations between the two sees were of a most peculiar kind. Oswald and his two immediate successors held the Southern diocese conjointly with that of lork, partly no doubt for influenee, and partly to eke ont their archiepiscopal ineome. Edward the Confessor made a grant of the see of Worcester to Aldred for his life, with power to nominate a deputy, and in right of his authority orer that diocese Aldred

* Gallia Christiana, xi., 572.

y Gervase, col. 1654. Malmesbury, 66 b. Labbe, Cone, x., 347-8. Wilkins, i., 363.

= Lanfranci Opp., 12, 301. Eadmer, IIist. Nov., apud Anselmi Opl., 30. Mabillon, Acta SS. ord. S. B., sace. vi., ii., 651. Anglia sacra, i., 1, 5, 253. Malmesbury, apud Savile, 65-6, 111, 118. Diceto, col. 48t-5. Bromton, col. 970-2. Gervase, col. 1653. Knyshton, col. 2348-9. Mat. Paris, 6-7. Capgrave, 130. Baronii Ann., xi., 52.2. Labbe, Conc., ix., 1211.

"Labbe, Conc., ix., col. $1213 . \quad$ Wil- kins, i., 326.

In Stubbs (1706-7), a letter from Urban II. to Thomas is alluded to, referring to the profession. It is given at lensth by Hugh the Chantor. 'The pope rebukes Thomas sererely for making the profesion contrary to Greugres's decree, and orders him to explain his conduret aither to himself or to his legate. IIe speaks as if the profession had only recently been mole, and he had just heard of it. There is a chronolosical difliculiy in this, as Urban dicl not become pope till 1088.

"Lanfranci Opl. 30\%. 
took away fiom it twelve rills, and appropriated them to York. I. that arrhbishop had only a life-interest in the see, it is clear thit these estates onght to have been restored at lis decease. When he died, however, they passed with his other estates into the hands of the king. Wulstan, the bishop of Worcester, was not disposed to wive them up. He desired that they should be restored at the comucil of Winchester at Easter, 1070, but as the archbishoprie of York was then vacant, the consideration of the question was deferrer. ${ }^{c}$ It will be remembered, that when Thonas went to Rome for the pall, he claimed the bishop of Worecster as a suffragan. Thi question was left by the pope to the determination of Lanfranc. It was settled in a synod which was held in 10\%2. Odo, bishop of Bayeux, was on the side of Thomis, but Lanfranc decided against him. The twelve vills wcre to be given up, and Worcester was for the future to be subordinated to Canterbury, and not to York. ${ }^{d}$ In this judgment, Thomas seens to hare quietly acquiesced. Wulstan and he became friends, and he requested him to pay him a visit in the North.e

We now eome to the dispute between Thomas and Remigius with reference to Lindsey. It will be recollected that Paulimus and Blecea erected the first church in that district, and that Sidnacester, or Stow, was under the espeeial care of the archbishops of York, who chamed and seem to have exereised the right of controlling the spiritual affairs of that part of England previous to the Conquest. In 1067, Remigius, a Norman, was arlvanced to the see of Dorchester. He seems to have been soon clissatisfied with the seat of the episcopate, and was desirons of transferring it to Lincoln. This project would meet with the strennous opposition of the archbishops of York. In loil, when 'Thomas and Lanfrane went to Rome Remigius arermpaniod them, and the guestion about Lindsey was mooted. Alexander referred it to the decision of a synod at home. Imong the decrees of that assembly, which was held in 1072 , there is no spercial reference to Lindsey, but the resolution that the $11 \mathrm{mmber}$ should be the boundary of the dioeese of York on the South was practically a settlement of the controversy. 'Thomas, however, by no means regarded it in that light. About

c Mat. Paris, 17. Hoveden, 2597. Sirmeon, col. 202. I)iceto, col. 483. liromtou, col. 96s. Stubbs, col. 1709 , who says that Thomas enjoyed the twelve vills for a while of the king's stift, but that William afterwards took them :Lway " nolimine Lanfranci."

"Vita S. Wulstani, apud Angl. Sacr., 3i., 25. Fin. Wigorm., 137. Symeon, col. 203. Diceto, col. 483. Bromton, col. 976. Hoveden, 260. Mat. Paris, 18. Baronii Amn., xi., 532. Labbe, Conc. ix., eol. 1204. The date of this spnod is variously given between 1070 and 1072 .

- Malmesbury, apud Savile, 66 b. Wendover, i., 374. 
1078 Remigins had his see formally transferred to Lincoln, and began to erect a eathedral on that "sovereign hill." It was finished in 1092, but Thomas refused to dedieate it. Ipou this Remigius sought the assistance of the king, and with the aid, as it is said, of a bribe, prevailed upon him to smmmon a large number of the English bishops to officiate on the occasion. This arrangement, howerer, was broken througl. The time was fixed, but two days before the ecremony was to take place Remigius died. Robert Bloet, the chancellor of England, was his suceessor. Thomas refused to eonsecrate him, and when in the following year he performed that rite for Ansehn, the new arehbishop of Canterbury, he forbade him to lay his hands on Bloet. Thomas had no objection to his being made bishop of Dorehester, but not of Lincoln, becanse he elaimed that place and a great part of Lindsey for his own see. Bloet was standing by when 'Thomas spoke to Anselm, and he took a surer' course than argument to gain his end. He is said to have paid a large sum of money to William Rufus to enable him to carry his point. $f$ The king, in spite of the strenuous opposition of Thomas, brought the dispute to a termination. Lincoln and Lindsey were taken away from Lork, and were transferred to Canterbury, and, in their room, the Northern primate reecived the abbey of Selby and the monastery of St. Oswald at Giloucester. ${ }^{g}$

$f$ Various sums are stated by the chroniclers, from $£ 500$ to $£ 5000$.

$g$ There is an account of this controversy in Fl. Wigorn., 458. Symeon, col. 217. Diceto, col. 490. Bromton, col. 953, 988. Stubbs, col. 1711. Knyghton, col. 236t. Malmesbury, aprid Savile, 165 b. Huntingdon, ibici., 213. Hoveden, 265 b. Hat. Paris, 13-15. Vita S. Remigii, apud Mabillon Acta SS. ord. S.B., wec. vi., ii., 766, and Anglia Sacra, ii., 410 , ete. Dugd. Mon., vi., 1269-70.

William's deed arranging the dispute is in Dugdale's Mon., vii., 1177. 'The confirmation by pope Paschal is in the Reg. Magnum Mbum at York, fol. 42. The king's charter is so curions that I give it in extenso. It is taken lrom the Register of Archbislop Creenficld, i., 15.

\section{"Carta Regis Willeum.}

"In nomine Patris et Filii, et S,iiritus Sancti, amen. Stummi Patric fuit consilium ut sanctam civitatem suam, celestem soilicet Jirusalem, guw superbia diaboli divisa erat, morte dilectissimi Filii Sui intercedente, redinte- gretur, et per redemproionem generis humani angelica dampua reparet; hac consideracione, eso Willehnus Dei gratia rex Anglorum, Willelmi regis tilius qui Edwardo regi hereditario jure sne. cessit, videns ecclesiam Anglormm ex parte divisam et discordantem, resartire concupimus gnod male scissmm fueral, et ad unitatem verae caritati: revocare ynod din indiscussum sub discordia manserat. Redemi igitur de meis propriis possessionibus calumpriam ynam habet Elooracensis ecelesia et 'Thomas ejusclem ceclesia arehicpiscojus suner Lincolnia et super Lindissin et super mansiones Ston et Ludim, et redi fro cis cecesia Saneti Petri Eboracensis jure perpetno gossidendas abbateiam saneti fiermani de Salehy ef eedesian Saneti Oswaldi de Glocestria, cum mulbus ad eas jure pertinentibus, of ita derli arehi-

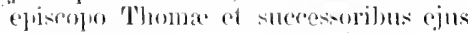
al,bariam Sincti (ierunatui, sient archi-

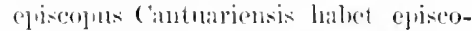

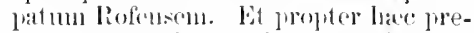
dicta benedicia benigne dimisit et sratanter Thomas arehicjiscopens in sternum, consenciente clero ejns, pre- 
It may perhaps be thought fiom what has been said that 'Thomas had an angry and a contentious spirit. It was not so. Those were days in which great changes were being effected in the English church; new landmarks were being laid down, and it was necessary for every prelate to be on the alert in the defence of his diocese. Violence and encroachment were too frequeutly triumphant. If Thomas had been better acquainted with English preeedents and customs he would probably have been more suecessful than he was. He tried boldly and honestly to do his duty, and lie eannot be blamed for doing so. When he was defeated he cherished no ill-will against his opjonents. Wulstan and he became good friends, and it was the same with Lanfrane. Thomas had promised to obey him as long as he lived, and he kept his word. They corresponded together. Thomas requested his brother-arehbishop to allow two of "his suflragans to consecrate for him a bishop of the Orkneys, and it was done. In 1075 he was present at the couneil at London $:^{h}$ in 1089 he was at Canterbury when the remains of Lanfraue were laid in the tomb. ${ }^{i}$ He would fully appreciate the virtues and the learning of that great and good man.

The see of Canterbu'y was vacant after the death of Lanfranc for several years, and during this time Thomas officiated in the Southern province when his services were required. $\mathrm{He}$ consecrated the bishops of Norwich, Chichester, and Bangor. ${ }^{j}$ In 1093 he was requested to do the same thing for Anselm, the archbishop-elect. Thomas went up from York, accompanied by the dean and the dignitaries of his eathedral, and there was a goodly array of bishops to join in the imposing ceremonial. The officiating prelates were in their robes, and Anselm's petition was read, in which he solicited consceration as primate of all kngland. 'This was too much for 'Thomas, who had subjected himself to Lanfrane during his life, but not to his sueressor's. Ho was now free to aet as he chose. He retired to the vestry with the officers of his own cathedral, and began to unrobe himself. The Southern bishops were excited and alarmed; they followed the Northern primate, and Walkeline of Winchester threw himself at his feet and implored him to return. He would not. "There are two metropolitans in Britain," he said, "and one of them can only be master at the expense of the other. I shall eonsecrate no one to rule unjustly orer myself." 'Thomas was at length the master of the

dictan calumpniam, in presencia mea et episcoporum et procertum neorum, mului et Roberto episcopo Lyticoln et successoribus cjus. Hujus antem calumpniæ redempcionem feci ego gratia ejuslem Roberti episcopi quia cancel- larius meus extiterat."

${ }^{3}$ Lanfranci Opp., 305-6. Vita ejusdem, ibid., 13-14. Wilkins, i., 362. 369 .

'Gervase, col. 1655. Wilkins, i., i Subbs, col. 1707. 
position, and he knew it. This was the counter-stroke of the scene in the synod of $10 \% 2$. The bishops were very urgent and importumate: they promised largely. The petition was altered, and the words, metropolitan of Canterbury, were snbstituted for primate of England, and then the prelates retnrned into the ehurch, and the eeremony was completed. ${ }^{k}$ The adrantige which the see of Canterbury had gained twenty years before was now lost. Anselm, indeed, did not give the question up, but, in all probability, the troubles in which he was involved and his unpopularity with the ling caused the matter to be shelved.

When William Rufus was killed Anselm was in exile, and it devolved, therefore, upon Thomas, according to ancient custom, to erown the new king. Thomas was at Ripon when the news was brought to him, and he hastened up to London to perform his office. He was too late, for Henry, fearful of delay, had availed himself of the services of some of the Southern bishops. Thomas was greatly amoyed, but the king and the prelates acquainted him with the reason for the haste, and begged him to overlook what had been done. He was easily appeased, and having paid his homage to the new sovereign, the weak and aged archbishop was allowed to retum into the North to die. ${ }^{l}$ I must now speak of his good works in the diocese of York.

I have elsewhere alluded to the wretehed state of the North at the death of Aldred. All the fury of the Conqueror and his opponents had fallen upon it, and the result was indeed appalling. There was scarcely a village or a homestead between the Tees and York which escaped from the fire or the plunderers. To add to the horrors of the time, a famine slew the greater part of those whom the sword had spared." It was when all this wretchedness was at its height that Thomas reached the diocese of which he was to be the spiritual head. The prospect was not a pleasant one. 'The bishopric of Durham was vaeant, and the head of that see was his only sufframan in England. Upon the Scottish prelates no reliance conld at any time be

${ }_{k}$ Eadmer, Hist. Nov., apud Anselmi Opp., 37. Symeon, col. 219. Jiceto, col. 491. Gervase, col. 1658. Stubbs, col. 1707. Wendover, i., 365 . Hoveden, 266.

Sir Thomas Grey also says, “ En le temps William le Conquerour comensa le debate entre lez ercevesrnes de Cantorbirs et Euerwik pur le porter de lour. croitz en autry dyocys" (Scala Chron., 2).

$i$ This fact is mentioned for the first time by Hngl the Chantor. The elironiclers givea different acconnt. Malmesbury and several others say that T'Tomas. crowned Henry. The chronicle of P'eterbro' informs us that Manrice, bishop of London, consecrated the kims, but that he was crowned by 'Thomas (69). ITalsingham, in his I podigma Nenstrice (Camden, 413), silys that both ofliciatel.

"'There is a sad accomnt in symeon, col. 199, and Siublss, col. 1708 . 
placel. There was no one to consecrate him when he was clected to the archlishopric! The greater part of the monastries also had been destroved or injured, and Durham and Bererley were almost the only two which had escaped. The light of religion in the North had been almost quenched! But 'Thomas was an energetic man, and he was not to be easily appalled. With the Norman love of labour and organization, he set himself manfully to work to reconstruct and restore. He began rery properly with the prineipal eity in his provinee. 'The minster at lork had been gutted and set on fire, although many of the old walls were probably still standing; the ornamonts and fumiture had of comse disappeared, and the munimonts and library had been given to the flames. Thomas rebuilt and renovated the cathedral as far as he could, putting on a new roof, and proeurng new service-books and decorations." IIe restored the old endowments, and added others in the shape of estates and ehurches to sueh an extent that Nahmesbury eharges him with impoverishing his see ; he eontributed from lis private pursc towards the necessities of the minster and its inmates, and repaired the dormitory and refectory ; he made still greater changes in the constitution of the aithedral,-lie eompletely remodelled it. Up to this time the number of the eanons had only been seren, - the old Culdee mmmler, and those at York still retained that peculiar name. Of these, one liad becn the abbas or superior, another the magister scholarmm.p and a third the custos civitatis. They had all lived together upon a common fund. Of these seven three only were at lork when Thomas arriver ; the rest were either dead or in some other place. The survirors were now reealled and reinstated nuder a different régime, althongh they were still seculats. A rlean took the place of the abbas, the magister schularmm becante the chancellor, and the treasurer was the

"There is some dombt as to the extent of thrise restorations. "Perpulcram ecclesian construxit, clericos multipliciter ditavit" (Bromtom, col. sti.t. Kuyshton, col. 235.5). "Ecclesiam a fundamentis inchoatam consummavit" (Nalmesbnry, $155 b$ ). "Eccleatie recooperta, et juxta possibilitatem stan restructe, eanonieos restituit" (Stubls, (ool. 1708). Sce "The Architeretural Hi-tory of Fork Cathedral," by l'rofessor irillis, p,p. 11-15. Ur. Willis is of opinion that Thomas first renovated the Saxon churel, and aftcrward crected a new cathedial, or, at all cuents, the greater liart of one. (f. Lel. Coll., ii., 337.
In 1075 an inrading Danish force went to Tork, broke into St. Peter's minster, and took away much treasure (Saxon Chron., 282).

" Halmesbury, apud Savile, 155 b.

p This oflice seems to have fallen into desnetude, and was revived by Thomas befure he proceeded to re-arrange the minster. Stubbs, whilst eleseribing the reation of the dean, treasurer, and precentor", says that Thomas "magistrum scolarum antea statuerat."

I hope to speak at greater length about the origin and duties of these officers in my account of the diguitaries of the cathedral. 
custos civitatis : a chantor or precentor was added, and the number of the canons was increased. The diocese was mapped out, and placed under the eharge of archdeacons. Those officers, indeed, had been for some time in existence, as they are mentioned in the Laws of the Nortlumbrian Priests, buit their duties and their districts seem to have been at this time properly defined. The common property of the minster wass also broken up and divided, and to each office there was assigned a separate endowment. This was done to allow each eanon to attend to and improve his own allotted portion, and due provision was at the same time marle for any other stalls which might subsequently be established. ${ }^{q}$ Thomas was also a benefactor to the minster in another way. He prevailed upon the Conqueror to increase the endowments of the hospital of St. Peter, which was better known in after years as that of St. Leonard. ${ }^{r}$

There were at this time three other collegiate churches within the diocese of York,-Beverley, Southwell, and Ripon, all of which were held by sccular canons. All the three liad been remodelled within the last century, but so firmly rooted in the North had the secular system become that in each instance it was perpetuated. Aldred was the first person who placed prebendaries at Sonthwell, and he is said to have established them at Ripon.s Alfric made alterations in the constitution of the chureh of Beverley as it had been arranged by Athelstan. He found there seven canons and seren clcrks; he added to them an eighth canon, a precentor, a chancellor, and a sacrist. This was the state of things at Bererley when Thomas came into the North. In course of time some complaints reached his ears about the management of the property of that ehurch, and he met the difficulty by appointing a provost. The first officer who bore that title was his own nephew and namesake, who was afterwards archbishop. ${ }^{t}$

The monastie system in the North was at this time literally extinct. The Danes had done their work well, and many of the

? Stublse, col. 1708-9.

r MSS., Cotton, Nero, D iii., 5 a. St. Leonard's Chartulary, a magnificent book. The writer fixes this grant at Pentecost, 1069, - a manifest error.

The arehiepiseolal seal of Thomas (not the matrix) is in existence. After him the series is nearly complete, and may be found among the arehives of the dean and chapter of Durham.

- I have nowhere seen the authority for this statement, which has been fiequently made. There werc eanons at
Ripon at the time of the Domeslay. Thomas is supposed to have besun the new minster at Rijon (Walbran's Ripon, 31). In Leland (Coll., ii., 337) it is said that Aldred fomded stalls at Ripon, York, and Beverley.

t Lar. Coll., iv., 103. Tugel. Mon. vi., 1308. Scanm's Beverlae, 522. Oliver's Beverley, 385. 'This alpointment was too good a one to verify the oll saying will regard to bishojs, " $\mathrm{Fi}$ lios Jeus abstulit, Sathanas dedit nelotes !" 
carly religions houses had totally disappeared; others were to be recognized only by eharred beams and tottering walls. The sccular's were the master's everywhere, and they were few in number and poorly endowed. Durham was the only place where any semblance of discipline was retained, and yet that famons nonastery was at that time in the hands of secular canons, who, save in one point, had abandoned altogether the Benedictine rule. This was the state of things in the North when, in 10\%4, three wandering Benedictines from Winchcombe and Evesham made a pilgrimage into that district to risit the holy shrines of which they had read in the history of Beda: a single ass carrich everything that they possessed. A change had come orer the country sinee the days of the great clronicler. Jarrow and Wearmonth were in ruins, and there were none to tell them there of Benedict or Beda; Whitby and Lastingham were neglected and destroyed. It is to those three faithful and energetic men that the North of England is indebted for the re-establishment of monastieism. They took up their abode at Monkehester, or Neweastle-npon-Tyne, and, after many adrentures, became at last the fomders, as we may eall them, of three famous Benedictine houses,-Durham, Whitlyy, and St. Mary's, York." With each of these establishments archbishop Thomas was more or less eoncerned. Whitby and St. Mary's were in the diocese of York, and the monks conld not be located there withont his support and consent. He looked indeed on St. Mary's for some time with a jealons eye, perhaps on accomnt of its propinquity to his own minster, ${ }^{p}$ but lie subscquently became its fricud. "He was intimately connected with the church of Durham and its bishops. He consecrated St. Carileph and Flambard, and arlministered the last offices to the former." He must have observed with pleasure the activity and the munifiecnee of St. Carileph when he replaced the sceulai canous of Durham by a colony of Benedictines, and reatred a noble cathedral upon that grey rock which overhanes the Wear. He permitted the monks of that place to powess their lands in Yorkshire free from any payment or corlesiastical exaction. ${ }^{x}$ There is a curious story connected

"symeon, eol. 199, 206, 210. Hist. Erel. Dumelne, 198, ede. Bromton, eol. 973. Malmesbury, apud Savile, 15) b. Mabilon, Lun. P.en., v., 81, 257. Tel. ('oll., ii., 382. J)rake's Eboramm, 578-9, ex IItst. Fundationis S. H. Ebor.

IThen Velby abber was fommed "per fotam Eluraci Sirian, excepua Dunelmensi ronerceratione, nee monachus nec momachorm locus aliquis in illis rlie. bus facile valuit reperiri" (Hist. Mon. Seleb., apud Labbe, Nov. Bibl., i., 601). Thomas was a benefactor to Selby.

" liake, ut supra, 579.

wl. Wigorn, 446. Symeon, col. 221. Stubbs, col. 1709. HIoveden, 263,268. Syneom, Hist. Eccl. Dunelm., 218, 245, 255. Lel. Coll., ii., 384. Carileph had been comnected with Bayeux.

$r$ Ilist. Dunelm. Scr. Tres, ed. Surtees bre., appendix, xi. 
with his charter of exemption. The archbishop had been ill for two years, and was a martyr to attacks of ferer. "Physicians were in vain." A vision warned him to seek for relicf in Durham, at St. Cuthbert's tomb. Me went and passech the night there in great distress and pain, as might reasonably be expected. Weariness at last brought on slecp, and the slumberer beheld the saint standing by him : he ran his hand orer his limbs, and the torture went away. But before the healer departed he must have his fee: he desired the prostrate are $h_{1}$ bishop to manifest his gratitude by granting to lis favourite place and see the immunities which were afterwards bestowed. Thomas, in an cneyclical letter, narrated his sufferings and his cure. ${ }^{y}$

Thomas seems to have rindicated and excreised his right to be the head of the Scottish bishops. The ecelesiastical superintendence of that country was entrusterl to him at the council in 1072. He consecrated Ralph bishop of the Orkneys. Foderoch, the bishop of St. Andrews, came to him at the bidding of Malcolm and his queen in the character of a penitent. He had been consecrated at home, but he acknowledged his oflence, and made his profession of obedience to Thomas. He is said to have acted as a suffragan within the province of York. ${ }^{z}$ 'These names, it must be observed, do not appear in the fasti of the Scottish Church. There must either be some forgery in this matter by the York historians, or a suppression of the truth by the Scottish chronielers.

Thomas died at York on the 18th of November, $1100,{ }^{a}$ having becn archbishop for abont thirty years. He had been infirm for some time before his death, and he must have been an old man. He was buried at York, and was interred in the minster near his predecessor Aldred. The following cpitaph commenorated him :-

\footnotetext{
"Orba pio, viduata bono pastore patrono

Urbs Eboraca dolet, vix habitura parem.

Qualia vix uni persona, scientia, vita,

Contiserit, Thome nobilis, alta, bona.

Caricies, Jilaris facies, statura venusta,

Angelici vultus splendor et instar erait.

Hic numero atque modo doctrine sen probitatis

Clericus omnis erat ut magis ommis homo.

Hre domus et clerus sub tanto presule felix,

Pene quod est et habet, muneris omme sui est.

Octavis Sareti Martini transiit ille,

Qui pietate Dei sit comes in requic."
}

\section{$263 \mathrm{~b}$.}

z Stubbs, col. 1709.

"Saxon Chron., 321. Symeon, col. 226. Chron. Mailros, 62. Fl. Wigorn., 472. Chron. Petrib., 70. Ann. de
Margan, apud Gale, ii., 3. Hoveden, 268 b. Mat. Paris, 47. Stublse, col. 1709, who sars that he died at Ripon "Octavis S. ilartini."

${ }^{b}$ IIugh the Chantor. Stubls, col. 1709 , lias several variations. 
These words are highly enlogristic, but the see of York owes a decp debt of gratitude to archibishop Thomas. I ean see him eren now as Malmesbury deseribes him in his later years-the graceful figure retaining cren then the spring and energy of rontlı; the noble presence, and the comteons bearing which captivated all; the handsome florid countenanee, and his hair as white as the down upon a swan. No one could impugn the purity and correctness of his life. ${ }^{c} A$ s to his learning and ability the cluroniclers are for once unanimous. He brought with him into England the literary stores of three countries. ${ }^{d}$ It was his delight to have his elergy around him to read with them and to argue. But musie was his master-passion. He knew it thoroughly, and was a composer as well as a singer. He conld play upon the organ, and was aequainted with its construction. If he chanced to hear any light or trivial air, he would parody it, as it were, with marvellons-may I say unfortunate-facility into a ly'mm. He made ehants and services, ${ }^{e}$ eschewing especially all soft and effeminate music..$^{f}$ One specimen only of his powcrs as a versificr has been handed down to us, an elegy upon the death of William the Conqueror. ${ }^{g}$ As the theme was an unfarourable one the effusion must be read with some little indulgence.

\footnotetext{
"Qui rexit rigidos Normannos atrue Britannos, Andacter vicit, fortiter obtimit,

Et Cenomanenses virtute cöerenit enses, Imperiique suis legibus applicuit,

Rex magmons farva jacet hic Gulielmus in urna, suthicit et magno parra domus domino.

Ter septem gradibus se volverat atque duobus

Virginis in gremio Phoubns, et hic obiit."
}

Gratr, hishop of Hereford, was translated to the archbishopric of York at the feast of the Epiphany, 1101. ${ }^{h}$ He was the nepliew of Walleline, the Norman bishop of Winchester, and of Symeon, abbat of Ely; and he was, therefore, a distant

Milmesburs, $156 \mathrm{~b}$.

dVita S. IV ulstani, apud Ancl. Sac., ii., 25.). Ric. of Hexham, col. 303 . Stublse, col. 1705. Roh., de Honte, al. Stevenson, 680. IImtingdon, $216 \mathrm{~b}$. 2315.

CBromton, rol. 968. Knyghton, col.

$f$ Mahnebury, apud Savile, $155 l$.

f Ord. Vitalis, apurl Turhesne, 663.
Wm. Nenbr., ed. Hearne, appendix 681-5, where this and two other epitaphs are given.

$h$ Hugh the Chantor, who wrote a life of Gerard, which is in the Reg. Magnum Album at York. Chron. Mailros, 62, in 1100. Symeon, col. 226. Diceto, col. 499. Bromton, col. 999. Cottoni Chron., 412. Hoveden, $268 b$. Mat. Paris, 47. 
commection of the Conqueror. ${ }^{i}$ We first hear of Gerard as the chantor or preeentor of the chureh at Ronen.j He next becime one of the chaplains of William Rufis, and in that capacity lie was sent by the king to Rome to make enquiries for him abont the relative merits of the two rival popes. ${ }^{k}$ It is also said that he was chancellor to William I. and II. ${ }^{l}$ Gerard was conscerated to the sce of Hereford at London, in June 1096, "by the two archbishops, having been raised to the pricsthood at Lambetl on the preceding day." In 1100 he was present at the consecration of the new church at Gloncester, ${ }^{\circ}$ and soon after this he is said to have officiated at the coronation of queen Matilda. ${ }^{p}$ In 1101 he was translated to York. Walter Mapes tells a curions story to account for his removal from Hereford. IIe says that Gerard crowned IIenry I., who, as a reward for his services, promised him the first vacant archbishopric. On the deatl of Thomas the king repented of what he had undertaken, and endeavoured to keep Gerard at Hereford, being willing to confer upon that sec an income equal to that of York and Canterbury, and a position as important as that of the bishop of Durlam. Gerard, however, would have nothing to do with this arrangement, and held the monarch to his word. $q$ I do not set any value upon the story, but it is necessary to mention it.

When Gerard was translated to York the old question of subjection was again opened out. Anselm demanded his profession, but he refused to make it. He had desired Anselm to give him letters to the pope to enable him to obtain the pall, but he was told that they should be given upon one condition, that he should either make his profession at onee or on his return from Rome. Gerard was ready with his reply. "When he came back he would do what was just and right," and therenpon he crossed the seas." He earried with him, also, a missive from the king to Paschal, begging him to bestow the pall npon the bearer. ${ }^{s}$ Gerard, however, had another errand to the eternal city. He went there as ambassador from the king of England. ${ }^{t}$

i Ord. Vitalis, apud Ducluesne, 761. Malmesbury, apud Savile, $155 \mathrm{~b}$. Anglia Sacra, i., 611 .

$j$ Chron. Rob., de Monte, ed. Stevenson, 680 .

${ }^{k}$ Eadmer, Hist. Nov., apud Anselmi Opp., ed. 1721, 44.

Hugh the Chantor. Stubbs, eol. 1710, Lel. Coll., ii., 337. Perhaps cancellarius is a clerical error for capellanus. The name of Gerard appears in no list of the chancellors that $\mathbf{I}$ luave seen.

"Fl. Wigorn. says on Jme 15.
Stubbs, Reg. Sacr. Angl., 2 t.

$n$ Eadmer, Ilint. Nov., 4.5.

"Symeon, col. 225.

"Recueil des Historiens des ranles, xii., 679. Symeon (col. 226) silys that Anselm erowned and consecrated her.

q De Nuris Curialimn, 221. Srmeon (225) says that Maurice, bishop of Lomdon, crowned IIenry. Gerard, however, was present (Wendover, i., 18s.)

$r$ Stubbs, rol. 1710 .

* Bromton, col. 999.

" Earmer, "supra, 61. Malmesbury, $92 b, 127 b, 155 b$. Ilalmesbury 
The dispnte between Anselm and Henry as to the right of investiture was ruming high, and the king was desirous of haring the pope on his side. Pasehal was too adroit a politician to take any decided part in sueh a controversy. Gerard obtained the pall, and was flattered and caressed. His learning was commended; his adviee was songht for, "whilst the king's ambassadors, as well as those of Anselm, returned to England with the firm conviction that the pope was their friend."

The true state of things would soon be diseovered, and some little coolness between Anselm and Gerard would probably ensuc. The relative position of the two prelates was a very critical one. They took different sides in the ehureh polities of the day, and it must have been very diffieult to avoid a collision. We find them, howerer, associated together in a great council lield at Westminster in September 1102, at which many ordinances were made relating to ecclesiastical discipline, but particularly to the marriage of the clergy." Even at that meeting there was a little manifestation of angry feeling. A seat had been placed for Gerard below that of his brother of Canterbury. He kicked it orer and ordered it to be replaced on a level with that of Anselm, invoking the wrath of God upon the perpetrator of that injury to his see..$^{x}$

In the following year the quarrel between the king and Anselm was at its leight, and Gerard was made a party in it. Three bishops stood in need of eonsecration, and Anselm refused to officiate unless they receired inrestiture from himself. This the king forbade, and requested Gerard to take the plaee of Ansclm anr act as consecrator. He was ready to do so, although his eonsenting manifested neither good feeling nor good taste. "Perhilps," as Fuller says, "he hoped thereby to hiteh his church and degree the higher,"'y perhaps only to oblige the king. The ceremony, however, did not take place. William Giffard,

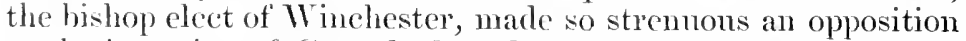
to the intrusion of Gerard, that the other prelates shrunk from the responsibility, and Giffard himself went abroad. $z$ Anselm, also, wearied and disgusted, songht again the protection of the pope.

charges Gerard with having given to the king a false report of the pope's ofinion with regard to investitures. This is probably the circumstance to whirh the pope alluded in a letter to Gerard, which is given by Eadmer.

u MSS. Lansdowne, ccecii., $27 \mathrm{~b}$. Bromton, col. 1000. Stubbs, eol. 1710 .

- We hear of Gerard and his brother ambassadors being at Marseilles on their return in Martene, 'Thes. Nov. Anee., iv., 126. Eadmer, Hist. Nov., 61.

"Fl. Wigorn., 474. Malmesbury, apud Savile, 129 b. Hoveden, 269. Symenn, col. 227. Bronton, col. 1001. Gervase, col. 1660. Stubbs, col. 1710. Eadmer, Hist. Nov., 63-4. Labbe, Conc. x., 728.

r Stublss, col. 1710.

y Chureh History, book iii., 20.

"Saxon Chron., 324. Fl. Wigorn., 475. Eadmer, 64. Malmesbury, 128. 
During the next three years, which Anselm spent in exile, we know little of the arehbishop of York. A letter from pouse Paschal is preserved, in which he is exhorted to be on better terms with Anselm; ${ }^{a}$ and that adriee seems to have had its due weight. A portion of the correspondence that passed between the two prelates is before us; it evinees much kindly feeling, although it diseloses the existence of some jealonsy and bitterness. ${ }^{b}$ Gerard joined his brother bishops in an affectionate bnt fruitless appeal to Anselm to return to England. ${ }^{c}$ He wrote himself to the exiled primate, and spoke of their friendship and past intercourse. He told him how much he wished that all this should be renewed, and assured him of his kind offices with the king in his behalf. ${ }^{d}$ It is quite possible that to Gerard's ageney is to be aseribed the return of Anselm, which took place in the autumn of 1106 . After this there was another chance of a feud between the two primates. Anselm required fom Gerard his profession of obedience, and he was backed in this demand by a letter from the pope. The king now questioned the neeessity of the claim, as the profession had been male before when Gerard became bishop of Hereford. Ansehm, howerer, was not satisfied with this; and Gerard is said to have laid his hand in that of Anselm, and to have promised to pay him the same obedience which he had rendered to him in a lower sphere. $f$ It is only just to say that some doubts have been thrown upon the truth of this statement. The reconciliation, however, secms to have been complete, and Gerard assisted his brother-primate in consecrating five bishops- the greatest number that had participated in that rite, at one time, since the days of archbishop Plegmund. ${ }^{g}$

Gerard induced the king to give the church of Laughton to the dean and canons of York, and this was made into a prebend. He also obtained from him six other churches. Of these, he gave one, that of Snaith, to Selby Abbey. 'The other five, those

Horeden, 269 b. Symeor, col. 228. Diceto, col. 499. Bromton, col. 999. Hemingford, apud Gale, ii., 470. Mat. Paris, 49. Chron. Petrib., 71. Möller's Life of Anselm, ed. 1842, 100. In Baluzii Misc. Sacra, ed. Mansi, ii., 173, there is a letter from Anselm to Iiemry protesting against any injury being done to Giffard on account of his resistance. 497.

a Anselmi Opp., 436. Diceto, col.

${ }^{b}$ Anselni Opp., 389, 431, 413.

c Eadmer, 73. Ans. Op.., 110. Wilkins, i., 38t. Möhler's Life of Anselın, 104. d Anselmi Opp., 136.

e Ibid., 413. Diceto, enl. 197. Malmesbury, apud savile, 1558 . Labbe, Conc., x., 617.

$f$ Falner, 76-7. Fl. Misorn., 179. Hoveden, 270. Symen, enl. 230. 1)iceto, col. 500. Gervase, col. 1659. Stubly (1710) denies this. Cotton (Cluon., 112) sass lluat lierard made his profession and obmlienoe.

5 Eismer, 77. Malmosury, 1296. ILoverten, 270. Symon, col. 230. Bromton, col. 1003. C'lron. Petrib. 74. Fisard consecrated a bishop uf Orknoy (Stub): rol. 1710). 
of Drifficld, Kilham, Pocklington, Pickering and Burgh, were bestowed upon his minster. ${ }^{h}$ He seems to have been a munificent person; indeed, his sucessor complained that he had imporerished the sce. ${ }^{i}$ Gerard was a great disciplinarian, and acted occasionally muler the advice of Anselm. ${ }^{j}$ He is said to have becn fond of correcting abuses, and on that account he secured for himself the dislike which too many are ready enough to manifest towards a conscientions and active reformer. ${ }^{k}$

Gerard has some pretensions to a literary reputation; indeed among his contemporaries he was famous for his eloquence and learning. Hugh the Chantor is guilty, perhaps, of a little clerical adnlation when he tells us he was quite able to contest the palm with Virgil in metre, and Tully in prose! The letters of Gerard, which are preserved, are well enough in their expression and Latinity, althongh in both respects they are inferior to those of Cicero." The following specimen of his verse is the only one that I have been able to recover. It is scarcely equal to the melodious number of the Eclognes or the Georgies. But it is hardly fair to judge a poet by eight lines, two of which are not his own.

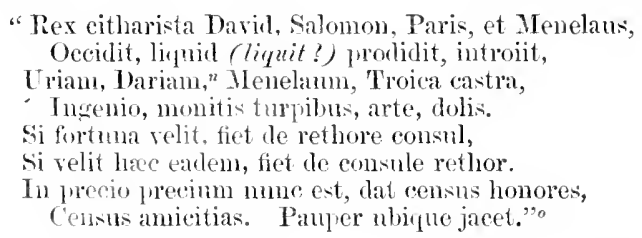

The death of Cierard was a somewhat remarkable one. It ocenred at Southwell, on his way to the court at London, ${ }^{p}$ on the :21st of May, 1108.q He was suffering from a slight illness. After dimmer he went to take his repose in the garden adjoining to his palace, and lay down to sleep in the open air among the grass and flowers with a cushion under his head. His elerks left him for a while at his request, and on their return their

h Stubbs, col. 1710. Rot. Clart., 121. Lel. Coll., 1i., 337. In the life of Thurstan, in Mss. Cotton, Titus, $\mathrm{A}$, xix., 55, it is said that the churches of l'ickering, Pocklington and Kilham, were given to the deanery of Iork, which had been previonsly poor, by IItury I., at the request of arehbishop Thurstan.

$j$ Anselmi Opp., 386, 431.

s Mirac. S. Joam. Jeverlac., apud Aeta S.s., NIay 2.

l Hoid., Wm. Nenbrig., i., 25. Malmeshury, 155 b. Stubbs col. 1710. n One of Gerard's letters is in Ans. Opp., 436. There is one in the library at Corpus, Cambridge.

"The allusion here is not quite clear. Was Gerard thinking of Hiram? Perhaps of Pharaoli?

o MSS., Cotton, Titus D, xxiv., 61.

$p$ Eadmer, 78.

$q$ Saxon Chron., 331. Symeon, col. 231. Stublse, col. 1711. Anu. de Margan, apud Gale, i., 4. Ann. Waverl., ibid., ii., 146. Rob. de Monte, ed. Sterenson, 680. IIoveden, 270. Chron. Petrib., 7 . 
master was dead. He had passed quietly away. His opponcuts asserted that this was a fitting termination of a wicked life. He had departed "unhouselled, manealed." A few persous carried his remains to York; but, on account of the way in which he died, they were not received, it is stated, with the customary procession of the citizens and elcrgy. The boys pelted the bier as it passed along, and, the canons denying the corpse a resting-place within the minster, it was interred imnominiously without the walls of the cathedral.r It was subsequently buried within the ehurch by his immediate successor in the see. ${ }^{s}$ These are the things which a monkish opponent is so fond of recording. Gerard was a reformer and a successful politician, and in both these characters he would be sure to create enemies. The most upright man is not excmpt from this. Gerard is arraigned by more than one chronicler for deceit and an evil life. ${ }^{t}$ He is also charged with being addicted to curious and forbidden arts. A treatise on magie, by Julius Firmicus, is reported to have been found under his pillow in his garden at Southwell, and he is said to have been much attached to it." The book was merely a work on astronomy. The same petty and rexatious spirit of ignoranee which regarded Gerard as akin to a sorcerer, threw Galileo into a dungeon.

Arfomas HE, the namesake and the neplicw of the first Norman archbishop, was the next primate of the Northern province, succeeding, as it were, by hereditary right." He was a member, strange to say, of a great clerical family. His father, Sampson, became bishop of Worcester; and his brother, Richard, presided over the see of Baycux from 1108 to 1I33." Thomas owed his advance in life to the care of his umele, whom he rescmbled in disposition, and under whom he was bronght up at York. ${ }^{x}$ In 1092, when the minster at Bererley was reformed, Thomas was made by his uncle the fir'st provost, and

r Wm. Neubrig., i., 25-6. Malmesbury, 155 b. MSS. Cotton, Vesp., $\Lambda$. ix. Harleian Misc, ix. 309.

s Malmesbury, ibid.

"Wm. Neubrig., i., 25. "Vita lubricus, in emungendis per indecoras etiam occasiones subditorum marsupiis callidus, et, ni plurimi asseverant, malificiis etiam assuetus."

"Knyghton, col. 2375. Drake's

\section{Eboracum, 415.}

- Hugh the Chantor. Stubbs, col. 1711. Knyohton, col, 2377. Hoveden, apud Sarile, 270. Mat. l'aris, 53.

or Gallia Christiana, xi., 360. Ric. of IIexham, col. 303. Malmesbury, apud Savile, 155 b. Stubbs, col. 1711. Tammer, Bibl. Brit., 709. 'Tlomas's Worcester, $1 \mathrm{H}$; and Appendix, 4.

${ }^{x}$ Hugh the Cliantor. 
he held that office till the ycar 1108." He was also one of the royal chaplains. The year 1108 witnessed the decease of Maurice, bishop of London, and Thomas was nominated to the racant post. Before the appointment was completed archbishop Gerard died at Southwell. At that time, II ugh the dean, and several of the canons, of York, were at the eourt, and they entreated the king to give them for their new primate the hishop-elect of London. Their petition was listened to, and Thomas beeame archbishop of York. ${ }^{*}$ The chapter of that eity would be delighted to weleome a prelate who had been so intimately comnected with their own body.

No sooner was the election of Thomas made known, than the monks of Canterloury prevailed upon Anselm to require from him the profession of obedience. ${ }^{a}$ Thomas resolved to take the opinion of the king, and set off for London from York, where he had been already most kindly received. He had accomplished half his journey, when a messenger overtook him, urexing him to be firm in terms which a long intercourse and familiarity could alone justify, and demanding that he should in no way commit or dishonour his ehapter. Thomas at length reached the king, who forbade him making the profession which had been demanded; and the opinion of the court was decidedly

y Srmeon, col. 231. Stubbs, 1711. The lists of the provosts of Beverley in Poution and Oliver are filled with ervors, many of which have their origin in the account of those oflieials, drawn up) before the Reformation by Simon Riliasel.

Archbishuy Thomas was the first prowost. IIe seems to have been succeerled by another person bearing the same name, who devot d himself to the Cistercian rule at Clairvan, but brohe his pledse, mueh to st. Bernard's grief. The saint tells us that he died, "Subita et horremla morte." St. Bernard wrote to, and abont him (S. Bern. Opp., ed. 1690, i., 111-15, 363-1). This Thomas was suceeded by a jerson of the name of 'Thurstan, bit not the arehbishop, as has generally been stated. II dier in 1153 or 1151 . John of Hexhan, col. 280), and was sneceeder by Thomas à Becket, who seems to have been inclebted for his appointunent to archbishop Theobald (Becket's works, ed. Giles, i., 10). Benerlict of Peterborongh reeords a miracle wronght in behalf of Thomas de Etton, knt., who har been an opponent of Berket whilst he wals frurost (Bened. P'ctrib., Yita S. Thome

\section{Cant., ed. Caxton Soc., 104).}

= Saxon Chron., 331. MSS. Lansdowne, eeecii., $20 \mathrm{~b}$. Symeon, col. 231. Diceto, eol. 500. Wendover, i., 461. Cluron. Petrib., 74. Dachery, Spicilegium, iii., 506.

a 'The aceount of this eontroversy is taken from several sources. The chief anthority is the life of Thomas, by Hush Sotevagina, thechantor and arehdeacon of York, whieh supplies some fresh information. See, also, Stubbs, eol. 1711-13. Anselmi Opp., 420-1, 44.5.50. (Several of these letters are not in their proper ehronologieal order). Eadmer, IIist. Nov., ibid., 79-83. Diecto, eol. 500-1. Gervase, col. 1660. Mahmesbmy, apud Savile, 156. Labbe, Cone., x., 758-61. Wilkins, i., 388-92. Ivonis Carnotensis Epp., ed. 1610, 790. Jo. Sare ber., Opp., v., 316, ete. Anglia Sara, ii., 172.

In 1108 there is said to have been a meeting of the elergy, at which Anselm and 'Thomas were present. Some enaetments were passed at it about the archdeacons and the elergy (Symeon, col. 231. Hoveden, $270 \mathrm{l}$. Labbe, Cone., $\mathrm{x.,} 756)$. 
in his favour. In the meantime Anselm was not idle. He tried to gain the king's ear, but in vain. He then sent Herbert, bishop of Norwich, to Thomas, to propose that the profession should be dispensed with, if he would only recognize the primacy of Anselm. 'Thomas, howerer, relied on the king's support, and declined to do so. Anselm now began to aet with promptitude and energy, and it was time. Thưgot of Durham, the bishop)elect of St. Andrews, was waiting to be consecrated. Thomas, of eourse, could not officiate; but Ranulph Flambard, the bishop, of Durham, was willing to act in his presenee, with the assistance of the Seottish prelates. Anselm refused to allow the ceremony to take place. He forbarle Thomas to exercise any episeopal functions. He told him that no bishop ought to be uneonsecrated for more than forty days, and desired him to be at Canterbury to receire that rite on the 6th of September following; saying that if he should be disobedient he wonld himself step into his place in the North, and enter upon the dutics which he was neglecting. Thomas wrote to Anselm in reply, and told him that he would come to Canterbury as soon as he conveniently could. At present he was in want of money, as the see had been much impoverished by his predeeessor; and he was preparing also, with the king's permission, to send a messenger to the pope to procure the pall. Anselm, upon this, forbade him to seck the pall before his consecration, and desircd him to be at Canterbury on the 2\%th of September. He wrote also to the pope, requesting him to withhold, for the present, the honour which Thomas wished to obtain. Thomas, in reply, told Anselm that he conld not act against the will of his chapter; and that body, about the same time, conveyed to Anselm the opinions which they had so strongly impressed upon their spiritual head. Anselm fixed another day for the consecration of his new brother, but to no purpose. He then resolved to try the effect of mediation, and sent the bishops of London and Rochester into the North. Thomas met them at Southwell, but all their arguments and entreaties were in vain. II said that he would gladly come to Canterhury to be consecrated if the objectionable condition was given up. He was now expecting, as he told them, the return of his messenger from Normandy whom he had sent to consult the king. This alarmed Anschin when he heard of it. He wrote a letter to Sampson, bishop of Woreester, the father of Thomas, begring him to prevail upon his son to adopt better counsels. The eantions prelate returned an evasive and an unsatisfactory reply.

In the meantime, Hugh, the dean of York, and some other friends of Thomas, had arrired at the eourt in Normandy. Henry wrote to Anselm, desiring that the dispute shonk stanid 
over till he returned to England; and the archbishop unwillingly acquiesced. The king, also, shewed his partiality towards Thomas by writing a letter, which Hugh earried with him to the pope. It contained a request that he would send over to England some competent person to settle the quarrel between the two sees, and to bring with him the pall which Thomas was minale to seek at Rome in lis own person. The pope readily assented, and Ulric, a cardinal, returned with the dean. Before they could reach Normandy and the court, Anselm had passed away out of this troubled scene into the peace and stillness that are beyond it. He had been failing for some time, and, possibly, this controversy with Thomas may have embittered and disturbed the last months of the old man's life. Upon his death-bed he is said to have indited a most striking letter, in which, in the sight of the Most High, he besought Thomas to return to his allegiance to Cainterbury. The curse of God was invoked upon him if that allegiance wcre withheld. There is something very awful in this. Surely a death-bed is a place for blessings, and not for eurses. Anselm, howerer, was then seeking for others, and not for his own aggrandizement, what he considered to be right. He dared to vindicate it as he was passing away to one whose highest attribute is His justice. That noble heart, palsied by suffering but unvanquished, was honest and faithful unto the end.

Whilst this was going on in England, Ulric and his companions came to Henry at the Norman court, and he sent them into his own kingdom, promising to be soon with them. When he came, the great cause betwcen Canterbury and York was mooted, and each side did their best to carry the day. It was debated at the feast of Pentecost. The result was that the king was prevailed npon by the dignitaries of the Sonthern provinee to alter his determination, and he requested the astonished and dismayed Thomas to make the required profession to Canterbury, without any prejudice to his suceessors or his church. He flatly refised to do so. The hot blood of the Norman prince boiled orer when he heard him. He threatened to ruin him and all his kindred if he remained obstinate. Thomas was still disposed to resist. Every influence was now brought to bear upon him. Robert, comte de Meulent, whose good offices Anselm had previons ly requested, endearomed to persuade the unwilling prelate. Stephen de Whitby, the ablyat of St. Mary's, York, entreated him to give way. Bishop Flambard sought in vain to warp the king's mind by a proffered bribe of a thousand marks of silver to himself, and an hundred of gold to the queen, but Henry wonld not relent. The mediation of the cardinal was begred lor'; but he dedined to em!roil himself in a controversy which 
might be productive of so mueh danger to himself and his ehureh. 'The king would not give way: would the prelate submit? At this crisis the father and-brother of Thomsts, fearful for their own safety and for his, went to him, and at their earnest entreaty he was induced to alter his determination. Stem necessity seems to have compelled him, and he gave "1p his position most sorrowfully and muillingly. On the morrow, Sunday, the $2 \gamma_{\text {th }}$ of June, $1109,{ }^{b}$ he made his profession, and was eonseerated at London by the bishop of that diocese. He obtained, however, some little compensation for his concessionr. The bishops of Norwich and Durham declared aloud in the ehureh, at the king's request, that Thomas had made his sub)mission to Canterbury in obedience solely to his royal master's wish, and not upon the merits of the controversy. Henry also gave lim a kind of encyclical letter which repeated "rerything that the two bishops had asserted, and added, besides, thint the aet was in no respeet to compromise the rights and privileges of the elumeh of York and its arehbishops.

Soon after this Thomas and the cardinal set out for York, where there was a noble welcome for them. In the beginning of August the pall was solemnly given to him in the minster; and when the eeremonial, together with the mass, at which Thomas officiated, were over, the new arehbishop, in the presence of Ulrie, eonsecrated Turgot of Durham, who had long been waiting for that rite, to the bishoprie of St. Andrew's. ${ }^{c}$ After a stay of three days, the cardinal, loaded with presents and thanks, set out on his joumey towards the South. Thomas eseorted him as far as the Trent; and, when they were about to part, the archbishop, instead of a friendly farewell, was astonished to receive a summons to Rome. Ulric told him that in making his profession to Canterbury he had broken the deeree of Gregrory and the eanons, and that he must answer for this at liome. Why had not the cardinal expressed the same opinion when his advice had been previously songht for, and when it ought to have been given? 'The entreaties, howerer, of 'Thomas and his friends indueed Ulrie to recal his words, and the two separated with mutual assurances of friendship and good will. ${ }^{d}$

The life of Thomas was too short to allow him to do much within his diocese. We find, howerer, that sereral of the Seottish prelates came to him for eonsecration. 'Tumot of St. Ancliew's

${ }^{b}$ Fl. Wigorn., 482. Symeon, eol. 232. Diceto, col. 501. Badmer, 83. Hoveden, $270 \mathrm{~b}$. Chron. Petrib., 75. Chron. Mailros, fit. Mat. Paris, 53. Labbe, Cone., x., 761. 79.

c Anselwi Olp., 421. Ealner, ibid., d Hurh the Chamtor. Symeon (232) and W. Wirorn., (16\%) say that the pall

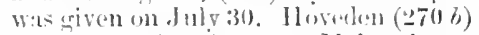
makes the las Itre. 1. Malumelumy, 156. Stubbs, (o)l. 1712. Chron. l'etrib., 75. 
las becn already spoken of, but he was more renowned for his comncxion with Durham, and his literary reputation, than for anything that he did at his see in Scotland. Wimund of the Isles, Michacl of Glasgow, and Ralph of Orkney, were also consccrated by Thomas, and paid to him their spiritual homage. 'T'o the two last the diocese of York was under some obligations. The bishop of Glasgow, who came to York at the desire of prince David, was on intimate terms with Thomas, and acted as a suffiragan within his diocese. He died on one of his episcopal journeys, and was buried in the church of Morland in Westmerkand. The history of Ralph, the bishop of Orkney, was a remarkable one. He was a native of the city of York; and because he was consecrated without the consent of prince, clergy, or people of Orkney, he was rejected by them all. He remained, therefore, in England, and acted as a suffragan to the diocesans of Durham and York. He was a great friend of archbishop Thurstan in all his vicissitudes of fortune, and represented lim at the famous battle of the Standard. ${ }^{e}$

We find but few traces of Thomas in the domestic affairs of his diocese. 'Two new stalls were founded at York in his time by Roger, ablyat of Whitby $f$ Thomas obtained from the king it grant of privileges to the church of Southwell, and freed the canons and their church from the claims and exactions of himself and his successors. These endowments had been made by Aldred at his own cost, but he had been unable to seeure the exemptions which were now obtained." The greatest work, however, which Thomas effected, was at Hexham. ${ }^{h}$ That once famous house had fallen from its first estate. A succession of twelve bishops had worn the mitre which rested on the brows of IFilfrid, but three centuries had elapsed since the death of the last of these prelates. 'The church and lordship, for some time, seem to have belonged in turu to the arehbishop of York and the bishop of Inulham, but at the begimning of the twelfth century, they seem to have been bestowed in perpetuity upon the Northerin primates. The ehureh up to this time was under the control of a prorost, the son succeding the father in the charge for several gencrations. Thomas I. appointed to this office a canon of Beverley of the name of Richard de Maton, and attached it to the stall of Holme at York. Maton seems to have been non-resident, lint a person of the name of Eilan, well

- Sinnoon, col. 232. Stubbs, col.

1713. Keith's Scottish bishops, n.e., $7,200,297$.

ILugh, the Chantor. Stubbs, (col. $1713)$ makes Thomashimself the formder.

* Silubbs, col. 1713 .

Rie. of Ilowlenn, col. 503-6. Sy. neon, col. 235. Stubbs, col. 1713. Iniac. S. Wilfridi, apted Acta SS. ord. S.P., sac. iii., i., 215-16. Lel. Coll., ii., $337-8,391$. There is an interesting raper by Mr. Longstaffe, on "The hereditary sacerdotare of II exham," in the Arch. Al., n. s., iv., 11-28. 
known in the ehronieles of the church of Durham, was his deputy. It was clearly wrong that a ehureh of antiquity and renown should languish under so fechle and imperfect an administration. The abbey seems to have been used as the parish chureh, and, with the exeeption of Eilau, there are no traces at that time of any resident ecclesiasties. On the first of November, 1113, Thomas was able to introduce a new system. During his visitation of the monasteries in his diocese he had made himself aequainted with the state of Hexham. He prevailed upon the provost to resign his post into his hands, and made it thenceforward a house of regular eanons under the control of a prior; Eilau, who promoted, and was anxions for, the change, being permitted to retain a life-interest in the cndowments. This he subsequently resigned, and ended his days as a professed monk among the Benedictines at Durham. Ailred, the learned prior of Rievanx, was his son. The path was now clear for Thomas and his changes. He establisherl a new régime. He gave to the canons, who were Augustinians by rule, four vills, a mill on the Tyne, and a fishery in that river. He bestowed upon them one lnundred shillings a year for thcir clothing. He furnished the church with its books and ornaments, and, had his life been spared, he would have been a still greater benefactor.

In the life of bishop Eata, there is an interesting aceount of an adventure of Thomas at Hexham. The ehureh of York had no saint enshrined within its walls, and the want gare much annoyance to the dignitaries of the minster. They entreated Thomas to bring away from Hexham the remains of Eata. The canons of that place were in despair as the archbishop lad made up his mind to deprive them of their saint. A singular circumstance is said to have deterred him. He had come to Hexham and was asleep, when suddenly Eata himself appeared to him in a vision. Not only did he chide Thomas in the strongest language, but he gave him two blows on his shoulder with his pastoral staff!

\section{" Bis baeulo tangens humerum."}

The poor archbishop was half-dead with pain and fear, and of course nothing more was done about removing the remains. ${ }^{i}$

One of the two learned priors of IIexham commends Thomas very highly for his kindliness of heart, his pleasant manners and comntenanee, his hospitality and learning.j Like his mucle he had a great taste for music, and he is said to have composed

¿ Biogr. Mise., ed. Surtees Soc., 121. Mabillon, Acta SS. ord. S. B., iii., sice. i., 222. j Wm. Neubrip., i., 26. Symeon, col. 236. Ric. of Hexhan, col. 303. Stubbs, col. 1713. Malmesbury, 156. 
some hymns, together with an Officiarium for the benefit of his

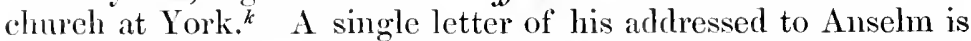
preserved. $^{l}$ In his personal appearance Thomas is said to have been stont and unwieldy, and to the inertness, which so fi'equently results from eorpuleney, the York historians have ascribed the too hasty surrender of the privileges of his see to the encroachments of Canterbury. ${ }^{m}$

Thomas died at Bererley on the 24th of February, 1114, and was interred at York near his uncle and his predeeessor Aldred. ${ }^{\circ}$ He had for some time been suffering from a peculiar complaint, and he might have survived it, if he had not had some conscientions seruples in applying the preseribed remedy. He felt it first when he was provost of Beverley, but he is said to have obtained some temporary relief from the aid of his predecessor St. John, whose assistance he had besought. ${ }^{p}$ The complaint, however, returned and carried him off. It was the same which in after years terminated the life of James Rossa, the archbishop-eleet of Lishon. Thomas was still a young man when he was ealled away. ${ }^{\prime}$

Flyurstan, a well-known name in the North of England, was the next archbishop of York. It is impossible to do full justiee in a few pages to this great and noble-minded man. Like several of lis predecessors, he was the son of an ecclesiastic, Auger, prebendary of Kentish Town, in the church of London." Thurstan was a native of Baycux, and his brother, Andoenus, was for many years the bishop of Evreux. ${ }^{t}$ Thurstan's sagacity and

\& Bale, cent. xiii., 132, where he is eonfused with his uncle. 'Timner Bibl. Brit., 709. Wright Bingr. Lit., ii., 109.

$l$ Earmer, IIist. Nov., apud Anselmi Om., 80.

m IIugh the Chantor. Stubbs, col. 1712.

n Fl. Wigoln., 488. ILoveden, 271. lice of Hexham (306) makes the date Feb. 16, and Stubls (1713) Feb. 18. Sixm Chron., 331. Chron. Petrib., 77. Chren. Mailros, 65. Wikes, apur Gale, ii., 25. Symeon, col, 236. Matt. Paris, 55.

- Ric. of Hexham, col. 396. Stubbs, cul. 1713.

$r$ Ric. of Hexham, col. 303-1. q Wm. Neubr., i., 26. Stubbs, col. 1713.

r Newcourt, i., 169. Godwin, ed. Richardson, 668. Auger was succeeded by liis son, who is called "Audoenus frater archiepiscopi."

s Ord. Vitalis, apud Duchesne, 858.

t He was born at Bayenx, and was a very learned man. He was scribe and afterwards chaplain to Henry I. He was bishop for twenty-four years, and died in 1139, having rebuilt his ehurch which had been burnt down. He was interred at Merton, having before his death taken upon him the habit of a canon. (Gallia Christiana, xi., 573-6. Recueil des Historiens des Gaules, xii., 769. John of Hexham, col. 265.) 
energy of character soon gained him a position in the world. He became a member of the honsehold of William Rufiss, and was a great favourite of his master. At the death of that monarch, Thurstan was made the chaplain and the confidential secretary of his brother, the new king." He was clearly marked out for greatness, but up to this time the only clerical appointment which he enjoyed was a canonry at St. Panl's."

Archbishop Thomas died in 1114, and Thurstan was nominated by the king to succeed him. This was done at Winchester on the festival of the Assumption of the Blessed Vikgin." The difficulties which had beset his predecessors soon forced themselves upon his consideration. 'Thurstan had a stouter spirit and far greater influence than those who went before him, and he was not disposed to submit to the elaims of Canterbury, to which they had been obliged to suecumb. He speaks about the matter to the king. ${ }^{x}$ He tells him that it was improper that a metropolitan should make two professions of ecclesiastical subjection, one to the pope, and the other to his brother metropolitan. Supposing that a dispute arose between the king and the Southern primate, the archbishop of York, in consequence of his oath, would be obliged to obey the latter. The king, in reply to these words, told the comte de Meulent that he would not require Thurstan to make any profession to Canterbury.

Thurstan, at this time, was only a subdeacon, but in the

u Saxon Cliron., 33t. Chron. de Mailros, 65. Stubbs, 1714 .

"His stall was the prebend Consumpta per mare, the corpus having been swallowed $u p$ by the sea before the Conquest. (Newcourt, i., 141.) When Thurstan became archbishop, the bishop of London allowed him to resign this stall. (Hugh Cantor.)

The Beverley historians made Thurstan the second provost of that church, but there is no proof that he was at all comnected with the place (Poulson, 616. Oliver, 385.) ILerbert de Losinga wrote a letter to a person whom he addressed as "Thurstin, monachus," who may perhaps be identical with our arehbihop, recommending cantion and fleedom from wolldly-mindedness, and beginning "tuam abhorrens hxereditatem, frater Thurstine, peregrinis delectaris divitiis, et nostra armdinea condempnens tuguria, marmoreis habitas in palatiis" (Epist. ed. Anstruther, 8vo, $1846,58)$. In the same volume $(217)$ there is also a letter from Whmer, prior of Canterburs, "ad 'Turstanum, archidiaconum," on religious subjects.
* Saxon Chron., 331. Fl. Wigorn., 488. Chron. Mailros, 65. Symeon, col. 236. Bromton, col. 1005. Hovoden, 271. IIemingforl, apmel Gale, ii., 472. Eadmer (Hist. Nor., 90) says that he was elected "connivente Radulfo archiepiscopo, et aliam quam rei exitus probavit, de eo liabente opinionem." Rob. de Monto, 688 .

s. The narrative of the troubles and exile of Thurstan is taken from the account of his life by IIugh the Chantor, which is still $1 \mathrm{mpublished.} \mathrm{The} \mathrm{writer}$ was an officer in the chureh of Iork aml was well acquainted with Thurstan, amd tells us a cood deal about him, which has beew hitherto monown. I have bised my life of the archishop this MS. The character of Thusstan has been judged and comlenumed 11 , to this lime on the testimony of the partizans of Cantor)ury, now audi alleram

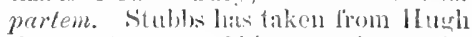
the greater lart of his narative, omitting muel that is important (col. $171 \mathrm{k}$ 20). I have given ruferences to other writer when they corroborate or diller froml Huglh. 
month of December he was advanced to the diaconate by his old friend and patron, William, bishop of Winchester. He then paid a visit to the North. At York he met with an honourable reception, and was solemnly euthroned in the minster by Robert, bishop of Liehfield. He went from thence to Durham, and became the guest of bishop Flambard, an umprincipled but potent statesman. He there beheld, probably for the first time, the noble eathedral which St. Carileph had begun, and within its walls he had an interview with 'Turgot, who had left his see of St. Andrew's to die in the monastery of St. Cuthbert, of which he had been the ornament and the head. The great scholar was stretched upon that bed which he never left alive. ${ }^{y} \mathrm{He}$ was delighted to see his new superior, and promised him his allegiance if he were spared to render it. Thurstan spent, after this, a few days at Hexham to supervise the good work of Thomas, and then he returned to York. As soon as the bishop of Lichfield left him he began to busy himself with the affairs of his new cure, and to meditate upon the future. The thought of the dreaded profession which he would soon be required to make induced him to seek for counsel from his ehapter. They declined to give him any adrice, as their past difficulties were still remembered. They told him, however, that on his side there would be eustom, justice, and the decree of Gregory; on the other, the king and nearly the whole of England: no one was more conversant with the canons than himself, and it was not for them to recommend him what to do: if he declined to make the profession, and should be ejected for his contumacy, they would oby no one else. The frankness of this reply would please Thurstain, and he told them that he was unwilling to make the required profession of inferiority, and that he wonld go to Rome, if possible, and refer the matter to the pope. They then gladly acknowledged him as their ecclesiastical superior, althongh he was only in deacon's orders. They drew up letters to the pope annomeing his election, and Thurstan, having selected sereral of the canons to accompany him, prepared himself to cross the seas. The king had been for some months in Normandy, and Thurstan wished to see him.

The archbishop of Canterbury had already desired him to come to him to be consecrated priest and prelate, and now the summons was repeated. It was deelined, and Thurstan, about Christmas, 1114, reached the court in Normandy. He re-

y In Eadmer $(90,97-100)$ are letters from the kine of scotland to arehbishop Ralph announcines Turgot's death, and arking his advice abont his successor. Laduer's own difficulties about this see prompted the pen of Nicholas to write the letter on the right of the see of York to the primacy of Seotland, which is printed in the Anglia Sacra, ii., 230-6. 
quested permission to visit Rome, but the archbishop had anticipated his petition, and the king put his veto upon the proposed journey. The cardinal-bishop of Praneste was at that time the papal. legate in France, and IIenry, who scarcely knew how to act, sought for his adviee. What was he to do with Thurstan, who was not a priest, and whom the primate of Canterbury would not consecrate without the profession which the other would not make? 'The answer of the legate was prompt and decisive. He told the king that 'Thurstan might casily be ordained priest by one of the suffragans at the court; when that ceremony was over, he would limself direct him to the pope, who would solve the difficulty at once by consecrating Thurstan himself, and giving him the pall. This adrice was only followed in part. To the consecration at Rome Henry would not consent, but he permitted Flambard, bishop of Durham, to ordain Thurstan priest. This, according to Stubbs, was done at Bayeux in Normandy.

The year advanced, and things remained as they were. The court, however, returned to England. The delay was most annoying and wearisome to Thurstan, but this was only the beginning of his troubles. About Michaehmas there was a council at London, and the king alluded to the unfortunate dispute between Canterbury and York. The comte de Meulent and Nigel d'Albeniz were standing by, and Thurstan, availing himself of the opportunity, complained with justice of the great delay in his consecration. Henry advised him to take some honourable and trustworthy person, and to go and ask the archbishop to grant his often-preferred request. If any ujust demand should be made, he had the king's permission to refer the matter to the pope. Upon this 'Thurstan went to Ralph; Geoffrey, archbishop of Rouen, John, bishop of Lisieux, his old friend Ranulph Flambard, and many others, accompanying him. Ralph, however, refused to consecrate without the profession. Thurstan then announced his intention of appealing to Rome. "If the pope were to meet me face to face, and order me to waive my demand and consecrate you, I would not obey him," was the hasty and ill-judged reply. The party then returned to the king, and Thurstan begged carnestly to be permitted to visit the papal conrt. He was emboldened by what Henry had recently said, and he spoke out, "It was a sin and a crime that the matter should remain so long unsettled. The church of York was being injured; the diocese was going

$x$ There is a long acconnt of this distinguished person in L'Art de vérifier les Dates, ed. 1784, ii., part ii., 692. Nigel d'Albeni afterwards assumed the name of Mowhray, and was the progenitor of a long line of illustrious baruns. 
to ruin. It was hard to be an arehbishop in name only without the power to act. The king would be blamed at Rome for sanctioning all this, and was that right? Would Henry allow him to go, or, at all events, to schd a messenger to Rome?" The king would not move. He was too indolent to be an active partizan, and the archbishop of Canterbury reproached Thurstan in his hearing for having summoned him to Rome without the permission of the sovereign. Henry had neither the spirit nor the faimess to say that that leave had just been given.

In the meantime the letters which the chapter of York had written to the pope annomeing the election of Thurstan, and deprecating any farther delay in his consecration, have been lost sight of. They were drawn up in the winter of 1114 , but a whole ycar elapsed before they were delivered. ${ }^{a}$ Before that time the chief pontifi must have heard of the dispute from other sources. ${ }^{b}$ He at last received the letters of the chapter, and answered them immediately. The reply was everything that could be wished for. Paschal confirmed the choice of the chapter, and directed the archbishop of Canterbury to consecrate Thurstan without any profession and without delay. The bearer of these missives arrived in England in Lent 1116, when the king was holding a council at Salisbury. Henry had gradually bcen brought over to take the part of Canterbury, and a vigorous attempt was now made to bring Thurstan to submission. The king brought his influence to bear upon him. He sent the comte de Meulent, William, earl of Warren his brother-in-law, William the chamberlain, and Nigel d'Albeni to Thurstan, beseeching him, in recollection of the kindness which he had received from himself and his brother, not to break the customs of the land, and seandalize the church by withholding the profession. Thurstan made a noble and a bold reply. He acknowledged with pleasure his debt of gratitude to the king and his brother. No one shall question his loyalty or his love of order. Where is the injury to the law or the seandal to religion in his standing up for his own chureh, which it is his duty to protect? To defend the right is one half of the diadem of the king,- " the brightest jewel in his crown,"-and the judge ought not to

" Eadmer (90) speaks of Thurstan setuling letters to the pope which were of 110 a rail.

${ }^{b}$ Iro, bishop of Chartres, writes to Paschal begsing him to defend the see of York and to confirm 'Thurstan's Aection, "Qui, quantum ad personam frertinet, continentis est vite et honeste fana, et utilis, quantum humana eoncientia de alterins vita potest judiare, sancts Dei ccelesine" (E)ist., ed.
$1610,482)$. There is another courteous and complimentary letter from Ivo to Thurstan in the same work (375). Hildebert, bishop of Mans, writes to Thurstan contradicting the report that he wished to go to Rome to take the part of Canterbury against him (Hildeberti episc. C'enomanens. Opp., ed. 1708, appendix, 1. 1. Ironis Carnotens. episc. Ejist., 790). 
make himself a partizan. Let the real originator of the scandal recollect who it was that said, "Woe to that man hy whom the offence cometh." He neither can nor clare make this profession in contravention of the decres of Gregory, Honorius, and Urban. If his predecessors rashly or by compulsion did otherwise, what is that to him? 'The sanctuary of God camot be inherited. He humbly intreated the kime to judge according to the right by himself and his church. The royal messenger's returned and told the king what Thurstan had said. He was then in his chapel with arehbishop Ralph. The hot blood of his father boiled within his veins. Hle sent them back to Thurstan to tell him that if he continued to refuse to make the profession, banishment and ruin should befall him and all his kindred, and that he should lose York altogether. ${ }^{c}$ It was this threat which extorted the compliance of two of his immodiate predecessors, but Thurstan was mulannted. Ile pansed awhile, for it was a time for deliberation, and then he made the comrageous reply, "It is painful indeed for me to incur the king's perpetual dislike, but it is much more painful to be a conscions offender against God and the church of Rome. I shall do neither: I shall restore to the king everything that he has giren me." The words were reported to the king. How strange they must have sounded in the ears of worldly and selfish men! The archbishop would not belicve that they had been spoken. The comte de Menlent, who was kindly disposed towards 'Thurstan, then observed that he did not understand that 'Thu'stan had refused to do what was required. Let him be summoned and answer for himself. He came and repeated what he had said before. He laid his hand on that of the ling and surrendered to him, as his suzerain, everything that he possessed." The scene was an affecting one, and many were in tears, nay, even the king was movel. Pleasure, however, was visibly written upon the face of Ralyh, who had not yet received his letter from the pope, for Thurstan had forgot to bring it with him. With a strange want of feeling he turned to the York clergy, and blamed them for depriving their head of his archbishopric by their evil counsels. They were all weeping, and the roice of Thurstan was raised at once in their behalf. He bore a noble testimony to the honesty of their motives, their

c Eaduner, 90, who is quoter by $\mathrm{Sy}$ meon, col. 237. Diceto, col. 502 . Bromton, col. 1006. Gervase, col. 1661. Kunghton, 2379. IIoveden, 271 b. Matt. Paris, 55. Chron. Petrib., 78. Wilkins, i., 393.

$d$ Eadmer (90) says that he gave it up and promiced never to seet for it again during his life. 'This is anjied by Fl. Wigorn., 190. IIoveden, 2716 . Fynteon, col. 237. Gervase, col. 16f61. Bromton, col. 1006 . II emingfort, aprud Gale, ii., 473.-Nahnesbury, 156. 
learning and their excellence, and declared that with their help lie was still ready to maintain the right.

The news spread far and wide through the English dominions on eitlier side of the channel. Astonishment and sorrow were uppermost in men's minds; astonishment, that so loyal and trusty a subject had been thus treated; and sorrow, that he had suffered in the canse of right and justice. The chapter of York wrote an affectionate letter to Thurstan, commending his past conduct, and exhorting him to endurance. The pope sent a shatrp reproof to Ralph, and ordered him to give way, but he neglected this mandate as he had despised the other. In the meantime Thurstan entreated the king to have pity upon the diorese which should have been his, and to appoint another archbishop. Henry, however, did not do this: he felt, probably, that he had gone too far already, and nothing more was done.

Henry now paid another visit to Normandy, and Thurstan went with him. He was still treated by his master with respect. 'The present position of himself and his chureh was uppermost in his thoughts. When he had requested Henry to nominate an archbishop in his room, he had declined, with the remark that the see, in his opinion, was not racant. What could now be done? Thun'stan began to regret his recent resignation : he could not properly make it, as he thought: how could he give up to the king what he harl not received from him? it was the pope who had confirmed his election; the pope ought clearly to be the arbiter. He urgently entreated Henry to allow him to go to Rome, and his friends seconded his prayers. It was all in rain. ${ }^{e}$ The king was numoved, and Thurstan remained at the court in what was, in point of fact, a kind of honourable restraint. $f$ He conld not steal away from his master, and he was afraid of exasperating him farther. Henry himself had sent the bishop of Exeter to Rome to take the advice of the jope about the question in dispute, and he now returned after a fruitless journey. He gave, however, a hint to the archbishop of Canterbury, of which that prelate at once availed himself, and the primate, at his suggestion, started at once for the papal court.

Ifter a lapse of three months several representatives of the lork chapter reached the king. That boly had resolved to demand their archbishop as a matter of right and justice, and for that purpose they sent two of their archdeacons-a canon of

- Wadmer, 30. Chron. Mailros, 63. Srmenn, col. 238. Gierrase, col. 1661. Hovoden, $271 \mathrm{~b}$. $f$ " Ab Anglia louga cathena retentus in Normanniam quasi sub custodia detimebatur" (IIngh). 
Bererley and a monk of St. Mary's Abbey. When these persons solicited an interview, Henry sent them a message to demand why they had erossed the seas without his permission. They replied that they thought that in such a ease the royal licence would be unnecessary. The king would not see them then, but fixed the day aud the place for an interview. He now began to weary them with delays. They were disappointed three or four times, but at length they obtained the wished-for meeting, Flambard, bishop of Durhain, and several other fricnels, accompanying them. They required their archbishop at the king's hainds, speaking of the injury which lis absence was doing to the church and diocese of York. It was at their request that Thurstan had been ordained deaeon and priest; they had made him the prorost of their souls, and had promised to obey him, why should they lack his superintendence? If they could not have him, whom were they to have? The pope alone could absolve them from their oath of subjection to Thurstan, and give them another arehbishop.g 'There was much reason in what they said, and the king, at their most carnest request, promised to take the subject into his immediate consideration. After a conference with Thurstan they proceeded homewards. As soon as they were gone Thurstan renewed his old petition, but withont effect. He was desired to wait till the archbishop of Canterbury returned. Thurstan then mentioned a report that Ralph had resolved to make a pilyrimage to Jerusalem, in which case there was little chance of his coming home. "It matters little to me," said the king, "what either of you say or do; it is my wish to hear the opinion of the pope from his own lips." Ralph at last came back vexed and disappointed with his journey, and Thurstan again made a fruitless appeal to Henry, reminding him of his past promises. The heart of the king was hardened like that of Pharaoh. Ralph had been whispering in his ear that his adversary, if he went to Rome, might perhaps be conscerated, and that was, of all things, to be prevented. Thurstan was bitterly disappointed. He would not make the king his open enemy, but how vain it was to hope for an alteration in his opinion. He began to east in his mind what he should do. It was ignominions and unjust that he should be thus treated. IIe secms to have thought of leaving the court without the king's permission, and in this cmeresency he again sought the advice of the chapter'. 'They entreated him, if it were possible, to retain Ilemry's good opinion. If his departure should be sanetioned he night take any of their body with him: in any ease he might have them, but if he left the 
comrt by stcalth it would be imsafe and unfair to leave them behind. Willian de Bererley, their last messenger to the pope, had been very elusely questioned by the king. At the same time the chapiter sent to 'Thurstan another epistle, which he was to deliver to the pope. In it they appealed to his justice and compassion. Their hopes and hearts were fixed upon him. 'They told him that kalph liad inveighed against the venality of the papal court, which all the world, they said, knew to be a fillse chalrese. 'The letter' was an adroit mixture of flattery and abuse. It was conveyed, in all probability, to Paschal by some messenger of 'Thurstan or the chapter.

The pope's reply reached the English court in Normandy by the hands of Anselm, afterwards abbat of St. Edmund's, who was a ncphew of the eclchrated archbishop, and the legate to England. Paschal requested the king to restore the see of rork to 'Thurstan and to haston lis consccration, and he took upou himself' to settle any dispute which might arise. ${ }^{h} \mathrm{He}$ ordered Ralph to do his duty at onee without the profession, which he had no right to demand; if he persisted in refusing, the suflingans of the see of York should act in his stead. This letter, howerer, was not given to the archbishop at the time. 'The decision of the roval eouncil was manimous in Thurstan's firour, and he was restored to his lost position. ${ }^{i}$ It was his intention to place the pope's missive in the hands of Ralph as soon as he returned to his prorince, where alone he could consecrate him. In the meantime, full of joy at his good fortune, 'Thurstan weit back to York. Several months pass away, and Ralph nerer comes to England. He was evidently loitering aloroad to avoid the fulfilment of the papal mandate.

It was now the month of February, 1118, and there was every expectation at York that the great dispute would speedily be terminated. "There is many a slip between the eup and the lip." The mexpected news was brought of the death of Paschal, and of the accession of John Gactano to the papal chair under the title of Gelasins II. Everything was to be begun again, and no time was to be lost, as the new pontiff was in France. A messenger was at once sent off to state the case, and enlist the sympathies of the pope, and Thurstan prepared to follow him. He must cross the scas to Normandy, and pass on to have an interview, if possible, with Gelasius. It was treason to leave the comity without the permission of the king, and the ntmost secresy was necessary. Thurstan and a few companions make their way to London, seemingly upon a different errand.

s This letter is also printed in Eadmer, 92, and Mílmelyury, 156. Labbe, Conc., x., 655. Wilkins, i., 376. Ivo-

nis Camotens. Elpisc. Epistolx, 793. Rymer's Fiedera, n. $e$, i., 9.

i Eadmer, 92. 
They now separate to reach the coast as they best can. $\Lambda$ rendezrous in Normandy had been appointed. T'hurstan condescended to disguise himself, and rode to Dover with his father, and got safely across : the rest of the party took ship at Hastiniss. The plans of the adventurers had been laid with the greatest secresy, but still some rumours had reached the king, and Thurstan had been waiting for the rest a single night in Normandy when he was discorered. Henry demanded the reason of his coming,' and 'Thurstan, who was too honest to shur over or conceal the truth, gave him a prompt reply, "It is neither" fit nor deeent for myself or my church that I should remain in York an archbishop merely in name. I know too that the arehhishop of Canterbury is the cause of this. He is aware that I have letters from the pope commanding him to consecrate mic. By his staying here to thwart me he has deprived both York and Canterbury of its metropolitan. I have come to see the new pope, that he may release me from my sinceure, but I shall not go to him without your knowledge and consent." 'The ling, satisfied apparently with the answer, told him that he would reply to what he liad said on the morrow. Some letters from Gelasius, evoked no doubt by 'Thurstan's messenger, had already reached him. The pope took up the cause of York with more warmth than his predecessor. If the dispute were continued, he desired Hemry to send both Ralph and Thurstan to the papal court. To the former he used the strong language of indignant reproof.

Soon after this Thurstan had an interview with Ralph, and offered to give him Paschal's letters which he had so longr retained. Ralph would not receive them. Of what use are they, he cried, for that pope is dead? At last he promised to inspect them, and then to give his answer. He now began to defend his conduet. He could not, he said, consecrate Thurstan out of England, and, at present, he had no intention of returning, as he was going to see the French king. Thurstan upon this again begged Henry to allow him to meet the pope, but in vain. He might send a messenger, if he liked. Nnother delay now mexpectedly arose. 'Thurstan's messengers were with the king of France at Vereignies when they heard that Gelasins was dead, and that he had been interred at Chony.

Guy, arehbishop of Vieme, was his suceessor moler the title of Calixtus II. He was elected to the papal chair in the becrinning of February, 1119. As he had been so recently appointed, he very properly declined to proecel to the immediate consideration of appeals. He spent some time in a tour through bur-

$j$ Eadmer (93) says that Thurstan came to the king at Rouen. He fort- bade his journey "donec certioren de wrocesu japa sententian edisceret." 
gundy and Aquitaine, and at length held a couneil at Narbonne. IIe there heard from many moutlis the story of the wrongs of Thurstan. He wrote at once an angry letter to Ralph rebuking him for his pride and disobedience. The archbishop was alarmed, and wished to explain his conduct in a personal interview; but the king of France and the comte de Angers, who had warmly espoused the eause of Thurstan, refused to grant him letters of safe-conduct, or to allow him to enter their territories. Ralph, therefore, conld only write a deprecatory letter. He begged not to be censured unheard. He expressed his willingness and ability to explain everything to the pope, if he were only permitted to visit him. He had not received the mandates of Paschal and Gelasius whilst they were alive; how then could he obey them? In a subsequent epistle he spoke in a somewhat humbler tone, and endeavoured to vindicate himself from the charge of pride.

It was most necessary for Thurstan's interests that he should have an interview witl Calixtus, but he was retained by the ling's side. Ralph was now thoronghly alarmed. He knew that the pope was offended at him, and that Thurstan had many powerful supporters. Calixtus was at no great distanee, and he was terrified at the idea of his opponent reaching him. He entreated IIenry to send Thurstan lome to England. He, it will be imagined, was as anxious to remain. Of what use, he said, ean I be in my church of York at the festival of Easter which is approaching? How can I consecrate or celebrate as I ought? 'The matter was deferred; but Henry expressed a wish that he should return as soon as Easter was over. Thuurstan placed himself at the disposal of Crod and of the king.

The pope had now resolved to hold a council at Rheims; and summoned to it the prelates who bare office in Franee, (icrmany, Burgundy, and Provênee. He requested Henry to send his two archbishops, and told Ralph that he would there be obliged to answer for his disobedienee. The king was perplexed. 'Thurstan saw by this time the folly of trusting to his promises, and resolved to leave Normandy before long, whether If nury wished it or not. He songht, for the last time, his leave to be present at the council to which he had been invited; but it was refused unless he would pledge himself not to receive consccration from the pope. Thurstan would promise nothing; and sheltered himself moder a text, that never-failing resource of ecclesiastics when they were in a difficulty. He wonld render unto C'asar the things that were Casar's, and unto God the things that were God's. ${ }^{k}$ At this crisis the bishop of Exeter,

$k$ Farmer (91) says that Thurstan was ander a strict obligation that he 
the well-known William de Warlewast, eame to Henry from Calixtus, and told him that Thurstan might safely be permitted to depart, as there was no ehance of his being consecrated. The king, therefore, allowed him at last to go.

Thurstan left the court with the delight which the released captive feels. He had been too long one of Pharaoh's bondsmen not to value the blessings of liberty and freedom. He was speedily at Chartres, where several of his friends were waiting for him who had promised to aid him in his flight, for which preparations had been made. They were overjoyed to find that he was not a fugitive. Four days after this the party reached the papal court at Tours. His reception was cordial in the extreme. Pope and prinee secmed to vie with each other in the warmth of their praises and attentions. The sufferings which the honest-hearted English priest had borne so heroically for five long years had won the sympathy of all. ${ }^{l}$ He met Calixtus at the celebration of the great feast of Easter in the ehureh of St. Maurice at Tours, and for half a year he was seareely ever from his side. The charm of manner which had fascinated the Red king, and captivated or mollified his suceessor was now visible to all. Thurstan played the courtier with the ease and dignity which were native to him. He was full of ready wit, with a great facility of expressing himself, and a marvellous power of adapting himself to others. No one was more realy to receive or to manifest a kindness. He beeame a great farourite with king Louis and his nobles. He was flattered and arlmired by all. And yet in those days France had children of her own who were full of piety and genius. What country has not heard of Clairvaux and its sainted founder? How many have wept and wondered at the learning and the loves of Abelard?

There would be much curiosity to know what Calixtus would do to restore Thurstan to his right. At the castle of Blois two of the York arehdeacons and a scholar, who had aecompanied the exile, placed his case before the pope, who promised, in kind terms, to consult with the Sacred College. They spoke to him again near Paris, some time after this, when Calixtus was leaving the church of St. Martin des Champes, and he expressed his hope that everything would be arranged at the comeil.

and that the pope had also made a promise to Sieffrid, the king's messenger, that he would do nothing to injure the see of Canterbury. This statement has been adopted and followed by Symeon, col. 240; and Malmesbury, $156 b$; and, partly, by Diceto, col. 503 . Bromton, col. 1008, 101 t. Gervase, col. 1661. Wendorer, i., 470. Chron. Petrib., 79.

1 Earlmer (91) insinuates that he won their favour by bribes. Ile is followed and rutoted by liceto, col. 503. 13romton, col. 1014 . Wendover, i., 170. Chron. l'etrib., 79. 
'That assembly was held at Rheims in October, 1119. It was to begin on the Monday. On the Saturday erening the pope sent for' 'Thurstan, and told him, to his great delight, that he should be consecrated on the morrow. The archbishop of Canterbury was not coming, and the bishops from Normandy and England had not yet arrived. Ralph, bishop of Orkney, was at Thurstan's side. He had come to Rheims two days before with one of the lork arehdeacons, on a visit to the exiled primate.

The scene at Rheims on Sunday, the 20th of October, 1119, must have been a magnificent one. Many a brilliant speetacle, many a stirring adventure, has that fair city witnessed. It is associated with French history from the very earliest times. The sovereigns were crowned within its walls. We think of the trimmphs and the munifieence of Clovis, and the most striking incident in the vietorious eareer of the Jungfrau. We see her looking upon the city, and listening to the words of the black knight:-

\footnotetext{
"Schan hin! Dort hebt sich Rheims mit sciner thürmen, I as ziel und ende deiner fahrt-die krrppel Der hohen kathedrale siehst du lenchten, Dort wirst du cinzichn im triumplyepräng, Deinen könig krönen."”
}

Hodoardus has deseribed the glories of the archbishoprie which diates from the close of the third contury. No less than nine of the early prelates who presided over it are enshrined in the calcudar. We can still read of the learning of Hincmar, of the miracles of Romigins, and his wondrons walk. In the beginning of the twelfth century Rheims was one of the greatest sees in Emrope. At least fifteen comeils had been held at that place; and, at the most recent, the terrors of exeommunieation had been thmolered against the emperor Henry. On the occasion which 1 shall now describe, the great church of St. Mary was (rowded with illustrions ecclesiasties who had come to take part in the clelibcrations that were to begin on the morrow. An honest and simple-hearted priest was in that throng to wituess, after year's of suffering and neglect, his own triumph. There would be but few there who were ignorant of Thurstan and his trials. Now he was to be rewarded. Calixtus summoned him forth, and conseerated him with his own hands before that vast atsembly." One voice alone was raised against that act. John,

" Saxon Cluron., 331. Eadmer, 9.4. Fl. Wieorn., 194. Chron. Mivilros, 66. Sirmom, col. 210. Jolun of IIexham, (ril. 266, who says that 'l'hurstan was monserated "intereententibus cardimalibu." bicete, en?. Ser3. Brom- ton, col. 1008. Gervase, col. 1661. Kinyghion, col. 2379, who censures the pope. Nalmesbury, $131 b, 156 b$. Horeden, 272. Mat. Paris, 56. Ann. Waverl., ajnd Gale, ii., 147. Hemingford, ibid., 174. Iabbe Conc., ix., 878. 
archdeacon of Canterbury and the nephew of the arehbishop, was the only representative of his ehureh who was there. Indaunted by the presence in which he found himself, and careless of sympathy or aid, he arose, and, with an honest intrepidity, protested against this apparent violation of the privileges of lifis uncle and his see." What he said was disregarded. 'The Italians laughed at him; and as he left the church, he heard around him several expressions of contumely and insult. Ralph, when he heard of what had occurred, wrote a long expostulatory letter to Calixtus. ${ }^{\circ}$

Late on the same day, the English and Norman bishops arrived at Rheims. Henry had desired them to oppose the consecration of Thurstan, and to send him home if lie should be disposed to neglect their adrice. As they neared the city they heard of what had been done. They were greatly troubled and perplexed. There were some who looked with sorrow upon the too eertain eonsequenees of Thurstan's disobedience. The bishop of Exeter, in particular, reproached himself for advising the king to permit him to leare the court. All, however, were agreed as to the folly and heinousness of the offence, and they resolved to have no communication with the culprit. On the morrow, when they went to the council, they kept aloof from him. Flambard, his own suffiragan, would not sit beside him lest he should offend the king. The faithful bishop of Orkncy was the only prelate who was near him. Several of his old friends, however, seem to have seen Thurstan secretly during the continuance of the council. He heard from them that he would certainly be disscised of his archiepiscopal lands. The king of England was excessively indignant when he heard what had occurred. He rowed that Thurstan should never return to his country during his own life unless he professed obedicnce to Canterbury. ${ }^{p}$ He then marle enquiries about the pall, but no one conld say that it had been given. The pope presented it to Thurstan on the twelfth day after the conclusion of the council, and enjoined him to mention the eircumstance to no one as long as he was in France. Soon after

${ }^{n}$ Eadmer, 91. Labbe. x., 878, where it is said that the archibishop of Lyous kept away from the council on account of what was to be done. The jope, in answer to what John said, rindicited himself from the charge of breakings his word, "Quod feci, semper salvi justicia Cantuariensis ecelesice, si qua est, facio" (Hugh). In Martene ('I'hes. Aneed., iii., 881) it is said that Thurstan was at Rhoims with two suthing.

- Twysden, col. 1735-18, Milkins, i., 396-40.t, where the letter is printed entire. Sommer's Canterbury, part ii., 1.19 .

$p$ The elironiclers siy, in weneral terms, that he was forbidilen to retum, e.\%., Saxon Cluron., 310. Larmer, 9.1. Symeon, col. 21.1. 1)iceto, col. 503. birumton, col. 1008. Cierrase, col. 1661. Kuyerhtom, col. 2379. Malmesbury, 156 b. Mat. Paris, 56. Amn. II averl., apud Gale, ii., 117. Ileminglord, ibid., 473. 
this, when they were at Beanvais, Calixtus gave him a letter to his suffragans in the North of England, in which the bishops of Durham, Orkney, and Glasgow were addressed. The pope informed them that Thurstan had been dnly consecrated, and desired them to regard him as their ecelesiastical superior.

The comeil lasted eight days, and the pope was detained in Rheims for fifteen more, by an attack of illness. During this time Thurstan was not idle. Everything now depended upon his reconciliation with Henry; and how was it to be effected? He joined Conon, bishop of Preneste, and the other eardinals in entreating Calixtus to have an interview with the king, and to make peace, if that were possible, between France and England. He was desirons, also, that the pope should speak to the English king in his behalf. After much hesitation, Calixtus desired a conference, and mentioned a day and the place where they conld meet. Henry readily assented, for the pope and he were cousins. They saw each other at a church between the castles of Chaumont and Gisors, ${ }^{7}$ in the neighbourhood of Ronen. The king of France was at that time at Sens. On the question of peace, rery little seems to have been said. ${ }^{r}$ Both sides expressed their wishes for it, which it is easy enough to do when you have war all the while in your heart. The dispnte with Thurstan was then brought forward, and the pope and cardinals urged its speedy termination. Calixtus was indignant at Ralph of Canterbury and his disobedience. He had himself consecrated 'Thurstan, he said, to leave the matter undecided, and he was desirous of adjudieating upon it at Rome. He implored Henry to receive Thurstan kindly, as rumours of his punishment had alrearly reacher him. Henry, after accounting for the absence of Raluh from the conncil on the score of ill health, assured Calixtus that he conld not sratify him. He had made a row that Thurstan should not enter Gnoland during his life-time withont making the profession of obedience to Ralph, but not to his sneces:or's. Would the pope sanction and confirm this? Calixtus wonld not do so, and he told the king that as the profession would be mlawful, his vow was mulawful also, and that he wonld absolve him from it; but Henry cautionsly observed that he conld not aet otherwise withont deliberating with his conucil. All attempts to alter the king's determination were fruitless. It would have been undignified if Calixtus had begm to besecch. Nuthing more, therefore, was said at that time, althongh the pope was deeply offended and amoyed.

? This castle was built by William Rufuc, and strengthened by Henry, who frequently resided there (Win. Cieniticensis, alma Camden, 673). $r$ There is an account of this interview in Eadmer, 94-5. Symeon, col. 21. Bromton, col. 1008. Hoveden, 2726. 
Before Henry went away, some overtures were made to Thurstan, and he was entreated, for the sake of peace, to yield. They were indignantly rejected.

After this meeting, Henry returned at once to England and disseised Thurstan of his archiepiscopal property, without meddling with that of his elergy. He was reconciled with difficulty to the bishop of Orkney and the archdeacon who had been at Rheims, although they protested that their presence at the council had been accidental. Hard measures were dealt out to Thurstan at home, but, abroad, he was regarded with much sympathy and compassion. The pope was severely censured for not seeing justice done to him. Calixtus assured him that he should want for nothing from the chureh of Rome till he was restored. The cardinals made him their friend and companion. He heard causes among them, and was with them even in their secret conclaves. They gave him money and everything that he required. They openly expressed their displeasure at his not having been fairly treated by Rome. The archbishop of Rouen spoke on that point in strong terms. When the king and queen of France met them at the abbey of Ferrière, they begged him to advance Thurstan to a bishopric or some higher office, and he consented. When Calixtus was leaving Ferrière for Sens, he made Thurstan his legate in France, Aquitaine, and Normandy. This honour would have involved a separation from his friends and the retarding of his restoration. The exile would now think,-

\section{"Quam fessis finem rebus ferat, unde laborum Tentare auxilium jubeat, quo vertere cursus."}

With tcars and most earnest entreaties he begged for a contimnance of their good offices. They were at once promised, and from that time Thurstan was constantly in their company. They seemed to treat him with increasing kindness. At Auxcrre he contracted a friendship with two great and learned scholars, cardinal Peter de Pisa, and Guy de Castro, archdeacon of Pisa, and the friend of St. Bemard, ${ }^{s}$ better known in after-times as Celestine II. When the pope was crowned, Thurstan rode in the procession by the side of the bishop of Ostia, the most distinguished of the cardinals, and Calixtus gave him two hundred bezants of gold, the same sum which all the cardinals received. He raised, at the pope's request, the prorost of Geneva to the three minor degrees of orders, preparatory to his consecration as bishop of that beatiful province. He officiated at the dedication of churches, and arranged the programme on - such occasions. He was allowed to wear his pall eren in the

$$
\text { s. B. Bernardi Opp., ed. 1690, i., } 307 .
$$


presence of the pope, a very high and unusual privilege. Every little attention seems to have been shewn to him, which would gratify an upright man and raise the spirits of an exilc. ${ }^{t}$

Archbishop Ralph now made a last attempt to recover the ground which he had lost. Henry, at his request, sent the bishop of Exeter to the pope to see what could be done. Conon, the papal legate in France, had heard of his mission, and wrote about it to Thmrstan and the eardinals. Bishop Warlewast found Calixtus at Valencia. He was an old politician, and was well aequainted with the ways of the Roman court, but now he could do nothing. The cardinals and the pope were obdurate. As a last resonice, he desired Calixtus to make Thurstan render the recpuired profession, and then to send him as his legate into England. The meaning of this was so patent that there was no chance of its being aceeded to. Warlewast's bribes were of no avail, and his embassy was fruitless. He returned to Henry, haring shewn some better feeling towards Thurstan before he went. The shrewd politieian had probably observed some symptoms of a change. He must have witnessed the regard which all manifested towards Thurstan. Some too zealous elients of the Roman court were even desirous of molesting the ambassador on his homeward journey.

Calixtus at last resolved to act with energy and decision. He was in the neighbourhood of Rimini, the point nearest to Rome that Thurstan then reached." It was resolved that the church of York should he for erer fieed from the profession to Canterbury, and that to the eharter of exemption the papal bull should be affixed. This, together with letters to the clergy of the diocese of York and to Hemry, who was threatened with excommunication if he were contrimacious, was to be conveyed to the English court by the archbishop of Tours and the bishop of Beauvais. Thmustan now made himself ready for his departure. The pope gave him his benediction, together with some relics which Thurstan had desired, and which were treastred long afterwards in the minster at York. ${ }^{.}$He made him a present, also, of some holy oil. "If you had asked me for my own blood," Calixtus jocularly observed, "you should not have been refused." The bishops and cardinals escorted him without the town, and bade him farewell with many tears and expressions of their affection. For half a year he had lived with them as a brother, and he was deeply grateful for their kinduess. Before he started on his journey he had heard of the

t Eadmer (95) says with a sneer, "Thurstanus from secutus est, sed non diu ab eo, ne prasentia ejus gravarctur, detcutus." u The Saxon Chron. (341) tells us that he went to Rome.

" Fabric Rolls of York Minster, ed. Surtees Sioc., 152. 
death of his old adversary, Ralph of Canterbury, and every one wonld now feel that the chief stumbling-block in the way of his restoration had been remored. 'The news, however, was premature: Ralph had been seized with the palsy, but he survived this attack for two years. ${ }^{x}$

'Thurstan's journey resembled in some respects a triumphal progress. All along the route he was treated with eourtesy and respect. Every castle was open to him, and he was weleomed everywhere by the elergy and the laity. They assured him that if their resourees had not been erippled by the reeent visit of the pope he should have had a far more befitting reception. Thurstan entered Franee, but, prudently and like a good patriot, aroided an interview with the king, who was an enemy of England. He beeame the guest of Adele, eountess of Blois, and her son eount Theobald. That high-born lady was a daughter of William the Conqueror, and was sister, therefore, to Henry I. She was delighted to receive 'Thurstan. He soon paid a visit to Rheims, and thanked the archbishop, who scems to have supported him to a great extent during his exile, for his kinduess. At Soissons he met the legate Conon, who had always been his friend. After an affectionate greeting, Thurstan told him about the letters from the pope, and desired him to make provision for their transmission to the English court. After this he returned to the eountess of Blois, and was with her several days. ${ }^{x}$ During this time he had many conversations with her about taking the veil, and she resolved to do so. On Easter-day, 1120, he sang the high mass in the church of Coulomb, the first oeeasion of the kind on which he had worn his pall. Three days after this he had another interview with the legate, who informed him that the archbishop of Tours and the bishop of Beauvais were too much oceupied to go on the mission to Henry: two persons of repute and learning, an abbat and a prior, would act in their stead. Thuustan now went back to the countess of Blois, and with a noble train aceompanied her to the eonvent of Marcigny, where she professed herself a nun. She had been the wife of Stephen, eomt of Blois, in 1081, and had borne him six children, one of whom was Stephen, king of England. She was a woman of a masculine and intrepid spirit, with little feminine delicacy or softness." Her elder son was disinherited by his father through her instrumentality.

w In the Anglia Sacra (i., 7) it is said that this attack disabled Ralph, and made Thurstan bolder.

$x$ John of Ilexham (col. 266) speaks of the influence Thurstan had over this lady.

" "Qua, quidem, testimonio regis
Ludovici et principum totius Francix, nulla prudencior, nec melins composita, nee magis virilis virago ex multa retro rtate in tota Gallia extiterat" (IIngh). Iro, bishop of Chartres, did not hesitate to rebule her in strong lampuage (Ejist., ed. 1610, 1.322). Hildebert, 
Iler husband died in the East in 1102,z and after his decease, in conjunetion with her son Theobald or Thibant, she ruled orer the lands of Blois. She died in the convent of Mareigny in $113 \%$, having been a $n$ mu for seventeen years. ${ }^{a}$ She went to that place in all probability at the suggestion of Thurstan, who had bcen present when it was conscerated by Calixtus a few niontlis before the countess took the veil. ${ }^{b}$ About the same time, or a little later, we hear of Thurstan joining Geoffrey, arehbishop of Rouen, and attending upon Eudo, the dapifer, in his last sickness. ${ }^{c}$

The two ambassadors now started for the English court, and found Henry in Normandy. The letters were delivered authorizing the restoration of Thurstan, doing away with the profession, and quietly speaking of other weapons which the pope conld wield if his wishes and directions should be disregarded. ${ }^{d}$ The king's answer was, as usual, delayed. After three disappointments the messengers hinted to Henry the necessity of wise comnsels, as he would be written to, in the next instance, in a rery different tone. The king expressed his wish to follow the adrice of the legate, with whom he had hitherto been on unfriendly terms. Conon refused to meet him, and charged him with deceit and treachery, but at last he was prevailed upon to agree to the interview, which took place at Châteaux-Landon on the Sunday after the Ascension. Thurstan, who was at Marcigny, knew what was being done, as he harl a friend at court. At the king's request he came to the place of meeting, and whilst Henry and the legate were talking to each other, Thurstan was in the castle hard by. Henry told Conon that on aceount of his row he could not gratify the pope's wish unless Thurstan wonld make the profession to Canterbury. Conon told him what Calixtus had previously said, that as the profession was wrong the yow was also unwarrantable, and that he should be, and was, released from it. After a long and a somewhat angry debate, IIenry promised to reinvest Thurstan, and give him the temporalities of his see if he wonld not enter England for a time, and he desired the legate to assent to this. Conon refused, and there was every ehance of the negotiation being broken off, when some one limted to the king that Thurstan, perhaps, might be more eompliant than

lis-hol, of Mans, thought somewhat diffirmtly of her, especially when she trosk the veil (Hildeberti Elist., ed. $17(1), 5-7)$.

z Triveti Ann., 4.

a L'Art devérifier les Dates, ii., part ii., 615-16, ed. 17s1. Recmeil des Hint. les firules, xi., $58 \%$. In both these works the countess is said to have become a nun in 1122 .

$\checkmark$ Recueil des Hist. des Gaules, xii., 75. It was an ancient foundation, but the inmates now beeame nuns instead of canons (Mabillon, Ann. Ben., vi., S6-7).

r Ibid., 791.

d Eadmer, 101. 
his friend. It was a happy suggestion. The exile was waiting eagerly for the issue, and when Conon told him what had happened, he entreated that the point might be given up. With some difficulty he indueed him to eede it, and the two friends returned into the presence of the king. After many months, nay years, of anxiety and negleet, there was peace at last between the monareh and his subject. Kind words were at length spoken with mutual assuranees of forgiveness and goodwill. Things were to remain as they were till Miehaelmas, but Thurstan might come and go in Normandy as he pleased. A message was sent to England to annomnce his re-investiture. The party now proceeded into France, and Thurstan had an opportunity of exhibiting his diplomatic skill, and of returning good for evil. His influence with the legate and the chief estates of Franee was the chief cause of the restoration of peace with England.e Henry was most grateful and delighted. It was this ill-feeling between the two nations, and the peril which consequently threatened his French possessions, that had detained him so long in Normandy, and he was now eager to go home. It was Miehaelmas, and the king was ready for his journey. The peacemaker would gladly have aceompanied him, but he was again detained. The delay bore some good finits to Henry and his subjects. A couneil was held at Beauvais in Oetober, 1120, moler the presidency of Conon. Henry was desirous that the Norman bishops should be exempted from attendance, and they stayed at home. The prelates who were at Beauvais pronouneed them guilty of eontempt and worthy of exeommunieation, which would probably have been their pumishment had not 'Thurstan hastened to Beanvais when he heard of the danger, and mediated sucessfully in their behalf. Henry would now be more grateful than ever. He expressed his friendly feelings towards the legate in an interview at Gisors in the presence of the bishops of Châlons and Senlis, when he paid him the great eompliment of asking him to superintend the sees and abbeys in Normandy. Conon, upon this, ventured to hope that the negotiations about Thurstan would speedily be arranged to the satisfaction of Calixtus. Heury reeiproeated the wish, and promised that they should be eompleted. Many kind words were spoken on both sides, and IIenry, eonscious at last of Thurstan's value, told his bishops that he would as lief have lost five hundred marks as have been without him. The king was ready now for his homeward journey, and moved by slow stages towards the sea. He set sail fiom Barfleur on the 25th of November, 1120. IIe had previously requested 'Thur-

- Symcon, col. 212. Horedelt, 273. 
stan to remain behind till Christmas, as he wished to have an interview with the bishops of the English ehureh, and the archbishop assented. $f$ William, Henry's son, followed his father in another vessel with a great company of nobles. The hand of T'rovidence was npon Thurstan when he stayed behind. In a freak of mad folly the young prinee and his friends allowed their ship to run ipon a rock, and every person on board, but one, was lost. The disconsolate father was an altered man after that sad November: he was never observed to smile after his son was drowned.

\section{"The bark that held a prince went down, The sweeping waves rolled on; \\ But what was England's glorions erown To him that wept a son? \\ IIe lived-for life nay long be borne \\ Ere sorrow break its chain; \\ Why comes not death to those that mourn? \\ He never smiled again!"}

Thurstan was with the legate at Chartres when this disaster oceurred, and his heart bled for the master who in bygone days had so decply injured him. Henry, in turn, remembered him, for he was changed for a time and softened by affliction. At Christmas he ealled together the arehbishop of Canterbury and his suffragans, and shewed them the letters and the mandates of Calixtus. They dicl not dare to disobey them, and a royal messenger left England to summon Thurstan to his country. ${ }^{g}$ He was at that time at Ronen, and he was not slow in obeying the weleome invitation. Three days before the feast of the Purification he erossed the seas and hastened to the court at Windsor. The king, the queen, and erery one seemed desirous of making amends for the past. But he did not tarry there long. He hastened into the North. When he drew near to lork a rast multitude was ready to receive him. Great numbers of people, on horseback and on foot, lined the road along which the was to pass. Knights and nobles, canons and monks, men and women of erery grade and age, welcomed their longlost diocesan. That Lent would not soon be forgotten in the North: nor would the delight of the listening and admiring throng be diminished when, seater in St. Peter's chair, in that noble chureh whieh Thomas the Norman had so recently adomed and renorated, on the third day after his arrival, he recited in the ears of that rast crowd of worshippers ${ }^{h}$ the papal

soreden, 272.

g Saxm Chron., 311. Symeon, col. 24. John of Hexham, col. 266-7. Bromton, eol. 1011. Malmeshmy, 15t;b. Horedri, 272. Amm. Witreri., apme fiale, ii., 11s. Heminsford. ibid., 475.

${ }^{h}$ John of Hexham (267) says that Thurstan was enthroned on this occasion. A repetition of this ceremony would probally be necessary. 
privilege with the immunities to his church of which he was so proud. To win this he had spent years of exile and disgrace,sufferings, too, under which a craven spirit would hare giren way, and injuries and injustice that would have palsied any but an honest and an intrepid heart. At last he had been trimuphant, and this was his reward; and eren then, when he most of all required the aid of others, he was careless of himself. $A$ poor neglected exile returning from a banishment in which he was entirely dependent on the charity of others, might surely have accepted, what others generally were at all times too rearly to evoke, the generous benevolence of his compatriots and his clergy. But Thurstan would not. Instead of relieving himself, as he might very properly have done, he at once began to lighten the burdens which pressed npon his diocese.

Fain would Thurstan have spent the rest of his days in peace, studying the spiritual welfare of the North, from which he had been too long separated. There was to be more amnoyance for him still. It was scarcely to be expected that the church of Canterbury would forget her defeat. Archbishop Ralph, with the cold touch of the palsy alrearly benumbing lim, began another attack. He gained the ear of Henry, who scems to have been always amenable to his influence. He told him that the monks of Canterbury had discovered several papal grants and privileges, assuring to their church the rights on which Calixtus had trenched. ${ }^{i}$ He said that as there was one king, so there ought to be but one primate. Henry, too prone to gossip and mischief-makers, listened to what he said. In August, 1121, he sent a messenger to Thurstan to summon him to a great council which was to be held at Michaclmas. When the archbishop arrived, Henry, to his great astonishment, revived the old subject of dispute in bidding him make his profession to Canterbury. Thurstan's answer was an excellent onc. "If I refused to make this profession before I was formally exempted from it by the pope, I am much less likely to submit to it now. Why does the king ask me to do this, which, if done, would bring me under an anathema?" Henry lost his temper, according to his wont, but it was to no purpose. 'Thurstan told him that if the papal order were recalled he would profess at once. The privilege granted by Calixtus was scnt for, and tears of rage and vexation gushed from Henry's eyes as he read it. Flambard and Nigel d'Albeni, an old fricnd of Thurstan, were standing by in sorrowful amazement. 'The document was then shewn to the bishops, at the king's request, by some of Thurstan's officers, in the absence of their master. 
"It is a forgery!" they eried. "It cannot be that," said one of the lork clergy, "as I saw it myself eome from the pope's lands ; nay, there is one line of it which he wrote himself." No reply contel be made to this, and the men of Canterbury wore minte. Tro or three days after this Ralph was seized with the attack of illuess muder which he ultimately sank.

'Thurstan's troulbles were not yet over. In 1122 there eame a messenger frem Rome summoning the two English archbishops to a conncil at the Lateran. Ralph had already gone to his ineonut, but Thurstan received the papal mandate. It was soon whispered to the king that he had done so without the royal sunction, and Henry ordered him to be at court to explain his conduct at the next festival of the Purification, and to bring the nessenger' with him. 'This was quite impossible, as 'Thurstan har not the least idea where the man was gone. A council was to be held at Gloncester in February, 1123, to ehoose a new archibhop of Canterbury. Three clays before it met, Thurstan was with the king, and little, if anything, was said about the papal letter. He went in the royal train to Gloneester. William de Corbeil was there elected, after much angry debating, to fill Augustine's ehair. "Who is he?" asked the king, and then 'Thurstan and Adelulf, the prior' of Nostell, who was afterwards the first bishop of Carlisle, spoke in ligh terms of his piety and learning. Thurstan himsclf had taken no part in the election, as he was the liead of mother provinee, and the bishops would not permit him to be present. The duty of consecrating Corbcil, according to aneient custom, now derolved upon Thurstan. The king, who was aware perhaps that there might be some difticulty in the case, asked him if he should oppose the consceration of the new archlishop by his own suffragans? He told Henry, after some deliberation, that out of regard to him lie would be ready to waive his claim on this oceasion, but he decired every one to know that he was ready to do his duty. Ile then sent Geoffrey abbat of St. Mary's York, Adelulf, prior of Nostell, and others of the York archdeacons and canons to Corbeil to gire him the same intimation. The arehbishop(lect was with the bishop of London when they arrived. He told them that the separation of York from Canterbury had ahrogated the old custom.j In reply to this Thurstan's friends informed him that the assigning to each see its proper rights and privileges did not constitute division, and expressed, on the part of their master, his readiness to do his duty. The two prelates returned an evasive answer, that for the present it conld

j Symeon (col. 21s) puts the following words into Corbeil's ruoutl: "Si ne ut prinatem totius Angliw volueris ordinare, libenter me manibus vestris inclinabo, sin autem, inconsulte contra morem antiquam nolo oldinari." 
not be done. Thurstan now spoke to Henry of the pope's recent summons to the commeil, and asked his jermission to set out. The king begged him as a favour to delay his journey till the archbishop of Canterbury could go with him to procure the pall. He undertook, also, to aequaint the pope with the cause of his absence, and promised that the bishops from Normandy, and Jeremias, arehdeacon of Rouen, should remain in Rome, after the comeil was over, till they arrived. Corbeil and he were then requested to be at Woodstock on the first Sunday in Lent that they might start from thenee to Rome. All this was done in the spring of 1123 . They met at the appointed time, Corbeil in the meanwhile having taken the unwarrantable liberty of receiving consecration at the hands of the bishop of London and his own suffragans. ${ }^{k}$ Thumstan, however, seems to have made no complaint. At Woodstock Henry requested him, through the prelates and nobles, to assist his brother, when they were at Rome, to the ntmost of his power, and to make no mijust elaim upon him whilst they were there. To this Thurstan assented, and the two started on their jonrney. By an accident Thurstan reached the papal court bcfore his fellow-traveller, and he found there many of his old friends, who were rejoiced to see him. Corbeil arrived shortly afterwards with a long train of ecclesiastics, among whom were Bcrnard, bishop of St. Darid's, and the abbats of Glastonbury and St. Edmund's. ${ }^{m}$ He now became a suppliant for the pall. On this question there was a long debate. It was allegerl that Corbeil's election and consecration had been uncanonical, and it was decided that the pall should not be given to him, but that he should be permitted to aceept a bishopric. Thurstan now pleaded in his behalf; indeed, during the whole controversy he acted towards Corbeil in the most generons and honourable manner. He praised his piety and learning, and entreated the pope and the sacred college to alter their decision in consideration of his royal master and the emperor, who had furthered the suppliant's canse. After a suspense of fifteen days, through the ageney of Calixtus the sentence was reseinded, out of respect to the emperor, and Corbeil reeeired the pall. II is party now turned upon Thurstan in the most migrateful manner. As soon as the pall had been scenred, the bishop of St. Darid's raised the old question of the profession and the primacy in a tone which he afterwards regretted. He assured Calixtus that

${ }^{k}$ Symeon, col. 218. Gervase, col. 1662.

'Fl. Wigorn., 497. Chron. Mailros, 67. Chron. Petrib., 81. ILuntingdon, apud Savile, 219. Hoveden, 274. In the Saxon Chron. (217), it is said that Thurstan was reconciled to Corbeil, and swore subjection to him! 604.

"Symeon, col. 218-50. Diceto, col. 
the recent papal grant was in direct contravention of the old privileges of the church of Canterbury. 'Thurstan seems to have deprecated any discussion; he observed that he was quite umprepared for anything of this kind ; he had come at the present time to please the king; had he thought of himself he woukl have been at the recent comeil. Bernard was ordered to produce the privileges of which he spoke. He read them. They had a show of genuineness withont the sapor. He was now assailed with some awkward questions. "Had these privileges the bulls appended to them ?" "No; but the originals had whieh were at home." "Vould they swear that?" After some hesitation they said that the bulls were either wasted away or lost. At this there was a general titter. "If the leaden bulls liad wasted away, was it likely that the parchment was remaining ?" They then hinted the possibility of the nonexistence of the bulls at that early time, but this straw was plucked away from them. Bribery seems now to have taken the place of argument, and the ehamberlain of the pope,-a person of great influence at Rome,-scems to have been bought orer. 'Thurstan was asked about the muniments of the see of York, but he had none of them with him. One of his followers, however, had several copies, and the letters and decrees of Gregory, Honorius, Urban, Paschal, and Calixtus were recited. They could say nothing about the originals possessing bulls. It would, therefore, have been elearly unfair to decide the matter at present in farour of either disputant. Calixtus proposed to fix a time when the matter eould be debated upon proper eridence. Thurstan was ready to agree to this arrangement, but Corbeil declined to do so without the permission of his sorereign. The two arehbishops, therefore, returned home; the one with letters from the pope announcing the reception of the pall, the other with a commendatory epistle to Henry, in which Calixtus spoke in high terms of the wisdom and usefulness of his old friend. As soon as the Canterbury party reached the eourt in Normandy, many unkind speeches were made against Thurstan, but the slander seems to have made no impression upon Henry, if we may judge from the welcome which the arehbishop of York received on his arrival. He was accompanied by abbat Anselm ${ }^{n}$ and others, who told the king a very different story from that which he had heard. They said that Thurstan had behaved towards Corbeil in the most homourable manner, and that without his generous mediation he would

"Anselm was not a favourite. In 1131 , when he was elected to the see of London, Thurstan wrote to the pope and told him that Anolni was nore fit to lose his abbey of St. Edmund's than to gain a bishopric. He was not allowed to be consecrated (Diceto, col. 506-7). 
never have received the pall. In the following September Calixtus wrote to Corbeil blaming him for his attacks on Thurstan, and entreating him to banish malice from his leart.

In 1124 Calixtus died, and was succeeded by Honorius II., who sent the cardinal of Crema as his legate into England. Corbeil now renewed his claims and complaints against 'Thurstan, and desired the pope to anthorize his legate to bring them to an amicable arljustment. About Pentecost the two archbishops received a mandate from Honorins summoning them both to Rome. They went to the court in Normandy. 'T'un'stan was astonished when he heard the king require him to put his churches in the position which they had ocenpied during the reign of his father and brother, otherwise he should regard him as a traitor and an enemy. Thurstan, with his usual address, defended himself from the charge of treason, and said that he would gladly allow his churches to remain as they were in the time of his predecessor Aldred, who had crowned the Conqueror. "No," replied Henry; " they must be in the state in which my father left them." "Thurstan declined to do this, and appealed to the papal privilege as his warrant. He was now, he said, on his way to Rome, was it fair that he should be obliged to defend himself in two places against the same attack? Every effort was made by the king and his couneil to bring the matter to a conclusion. An offer was even made that if 'Thurstan would merely verbally acknowledge Corbeil as primate, committing his successors to a more humiliating form of subjection, the see of Canterbury should be dismembered, and the bishoprics of Lichfield, Bangor, and another, which is not named, should be given up to York. This scheme was to be formally proposed to the pope, and about this, as well as the other plans that were to be mentioned at Rome, the king commanded that on the part of the English prelates there should be no controversy or dispute. The most important proposition was this, that the legantine power should be secured, if possible, for Corbeil and his suceessors. This would give them an exeellent title for superiority as the immediate representative of the pope. Of all the plans that could be devised for terminating the never-ending feud between York and Canterbury, this, perhaps, was the most sure. The eardinal of Crema had made anything but a favourable impression in England, and if the archbishop of Canterbury became the permanent legate there would be no necessity for the appointment of a foreigner.

The two arehbishops visited Rome in 1125, 'Thurstan being

- Ann. Waverl., apud Gale, ii., 119. The Saxon Chron. (352) and Chron. Mail'os (68) make the date 1126. Sy- meon (251) says in 1126, will the lesate; and again in 1127 by themselves, when Corbeil was made legate. 
acempanied by his brother and faithful companion in trouble, Audoenus, bishop of Evrenx.p The controversy in the presence of the pope exhibited many phases and fluctuations. Nothing, howerel, secms to have been done except the appointment of ('orbcil as legate in England. 'This was done entirely in accordance with the wish of 'Thurstan, who, at that time, had a very farompable opinion of Corbeil. IIe soon had oceasion, unfortumately, to regard him in a very different light. The archbishop of Canterluny owed his very election to Thurstan, but he returued him evil for goor. He took the part of the Scottish bishops when they endeavoured to break away from their allegiance to York. "He forbade lim to bear his cross erect within his prosinee, or to take any part in the coronation of the king." When Corbeil, in virtue of his power as legate, called together a comneil at London, he summoned Thurstan to it, but he very properly stayed away. The Sonthern primate complained of this to Ilenry, and the king told him that his past ingratitude to 'l'hurstan had fully merited that slight. For' some time there was 110 communication whaterer between the two archbishops.

An allusion has been made to the fend between York and the Scottish bishops. This was only a continuation of the old controrersy. The claims of York were nearly always questioned by the Scottish prelates long before they were for erer set aside. rialph Nowell, bishop of Orkney, resided generally with Thurstan, as the people of Scotland and Norways rejected him on accomt of his English consecration, in spite of the remonstrances of Honorits and Calixtus. Thurstan is said to have made Cilaldane bishop of Whitheme. ${ }^{t}$ He also consecrated Robert, prior of Nostell, to St. Andrew's, after the death of 'T'urgot and the intrusion of Eadmer, " but at the earnest request of king Darid he required from him no profession. ${ }^{n}$ It was the wish of the Scottich people and king that the bishop of St. Andrew's shonld be the metropolitan of Scotland, and on that account they were frequently coquetting with Canterbury to

$r$ In 1132 Audoenus and Thurstan dedicated the church "B. II. de casa Irei parthenonis Fontebraldensis" (Gallia (hristiana, xi., 575).

q 'This oceurred at Wind or at Christnats, 1126 . 1)iceto, col.501. Bromton, col. 1016. Gervase, col. 166t. FI. Wicoru., 502. Chron. l'etrib, 83. In 1127 , Wendover, i., 1.76. In Dugd. Mlon., vi., 1188, is a letter written by iIonorius to king IIenry, desiring bim to allow Thurstan to bear lis cross and to rrown him according to ancient custom.

$r$ Diceto, col. 504 .

' In Dugd. Mon., vi., 1] isf, there are two letters in his behalf from popes $\mathrm{Ca}$ lixtus and Honorius addressed to kings of Norway.

t Stubbs, col. 1720. In Dugd. Mon., ri., 1187, there is a letter from pope Honorius to the bishop of Whitlierne, ordering him to obey the Northern juimate.

"Symeon, col. 251. The consecration was delayed for a time on account of the subjection.

"Dingd. Mon., vi., 1187. Although he was a canon of York (Flor. Wigorn., 506). Fordun, Scotichronicon, ed. Goodall, i., 310. Anglia Sacra, ii., 237. 
obtain the emancipation of that sce from York." But it was in John, bishop of Glasgow, that Thurstan found his strongest and most pertinacions adversary. He is said to have been a person of piety and learning, and had been the tutor of prince David. Pope Paschal consecrated him bishop of Glasurow in 1115. He would render no submission whaterer to the see of York, and the result was that Thurstan suspended him for insubordination. This was in 1122. John now went to Rome to appeal against this sentence, but, his cause having been giren against him, he went off to Jerusalem, and spent sereral months with the patriarch, acting as his snffragan. In the following year Calixtus summoned him home, and ordered him to his diocese. ${ }^{x}$ But still he rendered no profession of obcdience, and paid no attention to any papal order. In 1I25, when 'Thurstan and Corbeil were at Rome, John, in an unlucky hour, was there in the train of the archbishop of Canterbury. Thurstan, unwilling to lose so good an opportmity, pounced upon John before the papal court, reproaching lim for his neglect of the mandates of Paschal and Calixtus, ${ }^{y}$ his desertion of his diocese, and his disobedience to himself : he made at the same time a general complaint against all the Scottish prelates. John defended himself by saying that he was there as the ambassador of the king of Scotland. Honorius told him in a warning tone that he must not expect to be releascd from the obligation laid npon him by Gelasius and other popes, ${ }^{z}$ and a day was fixed in the following Lent when John and the Seottish bishops shonld meet Thurstan before the papal court, and the question should be decided. Christmas came on, and the day of meeting was drawing near. Thurstan was at the court at London, and there he met with David, king of Scotland, John's old pupil, and Conan, earl of Brittany. Darid with some trouble induced Thurstan, as a personal farour, to beg the pope to put off the hearing of the canse for another ycar. This arrangement was with difficulty effected, but there is nothing to shew that Joln crer made the submission that was required." Innocent II. followed the example of his predecessors, and orderer him, apparently in vain, to obey Thurstan. ${ }^{b}$ In 1138, when Alberie,

* There are letters on this subject between Alexander king of Scotland and archbishop Ralph in Eadmer, Hist. Nov., 90, 97-100.

x Symeon, col. 2.15, 218.

y I have not scen these letters of Paschal. Those of Calixtus are in Ingd. Mon., vi., 1187-8. These are larily about John and partly about the Scottish bishops. Wilkins, i., $4 \mathrm{SI}$.

- Stubbs, col. 1719. Hugh the
Chantor, where there is a long account of the scene at Rome.

a Symeon (col. 252) says that in 1125 Ilonorius wrote to king I a vid, saying that he latd empowered his lesate to settle the dispute between Thurstan and the soottish lishops.

${ }^{b}$ Dued. Mon., vi., 1187-8. In Wilkins, i., 480 , is a bull of pope Jumncent II. subjecting the Scot tish bishops to 'Thurstan. 
bishop of Ostia, was in England as legate, he was told that John had descrted his cliarge, and professed himself a monk at T'iron, and he was summoned home to answer for his conduct. Joln died in 114\%, and was buried at Jedburgh. ${ }^{c}$ He is said by the Scottish writers to have atoned for his wandering and restless disposition in early life by his subsequent activity in advancing the interests of his sce. ${ }^{d}$

So much of Thurstan's life had been spent in controversy, which he could not shum, that he had but little time to take that position in the affairs of the cherch and state at home for which he was marked out by his genius and energy. In 1129 he was present at the conncil at London, ${ }^{e}$ and in 1133 he had the honour of presiding over that which was held at Northampton. $f$ In 1135 he was at the coronation of king Stephen, but he did not officiate. $g$ In the same, or in the following year, Stephen was at lork, and Thurstan, who had known him in another country and in an humbler sphere, would give him a hearty welcome. In 1137 there was a cloud gathering in Scotland, and 'T'hurstan went to that country as ambassador, and had an intervicw with king Darid at Roxburgh, at which he indnced that restless monarch to make a truce with England till the return of Stephen from abroarl. ${ }^{h}$ In the following year the Scottish army broke into the North, and, after sweeping the whole country before them, the invaders found themselves at Cowton moor, near Northallerton, a little after Easter. The crisis was a most serious one, but Thurstan, broken down as he was with age, was not unequal to it. ${ }^{i}$ He was carried about on a conch or litter wherever he was required. He did everything in his power to excite the spirit of the North. He sent the priests with crosses and bamners and relics through the parishes to arouse the inlabitants. He gathered together with speed

John of Hexham, col. 264, 276. Ric. of Ilexham, 325. Fordum, scotichmicon, i., 419, where it is said that Jolun, according to old custom, acted as a bi-hop in Cumberland. Henry I., at 'Thurstan's dc.ire, marle a bishop of (arlisle, and upon this John went to 'Tiron.

d Keith's Scottish Bishops, ed. 1824, 231-2.

'Intingdon, apud Savile, 220. IIoveden, ibid., $27+b$. Wendover, i., 178. Ann. Waverl., apud Gale, ii., 150. Mat. Paris, 60. Tabo de Monte, 701. Labbe, Conc, x., 910, 940. Sereral rlates are given for this meeting.

Fl. Wigorn., 519. Labbe, x., 991. Wilkius, i., 413 . g Opera Thomæ Becket, ed. Giles, iii., 69 .

'John of Hexham, col. 259. Chron. Mailros, 70. Chron. Petrib., 89. Liber Vitre ed. Surtees Soc., 59, 67.

i John of Hexham, col. 261-2. Ric. of Hexham, col. 320-1. Ailred, col. 338, etc. Fl. Wigorn., 524. Diceto, col. 506. Bromton, col. 1026-7. Gervase, col. 1346. Knyghton, col. 2385. Huntingdon, apud Savile, 222-3. Hoveden, 277. T'riveti Ann., 6. Hemingford, apud Gale, ii., 480. Peter Langtoft, n.e., 114-15. Scala Chronica, 33. Mat. Paris, 63-4. Chron. Petrib., 90. Rob. de Monte, 712. Dachery, Spicilegium, iii., $14 \%$. 
and labour the great barons of the district, allaying their jealousies and fears, and an army was soon collected. 'The ensign which the arehbishop sent with it to the scene of eonflict gave to that field the name of the battle of the Standard. The mast of a ship was erected upon a car, and from it were fluttering the holy banners of the saints of York, Beverley, and Ripon. A silver pix, in which the blessed saerament was enclosed, was fastened to the summit. A sacred influence would thus seem to hover around the little band of Yorkshiremen. Thurstan would fain have been there himself had not the barons insisted upon his absence, but his suffragan, the bishop of Orkney, the arehdeacons and the clergy were on the field to bid the God of battles go forth with their eompatriots to the fight, and to minister consolation to the dying. 'The aged prelate was thinking all the while of those whom he conld not see; he was praying for them with bitter tears, and eommending them and their arms to the Lord, when the welcome news arrived of the victory that had been won. He might well be satisfied with his own personal exertions in securing it, for he had certainly saved the North of England.

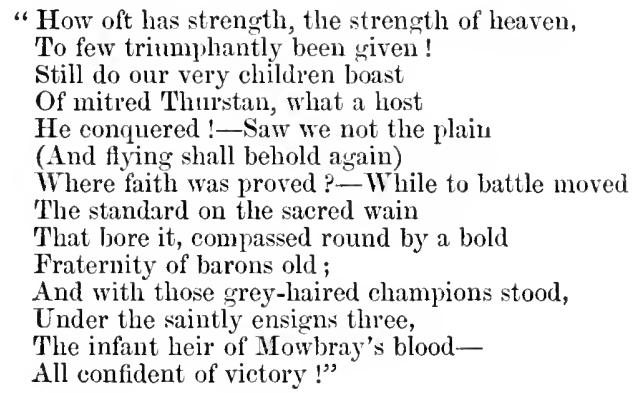

The province of York had good reason to remember the good deeds and the energy of Thurstan. The example which he set was worthy of all imitation, and his elergy might well regret his prolonged absence from his see. He was a man of learning, and several works have been attributed to his pen. Of these we have nothing but two or three letter's. In that which is addressed to archibishop Corbeil, describing the sceession from St. Mary's abbey, much kindly and devotional feeling is expressed, and the style is extrenely good and pleasing. ${ }^{j}$

$j$ Bale, cent. ii., 185, says that Thurstan wrote "De origine Fontanensis cænobii, lib. i. De suo primatu, ad Calixtum, lib. i. Contra jumiorem Anselmum, lib. i., et alia quredam."
The first of these works will be mentioned afterwards. Pits, 216. Vossius, De Hist. Latinis, 413. Wright, Biogr. Lit., ii., 109. Tanner, 728. Oudiuns, ii., 1122. 
The personal character of 'Thurstan was mimpeachable. ${ }^{k} \mathrm{He}$ hat learned in other lands the necessity of a stricter discipline than that which he saw at home, and, full of honest zeal and fervent piety, he was not afraid of practising it himself. Luxury was a strunger to his table. In his dress and demeanour he was almost an ascetic. The poor blessed him for his kindness and mmificence, for they had no surer friend than Thurstan. $\mathrm{He}$ was frequently on his knees, and tears streamed from his eyes when he administered the cucharist. He wore sackcloth next his skin, and disciplined himself with the scourge. Men of piety and lcaming found in him a patron and a friend. He was atlable and conrtcons, stem when severity was needed, and yet at all times ready to forgive. Thurstan did a great deal for his diocese, far more indeed than any of his predecessors. Pope lmocent advised him to divide the large parishes within his district, and this recommendation was most probably obeyed. ${ }^{l}$ It his enthronization he exempted his churches from the regnlar charge for the crisma, and made the fees for burial, cxtreme unction, and baptism, volmutary and not necessary."n He made aloo an ordinance abont the income of the canons thronghout his chmehes, which was beneficial to themselves as well as to the minsters in which they were located." Thurstan was most useful, too, and active in secing that all the ministers and ceclesiastical corporations were properly remmerated and cndowed. At York, Ilexham, Ripon, Beverley, and Southwell, he was a great benefactor ; and in 1137 there was a fire in the minster at York, which would be sure to eroke his munificence. ${ }^{p}$ II is also ('alled the fomder of the hospital of St. Peter, or Sit. Leonard, which was in comection with the cathedral. How fir this title was merited is somewhat doubtful. In 1122 Ifony I. kopt his birthlay at York; and at the request of fuech Matilla, who was instigated by Thurstan, the king yranted several privileges to that establishment himself, and prevailed npon his batrons to add to the endowments of the lonse." It was buned in 113\%; and, soon afterwards, it was

${ }^{k}$, Jolm of Hrxlam, col. 2067. Ric. of Hexlam, col. 306. Sinbls, col. 1711.

lier. Vian. Alhm at York, 53.

") subls, col. 1717, from Hush.

"Mid., 1720. Thimstan's Constitution, "De dubitis rlerieor'um defoncturum," is in Wilkins, i., 412.

dohn of Ilexham, wl. 267 . Pic. if Ilosiam, col. 306-7. Walbran's liijer11, 25.

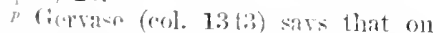
"Are. nomat d linii 1137. afud Eboracum combuntar. 1 B. Petri enclesia, uhi aedes est episs, et, extra muros, ecclesia B. II., ubi est abbatia, cum egregio hosjitali quod fundavit 'Turstinus archiepiscopux." Lel. also, apud Coll., i., 15. The fire in the minster was probably only partial in its effects and extent.

" IISS. Cotton, Titus A., xix., 55. Symeon, col. 216. There is a noble cliartulary of St. Leonard's among the Cottonian MSS., Nero D. iv. Some of the yearly account rolls of the hosfitul are also in existence. 
rebuilt by Stephen on a much larger scale, and reecived the name which it has since borne, that of the hospital of $\mathrm{St}$. Leonard.r At Ripon, Beverley, and Southwell, Thurstan was the founder of new prebends ;" and he was, doubtless, the means of the establishment, in 1133, of the bishopric of Carlisle, to which his old friend Adelulf, the prior of Nostell, was appointed. ${ }^{t}$ This was effected at the death of Ranulph Flambard, bishop of Durham, and the election of his successor, Geoft'ey Rufus, whom Thurstan consecrated at York." The see of Durham now subsided within the territorial boundaries which enclosed it until the Reformation. Within the last half-century it had been deprived of a great deal. It had lost Tynemonth and Hexham, Cumberland, Westmerland, and T'eviotrląle. The wiles and the instability of Flambard had, without doubt, been the main canse of this great dismemberment of his diocese. ${ }^{v}$

Thurstan is especially to be commemorated as the revirer of monasticism in the North. His intercourse with the ecclesiasties of other countries; the religions houses which he would see during his exile, exhibiting, as far as human ageney could effect it, the perfection of discipline and organization, would open his eyes to the wants of his diocese at home, and make him eager to meet and remedy them. The example and the exhortations of St. Bernard, with whom he was aequainted, would strengthen and nerve his hand. The letter which he wrote about the poor Cistercians of Fountains shews that he was thoroughly saturated with the monastic principle. His knowledge of it was of a kind that long study and practice could alone impart, and it seems to me that Thurstan, together with St. Bernard and two or three others, are to be regarded as the great Church reformers of the twelfth century. It was at Thurstan's suggestion that pope Honorius confirmed the privileges of the monastery of Sarigny, and he witnessed the grant of a hundred marks of silver which was made by Henry I. to the monks of Clugny, "w to which order the archbishop was especially attached. When Thurstan arrived in the North he would find there a very small number of religious houses, one or two of which were occupicd by Augustine eamons, and the rest by Benedictines. A new impetus was now griven to the diffusion of the monastic principle. The two existing

- Lel. Coll., i., 38.

s Dugd. Mon., vi., 1313-11. Walbran's Ripon, ed. 1858, 25. P'oulson's Beverlac, 531. Ferlera, i., 10, n.e. Thoroton's Notts, 310. Lel. Coll., ii., 391.

'John of IIexlam, col. 257. IIoveden, 275. Mat. Paris, 60. 'The fomdation of the see of Carlisle was com- fleted by king Stephen. Reg. Magn. Album, at lork, 53.

"Ifexham, ut supra. Simeon, Ifist. Eecl. 1) nnelm., 261. Stubbs, col. 1720. Chrom. Niailros, 69.

"simeon, ut supra, 256 , ete.

u IItrtere, Thes. Nov. Anecdot., i., 361, 382. 
orders were reformed and enlarged, and the Cluniacs and Cistercians, monks of a stricter rule, were bronght in. The time for their introdnction and for the revival of discipline was well chosen. The Norman and the Saxon elements in the English Chmreh were now happily blended together. Everything in religions as well as civil affairs was now settled and laid down. The great baronies and fees throughout the country were for the most part marked out. Peace and rest superindueed other and better thoughts. Many of the great knights and nobles had gricrons offences to atone for. They were living upon the possessions of others-very fretuently upon church property; and their lives had been stained with violence and bloodshed. The wish to make amends as well as to honour God, led them to establish monasteries where their souls might be prayed for, and to which their names, "in perpetuam rei memoriam," might be honomably attached. Wlien one leads, another soon will follow, and the erection and endowment of religions houses soon becane the fashion, but like every freak and sudden feeling of that kind it was only temporary. It began with the twelfth century, and it lid not outlire it. Thurstan was eminently successful in kindling this spirit of zeal in the North, for he was just the man that the feudal chicftains would most admire, although, on one oecasion at least, he was ill-treated by them. ${ }^{x}$ The energy with which he fought in his own conflicts was very much akin to theirs, for he was illustrious both in arts and arms. Between the years 1120 and 1125 six houses of Augustine canous seem to have been established in Yorkshire. Kirkham owed its origin to that great patron of religion, Walter l'Lispec," and Gisburgh to Robert de Brus, an ancestor of the well-known warrior, who was guiderl in what he did by Calixtus II. and Thurstan.z Bridlington, whieh overhangs the sea, was fonmded by Walter le Gant," and the arehbishop, who had probitbly directed him in his good work, was a witness to his charter of ('ndlowment. William de Meschines about the same time began to draw together the body of ecelesiasties which settled funally in the beantiful solitudes of Bolton, and Thurstan, to shew his sympathy, appropriated to them the neighbouring churches of skipton and Kildwick. ${ }^{b}$ The piety of Ralph Adlave, the confrissol of Hemry I., first seleeted the retirement of Nostel, ${ }^{c}$ from which, after a life full of romantic incidents, he was summoned in

Jolm of ILexham, col. 268. It is not quite clear that the offence here mentioned was perpetrated in Thurstan's life-time.

y Ailred, de Bello Standardi, col. 339. Ihigd. Mon., vi., 210. Burton's Ion., Ebor., 373.
= Bromton, col. 1018. Dugd., vi., 267. Burton, 340. There is some doubt as to the date of this foundation.

a Burton, $212 . \quad b$ Dugd. Mon.,

vi., 203-5. Burton, 115.

c Burton, 300. Hunter's South Yorkshire ii., 201, ete. 
1133 to be the president of the new see of Carlisle. In 1130, or thereabonts, Thurstan himself established the first mumery that had existed in the North since the Conquest, a house if Benedietines, at Clementhorp near York." In 1131 the beautifin monastery of Rievaux was founded, in memory of his lost son, by Walter l'Espee, and some Cistercian monks, who had be cu sent to England three years previously by St. Bernard, found a resting-plaee in that charming valley. ${ }^{e}$ ivilliam Paynel, at the instance of Thurstan, made a house for Austin canons at Drax, and another was erected at Wartre in 1132 by Geoffrey 'Trusbut, and was appropriated to the same order. $f$ The religious colony, also, which found its way to Byland, was greatly indebted to Thurstan for its suecess. The abbat of Furness and his monks had fled before the Scots, and had found an asylum in York, where the archbishop welcomed and supporter them. IIe recommended them to the kind offices of the widow of his old friend Nigel d'Albeni, who had assumed the well-known name of Mowbray, and she placed them at Hode till they were remored to Byland in 1138 by her son Roger, who was also the founder of the house of Newburgh. ${ }^{g}$ Thurstan had a great deal to do with the affairs of Selby Abbey, ${ }^{h}$ and he is said to have been mainly instrumental in restoring the church of Bardney. ${ }^{i}$ The York historians inform us that he was the founder of eight religious honses. How far this is to be interpreted it is diflicult. to say; at all events he seems to have been the chief agent in the erection and the establishment of many of those noble monasteries whieh used to be the pride and the boast of Iorkshire. With the history of these retreats rery few are acquainted. There are scarcely any who know the records of the adrentures of their first inmates, which are invested with all the thrilling interest of romance; their struggles to maintain themselves; their simple and earnest piety, and their subsequent suecess. As long as the ineurious reader turus away from subjeets like these he will know very little indeed of the inner working, nay

d Dugd. Mon., iv., 323. This house was given by archbishop Geoffrey in 1192 to the nums of Godstow (Benediet Petrib., 732).

e John of Hexham, col. 257, where the date 1132 is yiven. Ailred, col. 338. Bromton, col. 1028. Wm. Nenbrig., i., 51. Dugd. Mon., vi., 27 t. Burton, 358. There is some interesting information about the carly history of Rievaux in Opp. S. Berm., ell. 1690, i., 98-9. Martene, Thes. Nov. Anecd., iv., inter Statuta Capit. Gen. Ord. Cisterc.; Henriquez, Fascic. Ord. Cist.;
Miræus, Chron. Cisterc., ed. 1611, p. 89. 'The Reseripts of jope Alexander III. in Labbe, Conc., x. Mabillon, Ann. Ben., vi., 158-9. Chrom. Mailros. $f$ Jugd. Mon., vi., 297. Burton, 100,381 .

s Joln of Hexham, col. 259. Bromton, col. 1028. Wm. Neubr., i., 52-1. 1) ngl. Ion., v., 3 13-9; vi., 317. Burto11, 328 .

" Hist. Fund. Mon. de Selby, apud Labbe, Bibl., i., 608-10-a very curious historical tract with which few are aequainted. i Lel. Col., iii. 263. 
I will say, of the ontward features of the Church in the middle ages. If he will only take the trouble to examine them he will find that, witl all their faults, there were piety and devotion in times which too many have considered to be dark, and that there was some learning nursed and cherished within the eloister which later generations, with all their increased intelligence, liave been mable to surpass.

There was another monastery, greater than any which have ret been mentioned, of which T'hurstan, to a great extent, was the originator, and that was the far-famed abbey of Fountains. ${ }^{j}$ The history of its fomdation, as it has been described by Thurstan himself and the chronieler of the house, is a most touehing and charming narrative. In 1132 there was, what we may call, a rehellion in the monastery of St. Mary without the walls of lork. That well-known abhey had been but for a short time in existence when the Benedictine rule, which its inmates professed to follow, was practically despised. Immovations had crept in. Want of diseipline and neglect of duty had borne their bitter finits. All, however, were not polluted by the taint. Richard the prior and Gervase the sub-prior, upon whom the charge of the monastery to a great extent derolved, groaned in sfirit orer the growing evil. Fill of sorrow they sought counsel of their abbat, a kind-hearted but indolent man. Richard told him of his daily troubles, and of the insubordination of the monks. The immates of the house were noisy brawlers. They chattered and quarrelled when not a word ought to be spoken. In food and dress and many minute points their rule was neglected. How different they were from the monks of Savigny and Clainvanx whom they had reeently seen, and whose religious life was a mir'ror in which all might dress themselves for God. What was to be done? The abbat, like a timid man as he was, liesitated and delayed the matter, but rumours of the complaints which had been made reached the ears of the monks, who were axcessively indignant. They banded themselves together against the reforiners; threats were uttered, and there was malice written upon their faces. Fearful for the issue, Riehard and his friends had an interview with Thurstan, to whom the state of things at York was not unknown. After some deliberation with the abluat and the officers of the house, a day was appointed on which the archbishop promised to visit the monastery and enquire into the alleged misconduct. When the time arrived,

5 Joln of IIexham, col. 257. Ailred, col. 338. Bromten, col. 1028. Win. Neubrig., i., 50-1. Mat. Paris, 59. Lel. ('ol., i., 51; ii., 335 ; iv., 105. Durdale, v. 293, etc. Burton, 141. IImriquez, Phoenix Reviriscens, $69-$
70. Mabillon, Aun. Ben., vi., 204-5.

${ }^{k}$ The treatise, "De origine domus Font.," by Hugh de Kirkstall, is partly printed by Dugdale in the Mon., vi., 293 , etc. It is now being printed in extenso by the Surtees Society. 
he rode up to the gates with a goodly eompany which inchuded sereral dignitaries of the minster, Hugh the decn, Willian the treasurer, arehdeacon Hugh Sotevagina the historian and poct. William, the prior of the recently established monastery of (iisburgh, was also there, together with Robert, who appear's to have been the master of the adjaeent hospital of St. Peter. 'The party halted at the gate by which you still enter those sacred precincts, and, leaving their horses there, wont on foot towards the chapter-house; at the door of that building, whieh was filled from end to end by monks, strangers as well as residents, the abbat of the house received them, and deprecated the presence of any one but the arehbishop and his elerks. When 'Thurstan ventured to remonstrate, an nproar arose within which would have appalled a less intrepid man; they hooted and yelled like madmen. They rushed towards Thurstan with their arms stretched out as if they were eager for a wrestling mateh. They roared out that if he entered they would all of them depart. 'Thurstan's indignation was justly aroused. He told them that he had only come there to do his duty, and, as they interfered with him, he put their house under an interdict. What did they eare! "Stop it for a hundred ycars!" was the shout of a fellow of the name of Symeon, and the rest yelled their assent. "Cateh them, get hold of them !" was now the cry, and thcy seized the unfortunate prior and his comrades, and were going to imprison them or carry them off. The intended victims flung their arms around Thurstan and implored his aid. It was with some difficulty that the archbishop and his party, suppliants and friends, got away into the chureh, followed by discordant shouts of hatred and vengeance. The servants of the monastery were at every door and window, and the populace, aroused by the disturbanee, was rapidly assembling. Thurstan ordered the cloister door to be secured, and, after a brief deliberation in the church, finding that action was impossible and the rioters impracticable, he returned home. The prior and twelve of his brethren aceompanied him, and deserted their old abode to which they never afterwards returned. The arehbishop now befriended these poor onteasts. He wrote a long and most graphic letter to arehbishop Corbeil in refutation of the erroneous reports which were flying abont, in which he gave a full account of the insurrection at St. Mary's, and expressed simply and earnestly his own views on diseipline and monasticism. He sheltered the wanderers for awhile, and then gave them a pieee of ground for themselves in a roeky and

$I$ This letter is being printed entire for the first time by the Surtees Society in their forthcoming volume on Fountain's abbey. It has already been pub- lished, in fart, in Dugd. Mon., vi., 293, etc., and in S. Bernarli Opl', i., 386-91. ('f. Avesbury's Ekw. III., appendix, 271 . 
secluded dell near his residence at Ripon. It was in the winter that they songht for the fir'st time their solitary abode, but they cared not for the storm-winds or the snows. For awhile they were sheltered only by the rocks which hung over the waters of the skell, and, alterwards, they nestled beneath a large elm, which was spoken of and cherished by their descendants in a far distant encration. 'They now eommunicated their sorrows and aspirations to the eompassionate ears of St. Bernard, and placed thomselves at his disposal." That holy and intrepid man wrote to the abbat of St. Mary's, who had requested his advice, and desired that his former brethren should follow out the course which they had adopted. He expressed his gratitude also to 'Thurstan for' the kindness which he had shewn to these afflieted monks." "There was mueh in common between those two noble-hearted and energetic men, and they had probably becone acequainted whilst Thurstan was in exile. For two whole rears the dovoted and enduring monks subsisted merely upon roots and leares ; but their poverty and self-denial were the parents of their wealth. They had obtained St. Bernatrd's permission to seek another sanetuary, where they could kicep life together, when, most providentially, wealth began to flow into their empty coffers: a chureh was built, broad lands were given to cndow it, and a noble abbey arose by degrees upon the scene of their sufferings and their triumph. From the many springs which bubbled up beside it they gave to their abode the suggestive name of Fountains, ${ }^{p}$ and, by that title, one of the moblest monasteries in England was heneeforward known. Yon may see its decaying walls in that beautiful valley which seven centuries have not robbed of its repose, and which reminds us, eren in these latter days, of the munificence of Thurstan and of the piety and zeal of its first Christian colonists. The

$m$ s. Bernardi, Opl., ed. 1690, i., inter notis ad finem, $x$ l.

"Ibid., i., 99-100. At p. 292 there is another letter to abbat Geotfey, censuring him for the want of discipline in his house.

"In this they resembled the monks of Clinirvax, "qui pulmentaria sepuns ex follis fagi conficiebant" (s. Beru. (9), ii., 1673. There is a long accomnt of the trials of these poor monks in the narrative of IIngh de Kirkstall.

$r \mathrm{Wm}$. Neubrig. (i., 51) says, "Et voratur locus ille Fontes: ubi extunc et deinceps tanchum de fontibus Sal. vatoris tam multi hauserunt arpus salientes in vitam reteriam."

st. Bermard, with his love of mysti- cism, drew a great many thoughts and imases from the word Fontes. $\mathrm{He}$ speaks of the "quatuor fontes Salvatoris," the "quinque fontes Salvatoris," and the "quatuor fontes spiritualis Paradisi."

The name of his birthplace, Fontaines in Burgundy, was probably one great canse of his fondness for the word. The eldest daughter of Clairvaux, who was placed in the diocese of Chatons-sur-Marne, had the name of Trois-fontaines given to her by St. Bernarl. Fontenay, Mellifont, and Font-Morigny were children of the same parent (S. Bern., Opp., i., 70-2; ii., 1087. Miræe Chron. Ord. Cist., ed. 1614, 35. Mabillon, Aun. Ben., vi., 27). 
springs are still welling forth, and their waters are trickling into the Skell as they did when Richard saw them; but the roiee of worship is no longer heard within those walls which it once conseerated to God. Roof and roof-tree have been torn away, although you gaze still with a saddened eye upon the overhanging rocks whieh eovered many eenturies ago a little band of Christian heroes.

Thurstan's day of life was drawing to its elose. His health had been for some time failing. 'This prevented him from being present in 1138 at the battle of the Standard, and he was mable to attend the eouneil which was held at London in the same year under the presidency of Alberic the legate. He had already given a hearty weleome to that dignitary, aud he sent Willian, the dean of York, to represent him at the meeting.q Ile was too feeble to be there himself, for he was

\section{"Jam propior leto fessusque senilibus annis."}

He had been loved and honoured, he had done great things, but sueeess eannot obliterate the effeet of the trials by whieh it has been secured. 'Throughout his eareer he had been honest to his eountry and his see, but not withont mueh suffering and affliction in body and in mind. ${ }^{r}$ His heart would mou'n within him when he beheld the blood which seemed destined to track the footsteps of king Stephen. Oh that he could lay aside the cares of offiee for whieh he was unfit, and enjoy a foretaste of that repose which the world-worn pilgrim shall one day find! He would see that others had already reaehed it, if it were to be found on earth, in the eells of Clairvanx, in the valley of the Skell, and by the waters of the Rie. In 1139 he was wishful to resign his see in farour of his brother Audoenus, the bishop of Evreux; and, to bring his desire to pass, he sent Richard, abbat of Fountains, to Rome, to seeure what was uppermost in his mind, and to represent him at the comncil. A higher power brought everything to nought. Richard reached his rlestination, but he died there; and Audoenus followed him to the tomb, having assumed a little before his death the habit of a canon in the monastery of Merton.s What was 'Thurstan now to do? He communieated his secret thonghts and wishes to St. Bernard, and there is still extant a letter which that great man addressed to the aged and enfeebled prelate full of affectionate arlvice. He bids him retain his see, the wife to whom he had been so

q John of IIexham, col. 261. Rie. of Hexham, col. 327. Malmesbury, apud Savile, 103. Labbe, Conc., x., $992-4$.

$r$ "Pro salute patrix, tam pro dig- nitate tutanda, et multa incommoda perpessus est et sapissime in periculo fuit" (Polyd. Virgil, 210). Malmesbury, 156. Dachery, Spicilegium, iii., 506. "Ric of ILexhim, col. 329. 
lone wedled, and from whom, without the sanction of the pope, he could not properly be divorecel. Go, rather, and shew to the simple monk that he may find in a mitred bishop the pattem of a true ancetic. Dread not the nakedness or the poverty of that patli. 'The barer it is the greater will be its purity. God be with yon during the day, and nay He give you in the evening that rewand which lightens the toil and the heat, the penny which bears the image of the heavenly Cresar. ${ }^{t}$

These words, so inspiriting and so somd, sank deep into the old man's lecart. Ile set his lonse in order at York, rewarding lik finthful followers, making pestitution where it was required, and :mapping link by link that chain which had bound him to the world. In his youth he had made a vow at Clugny that lic woukl ally himscif to the monks who there worshipped; and he now resolved to join a little congregation of Cluniaes, at Pontefract, which occupicel the monastery of St. John. His parting from the ministers of his chureh in York was a most striking onc. Ife called them to him in his ehapel in the minster, and, after making his confession, prostrated himself with bared limbs before the altar of St. Andrew, and, confessing with many tears his past offences, he submitted himself to the scourge. "When this was orer he went to Pontefract, a great number of the elergy and the laity areompanying him. On the festival of the Conversion of St. Paul he took upon himself the rows and the garb of a monk within that little monastery, and deroted the remainder of his life to contemplation and devotion. Ile harl only becn there a few days when he felt the hand of death upon hin ; and he prepared to wrestle with the foc with that serene intrepidity which had characterized his life. The conflice took place on the fifth of Fehruary, 1140, and it was not one which the bystanders, and there were many there from York, would ever forget. The dring arehbishop recited in solemn tones the service for the dead, whom he was so speedily to join. He chanted, with solss and groans, the awful verses of the Dies Ire ; and then, whilst the rest were knceling and praying around him, he passed away to await in the land of silence the coming of that day of wrath, so terrible to all, of which he had just sjoken. ${ }^{u}$

II was interred, with befitting honom, before the lighl

t. S. Bernardi OF', i., 297.

"John of ILexham, col. 267, is the authority for this parasxaph. Brominn, col. 1028. Gervase, col. 1350. Kingehton, col. 2385. Hemingford, ajuld riale, ii., 485. Chron. Mailmos, 71. Wm. Nenbrig., i., 50. Stubbs, col. 1720-1. 'Trivet, 16. Iachery,
Spicilegium, iii., 1.17.

There is some doubt as to the exact day on which Thurstan died. Gervase and Stubbs say that he died on Feb. 5. John of Hexham on the 6th. His obit was observed at Durham on the sth (Liber Vitx, ed. Surtees Society, 339). Itugh the Chantor plaees the 
altar in the monastery at Pontefract, and, after many years, when a party of too curions monks looked into his grave, they found, it is said, the body robed in its restments withont it symptom of decay."

A few days after his dcecase Thurstan is said to have appeared in a dream to Geoffrey Troeope, archdcacon of Nottingham. It was in the stillness of the night, and there was his old master before him in his arehicpiscopal attire. The thought of the fearful death-seene which he had so recently witnessed perhaps prompted the question, "Is there a hope of thy salvation, oh my father?" and, then, from the fleshless hips there issued the solaeing reply, "To me to live is Christ, and to die is gain," which the listening friend thus turned into verse,

\section{"Vivere carne mihi fuerat, sed carne resolvi}

Est modo vera salıs, vita beata milit."'x

Geoffrey, in eonjunction with a person of the name of Hugh de Pontefract, drew up a life of Thurstan, partly in prose and partly in verse, which is preserved in the Cottonian library. ${ }^{x}$ It adds nothing to the information which we possess from other sources, and is singularly meagre and uninteresting. A short extract will shew the calibre of arehdeaeon Geoffrey in the sweet path of poesy. It is a lament for 'Thuistan.

\footnotetext{
"Gemma sacerdotum, jubar ecclesix, monachorum

Dux, flos pastorum, elaustri speculum, vía mormm,

Semita justorum, smpplantator vitiorum !

In te cunctorum rignit mixtura bonorum.

Transiit antistes ad gandia summa polormm,

Præmia sumpturus inde finita laborum.

Proh dolor! Anglorum flos marenit, aruit iste

Mundo, sed celo vivat te jraside, Christe.

Heu nulli precio mors horrida, mors metnenda,

Mors pietate carens, mors invida, mors fugienda.

Incutis horrores, infers truculenta parores,

Fundis merores facis et post leta dolores.
}

Ergo non doleat quisquis licet hic moriatur,

Celiea vita beat hume qui Christo famulatur."

There is another aecount of Thurstan, also mupublished, by Hugh Sotevagina, the precentor and arehdeacon of lork.y

day on the Ides, meaning, I presume, the 13 th.

v John of Hexham, col. 268. "Tiepertum est odoriferum in ineorruy, tum" (Hush de Pontefract, 55).

w John of Hexham, enl. 267-8.

T Titus, A. xix. Vita S. Thumstani Archiepiscopi Ebor. pratim oratione ligata, partim soluta, per Hugonem de Pontefracto monachum, et Gialfridum de Nottingham. There is a life of
Thurstan in Ifenriquez, Phrimix Reviviscens, $160-175$. He says that the archbishop was a cistercin monk, and that he died in 1136!

"In the liegr. Harnum 1 lbum belonging to the dean and chingter of York, - a splendid volume contitumes the most ancient privilenes and evidences of the church. They have been tranceribul at a eomparatively bite period, as the writer coufesese his inability 
Hugh was Thurstan's contemporary and friend, and he gives us, tharefore, much information alont his patron which is not elsewhere: to be discosered. Ile restriets himself, however, too murele to what may be called the forcign policy of 'Thurstan and lis rhusel. We slesuld have been even more obliged to him loal he: told us a litele more: about the private life of the arehbislope, and liis work within his dionecec. Ilis account, also, torminates abmetly, and wo kurow nothing from the writer alont lhe battle of the Standarl or of 'Thurstan's latter days.

I comp fturoac, abbat of fombains, was the next actual

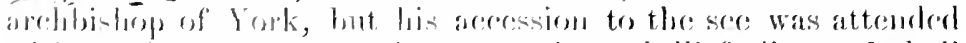

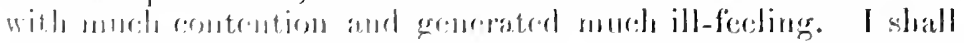
-ay in another places hese it aprose.

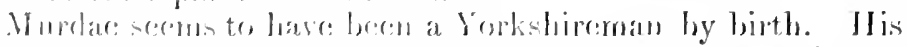
farnily was one of distuetion, and he inherited from his pa-

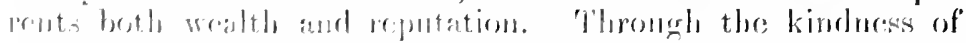

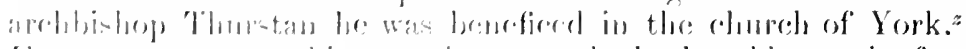

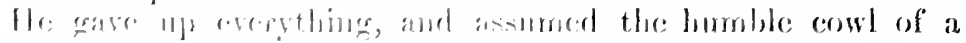

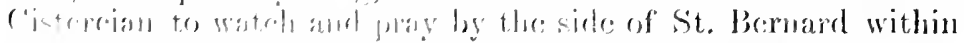

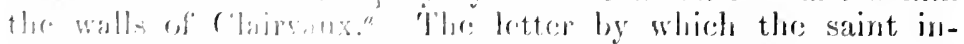

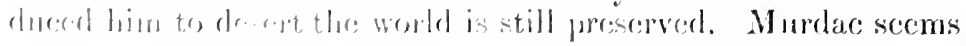

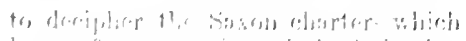

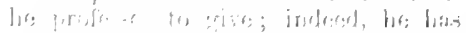

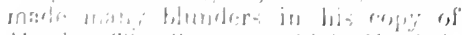

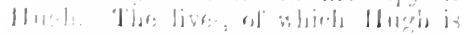

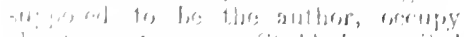

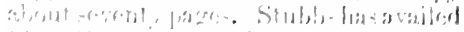

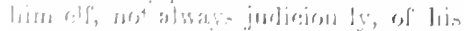

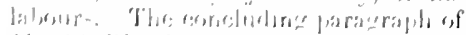

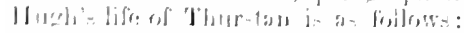

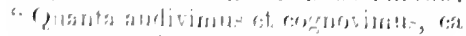

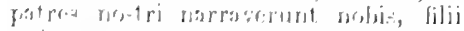

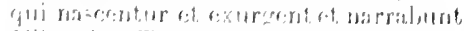

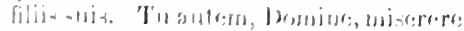

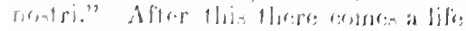

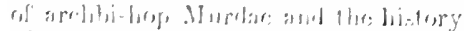

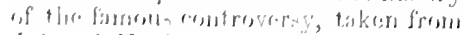

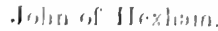

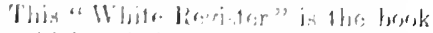

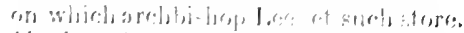

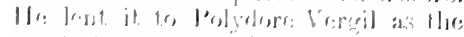

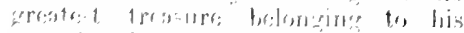
aloreth. It still beste, I ledirave, in the

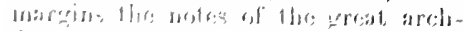

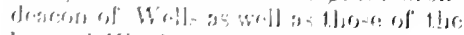
Jearsured bistires.

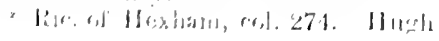

Mrerlare, a justice itinerant, became

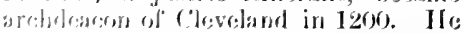
wat the fonduler of the filluertine priory os St. Amlrow at York. There is a peddieres of tle fanily of Murkas; ol (Amuptou Merdac in Dugdale's Warwirkelites, 101, and another among 1.les

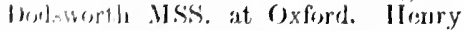
Murdar wa a jutice itinerant in 1189 (lixs's Jurleses, i., 401). Ralph Murdac wh rematalies of Nottingliam onstle temp. leic. I. (IJoveden, 41!). Galfrid Burdar witnrsises a charter granted by ardhislu], 'l'hurstan in 1128 ( $\mathrm{An}$ Hian Sincere, ii., 2:37).

"Vila S. Lernardi, apoud Opp., ed. 16:)(0, ii., 1112. Comtin. Hist. Croylixurl, ajud riale, iii., 112. Wm. Nembr., i., 5x. J'rivot, 17, Reoucil des llistoriens des finlese, xiv., 368 . Wob. de Hente, 72\% Inoliery, Sricilesgium, iii., I 17. Malbllon, Ann. licn., vi., 189, 2z?, where Nurdac is called " roobilis Anolus," and "in schola proce["r.tus." 
to have had some communication with him before it arrived. How tenderly Bernard entreats him to taste of that fountain whose waters he himself had found so sweet! He pleads with the enthusiasm of a poet and the deep fervour of a saint. Oh! the eharms of retirement which the Saviour himself delighted in, and which He left at last to join His fisher-brethren and evangelize the world! Believe me, thon wilt find more in woods than in books; the stocks and stones shall teach thec what a master eammot. Thinkest thou not that honey can trickle for thee from the rock, and oil from the flinty erain? Camnot the mountains drop with sweetuess; the hills flow with milk and honey, and the valleys laugh and sing with corn? Oh, that thon wouldest become my fellow-learner in this holy school with Jesus for our master!b Murdae was persuaded by these tonching entreaties, and well he might be. Ther were made to others in the North of England with a like effect. The abbeys of Rievaux and Fomntains were the fruits of that earnest pleading. It drew the robe of a Cistereian, within the walls of Clairvaux, over a prior of Hexham, and all but indueed Thomas, the provost of Bererley, ${ }^{d}$ to resign his post.

Those who are well acquainted with the life and writings of St. Bemard eamot wonder at the influenee that he exereised. Seren ecnturies have not lessened the feeling of veneration with

b S. Bern., Opp., i., 110. "O si semel paublum quid de adipe frumenti, unde satiatur Jerusilem, degustares! quam libenter suas crustas rodendas litteratoribus Judxis relinqueres! $O$ si te imquam in schola pietatis sub magistro Jesu merear latbere sodalem! O si mihi licent puriticatum prius tui pectoris vasculum sujponcre unetioni, qua elocet de omuibus! O quam libens tibi pariter calidos panes, quos utique adhue fumigntes, et quasi modo de furno, ut aiunt, recens tractos, le calesti largitate crebro Christus suis pauperibus frangit! litum si quam milis guttam quindoque de phrvin voluntaria, quam segremvit hereditati sua, stillare dignetur in dulcedine sua pauperi lous, mox eam tibi possem refundere, et rursus a te vieisim recipere quod senseris! Experto crede: aliepid amplius invenies in silvis quam in libris. Ligna et lapicles docebmut te, quod a macistris andire non posis. An non putas posse te sugere mel de petra, oleumque de saxo durissimo? An non montes stillanit dulcedinem, of colles thum lac et mel, et villes abumdint frmmento." Nt. bermard addresses
Murdae as " magister," which seems to shew that he was a griduate.

\footnotetext{
" Eooks! 'tis a dull aml endless strite:

Come, hear the woodland linnet.

llow sweet his music! in my life

There's more of wistom in it.
}
"Alad hark! how blithe the throstle sings!
lle, too, is no mean preacher:
come forth into the light of things,
Let Nature be your teacherr.
"She has a world of ready woalth, Our minds mol hearts to bless:
spontaneous wislom breathed by health,
Truth breathed by cheerfulness.
"One impulse from a remal wool
Alay toach you more of num,-
oi moral esil and of gond,
Than all the sages can."

\section{c Joln of Hexhm, col. 271.}

$d$ s. licmarli Opp., i., 111-17, 363. Thumas ehanged his mind, and died, as St. Bernard tells uls, "subitis et hor" renelis morte." I new edition of the works of st. Bermarl, properly (ortrected, is a great desideratum. 'The Paris edition of 1 s.39 is merely a reprint of that by Iabillon, in which

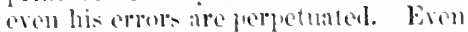
that of Migur ean be munch impreved. 
which "the last of the fathers" is regarded. We still see before IIs that frail and yet striking figure attemuted by the most frimhtful discipline; we gaze upon that countenance with its mcarthly pallor, and yet so beantifully transparent that you would ieem it "lit with an inmer light," and think that his soul in all its purity and holiness was looking through it; we may listen in fancy to that voiee so touching and so earnest, that the very lireath was held lest a single aceent should eseape. What multitudes flocked around him, to embrace him, to kiss his feet, to tonch his very gament, and yet flattery and honours conld not attract him. A simple, honest-hearted, self-denying monk he lived and died. But this was the man on whose word all Christendom used to hang in brcathless expectation! $f$ This is he who preached a crnsade, who elected a pope, chose bishops and arehbishops, and ehided kings! All these things our fathers have told us, but we can read for oniselves the words by which they were carried away, the heavenly contemplations, the almost divine musings with which they were fascinated. Surely the pen that handed them down to is

\section{"Dropped from an angel's wing."}

Never did any man's inmermost thoughts and feelings colour his writings with a more vivicl, a more speaking light. His whole sonl shines through them like the sun at mid-day through his reil of clonds. The radiance appals us. We shrink, alas, too conscions of on own muwthincss and inferiority, from the presenee of so muel prrity and holiness.

The life of Murdac is intimately comnected with the history of Fomitains abbey. T'he first abbat of that house was Richard, the ynondam prior of St. Mary's, and to him, with the assistance of cicoffrey, St. Bermard's fricnd, is due the credit of the establishment aut arrangement of that monastery, especially in

- Tennyson's Poems, er. 1833, from a puem in one of the rare editions which hat not beer reprinted. Richard (rithar, "poet and saint," thus expresese the same thomght:-

\footnotetext{
"A soul slueath'd in a christal shrine,

Through which all luer bright timtures shine, A \& whitl it piece of wanton lawn,

A thin arial veil, is alswo

cror beanty's fiwe, stombing to hide,

d) we swerly shews the blushing lide."
}

I camot refrain from quoting bishop labliot s chopuent deserifition of st. bermad (Epist., i., 119$)$ : "() guis (mo) sum, flut fatstorem illum sanctum wempte fideundissimann, Clatrevallen. senu abbatem charissimum, digne commemoren? (Muis mihi stifus aut que facundia, ut virtutis ejus, vel in morico, culmen attingam? Vir scientia clarus, simctitate notissimus, sine fuco sanctisimms, scriptor insignis, pradicator egresius, ordinis speculum, ecclesice dilatatio, sni temporis sol, nebulæe distipatio, abjectus sibi, mındo Christopue carissimus, sacerdos magnus, qui disbus suis Den placens et justus inventus, iracundia tempore in ijuso mirabiliter operante Domino Jesu, dissidentium factus est reconciliatio. Quem ftum corporalis intnebatur oculus, mundo despicabilis habebatur. Qumm spiritualis attendelyat, nostri temporis hominem longe virtutum meritis anteibat. Quis cjus labores digne referat." 
discipline. The saint, who during his life appears to have exercised orer Fountains a protecting care, commended the progress that had been made, in a letter to the abhat and his hrotherhood.g Richard was a man of no mean character and learning. In 1138, when Alberic eardinal-bishop of Ostia, the papal legate, arrived in England, the abbat of Fountains and the bishop of Hereford were the two persons whom he chose to accompany him on his tour. ${ }^{h}$ In the following year Richard went to Rome on behalf of archbishop Thurstan, who was desirous of giving up his see, and it was at the eternal eity that he died. ${ }^{i}$ His place at Fountains was supplied by a namesake and a friend who hat originally been a Benedictine at St. Mary's. ${ }^{j}$ 'This person, who took some interest in the controversies about Thunstan's suecessor in the see of York, died at Clairvanx in 1143. ${ }^{k}$ St. Bernard himself annomiced his decease to Alcxander the prior of Fountains and his monks, and desired them to make choice of a fitting superior with the advice and assistanee of William the Cistercian prior of Rievaux and the abbat of Vauclair. ${ }^{l}$

Murdac was the person who is last mentioned. After residing for some time at Clairvaux, and wimning the confictence of St. Bernard, he was sent by him in 1135 to found a Cistercian house at Vanclair, in the diocese of Leon, and to be its first abbat." When Richard, the seeond superior of Fountains, died, Murdac was engaged in a sharp controversy with Luke the albat of the neighbouring monastery of Premonstratensians at Cuissi." St. Bernard intended him to move in a very different sphere. In the letter which he wrote to the prior and the monks of Fountains, he told them that Murdac was coming in his behalf to inspect their house, and that in the selection of their new head they were to be guided by his opinion. ${ }^{\circ}$ Walter, tho bearer of this epistle, would no doubt eonvey to them the wishes

g S. Bernardi, Opp., i., 101, and Dugd. Mon., v., 298.

${ }_{h}$ John of Hexham, col. 261. Ric. of Hexham, col. 325, where he is called "magne religionis et anctoritatis virum." Dugd. Mon., v., 299.

i John of Hexham, eol. 265. Ric. of Hexham, col. 329 .

$j$ S. Bern., Opp., i., 101, annot.

$k$ John of Hexham, 27 t, the flace not being mentioned. Disgd. Mon., v., 300. S. Bern., Opp., i., 297-8. Mabillon seems to ignore the existence of this seeond Richard. IIe says that Richard died at Clairvanx on Miay 15, 1138, and that Murdae sureeeded hin.

's. Bern., Opl'., i., 297.

n I bid., i., 295, amot. Recucil lies
Ilist. des Ganles, xiii., 698, ex chronico Alberici. Gallia Christiana, ix., 633 , where he is said to have been abbat 1135-8. Mirxus, Chron. Orel. Cistere, el. 1614, 9\%. 'Thure is an account of Viluclair in the Voyage Lit teraire de denx Benedietins, in which Murdac is mentioned. He was the greatent abbat of that house. Mabillon, Ann. Ben., vi., 223; where the yenl 1131 is given as the date of the fommlation.

$"$ S. Bern., Opp., i., 298, annot., ex IIslmamo monacho Lamblun', iii., eap. 16. There is nothing about this dispute in the acconnt of Conssi in the Dm. P'remomstrat. Orel., i., lxiii., ete. "s. bern., Oplu, i., egs. Dusil. Mon., v., 301. 
of the saint that Murdac should be the new abbat, and, at the same time, Bernard sent a letter to Murdac limself, entreating him to aceept the post should he be appointed to it. Bernard spoke as if his election were a certainty, and promised, if he would go into England, to look well to the abbey of Vauclair, which he would be obliged to leave. ${ }^{p}$ Murdac was appointed abhat of Fountains, and he accepted the proffered honour.

Murdac went to Fountains in $1143 .^{4} \mathrm{He}$ was a rigid clisciplinarian, for he had been brought up in a strict school. $\mathrm{He}$ was soon actively engaged in his new charge. He put everything in order; for although the Cistercians had only been at Fomitains for ten ycars, the full severity of their rule was not entirely observed. It was otherwise now. The endowments of the house began to increase, and the revenues were administered in a noble manner. Before the monastery, still in the freshmess of lier' youth, had come of age, she had become the parent of seven religions louses. Seven daughters had been born to her,

"All daughters of one mother."

Fire of these, Woburn, Lisa, Kirkstall, Vaudy and Meaux, came into existence whilst Murdac was the abbat. ${ }^{r}$ One of these eells,--that of Lisa, otherwise called the House of Light, was fomded at the request of the bishop of Bergen, who came to see Murdac, and she carried the discipline and the fame of her parent to the wild shores of Norway. Meanx, the youngest of the family of seven, was bom in 1150, and then the still youtliful mother ceased to hear.s All her energy was henceforward rlevoted to the development of her own resources, and the purifying of the flame which arose to heaven from her own altars.

Where conld there be a better place for a Cistercian monastery than that secluded valley? Here was their Jerusalem, their ahode of peace; and they could say of it, as St. Bernard said of ('lairvanx, "Lo, we heard of the same at Ephrata, and found it in the wood.",

\section{"Here man more purely lives, less oft doth fall, More promplly rises, walks wilh stricter heed, More safely rests, dies happier, is freed Earlier from cleansing fires, and gains withall A brighter crome. On yon Cistercian wall That confident assurance might be read."}

p.s. Bern., Opl., i., 2:8-9. Dugd. Ion., v., 301. John of Hexham (col. 27 ) say sthat St. Bermardapnointed him.

7 There is a chronologiteal dillienty lice. Richard, abbat of Fountains, died on Oet. 12, 1113 . From Jom of Ilexham it miay be gathered that Murdiac did not berome abblot till 1145.

I finl aceoment of the origin and progress of Fountains is to be found in the work of Hugh de Kirkstall, which is being printed by the Surtees Society. A grent part of it is in Dugd. Mon., v., 298 , ete.

"Hace novissima filiarum quas genuit mater mostra, et cessavit iterum parere" (1) ngid. Mon., v., 302).

tS. Bern., Opp., i., 6.t. 
Where conld a place be found more fit to convince the recluse, if it were only by the force of contrast, that the retirement which he enjoyed was superior to the eharms of the workl beyond him? Where could he live more prirely, more derotedly, to God? The great book of nature was daily open to the Cistercian there, and he would see in it what to other rearler's wats meaningless and vain. The hearens looked down upon him with their many eyes picreing him through and throngh, and telling him that everything was visible to their viewless Lord. Strange voices seemed to eommune with him from between the wings of the wind as it arose and fell in that solitary vale. In everything around him, pure and simple as it was, there was something to direct him hearenwards, a type or symbol of some better thing to come.

\section{"Sum nemorum studiosus, ait."}

"There was a spirit in the woods" through which he walked, and he would think of the green tree and the dry. The murmurings in the elm, the twinkling leaves of the bech which St. Bernard loved to watch, the wanton airs which ran in and out like sportive children among the branches of the oak, were as significant to him as the prophetic brecze which stirred of old " the tops of the mulberry-trees." In those rocks, once a shelter to him when he came for the first time into that "weary land," he would see a type of that great "spiritual rock" on which the Church was built, and he would beseech IIim who had "poured down the stones into the valley," to be to him "a house of defence," and " a rock of habitation." The waters which bubbled up and sparkled among the elefts would remind him of the "pure fountain of life and the erystal sea;" and when he mused upon the perfections of Him who had sent those "springs into the valleys," he would join in the exclamation of the Psalnist, "All my fresh springs shall be in Thee. Benedicite, Fontes, Domino."

At the death of archbishop Thurstan in 1110, no small controversy arose as to his suecessor. The court was in farour of William Fitzherbert, the treasurer of York, who was actually elected and eonsecrated. As there was some suspicion of his having used undue influence in securing his appointment, William encountered the most strenuous opposition from all the reformers of the day. The whole of the Cistereian order seem to have been banded together against him, and among them were two abbats of Fountains, Richard" and Murdac. Murdac,

u S. Bern., Opp., i., 317. A letter to the pope on behalf of the nomks of Fountains, who, as Mabillon thinks, had gone to Rome to oppose William in 1111. John of Hexham. col. 271. 
indered, secms to have led the opposition in England. ${ }^{*}$ He was a suflerer for what he diel. In 1146 pope Eugenius, instigated by st. Bemard, suspended William, and some of the arehbishop's kimmen in Eirgland determined to wreak their vengeanee upon Murrac, whom they would consider to be the ehief agent in the degradation of their master. They made their way to Fountains to seize the abbat. They could not find him. They burst open the foors, and sacked the monastery and its buildings. They then set the place on fire, and everything is said to have been consumed with the exception of a part of the oratory. All the while Innelac was stretehed in prostrate adoration before the altan, expecting, momentarily, his end; but he was not observed. When the destroyers had departed he thankfully eommeneed the restorition of his house. Arehbishop William, in after years, milde amends for the excesses of his adherents, and expressed his deep sorrow for what had oceurred.w

This ast of violence created a great sensation at home and abroad. It was probably the immediate cause of the deprivation of William by pope Engenius, ${ }^{x}$ as Murdac was at Rheims when the scutence was passed.y This was done in 1147, and on the rigil of the festival of St. James in that year a great clerical asicmbly was liekl at the monastery of St. Martin, near Richmond, to eleet a new arehbishop. Robert de Gaunt the dean of York, and Hugh de Puiset the treasurer of that ehurch, who laad been prefered by William, were in favour of Hillary, one of the chaplains of the pope, who was afterwards raised to the see of ('hirhester. These two, in all probability, would express the wish of the court, as the former was the chancellor of Bugland, and the latter the king's nephew. Opposed to them were the bishops of Thrham and Carliste, William de Augo the presentor, and the arehdeacons of York, who were in fimsur of Hurdae, and he seens to have been eleeted, although uot without much controversy and opposition. $\tilde{*}$ Murdac after this went to Clairvaux to pay a risit to St. Bernard, his old fricurl amel advirer," who had been actively employed in promoting his clection. ${ }^{b}$ From thenee he went to the papal court at 'Theres, where he had a hearty welcome. Eugenius put an end

" Jolun of Hexham, col. 275. "Phrimm pricsmones sibi de gratia $\Lambda_{1}$ \%st.Hici." Hist. Mon., r., 30:-

is Bund. Hon., v., 30\%. Tel. Coll., iv., los. John of IIexham (col. 275) sirs a different aceoumt from the Fantain chrmicler. He unely says,

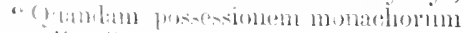

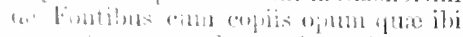

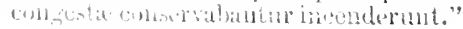

$x$ S. Bern., Opp., i., 249. Berrard wrote to the pope on this occasion urging promut action.

y Gervase, col. 1363.

z Juln of Ilexham, col. 276. Miracts, Chron. Cistere., ed. 1614, 122.

" hust. Mon., r., 302. Lel. Col., iv., 108 .

is. Buru., Opr., i., 298, annot. 
to all difficulty and contention by consecrating him arehbishop on the 7 th of December, and giving him the pall.c

Murdae returned to England in the following year to find a scene of tumult and dissension, for which he was not prepared. The deposed arehbishop was a cousin of the king, and a person of wimning demeanour, and his sufferings had won for him universal sympathy. Stephen would not receive Murdac. He sequestred the stalls at York, and fined the inhabitants of Beverley for admitting the archbishop within their walls. The kinsmen of the deposed prelate were loud in their threats of vengeance, and canght the senior arehdeacon, who eseaped with diffienlty alive. The eitizens of York, however, were Murdae's bitterest opponents. They closed the gates of their eity against him, and if any one went out to join him, the offender, if he were caught, was driven from the place and muleted of all his property. The archbishop, upon this, exeommunicated Hugh de Puiset, the treasurer of York, and all his enemies in that city. Puiset returned the compliment; and, as he was ommipotent in the minster, he would not allow the scrvices to be suspended. They eame, however, to an end, but Eustace, the king's son, made an order that they should go on; an act of interference which induced the arehbishop to complain, formally, to the pope. Murdac took up his residence at Ripon whilst this unseemly disturbance was going on. ${ }^{d}$ He would there be near his old monastery of Fountains, which he is said to have moderated during his life. ${ }^{e}$ He made several exeursions from Ripon. He paid a visit to the bishop of Durham; and at Carlisle he had an interview with king David, and was weleomed by his suffragan Adelulf. $f$

In 1150 there was peace at last between Murdac and his foes. Hugh de Puiset, at the request of the pope, was absolved from excommunication, and was reeoneiled to the archbishop at Yarm; and Eustace, the king's son, beeame his friend. In the

c John of Hexham, col. 276. Ord. Vitalis, apud Duchesne, 983. Chron. Mailros, 73. Wm. Neubrig., i., 58. Trivet, 17. Bromton, col. 1029. Gervase (col. 1363) says that he was consecrated at Auxerre. In Durrd. (Mon., v., 302) it is said that he got the pall at Rome. Acta SS., Bollandists, June 8.

d John of Hexham, col. 277-8. Wm. Neubr., i., 58-9. Trivet. 17-1S. Dilchery, Spicilegium, iii., 117.

$e$ Turold and Manrice were probably the principals of the monastery under Burdae. Cf. S. Bern., Opl., i., 286-7. Join of Hexhan, cul. 274 .
Turold got into some trouble, and was removed from Fountains to Trois Fontaines. St. Bermard defended this aprpointment against the strictures of the bishop of Ostia, and said that if he lat been an mworthy ferson Murdac would never have griven him an oflice "cui ipse prafuerat." This scems to shew the continuance of Murdac's connection with the monstery, but not in the eapacity of abbat. 'Tliere are lives of Manrice, Thorold, and Ric. Fastolph, abhats of Fountains, and their wolks, in Ilenriquez, l'hremix Reviviscens, 82, 159.

f Juhn of Ilexham, col. 277. 
following year Murdac regained the favour of Stephen, and was solemuly cuthroned at York on the day of the conversion of St. P'anl. He laid upon the high altil' on that oecasion the ancient mivileges, etc., of the ehureh, which he had reeovered and redeemed. 'They had been pawned, with many other treasures, hy Willian to raise money to defray the expenses of his jonneys to Rome. Murdac now invoked the curse of God upon any one who dared to alienate them again. He gave, also, probably at this time, several relipues to the minster. ${ }^{g}$ Soon after this the arehbishop crossed the seas, and spent his Easter with pope Engenius at Rome. He went there in the eapaeity of an ambassador' and he was to procure from the ehief pontiff, among other things, a formal recognition of the right of Eustace, king Stephen's son, to succeed to the throne of England. ${ }^{h}$

In 1153 Murdae was in another diffienlty, into whieh he was forced by his eonscientions wish to do his duty, regardless of consequences. William de St. Barbara, bishop of Durham, died, and Laurence the poet-prior, Wazo and Ranulph the arehdeacons, and the rest of the clergy, chose Hugh de Puiset as his snecessor. 'This appointment gare great offenee to Murdae and St. Bernard, not only on aceount of the eharacter of Puiset, his youth, worldly-mindedness, and inexperienee, but beeause, in their opinion, the metropolitan onght to have been eonsulted before the election was marle. Wazo, and Nicholas the prior of Brinkburne, went to Beverley to announce formally to the arehbishop what had been donc. He astonished them by setting the clection at naught, and by exeommunieating the prior and the archdeacons. This act of sererity gave mueh offence. When the offenders eame to York to beg the merey of Murdae, the eitizens, indignant at the treatment which they had received, arose against their diocesan, ealling him a traitor, and threatening him with their rengeance. He made his escape from the eity, and never returned to it agam. King Stephen and his son entreated him to be lenient, but, with the true Bernardine spirit, he scomed to please them by his complianee, at the expense of what lie deemed to be his duty. The culprits followed him from lork to Beverley, and there, at the request of arehbishop Theobald, Murdac at length absolved them, but not before they had submitted themselves to his anthority, and had been publicly seourged at the cutranee of the minster. Puiset went to Rome, where he was conseerated by the pope. Laurenee aceompanied him, lut he died on the journey as he was passing through linince. ${ }^{i}$

p Fahric Rolls of York Minster, ed. Surterestoricty, 152.

h. Jhen of Hexhan, cul. 279. i IIist. Dunelm., Scr. Tres., ed. Surtees Society, 1-5. Symeon, Hist. Eccl. bunelm., :98, and alpendix, 385. 
Murdac stayed for so short a time at York that he harl not the opportunity of doing much. He spent a great portion of the summer of 1152 at Hexham, and tried to bring the canoms of that place under a stricter discipline. In 1153 he remored the prebendaries from the ehureh of St. Oswald, at Gloucester, introducing canons-regular in their room, and placing them under the charge of Humphrey, a monk from Lantony abbey. He was desirous also of eflecting a similar change at Bercrley on the death of Thurstan the prorost, but his own decease prevented it being carried ont.j Murdac, it will have been seen, was a most severe disciplinarian, and it was a matter of conscience with him to sec that every one did his cluty to the fullest extent. This unbending sternness made him unpopular, for the Cistercian rule was obnoxions, from its rery strictness, to a great part of the Christian world. 'The chureh reformers of that age would hear of no compromisc, and would not tolerate what they saw around them. A little judgment and common sense would have secured for them a strong and culluring position. As it was, the influcuec of the Cistercians, to a great extent, passed away when they lost St. Bernard. Excessive severity was not the way to sceure the favour of the English barons. Whilst many of them were building and cudowing monasteries, others scem to have been as carcless of the simplest principles of religion; a strong reaction was, as it were, setting in against discipline and reform. 'The turbulent Comy'n turned the clumeh of Merrington into a fortress. Alan, Earl of Richmond, plundered the possessions of the see of York, and breaking with an armed band into the minster at Ripon, insulted archbishop William as he stood near Wilfrid's shrine. ${ }^{k}$ The murdcl' of Becket was the climax of this fecling of irreverence. 'Two strong waves were at this time mecting, and the collision was a startling one. But however indiscreet the Cistereians and the other ehureh reformers may have been, no one can impugn the honesty of their purpose, or the sincerity and simplicity of their lives. If they censured others they did not spare themselves. In this respect Murdac rescmbled his master St. Bermarl. IIe wore sackeloth continually, and practised the severest ansteritics. Murdac died at Beverley on the 1 th of October,

Gervase, col. 1375. John of Hexham, col. 281. Hutchinson's Durham, i., 166-7.

$j$ John of Hexham, col. 280. Duerd. Mon., vi., 82. Fosbroke, in his Ilistory of Gloucester (p. 288), salys that the priory of St. Oswald was built by Thurstan. There was a grood deal of controversy about it in after yeirs.

Murdac, also, made Germanus, prior of Tynemonth, abbat of Selly, to revive the discipline of that homse (Matt. Paris, de s. Albani abb., 1(15) - im appointment which cansed a great "1]roar in the monatery (Ilist. Mon. Seleb., apud Labbe, Bibl. Nov., i., 620.)

${ }^{k}$ Jolin of IIexham, col. 273. Symeon, Hist. Eecl. Bumelm., 285.

'stubbs, col. 1721. "Ilomo magnanimus et in causa (in)justitia' omnino 
1153. His remains were brought to York, and were interred in the minster in the place where the archbishops were laid." Sonne time after his decease he is said to have appeared in a vision to an inmate of the numnery of Watton, and to have miraculously assisted her." It is umnecessary to make any firther allusion to this case. Ailued, in my opinion, has not added to his reputation by detailing, as meritorious, an instance of revenge of the most disgraceful and fanatical kind.

The same year in which Murdae died witnessed the deccase of two men, to whom, of all others, he was under the greatest obligations, pope Eugenius and it. Bernard. The sun of the Cistercians set with their sainted leader. The historian of Fonntains, when speaking of the death of the arehbishop, makes a tonching allusion to those fiowers of the chureh which had been plucked before him. Nurdac went to the tomb, he tells 11s, "sequens cos quos amarit. Dilexerunt se invicem in rita sua, in morte non separati, duces gregis Domini, columna domus Dei, luminaria mundi."

TI illiam ffitsyerbert, better known under the name of st. William of Jork, was a person of noble origin. His father was Count Herloert, who is said, by Stubbs, to have been chamberlain and treasurer to king Henry; and his mother, Limma, was a grand-daughter of the Conqueror, and was sister to king Stephen; from his infancy, therefore, William was brought up in the lap of luxury and wealth. ${ }^{p}$

Shout the year li30 we find William, as treasurer of the church of York, witnessing arehbishop Thurstan's charter of

invincibilis, eligens magis pro justitia lericlitari quan ut justitia se presente periclitetur" (Busl. Mon., r., 301).

m John of Hexhan, col. 282. S. Bern., Opl., i., 298. annot. ex necrolog. Tallis Clare. Srmeon, Hist. Ecel. binelm., 291. Stubbs (col. 1721) says that he died at Sherburn, in which he agrees with the statement in the " wresirdent" bork of Fountains, which tixes the late of Nurdac's death on " prid. I4. Ort., 1153." Chron. Mailros, 75. Ann. Waverl., apud Gale, ii., 158. Rob. de Ninte, 735 .

" Ailreshs. Ihe sanetimoniali de Watton, (o) 419. Murdae had something to do with the foundation of this nunnery (I)ugd. Mon., vi., 955).

"Dugd. IIon., v., 303. Bromton, col. 1029. Wendover, i., 509. Wm. Neubr., i., 87. In Foliot's Letters (i., 92, 107) there is a letter to Murdac berging his kind oflices on behalf of Gilbert, the precentor of York. Murdac is also nrentioned in Opp., Joann. Saresber., i., 3.

p John of Hexham, col. 274. Bromton, cal. 1029, 1010. Stubbs, col.1721.

IIm. Ncubr., i., 58. I do not find count Ilerbert mentioned by any other writer as an oflicer of Henry; indeed, llere is nothing known about him. 
foumdation of the numuery of Clementhorp." There is a deed, also, without a date, in which IIenry I. grants the ehurches of Wallop and Wichtona, and the chapel of Gratcleia, in which William the treasurer had a life interest, to be the corpus of it new prebend at York." I have secn a charter of king Stephen, in which that monarch grants to William, the treasurer of York, his chaplain, the ehurehes of "W caverthorpe, Londesburgh, Cleve, with their chapels, and the ehureh of Stanton; all of which he held of the fee of his brother Herbert. ${ }^{s}$ This probably is the nobleman whom Dugdale introduces in his Baronage, ${ }^{t}$ and of whose parentage there has, hitherto, been nothing known.

Archbishop Thurstan died in 11.10, and the chapter of York seem to have had great diflienlty in selecting a person to sueceed him. At the instance of Hemry de Blois, bishop of Winchester, and the king's brother, they fixed upon his nephew, Henry de Sully. That ecclesiastic was the abbat of Feamp in Normandy, and the pope would not allow him to become arehbishop because he refused to give up his monastery." In Jamary, 1141-2, the clergy again met to choose a president, and the majority fixed "pon William, the treasurer. ${ }^{v}$ As he was one of the king's nephews, the court influence seens to have been brought to bear upon the eliapter, and William, earl of Albemarle, was present at the elcetion, in which he took an especial interest. That nobleman, unfortmuately, shewed himself a hasty partizan, and did much mischief to the eause of William. Master Walter, of London, and the rest of the York arehleacons were opposed to the eloice which the elergy had made, and were on their way to the king to state their case, when the stout earl arrested them and shnt them up in his castle at Bytham. In the meantime the archbishop-cleet went to Stephen at Lincoln, and was kindly received, and invested

$q$ Dugd. Mon., iv., 323.

r Chartular. thesaurar. Ebor., apud Ebor. About the same time, "J, clerieus, filius regis, canonicus Ebor," quit-claims to the treasurer the homage of Reginald, son of Juhn, son of Sweyn (ibid.). Who could this be? The name is quite new.

- MSS. Cotton, Vitellius, A ii., 107. This charter is printed in 1nerd. Mon., vi.. 1196 , where there are other deeds connected with the same plaecs, giving some interesting information about the sons and grandchiliren of Herbert the chamberlain.

t Dusd. Bar., i., 621. IIerbert :cems to have been the elder son, and to have succeded to his father's estates in the fifth of Stephen. IIerbert filius IIerberti and IVilliam, treasurer of York, his brother, are mentioned as benefactors to Nostel priory in Rot. Chart., 215.

"John of Mexham, col. 26s, where it is said, erroneonsly, that Sully was abbat of Caen. He wis a Clumiac nonk, and was the fifth abbat of Fecmun (Recueil des 15int. des (iatules, xiv., 351), and died, holding that ofliec, in $1188-9$ (Gallia Christima, xi., 209). Mabillon, Ann. Ben., vi., 323, where he is called Coilli. Chronicon Firmucnse, aţul Lablu, Nos. Bibl., i., 32s. 1028 . 
with the temporalities of the sce. The bishop of Winchester, another mele, who was at that time the legate in England, then sent him to Rome.

The opposition, howerer, was not so easily quelled, and the larsh measures of the earl of Albemarle would not allay it. The discontented party determined to follow William to Rome, and make their appeal to the chief pontiff. It was a contest between the conrt and the most influential portion of the elergy. The elerical party was ably represented, and was backed by the reformer's in the church, particularly by the Cistercians. The canse was heard in 1142 in the consistory of pope Innocent. Wilter of London, the archdeaeon, who had escaped from the clutches of 1 themarle, presented the allegations against William, which were supported by William abbat of Rievaux, ${ }^{x}$ Riehard abbat of Fountains, Cinthbert prior of Gisburgh, Waltheof the famons prior of Kirkham, and Robert the master of the hospital at lork. Willian was charged by them with having secured his election by bribery. Immoeent listened to what was said, but would make no decision at that time. He ordered both partice to present themselves before him on the third Sunday in Lent in the following year. ${ }^{y}$

They camc to Rome at the appointed time in 1143, and the case wais heard. The main point against the validity of William's clection was this, that the earl of Albcmarle had come into the chapter-house, and had vitiated the proeeedings by giving a message fiom the king that William should be ehosen. The pupe very properly declared that if, in addition to the personal denial of the imputation of unclue influence by William himself, the dean of Tork wonld state on his oath that no such message from the king had been delivered, that then the arehlikhop-cleet might be consecrated. The dean also, who was not present at the consistory, was to be allowed, if he ehose, to take the oath by deputy. That dignitary had other things to think of, as he had just been nominated to the see of Durham by the

" Jolm of Ifexham, col. 268, 271. Ann. Waverl., ol. Gale, ii., 15t. Waltheof, prior of liorkham, would probathy liave been appointed archbishop of York on 'Thurstan's decease if king stephen had not interfered. IV altheof Wits a s reat filvourite of llavid of Scotland, and stephen was afraid that, if arguinted, Wiltheof would play into his hands (Aeta SS., Bollandists, Ang. 3).

A farson much concerned in the ecelediatical reforms of the daty. IIe was a sreat light among the early Cis- tercians, and Henriquez gives a life of him. St. Bernard wrote two letters to him exhorting him to bear "xquanimiter" the elcetion of William (Opp., i., 320, 321). He died in 1145 (John of Ifexham, 274), and his metrical epritaph, together with that of Robert, ablot of Newminster, is in MSS. Cottou, Titus D, xxiv., 81.

y John of Hexham, col. 271. Bromton, col. 1029, 10\%1. Stubbs (col. 17:1) says that Osbert, the archdeacon of York, was the chief promoter of the attack on William. 
prior and the clergy. William returned from Rome in September 1143, and following the advice of the legate, submitted his case to a council which was held at Winehester. Every one seemed, not to request, but to demand, lis consecration; and not a murmur was heard against anything that he had done. The bishop of Durham had been expected to take the oath about the election in the chapter-honse at York, whieh had becu prescribed to him by the pope, but he was mavoidably absent. Ralph bishop of Orkney, Sanaricus the abbat of St. Mary's, York, and Benedict abbat of Whitby, took it in his behalf, and swore to the absence of simony and undue influence. What more could be required? On the 26th of Scptember William was conseerated at Winchester by the bishop of that diocese, who was his uncle and his friend. ${ }^{z}$

In 1145 cardinal Hinemar, a legate from Lueins the new pope, visited England, and bronght with him a pall for William. They did not meet, for William was a person of an easy and indolent disposition, and saw no reason for promptitude or liaste. ${ }^{a}$ In the meantime the pope died and was succeeded by Beruard, the abbat of the house of St. Anastatius at Rome, under the title of Engenius III. He was a rigid Cistercian, and humg npon the lips of St. Bernard. The opponents of William now began most ungenerously to reopen the old sore. They could carry the day now, as they thought, and they resolved to try. They were decidedly in the wrong. William had complied with all the conditions which Imnocent had laid down, and his consecration had been regular and proper. Why was he to be opposed? There must have been some personal fecling prompting his opponents, that curse which, mider the colom of conscience and justice, has in every age instigated so many great men to be persecutors and maligners. William about this time shewed his love of peace by effecting a reconciliation between the bishop of Durham and the turbulent Comyn. ${ }^{b}$ With Alan, carl of Richmond, he was not so fortumate. ${ }^{c}$

Hincmar returned to Rome in 1145 , carrying the pall with him, and, in the following year, William went in quest of it himself to the court of Eugenius. The charges against him had been revived isy the Cistercians, Hemry Murdac, the abbat of

z John of Hexham, col. 272-3. Gervase, col. 1357,1665 , who says that archbishop Theobald dechined to consecrate. Chron. Mailros, 72. Rob. de Monte, 714. I have used Mr. Stevenson's edition of the last-mentioned work. The original text may be found among the collected works of Guibert, and in Pertz, Monumenta Hist. Germ., viii., $475-535$.

"John of II exham, col. 271.

- Symeon, Ilist. Ered. Bunclm., 283-4, 292. There is a eurions aceount of an adventure at St. Cuthbert's (omb), when William wis there, in liegrinaldus, De admir. B3. Cuthberti Virtutibus, cd. Surtees Soriety, 198.

c John of Hexham, col. 273. 
Fountains, taking a prominent part in the attack. ${ }^{d}$ But William had a more serious opponent in St. Bernard. That great man, whose zeal in this instance overpowered his judgment, had been al constant opponent of the appointment of William. He wrote trong letters asainst him to popes Celestine and Innocent and the cardinals. He now excrted for the same purpose the immense influcnce which he excreised over Engenins. ${ }^{e}$ The cardinals, howerer, were in William's farour, and the pope was in a diffieulty. At length Eugenius resolved to deprive him, until the bishop of Durham should take the oath which had been formerly required from him, and the cardinal-bislop of Ostia read the sentence of depriration.' 'This was unfair treatment. It was tantamount to trying a person a second time for the offence of which he had already been acquitted. William left Rome in disgust, and spent some time at the court of Roger king of Sicily, as the guest of liobert, the chancellor of that monareh, who was an Enghishman by birth. Whilst he was staying there, the indignation of lingenins was aroused by the account of the attack upon Fomntains ablocy which had been made by some of William's indiscreet partizans. This unfortmate occurrence, together with the uresent appeals of St. Bernard, probably induced the pope to take summary messures against William. Nurdac and the York clergy were present at a conncil which was held at Rheims in 1117, orex which Eugenins himself presided, and there, in compliance with thcir request, THilliam was removed from his axclibishopric, and the bishop of Durham and the chapter of lork were ordered to proceed to the election of another primate within forty dars after the reecipt of the papal mandate. ${ }^{g}$

IIenry II urdac now stepped for awhile into the see of York, as has been already stated, and William, returning from the Sicilian connt, fonnd an asyhm with his uncle at Winehester. The opposition that was made to Mudac shews the sympathy Which was felt for the ejected prelate. At his uncle's palace William received all the honours thit could be paid to an arehbishop. Iligh and low regarded him with affection and compassion. He made no murmul himself against the sentence of Eugenius. ${ }^{h}$

William, whilit he was at Tork, promuligated some orders about the trees and rats in elumelyards (Wilkins, i., 42\%. Lable, Cinc, x., (o)l. 1131).

d' Johin of Hexhimi, col. 275.

s. Bern., O1p., i., 229-37, 316. Baluzii Misc., ed. Mlansi, i., 146. There is a long aceount of this controversy in Arta S., Bullamlists, durte 8,1 to; and

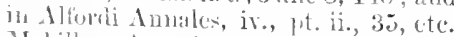
Vinfihn, Inn. lixll., vi., 326.

$f$ (intike, col. 13633. g John of IIexham, col.275. Stubbs, col. 1721. Win. Neubr., i., 58. Chron. Mailrus, 73, the bishop of Durham "nolens elm sacramento purgare." 'Twisden's Inistorical Vindication of the Chulch of Engtand in point of Schism, 58.

h John of Hexham, col. 276. Bromton, col. 1029, 1041. Hoveden, 278. Tim. Nerulr., i., 58. Jo. Saresber., (1)., ii., 172. Thachery, Spicilegium, iii., 117. 'Trivet, 17. 
"His duty is to stand and wait,

In resignation to abide

The shock, and finally secure

O'er pain and grief a trimmpli pure."

The luxury and inertness of his previons life seem to have deserted him. He was an altered man. He was sedulous in his devotions and study. Not a har'sh word against those who had wronged him ever passed lis lips. Affliction had wrought in him the end for which it was designed. It had given him

\section{"A soul by force of sorrows high \\ Uplifted to the jurest sky \\ Of undisturbed humanity."}

William seems to have lived in retirement at Winehester during the whole of the arehiepiseopate of Murdac. When that prelate died in 1153 the hopes of the sufferer again arose. The majority of the chapter of York elected him their superior, and he hastened at once to Rome, not to complain of his past wrongs, but to beg for present justice. All now seemed willing to befriend him. Gregory, one of the most influential of the cardinals, took up his cause with warmth, and William's cousin, Hugh de Puiset, who was then at Rome to expedite his own consecration as bishop of Durham, did what he could for him. Anastatius, the new pope, was moved by the aceomt of his trials and the earnestness of his pleading, and restored him to the honours of which he had been deprived, giving him the wished-for pall. William returned to England with a light heart, and kept the Easter of 1154 at Winchester, where he had so long resided.j Whilst he was in the South he is said to lave paid a risit to Canterbury, and there he had mueh friendly intereourse with Roger the arehdeacon. "That man shall be my successor," is said to have been his remark. ${ }^{k}$ And so he was.

William now set out for York. Before he had entered into the city he was met by Robert the dean and archdeacon Osbert, who had withstood lis clection by the chapter, and they, hoping to prevent his approach to their church, announced their intention of appealing from the decision of their brethren to archbishop Theobald. William's progress, however, was not delayed by their opposition. IIe reached the eity on the 9th of Miay, a vast and rejoicing crowd aceompanying him. As the party was erossing the Ouse, the bridge, which was then made of wood, gave way, and a number of persons were precipitated into

i Diceto, col. 510. Bromton, col. 1029. Stubbs, col. 1722. Hoveden, 281. Wm. Neubr., i., 86-7. Matt. Paris, 77. Chron. LIailros, 75. Ann. Waverl., apud Gale, ii., 158. Rob. de
Monte, 736. Cotton's Chron., 69.

$j$ Gervilse, eol. 1376.

${ }^{a}$ Stubbs, rol. 1722.

$l 11 \mathrm{~m}$. Neubr., i., 88. 
the river. William is saicl to have wrought a miracle in their behalf. We atre told that he made his prayers with tears to (Fod for the sufferers, and, making orer them the sign of the 'ross, they were all sared.". When a bridge of stone was erected at that place, a chapel npon it, dedicated to St. William, reminderl the wayfarers of the legend.

Willian was in York but thirty days. On Trinity Sunday he officiated in the minster, and almost before the service was orer he was seized with a rery sudden and alarming attack of illness. He returned to his residence, which was hard by, and a banquet was prepared for his friculs, whilst the archbishop songht his chamber, which he nerer left alive. Like many others, he had a presentiment of what was coming on." For eight days he was on the bed of sickncss, and then, on the 8th of June, he diell. ${ }^{\circ}$ There was a story current in the middle agres to the eff'ect that he had been poisoned by something which his clerks or enemies had put into the eucharistic wine, ${ }^{p}$ and on that account he was afterwards regarded as a martyr. There is, howerer, no allusion to this tale either in the MS. life of William, or in the account of him by Stubbs. William of Newburoh, also, speaks contemptnously of the report, and denies it on the authority of a mouk of Rievaux of his acquaintance, who had been intimately connected with the archbishop, and had been present when he died. William dicd of a fcrer, and the suddenncss of the attack made his friends imagine that he had been poisoned." Archdeacon Osbert, who had constantly opposed William, was looked upon as the culprit. Symphorian, one of the elcrks of the deceased prelate, charged him with the erime in the presence of the king and comncil, and was desirous that the matter might be decided either by the combat or the ordcal. Osbert professed his willingness to abide by the decision of an ecclesiastical tribumal. We are told by John of Salisbury that he failed to purge limself from the charge, but we do not know to what test he was subjecter. Gilbert Foliot, however, expresses a strong opinion as to the inmocenee of

"' Bromton, col. 1029, 1011. Stubhs, enl. 1722 (on 7 Id. May). Polydore Verwil (210) makes the bridge at Pontefract.

$n$ 'The following extract from the J'S. hife of St. William contains an allusion to his end:-" In ommibus, igitur, se exhibens ut Christi minister; post disciphinas diras quibus Domino muletahat, jost lngubrationes nocturmas et crebras, post fletus amaristimos 'pues lrateritorum delietormu recorlatio ex inis pectoribus ernctabat, lorica justieiæ circumdatus, ad præparationem evangelii calciatus, sacris altaribus debitis horis libenter astabat, ut patri filium immolaret."

- Stubbs, col. 1722.

${ }^{p}$ Gervase, col.1376. Hoveden, 281. Chron. Mailros, 75. Fordun, Scotichronicon, ed. Goodall, i., 448. Mat. Paris, 77. Ann. Waverl., apud Gale, ii., 158. Rob. de Monte, 736. Serlo, the eluronicler of Fountains, speaks of the report (1)ugd. Mon., v., 303).

$q \mathrm{Wm}$. Neubr., i., 88-90. 
the accused person, and the injustice of the proccedings against him. ${ }^{r}$

William was interred ${ }^{s}$ in the minster of Jork by his old friend bishop Pudsey. ${ }^{t}$ His sufferings and charaeter, the gentleness of his disposition and his minely end, won for him gencral sympathy. 'The elnurch of lork had no saint at that time? peculiar to itself, and the chapter were most anxious, if possible, to procure the canonization of William. Thirty-six miracles are said to have been wrought throngh the mediation of the deceased archbishop," and a holy oil, one of the medieval accompaniments of supposed sanctity, is said to have flowed from his tomb." In 122\% the archbishop and the chapter of Iork entreated Honorius IJI. to enter William on the calendar, sending as their representatives Godard the penancer, Elias Bernardi, one of the canons, and Laurence, canon of Aquileia. Indulgences were also granted by the archbishop of Canterbury, the bishops of Rochester, London, Lincoln, Ardfert and Dublin, to those who visited the tomb; the papal assent, however, was not immediately given, and a commission seems to lave been issued to make a full enquiry into the circumstances of the case. The canonization was not completed until the pontificate of Nicholas III., when it was effected by the money and urgent entreaties of the bishop-clect of Durham, the magnificent Anthony Bek, who was represented at Rome by his cousin

r Foliot's Letters, i., 152. Joh. Saresb., Epist., i., 158, 170. The author of the history of the foundation of Selby abbey says that after Murdac's death archdeacon Osbert was degraded by the legate in synod assembled, for lis conduct towards Selby abbey, and that he went to the priory S. Tirin. at York (Hist. Mon. Seleb., apud Labbe, Bibl. Nov., i., 620).

- There is a story of there being an accidental fire in York on the night of his death. A part of the "domus orationis," in which the archbishop's corpse was laid, was consumed, but the body was preserved (Brev. in $11 \mathrm{sm}$ eccl. Ebor., pars lyemalis, ed. 1526, fol. cxiii).

There is a curious piece of eridence in a charter, by which Alice de Gant, widow of Roger de Mowloray, gives lands in Cave to the church of York. "Hanc donationem feci publice in ecelesia Beati Petri et prasentis cartre attestatione confirmavi, anno Incarnationis Domini $\mathrm{m}^{\circ} \mathrm{c}^{\circ} \mathrm{l}^{\circ}$ quarto, v Idus Junii, regnante rege Stephano, vacante ecclesia post obitum archiepiscopi Wil. lielmi, eodem etiam nondum sepulto" (Dodsworth MSS. I an indebted for this information to $\mathrm{my}$ friend $\mathrm{Mr}$. Walbran).

Hoverlen, 281.

" MSS., Harl., 2. York Breviary, 113. The thirty-six miracles are recorded by Dodsworth, who obtained his information from a table in the registry of York miuster (MISS. apmd Oxon., 125). In the book of chapter acts the following extraordinary circumstance is said to have oceurred on St. Willam's day, 12!90. I give it withont comment. "Mntus guidan! ad tumbam josius Saneti nsum lingure recepit in aurora diei, cujus lingui ante triennium per latrones fuerat anputatis !"

"Stubbs, col. 1722. Brev. Flor., 114. b. Recueil des Ilist. des Ganles, xiii., 698. Chron. Joh. de Oxenedes, 148. Matt. Paris, 267, who seems to say that the oil began to flow in 1223.

w MISS. Cotton, 'Titus J). xxiv., $50 \mathrm{~b}$, etc.

Q 2 
Stephen de Manley, archdeacon of Cleveland. ${ }^{x}$ The depositio of William was commemorated on the 8th of June, ${ }^{y}$ and his tramslation on the sth of Jannary. At a comneil held in the minster on the 29th of October, 1178 , the last-mentioned ceremonial was transferred to the Sunday next after the Epiphany, and it was ordered to be observed as a double and principal festival.

The renains of William wcre interred in the nave of York minster, near the south-west pillar of the lantern; they were removed in solemn state to a nobler resting-place in the choir, on the 8th of Jamuary, 1283-4. ${ }^{a}$ On no other occasion has the cathedial reccived within its walls a more illustrious assemblage. A double ecremony bronght it there that day-the translation of St. William, and the eonsecration of that noble-minded man who had secured for the church of York the canonization of its arehbishop. Bek, who was called

\section{"Le plus vaillant clerk de roiaume,"b}

was surrounded by the chief estates of England, inchuding Edward I. and his gentle consort. The king had reeently fallen from an eminence, and had escaped unhmrt. He ascribed his good fortune to the agency of St. William, and hastened to York to shew his gratitude by being present at the translation of his body. The ceremonial on that oceasion has been detailed with in interesting nimuteness. ${ }^{c}$

On the night of the 6ith of January, archbishop Wickwaine, attenderl by the dean and the canons, went into the minster, Anthony Bek, and his brother Thomas, the bishop of St. David's, accompanying them. The solcmnity of the place and the time

* Hiscell. Doe penes Dec. and Cap. I)unelm., 495. The whole history was detailed on a table which was formerly ken,t in the minster. Stonford's Errors of Rome, 20!).

y Martyrologim Tsuardi, el. 1711, 325. Acta ss., Bollandists, June 8th.

A Vemorial of ancient liritish piety, 88.

= Iork Breriary, ut supra, 113.

a Trived, 260.

b Virolas's sictre of Carlaverok, 53.

- This account of the translation is taken from a most rare volume, a copy wh the Fork Breviary, which was given in 1733 by Rokeby Scott, clerk, to the minster library at York. I sive al coly of the title. The words in italics are in red lotters: "Brevinim ad usum insigis Metropolitane ecelesie Eboracensis: 1ura cmm pica dilicentisime, accuratisimeque recognitum et enen- datũ : in jreclara Pairhisiensi acadenuia : ì edibus videlicet Francisci Regnault improssum: ac expensis honesti viri Jocennis Galcheti: in predieta Eboracèsi civitate commorātis: hic suum capit exordium pro tempore hyemali. Anno nostre reparationis 1526." The class mark is X. P. 7. I have compared it with another edition of the same work (X. O. 21), which is imperfect at the berimning and the end. It contains a number of the festivals. The Bollandists have transferred the accomnt of the translation of St. William to their pages (June 8). Cf. Hist. Dunelu. Scr. Tres., ed. Surtees Society, 61, where a curions circumstance is mentioned about Bek and St. William's remains. l'rynue's Coll., iii., 307. ('hron. Petrib., 151. Walsingham, apud Canden, 51. 
did not appal them, for they were bent upon a holy work. They went to the tomb of William, and prostrated themselres in lowliest obeisance. When their devotions were finished, they arose and removed reverently the stone which served as a lid to the sarcophagus in which the archbishop was laid. The body still bore the restments in which Puiset had committer it to the grave, and was steeped and redolent, as the narrator tells us, with an odoriferous oil. They began by removing the paten and chalice which lay beside the remains; and then the archbishop and his companions carefully and deroutly gathered together the bones from the head downwards, and rolling them up, with the other things which were there, placed them for the night in a capsule or case, which was sealed up and eoncealed until the morrow. On the following day the reliques were minutely examined, and everything that pertained to the body was deposited and secured in an appropriate feretory. On the day after this was the festival of the translation; and abont the hour of prime the royal party, and a goodly company of lords and prelates, were assembled in the church. The archbishop preached a sermon in which he expatiated largely, no doubt, upon the merits of his now sainted predecessor. When this was over, the feretory was raised upon the shoulders of the kingle and others, and was borne, prohably with joyous music, around a portion of the choir to the elerated shrine in which it was henceforward to be preserved.

The place in which the feretory was deposited was in all probability behind the high altar, in the vacant space between it and the eastermost screen..$^{e}$ It was here that the shrine was erected and decked with the offerings of the worshippers. It seems to have been divided into two parts, one fitting into the other. The smaller part, in which the reliques were enclosed, could be lifted, and seems to have been borne processionally, on solemn occasions, through the minster and the eity. There were appended to it the little gifts which piety or superstition had suggested-images, beads, rings, girdles, and jewels of every description, of gold, silver, or precious stone. The skull of the saint was kept by itself in a case of silver gilt. It was most richly decorated. When the storn of the Reformation broke over the church, this relique had a curious fate. On the $2+t h$ of October, 1541 , the dean, Richard Layton, who was a minion of the king, eansed a chapter act to be passed by which

d In the Liber Garderob. of Edward I., p. 39, etc., will be seen the offerings which he made at St. William's feretory and tomb.

$e$ Willis's Arehiteetural History of York Cathedral, 50-3. Fabric Rolls of York Minster, 152, 195, 221, 221. When Henry $1 \mathrm{~V}$. stopped the inthx of worshiplers to archbishop sicrope's tomb, their offerims were transferred to that of St. William. Test. Ebor., el. Surtces society, ii., 233. 
the head and its ornaments were to be appropriated to the use of the cathedral. $f$ The bones of William were now unhoused. In May, 179:., Mr. Drake, the historian of York, removed the stonc in the nave of the minster muder which the remains of IIilliam were said to have been deposited, and found under it, in a leaden box, a number of bones huddled carelessly together withont any order or arrangenent. It seems probable from this that the reliques had been laid in their old restingplace alter the feretory and the eapsule had been destroyed. $g$

The chapter of York in the middle ages paid great honour to St. William, althongh, perhajs, his shrine had a less brilliant reputation than that of any other Northern saint. As early as 1230 a chantry was founded at the place of his interment by Lias Bernardi, one of the eanons who had been most anxious to secure his canonization. ${ }^{h}$ A chapel dedieated to him was erected upon Onse bridge, to eommemorate what had occurred when William came into the city before his death. ${ }^{i}$ In the fifteenth century, a college, wilich bears his name, was built for the use of the ecclesiastics in the minster, at the east end of the cathedral. A considerable portion of it is now in existence. ${ }^{j}$ 'There is still in the ehoir of the ehurch of York "a storicd window richly dight," detailing the principal events in Willian's life. The monks of Meanx treasured carefully anong their reliques some of the hair of the sainted archbishop. ${ }^{k}$

St. William is not without his biographer. Some unknown writer hats dham 7 ? an account of his life, which is now preserved in the British Museum among the Harleian MSS., No. 2. It is in a hand of the twelfth century, and belonged at one time to 'Thonton abbey. The style is rery inhated and diffuse, and the work contains nothing that we were not previously acquainted with though the pages of John of Hexhan and William of Newburwh. There was another life of William among the MSS. formerly brelonging to Sir simonds d'Ewes, which I have been mible to trare.' ('aperave, also, gives a short account of him in his Legende, which has been transferred by the Bollandists to their Actu Sanctorm." The compilers of that invaluable

$f$ Chajeter Aets. This hear was the createst treasure that the chureh of lork poseswenl. When Marniret, dinchiter of IIenry VII., visited the minuter, the hearl was brotight for her at kis.

5 Drake's Eboramm, 120. Torre's IIs. aceromt of Tork Hillster, 16i2. Crent's Ripron, 103. Thake gires an (M) raving of the sareophates which he fortunt.
${ }^{h}$ Fabric Rolls of Fork Minster, ed. Surtees society, 305. MSS. Cotton, Titus D. xxiv., $50 \mathrm{~b}$.

i Drake's Eboracum, 280.

$j$ Ilid.. 570. Fabric Rolls of Tork Minster, 72. Ingd. Mon., vi., 118 t.

h P'oulson's Holderness, ii., 313.

l'Smitl's Catalogue of MSS.

"n Calspave's Nova Legenda, 310-11. Acta ss. June 8. 
collection were unaequainted with the existence of any umpublished life of the saint.

I now give two hymus addressed to St. William. The first was discorered aecidentally in the Cottonian library." Alford, in his Annals, ${ }^{\circ}$ could only quote a few lines of it; and the writer of the life in the Acta Sanctorum, when he alludes to it, says regretfully, "totmm utinam dedisset." The second is gathered from the Responsoria, ete., in the serviee for the translation of St. William in the breviaries of the York nse. 'T'o those who are accustomed to hexameters and pentameters the metres will be novel and refieshing.

I.

"Pasci gregres de pastore

Aure discant, dicant ore Jubilum preconii ;

Sat mel ori melos auri

Nomen nostri mune thesauri Quondam thesaurarii;

Fraudulenter qui cassatus

Ab honore presulatus, Latensque septemio,

Vacat contemplacioni;

Magnum malnm magni boni Sixpe fit occasio.

Statu cause reformato,

Romam retit iterato, Nullis adversantibus.

Eboracum presul redit,

Pontis casus nullum ledit De tot turbe millibus.

In octaris Penthecostes

Quidam malignantes hostes

In eum pacifice,

Et ut ipsum privent vita

Celebrantis achonita Propinat in calice.

Toxicatur a proplanis

Ille potus ille panis Per quem perit toxienm.

Ambo jresul amplexatur,

Ut per unum moriatur Et vivat per reliqumun.

Tivit moriturque quislem,

Sed non asunt eirea iriem Fermentum et azima.

Corpus obit pré fermanto,

Arimorum alimento Vegetatur anima.

Tirns bibit noenum risum(ne perpetum brevi merearis lacrina, Mortem subit optimam dum sacrando victimam fit et ipse victima.

O Willelme, martir ('hristi,

Per eundem ruem bibisti

" MSS. Cotton, 'Titus A., 19, 150.

- Anuales, is., part ii., 35, etc. 
Salutaris calicem,

Fer solamen mundo tristi

Et quem tibi placuisti

Nobis placa judicem. Auen."

\section{II.}

"In Willehmi laudibus laxet clerus ora, Sit in lymuis canticis concio canora.

Pii patris holie corpus est translatum Quod in imo jacuit in alto loeatum. ${ }^{p}$ Quondam thesamarius jam thesaurus cleri Dedit ofms medieum, nune dat open veri. Cochum solum sitiens gazu Christi miles Ne scaudentem retrahant calcat ut res viles. In doctrina solidum cibum dat provectis Et lactis dulcedinem miscet imperfectis.

Nostri patris in natalicio

Latas laudes dictet devotio, Cali resem lactet oratio,

Ut jungamur ejus consortio.?

()rtus elari germinis hume nobilitavit, Et mentis nolilitas genus geminavit. ln agendis stremus, fidns in commissis, Ail censuram rigidus, firmus in promissis. Mlitis in consortiis, in lorpela rarus, In responsis providus, in sensu praclarus. Voluntatis trutina non legis cassatus, Virum noxum induit coelitus mutatus. Juventutis januas claudit cassatio, Sie malum sejins boni fit occasio. Vir ad sui gloriam redit inglorins, Lt mrenti rasculum mumdetur melius.

Lachrimarum lavacro purgatis jersonis, ('onfert divinitus munus unctionis.

hateratum exulem morsibus malignis

Xec faux frangit odii, nee livoris ignis.

Probat hunc exilium sicut hyems laurum,

In fornace ponitur, purum exit aurum.

Ne Samsonem balida faciat perire, llic carnem spiritui cogit obedire.

A.rum ment is seminat sementis virtutum, Et mundi delicias spernit velut lutm.

Ne recentes flosculi virtutum marcescant, Hlos seripture rivulis irrigat ut erescant. Factus Jacob visilat extra supla wesem, Noc minus interins legmu sarit Regem. Iarthie ministerio cophlat Miuriam, Rachelis amplexilus firuitur lost Lyam.r fragat odor fresulis Roman venientis, Occurrit frasmence plebs mins mentis. Ex longinquis reninut nee sunt fatigati, Longa via visa est curta caritati.

" In the edition witlout date these lwo lines are substituted :-

"I'ius pater hodio ex hace valle fletus Ad supromum soliuns syon transit laxtus."

"In the elition of laze the lines, "1) to this foint, come at the end of the service and not at the beginning.

r A Belnarline expression. There is something similar to it in Foliot's Lettcrs, ii., 3:s, and in "Memorials of Fountains Abbey," ed. Surtces Society, 74 . 
Plebs oceurrit presuli, cadit pous dissutus,

Sed a casu popmlus mens redit tutus.

Unda ruens fopulum recipit ruentem,

Et se pontem eflieit per Ombipotentem.

Ne cursus ad superos animo claudatur,

Mens Dei dulcedini tota eopulatur.

Servit elemosinis manus insopita,

Quibus se dat funditus vir Israclita.

In sublime levat, ut palma, comam spei,

Et imputrescibilis vivit cedrus Dei.

Fide fuit Finees, ut Job mansuetus,

Patiens ut Israel, ut Noe discretus.

Fidelis ut Abraham, ut Loth lospitalis,

Sagax ut Samuel, ut Joseph liberalis.

Virum Christus oleo tam larse linivit,

Quod adhue in mortuo olei fons vivit.

Ut sit nomen prosulis oleum eflusum,

Corpus fundit oleum ad xyrorum usum.

Adit Sancti tumulum languidorum ccetus,

Et qui plangens venerat plaudeus redit loetus.

Prasulis antidotum presens est exrenis,

Quo devotos liberat pluribus a paenis.

Claudi recti redemnt, furor effugatur,

Epilepsis prassio sanitati datur.

Purgantur lyydropici, laudes fantur muti,

Datur paraliticis suis membris uti.

Lepre tergit maculas, membra dat castratis,

Lumen datur pluribus sine luce natis.

Rapiunt a pugile lex et lostis lumen

Quod per sanctum reparat eceo culi numen.

Ab abyssi fancibus biduo submersum,

Mater natum recipit a morte reversum.

O Willelme, pastor bone,

Cleri pater et patrone,

Mundi nobis in asone

Confer opem, et deprone

Vita sordes, et eoronse

Coelestis da gaudia."

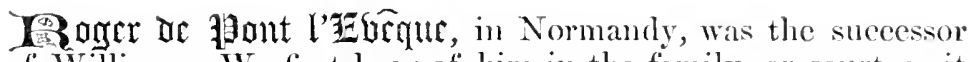
of William. We first hear of him in the family, or court as it was ealled, of Theobald, arehbishop of Canterbury. That prelate had many elerks around him who were conspicuous for their abilities, and Roger was inferior to none of them. 'Theobald's residence seems to have been a little school of the prophets. Among the companions of Roger there was a youth who was destined in after years to surpass lim in the vigour of his acts, and the splendour of his preferments. This was the well-known Beeket. One of the many hiographers of the martyred primate informs us, that at that time Roger was his superior in learning, but not in eharacter and bearing. We are told that there was 
some jealonsy between them, and that Roger on two occasions attempted to deprive Becket of the good opinion of the archbishop. He was successfully defendled by Walter, archdeacon of Canterbury, who afterwards beeame bishop of Rochester. ${ }^{s}$

In 11.18 the consecration of Walter vacated the archdeaconry of Canterbury, which was giren by Theobald to Roger. ${ }^{t}$ For the next six years we know very little of his life, with the exception of the fact that he was made one of the royal chaplains. He was also involved in a controversy about his office at Canterbury, from which his friend, bishop Foliot, strove to extricate him." In 1154 William of York died; and Robert the dean, and archdeacon Osbert, secured the election of Roger, even thrcats being used, as William of Newburgh states, to gain the suffrages of the chapter. This was brought about by Theobald, who was well acquainted with the merits of his archdeacon, and who would be glad to have a client and a friend at the head of the Northern province.w The archbishop consecrated him in Westminster abbey on the tenth of October, as many as eight bishops being present. ${ }^{x}$ After this Roger went to Rome and received the pall. ${ }^{y}$ He was present in December, 1154, at the coronation of Henry II. ${ }^{z}$

The ccclesiastical history of England during the early part of the reign of Henry II. centres in Thomas a Becket. It is very difficult even now to make a proper estimate of the character of that extraordinary man. Modem writers have weighed it with too much partiality or severity. They have been bewildered by the strong lights and shadows with which his life abounded. 'There were in him many noble impulses, a vigorous and independent will, a fearless intrepidity, swayed and marred oceasionally by a waywardness of disposition, and an infirmity of temper to which exalted minds are too frequently subject. 'These defects rery often set off' a noble character. There is true strength occasionally in weakness. Every one, however, must admire that eight year's' struggle for the privileges of his

s Becket's Works, ed. Giles, i., 10, 99, 184-5. Roger gave Becket the sobriquet of Thomas" cum ascia sive securi," or "Baillehache."

¿Gervase, col. 1362. Somner's Canterbury, part ii., 150 .

u Stubbs, col. 1722.

" Eyist. Gilb. Foliot, i., 30, 124. Jown. Saresber. OPp., i., 175 .

" Becket's Works, i., 10. Roger de Pontinny (ibid., 100) says that this was done with the connivance of the king, anit that Becket was preforred to the archdenconry of Canterbury and the lrowstship of Bererley " "qua Rogerius obtinuerat." Roger was never provost of Beverley. Wm. Neubrig., i., 90 . Bromton, col. 1012. Rob. de Monte, 736.

IIapes mentions Roger in connection with Coxwold (De Nugis Cur., 50).

x Gervase, col. 1376. Diceto, col. 529 -with no profession. Bromton, col. 1042. Anglia Sacra, i., 8. Ann. Thaverl., apud Gale, ii., 158. Hemingford, ibid., 489.

$y$ Trivet, 23. Bromton, col. 1042. Stubbs (col. 1722) says that the pope consecrated him.

Lob. de Monte, 738. 
ehureh and his see, to which Beeket saerificed the ease and the enjoyments of his position, and, nltimately, his life.

Becket suceeded Roger in the arehideaeonry of Canterbury in 1154, and in 1162 he was elevated, against his will, to the archbishoprie. The two elerks of Theobald were now at the helm of the Chureh of England. They were soon placed in an antagonistic position to each other, not that there was any illwill on the part of Roger towards his old friend, although many have laid that to his charge, but in those days even moderate and quiet men were obliged to take sides in the disputes of the time, and Roger must not be condemued because he was oceasionally opposed to Becket. Becket was not a person who could at all times be supported, and it was too much the habit among the writers of that age, who were satmated with his spirit, to deery all who refused to render to their farourite their unreserved and unqualified assistance. Whenerer there was a quarrel between the primate and the sovereign, the arehbishop of York was in a peculiar and eritical position, from which it was difficult for him to extrieate limself without offending against his loyalty or against propriety. When Becket became arehbishop, Roger offered to consecrate him, in aceordanee with the old custom, but his services were set aside. ${ }^{a}$ 'Their friendship, however', was not then interrupted. About Whitsuntide 1163 the two arehbishops went to fours to a great couneil which was held by Mlexander the new pope. That dignitary was then insecure in his scat, and was grateful for the support of the English prelates and their king. He shewed his appreciation of it in a manner which would searecly please some of his friends abroad. At the conneil Becket, by his desire, sat on his right hand, and Roger, who was accompanied by the bishop of Durham, on his left. ${ }^{b}$ When they returned from Tours there was a begimning of the troubles which embittered the remainder of Becket's life. Whilst he was ehancellor no one could be more active in adrancing the royal prerogative; his time and thonghts were frittered away in sports and levities which ill-besecmed an eeclesiastic, but as soon as he was plaeed at the head of the English church he was an altered man. He immediately atlapted himself to his new position, and resolved to do his duty as archbishop, howerer painfully it might be eontrasted with lis previous life. II felt that he had been in the wrong, and eared not for remarks or eonsequences. He soon eame into collision with royalty; he began to assert the privileces of the elureh, and to ecusure offenders of whom little notice had been hitherto taken. Henry

"Gervase, col. 138:.

b Matt. Paris, 81. Diceto, col. 512, 535. Wendover, i., 539. 
was now nettled, and began to oppose Becket; he claimed for the erown the privilege of pmishing ecclesiastics in the civil conrts, but in this he was resisted by the whole bench of bishops. The king was elearly in the right. It was most improper that the cleroy should have for their ecelesiastical tribunals the power of life and death, and it was most unscemly and wrong that any clerk who had been guilty of a capital offence should escape from punishment by sheltering himself under the privileges of his order. A case which illustrates the subject in dispute occurred within the provinee of York.

Henry was at York in 1158, when one of the burgesses of Scarboroingh came to him with a complaint. He said that he had been amoyed by a rural dean, who, withont any witness, had condemned his wife as an adulteress, and had extorted twenty-two shillings from him on that account, contrary to the custom of the realm. The offender was summoned before the king, in the presence of archbishop Roger, the bishops of Lincoln and Durham, and John the treasurer of York, who afterwards became the president orer the see of Poictiers. The rural dean asserted that the woman had been accused by a deacon and a layman, and that the husband, to secure mercy for his wife, had given twenty shillings to the archdeacon, and two to himself. He said, besides, in justification of the practice, that it was what the other archdeacons and rural deans, throughout the country, were accustomed to do. The king, with the barons and ecclesiastics, now began to think what should be done. John, the treasmer of Iork, recommended that the money should be restored to the burgess, and the dean handed orer to his archbishop. Richard de Lucy then asked, "What satisfaction then shall the king have for this breach of the law?" "None," said Joln, "for the offender is a clerk." 'The ecclesiasties in this case seem to have carried the day, but not without arousing some angry feeling. ${ }^{c}$

The general question of the correetion of the delinquent clergy was raised in 1163 at a council at London, and Becket and lioger, with the whole bench of bishops, asserted and maintained the privileges of their order. ${ }^{d}$ The king and Becket were, consequently, cnemies, but as long as the other prelates took the side of the primate, Henry could do little or nothing. Abont this time Armulf, bishop of Lisienx, came orer to England; he was most earnest in his attempts to reconcile the king and Becket, but without effect. At last he advised Henry to gain some of the bishops to his side, as by so doing he would have the best chance of making peace, or, at all erents, of effecting 
a compromise. Henry adopted this arlvice, and called several of the prelates to him at Gloneester. He talked quictly and reasonably with them, expressing his wish for peace and justice, and his disinclination to do any injury to the chmreh. The archbishop of York, and the bishops of Chichester and Lineoln, assented to his riews, ${ }^{e}$ and Becket, after this, spoke of Roger with anything but kindness. $f$ By the means of these prelates, and the entreaties of a papal messenger, and the nobles of the realm, Beeket was indnced to give way. The matter was then settled in a formal manner. The points in dispute were net and arranged in the well-known Constitutions of Clarendon, which were then drawn up. One of the three copies of these important enactments was placed in the hands of the archbishop of York. $g$

Henry was grateful to arehbishop Roger for the assistance which he had given him. As a reward for his aid, and with the wish, no doubt, of humiliating Becket, he was desirous that the pope should make him his legate in Britain. ${ }^{h}$ Roger, also, desired to have the power of bearing lis eross erect in any part of England, and that he might crown the king. These were privileges which had been peculiar to the sce of Canterbury for the last forty years. They depended upon the papal grant, and, therefore, the same hand that gave them conld also take them away. They had been obtained in the first instance in a questionable manner, and Roger camnot be blamed for making an attempt to gain honours for his own archbishopric which were only accidents to the other. The old fend between York and Canterbury was revived, greatly to the indignation of Becket and his party, who censured Roger in the strongest language. The pope at first granted all that Roger sought for, but the unflagging resistance of Beeket made him waver, and he changed his mind. The vacillation of Alexander was most remarkable. He gave leave, in the first instanee, to Roger to act as his legate, then he requested him not to act for a while,

e Becket's Torks, i., 25, 120; iii., 22. Jo. Saresb. Opp., i., 13. Hoveden, $282 b$. Martene, Thes. Nov. Anecdut., iii., 655. Pertz, Monumenta Germ. Hist., viii., 458.

$f$ Becket's Works, iii., 51, 68, 79, "Areh. Ebor., qui malonum omnium ineentor et caput est." 202, " фui ex quo a Cantuariensi ecelesia in archiepiseopatum promotus esi, ei quantas scivit et potuit, tetendit insidias." Becket's tongue was like a razor. Jo. Saresb. Opp., ii., 260. Gervase, col. 1394, 1412, 1459. Hoveden, 301, "diabolum illum!" Chron. Petrib., 101.

g lecket, ii., 10. Roger and the bishoys of London and Salisbury are satil by Fitz Stephen, in his life of Becket, to lave frompted sone of the conditions which were offered to him before the comncil of Clarendon (ibid., i., 217). (iervatse, col. 1359.

$h$ The king preferred this request throngh the bishop of Lisicux and the arehteacon of l'oietiers. Becket, i., 32,$128 ;$ iv., 1, 2. (iervase, col. 1388. Hoveden, 252 $b$. 
then lhe ordered him not to aet at all, and not to bear his cross, ${ }^{i}$ which last injunction, howerer, scems to have been oceasionally disoberedi

Soon after this some farther negotiations took place between the king and Becket, between whom the bishops endearoured in rain to mediate. Their own position at this time was peculiar and critical. They were divided in opinion, and seareely knew what to do. Becket reproached them bitterly for joining his adversaries, and he charged them to take no part with the barous at the trial to which he was to be brought. He put himself under the protection of the pope, and when he came to cont, was bold cnongh to carry his cross erect, in token of his anthority. The archbishop of York and two or three others remonstrated with him on the folly and imprudence of the aet, and told him that it wonld be considered as the beginning of an attack in which he was sure to be worsted. Beeket's reply was that the spiritual sword could give a more deadly wound than any weapon which tho king conld wield. ${ }^{k}$

Ilenry was now in a towering passion; he was desirous that Becket should focl the full screrity of the law, as he had broken the pledge which he had made at Clarendon. The bishops, lowerer, would not renture to proceed against their superior in England, but they resolved to appeal against his conduet at Rome, and procure there, if possible, his deprivation. Soon after this Becket made his escape from England, and Henry sent a noble emluassy to the pope to state his ease against the prinate, and justify his late proceedings.' Arehbishop Roger was at its head. The ambassadors found the pope at Sens, and the bishops of London and Chichester, who were the chief fueakers, opened the case against Becket with some asperity of manner. They endeavoured to exculpate themselves and defended the policy of their master. Roger spoke afterwards in a more moderate tone." He shewed his good taste hy appearing in the backgromul. 'The cfiorts of the party were fruitless, although Becket was unable to return to England. He spent several ycar's in rxile, playing the courticr to Louis of France, or lclioliting his frienids, the Cistercians, by living a retired life within the walls of Pontigny." He wrote two expostulatory

Becket, iii., 213; iv., 43, $16,255$. Mlatt. Paris, 93. Recueil dos Historiens des ranles, xv., 828-9. Labbe, x., $1191,1219$.

$j$ Beeket, i., 226 ; ii., 21.

k Becket's Works, i., 42-3, 137. IIrveden, 2S36.

"Berket"s Works. i., 51, 139, 151, 237, 210-1,317. Foliot's Letters, ii.,
279. Hoveden, col. 281. Twysden, col. 714. Gervase, col. 1394. Labbe, Couc., x., 1436.

"n Becket, iv., 270. Gervase, col. 1395.

"An anonymous friend, probably a Cistercian, told Becket in his troubles, "Apud Clarevallim, Cistercium et Pontiniacum, intercessione domini papa, 
letters to arehbishop Roger about this time, chiding him for his opposition, and in one of them he enjoins him and the other prelates to suspend the services in their dioeeses until justice should be done to their ecelesiastical superior. ${ }^{\circ}$ 'The pope backed this letter by ordering Roger, on his obedience, to aid Rotro arehbishop of Ronen, and Bertrand bishop of Nerers, his legates, who were to compel Henry, if possible, to make peace with Becket by the threat of an interdict, and by directing him to observe everything that they resolved upon.p Henry, on his part, was equally firm and energetic. Fit\% Stephen says that he ordered his subjects to take an oath that they would ineither receive, nor obey, any papal mandate albout bicket, and that Roger and the other bishops allowed it to be taken within their dioceses. ${ }^{q}$ In 1168 the king took a more violent step. He sent a letter to the arehbishop of Cologne, stating that he was about to send an cmbassy to Rome, with Roger at its head, to demand the immediate removal of Becket, and to threaten the pope, if he withstood him, with his bitterest opposition. A partizan of Canterbury ascribed this obnoxions cpistle to the pen of Foliot bishop of Lonclon, and gravely tells us that whilst that prelate was ruminating by night upon the sulject, the evil spirit endearoured, in vain, to startle him by crying out in a thrilling tone,

\section{"O Gilberte Foliot," \\ 1)um revolvis tot et tot, \\ Deus tuus est Ashtoroth !'”}

In 1170 Roger took a step which placed him in some peril, and eaused him much diffienlty and amovanee. At the desire of his royal master, in conjunction with the bishops of London, Durham, Rochester and Salisbury, he erowned prinee IIcury king of England in the mildle of June.s Becket, upon whom that duty would have devolved, was not in England, and he took it much amiss. He protested against the act, and made great complaints. ${ }^{t}$ Becket, who had heard of what was intenderl

oratur assidne pro vobis" (Works, iv., 255). Foliot's Letters, ii., 24 , who says that Beeket went to Pontigny at the desire of John bishop of Poictiers. Herb. de Boseliam, ii., 216. Diceto, col. 539. Gervase, col. 1398.

- Becket's Works, iii., 22:7-9.

$p$ Ibid., i., 55 ; iv., $47-8,13.4$.

$"$ Ibid., i., $267-8$.

r Wendover, i., 556. Mat. Paris, 90.

- Becket's Works, i., 56, 157; ji., 25, 112 ; iv., 159. Chron. Mimmix, ed. Stevenson, 394. Geraldus de Instit. Princ., ed. Stevenson, 177. Chron. Jol. de Oxenedes, 62. Chron. Mailros, 82. Matt. Pirris, 101. Trivet, 5t. Rob. de Monte, 773. Hemingford, apud (iale, ii., 197. Hoveden, $296 \mathrm{~b}$. Wendover, ii., 11. Diceto, col. 552. Bromton, col. 1061. Gervase, col. 1112. Stıbls:, col. 1722. Kuyghton, col. 2396. P'rtz, Monumenta ilist. Germ., riii., 113. Benediet Petrib., 4. Contin. Fl. Wigrorn., ii., 138.

'becket's Works, i., 271-5; ii., 26, 112 ; iii., 67-9. Bromton, 1061 . Benediet l'etrib., 6. Contin. Fl. Wigorn., ii., 141 . 
before the ecremony took place, ${ }^{\text {s }}$ sent intelligence to the papal compt, and Alexander mrote to Roger forbidding him to officiate. ${ }^{\circ}$ If Roger received the letter he disregarded the injunction, and now paid the penalty for his rashmess. The pope, at Becket's request, suspended him and his suffragan, Hugh de Puiset, whilst he excommmicated the Southern prelates who had officiated at the coronation.w He expressed, however, his willingness to withdraw the ban if the eulprits would be obedient to Becket, and render satisfaction to him for their conduct. ${ }^{x}$ The king, who was afraid of the papal eensure, shewed some disposition to abandon the prelates, although it was to please him that they had got into this serape. ${ }^{y}$

Roger and his brethren in tronble were undaunted, althongh somewhat dismayed. The pope's censure had not yet reached them, although it had been entrusted to Becket's eharge. $\mathrm{He}$ was coming back to Englind, and they tried to prevent his landing. The exiled primate heard of their design, and took eare that the letters shonld precede him, and they were delivered at Dover to those for whom they were intended. He himself, with some difficulty and risk, got safe to England. This was in 11\%0. When Becket arrived at Canterbury, the messengers of the archbishop of lork and his friends who were in disgrace, came to him, and reproached him for trampling down his brother bishops, and for using fire and sword when he should have songlit and praetised peace. Beeket laid upon their masters the wriilt of the juresent strife. Ifter this some persons eame from the conrt with an order that lie should absolve the condemned prelates. He told them that it was not in his power to reverse the decision of his smperior, and that no one eould do that; but if the bishops of London and Salisbury would pledge themselves to ober the pope's order, he would not object to absolve them.z This reply was brought to the bishops, who were on the point of giving way, till they were told by Roger that they conla make no such promise without the king's permis,ion, otherwise they wonld be guilty of treason. Their adviser is also reported to have said, "I have $\mathrm{E} 8000$, God be thanked, and 1 will spend it all to the last farthing to pull down the

" Becket, i., 269; iv., 287, 302. He had spies, "amici," as they are called, all over.

"Ibid., i., 268; ii., 26 ; iii., 64; iv., 47. Diceto, col. 513, 55\%. Labbe, ('one, x., 1219. Rymer's Fed., n.e., i., 2-5.6. Wilkins, i., 459.

"llecket, i., 332; iii., so ; iv., $15-$ $52,61-5,102$. C Chron. de Mailros, 83. Matt. P'aris, $101-2$. I'eter Langtoft, 130. Clirun. Petrib., $100.15 \mathrm{~m}$.
Neubr., i., 185. Hoveden, 297. Diceto, col. 553. Bromton, col. 1062. Labbe, Conc, x., 1219-22. Wilkins, i., 159. Benedict Petrib., 8. Contin. Fl. Wigorn., ii., 142.

x Becket, iv., 102, 283.

y Gervate. col. 1+12.

z Becket, i., 280-4; iii., 83. Joh. Saresber., Opp., ii., 243 . Gervase, col. 1113. Iloveden, 298. 
arroganee of Becket, which is greater than his conrage. Let ns go to the king, who has hitherto stood our friend. If you retumn to Beeket, the king, if he takes it amiss, will deprive us of our possessions. What will you do then ?" a

Roger, and the two prelates who had been persuaded by his arguments, eross the Chamel to Henry. 'They took with them, at the king's request, four or six elergy from the vacant sces to represent their chapters in the Norman eourt, with the strange expectation of being thus able to make a new election, and fill up the places of the suspended bishops. When the party came to the king, Roger was the spokesman. He protested against the sentenee pronounced against them, which was the penalty of their loyalty to their sovereign. He spoke of the amoyance and the unmerited disgrace to which they were subjected. He told the king of Becket's present movements in England, how he was travelling about with guards and soldicrs in a warlike guise. The hasty temper of Hemry now burst ont against Beeket. Half angrily, half querulonsly, he deplored his own unhappy position. ${ }^{b}$ The fatal fruits which were borne by that unfortunate speech are matters of history. Four daring and unhappy men, with the words of the sorereign still tingling in their ears, hastened aeross the seas to Canterbury, and demanded of Becket the absolution of the bishops. His reply was the same which he gave before, that it was beyond his power to do what they required. ${ }^{c}$ Ere that day was over he was stretehed in death before the altar of his own chmeh. He was laid in the tomb within the walls of that noble eathedral which he had served perhaps too faithfully and too well.

A thrill of horror ran through all Christendom at this deed of wrong. Whatever Becket's faults may have been, and they were many, he made a full atonement for them in his death. Henry, the innocent cause of the murder, was stricken with sorrow and dismay, and Roger eonld not fail to be deeply mored. An enquiry was immediately made into the case, to see whether he was in any way the inciter of the erime; and he promised to abide by the decision of the pope. 'The archbishop of Ronen and the bishop of Amiens were the examiners. Roger net them at Albemarle on the feast of St. Nicholas, and he there swore that he was altogether innocent of the death of Bocket. He also took an oath, that, before the recent coronation, he harl not received the pope's inhibitory letter. He was mamimously aequitted from all blame, and his suspension was remored. ${ }^{\circ}$ 30 .

${ }^{a}$ Becket's Works, i., 281 ; ii., 29-

${ }^{b}$ Ibid., i., 289-90; ii., 130 ; iv., 308. Benedict Petrib., 9-10.

211

c Ibid., i., 162-3. Jo. Saresb., ii.,

d Becket, iv., 67-8. Foliot's Letters, ii., 260. Wendover, ii., 19, 20. Di- 
Roger wrote a long letter to his old friend, bishop Puiset of Durham, and to the chapters within the diocese of York, acruainting them joyfully with the result, and announcing lis specdy retimn.e The style of the epistle is somewhat peculiar and inflated. The archibishop would have us believe, that during the recent enquiry the radiant figure of the Redeemer had stood on his right hand, slewing by His presence there the innocence of the aceused. About the same time Roger interceded very warmly and kindly with the pope in behalf of Foliot, the bishop of London, who had been for a whole year under the ban of excommunication. ${ }^{f}$ Roger was now enabled to return to his province; but the partizans of Canterbury never seem to have withdrawn the charge that he was one of the chief causes of the misfortmes of their now sainted favourite. ${ }^{g}$

Roger was not on the best of terms with Richard, Becket's snccessor in the see of Canterluny, indeed it was almost impossible for the two archbishops in those days, whoever they might be, to avoid bickerings and contention abont privileges and position. In 1175 Roger was not present at the synod which Richard held at Westminster, nor did he explain his absence ${ }^{h}$ his clerks, howerer, were there, and made several elaims on the part of their master. ${ }^{i}$ 'They asserted the right of the archbishops of York to bear their cross erect within the province of Canterbury; and to have the spiritual control over the sees of Lincoln, Lichfield, Worcester, and Hereford. On these two points they summoned the archbishop of Canterbury to Rome. They appealed also to the same anthority against the sentence of cxconmmication which Richard had passed against the offieers of the conventual chureh of St. Oswald at Gloncester, which belonged to York, for refusing to pay him their obedience. ${ }^{j}$ Nothing seems to have been done at the time, but soon afterwards, at Winchester, the king trich to act as a peacemaker between the two prelates. After a long debate he was partially successful. Richard of Canterbury consented to absolve the clergy of St. Oswald's, and to make that house as free and independent as a royal chapel. It was also agreed that with reference to the other points in dispute, especially that about the cross, that they should be decided by the arehbishop of

ceto, col. 558. Stubbs, col. 1723. Matt. Paris, 101-5.

'Foliot's Letters, ii., 173. Joann. Sareber., ii., 261. Chron. Jo. de Oxenedes, 65.

$f$ Foliot's Letters, ii., 171-3.

g Becket's Iforks, i., 10, 99, 370. Bromton, col. 1062.

${ }^{h}$ I)iceto, col.585. Matt. Paris, 109.
'Iloveden, 311. Rob. de Monte, 787.

j Diceto, 583. Bromton, 1100-2. Becket's Works, iii., 322. Foliot's Letters, i., 140. Opp. Jo. Saresber., i., 33. Benedict Petrib., 94, 106-7, 126-7. Cf. Prynne's Coll., iii., 984, 1026, and Reg. Ab. Corbridge. 
Ronen, and the French bishops in that neighlouthood. 'They' resolved, in addition, to have a truce for five years, and to start no new points of debate before the old were settled. This last engagement was not entirely adhered to. The legate IIngurerio was unconsciously the cause of a rather amusing but unlieconing scene. In 1176 he had been with Roger at York, and he accompanied him to the court at Nottingham. ${ }^{k}$ They were together, soon afterwards, at the council at Westminster. The old question of precedence in the presence of the legate was then revived. Which of the two archbishops was to sit on the right hand, a position which has excited angry feclings in nobler minds than theirs? Richard had taken the coveted place, when Roger seems to have pushed himself in between the legate and his rival-nay, he is even said to have sat down in Richard's lap; but this is probably only one of the Canterbury embellishments with which the story seems to be garnished. This was too much for the sensitive feelings of the friends of Richard. Ecclesiastics and laymen alike manifested a strange excitement, and even bishops

\section{"Tartæne animis cælestibus iræ?"}

shewed that they conld be subject to the same passions which run riot occasionally in less exalted minds. They pounced upon Roger and threw him down. They cuffed and beat him to their heart's content. They trampled him under their feet. When they were at length satisfied, the suffercr was permitted to rise, with a torn cope, and covered with dust and shame. They langhed at him when he remonstrated. When he went out to seek the king and demand redress, they shouted after him the old calumny, "Away, away, betrayer of St. Thomas. His blood is still upon thy hands." Roger was excessively indignant, and singled out from the others Geoffrey Ridel, bishop of Ely, as one of his most vehement assailants. Nothing, however, seems to have been done. The seene was far too ludicrons to necessitate any severe or vigorous remedy, but it was most discreditable and unseemly. ${ }^{l}$ An end, howerer, was put, abont this time, to the long-continued controversy abont the profession. A bull of pope Alexander settled the question in accordance

${ }^{k}$ Hoveden, 313. Bromton, 1107. Benedict Petrib., 130. At another council at Nottingham in 1181 Riehard of Canterbury carried his cross erect in the presence and within the diocese of Roger (ibid., 368).

Diceto, col. 515, 589. Bromfon, col. 1109. Gervase, col. 1483. Wm. Neubr., i., 232-3. Hoveden, 316. An- glia Sacra, i., 9. Geraldus de Instit. Prine, ed. Stevenson, 178. Fordum, Scotichronicon, ed. Goodall, i., 475. Jemingford, ed. Gale, ii., 506. Bonıdiet Petrib, 139, 146. There is an amusing account of the scene, and in history of the controversy, in Fuller's Church IIistory, book iii., 38-9. 
with the old decree of Gregory the Great, forbidding altogether that token of submission. This was agreed upon at one of the many comeils whieh were held at the Lateran, in $1179 .{ }^{m}$

Roger, like many of his predecessors, had frequent controversies with the Scottish bishops. During the life-time of Becket, he had a dispute with Richard, the bishop-elect of St. Andrew's, who had refused to be consecrated at York; and he appealed against him to the pope, desiring that he might be suspended, but without success. About this time Roger was invested with the legantine authority, a power which, although he was deprived of it in Englind, he seems to have always excreised in Scotland. He held a meeting at Norham, on the Tweed, and summoned thither the Scottish ecclesiastics, in the vain hope of indueing them to own their subjection to York." One of the elergy who was there, Ingelram, the bishop-elect of Glasgow, set him still farther at naught by being consecrated by Alexander III. at Sens, in spite of the stremuous opposition of the representatives of York. In 1174 Roger was at Falaise in Nomandy, when William king of Scotland, then a prisoner, made a treaty of peace with IIenry. In the following year the two monarchs met at York, and the conditions assented to at Falaise were solemmly sworn to and confirmed. They subjected the state of Scotland entirely to England, and the church, also, in all that was right and proper. In token of his submission the Scottish king deposited his spear and shield upon the altar of St. Peter in the minster, where they were for a long time preserved. ${ }^{p}$ In $11 \% 6$ there was a commeil held at Northampton q $^{q}$ at which the provisions of the treaty of Falaise were thoroughly examined and discussed in the presence of the Scottish king and his bishops. These prelates were required by Henry of England, on the strength of their allegiance, to own their subjection to the English church as they had hitherto done. 'Their answer was that they had nerer been subject to that church, and that the acknowledgment was unnecessary and unfair. Archbishop Roger led the argment against them, and produced documents which shewed, in particular, that the sces of Glasgow and Whitherne had always been dependent upon York. Upon this, the bishop of Glasgow asserted that his ehureh was under

n Diceto, col. 589. Foliot's Letters, ii., 71. Labbe, Cone., x., 1553, 1689.

"Fordun, Seotichronicon, i., 461 . Chron. Mailros, 79. The historian is nut eomplimentary when he speaks of Jogrer as "dephinum ilhm." As soon as Roger had obtained the prall, Adrian IV. wrote a letter to the Scottish bishols charging them to obey him.
Wilkins, i., 481 .

- Hoveden, 283. Chron. Mailros, 79.

"Bromton, col. 1103-5. Hoveden, 311-12. Rob. de Monte, 786 . Benedict Petrib., 113. Knyghton, col. 2396. Chron. Mailros, 88.

q Bromton, col. 1108. Knyghton, col. 2396. Hoveden, 314 $b$. Benedict Petrib., 137-8. 
the especial protection of Rome, and that it was subject to no other power. No decision was then arrived at, principally, it is said, through the means of the archbishop of Canterbury, who was desirous of being the head of the Scottish church himself. Fordun gives a different account of the debate at Northampton. The bishops, he says, were summoned thither by the legate, who endeavoured to induce them to own the supremacy of lork, and thus strengthen the efficiency of the Northern church. They were silent for fear of giving offence, when a young ecclesiastic of the name of Gilbert stood up, and combatted the arguments of the legate on behalf of his compatriots with so much boldness and ingenuity, that the demand was waived. "Well shot, master Gilbert," said Roger of York, laying his hand on the shoulder of the youthful orator, "but that shaft did not come from your own quiver."

“Ex propria pharetra non exiit ista sagitta.".

The truth of this story may be gravely questioned, at all events Fordun seems to be in error when he says that the youth, as a reward for his zeal, became bishop of Caithness; St. Gilbert, who actually presider over that see, did not die till 1245. Soon after the meeting at Northampton cardinal Vivian, the papal legate, held a council at Edinburgh, to which all the Scottish bishops were summoned. Christian bishop of Whitherne was not there, and the legate suspended him for his absence. Christian thew himself upon the protection of Roger, by whom he had been consecrated, asserting that he was the papal legate and the superior to whom his allegiance was due. ${ }^{s}$ In 1178 a violent controversy broke out between the pope and William king of Scotland, in which Roger played a part. Richard bishop of St. Andrews died in 1178, and John Scotns was ehosen by the chapter to succeed him. When the king heard of this selection he was excessively indignant. He expelled Johm from Scotland, and gave the see to Hugh, his ehaplain, who was consecrated by the Scottish bishops. John, upon this, went to Rome and complained to the pope, who sent as his legate a person of the name of Alexis, to enquire into the ease. 'The report was in favour of John, who was consecrated in 1180, the election of his rival having been cancelled. The king, however, drove John, for the second time, into banishment. Ipon this, Alexander wrote to the Scottish bishops, confirming the proceedings of his legate, and excommunicating Hugh. He charged the king and his prelates to permit John to enter quietly into his see, otherwise the archbishop of lork, who was

$r$ Fordun, Scotichronicon, i., 176-8.

- Bromton, 1111. 11oveden, 321. lienedict Petrib., 211-12. 
his legate in Scotland, wonld put the country under an interdict. ${ }^{t}$ The warning, however, was despised, and, in 1181, Roger, by the desire of the pope, inflicted the threatened pumishment, and exeommunicated the king." I shall mention in another place what was the conchusion of the difficulty.

From what has been already stated it will have been seen that Roger was one of the leading politicians of the day. There were other occasions on which he was engaged in the service of the state. He was very frequently in attendance upon the king. ${ }^{p}$ In 1162 pope Alexander, through the means of Roger, and the bishops of Evreux and Lisieux, endeavoured to persuade Henry II. to ally himself to Louis of France. ${ }^{w}$ In 1172 Alexander would not allow him to erown Henry and his queen, although he had officiated in that eapacity before. ${ }^{x}$ In 1174 he took a conspicnons part in the military affairs of the North. He entertained and aided Geoffrey hishop of Lineoln, the king's son, when he assanlted and captured the castle of Kirkby Malzeard; and, when he returned, the arehbishop took charge of the fortress on behalf of the king.y He also weleomed the barons who were going against William of Scotland, and sent the news of

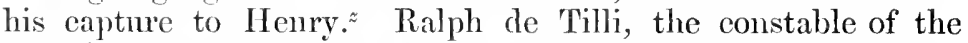
arehbishop's household, was at Alnwick when the Scottish monarch was taken prisoner, and was one of the party who rescued Prudhoe eastle from the invading army. ${ }^{a}$ In 1177 Ilenry gave to Roger the custody of Scarborough castle. ${ }^{b}$

Roger was a man of learning and ability. He was as ready with his pen as with his tongue. He wrote fluently and well. At the little court of Theobald of Canterbury, where the talents of Becket were of 110 repute, Roger had formed the acquaintance of most of the scholars of his day, among whom he oceupied a distinguished place. With John of Salisbury he was on familiar terms. ${ }^{c}$ Gilbert Foliot and he were great friends. 'They corresponded together', and when Foliot was under the papal censure, for his share in the opposition to Becket, he

Tabbe, Cone, x., 1239-41. Benedict Petrib., $316-9$.

"Stubbs, col. 1723. Hoveden, 341-

51. Benedict Petrib., 331, 370.

" Bromton, col. 1108, 1126-7, 1133. Benerlict Petrib., 202, 231, 368.

"Recueil des Hist. des Gaules, xv., 785. There is a letter probably referring to this in Becket's Works, iv., 206.

${ }^{x}$ Diceto, col. 560. Gervase, col. 1121 . Matt. Paris, 109.

y Bromton, col. 1093. Hoveden, 307 b. Vita Gerardi Arehiep., apud
Angl. Sacr., ii., 379. Benedict Petrib., 78.

z Chronique de Jordan Fantosme, ed. Surtees Society, 78-9, 91, 93.

" Hoveden, 308. Benedict Petrib., 74.

${ }^{b}$ Ibid., $323 b$. Benedict Petrib., 203. Hinderwell (History of Scarborough, ed. 1832, p. 50) makes him hold that office till he died. Roger had also the custody of Roxburgh castle (Ben. Petrib.)

c Olp. Joann. Saresber., i., 75. 
found an asylum at Bererley. Roger afterwards intereeded in his behalf with the pope. ${ }^{d}$ Hugh de Puiset, the famous bishop of Durham, of whom there is too little as yet known, and the archbishop of York, were intimately comnected in prosperity and adversity.e Roger and pope Alexander III. corr'esponded on matters of discipline and on the public events of the day $f$

It has been said that Roger was opposed to the monastic system, and that he expressed his opinion that 'Tlumstan's greatest mistake had been the establishment of Fonntains. $g$ This is, probably, merely idle gossip. It is quite possible, however, that Roger discovered the inherent defects of the monastic system, which are not slow in dereloping themselves. He was a bold man, and was not afraid of checking what he thought to be wrong, and when we find him in collision with the canons of Newburgh, and suspending the prior of Gishurgh, ${ }^{k}$ we well understand how his activity sharpened those weapons of abuse and railing which monkish chroniclers are too apt to use. It is also a remarkable fact that, with the exception of the abbey of Welbeck ${ }^{i}$ and one or two other places, all the religious houses which were founded in the diocese of York during the archiepiscopate of Roger were Cistercian or Benedictine numnerics. ${ }^{j}$ There was a superalumdance of monasteries, and a reaction had begun. The age of great endowments and large eeclesiastical establishments was passing rapidly away. The system was being gradually refined, and eonsequently deteriorated.

Roger has also been charged with miscrly and pemurions habits, and with imporerishing his elergy and lis diocese. ${ }^{k}$ That he was a rich man there can be no donbt, for he had presided over a wealthy see for nearly thirty years, and he was a prudent husband of the fortune which he had amassed. We licar of him endeavouring to recover, at the papal court, the property

d Foliot's Letters, i., 135-45, 293; ii., 75. Becket's Works, iv., 308.

- There is an account of a miracle wronsht on one of Rogrer's clerks at St. Cuthbert's tomb, in Resinald, de admir. B. Cuthberti virtutibus, ed. Surtees Society, 261.

$f$ Hoveden, 325. Foliot's Letters, ii., 72, 75 et seqq. Labbe, Conc., x., $12+5,1488,1564-7,1573,1585,1590$, $1603-4,1612,1620-1,1666-7,1684$, 1698, 1706, 1721. Baluzii Mise., ed. Mansi, iii., 375. Wilkius. i., 457.

g Wm. Nenbr., i., 268. Brouton, col. 1142. Hemingford, apud Gale, ii., $506-7$.

$h$ Labbe, Conc., x., 1597, 1626-7.

i Annal. Ord. Priemunstrat., ii., ap- pendix, 711-12. Soon after 1172 Roser witnessed the eharter of fomdiltion of the monastery be IBosen Raherii, near'Tours. (Martene, 'Thes. Nor. Aneed., i., 573.)

$j$ At least a dozen of these numneries may be reckoned mp.

$k$ Wm. Neubr., i., 267-8. Rob. de Monte, 805. Newhurph is ond rageonisly violent against Rourer, and salys. "In vita sua tonderdis malsis getan bascendis ovibus Dominicis intemdit." Bonediet of Peterboronsh (119) sals that le bonght the elancellorship for cireolfrey, provest of Beverley, for eleren thensaid minte.s. 'This person wats Roger's nephew, and was drowned in 1177 (ibil., $250)$. 
of which he had been deplived by the carelessness or waste of his two inmediate predecessors. "Althongh in this respect he sccms to have been unsuceessful, he took care that the deficiency was made np from other sources. Ife whom the lips of calumny have stigmatized as a miser, was the most munificent ruler that crer presided over the see of York. He made the archbishopric richer in every respect than he found it. Robert de Monte tells us how he added to the endowments of his churches and rebuilt all his residences so magnificently, that they could almost rival those in the Southern province. ${ }^{m}$ He began a new basilica at Ripon, and gave to the work the rery large sum of $£ 1000 .{ }^{n}$ At lork he erected the arehiepiscopal palace on the north side of the cathedral, of which scareely any portion now remains. IIe decorated the minster with a new choir, worthy of the glorions work of Conrad, with which Canterbury had been adomed. ${ }^{\circ}$ On the north side of the ehurch, between his new palace and the cathedral, he founded the chapel of St. Sepulchre, which was dedicated to the Blessed Virgin and the Holy Angels. The culowment was a noble one. Eleven churches were appropriated to it, five of which he purchased with his own funds. $A$ staff of thirteen officers belonged to it, all munificently provided for, and care was taken that there should be no jealonsy or collision between the officials of the chapel and the dignitaries of the adjacent minster. ${ }^{p}$ Roger gave also to his metropolitical church onc of the bones of St. Peter, and a portion of the sandals of that apostle, which he brought from Rome. These, and some of the more precions relies which the minster of York possessed, wre deposited in a hollow crucifix of gold, which was given to the chapter by the same prelate. This and other treasures beknging to the eathedral were given up to secure the ransom of ('emr' de Lion from his Anstrian eaptivity, but they were subserguently redeemed.q

In November, 1181, Roger, who had been prevented by ilhess from attending a council in $117 \%,{ }^{r}$ felt his end approaching. Ile was at a place ealled Cowila $;^{s}$ and he called around lim the abbats, prior's, and ccclesiastics of his diocese. In their presence he made the following munificent bequests. He grave more than five hundred pounds' worth of silver to William,

Becket's Works, iv., 237.

"n Lish. de IIonte, 805. Hemingford, :1]ut ciale, ii., 506-7. Trivet, 82.

n Walbran's Ripon, 25.

"Fumlavit clormm et testudines

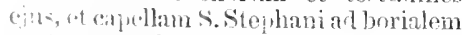
Iratcint templi" (Lel. Coli., i., 121).

$p$ Stubb; col. 17ะ3. Lel. Coll., i., 39. Hugal. Non,, vi., 1181 .
9 Fabric Rolls of York Minster, 152.

$r$ Bromton, col. 1122. Benedict Petrib., 181 .

$s$ IIoveden, $350 \mathrm{~b}$. I cannot identify this lace. Perhaps it was Cawood? Stublus (col. 1723) says that Roger died at sherburn. Antony à Wood makes him die at Osney abbey (Antiq. Univ. Oxoll., i., 166). 
arehbishop of Rheims, and the French bishops, for the necrly in their dioceses. A similar sum, for the same use, was uriven to the arehbishop of Rouen and the Norman prelates; and a third, equally large, to his brother of Canterbury and his sufliagans. All the rest of his treasure was also for the benefit of the poor. After this Roger was removed to York, and there he died at nightfall on the 22nd of November. ${ }^{t}$ His noble bequests were altogether misappropriated," and everything that he possessed eame into the hands of the king, to whom he had been a faithful servant. ${ }^{p}$ It was suggested to Hemry that the deceased prelate had made a rule within his diocese, which had been sanetioned by the pope, to the effect that no will of an ecelesiastic should be valid which was made in his last sickness. Who could interfere with what a dying archbishop bequeathed but his sovereign? The king immediately scut his messengers, who seized upon the money, which was the property of the poor. But he did more than this. The archbishop, it was well known, had been possessed of immense wealth. He had died intestate; who was to have it? The bait was too tempting for an avaricious and ungrateful king; and he ordered everything that had belonged to Roger to be gathered together by the justices, and appropriated to his own use. The large sum of $\mathbb{E} 11,000$ of silver, and plate, and valuables of every description, thins found their way into the royal treasury. The curse of God, which settled upon Ahab, seems henceforward to have rested upon this plunderer of the poor. The gathering in of the spoil was not made without difficulty and controversy. The king's justices heard that the bishop of Durham had received three humdred marks of the archbishop's money, and they required them at his hands. Puiset told them, with the spirit which was native to him, that the money had been given for the weal of his friend's soul, in accordance with his desire, to the leper, the lame, the halt, and blind; that it had been spent in restoring churehes and bridges. He had none of it, and those who wanted it must seek it for themselves. The king, upon this, was full of wrath, and seized upon the castle of Durham, regarding its high-spirited owner with the bitterest ill-will.

- Hoveden, ibid. Chron. Mailros, 91. Dieeto (col. 613) makes him die on the 20th. Stubbs (eol. 1723) on the 26th. Gervase (col. 1159) says in September. Cotton's Chron., 79.

u An aceormt of the death-srene of Roger, and the misappropriation of his wealth, is to be found in IIovelen, 350-1. Wm. Neubr., i., 267, ete. Bromton, col.1112. Matt. Paris, 116-
17. Benedict Petrib., 371, 378. Dieeto (col. 517, 611). He says that the confiscation was made when logrer was on his death-bed. This robbery aetually makes Foxe eushrine lioger in his calendar of martyrs!

"lioger took the king's part when his sons raised a rebellion against him. Benelict Petrib., 58. 
Puiset performed the last solemn rites for Roger, as he had done, nearly thirty years before, for his predeeessor William. The remains of the arehbishop were interred in the choir of the minster which he had rebuilt $;^{w}$ and when, after a lapse of nearly two centuries, it was again removed to make way for a more magnifieent structure, the body of Roger was probably transferred by archbishop Thoresby to a new sepulehre at the easternmost extremity of the choir. ${ }^{x}$ 'Tradition has for centuries aseribed to Roger the tomb in the north aisle of the nave, hard by the entranee into the chapel of St. Sepulehre. ${ }^{y}$ The monument, however, is none of his. It is in a most debased style, and is not earlier than the reign of Henry VII.

When arehbishop Roger died, the king of Scotland was under a sentence of excommunication, and his land under an interdict. William was overjoyed when he heard of his decease ; and, after conferring with his comeil, sent off Joeeline bishop of Glasgow, Armulf abbat of Melrose, and others, to Lucius the new pope, to proeure, if possible, a reversal of the sentence; and, rather than they should return without it, they were to promise that John, bishop of St. Andrew's, should be deposed. $z$ The embassy was entirely suceessful. The ban was removed from king and eountry, and two papal eommissioners, Roland bishop-eleet of Dol in Brittany, and Silvan abbat of Rievanx, were despatehed to Scotland to examine into the dispute about St. Andrew's. The difference was settled for a time, by both John and Hugh resigning their interest in that see into the pope's hands. Lueins then gave St. Andrew's to Hugh, and appointed Joln to Dunkeld. The quarrel was soon afterwards opened out again by the jealous and eontentious disposition of the two prelates, and it ended at last, after much angry discussion, in another compromise, into which it is unnecessary to enter.

In 1191 pope Clement made a most important declaration respecting the position and independence of the Scottish church, at the request of the king. It refers to every see but that of Whitherne, which seems to have been given up to York by rommon consent. 'The Seottish chureh was made independent of erery authority lout that of Rome, and no one was to excommunicate or lay an interdiet on the kingtom, unless he were the chief pontitt or his deputy. No alien was to act for the future as a legate within that district, unless he was a special emissary from Rome; and nothing relating to Scotland was to be settled in another comntry, exeept at the papal court. This

"Hoveden, $350 \mathrm{~b}$. Stubbs, col. 1723. Benerlict Petrib., 371.

${ }^{x}$ Prefice to York Fabric Rolls, xvii.

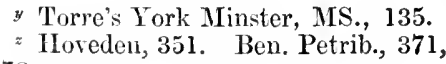
372 . 
most important deeree, it will be observed, disposes summarily of the claims of the see of York. The archbishopric, it will be remembered, was at that time vacant. It would have becu more just and fair if this sentence had been delivered when there was a Northern primate. He would then have had an opportunity of asserting the claims of his church to the ceclesiastical control of Scotland, which his predecessors had always vindicated to themselves. ${ }^{a}$

The see of York was all this while vacant, the rerenues flowing into the royal coffers. ${ }^{b}$ Henry II., however, on more occasions than one, shewed some interest in the appointment of a primate, and the welfare of the Northern diocesc. In 1181. the canons of York, and Hugh bishop of Durham, met at the king's request to fix upon an archbishop, but nothing scems to have been done. ${ }^{c}$ In 1186 Henry sent Puiset back to England to be present at the festival of Easter in the province of York, in which there was at that time no prelate. ${ }^{d}$ In Scptember, 1186, the canons of York were present at the conncil at Marlborough, and nominated fire per'sons in sncession as archbishop; Hubert Walter their dean, Hamund or Hamo their precentor, Laurence archdcacon of Bedford, Bernard prior of Newburgh, and Roger Arundel. All of them were rejected by the king ; for what reason we are not informed. ${ }^{c}$ In the archbishop who was ultimately selected, Hcnry himself had an espeeial interest.

(B) caftrey 住lantagrnet, an illegitimate son of Hemry II. He was one of the king's elder children.$^{f}$ His mother is said to have been the well-known Rosamond Clifford, the Fair Rosamond of story ; and this assertion gains some weight from the fact that in after years Geoffrey appropriated the religious house of Clementhorp, near York, to the numnery of Ciodstow, in which Rosamond was interred.g 'There are, however, some

a For these Scottish affairs see Ben. Petrib., 371-2, 375, 379, 381, 510, etc., 528, etc., 538. Hoveder, 351-2, 351 , $356,360-1,368$, ete., 371-2. Labbe, Conc., x., 1735, 1713, 1753, etc. I have not gone into the subject at length, as it is not my purpose to write a history of the Scottish Church. 'That task has already been very creditably and honestly performed by Mr. Grub of Aberdeen. There are, however, omissions in that work which may be supplied by a careful examination of the ninos English chroniclers and tho writings of Foreign historians.

${ }_{b}$ Win. Neubr., i., 270. Madox, Bar. Angl., 87.

c Ben. l'etrib., 113.

d Ibid., 41. e Ibicl., 453.

$f$ Gerald Cambrensis, apud Angl. Sacr., ii., 378. The nume of Ceoffrey came from his paternal grandfather, Geoflrey comte d'Angers.

E Iloveden, 408b. Ben. Petrib., 732. 
chronologieal difficulties in the way, ${ }^{h}$ and it scems probable that Geoffrey had for his mother some more insignificant person. Walter Mapes, if he is to be trusted, gives lier the name of Tkenai, and a very low character. ${ }^{i}$

Geoffrey is said to have been born in 1159 . When he was merely a child he was made archdeacon of Lincoln; ${ }^{j}$ and in 1173, when, if the previous date be correct, he could not be more than fourteen years of age, his father procured his election to the bishopric of that see, and the appointment was confirmed by the arehbishop of Canterbiry at Woodstock. ${ }^{k}$ The pope, also, seems to have winked at the irregularity. The youth, howerer, was not in priest's orders, and how could he be consecrated? Wikes tells us that Geoffrey himself was disposed to wait, because he aspired to something higher ; ${ }^{l}$ and there is probably some truth in this statement, when we remember that he had the same wish on a subsequent occasion. It was necessary, however, to conciliate the pope; and he crossed the seas in $11 \%$, at his father's suggestion, to visit the papal court in

"h Geoffrey was born, according to the Kirkstall Chronicle, in 1159, whilst Rosamond is called by bromton a puelle in 1173. 'T'he Kirkstall Chron., from the quotation from it which I lave seen, appears to be singularly inaccurate. The question of Geotfrey's birth is discussed by Messrs. Bowles and Nichols in their History of Lacoek abber, 102. Cf. Sandford's Kings of Frgland, 71 .

"Inprosuit autem ei in principio reni sui meretrix quadam publica, niliil immonditixe dedisnans, filium quem a populo snsceperat nomine Gaufridum, fuem injuste minusque discrete tranquam sum acceptans, in tantum promovit ut hodie sit Ebor. archiepiscopus. Nomen autem matris ejus Ikenai" (Mapes, De Nilgis Curialium, 223). Mapes, it must be remembered, wats rery bitter against Geoffrey.

The following illegitimate children of Ilenry II. were also connected with the North. Peter, brother of Geoffrey, was archdeacon of Lincoln from about 1190 to 1202 (Le Neve, ii., 43). In 1194. Geoffrey tried to get him made dean of York, but he was then at Paris, and the opportmnity was lost (lloverlen, 115-16). A year or two after this we find the brothers bitter enemies (Ibid., 42s).

Horyan, a brother of Geoffrey, and an illegitimate son of Henry II., by the wife of Sir Ralpli Bloeth (Hist. Dunelin. Scr. Tres, 35; Sandford's kings of England, 72), was advanced by Geoffrey about 1201 to the provostship of Beverley upon the death of Robert (Hoveden, 468). In 1214 the monks of Norwich elected him their bishop, but the king knew nothirg about it, and the election was set aside (Hist. Dunelm. Scr. Tres, 31). In 1223, heing still provost of Beverley, the monks of Durham chose him as their bishop, and he went to Rome to be consecrated. His illegitimacy was the cause of the pope's refusing to confirm his appointment (Ibid., 35; and Lel. Coll., ii., 333.) Morgan was commemorated by the following epitaph (Camden's Remaines, ed. 1674, p. 495).

"Larga, henigna, decens, jacet hic stirps regia,

morum
Organa Horgano fracta jacente silent."

"John clericus, filius regis, canonicus Ebor.," is mentioned in a chartulary of the treasurers of York : ef. p. 221 .

$j$ Ger. Cambrensis, ut supra, 378.

k liob. de Monte, ed. Stevenson, 780 . Gerald, 378. Diceto, col. 568. Contin. Fl. Wigorn., ii., 157.

I Wikes, apud Gale, ii., 32. Neubr. (i., 176-7) ascribes the delay solely to Geoflirey's cupidity, "oves Dominicas nesciens pascere et doctus tondere." This is a favourite phrase with Newburgh. 
or of St. Gicorge's, Blonmsbury: Preacher of Lin. s Inn, and Principal of I'ing's College, London. $\mathrm{He}_{\boldsymbol{e}}$ became Provost of Etom, and Archdeacon of IIiddle$\mathrm{He}$ was consecrated Bisbop of lichficld, December 1843, and died October 19th, 1867, aged 79. The pp, who was highly esteemed in his dimese, had ded an educational meeting at Stafford during the noon, and had made two or thres short speeches. he returned home, he complained of being unwell, diced befors medical assistance could be obtained. a photographic portrait of him see his " Tife," 1868 , ir fidmund Beckett (Denison), Bart., Lord Grime, who married one of his daughters; see also "Mlen e 'Time." 7th edition, 1868, with an engraved portraio 'ound, \&c. > Statues of Bishops Lonsdale and Selwyn been placed in front of the south-west tnwer of field Cathedral. In all 27 figures have nuw been al in their respective niches.

\section{A IORD CHIEF JUSTICF}

ughborough Alexi. Weduterburi, frord, ex.M.P. Richmond, Yorkshire, and of Wedderiourn Fouse, ogate, married the daughter of Mr. John Dawof The Hall, Morley, neal Leeds. On the south ile ald graveyard at Morley is the sepulchre of T Loughborough, a person of rank and fortune. slab containing her memorial is of a soft blue , and the inscription is now illegible. The fol$g$ is a copy of the epitaph:- "Within this tomb the remains of the Right. Hon. Lady Lough. ugh, wifo of Alexander Loughborough, Lord f Justice of the Common Plas She was the daughter of John Drawson, Fsq., and his wife beth. Ener Ladyship died the 14th of Fcbruary, aged 36," and was interred there on the 28 tb sbruary. The following particulars, gleaned from er source, will furnish further evidence of the ion and rank of this lady:-"1781, February Jied at Morley Hall, and buried in the old I graveyard, Botty Anne, daughter of John Daw. Esq., of Morley. Sho was the wife of Alexander lerourn, who was born in 1733; became Solioitor:al in 1771; Attorney-General, 1778; Lord Chief :e of the Court of Common Pleas, 1781 ; created 1 Inoughborough, in the county of Leicester, and e heirs male of his body, by patent, dated 14.h $1780 ; "$ and Earl Rosslyn in 1801; and died hts were in the train of the
iry 3rd, 1805, ager 72. See Cunninghan's des," vol. vi., p. 434; Grainge's "History of is father at IInutingrom. igate," and Smith's "History of Morley," \&c. nd ralour, and said of lhim are sereral portraits of him, after Jaokson, by other childlecu are indeed , \&c., with numerous aneedotes.

\section{The rey ute soll.}

We hear little of Geoffrey after this for several ycars.' IIe seems, however, to have done a great deal for his diocese of

"n Diceto, eol. 582.

$n$ Peter of Blois says this in a letter to Roger, dean of Lincoln. (Oply., i., 222-4.) o Ben. Peirib., 111.

$p$ Ibid., 58. q Ger. Cambrensis, 378.

r Ger. Cambrensis, 379 . Diceto, col. 577. Bromton, col. 1093. Ben. Petrib., 77-8. Matt. Paris, 108. IIoveden, $307 \mathrm{~b}$.

reted very properly, and luee ycalis." Ipoll this, sscutied to this decision, "Touts.'

side lis books, as we find

His filial aflection was il rebellion arose awainst ; but the young bishop$\mathrm{m}$ his allegiance and his chaneellor he collected a iocese for liis father's use, priety of the exaction, lie I gathered together. IIe , but in a somewhat unoags away to take up the hbouring baron of great and Geoftrey never pansed his castle in the Isle of , he now passed onwards sheriff and the archbishop, inst William of Scotland, 1d. He hastened at once re archbishop. He hat a n the eity. The next day lliam. Upon this Gicoffrey whray's fortresses, that of garrison to surrender after th of allegiance to Ilngh, sd of treason. A rumour $\mathrm{ng}$ was before the castle of ue. The report, lowerer', ned into the South. As- 
chronological difficulties in Geoffrey had for his mot Walter Mapes, if he is to Ylienai, and a very low ch

Geoffrey is said to has merely a child he was m: 1173, when, if the previo more than fourteen years o to the bishopric of that sce by the archbishop of Can also, seems to liave wink howerer, was not in priest' secrated? Wikes tells us to wait, beeause he aspires probably some truth in this he had the same wish on a sary, howerer, to conciliate $11 \dot{r}$ t, at his father's sugre

"Geoffres was born, aceoldins the Kirkstall Cluronicle, in 1159 , wl lowimond is called by bromtor puella in 1173. The Kirkstall Chr from the quotation from it whic have seen, appears to be singularly accurate. The prestion of Geolfr lifith is discusied by Mesers. Bor and Nichols in their llistory of Lat abher, 10\%. Cf. Sandfort's Kings Engiand, 71 .

i "Impostuit antem ei in prine remii sti meretrix quxelam peubl nitil immunditia dedimnans, fili quem a jropuks:unseprerat nomine $G$ : frilum, guen injuste minusque diser tumpluan stum aceeptans, in tant romosit ut holie sit Ebor. arel episcopus. Nomen autem matris e Thonai" (Mapes, De Nugis Curialiul" 220). Mapes, it nust be remember was very bitter asainst Geofliey.

"The following illegitimate children of Ihoury II. were also commected with the North. Peter, brother of Geoffrey, was archdraeon of Lincoln from about ]1:0 to 1202 (Le Neve., ii., 13 ). In 11:11 Gooffrey tried to get him inade deall of York, but he was then at '?aric, and the opporimity was lost (Hovedru, 115-16). A year or two altcr this we find the brothers bitter (4) 1 unis (Ibid., 128).

lyorman, a brother of Geoffrey, and an illogitinate son of IIenry H., by

\section{SPORTS AND PASTIME CRICKET, CYCLING, SWIMMING, 8}

Shasex just failed to beat Worcestenshire at Worc on Saturday last, owing to the fact that Ranjitsinhji not close the Sussex second imnings till he was 400 to the grod. When the time came for drawing str the last two Worentershire men were together, their side was 184 runs behind. Fssex won the with Middlesex at Ieyton by 94 runs within tw minutes of time. Douglas made a splendid effor save the game, scoring 151 out of the total of Middlesex, of murse, were greatly handicapped by a.bsence of 'Trott, who was able neither to bowl ni bat. The Hampshire and Surrey match at Southam had to be abandoned as a draw. At Harrogate $\mathbf{X}$ shire defeated the Sonth Africans by 151 ross.

In every kingle particular, the opening of the re match between the rival Roses at Headingley on No was a splendid cuccess. The weather, if cloudy. mained fine, and there was a record crowd. At farnous Jubilee match with Surrey four years ago, attendance on the first day wase 30,004; on Monday 3 perple passed through the turnstiles-this includes $I$ bers and county ticket-bolders-and the reoeipts rea the magnificent figure of $£ 1,2787 \mathrm{~s}$. 6d. During the the Yorkshire players and others mado a collectio the ground, and the sum of $£ 625 \mathrm{~s}$, was realised, so the full raxeipts were $£ 1,340$ 12s. 6d. Yorkshiro

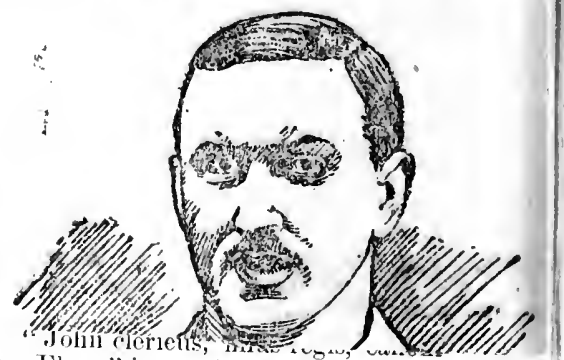

cus Ebor.," is mentioned in a ehartulary of the treasurers of York : ef. p. 221.

$j$ Crer. Cambrensis, ut supra, 378.

${ }^{k}$ Rob. de Monte, ed. Stevenson, 780. Gerald, 378. Dieeto, col.568. Contin. Fl. Wigorn., ii., 157 .

i Wikes, apud Gale, ii., 32. Neubr. (i., 176-7) ascribes the delay solely to Geoffrey's eupidity, "oves Dominieas nesciens pascere et doctus tondere." 'J'his is a favourite phraze with Newburish. 
person, or by deputy. ${ }^{m}$ The pope acted rery properly, and deferred Geoffrey's consecration for three years. ${ }^{n}$ Ipon this, Hemry, who seems quietly to have assented to this decision, sent his youthful son to be edneated at 'Tours. ${ }^{\circ}$

Geoffirey must soon have thrown aside his books, as we find him back at Lincoln in the same year. His filial affection was then put to the proof. An unnatural rebellion arose against Henry, fostered by three of his sons; but the young bishopelect of Lineoln would not swerve from his allegiance and his duty. ${ }^{p}$ At the suggestion of the lord chancellor he collected a very large sum of money within his diocese for his father's use, but having some doubt as to the propriety of the exaction, he returned every farthing that had been gatliered together. $\mathrm{He}$ now exerted himself in a more uscful, but in a somewhat unclerical way. He threw the money bags away to take up the sword. Roger de Nowbray, a neighbouring baron of great influence and power, was in rebellion, and Geoffrey never paused till he had stormed and pulled down his castle in the Isle of Axholme. ${ }^{q}$ Flushed with his sucess, he now passed onwards into Yorkshire at the invitation of the sheriff and the archbishop, who were anxious to have his airl against William of Scotland, who was at that time invading England. He liastened at once to York, where he was the guest of the archbishop. He had a noble reception at the minster, and in the eity. 'The next day brought the news of the retreat of William. Upon this Geoffrey led his troops against another of Mlowbray's fortresses, that of Malzeard near Ripon, and forced the garrison to surrender after a short siege. ${ }^{r}$ He then put the oath of allegiance to Iugh, bishop of Durham, who was suspeeted of treason. A rumour now reached him that the Scottish king was before the eastle of Bowes, and he hastened to the rescue. The report, however, was a false one, and Geoffrey returned into the South. As. many as one hundred and forty knights were in the train of the young soldier when he reached his father at IImtingrlon. Henry was delighted at his loyalty and valour, and said of him before many bystanders, "All my other children are indecd base-born, but this is my true son.",

We hear little of Geoffrey after this for several years.' IIe seems, however, to have done a great deal for his diocese of

n Diceto, col. 582.

$n$ Peter of Blois says this in a letter to Roger, dean of lincoln. (Opp., i., 222-4.) 13en. Petrib., 111.

${ }^{p}$ Ibid., 58. ${ }^{q}$ Ger. Cambrensis, 378.

r Ger. Cambrensis, 379. Diceto, col. 577. Bromton, col. 1093. Ben. Petrib., 77-8. Matt. Paris, 108. Hoveden, $307 b$.
* Ger. Cambrensis, 380.

$t$ It is stated in the Chronicle of Kirkstall that Geoffrey was made a knight in 1179 , and several molem writers have followel in its rake. Hoveden (351) say's expressly that the per:on who received that honour was Geolfrey, carl of Brittany. 
Lineoln, although he was neither priest nor bishop. He attended carefully to the property of his see, and promoted men of learning and reputation. He redeemed the ornaments of the ehureh of Lincoln, which had been pawned for three hundred marks to Aaron, the Jew of Lincoln, and he added others, giving besides two large and fine bells to the eathedral." But still he was unconsecrated, to the great injury of his diocese, although he was all the while enjoying the revenues of the bishoprie. The three years preseribed to him by the pope had long since elspsed, when, in 1181, Alexander III took the matter up, and wrote to the archbishop of Canterbury desiring him either to require his youthful suffragan to reecive ordination and eonseeration, or to oblige him to give up Lineoln altogether. Geoffrey was now in a diffieulty, but he did not shrink from doing his duty. After consulting with his father, brother, and several prelates, he wrote from Marlborough to the arehbishop giring up the see, for which he modestly eonfessed himself to be unfit. He sent a letter also to the ehapter of Lineoln, begging that body to ammul his election."

Geoffrey was no loser, in a worldly sense, by this ehange. His father made him ehaneellor, and gave him offiees and rents to the rearly value of five hundred marks in Normandy and England." Among these must probably be enumerated the eastles of Beaugi and Langeis, the arehdeaconry of Rouen, and the treasurership of the chureh of York. ${ }^{x}$ For the next few years Geoffrey seems to have been generally with his father, to whom he was tenderly attached. He was present in 1182 when Henry made his will, in which his favourite son is made one of the dispensers of his eharitable bequests.y He remained faithful to his sire in spite of the disloyalty of his brothers. In 1187,

u Ger. Cambrensis, Vitæ Epise. Lincoln., apud Angl. Sacr., ii., 418. There is a letter from him as bishop of Lincoln to a Mr. R. Blondus, censuring him for disobedience and neglect of duty. The writer seems to be Peter de Blois (Petri Bles. Opl., i., 184-5).

"Ger. Cambr., 380-1. Rob. de Monte, 802. Ben. Petrib., 354-5. Trivet, 82 . Ticeto, col. 517, 613. Gervase, col. 1458. Stubbs, col. 1724. Horeden, 348-9. Matt. Paris, 117. Angl. Sacra, ii., 118. Fxdera, n.e., i., 37.

" Rob. de IIonte, 802. Trivet, 82. Ben. Petrib., 356. Horeden, 349.

$s$ Ger.Cambr., 380. Lel. Coll., i., 290, ex. Ginalt. Coventr., where it is said that Richard I. gave these places and posts to Geoflrey. Gerald is the sole anthority for his liaving been treasurer of York.
The Beverley historians claim Geoffrey as one of the provosts of their minster. He had nothing to do with it. Geoffrey provost of Beverley was a nephew of archbishop Roger, and probably succeeded Becket in his office. In 1176 his mele bought for him, for the large sum of 11,000 marks, the post of chancellor to Henry Fitz-Henry the young king. He was lost at sea in the month of October in the following fear, as he was crossing from England into Normandy. $\mathrm{He}$ was also archdeacon of Tork (Ben. Petrib., 149, 249. Diceto, col. 589, 599. Hoveden, 315. Trivet, 73. Bromton, col. 1115).

y Gervase, col. 1459-60. Gerald de Instit. Princ., ed. Stevenson, 160. Fxdera, i., 47. Nichols's Royal Wills, 7. Nicolas's Test. Vet., 2. 
when Philip of France raised the oriflamme against IIenry of England, Geoffrey buekled on his harness, and the king gave him the eommand of a fourth part of his army. ${ }^{*}$ He was with his father in the town of Mans when it was surrounded and fired by the Freneh soldiery, and after many attempts to extinguish the flames, and a vigorons resistance, he made his escape with Henry and his men to the eastle of Fresnclles. Many had fallen down by the way-side from fatigue, and Henry himself was worn out. Geoffrey desired him to repose, and wished to wateh on the outside of the eastle to proteet his father from an assanlt. Henry would not permit him to do this; and replenished from his own stores the wardrobe of Geoffirey, which had been lost at Mans. On the morrow Henry got himself away to Angers; and Geoffrey, after a perilons jouncy, in which he was followed by a hmodred knights, joined his father at Savigny. What a contrast to the baseness of Jolm, the youngest and the best beloved of all his ungrateful ehildren! ${ }^{a}$

In June 1189 Henry was still abroad. After the capture of Tours a disereditable peace was made with France, at the making of which Geoffrey, full of indignation, would not permit his sick father to be present. The end of the king was now at hand, hastened as it was and embittered by the treachery of $J_{\text {ohn. }}^{b}$ He was in the eastle of Chinon,

\section{"Zu Chinon hält der könig seinen hof,"}

and Geoffrey never left his side. One day the head and the shoulders of the sick man were resting on his breast; he was driving away with a fan the flies that buzzed around his father's face, whilst a knight at the end of the bed held in his bosom his master's feet. The eyes of the enfeebled monareh opened and fell upon his son. His harshness was gone, and he spoke, for at such times even stern and cold-hearted men eannot be silent. He told Geoffrey that, basely-born although he was, he had been a truer ehild than all his rightful children. Should his life be spared that filial affection should not be unrewarded. He bade him prosper and be blessed. The tears rushed from the listener's eyes, and muttering a few affeetionate words he left the room and the seene which had eaused him such poignant sorrow. The fever meanwhile inereased in violence, and Geoffrey, unable to refrain limself, songht again the chamber of his sire. Henry was now dying. His eyes were closed, but when he heard the expressions of sorrow which his son was unable to repress, they opened upon him again. He knew him

= Ben. Petrib., 467. Bromton, col. 1133.

${ }^{a}$ Ger. Cambrensis, 381. Ben.Petrib.,
452-3. Recucil des IIist. des Gaules, $\mathrm{x}$ viii., 216.

${ }^{\circ}$ Polydore Vergil, 276. 
and faltered out his wish that he might beeome bishop of Winchester or archbishop of York. He blessed him for the last time, and stretched out to him, as a final token of his alforction, a precions ring of gold, with a panther graven on it, which he had destined for his kinsman, the king of Spain. He gave him, also, another more costly jewel, a ring with a noble sapphire, which secms to have aeted like a talisman. ${ }^{c}$ After this the king passed away, and (icoffrey committed his remains most reverently to the tomb. The body was laid upon the bier in the church of Fonterraud, when Pichard, one of the dead man's rebellious ehildren, unexpeetedly and hastily came in. He gazed for the last time upon the faee of his injured sire. There he lay subdued at last, his comtenanee still retaining the stern expression which it had worn in life. In that awful presence Richard would remember that filial ingratitude had made that proud heart cease to beat.

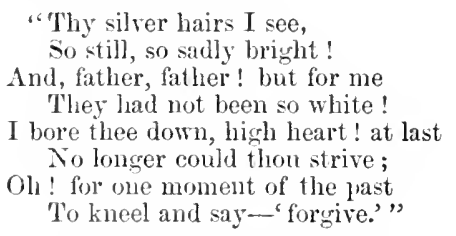

Ife groaned in spirit, and throwing himself on his knees beside the corpse, secmed to be deeply penitent. ${ }^{d}$

As soon as the funeral was over Geoffrey gave up the seals of the chancery, which he had held for several years. There secmed to be every prospect of peace and affeetion between him and Richard. I ain lope! Geoffrey, after visiting lis possessions in the vicinity of 'lours and Angers, rejoined his brother, who was then in Normandy, but he was met by eold and angry looks. Evil influences harl been unliappily at work, indl Richard's mind was warped. Geoffrey returned to England. When he arrived at Lourlon he was met by a large body of the York ecclesiastics, informing him that he had been eleeted to the see of York, which had been long vacant, and desiring him to come to them. He declined positively to aeept the honour. Ile was not fit for it. IIe told them that he was fonder of dogs and hawks than of books and priests. The Yorkshiremen made a charaetcristic reply; they told him that it was not necessary that he should altogether abandon those tastes when he eame

A legacy which reminds us of the lines of IIngo Grotius in his Dactyliotheca,

"Anmule, cui moriens, et villas credit et agros, Tutulamelue sure prolis, opesque pater:
Anmule, qui pestem, fædumque arcere venenum Pectore, qui philtri crederis esse loco."

${ }^{d}$ Ger. Cambrensis, 381-2. Ben. Petrib., 317. Hoveden, $372 b$. Matt. Paris, 126. 
into the North.e This temptation, and the recollection of his father's wish, ${ }^{f}$ secured Geofliey's eonsent. It may be woll to observe that his election by the chapter of York had been by no means an unanimous one, and this division of opinion had been cansed, to a a great extent, by his own indiscretion. It would appear that Richard had promised him the archbishoprie soon after his father's death, upon which Geoffrey had hastily sent his clerks to England to displace the enstodiers of the temporalities and spiritualities of the sec. 9 On the 10 th of August the ehapter of York met, in obedience to the royal mandate, to elect a new archbishop, and knowing as they did the wishes of the late king and his sucessor, ${ }^{\prime}$ their ehoice, naturally enongh, fell upon Geoffrey. Hubert Walter the dean, the bishop of Durham, and many of the canons were not present, and the election therefore was objected to as informal. Walter, who had at one time been himself nominated by the chapter, appealed to the pope, and with the assistance of the quecnmother, who had a stepmother's dislike to Geoffrey, he prevailed upon Richard to make an order that everything at York should continue as it was when his father died. The spiritual charge therefore of the diocese returned into the hands of the dean, and the temporal possessions to the eare of their old eustodiers. ${ }^{i}$ This was the state of things when Geoffrey, after accepting the arehbishopric at the hands of the representatives of the chapter, went to the court at Windsor. Every one secmed to be against him. After a long controversy the matter in dispute was amicably arranged. The coronation of the king took place, and, afterwards, on the 16th of September', when they were at Pipewell abbey, ${ }^{j}$ Richard confirmed the election of his brother, and the fact was formally announced by Puiset bishop of Durham.

When this was over the king impressed upon his brother the neeessity of his being ordained a priest, and threatencel in the end, if he did not eonsent, to seize the revenues of the archbishopric. Geofirey was now in a dilemma. IIe had some lingering hope of having a share in the kingtom; he would lose this if he became a priest; if he shonld not be ordained, he would be ejected from his see. Ifter much hesitation he was admitted to the pricsthood at southwell, by his

$e$ Ger. Cambrensis, 382-3.

$f$ Hemingord, apmd Gale., ii., 518. Fordun, Scotichronicon, i., 198.

$g$ Ben. Petrib., 5 19. $\mathrm{Wm}$. Neubr., 357. Chron. Jo. de Oxenedes, 72. Bromton, col. 1155. ILoveden, 373 l. Mitt. Paris, 127.

" ITm. Teubr. (357-8) spealis of letters having been writter to the chapter to that efliect. I Ioverlen, $373 \mathrm{~b}$,

i Ben. Petrib., 553-t. Diecto, col. 653. Bromton, col. 1156-7. Hoveden, $373 b$.

j Ben. Petrib., 562. Wm. Neubr., 357. Niceto, col. 653. Bromton, col. 1161. Hoveden; 375b. Matt. Par., 129. 
suffragan, Joln bishop of Whitherme. ${ }^{k}$ Puiset, the bishop of Durham, was an encmy of lis, and Geoffrey would not allow him to officiate, a shight which Puiset never afterwards forgot. ${ }^{l}$ Geofliey had also made up his mind that the pope should consccrate him. In the month of October he paid a visit to York, but amid the festivities and gratulations which greeted his adrent, lic manifested his customary want of tact and infirmity of temper. The new dean and treasurer, Henry Marshall and Buchard de Puiset, a nephew of the bishop of Durham, besonght lim to install them, but he refused, inconsiderately, to do so till his own appointment had been confirmed by the pope. This added fuel to a fire which had been for some time kindled.

One incident in the long contention which followed is peculiar and amusing. Geoffrey was coming to the vespers in the minster, but being somewhat late, the dean and the treasurer ordered the service to begin withont lim. He arrived soon after with 1famo, the precentor, and several of the canons, and was very indignant at the slight. He and the precentor bade the scrvice cease, the dean and the treasurer giving a contrary injunction. The singers, however, were silent, and Geoffrey began the vespers again. The treasurer then directed the tapers to be extinguished, and there was an end of everything. The archbishop-elect now put the chureh under an interdict. On the morrow when, according to their wont, for it was a high festival, the whole population of the city flocked to the minster to hear the scrvice, Geoffrey, the dean and his brethren, were in the the choir endearouring to come to terms, but the two eulprits would render no satisfaction, and added insult to injury. The crowd would have rushed mpon them if it harl not been restrained by Geoffiey. Buchard and the dean were Ereatly alamed. One fled to the deanery and the other to St. William's tomb. They were excommmicated and the interdict eontiuned. ${ }^{\text {nn }}$

Complaints of the conduct of Geoffrey were made to the king, and Richard, who for other reasons was annoyed at his brother, took possession of all his private property at home and abroad. When Geoffrey's messengers wished to go to the papal court, to olstain the pall for their master, the king wonld not allow them to leave the comntry." The two brothers met again in December. William king of Scotland was summoned

k Ger.Cambrensis, 383. Ben. Petrib., 56.5. Bromton, col. 1162. Horeden, 375\%. Matt. Paris, 131. Diceto (col. fi53) said that the ordination took place in the lresence of Fuhmar, archbishop of 'Treves.
'Ger. Cambr., 383.

" IIoveden, $378 \mathrm{z}$.

"Ben. Petrib., 569. Bromton, col. 1166. Hoveden, 3756 , who puts this occurrence in a somewhat different liace. 
to the English court, but he refused to come unless Geoffirey would escort him. Richard, upon this, desired the arehbishopelect to do so, and he attended the Scottish monarch from the Tweed to Canterbury. ${ }^{\circ}$ He entreated the Seottish king to prevail upon his brother to restore his property, and William made a promise to do so, but forgot it. Soon after this Richard made a vain attempt, through the bishop of Durham and several other dignitaries, to induce Geoffrey to give up his archbishopric on the plea that his election had been an informal one, and when he refused to do so, he deprived him of the temporalities which were entrusted to Puiset. A few days afterwards the dispute came under the cognizance of John of Anagnia, the papal legate. Every attempt was made to dislorlge Geoffrey, but to no purpose. P'uiset and Huber't Walter, who was now bishop of Salisbury, brought forward the informality of his election; the new treasurer and the dean depreciated his charaeter by saying that he was a homicide and born in adultery; the messengers of the king tried threats and bribes. 'The legate, however, was obdurate. At this crisis a compromise was effected, and a general amnesty was proclaimed. Money. carried the day when reason and argument were powerless. Geoffrey promised his brother three thousand marks towards the expenses of the crusade, on which he was just cmbarking. Richard, on his part, restored Geofl'rey's private property and the temporalities of his see, and prevailed upon him to confirm the privileges of the York chapter and Puiset, the dean, the treasurer and the bishop of Durham having relinquished the appeals which they had made against him. ${ }^{p}$ His election to the arehbishopric was solemnly confirmed by the legate and the pope.q Geoffrey's chief anxiety now was to raise the money for which he had pledged his word, and he was obliged to ask his clergy for a subsidy. It would probably have heen given if the bishop of Durham had not opposed it. Soon after this, in the beginning of 1190, he was summoned abroad, and found his brother at Lyons. When Richard heard that he hard come without the subsidy he was in a fury. It was in vain that Geoffrey gave him the reason for his insolvency, and requested him to take the revenues of his see till they satisfied his chaims. This was not enough for Richard, who seized upon them all without reserve. He sent also the bishop of Bath and $1 \mathrm{I}$ clls, the dean of Mans and Buchard de Puiset to the pope, that Geoffrey's election might be ammulled. In this he was too late, for the archbishop was a far readicr politician, and had ont-generalled

- Ben. Petrib., 575-6. Diceto, col. 619. liromton, col. 1167.

p Ger.Cambrensis,385. Ben. Petrib.,
577-9. Bromton, col. 1169. Iloveden, $377-8$.

" Diceto, col.653. Matt. Paris, 131. 
him. He had already sent some of his clerks to Rome, and the royal messengers met them as they were returuing, bringing with them the official confirmation of Geoffrey's appointment as well as the pall. ${ }^{r}$ Opposition was therefore useless, and the two brother's were reconciled at 'Tours. An arrangement was made about the payment of the money, and then Richard, who had already assumed the staff and the scrip of the pilgrim, went on his journey into the East. His favours, however, were always marred by some qualification or reservation, for he was full of mean subterfuges and petty jealousies. Before he went away he left a strict injumetion forbidding any archbishop in his dominions to consecrate his brother. Geoffrey was all the while in possession of a gencral licence from the pope which authorized lis consccration by any prelate of that high degree. Richard is also said to have extorted a promise from his brothers, John and Geoffrey, that they would not return to England for three years after his departure without his special permission. Ile subsequently withdrew this restriction in the case of John, ${ }^{s}$ and Gerald Cambrensis informs us that Geoffrey lad the like concession, but in this he seems to be mistaken. ${ }^{t}$

(reoffrey was now at peace with his brother, but he was not a man who conld remain loig quict. His old fend with the family of Puiset seems to hare revived. Geoffrey had exromminicated Buchard, the treasurer of York, but that dignitary, nothing daunted, had made his way to Rome, and pleaded his canse before Clement III., with such suceess, that not only was the bar remored, but the pope had refused to confirm the election of Genflrey and to send him the pall. He hard allowed, also, the bishop of Durham to be altogether independent of the see of York." In the spring of 1191 the queenmother secms to have gone to Rome, at the king's request, to beg the pope to reverse his sentence and to consecrate Geoffrey. Soon after this Celestine III. ascended the papal chair, but lichard, as has been already stated, had ehanged his mind with reference to his brother. The archlbishop-elect, however", dispatched Simon de Apulia," one of his elerks, who was a ('alabrian by birth, and a man of eloquence and lcarning, to the papal court. Ile was accompanice by Hamo, precentor of Tork, William Testard, archdeacon of Nottingham, and Ralph ke Wigetoe, ${ }^{x}$ canon of Ripon. 'They were so suceessful that

$r$ Gerald Cambrencis, 386-7. Diceto, (") 6) 6;63.

Ben. Petrih., 581. IIoveden, $378 \mathrm{~b}$. Rie. Itivis. Chom, 15. Bromton, col. 1171. Ger. Cambrensis, 357.

ben. Potrib., fizy. Ifoveden, 3s7-8. Biponton, ant 1100.
"IToveden, 392.

w II m. Neubr., 405. He was afterwards dean of York and bishop of Exeter.

x" There is an extraordinary story abolt this man in IIoveden (437). He was sick minto death at Rome in $\mathbf{1 1 9 6 ,}$ 
not only was bishop Puiset deprived of his privilege and ordered to render obedience to York, y but, in addition to this, the chureh and diocese of York were exempted from the anthority of any papal legate, unless he was some cardinal of high degree or honoured with some special mission. By the same messengers there arrived an order from the pope addressed to the arehbishop of Tours, eommanding him to consecrate Geoffirey withont delay. $z$ The eeremony, therefore, took place in the church of St. Maurice at Toms on the 18th of August, 1191. 'The archbishop himself officiated, and was assisted by eight other yrelates with much pomp and circumstance. ${ }^{a}$ The arelibishop of Canterbury and his suffragans were greatly offended at what they considered to be an infringement on the rights of the English metropolitan. When Baldwin had first heard of Geoffrey's election, he had made an attempt to assert the old privileges of his see, and had made a fruitless order that the arehbishop of York should be consecrated by no one lut himself. ${ }^{b}$

We now come to one of the most extraordinary scenes in Geoffrey's life, a scene which possesses all the initerest of a romance. $^{c}$ He was wishful to retmrn to England, and his brother Joln urged him to embark, but there was his promise to the contrary to prevent him. England was then under the charge of William, hishop of Ely, who is said to have had some strong reasons for kecping Geofirey ont of the way ; ${ }^{l}$ and at his

and therehe confessed to the popeand the cardinals that he had got many forged letters in the Roman court for himself and his master Geoffrey. The pope desired the archbishop of Canterbury to seize them. A man of the name of Roger de Ripon was canght at London with some of them in his possession, and poison was found on him, which had been given to him, as he said, to destroy Simon de Apulia, then dean of York, aud several of the camons. Simon was sent for to London, and the poison, some gold rings and a heantiful zone, all poisoned, were handed over to him and were burned. The bearer was imprisoned. Geoffrey was blamed for all this by his enemies. Reeucil des Itist. des Gaules, xviii., 77.

y Ben. Petrib., 691. Bromiton, col. 1224.

z Ben. Potrib., 691. Gerald, 397. Bromton, col. 1222. IIovelen, 399. Knyghton, col. 2102. Wm. Neubr. (405) says that the bishop of Ely was the great canse of the delay in Geollirey"s consecration, having seized and wasted the archiepiscopal property whilst he was abroad. Bromton (1221) says that the bishop seized Gcothrey's goods in consequence of his consecration.

a Gerald, 388. $11 \mathrm{~m}$. Nenbr., 405. Ann. Warerl., ed. Gale, ii., 16l. Ric. Divis. Chron., 31. Diceto, col. 521, 663. Bromton, col. 1221. Contin. Fl. Wigorn., ii., 159. Matt. Paris, 136.

b Ben. Petrils., 563-1. Hloverlen, $375 \mathrm{~b}$. Bromton, col. 1162. Gervase. col. 1570-1. Anelia Sacra, i., 10. Henripuez, Phoxnix Revivisenes, 20.

" This secne is described in Gerald, 359-92. lien. I'ctrib., 695. $11 \mathrm{~m}$. Neubr., 106. Ann de Marman, ajud (ale, ii., 10. Amn. Waverl., ibid., 161. Ric. Divis. Chrom., 3t-6. 1)iceto, col. (66i3. Brontme, col. 122. t. Gervace, col. 1576. Hoveren, 3399. ('ontin. FI. Mirorn., ii., 15\%. Mal1. P'aris, lasto. Polfore Tersil, 24. Reencil des Ilist. des Gialles, xviii., 63.

"l'oo murch alsuse lats been henped npom the bishop for his share in this aweonture. It serems to me that he was ouly doing his duty. 
request the countess of Flanders and Boulogne forbade the archlishop to pass through her territories, or to sail from any of her ports. His suite might go, if they chose, but they must go withont lim, and they were to land at Bover. Geoffrey, who lated resolved upon the joumey, was not to be kept behind. His train reached Dorer in safety, and whilst every one, no doubt, was examining it with eurious eyes for the archibishop, Geoffrey was on the sea with a small party of his friends in an English fishing-smack. The constable of the castle was brother-in-law to the bishop of Ely, who seems to have ordered every one to keep a sharp look-out. The exile neared the shore very early in the morning, but he could not even then eseape the vigilanee of the garrison. He had disguised himself, but a royal face is not casily concealed. He was ordered into the castle, but he refused to go. He got upon a swift horse and galloped towards the priory. A horseman from the castle followed him in hot pursuit, and stretehed out his hand to scize hold of Geoffrey's rein. The archbishop, still mindful of his old prowess in the field, gave the steed of his pursuer a kiek with his right foot which nearly orcrthrew it, and then escaped to the monastery. It was immediately surrounded by a band of soldiers. The constable of the eastle sent messenger after messenger in vain, ordering him either to take the oath of allegiance, or to return. What lard they to do with it? He woukd do neither. The princebishop was undaunted, and confronted his foes with a fearless bearing from his chair beside the altar, arrayed in his stole and all, and bearing in his hand his crozicr wrought with ivory and solfl. When the soldier's gazed upon him as he sat, they would think of the martyrdom and the intrepidity of Becket. A sudilen morement now came over them. 'They threw themselves on their knees before the altar, and beat their breasts, as if to beg forgircness for what they were going to do, and then they canght hold of Geoffrey by the arms and shoutlers, and dragged him to the door. He resisted, and his head was dashed against the parement, but they earried him out by the feet and arms. 'They tried to force him on his horse, but he would not mount it, so they pushed him along throngh the wet and mud, still bearing his crozier in his hand. They took him to the castle, where the constable received him on his knees with tears streaming down his cheeks. On that night a wind came roaring orer the sea, and a storm arose which shook those massire walls to their foundations.

Geoffrey was in Dorer castle for eight days without fire, wate' 1 , or food, save such as his servants could buy for him in the town. If is horses were scht ofl to the bishop of Ely, who was overjoyed at what had taken place, and he endeavoured to 
tempt his prisoner either to leave the comntry, or to take the oath of allegiance. He would do neither; for a grierous insult had been offered to him, and he knew that he wonld soon be in a position to dictate terms instead of aecepting them. The tide of popnlar sympathy harl alrearly set in towards him. The mob, when they wcre carrying him to the castle, had shonted at the soldiery, indignant that a priest and the king's brother should be thus treated. The constable, who had been an mwilling tool, requested and obtained Geoffrey's pardon for what he had done. The news soon ran throngh the whole country, and caused much indignation and excitement. The bishop of Ely was anything but popular, and this fieak made him more disliked than ever. The bishop of Lineoln at onee excommunieated the perpetrators of the outrage. The bishops of London and Norwich threatened and remonstrated with their brother of Ely. Prince John, who was at Lancaster, took up the matter with great warmth. He ordered the regent, at his peril, to release his brother from his prison. The bishop of Ely did not dare to be disobedient. II sent Geoffrey's uncle, Hameline earl of Warren, to Dorer to anthorize his discharge on eondition that he came to London to the council, and promised to abide by its decree. The pledge was given, and the captive left the castle in the same lumble guise in which he entered it, passing through a rejoieing crowd. He halted for a while at Canterbury to visit the tomb of the martyred primate, and, soon afterwards, arrived at London. At Reading he met his brother John and many of the hishops and nobles of the realm, making his complaint against the chanecllor, and begging for redress, which was soon promised. The bishop of Ely, however, would make him no amends. He set prince John's friends at naught; he would not meet them, and received all their overtures and proposals with the greatest eontempt. He pairl a bitter penalty for his folly and want of tact. He was cxeommunicated and deprived of his chancellorship, and was ohliged to seck safety by an ignominions flight. Geoflrey now went on a visit to Northampton, where he had formerly been a student, and received a hearty weleome. He then set out for lork, where he was solemnly enthroned in the minster on the fustival of All Saints. ${ }^{e}$

Geoffrey was at this time in the middle of another eontroversy with the bishop of Durham. That restless prelate had left no stone unturned to procure the liberation of his see from its allegiance to York. II made appeal after appeal to Rome.

e Gerard Cambrensis, 392-407. 13en. Petrib., 697-700. Wm. Nonlly., 106; etc. Ric. Divis., 37-12. Directo, cul.
661-5. Bromtom, col. 1205-8. Knychtom, col. 210t. Iloretlen, 394-100. Dith. I'aris, 139-110. 
Ile refused to pay the sums which were due from those churches within the diocese of York which belonged to Durham. Geoffrey wrote in vain to him to demand redress, and to require his sulmission. Puiset recrarded his threats and his entreaties with contempt. He said that he had made his profession long ago to archbishop Roger, and that was quite enough. Geoffrey, npon this, thundered at him the scntence of excommunication from his minster, with candle, book, and bell.f His meontrollable temper manifested itself in several ways. He overtlrew the altars at which Puiset had ofliciated, and broke the chalices which he had used. IIe was very angry with his brother, prince John, because he had been at the same table with the bishop of Durham after his excommunication; and he held aloof from him till he had expressed regret for what he had done.g Puiset secms to have cared but little for these censures of his rival. In the following year, 1192, the ban was repeated, on the festival of the Purification, but it was looked upon with contempt. Puiset, howerer, was on his way to the papal court to prosecute his appeal, when he and Geoffrey had an interview at London, in the presence of the quecn-mother. 'The case of each was heard, and Puisct expressed his readiness to abide by the decision of the queen and the archbishop of Rouen. Geoffrey would have none of this, unless his rival would first come to the church of York to seek for absolution, and to render his obedicnee. Puiset then said that he wond make no peace with him unless he would solemnly proclaim, in the same place, the remoral and the needlessness of the scntence which he had passed. Geofliey of course refuscd, and the matter was at an cud. It was during this visit that the arehbishop excited the wrath of the Southern prelates by having his cross carried erect from his residence in the New Temple to Westminster. They would lare broken the sacred symbol miness some royal personages had interfered, and the bishop of London forbade the celebration of divine service in the New Temple, which comyelled Gicoffrey to lower his cross and to desert his residence. Puiset now pushed his appeal at Rome. ${ }^{k}$ He complained to the pope that he had been excommmicated whilst his appeal to the papal court was undecided, and Celestine revoked the sentence on the ground that it had been hastily and imprudently made. ${ }^{i}$ IIe also sent a message to the bishops of Rochester and Lincoln, and the abbat of Peterborongh, to the effect that if, upon

f Ben. Petrib., 716-17. Bromton,

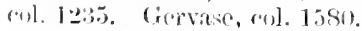
1236 h Hbill., 729-30. Bromion, col. 1237-8. 1Loverlen, $108 \mathrm{~b}$.

i Ben. Petril., 733. Wm. Neubr., 113-5. Bromton, col. 1238. Hoveden, 165-6. Lable, x, $176 \%$. 
enquiry, they found that Geofliey had really destroyed the altars and chaliees, as was stated, that then Puiset should be altogether released from his subjection to Gcoftrey during his life. ${ }^{j}$ The two combatants met after this at Northimpton; and then, at the request of the bishop of Lineoln, the farther consideration of the question was deferred to a future day.

The feud between Geoffrey and the dean and chapter of York had been temporarily settled, but this and erery other armistice only scemed to inspire them with new rigour for assant and defence. The quarrel was now raging again, and Puiset, who was a man of war himself, did his best to see that the chapter' were victorious. Henry Marshall the dean, Buchard the treasurer, Hugh Murdac and Adam de Tonnorere, canons of the church, and Peter de Ros, clerk of the bishop of Durham, had been put by Geoffrey under an anathema. 'The arehbishop' of Ronen and the other justiciars of England ordered the Northern primate to restore to them everything of which they had been deprived, and, if he refised to do so, William de Stutevill and other powerful barons were directed to compel him, or to seize upon the temporalities of his sec. Geofficy was inexorable, unless the culprits would present themselves at the door of the minster in the guise of penitents, and receive absolution; promising, at the same time, to abide by the decision of the chapter in all future eontroversics. Wcaricel with delays and opposition they complied with his request, and another truce was made. 'The dean, howerer, a brother of William the carl-marshal, refused to stoop to the conditions, and spoke high words against his diocesan. Gcoffrey met him with equal spirit. He put the city under an interdict, and would allow no divine service to be performed in it whilst the dean was within the walls. ${ }^{k}$

In 1193, whilst lichard I. was in captivity, prince Joln, it is well known, began to intrigne against his alssent brother. His conduct aroused the indignation of Geofliey. Whilst the barons in the Sonth were taking up arms to protect the rights of their imprisoned sovereign, he collected together the forees of the North. IIngh Bardolf, the sherifl of Forkshire, and William de Stutevill were with him, and they went to Doncaster, and began to fortify the town. Geofliey, mindtinl of the exploits of his yonth, was eager to invest the neighbouring castle of Tickhill which belonged to his rebellious brother; but Bardolf and Stutevill refised to accompany him, on the plea that John was their suzerain. The arehbishop, full of wath, called them traitors to their king and comntry, and withdrew 
from them with all his men. Gcoffrey, who with all his impetrosity harl an aflectionate heart, was much concerned at the misfortunes of his brother. Rieharl wrote to him from his prison, begging him, above all others, to wateh over his kingdom, and to raise the necessary funds for his release. Whilst the Cistercians and the Gilbertines were surrendering their wool, and stripuing their churches of their plate, to contribute their share towards the King's ransom, the canons of York refused to listen to their arehbishop when he asked them to give up a fourth part of their ineome for the same purpose. ${ }^{l}$ It was, no doubt, merely their personal dislike of the asker which prompted their refusal. In course of time this opposition seems to have been orercome, as the treasures and relies of the chumeli of lork were pawned for a while to alleviate the necessities of Richard." When that monareh returned to England, there was on the whole but little friendship between him and his brother Gicothrey, for the children of Henry II. were united together by no strong fraternal ties. In 1195 , after a visit to Sherwood forest, and an interview, as the legend tells us, with the famous

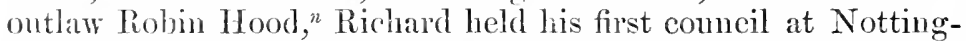
lıam. Geoffrey sat at his right hand, and purehased, for the large sum of 3,000 marks and a rent of 100 marks per annum, the shrievalty of Jorkshire. Many complaints were made at that meeting, by eeclesiasties as well as laymen, of Geoffrey's cxactions and extortions, but he treated them with contemptuous silcuce, and no investigation scems to have been made. $p$ He was not present at the coronation, as his brother wonk not allow him to bear his cross." On the 23rd of April in the same year (1195), when Richard was at Waltham, he confirmed to Geoffrey his possessions abroad, and reconeited him to his old enemy, of whom we have lost sight for some time, the bishop of Ely. Soon after this the archbishop fell into disgrace for having injured the eanons of York, and was deprived of the temporalities of his see, which remained for some time in the king's hands, being held for him by William de Stutevill and Geoffrey Ilaget. Geoffrey was at this time suspended from his spiritual dutics, and his fortunes were at their lowest ebb. The only place that was left to him was the manor of Ripon, at which he for some time resided; and it was here probably that le was brought into more immediate connection with the learned

' Horeden, $412 b, 416$.

in Fabric Rolls of York Minster, ed. Surtees Soc., 152.

" "The kynge came to Notynghame, With kuyghtes in greto arave,

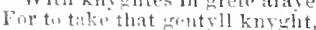
Aud living llude, if ied nay."

- Hoveden, 419. Madox, Hist. Exchequer, i., 459.

$p$ Hoveden, $419 b$.

$?$ Ibid., 420. Ben. Petrib. (556) sars that he was there: so do Bromton, col. 1157; alul Peter Langtoft, n.e., 112 .

$r$ Iloreden, $4206,423$. 
Peter de Blois, one of the canons of that place, and incited lim to commemorate, in a work addressed to himself, the life and merits of St. Wilfricl.s In the antumn of the same rear Geoffrey went into Normandy to see his brother, and purchased his forgiveness for the sum of 3,000 marks, which restored to him all the temporal possessions of which he had been deprived. He seems to have lost them again immediately for his intemperate language against the king for dispossessing him, ${ }^{t}$ for he had not the slightest particle of discretion; and Fuller is not far wrong when he says that Richard was kinder to him "than his tumultuous nature did deserve." "The king was again in possession of the temporalities of the see. He would gladly have seen Geoffrey deposed, and it was with great regret that he heard, in 1196, of his being restored to the farour of the pope. He was more bitter against him than erer, and determined to let and hinder him as far as he possibly conld. He persisted in giving away the stalls and offices at York, a course of conduct which brought the two brothers into collision. 'This state of things seems to have continued until 1198, when Geoffrey went to the court in Normandy at his brother's request, and they were again friends, Richard giving him back lis temporalities, and promising to interfere no more with the appointments in his cathedral. He changed his mind a fow days after this in consequence of the representations of the York chapter; and it was in rain that pope Innocent, by promises and threats, endearoured to persuade him to be reconeiled to Geoffrey. Richard's sudden death, which took place shortly afterwards, put an end to all negotiations.

It has been already stated that the chapter of York refused to listen to Geoffrey when he urged them to contribute towards the ransom of his brother. Their disinclination to grant what he demanded was caused by the reviral of the old feud, into which it will be necessary, althongh perhaps tedions, to enter. A second quarrel between friends who have been temporarily united is always worse than the first, and in this instance the trite observation was eompletely verified. In 1194 the promotion of Henry Marshall to the bishopric of Exeter racated the deanery of York. Geoffiey, who was then at lipon, gave the post to his brother Peter. Peter, howerer, was then at Paris, and the king urged his brother to bestow the dignity on John, provost of Donay. Upon this the arehbishop strore to

- Bale, cent. iii., 231. Vossius, 426. There is a letter from Peter de Blois addressea to him exhorting him to resist hereties (Petri Bles. Oply, i., $350-1$.

\footnotetext{
t IIoveden, 125, 128. Ann. Burton., aptud Gale, iii., 203.

" lutler's Church IIistory, bk. iii., 15.

" Horeden, $135 b, 412 b, 416 l$.
} 
extricate himself from the diffieulty by giving the deanery to one of his elerks, Simon de Apmlia. When the chance of a controversy seemed to be over, he endeavoured to prevail upon Simon to occupy it merely as the deputy, and for the benefit of l'eter. As this was a very questionable transaction, the chapter of York shewed their opinion of it by clecting Simon at once to the deanery. Geoffrey now made another move, and gave the office to a great favourite of his brother, Philip de Poietiers, archdcacon of (anterbury, who was subsequently bishop of 1) wham. The chapter were immediately in arms, and the battle begum. They held aloof from their arehbishop, and claimed the rimht of eleeting their own superior. They would contribute nothing towards the ransom of king Richard. 'The messengers of Geoffrey were sent to make an appeal at the pajal court. They were to halt, however, in Germany to see the king, and there they found that Simon had preeded them. Richard forbade either party to appeal to Rome. He would settle the dispute limself; and one of Geoffrey's friends was sent to England to bid him hasten to his brother. In the meantime the canons had put an end to the service in the minster, the bells were silent, and all the eity was in a commotion. The archbishop's stall and the door which led into the nave from his palace were locked. When Geoffrey sent to require the contimuance of the service, they paid no attention to his request. If went to the minster at Christmas, 1194, and finding it empty, filled it with his own elerks, and exconmmuieated four of the dimitaries of the eathedral for their contumaey. The sufferers, aceompanicd by the superiors of the houses of St Mary's, York, and Scllyy, and many of the Premonstratensian abbats, erossed the seas to Riehard, who was angry at Geoffrey's disobedienee, and obtaining his consent proceeded to the papal court, where the archbishop was also represcnted. The pope, on this oecasion, set aside the claims of both sides, and gave the deanery, of his own authority, to Simon. The dean and his eompanions then lairt many serions complaints against Geoffrcy, relating for the most part to his mal-administration of his diocese. They said that he did nothing but hmot, and hawk, and busy himsclf with military aftairs, whilst his spiritual charge was in the meanwhile uncared for. There were no ordinations, no consecrations nor synods; no abbat could obtain his benediction, although he micht find himself excommunieated. The liberties of the minster of York were set at nanght. Some of the eanons liad been put under an anathema; the vicars and officers of the church had been ejected. If any one talked of making an appeal to Rome he was thrown into prison. The arehbishop would not institute elerks to benefices, but gave them to boys 
and base persons. He made livings racant at his plcasure to obtain the revenues, and broke open the doors to get possession of the chumelies. These were very serions eharges, and Celestine seems to have listened to them with attention. Ile deternined to have them thoronghly investigated. He issued a eommission of enquiry on the 8th of June, 1195, addressed to the bishop of Lincoln and two others, anthorizing them to examine into the truth of these allegations. A few days before this, on tho $31 \mathrm{st}$ of May, the pope had written to IIamo dean of Lincoln, and the arehdeacons of Iseicester and Northampton, anthorizing them to reinstate the vicars and ministers of the church of York in their offices. The dean had told him that Geofliey had ejected them, a statement which, if Hoveden, a contemporary, is to be relied npon, was certainly unfounded." When the papal mandate arrived at Lineoln the bishop fonnd that (icoffrey had already appealed to Rome, and that he was on his way to that eity. The day of the examination, therefore, was deferred. Gcoffiey never arrived at the papal court, as Richard forbade his progress; and he was afraid, besides, of the autumnal fevers which still ravaged the old eapital of the world. His clerks, however, acted in his stearl, and obtained a decree which frustrated every order that had been made in their master's absence. He was ordered to be at Rome to answer for himself at the following Martinmas; and when he failed to appear either in person or by deputy at that time and at Christmas, he was suspended from his oftice. He had, shortly before this, met with a sad reverse in England. Some of his servants had becu brought, at the instance of the canons of York, before the archbishop of Canterbury, the king's justiciar, and his fellows, on a charge of robbery; and Geoflrey, failing to exculpate cither himself or them, was disseised of the possessions of his arehicpiscopate, with the exception of the manor of lipon, and he lost his shrievalty as well. ${ }^{x} \Lambda$ short time before Miehaelmas, the dignitaries of the minster, who had been at Rome, returned to York. They brought with them the pope's absolution from the sentence of excommunication, which Gicoffrey had pronomeed against them; this was read solemmly in the eathedral by bishop Puiset, and then, with the assistanee of the secular arm, they were restored to their preferments. Ralph, arohdeacon of the West Riding, had died as he was returning, but Hamo the precentor and the archdeacons of Nottingham and Cleveland reached rork in safety. Geoflrey appealed against all this to the pope, but Celestine merely suspended him on accomt of his non-appearance at lome in contravention of his promise. ${ }^{y}$

* Iloveden, 415-17, 426-7. Labbe, Cone., x., 1773, 1775 . $x$ Hoveden, $416 b, 423$.

y Ibid., $1176,423,125$. 
In the midst of this confusion, an erent took place which nuder anotlicr state of things would never have occurred. This was nothing else than the presence of the archbishop of Canterbury at York, to hold a comeil in his capacity of legate, an honour which the pope had conferred upon him on the 18th of March, 1195. $\approx$ Cclestine, when he granted it, had stated that his commission was to override any privilege that Geoffrey might enjoy to the contrary, and this seems to shew that there was some iudcrstanding between the pope and the archbishop with regard to the council in the North of England. We may he sure that there was great need for such a meeting, and for the enforcement of discipline and order in the distracted diocese of York. Hubert of Canterbury wonld be proud indeed to visit the fair city of lork as the representative of the pope, and to cuter that cathedral over which he had himself presided. Geoffrey and he liad come into collision on two or three occasions about the bearing of the cross, ${ }^{a}$ but Hubert was a man of wistom and discretion, and was more ready to allay contention than to exeite it. It was clearly his duty now to go into the Nortl. In the summer of 1195 , he sent two messengers, Peter prior of Bincham and Master Geoffrey, to York to exhibit his credentials, and to make arrangements for his intended visit. In vears gone by he would never have been permitted to enter within the walls of the cathedral, and eren now, in spite of their dislike to Gcoffrey, the dean and chapter still retained a shadow of their old independenee. They told him that he might come to them as legate, but not as archbishop. Hubert arrived in the metropolis of the North on the festival of St. Barnabas, and for albout a week was very usefully employed. He began by holding an assize in his capacity of "justiciar. He then visited St. Mary's abbey, and deprived Robert the abbat for incompeteney. After this he held a large assembly in the minster, at which the greater part of the ecelesiasties of the North were present. The legate shewed no ill-will towards his brother archbishop. Geoffrey's officers liad, indeed, forbidden his approach, for which they were excommunicated; but he allowed them to resume their dutics, and they took a part in the proceedings of the meeting. Every one scems to lave been pleased with Hubert, who was courtcous and obliging. ${ }^{b}$ The decrees which were made at the two days' sitting at York have been preserved.c

: Diceto, col.679-80. Hoveden, 429 . Lalbbe, Cone., x., 1775.

"Gervase, col. 1581-6, 1679. Hovecte $11,418-9$.

b Ticeto, col. 694. IIoveden, $430 \mathrm{z}$.

- An account is given in Wm. Neubr., 527 , ctr., torether with the datails of the controversy for precedence between Canterbury and York, and in Bromton, col. 1263, etc. Newburgh says that Geofirey was then abroad, "ad placandam reyis iram." Diceto, col. 693. Matt. Paris, 150. Hoveden, 429-30. Hist. Dunelm. Scr. Tres, 17. Labbe, 
They relate, for the most part, to minute points of disejpline and ritualistie observanees, the administration of the sacraments, the dress and morals of the clergy, and the payment of tithes. 'Two or three of the enaetments are rather amnsing. No relerk was to drink in public, or to frequent taverns, and he was to aroid flirtations and their consequenees. Great attention was to be paid to his tonsure. Any one who neglected it, and possessed a benefiee, was to forfeit his eure. If he were not thus provided for, the rural deans and the archdeacons were to take the offender and deprive him, with their sacred fingers, of his flowing loeks.

We must not lose sight of the bishop of Lineoln and his colleagnes, whom the pope had empowered in June, 1195, to examine into the quarrel between Geoffrey and his chapter and clergy. The commissioners met at Yrork, apparently to arrange how to proceed, and afterwards at 'Torkley and Ancaster'; and the chapter proved in their presenec that they had been losers through the arehbishop of one thousand marks. ${ }^{d}$ It was in vain, however, that they begged the arbiters to proceed to extremities against Geoffrey. "I would as lief be suspended myself as suspend him," was the bishop of Lineoln'se reply ; and so little seems to have been done that the complainants were discontented, and sent messenger's to Rome to tell the pope of the negligence of his representatives. Celestine, howerer, had antieipated their wishes, and had suspended the archbishop. At the instance of the chapter he committed the spiritual charge of the dioeese to dean Simon and his brethren on the 23rd of December, and renewed the eommission of enquiry which he had issued a few months previously to the bishop of Lincoln and his eolleagnes. ${ }^{f}$ In February, 1196, the dean returned from Italy to York to take possession of his office, but some messengers of the arehbishop met him, and protested against his being installed until the controversy about the deanery had been formally settled by the pope. Hot words and blows ensued which brought upon the oflenders the sentence of excommunication. There was much angry feeling between the combatants. When Geoftrey's suftragan, John bishop of Whitherne, came to York to consecrate the chrism and the oil, the dean and ehapter would not reecive them; and when he hallowed them at Sonthwell, Geoffrey Muschamp, archleacon of Cleve-

x., 1791. Wilkins, i., 505. Gervase, col. 1589. Hubert went to Dirliam, and the Northern monasteries seem to have been regularly visited.

${ }^{d}$ Hoveden, 426, 428.

e Hugh, bishop of Lincoln, died in 1200 , and Geotfiey was at his funcral.
(Matt. Paris, 17z.) IIe was camonized in 1220 (c'lrom. Lanercost, 2s). 'There is a life of him in $\mathrm{P}^{\prime} \mathrm{e}, \mathrm{B}, \mathrm{Bibl}$. Ascetica, ed. 1723.

f lloveden, 131-2. Lable, Cone, x., 17-1-3. Reeneil des llist. des Gauleי, xviii., 77. 
land, is actually said to have thrown them upon a dunghill. This was, indeci, a most muappy time for the Northern church.s

Whilst matters were thus complieated Gicoffrey resolved to pay the risit to the papal comt which lie had too long neglected. IIe went and was there a long time, as he could make but little progress in his business. The pope was greatly annoyed at him, and shewed his displeasure by the delays and impediments which he threw in his way, and by his mufiendly bearing. ${ }^{h}$ At length he obtained a hearing, and the charges brought against hini were thoroughly examined. The rerdict was manimously in Geofliey's favonr, and was a complete aequittal. He was restored to his archbishopric, and the accusations of his enemies were pronouneed to be worthless and malicious. He would now be anxious to jeturn to England, and to get possession of the temporalities of his see; but the king refused to see him, so he returned to liome and resided there for some time. ${ }^{i}$ In the year 1198 Geoffrey and his chapter were summoned to Richard's court in Normandy, as the king was most desirous that they should at length be reenciled. The dean and the ehapter did not come at the appointed day, and the arehbishop, who had made his peace with Riehard, went off to Rome on his own atlairs as well as on those of his brother. Three days afterwards the lork party arrired, and, with a bitter spirit of revenge, eroked Richard's feching of jealousy against Geoffrey to such an extent, that the performance of his promise that the temporalities should be restored to him was for a while deferred. The dean and his friends retmrned home in high glec, boasting foolishly of their intimacy with the ling, and of the mischief which they had effected. In the same year the archbishop and his opponents seem to hare had another meeting in the presence of the king in Normandy, and Richard was most wishful that they should comsent to abide by the dceision of the arehbishop of Rouen, and the bishops of Winchester and Woreester. Geoffrey was ready cuough to do this, but the dean and his brethren would refer" the dispute to a tribumal of secular eanons, and to no one else; and they aronsed the king's wrath by stating that the arehbishop had not confirmed the appointments which he had made in their eathedral. It is impossible to reprehend in too strong terms the eonduct of the dean throughout this long controversy. Geoffrey was indeed hasty and inconsiderate, but Sinon shewed himself to be full of malice and mischief-making. In the same year the new pope, Immocent III., tried to mediate

Bormden, 126, 127\%.

h riervase, col. 1590 . Iforeden, 435 b.

- Cicruase, coll 1597. Horeden, 136. Hatt. Laris (162) sleaks of this reconciliation, and sass that the cause of Richurd's anger was the deposition of the chancellor during his own captivity. 
in Geoffrey's behalf. 'The king sent the bishop of Durham and four other prelates to his brother, to say that the temporalities would be restored to him if he would confirm the presentations. which he had made to offices in the minster at York. Their. mission was fruitless, and the archbishop went again to Rome followed by the king's messengers. Imnocent was now indignant, and threats of an interdict were made if satisfaction wcre not rendered to Geoffrey. ${ }^{k}$ Even these appear to have becn ineffective, and Richard's death, in all probability, prevented anything being done. About this time Imocent wrote to Geoffrey and the ecclesiastical dignitaries of his diocese, exhorting them to assist in the formation and equipment of a new erusade. ${ }^{l}$

The death of Richard I, which took place in 1199, placed his brother John upon the throne, and with him Gicoffrey had hardly ever been on familiar terms. 'The archbishop was still without the temporalities of his see, and the quarrel with his ehapter was unsettled. Geoffrey's first step was by no means favourable to the eause of peace. He was at Rome when Richard died, but the bishop of Durham was probably only acting in his behalf when he protested against the coronation of John taking place during his absence." No notice, however, seems to liave been taken of the slight; and John ordered Stephen de Turnham, who for two years had been the kceper of the temporalities of the archbishoprie, to surrender them to Ralph de Kyme and two others for the use of Geoffrey. They were given up, although the king, full of avariee as he always was, retained them in his own hands beyond the stated time. Soon after this the two brothers met in Normandy, and many mutual assuranees of friendship and affection seem to have passed between them. Whilst they were there a message came to the king from the arehbishop of Canterbury, and Geofin'ey Fitz-Peter the justiciar, entreating him, at the request of the York ehapter, to detain Geoffiney in Normandy till he returned to England himself, as the coming of the arehbishop wonld produce nothing but dissension. 'Their wishes were not attended to; and in the same year some propositions were made for

${ }^{k}$ Horeden, $412 b, 414,416 b$. Balnz, Epp. Innor. III., i., 369-70. Ibid., p. 617, the pope desires the bishop of Ely, the dean of Lincoln, and the arehdeacon of Bedford, to examine into the charges brought against Geoflrey by his chapter, and (p. 746) there is a letter to Geoffrey beginim him to shew his good offices to his nephew Otho.

1 Hoveden, 447. Fodera, i., 66. A somewhat similar letter in belialf of pilcrims to the Hnly Land had been addressed some time before this by IInbert to the oflicials of the see of Tork (IIoveden, 131. b).

"' Bromton, col. 1281. Hoveden, 451. Matt. Paris, 166. Feoffrey is blamed by Jordan de Brakelonda for speaking ill of the arrhbislop of Canterbury before the pope whilst he was at Rone (Chron., 15, 6.2). 
making peace between Geoffrey and his chapter in the presence of cardinal Peter de Capua, the papal legate. They agreed to submit to the arbitration of Hugh bishop of Lincoln, and two others; and Geoffrey promised to forfeit to the chapter two humdred marks if he should act in contravention of this arrangement. 'The chapter demanded the payment of the penalty soon after this, when they were impleaded by the officials of the archbishop in obedience to a papal mandate. The referees seem to have done nothing, as in the year 1200 we find Geoffrey and his adrersaries in Westminster abbey before the bishop of Salisbury and the abbat of 'Tewkesbun'y, who had been appointed hy the pope to examine into the ease. That high dignitary had done his best to make peace, and Geoffrey at length became reconciled to William Testard archdeacon of Notts, Reginald Arundel the precentor, and Simon the dean of York, on condition that they rendered satisfaction to him for his claims in their own chapter." In the antumn of the same year Geoffrey was again in disgrace, and was deprived by his brother of all the temporalities of his see." John was annoyed at him for several reasons. (ieofliey had refinsed to accompany him to France to be present at the making of a peace with that country, and at the marriage of the king. He had also declined to allow the sherift of Yorkshire to collect the tax of a penny on each carucate of land, and had beaten the servant of that official. In addition to these offences, the sum of three thousand marks which he had promised to his late brother Richard was still umpaid. Geofliey was excessively indignant at this treatment. When the sheriff of Yorkshire, James de Poterna, entered upon his manors, and wasted, it is said, all his goods, the archbishop excommunicated him and his men, together with all those who had comselled the king to inflict upon him this punishment. The same heary sentence fell upon the burgesses of Bererley for breaking into his parks, and injuring his effects; and their town was placed under an interdict. ${ }^{p}$ The king does not scem to have met the archbishop in the same violent spirit, as he restored to him his temporalities, merely appointing a day on which he should come to court to reply to the eharges he had against him. We are told nothing of the result, but it does not appear that the ill-feeling that existed between the two brothers was remored. In 1201 John was in Yorkshire, which hal been startled in the month of Jamuary by an earthquake. Ile went to Beverley, and shewed his contempt for his brother by becoming the guest of a person of the name of John Crassus, whom (icofficy had exconmmunicated. The canons wished to

" IIoreden, 451 b, 452-3, 458.

p Hoveden, 461. Matt. Paris, 170.

- Ibid., Rot. Chart., 102. 
receive their monareh with all the eeremony that their church could afford; but it was still under an interdict, and the arehbishop would not remove it even for the occasion. John was very angry. He ordered all Geoffrey's servants to be seized, and directed one of them, of the name of Henry de Capella, to be thrown into prison for refusing to give him access to the wine in his master's cellars! I In the middle of Lent the king and queen were at York, and the archbishop made his peace by submitting to a fine; and it was determined that the subjects in dispute should be arranged by four bishops and four barons. John soon after this released his brother's servants, restoring his possessions, which he eonfirmed to the see; the arehbishop buying that farour at the cost of one thousand marks, to be paid within a year. ${ }^{r}$ At the same time Geoffrey, who was never quiet, was in the middle of another quarrel with his chapter about the appointments to two arehdeaconries, in which he again availed himself of the thunders of excommunieation. One of the two sufferers, Honorius arehdeacon of Richmond, carried the story of his wrongs to the pope; and Imnocent ordered that justice should be at once done to him, and ehided Geoffrey in language which he seldom heard.s 'The archbishop's feud with the dean broke out again when he gave the provostship of Beverley to his brother Morgan. ${ }^{t}$ John cardinal of St. Stephen, on the Caelian hill, ehanced to be at York in the same year as the papal legate, and he tried in vain to settle the dispute. This high dignitary, who might, perlaps, at one time have occupied the papal ehair, was what we call in these days a teetotaller and a vegetarian. The defieiency in one taste was supplied, as it very frequently is, by exeess in another. 'The cardinal, as Hoveden quaintly olsserves, had a great thirst after gold and silver."

It is refreshing to turn aside from the meeasing record of wranglings and dissensions to something of another kind, although it also reveals to us a weakness, and shews to what an extent eredulity and folly may be carried. $\Lambda$ fanatic of the name of Eustace, who was the Cistercian abbat of Flay, came

$q$ In 1201 the burgesses of Beverley paid a fine of five hinndred marks for the king's favour, and he promised to protect them from the encroachments of Geoffrey (Rot. de Obl. et Finibus, 375 .

$r$ Hoveden. Rot. de Obl. et Finibus, 146.

Hoveden, 461 b, 465, 166, 468, et serq. Matt. Paris, 170.

It rould appear that simon ob- tained the offiee, as on the 1 th of March, 1204, the king presented simon, provost of Beverley, to the elureh of Cave (Rot. Pat., 39). Morgan perhapss grot the post when simon was made bishop of Exeter.

"IIovelen, 168, I now lose the assistance of this ablo and excellent historian. II is name onght progerly to be written Honerlen. 
into England as a peripatetic adrocate of Sabbatarianism. ${ }^{v}$ The minds of the men of the day must have been singularly hungry when they were willing to swallow the trash with which they were fed by this waudering divine. His eredentials professed to loe a letter found on Golgotha by the patriarch of Jerusalem, which contained, in our Lord's hand, a general command that 110 work whaterer should be done between the ninth hour on the Saturday and sumrise on the Monday. On the strength of this injunction Eustace paid a visit to England, where he had a wonderful success. His subject was exciting, and it was something new, which was a great thing. The preaching of this apostle scems to have borne considerable fruit. In the course of his tour he found his way to rork, and in their reception of him Gcoffrey and the elergy and laity of his diocese seem to have been for once mited. The people of the North were carried away by his words. They would sell nothing for the future upon Sundays save refreshment to the wayfarer. A portion of the profits of the vendor was to be devoted to sacred purposes, and every church was to possess an alms box in which it was to be deposited. Nothing was to be sold in or near a church, which had been too frequently made into a fair, and the wealthy were to be regularly taxed for the benefit of the poor. No onc can ohject to the adoption of such reforms as these, but the means resorted to wore objectionable, and the change, like all other sudden movements and hasty impulses, was not lasting. Eustace, howerer, seems to hare done his best to bring about a better state of morals and manners, and to make it permanent. A flock of miracles is said to have attested the truth of what he said, like the references which, in these matter-of-fact days, bear witness to the potency of specifics of a less romantic kind. A certain carpenter of licverley, poor man, disregarded the wholesome conusels of his wife, and made a wooden instrument on a Saturday aftemoon, for which he was struck with paralysis; and the like fate befel a woman who was weaving. Nafferton, in the East Riding, a place which in these days is proverbially famous for something very different, witnessed a strange scene. A man had baked himself a cake on the Saturday, and, when he broke it on the Sunday, blood eame flowing from the fissure! But Wakefield saw the most striking judgment on the sabbathbreaker. Two worthies have alreary inmortalized that merry town, but the pair must now be turued into a trio by the addition of a miller. He, unhappy man, was plying his trade on the sacred day, when, lo! blood rushed from between the stones instead of meal, and the wheel, in spite of the pressure of the

v Ifoveden, 466-7. Matt. Paris, 169. Bromton, col.1274. Chrou. Petrib., 112. 
water, refused to turn. Yorkshire is also said to have been remarkable in this year for the appearanee, at one and the sane time, of fire moons! $w$

A cloud hangs over the remainder of Geoffrey's life, although gleams of light break occasionally through the darkness. Ilarl everything been clear and bright we should probably have fomd Geoffrey still embroiled in the dissensions of which he seems to have been so fond. The ehroniclers unfortunately desert us, especially Hoveden; but the Patent Rolls give us a faint pieture of what was occurring in the North. In 1202 there had becu a quarrel between Geoffrey and the king, arising from something that had been done by the royal servants; and John informs the bishop of Ely that it was at an end. ${ }^{x}$ In 1201 the archbishop was in arlear for his escrage to the crown, and measures were taken by the king to secure its payment. ${ }^{\text {In }}$ March, 1205, John was at York, and the bishop of Durham, the dean and chapter of Tork, and the great ecclesiastical dignitaries of the province, expressed their willingness to be obedient to Geoffrey; but as a matter of precaution for themselves and their estates they appealed against him to the pope. ${ }^{*}$ 'This shews that the archbishop's mhappy temper had again been getting him into trouble, indeed his whole career seems to have been one of determined opposition to propricty and the law. In the spring of 1207 he was reconciled to his brother, and was restored to the possessions of which he had been deprived. ${ }^{a}$ We are macquainted with the cause of the quarrel which was thus terminated, but soon after this in the same vear there was an irreparable breach between the king and Geoffiey. The arehbishop set his face most stoutly against the umpopular tax of a thirteenth, which Johm extorted from his indignant subjects. He excommunicated those who ventured to eollect it within his provinee, and finding probably that his personal liberty was in danger, he consulted for his safety by flight. ${ }^{b}$ He left England, and never returned to it again. 11 e appealed to the pope against his brother's conduct; but the interference of Innocent in his behalf appear's to have been uscless, althongh he went so far as to put the ehurch of rork under an inter-

w Knyghton, col. 2117.

$x$ Rot. Pat., 5 .

y Rot. Claus., 11. Prvmne's Collections, iii., 9. Geofrey is also mentioned in connection with payments, etc., to the king, in Rot. de Obl. et Finibus, 43. Rot. Clans., 35, 16, 65, $75,90,99$.

" Rot. Pat., 51. In 120 t the king took the chapter of York under his protection. (Ibill, 40. II 4utchinson's
Durhim, i., 189.) " Ibid., 58, 62.

b Chron. Joh. de Oxcueles, 119. Cottou's Chron., 96. Matt. Paris, 186, 189. Contin. Fl. Wigorn., ii., 167 . Hist. Thmelm. Ser. 'Tres, 23,27 . In Chron. Petrib. (115) the date is male 1208. In stubbs (col. 1721) it is said that the thirtenth was exacted "nsune ad dimidium baconem!" Rot. Cmiae liecris, ii., 196. Reeneil des Hist. des Gaules, sviii., 166. 
dict." The remainder of his life, of which we know nothing, was probably spent upon his estates in Normandy that were given to him by his father, and which he would be permitted to retain. He clied in 121:2, it is said, at Grosmont in Normandy, far away from the comntry which had looked so often with dismay upon the feuds and heart-bunnings that he had originated. It is to be hoped that he learned in retirement what a blessed thing peace is.

(icoffirey was a man who had warm friends and very bitter cnemies, $f$ inpon whose animosity he looked with supreme contempt. He was passionate and regardless of consequences, like all the children of Henry II. It is quite possible that the slu upon his escuteheon, with which he was often taunted, would make him sensitive and impatient. It is a stain which all who are in his position have continually in their thoughts. (icoffrey, however, was capable of generous and patriotic actions, ${ }^{g}$ and his filial affection is not to be forgotten. He had, unfortunatcly, been pushed into a path of life for which he was unfit. Ile onght to have been a soldier. He borrowed from the profecsion of arms his spirit and his encrgy. They were alien altogether from the quiet habits and the patient demeanour which onght to characterize a bishop. Who can fully estimate the mischief which was done to the cause of religion in the North by Cicoffrey's reckiess animosities, his thoughtless assaults on decency and oider, and his jealonsies and contentions? These were the things which made him miserable at home, and banished him in the end from his conntry and his see.

The story of the early part of Geoflrey's life has been written down by that courtly sycophant Gerald Cambrensis, 412 .

Bahrz, Ely. Гnuoe. III., ii., 175-6,

d Am. Waverl., ed. Gale, ii., 173. Stubls, col. 172t. Matt. P'aris, 19. 196. Lel. Coll., i. 295 .

forlwin (n.e.,677) is the sole anthority for the statement that Geoftrey died at Grosmont. Recueil des Hist. des Gaules, xriii., 169.

contin. Fl. Wigorn., ii., 14n. Malilkn, Lan. Ben., vi., 108. P'rynne's Collections, iii., 23. Ingl. Mou., vi., $10 \mathrm{~s}$.

$f$ among then was Wallex Mapes, who grives a long aecount of his fend with Geotfrey in his Nurre Curialium, 235-7. Milies alludes in a eontempitu1, ws way to lis illeritimacy. The sime slur and the pride of the archbishop roked the following scurrilous lines, which may be seen in MSS. Cotton, Cleopatra, B, ii., $39 b$ :-

"Versus magistri Michaelis Malebuche de Galfrido arehiepiscopo Eboracensi, tui filius IIenrici regis genitus de quadam meretrice.

spurie, quid jactas atavis te regibns ortum, 1'ulluit insignes titulos ignobile scortum. l'atris ad alta mlans vel matris ad ima peribis, Frgo t the melium, medio tutissimus ibss. Spurius es regis, cleri fex, ordinis hostis, 'Templi turbator, Veneris ras, presulis umlora. Non es sufficiens ad tanti culmen honoris, sie mihi sufficiat Deus hae et mnibus horis."

In the Flores Historiarum, p. 253, it is said that when Geoffrey became bishop of Lincoln "extume Deo et hominibus extitit reprobuset detestabilis."

\$ Stubbs (col. 1721) speaks of Geoffrey as "vir magne abstinentixe et summe puritatis." 
and is printed by Wharton in his Anglia Sacra. ${ }^{h}$ It was composed, in all probability, at the request of the arehbishop hinself, and it terminates with the controversy with the bishop of Ely. The writer probably found that he would injure his own popularity by extending the biography. The work contains some interesting historical information, but the style is ornate and heavy, and is more worthy of a courtier than of a chronicler. The character of the bishop of Ely is blackened in an extraordinary mammer, whilst the archbishop is elevated into a hero. It is not to such men as Geoffirey that posterity will look for an example.

After the flight of Geoffrey the temporalities of the arehbishoprie came into the king's hands, and they remained in them until the appointment of Walter de Gray in 1216. Brian de Insula and Robert de Lexington had the charge of them, ${ }^{i}$ and the bishop of Whitheme seems to have attended to the ecclesiastieal requirements of the provinee.j The care of the spiritualities was in all probability eommitted to the dean and ehapter of York.

TIT alter de Gray is next upon the list of arehbishops of which he was a most distinguished ornament. More than six eenturies have passed away since he was laid in the tomb within his own eathedral, but lis name is still mentioned with respect and gratitude. We think of the cautions and wise statesmim who was at the helm of England in times of danger and distress, and remember the piety and mmifieenee of the prelate among the many memorials of his zeal and greatness which eren now survive to us. He found the province to which he was translated a barren wildemess, he left it a fruitfinl garden.

Walter de Gray ${ }^{k}$ was a scion of a family which in its many branehes has accumulated both wealth and honours.' It his

${ }^{h}$ Anglia Sacra, ii., 374-108. Whiarton says that it was written in 1193. There is a MS. of it in the library of C.C.C. Cambridge (Smith's Catalogue).

i Rot. Pat., 88. Rot. Clans., 208, etc., 222.

$j$ Rot. Claus., 173, 181.

$k$ I adopt the old mode of spelling this name. In his own roll at York the archbishop is always called Gray or Gra.

$l$ The genealogist will find pedigrees and notices of the family in 1)ugdile's Baronage, i., 709; laker's Northants, i., 1 to ; Nichols"; lecestershire, iii., 682; Lipseombe's Bucks, i., 160; Blore's lintlandshire, 165; Blomefield's Norfolk, n.e., ii., 300-1: Arrliawlogia, xxxii., 59; l'rost's Notices of the 'Town of IIull, 59; Stapleton's Aceomut of the Holy 'Trinity l'riory, lork, 151, cte.; Ashmole's Berks, if., 280. The Close and Patent Rolls abousd with information about the family. 
given great men to England, and is still represented on the roll of peers. The nember of it of whom we shall now speak was a younger son of John and IIawisia de Gray of Rotherfield. ${ }^{m}$ His imele, another Jolm de Gray, who was a statesman of some note, became bishop of Norwich and a justieiar, and died in 1214. It was to his influence, no doubt, as well as to his own merits, that his nephew was indebted for his introduction and his suecess at conit.

Walter de Gray received his education at Oxford, ${ }^{n}$ and in after rear's that university, of which he was a distinguished member, established a solemn service to commemorate him on the amiversary of his decease. ${ }^{\circ}$ In 1242 , when Henry IIJ. was going abroad, he made him the protector of that abode of learning,,$^{p}$ and it was, no doubt, the eonsciousness of the advantages which he had reaped in Oxford that indueed Gray to persuade Edmund de Abingdon to derote himself to the study of theo-

m This is a disputed point. Dugdale makes him a son of 11 enry and Isolda de Grav of Thurrock, and he is followed by Mil. Léchandé-d'Anisy et de Ste IIarie in their liecherchessin le Domesday, i., 167. The objection to the archbishop's bein the son of John de Gray is, that if this were the ease, there were two Johns, brotliers, in the sume generation. This, however, is by no neans imprsible, and I prefer to follow Mesrs. Nichols and laker instead of Jurdale. The fotlowing pieces of evidence, which have never been applied to the pedigree of Gray, militate against Dugdale"s view.

IIavisia de frey, widow, grants the chureh of Cormull to Oseney abhey, "pro animabus antecessorum et praciwe pro anima Johannis de Cxey, liatris mei, quoudam epi-eopi Norwicensis, assensu domini Roberti de Grey filii et lacerlis mei. Teste Waltero de (irey episcopo Wimorn., filio meo." (Blomefiell's Norwich, i., 475).

sept. 17, 1235, arehbishop Gray srants to Sir Robert de Gray, his blotler, a carneate of land in Foukthorpe, etc., and on Sept. 15, with the assent of his brother, he grants to Thoulas, som of li. de Mrrese, in marriage with Isabella, daughter of Jiobert (lo Monasteris, lands in Everton and Beckingham (Rot. Gray. See Drake's Lhoracum, appendix, 61).

In 1210 (21) the arehbishop grants to his brother, Robert de Gray, "terram quam ex concessione domina Evæ de Gray habuimus in Rutherfeld, cum adrocatione ecclesiae, excepto tamen homagio et servicio domina Hawysixe de Gray matris mex (Rot. Gray). Hawisia is mentioned as the mother of the archbishop in 12.27 (Excerpt. e Rot. Finium, i., 161).

June 5, 1238 (22), Walter de Gray was instituted "in eccl. de Semar ad pres. abb. and conv. de Whitby" (Rot. Gray). He was, I believe, mebendary of Soutliwell in 1242 and 1257 (Le Neve, iii., 46,1). Henry de Gray was canon of York in 1241 (Dugd. Mon., vi., 1195).

April 28, 1246 (30), Walterus de Gray, nepos domini archiepiscopi, habet custodian Thone de Burgo qui sororem ipsins Walteri duxit in nxorem, cum omnibus terris suis; item custodiam terre que fuit Alexandri de Hylton in Wrvestow (Rot. Gray.)

Walterus Gray, archiepiscopus, dedit homagium Walteri de Mikelfeud domino Waltero de Gray militi, nepoti suo (Reg. Giffard). Cf. Plac. de Quo Warranto, 665.

1268. Robert de Gray, son of Sir Walter de Gray, knight, presents his brother, John de Gray, clerk, to a moiety of the church of Jinton (Reg. Gitfard). n Wood's Antiq. Univ. Oxon., i., 232.

- On April 30. Avesbury's Edw. III., 304. Rot. Hundred., ii., 805. $r$ Antiq. Oxon., ut supra. 
$\operatorname{logy}_{9} q$ His friend became archbishop of Canterbury, and a saint.

Walter de Gray's preferments in the church were all of them owing to the favour of king John. On the 23rd of Jannary, 1206-7, that monarch gave him the prebend of Mallinges at Rochester, ${ }^{r}$ and a stall at Exeter, with the archdeaconry of 'Totness, on the 10th of May.s On the 28th of Augnst he was mute vicar of a moiety of the ehurch of Holkham. ${ }^{i}$ On the $26 \mathrm{th}_{\mathrm{h}}$ of March, 1208, he became rector of Stradbroke in Norfolk," and on the 3rd of December, 1212, he obtained the living of Cossey in the same county. In the following February lie became the dean of St. Berians in Colnwall." On the 14th of July, lis 13, the king gave him the ehurch of Kirkham for his life, but he almost immediately resigned it. ${ }^{x}$ Gray was destined to sit upon the episcopal beneh. Geoffiey de Misehamp, bishop of Coventry and Lichfield, died in 1208, and the chapter of Lichfield fixed upon Gray as his snecessor, in opposition to the nominee of the monks of Coventry. Pandulph, the papal legate, wonld admit neither of the two to the see, and after much angry feeling on the part of the elector's a thind person became the prelate. ${ }^{y}$ Gray was more fortumate on another oceasion. On the 20th of January, 1213-14, he was made bishop of Worcester, resigning the pieces of preferment which have been already enumerated. He was consecrated at Canterbury on the 5th of October. Of what he did at Worcester there is little known.z The see of York was all the while vacant, having been withont a pastor ever since the retirement of Geoffiey in 1207, and several other bishopries were in the same condition, as the king would not allow the ehapters to eleet in aceordance with enstom and law. ${ }^{t}$

q Martene, Thes. Nov. Anecdot., iii., 1788.

$r$ Rot. Pat., 58.

- Ibirl., 71, 75. Le Neve, n.e., i., 401. Madox, Hist. Exch., ii., 42.

t Rot. Chart., 169.

« Rot. Pat., 81. iIadox, ii., 42-3.

"Rot. Pat., 96. Blomefield's Norfolk, ii., 417.

w Rot. Pat., 96. Oliver's Monast. Exon., 7.

$x$ Rot. Chart., 193. Rot. Pat., 102. On 7th June, 1238 (22), archbishop Gray instituted William de Ebor., canon of York, to the living of Kirkham on the presentation of Richard earl of Cornwall (Rot. Gray). The church was appropriated by Honorius IV. to the abbey of Vale Royal, and in 1287 Edward I. ordered that honse to compensate Henry Newark, arcludeacon of
Richmond, for the loss which he thereby sustained (Prynne's Collections, iii., 373).

$y$ Elected in 1211. Matt. Paris, 193.

$\approx$ The king's assent to the election was given on the 26th of January, on which day he ordered the temporalities to be restored, and desired the arehbishop of Canterbury to consecrate Gray (Rot. Pat., 109. Prymie, iii., 22). Mandate to the bislop of Winchester to give him seisin of his hishopric on duly 7 (Rot. Claus., 168). lie Neve, iii., 51. 'Thomas's Accomint of the Bishops of Worcester, 123, etc. Reg. Saer. Angl., 37. Matt. Paris., 212. Trivet, 161.

On the 28 th of $\mathrm{May}, 1228$, archbishop Gray granted an indulgence for the cathedral of Worcester (liot. Gray).

“Chron. l'etrib., 118. 
The election of a new arehbishop had been more than once sluggested. In January, 1:14, John wrote to the dean and chapter by the abbats of St. Mary's York, Beaulieu and Selby, Willian Briwere and William de Cantilupe his seneschal, giving them leare to choose a new primate with the assent of the bearcrs of the royal missive. As this was clearly an encroaehment upon the pririleges of the ehapter nothing seems to have been done. It was most neeessary, however, that the Northern province should have a superior, and on the 13th of May, 1215, the king wrote again to the eliapter urging them to elect and demand no objectionable person. ${ }^{b}$ This had reference to Simon de Langton, brother of the well-known archbishop of Canterbury, whom the dean and eanons of York were most desirous to secure as their head in opposition to the wishes of the king. ${ }^{c}$ On the 18th of June, 1215, the York dignitaries again received the royal permission to proceed to an election, and the monareh, perhaps too eagerly, expressed his desire that they should fix upon the bishop of Woreester." The ehapter were obdurate; and passing Gray by as an illiterate person they nominated their farourite Langton in dircet contravention of the order of the sovereign. When the king heard of this, he sent at once to the pope to tell him that there would be no peace in England if the brother of a traitor should become the Northern primate. Innoeent, upon this, wrote to the eliapter on the 13th of September to say that he had rejeeted Langton, and had forbidden him to press the matter farther, and enjoined them to send their representatives to Rome by the lst of November with some other nominee. Their spokesmen arrived at the appointed time, and clung to their old candidate, bnt the pope at once set him aside, and told them that if they would name no one else he slould choose for them himself. The eanons were provided argainst this contingency, and mentioned the bishop of Worcester whom they commended for his chaste life. "Per Sanctum Petrum," said Innocent, "virginitas magna virtus est et nos eum damus vobis." Gray was then at Rome, and when he had reecived the pall lie returned to England. The king was

${ }^{b}$ Rot. Pat., 111. Le Neve, iii., 101. On the 23rd of May, 1215, pope Inmocent wrote to the chapter of York $u r g$ ins them to selest a proper person (Baluz, Epist. Immoc. III., ii., 822).

- Rot. Chart., 207. Rot. Claus., 269. Simon de Langton at the time of his divippointment was canom of Strensall at Jork (Rot. Claus., 178. Cal. Rot. lat., 5). He afterward. was made chaticellor of Datulhing and archdencon of ('anterbury, and he took some part in state affairs. He was also a hard student and an author, and died in 124. (Somner's Canterbury, ii., 152. Fredera, i., 214, 218. Matt. Paris, 227, 230, 237, 251, 655. Rot. Claus, etc.) ITe is said to have been a Lancashire man (Baines's Lancashire, iv. 385̃), and, atso, to have been born in Lincolnshire (Hist. Co. lincoln, ii., 175). There is an account of the family of Langton in the Gentleman's Magazine for June, 1862. d Matt. P'aris, 227-8. 
delighted at his promotion. It is said, howerer, that the arehbishop was obliged to pay the immense sum of ten thonsand pounds to procure the papal assent to his elcetion.e

We must now turn to Walter de Gray's offices in the state, and his public acts which made him the favourite of two kings and enabled him to pass throngh life enjoying the goodwill of his contemporaries. With king John he was a great favourite, but he is said to have won his regard by the readiness with which he complied with his wishes. We do not know when he was first introduced to that monareh's notice, but he must have gained a considerable position in socicty when, on Octolser 2 nd, 1205, John made him chancellor of England, he having paid a fine of five thousand marks to be permitted to hold that office for his life. ${ }^{g}$ He seems to have retained it mutil the antumn of $12144^{h}$ On the 5th of Angust, 1206, his master made him a present of a hundred marks in consideration of his faithful services. ${ }^{i}$ We are not told by the chroniclers that Gray was one of the advisers who eounselled the reckless monareh to adopt the measures which degraded his kingdom and nearly robbed him of his throne; he was present, however, in 1:213, when John resigned his dominions into the hands of the pope, ${ }^{j}$ but, if Lord Campbell is to be credited, the chancellor refused to set his official seal to the conveyance. ${ }^{k}$ In the same year Gray had a great deal to do with the foreign affairs of the country. On the 26th of June he and another receired letters of credenee from the king to earry them to the count of Flanders, and in the following year he was in charge of the treasure which went with the English force that crossed the seas to support the connt against the French." During the famons controrersy with the barons, that ended in the granting of the Magna Charta in 1215, Gray seems to have been on the side of the king, and he

e Ibid., 230. Ann. Waverl., apud Gale, ii., 183. Hemingford, ibid., 561. Hist. Dunelm. Scr. Tres, 29. Labbe, Conc., xi., 234. Recueil des Hist. des Ganles, xviii, 179.

He was translated to York on the $27 \mathrm{th}$ of March, 1216 (MSs. Cotton Vitellius $A$, ii., iii. $b$. Stubbs, col. 1724). The king ordered the temporalities to be restored to him on Feb. 19 (Rot. Claus., 218). Cf. 'Twisden's Historical Vindication of the Chureh of England in point of Schism, 45.

$f$ "In omnibus regni agendis regis studuit facere volmitatem" (Matt. Paris, 192).

8 Matt. Paris, 209, where a wrong date is given. Rot. de Obl. et Finibus, 368. His uncle, John bishop of Nor- wich, was his bondsman. Cal. Rot. Pat., 2. Foed., i., 93. Madox, Hist. Exch., i., 63.

h Foss's Judges, ii., 79-S0. Mr. Fuss, in a paper in the Archeologia, xxxii, 90 , etc., says that Gray gave uy the oflice for a while in October, 1213, when he went into Flinders, but resumed it in the montl of Jimnary following.

i Rot. Pat., 66. An order to piy him et. on Jan. 20, 12 L4 (Rot. Claus., 161).

$j$ Fordera, i., 115.

${ }^{k}$ Camphell's Lives of the Chancellors, i., 123.

'Foedera, i., 113. Rot. Clans, 160, 162.

" liot. Claus., 206. Matt. '’aris, 208. 
was present with him at Rumnymede, when that great deed of privilege was made, in which he is mentioned as one of the advisers of the sorereign." He was also one of those whom John despatched soon afterwards, when he repented of what he had done, to collect forces abroad to resist the barons. ${ }^{\circ}$ It is impossible to say what share Gray took in the many scenes of riolence and peril which occurred during the next two years. His interests seem to have been bound up with the fortunes of John, and he did not desert him in his adversity. The king, who loved him well, was always showering his favours upon his trusty adherent. The public records contain many eridences of the regard that he bore to him. ${ }^{p}$

After the leath of John, in 1215, the archbishop took the part of his son, Henry MII, in opposition to the barons and their French allies. IIe was as great a favourite with the new king as with his father. In conjunction with the legate he anointed him sovereign." In 1217 Gray was at Lincoln when the great battle took place between Hemry and his enemies, ${ }^{r}$ and the youthful monarch and his advisers shewed how highly they appreciated his comsel and support by giving him the lands of sereral of the rebels and many other farours in addition. ${ }^{s}$ Shortly after this Gray removed the sentence of excommunication which the papal legate lad passed against Alexander king of Scotland for doing homage to the invaders ${ }^{t}$ and in 1221, when William earl of Albemarle expressed his penitence for his rebellion against the young sovereign, the archbishop of York conducted him to Henry who pardoned him on account of his loyalty in bygone years. " Gray had previously been present at the reduction of his stronghold at Bytham. ${ }^{v}$ The older Henry grew the greater was the confidence which he scems to have reposed in his father's friend, and the more numerous the kindnesses which he shewed to him." In 1221 Gray formed one of the escort of Alexander king of Scotland to York when he was married to Joan the sister of the English monarch, ${ }^{, x}$ and the

"Matt. Paris, 215. Foedera, i., 131. Statutes of the Realm, i., 8, 9.

- Matt. Paris, 222.

p Rot. Clans., 160, 176, 189, 218.

q Recueil des Hist. des Gaules, xviii., 315. In 1217 Gray was one of those who prompted the granting of the roval eharter De Foresta (Statutes of the Realm, i., 20).

$r$ C'hron. Mailros, 131.

s The lame of Robert Constable in Gloncestershire (Rot. Claus., 308) that of Robert de Ereringham (ibid., 313). Rint. Claus., 297, 312, 341, 346, 351, 351. Excerpta e Rot. Finium, i, 59.
Abhrev. Rot. Orig., i., 24.

${ }_{t}$ Chron. Mailros, 132.

"Matt. Paris, 261. Chron. Joh. de Oxenedes, 146. The earl got into trouble afterwards (Prynne, iii., 62).

"Rot. Claus., 475.

" Ibid., 361, 405, 421, 475, 497, 515, 535, 536, 573. Excerpta e Rot. Finium, i., 335.

$x$ Matt. Paris, 263. Rot. Clans., 462, 476. Lel. Coll., ii., 536. Henry was there four days. Chron. Lanercost, 29. Chron. Mailros, 138. Scala Chron., 99. 
archbishop officiated on the occasion. ${ }^{y}$ The two sorereigns liad been in York in the preceding year, when the preliminarics of the alliance were drawn up..$^{z}$ In 1224, when the barous were again disposed to be turbulent, Gray demanted of the carl of Chester the surrender of the castles and honours which he hold of the crown, and they were unwillingly given up. ${ }^{a}$ In 1.225 he was at Alnwick when Roger Bigod was married to Isabel sister of the Seottish king. ${ }^{b}$ In 1:22\% the diplomatic powers of the Northern primate were again called into requisition. The hasty coronation of the new king of France had given great offence to many of his nobles, and Henry believing it to be a fit opportunity for endeavouring to regain his influenee among the magnates of Normandy, Anjon, Brittany and Poicton, who were bound to pay him their allegiance, sent Gray and other's to make the attempt. 'The events of the last ten years had greatly weakence their loyalty to their suzerain. ${ }^{c}$ In the month of January the ambassadors were sent to Hugh count of Mareh and Angoulême, and they returned home about Laster; but in the following September they went again with letters of credence to the princes and prelates who were to meet at Antwerp. $^{d}$ Nothing, lowever, seems to have been done. In 1:2:8 Henry kept his Christmas at York, ${ }^{e}$ and he was there at the same time in 1230 with Alexander king of Scotland. 'The arehbishop was also present with a large party of the nobility, and the great festival was observed with much splendour and rejoicing. $f$ In 1.233 Gray objected in a formal manner to Alexandler being crowned in Scotland, to the prejudice of England and his own see; and, on the 6th of May, Henry III. endorsed his protest.g The result was probably unfavourable to the arehbishop, and in a subsequent year Innocent IV. gave another blow to the privileges of York by sanctioning the opposition of the Scottish bishops. ${ }^{h}$ In 1235 pope Gregory addressed Gray and the bishop of Carlisle in the bull in which he eonfirmed the treaty which had been recently made between England and

y Chron. Petrib., 124.

$\approx$ Matt. Paris, 260, the archbishop taking a prominent part in the treaty (Prynne, iii., $51-2$ ).

a Chron. Joh. de Oxenedes, 150. Gray had something to do with this nobleman in 1217 when he wished to leave Eugland (Prymne, ut supra, 37).

- Excerpt. e Rot. Fin., i., 128.

c Matt. Paris, 282.

a Foedera, i., 181, 187.

- Chron. Joh. de Oxenedes, 155. Matt. Paris, 290.

$f$ Oxenedes, 159. Matt. Paris, 307.
On 21st Jamuary, 1229, the king mentioned his intention of being at York in Lent with Alexander (Ford., i., 193).

g Fredera, i., 205. Prynue, iii., S5. Cal. Rot. Pat., 16.

th Chroz. Lincreost, 61 . There is a brief abstract of a letter from Grogery IX. to Gray about the patronage of the ehurch of (iameford (Gianford ?) in Labbe, xi., 379. In 1238 I fiml it stated, that the pope harl permitted tho archbishop to mant dispensations to forty rlerks within his province (Rot. Gray). 
Scotland; and, on the 12th of 1)ecomber in the same year, Henry 111. desired the archbishop and others to escort king Alexander and his queen to London, to be present at the celeJ)ration of his muptials. ${ }^{i}$ In $123 \%$ Ilenry sent Gray with Richard carl of Cornwall to a large mecting which was called together by the cmperor Frederick; and in that year he took a great: interest in the clection of his suffragan the bishop of Durham, and was uresent at the council in St. Paul's cathedral, which was presided orer by the legate Otho. The archbishop of Canterbury occupied the scat on the right hand, and Gray made the nsial protest and claim, which the legate adroitly put aside for the time, leaving the question still open. ${ }^{j}$ There was a meting also of the kings of England and Scotland at York, at which Alexander resigned his right to the counties of Northumberland, Westmerland and Cumberland, and the archbishop was present on the occasion. ${ }^{k}$ In the following year Gray was again associated with the legate at a comncil which was held in the month of Jume, and he was present in 1240 when a treaty was made between the king and David son of Llewellyn prince of 1 ales. In In 1211 he was at the court when IIenry paid some extravagant honours to the representative of the pope, ${ }^{n}$ and he was one of the prelates who met at Oxford and agreed that prayers should be offered up for the weal of the church which was at that time in a deplorable eondition. ${ }^{\circ}$ On the 9th of June in the same year he consecrated Nicholas de Faruham bishop of Durham at Gloucester, and received his profession of obedience, a concession upon which much stress was subsequently laid in the controversies between York and Durham. ${ }^{p}$ In 1212 the king made up his mind to go to France, and the archbishop of York, Richard earl of Cornwall and William de Eboraco provost of Beverley were the exponents of his wishes to the council of the nation. When Henry set out on his royage against the will of his subjects, archbishop Gray had the high distinetion of being appointed the regent during his absenee, ${ }^{q}$ and he performed the many duties of his office in a manner which fully justified the confidence that had been reposed in him. During the king's stay abroad, which lasted for more than a year, the regent was variously employed. 'The wardens of the Cinque ports sought his aid when they had

i Fordera, i., 214, 221. Wilkins' Cone., i., 630.

j Matt. Paris, 371, 377-8. Hist. Denrelm. Sor. Tres, 38; and appendix, lxviii.

${ }_{k}$ Watt. Paris, 377. Wilkins, i., 647. Firdera, i. 233.

' Watt. Paris, 397.

" Findera, i., 2399.

Matt. Paris, 18:9.
- Wilkins, i., 682.

$p$ Matt. Paris, 502. Nothing is said about this profession by the Hist. Dun. Scr. Tres, 41. When bishop Farnham resigned his see in 1249, Gray was one of the three prelates who made a provision for him (Matt. Paris, 658).

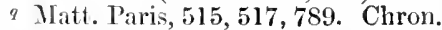
Joh. de Oxenedes, 170. Fordera, i., 244. Cal. Rot. Pat., 19. 
been roughly handled in their attempts to do mischicf to the French shipping. Ile collected men, money and stores, and transmitted them to Ilenry. From the archbishopric of Canterbury and the other sees whieh were at that time in the king's hand, he gathered together a vast (puantity of provisions, but he tried in vain to obtain a grant from the Cistercian houses in England of a ycar's income in the shape of the wool from their sheep, which, in point of fact, was nearly everything that they possessed. The king, howerer, to the archbishop's great astonishment, complained that scareely any of the smpplies liad reached him, and it was Gray's belief that they had becn lost at sea. A new and heary tallage was therefore exacted from the citizens of London. In the meanwhile Henry repented of the hasty comsels which had led him beyond the scas, and ordered the regent to eollect a fleet at Portsmontl and to be rearly with the nobles for his arrival. They were waiting for him on the coast till they were all wearied. After many delays Henry returned at length to his own comntry which lie onght never to have left.r In the same year the pope made the archbishop of York and the bishop of Durham his deputics to adjudicate in a controversy which had arisen betwecn (irostête bishop of Lincoln and the monks of Canterbury, ${ }^{s}$ and we also find Gray officiating at the marriage of the queen's sister to Richard earl of Cornwall.t In 1241 he was constalsle of the tower of London," and he was mainly instrumental in allaying the quarrel that was likely to arise between the kings of England and Scotland; and in 1248 he was present at the meeting of the parliament at London, at which great fault was foumd

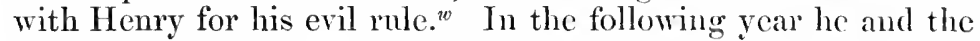
bishop of Hereford were employed on a fruitless necrotiation, an attempt to contract a matrimonial alliance between the royal houses of England and Provence. ${ }^{x}$ In every important event whieh took place in the history of the nation Gray was more or less concerned; but the cautious wistom which was able to preserve his own character from the reproaches of contempo-

r Matt. Paris, 519, 522, 527-529, 531. Prynne, iii., 100. Fordera, i., 246-7, 250, 253. Wilkins, i., 683.

$s$ Matt. Paris, 535. Grostite's Letters, 325. Grostête wrote again to Gray in 1245, urging lim to adrocate the claims of the bishop of ('ervia (Ibid., 469, and Gratii l'ascic. liermm Expetend., ii., 427). A bout this bishop and his atfieirs there is an accomt in Ughelli, Italia Saera, ii., 469. He had a quarrel with the archlsishop' and people of Ravenna.
${ }^{t}$ Amm. Warerl, apnd Gale, ii., 203.

"Cal. Rot. Pat., 20. liudera, i., 256. On Nov. 2, 1220, Gray was ordered to take the charge of Nowcastle-on-Tyme on the death of Philip) de Tleotes (Rot. ('laus, 473); and in the twenty-second of IIenry III. Kenilworth castle was giren of to him as a residence for cardinal Ottoboni (Nemoirs of Northumberland, 6ii).

"C'mon. L'etrib., 137. ('hron. Mailros, $156 . \quad$ Mntt. Paris, 616.

* Fadra, i., 270, 277. 
l'aries and posterity could not moderate the follies and the caprices of his master. After his decease, when the barons' war broke ont, Hemry would at length appreciate the merits of his faithful councillor and wish that he had adopted his advice. How often had Gray stood in the breach when the storm was lowering, and stilled it by lis courteous and persuasive pleading and the serenity of his bearing.

The most brilliant scene, perhaps, at which the archbishop was ever present was witnessed at Tork in 1252. Henry III., his queen, and the whole cont kept their Christmas in that city, and they were joined there by thie royal family of Scotland. Then it was that Alexander, the yonthful monarch of the Scots, was married to Margaret, Hemry's daughter. He did homage for the territories which he held of England, and had been made a knight,

\section{"And on the morwe whan the day gan spring, Of hors and harneis noise and clattering Ther was in the hostelries all aboute: \\ And to the paleis rode ther many a route Of lordes, upon stedes and palfreis."}

The ceremonial in the minster at the celebration of the nuptials must have been a magnificent one. More than a thonsand knights in silken attire were in the train of the bride, and, when the wedding was orer, such a banquet took place that the historian of the occasion, conscions of his inability to deseribe it, shrinks altogether from the task. No bill of fare has been launded down to us, and we know nothing, most unfortmately, of the dresses of the ladies. 'The archbishop contributed as many as sixty oxen to the feast. Matthew Paris is most eulogistic when he speaks of his hospitality. He seems to have kept open honse, and to have entertained his illustrious visitors orer and over again with a princely grandenr. To the poor he was equally lavish of his charity and his munificence, and he is said to have expended on this oceasion the large sum of four thousand marks. All this was done with a generous spirit, which befitted the time, and with a dignity which was characteristic of the donor. ${ }^{y}$

After this great meeting at York the archbishop seems to have taken little interest in state affairs. He was an old man, and stood in need of rest. There was another reason also for his quieseence. Ile conld not approve of all the measures of the king, and he was too cautions to involve himself in difficulties and annoyance. It was for this reason, no doubt, that he stayed

y Matt. Paris, 715-16. Contin. Fl. Wigorn., ii., 1s3. Kunghton, col. 21t1. Joh. de Oxenedes, 116. Chron.
Lanercost, 56. Chron Mailros, 179. Chron. Petrib., 139. Fœdera, i., 278. Lel. Coll., iii., 6 . 
away from the parliament of 1252 ; at which there wore some dissensions between Henry and the bishops, in which (iray, if he had been present, would have been obliged to take a prominent part. He was absent also from the parliament in the following year, pleading as his excuse his old age and the length

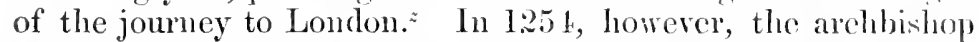
was drawn from his retirement, for when the gueen went abroad to join her husband, who was in Gascony, he was made, for the sccond time, the regent of the kinglom. ${ }^{a}$ There was no event of any importance to amoy the aged prelate, who aceppted most unwillingly the responsibilitics of office; but his serene wistom could not fail to discern the tokens of the storm which was so soon to burst upon his comtry. In the begiming of 1255 the king returned to England, and a parliament was assembled in London at which Gray was present. The time was a melancholy one; for never had the monarch been in greater disrepute, or the nation in greater suffering. Henry was an obstinate and a thoughtless man, with little regard for the wishes and the welfare of his suljects, if he could give the rein to his own folly and extravagance. He was orerburdened with debt, and he tried to free himself by starring his groaning and oppressed people. There were many angry words, and much murnming and grumbling in that parliament, with great uncasiness and discontent. The whole country was in a state of sullen indignation. To add to the general alarm, the spring of that year was most ungenial. From the middle of March not a drop of rain had fallen, and any appearance of regetation, which the sun mercilessly elieited, was scorehed and withered by a morth wind that ncver ceased to blow. It was in vain that the chicf men of the country humiliated themselves by fasting to proeure from the hands of the Great (iver the blessings of peace, and a fruitful season. The severity of the religious exereise, and the inclemeney of the weather, only laid them on the bed of sickness, and the hearens were closed. ${ }^{b}$

The aged archbishop of lork was one of these suffercrs. He was borne down now with ycars, and was incapalole of exertion and fatigue. The fasting, which he had daily practised, had affected his head; and his mind was oppressed with a heary burden of anxieties and ficars. The scenes in the recent parliament had ammoyed him greatly ; lis life-long excrtions for his country had apparently becu finitless, and the future, alas, was threatening and clouded. llis heart gave way, and his 765.

* Matthew Paris, $732,715,750$,

a Ibid., 765. Wikes (Gale, ii., t!)

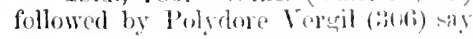

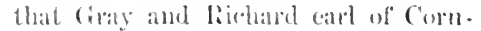
wall welo the lewents.

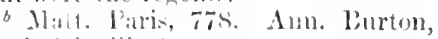
aplul ciale, iii., 211. 
lealth aceompanied it in its decline. Ilis appetite was gone, and lis days seemed to be at an cud. The parliament had been disiolved, and, at the request of the bishop of London, the sick nian went to seck for quict and repose at the palace of Fulham. Tle had only been there three days when he died, on Saturday the 1st of Miy, 1255, having prejared himself for his departure by receiring the last sacraments of the Church. His body ${ }^{d}$ was bor'ne honominlyly to York muder the escort of Walter Kirkham bishop of Durham, who, to slicw his reverence for the dead, distributed late sums erery dicy in eharity as the procession arlvanced into the Nortls. The remains of the arehbishop were interred in the minster at York, within the sonth transept, which he had himself erected. He had ruled over that church and diocese for nearly forty years, and they lost in him a nmmificent and an enilightened pastor, and England a true patriot, and an honest and an upright statesman.

We must now turn from archbishop (iray's faithful service to his comntry and her kings, to the works for which he is still remembered within the diocese of lork. I am not giving him ton ligh praise when I call him the greatest prelate of the rentury in which he lived. The same thonghtful eare and watchfinl pruclence which made all men like him, ${ }^{e}$ in an age when there were many bitter enuities, and secured for him the uninterinpted favour of two kings, the same uprightness which moderated all his actions in the court and council-chamber, the same munifiecuce which he manifested in all places, seem to lave been the miform characteristies of his arehiepiscopal 'ar'er'. To one can examine the rolls on which his official acts are recorded, withont being profomdly struck by the vigour of his pastoral rule, and the expansiveness of his charity. Everything seems to have been done on the most perfect system, and apparently moder the personal inspection of the arehbishop. The carchessness and the recklessness of his predecessor had turned the diocese into a wild; it was Walter Gray's high privilege to have the will and the means to till and sow the long harren ficld, and God gave him length of days that he might limself behold the harrest. It was the same in the temporalities as in the spiritualities of his see. He was a good husband of his revennes, and dispensed them nobly. Throughout his whole

c Stubbs, col. 1725. Knyohton, col. 211. Mrs. cotton, Vitellius, A, ii., $111 b$. Hemineford, apud Gale, ii., 561 . Ann. Burtoll, ilide, iii., 3 il. In the liber Vita of Durham (ed. Surtees siec., liso) Gray is said to have died on May 6 (2 Xio).

fintony a llood says that Gray died at Orney abbey. In 1221, singnlarly enough, Richard Gray became abbat of that house (Rot. Claus., 470). " "Facta anatomia." The process need not be described. Matt. Paris, 778.

- Wikes, apud Gale, ii., 50. Polydore Teruil, 311. 
diocese he seems to have been the great re-organizer of the parochial system, effeeting subdivisions, and arranging the distribution of endowments. He held a provincial council at York, and promulgated some valuable constitutions relating especially to the furniture and ornaments of his churehes, and to tithes. $f$ He was sechlously attentive to the interests of the monasteries, and was their generous benefactor. ${ }^{g}$ The subsequent archbishops of York had good reason to remember him. He made a rule that on each of the manors belonging to the see a eertain quantity of stock should be reserved at the death of each prelate for the benefit of his successor, and he obtained the sanction of the king and pope for this arrangement, which he inangurated himself. ${ }^{h}$ He purehased the village of St. Andrewthorpe, which he appropriated to the see, charging it merely with an anmul payment of twenty marks, half of which was to provide for the keeping of his own obit in the minster, whilst with the other moiety the ehaplain within the manor of Thorp was to be supporter. ${ }^{i}$ This is the origin of the present palace of the archbishops, for the name of St. Andrewthorpe was soon changed to Bishopthorpe. It was to Walter Gray also that his suecessors were indebted for their house in London. The history of that palace is a remarkable one. It was the residence of the famous Hngo de Burgh, earl of Kent, who gare it in a fit of generosity to the Black Friars, from whom Gray purchased it, and presented it to his see. It bore the name of York-place until the time of ILenry VIII., when that imperious monareh demanded it of Wolsey. It was given np, and we know it for the future as Whitchall.

"Sir, yon

Must no more call it York-julice, that is past;

For since the cardinal fell, that title's lost;

'Tis now the king's, and call'd-Whitehall."

$f$ These are given in Wilkins, i., 698-9. Cf. ibid., 755. 'The archbishop' had a controversy with Robert de 'lhweng about the church ol' Lythe (Matt. Paris, 460).

g 'To give instances. In the cluarter in which he confirms the foumdation of Healaugh, he speaks of the "novellam constructionem domus per sollicitudinem nostram" (MSS. Cotton, Vespasian, $A$, iv., 7,8$)$. He obtained from Henry III. a grant of fairs, and a market for IIexham (Ibid., Claudius, 13, iii., 95). He granted to the camons of Nostell twenty marks per ammum out of the church of "South Kirkby (Ibid., 1tb). On Jume 16, 1:200, he gave the monastery of Blyth an ammal pension of tive marks ont of the rhutech of Westom to enable the monks to kexpl lospitality (Rot. (iray). He made parks in Hecksorave, ILockwode, and Nordwode, co. Notts (Rot. Hundr., ii., $311)$.

'Tluese gifts are mentionediustubbs, col. 1721-5. 'The eraut of Thorp) is printed in Dusal. Mon., vi., 1191-5.

i 'The archbishol' ennveyed it to the chapter of York, and they ensage to re-convey it to the linture primates on the rayinest of the 20 nurks. The chaplain was to pray, specially, for the sonk of king Jolin and arebbishopy fiay (1)omeslay book, apme bibor., 99). 
If the walls of that palace rould have spoken, they could have told a woudrons tale. They beheld in turn the intrigues and fistivities of Wolsey and his master, the brilliant courts of lilizabeth, the fawning servility of Steenie, and the execution of ('harles.

Arohbishop Ciray translated the remains of his predecessor St. Wilfrid at Ripon, and placed them in a befitting shrine.

"Wilfrill reliquias de theea levarit,

In ea]wam arsenteam digne collocavit.";

lle fomded the prebend of Stanwick in that ehureh, ${ }^{k}$ and I aspee with $\mathrm{Mr}$. Walloran in ascribing to him the erection of the beantiful west front of that eathechal. ${ }^{l}$ But it was upon the church of York that lis benefactions were showered. The subdeancry and the subchantorship of the canons were established whilst he was archlishop, and it is quite possible that lie fomder them; at all events he attached the living of Preston to the subdeanery. The stall of Wistow was eonstituted about the same time, and he revired that of Weighton, which had fallen into deeay. In 1218 he annexel the prebend of Newthorpe and the church of Acomb to the treasurership. ${ }^{m}$ He appropriated the living of Mappleton to the arehdeaconry of the lisist Riding, that of Wawne to the chaneellorship, 'Tunstall to the newly established subchantorship, and Withernwick to the probend of llolme. Ho lad obtained these benefiees from the abbat and eomvent of Albemarle, and he bestowed them upon the minster with the consent of the dean and ehapter." He wave to the same chuch thirty-two eopes of blue and purple, ${ }^{o}$ it valuable mitre, a chalice and paten of gold and precions

j From the notrical history of the archbishres in Mlss. Cotom, Cleopatra, rivi:

i Rot. Gray.

Matt. Paris (313), moler the year 1231, gives a curions account of an arventure at Rifon. It was a vear of fintuine, and the archbishop had sathered tousther as mole corn as posible, to the injury, as we are informond, of the pur. It was kept so lome that it deraycel, and the ereaturestlat foumd a lome in it wrestupuod to be suecial anissaries of the evil one, and to be sent to punish the ataries of the arehfishop. 'Tlor bailifls at first ran away, sin I the motics, whom they emmelled to npen ont the stacks, were obliged to follow their exminle when they heard as strange voice ont of the eorn bicklings then desist, "uplia archimiscopss of cmmia place habebat diatoli jowestio erat!" The whole thing is ridieulously absurd.

On the 21st of Oetober, 1222, Henry III. ordered Galfrid de Neville to give to Gray ten bream out of the royal fish-pond on the Foss to stock his stew at Ripon. There is still a pond in lipon farks which contains a number of this rare fish. Were they geucalogists they might make out a very capital predicree (Rot. Claus., 515).

${ }^{m}$ MSS. Torre. Rot. Gray.

" Rot. Gray. Dugd. Mon., vi., 11912. In Le Neve, iii., 102, it is said that Gray founded the subdeanery, the succentrirship, and two lrebends at Tork. Iie augmented the prebend of Grendale to 10 marks (Rot. Gray).

"Strubse, col. 1725. In MSṠ. Cotton, Cleopatra, C, iv, the number is said to be twenty-six. 
stones, a morse of gold in the shape of a rose, with a large ruhy in the eentre, and other ehoice stones, weighing more than it pound, and a tippet also decorated with gold and jewcls.p But Gray's noblest work at York was the erection of the sonth, transept, in which he is interred. It is the choicest portion of that glorious temple, and the early Euglish style of architerture may there be seen in the supremacy of its beanty. In boldurss of arrangenent and design, and in riehmess of decoration, the south transept is without a peer. How many of those who waze with eurious and admiring eyes upon areade and carving, are: ignorant of the piety and merits, nay, of the rery name of the prelate who called them into being more than six centuries ago.?

There he lies on the eastem side of the same transept, in the grave which received him on the rigil of the feast of Pentecost, 1255. ${ }^{r}$ The place in which he is interred was in all probability seleeted by himself.s The altar of St. Michacl, at which the arehbishop founded a chantry in 12/1 for the woal of his soul, ${ }^{t}$ stood between the sepulehre and the wall; but all

$p$ Fabric Rolls of York Minster, ed. Surtees Society, 213, 215, 222.

$q$ From the fact that Gray granted an indulgence for the chureh of York in 1227 , and that several other gifts to the fabric were made about the same time, it may reasonably be inferred that the building of the transepts was then going on (Fabric Rolls, 146-50). That on the south side must have been com. pleted before 1211 , the year in which Gray fornded his chantry at the altar of St. Michael. Sewal de Bovill, who became dean about that time, confirms a srant of two bovates and two acres of land in Milford which the archbishop had made to Gilbert de Corbrigge, carpenter, "qui in ejus servicio diu stetit et tam pro ipso quam pro ecclesia Ebor. multum et fideliter laboravit" (MSS. Cotton, Claudius, B, iii, $113 a)$.

The north transept, which is aseribed to John Romanns, senior, was probably built shortly before Gray's work. It is less rich and probably, therefore, of an earlier date. Romanus became subdean in 1228, and died in 1256 . IIe and Gray must have been sreat friends. On Nov. 27, 1237, the arehbishop granted him an annual pension of 20 marks (Rot. Gray).

There is an interesting legend abont the beautiful little church of Skelton near York. 'The antiqulary Gent, writ- ing in 1731, "mounted on his courser" to visit it, "becanse it is aflimesl 'twass built with the stones that remain'd after the sonth eross of the minster hat been timished by the arehbishop Walter Grey" (Gent's Ripon, pt.ii., 3). There is an aceomt of this arehitectural sem, I had almost said toy, in "The ('hureles" of Yorkshire," and a work hils been specially devoted to it, viz., "Architectural Illustrations of Skelton C'bureh, by Ewan Christian, with an account of" the butldins. Folio. fondon: 181fi."

$r$ Ann. Burton, apud Gale, iii., 311.

- As Professor Willis observes, "The pier arch nnder which the tomb stands is made wider than the others, aty: rently to give it importance." It was probably made so that the fommder might rest beneath it Architecturil IFistory of York Cathedral, 20).

¿ Founded March 22, 1211, for one priest, with two chaplaius amd a clerk under him, and liberally endowed (Fabrie Rolls of York Minster, 2!7. MSS. Cotton, Clandins, 13, iii., $76 b)$. Stulbs speaks of Gray ordaining three pereleshat chantries at this altar (col. 17:5). Giray bat secured to himself the elmereh of Billum, with which the chantry was endowed, between lezs and 12:30, but the actual deed of fommintion wats not drawn up till 1291, when the transept was probably tompleted. Arohbishep (iray was also conninemorated 
traes of it have disappeared, sare a figure of the arehangel in the winclow abore, still thrusting his spear into his prostrate foe. The monmment on which you gaze is one of the most striking menurials of the age in which it was set up. The archbishop, who seems to have been of small stature and a slight frame, is stretehed out at full length with his pastoral staff in his hand, which is thrust into the mouth of the scrpent. The details of the figne and its adjunets are fill of simple elegance. Above the slecping prelate, on ten light and graeeful pillars, there towers a magnificent canopy, which terminates in fimials of the most beantiful design. Many will be surprised to learn that these are of modern workmanship, and that they were moulded less than a century ago by an Italian of the name of Bernasconi, a senlptor of great merit. I camot bestow too high praise on what he has done, for he seems to have been imbued with the true spirit of Christian art. 1Ie has crowned each finial with two thrushes in full song, wronght with exquisite skill, and resting upon wool-packs." Had the carving been really old I wionld have ventured to suggest the meaning of the device. The packs wonld have been an allusion to the office of chancellor, which the archbishop once crijoyed, and in the thrushes there would have been, perhaps, a canting allusion to his name. The thrush in the North of England is at the present day frequently called the grey bird. It may well be singing, for what an offering of praise and worship is above it. The monument, I must add, is surpounded by a brazen sereen of excellent and alphopriate design. It was set in its present position by arehbishol, Mlarkham, and his gift prompted the following lines from the earl of Carlisle:-

\footnotetext{
"From rude approah and from the touch profare 'Thus gen Tous Markham guards this crumbling fane; Rerises just praise to Grey, makes widely known A course of lib'ral actions like his own. And should at biser age ummov'd survey Our mich lov'd prelate's mould'ring tomb decay, Vicw 'lime's coarse hand each srateful line efface, Nor the broad tablet to his worth replace; Yot on the spot where once was plac'd his urn, shall true religion ever weep and mouru; $A$ reverential awe around shall siread, And learning point where rests his holy head."
}

at the altar of St. Stephen, which was fontuded by Willam re Langton, nerhew and heir of Willian de Langton, late than of York (Fabric Rolls, 301). When we recollocet that the dean was also called IVilliam de Rotherfield, Gray's paternal astate, we can see at onee to whom he was indebted for his prefer- ment at Iork. Langton was interred in the sacred corner where the remains of archbishops Gray, Bovill, and Ludham were deyosited.

"The finials are merely of plaster. Bernaseoni has introdured a thrush on one of the ornaments of the north side of the tomb with less snceess. You 
Walter de Gray is the first archbishop of York whose official acts have been handed down to ns. These are registered npon two rolls of unequal size called the major and the minor, which have originally been one, and which onglit to be re-mited. They commenee, most unfortmately, with the procecdings of the tenth year of Gray's archicpiscopate. 'T'hey are of rery great length, and exhibit docmments of great interest and value.o The writing, which is on both sides, is singularly beantifinl and minute; and no one can examine the roll withont being deeply struck, not only with the ealigraphy, but with the picty and energy of the arehbishop, and with the perfect order and system which he observed in the management of his diocese.

Srimal or Bobrill, dean of York, was (rray's sucecssor. His origin appears to have been an humble one, and of his early life there is little known. He was one of the scholars who attended the lectures of Edmund de $A$ bingdon, afterwards St. Edmund, at whose feet Grostête and Roger Baeon nsed to sit in the University of Oxford.w IIe would there be brought into contact with some of the most learned men of the day, anong whom he is said to have distinguished himself by his works. ${ }^{x}$ Borill was greatly attached to his master, and, in after years, when the merits and snfferings of Edmumd began to attract both srmpathy and attention, he wrote to Innoeent IV., urging him in stronix terms to canonize his old instructor. He speaks of his former tutor in terms of the warmest praise and aflection, and tells the

may see at once of what materials it is composed. In 10rake's Eboracum (127) there is an engraving of the tomb before Bernasconi meddled with it. It is at present, I am sorry to say, in a dilitidated condition.

Drake mentions a curious story which was believed in his day, that the archbishop had died under a sentruce of excommmnication, and that his body therefore had not been laid in the sacred earth, but in the cinopy wer the pillars. The too curions antifunary marle an incision into the stone-work, and soon found that there was no hollow within.

v Two or three extracts may be given. June 1, 1229, a pension of 5 marks from the chureh of Branecpeth to Peter de Villibns, elerk. July 16 ,
1233, licence to the prior and ronvent of Wartre for a cliaplain to pray for the soul of liobert de l'erey in the chapel in which lae is interred. Nov. 15) 1251, a perlsion of tos. jer annum to Roger Fit Irlan, clerk, nephew of our most dear friend, Fr. William, chamberlatin of our lorel the kiner.

" Martene, Jhes, Xor. Anerelet.,

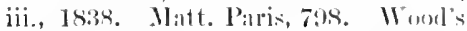
Antiq. Eniv. Oxon., i., 1!k, liowles's lacock lbbre, 202. In Walter de Giay"s roll the ditlo of majister is griven to Borill, which shows that he wats a gralliate.

2. Bale (rent. iv., 311-12) makes Bovill the atullor of "Brovilow Alexalulrum ; Statnta Symulalia; Arl slos sitcerdotes; Scrmones et Ejpistolas." 
pope that he had been his pupil in bygone days in the school of ants at Oxford." Eclmund, whoscems to have had a deep insight into character, had told Bovill what would come upon him in after-life, and one part of his prediction had been already rerified. lle said that his scholar should be advaneed to a high estate, but that he should be distinguished by his sufferings as well as by his temporal suceess. ${ }^{z}$

Bovill became the dean of York about the year 1210, holding at the same time the stall of Fenton. ${ }^{a}$ He was also made archleacon of York in 1:249, on the death of Laurence de Lincoln, whose will he cansed to be excmplified. ${ }^{b}$ In compliance with the wish of his friend, whom he succeded, he established a chantry at the altar of St. Lanuenee, in rork minster, on the lith of Jamuary, 1:250.

I pon the death of Walter de (iray the chapter elected their dean in his room, and the sclection seems to have been a good ane, as . Natthew Paris sipeaks in high praise of Bovill's modesty, piety, and learning.d The king, however, was too fond of money to allow the teminoralitien of the see of York to pass so speedily from his hands. "I have never had them before," he is reported to have said, "and they shall not slip ont of my fingers yet." II took possession of crerything he could to the great grief of the archbishop-clect, ${ }^{e}$ and justified his proecedings by saying that Borill hat becn born out of lawful wedlock. It was his wish, I behicre, to secture the see for his brother Ademar, bishop of Winchester." The chapter, howerer, supported their late dean with rigons and resolution. They bon'rowed two hundred marks of Peter the subchantor, to enable them to prosecute the matter at Rome; and on the lst of October, 1255, they assigned to him as a security the elutrelies of South Burton and Brothertom. ${ }^{h}$ 'The procectings at Rome were entirely in Bovill's favour. the pope sont him a dispensation which obriated the irregularity of his hirth, confirming his election, and giving him the pall. ${ }^{i}$ The chapter now broment the matter to a termination with the aid of Roger de Iloldemess, their representative.j It was useless

y Martene, ut supra.

= Mat1. Paris, 798, 803, 827 .

"From Rost. Ciray it appears that he lial a stall in 1237. MSs. Cotton, ('landius, I3, iii., 8, 31, 45. NIss. Torre. Lar Nore, iii, 121, 18t.

b Yss. Torre. Le Nere, iii., 132. Demestay Book, penes ber. et rap. Ebor., 57 a. York Fubric Rolls, $29 \%$.

d Mate. Paris, 7st. Wikes, apud (inde, ii., 50. Polyture Veryil, :311. Fuller's Wortlies, n.e., ii., 539. Whie temporalities had been in the hands of John Clarel and Adam de Hylton ( $\mathrm{Ab}-$ brev. Rot. Orim., i., 15).

- Matt. P'aris, 779, 781, 786.

$f$ Ihid., 786. Stubbs, col. 1725.

5 IVikes, apud Gale, ii., 50.4 per.son of great influence with Henry III. Cf. Mon. Francise., 254.

h Rerp. Giffard, $108 b$.

i MSs. Cotton, Vitellius, A, ii., III. Wikes, apud Gale, 50.

$j$ Matt. Paris, 78t. When Ludlam was made archbishop, Roger de Hol- 
for the king to resist. The royal assent to the nomination of the ebapter was granted on the 4 th of May, 1256,k and Bovill was eonsecrated archbishop at York on Sunday the 23rd of July.

Soon after this eeremony took place Adam de Marisco, the learned Minorite, addressed the new prelate in a letter which assumes the eharacter of a little treatise, as it extends to fortyseven ehapters." Bovill, who was a timid man, seems to have aequainted his friend with the doubts and fears which his new position aronsed in his mind, and to have solicited his counsel. The reply of the eelebrated friar reminds us of the letter which Beda wrote to Egbert. He begins by expressing the joy that all good men feel at Bovill's promotion, ${ }^{n}$ and then he tonches upon many points of great importance to a Christian bishopthe kind of life that he should adopt, the necessity for wise eoadjutors, the eare to be taken in making appointments and elroosing clergy. All this is to be done with the aid of One above who is to be approached by prayer, upon the nature and degrees of whieh Mariseo speaks at some length. He then turns to a subjeet upon which the Minorites were always elognently indignant-the viees of the elergy, and he urges Bovill to repress them with a strong hand. After this the writer speaks of religion in its politieal aspeet, and the wrongs which the churel endured at the hands of the eivil governors. All this is to be withstood temperately and firmly. Grostête is held up as a pattern worthy of imitation, and Marisco tries to eheer his friend by telling him that persecution is not only useful, but a blessing. We can well eoneeive that Bovill had been speaking to Mariseo about the predietion of Edmund de Abingdon, to whieh the last picec of advice has an especial referenee. The letter is an interesting doeument, and it is the key, no doubt, to Bovill's subsequent conduct.

Bovill's name oceurs but onee in eomeetion with the state. On the 20th of July, 1257, he was one of the commissioncrs who were appointed to settle, if possible, the rlisputes betwern the king of Seotland and his nobles. ${ }^{\circ}$ In the same year I find him mentioned as a worshipper at the tomb of St. Alban. ${ }^{p}$ IIo

derness, alices de Skefling, became dean.

$k$ Le Neve, iii., 102, ex Rot. Pat.

l MSS. Cotton, ut supra. Stubls, col. 1725. Anclia Sacra, i., 310. 1lemingford, apud Gale, ii., 578. Irikes, ibid., 50. Knyghton, col. 211. Matt. Paris, 801. Flores 1List., 363.

n Printed among the Monumenta Franciscana, 438-189. $n$ Marisco says of him, "Cijus in. dies nsfuenuayum leer effectnmm evidentias universis clareseit illnstrins et virtus invincibilis, of sensus inliallibilis, et zolus intemerabilis, et actus indefatiGabilis" (ibid., 410).

- Ferdera. i., 362. IIutchinson's Durhan, i., 210, where the date 1258 is given.

$p$ Matt. Paris, Sug. 
did, however, some good work at Vork during his brief tenure of the archiepiscopate. He remodelled the constitution of the chapel of St. Sepulchre, which had been founded by archbishop lioger, changing the clergy into canons, and making provision for the managenent of - the common property and the performance of the services." Borill, however, conferred a still greater boon upon the chureh, and his vigour and persistency in standing up for the rights of his cathedral when they were menaced by an insolent intruder, won for him the praises of his contemporaries, although they involver him in the troubles which his old master had foretold.

The deanery of York, which Borill's own promotion had racated, was given to Godfrey de Lindham, who succeeded him also in the arehbishoprie. Ludham's tenure of office was destined to be an uneasy one. One day three strangers found their wiy to the minster of York.r No service was being performed, firl the priests and elerks at that time were otherwise employed. The men entered into the cathedral, and found a solitary worshipper at his derotions. They asked him which was the dean's stall", "This is it," he said, pointing to the place. 'The three then went up to it, and, one of them taking possession of the seat, the other two sail, addressing him, "Brother, we install thee by the anthority of the pope." The arehbishop and his chapter, nay, the whole of England, were amazed and indignant. Withont a word having been said to any one, the pope had given the deanery away to an Italian cardinal of the name of Jordan, who hat got prosession of it by this audaeions and disereditable trick. Bovill, who seems to have been natmally of a quict and retiring disposition, had a just canse to defend, and he would not submit to this dictation. The whole of England was being stocked with these Italian pricsts, who came orer hungering after preferment. They had for some time made a prey of the church of ' lork. On this oecasion Bovill exhibited such a determined front that the intruder went home, and made a complaint to the pope. The archbishop was now subjected to the rancour of disappointed and angry men, and endured a bitter persecution. Ile was suspended from his offiee; the minster was put under an interlict; Bovill's cross was taken away from him, and,

7 Stubbs, col. 1725-6. Reg. Greenfickl. Mnst. IIon., vi., 115:.

Mitt. Paris, so3, s:0, 8:7. Ann. Jurtrm, apun Gale, iii., 356.

- Many instances might be given. In 1250 Dagister linstandus, the subclearen of the prope, come to Enrland, and a sall at York wis criven to lim by the kine (Matt. Paris, 785). Joln
Romanus, archdeacon of Richmond, is blamerl for urring the Romans to enrich themselves in England (ibid., 792). Cf. Twisden's Historical Vindication of the Chureh of England in print of Selism, 61. In 1207 the king received 611 . 4s. 6 d. "de prebendis Romanorum in dioc. Ebor." (Rot. Claus., $99)$. 
finally, he and the dean were excommmicated. I eannot say whether these marks of the papal displeasure were erer altogether removed. It seems, however, probable that the sentence was reseinded, as Matthew Paris mentions an arrangement, which looks rery like a compromise, that a pension of a hundred marlis should be paid yearly to Jordan till some other preferment conld be provided for him. ${ }^{t}$

These troubles and persecutions broke Bovill's heart, and he was soon upon his deathbed. At that solemn time the sinking prelate raised his hands and his eves towards hearen, and appealed to the Redeemer from the mimighteons dealing of His pretended deputy upon earth. The dying man then thonght upon the bold words of his old college friend Grostête, and resolved to follow his example and acquaint the pope with the evil he had done, protesting against the injustice. He bade him imitate the lummility of his sainted predecessors, and not to tyramnize over the church, " for the Lord said to Peter, feed my sheep, and not, shear them, skin them, tear out their entrails, or eat them up." This was strong language; but it secms only to have provoked a smile of pity and contempt on the fare of him to whom it was written." "There were many, howerer, who would be proud to think that men were not wanting to point out the erils of the times, and to lay the lash npon the real offender's.

Borill died on the 10th of May, 1258. ${ }^{\circ}$ On the Easter day before his decease he had made a great feast for the poor, and he left it and them to take a part in the services of his chapel. The memory of his rirtues was long cherished in the North, and miracles, ete., are said to have attested the holiness of his life."

Archbishop Bovill was interred in the south transept of the minster near the remains of Walter de Gray. A plain marble slab eharged with a fioriated cross, and elevated upon low pillars, still marks the spot. The gromd was opened abont 1735, and a gold ring was taken ont of the grave, which is now preserved in the vestry. It is of simple workmanship, and withont any ornament.

$t$ Matt. Paris, 813. In the Anglia Sacra (i., 494) it is said that Bovill was excommunicated by the arehbishop of Canterbury in obedience to a papal mandate. Another accont is thiat Jordan suspended him, and that he was suspended at the time of his death, the pope knowing notling of it -a most unlikely thing (Chron. Petrib., $142)$.

u Matt. Paris, S31.

$v$ MSS. Cotton, Vitellins, $A$, ii., 111. Stubbs, col. 1726.

${ }^{w}$ Chron. Lanercost, 71-2. 


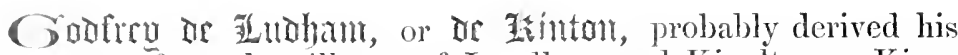
smmanes from the rillages of Loudlam and Kinalton or Kinston in Tottinghamshine, of which eounty he seems to have been a native. 'The ('hristian names of his parents were Richard and lida, and he had a brother, 'Thomas de Ludham, who was ehaplain to the pope and a prebendary at York and Sonthwell. ${ }^{x}$

On the 17th of June, 12:27, arehbishop Gray granted to $\mathrm{Mr}$. Ciodfrey de ludham a prension of ten marks per annum, and on the 26 6 th of Augnst, 1:299, he collated him to a moiety of the living of Peniston in the West Riding of Yorkshire. ${ }^{\text {" A }}$ Abont the year 1250 Ludhain was precentor of York whilst Bovill occupied the deancry, $\approx$ and when the dean was advanced to the archbishoprie the precentor succected him in his office. He was immediately involved in the troubles that orerwhelmed his diocesan. 'The jope, it will be remembered, attempted to thrust at eardinat of the name of Jordan into the deanery, and excommunieated Bovill and Tulham for opposing lim. ${ }^{a}$ There is, howerel, reason to belicre that this sentence was soon withdrame.

liovill died in the begimning of May, 1258, and on the 29th of that month the king anthorized the chapter to elect another alehbishop. ${ }^{b}$ They fixed upon Ludham on the 12th of July, and the royal assent was given on the 25th.d Lutham took the jurecantion of going limsclf to Rome to secure the favour of the jope, and, after inmel tromble and cxpense, ${ }^{e}$ he was consecrated there on the esend of September, and obtained the pall. $f$ On his return to England he boldly entered London bearing his rross erect, and went to the conrt, where he was kindly welcomed by the king. Ifter this, he set ont for the North. On the J t of December he received the temporalities of his see, and about Chustmas he was enthroned with mueh rejoicing. He som shewed his regard for lioger de Holderness by giving him the deanery. They had becn friends for some time, and had been associated together at St. Albans.y

$\approx$ Fabric Rolls of Tork, 293. It is mentioned in Meton's Register, in a dreument rekating to the prebend of Wentwan, that Thomas and Godfrey d. luthlam were bothers.

IV:alter de Ludham, knirht, wit-

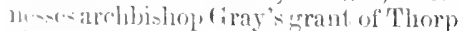
(idacil. Mot., vi., 1195). Cf. Thoro1un's Nofts, 2S9. y. Rot. Gray.

Mss. coltom, C'laulius, B, iii., i2

a Ann. Burton, alnul Gale, iii., 356.

$\checkmark$ le Xeve, iii., 102.

chron. hatneresst, 66. d Le Neve, iii., 102.

- Matt. Paris, 831, 839.

$f$ MSS. Cotton, Vitellius, A, ii., 111. Cal. Tot. Pat., 31. Stubbs (col. 1726) says that he was consecrated on Sept. 23.

g Matt. Paris, 810. In 1260 the archbikhop, was ordered to find men to sirve in Wales (Fod., i., 399), and on sept. 3 he was commanded peremptorily to collect the disme in his province (ibid., 115). 
There is very little known of Ludham's conduet as archbishop. His register has not been preserved, and the chroniclers are silent about him. We learn, however, from Stublus that in the third year of his archiepiscopate he pout the eity of Tork under an interdiet, which lasted from the begiming of Lent to the festival of the Invention of the holy eross, ${ }^{h}$ and the chronicle of Peterborough tells us that this severity was to punish the citizens for some injuries which they had done to their diocesan and the chapter of York. In 1261 Ludham held a provincial council at Beverley, ${ }^{j}$ and the people of that town were for some time under his displeasure for breaking into his parks. In the register of archbishop Giffard mention is made of some statutes which his predecessor drew up for the better management and discipline of the regular orders. ${ }^{k}$

Archbishop Ludham died on the 12th of Jamuary, 1265, and was interred beside his predecessors Bovill and Gray in the sonth transept of York minster. A simple cross carved in stone marked the place of his sepulture. When the old parement was taken up, about 1735, Ludham's monument was removed to the presbytery. It was injured in the fire of 18:29.

Ludham left a will, the provisions of which seem to have been neglected. On the 8th of March, 1268, the exceutor's were ealled to accoint for their short-comings. They were four in number; the prior of the house of the IIoly Trinity, London, William dean of York, Robert arehdencon of the Last Riding, and John de Steinton, a layman. Thomas de Berneby, subdeacon of the pope, and John his brother, a layman, two of Ludham's ereditors, made a petition to Octobonus the papal legate in England, that the executors should be obliged to pay the debts and legacies of their late master, and they were ordered to do so. On the 20th of February previous, arehibishop) Giffard had issued a eommission to Nicholas de Wudeford, canon of Westbury in the diocese of Worcester, empowering him to enquire into the effects belonging to his predecessor in the sce."

'Thomas de Ludham, the arehlishop's brother, founded a chantry at the altar of the Blessed Virgin and St. John in York minster, at which the souls of the deceased primate, the founder", and their parents, were to be especially rememberest. Three chaplains were to officiate at it, and it was cndowed with lands in Skelton, Middleton and Boynton."

h Stubbs, col. 1726. Chron. Laner$\cos t, 71$.

i Chron. P'etril). 113.

$j$ Flores Hist., 379.

h Reg. Giffard. The rules which Ludham laid down for the manaement of the monastery of Ifexham are preserved.
'Stubles, 1726. Wikes, apud Gale, ii., 66. Mss. Cotton, Vitellius 1, ii., $111 b$.

"h Brownes Sork Miunter, 58.

"Regr. (iiltared.

" Fork Fabric Rolls, etl. Surtees Society, 293, and MSS. D. and C. Ebor. 
On the 30th of Jamuary, 1265, the king gave the ehapter of lork permission to clect a new archbishop, and they again fixed unon their dean, William de Langton alias de Rotherfield. This appointment was made on the 1:oth of Mareh, and the king atsented to it on the lst of April. The pope, however, set it aside on the gromel that Langton was a pluralist, although he held only a single living in addition to his deanery. Bonaventura, the famous Francisean, was nominated by Clement IV. in Langton's place, but he seems to have waived his claim, as there was the prospect of a storm. ${ }^{\prime}$ The dioeese of York would indeed have been honomed if that illustrious man lad been placed at its head. The piety and the works of the "seraphic" doctor were famous throughout the Christian world. They attained for hin, among other homours, the rule of the order of the Minorites, the honours of the cardinalate, and a place in the calendar of the saints.

William de Langton, dean of York, who was rejected by the pope, was a great man. In 1205 he was summoned to parliament as dean, and in l:2is he declined the bishopric of Carlisle. Ile thed in 1:259, and was interred in the south transept near his friend and patron, archbishop Gray. He was commemorated hy a rery remarkable momment, which is now destroyed. Waltip de Langton, bishop of Lichfield and Corentry, and a distinguished statesnam, was his nephew.

II altre Giffard was the son of wealthy parents, and could bent of an illustrions ancestry. He was the son of Hugh Giffard of Boyton, in Wiltshire, by Sibilla danghter and co-heiress of Walter de Cormeilles. The Christian name of the archbishop was probably derived from his maternal grandfather, but it would also remind lim of Walter Giffard, lord of Bolbec and Longneville, a great Norman baron who came into England with the Conqueror, and fought by his side at Hastings. ${ }^{r}$

There is very little known of Giffard's early history. In 1256,

p MS. Vitellius, 1, ii., 111. Kny ghton, (a). 2151. Stubb), col. 1726. Chron. T'ot ib., 119. Le Neve, iii., 103,121. Cal. lint. P'at., 37. Wikes (apur Gale, ii., 71) says that Bonaventura resigned

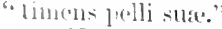

"II uare's Wiltwire-history of

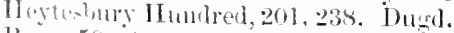
liar., 59, 199, ote. The archbishop wits lombably lle eldest wn, as the es- tate seems to have come into his hands. There is a life of Hugh Giffard in Foss's Judges of Ensland, ii., 351. Godfrey Giffard, bishop of Worcester, was the archbishop's brother, and I shall mention several others who were his kinsmen. Abbrev. Rot. Orig., i., 23.

Master Waces Chron., 256, ete. 
Henry III, permitted him and his mother to reside in the castle of Oxford ; and on another occasion he was indebted to the rood offices of Adam de Marisco, the learned Franciscan. ${ }^{t}$ On the 22nd of May, 1264, Giffard was elected to the bishopric of Bath and Wells, being at that time a canon and an archdeacon in that church, as well as chaplain to the pope. Six days after this the king assented to the choice which liad been made, and on the 1st of September Giffard received the temporalities of his see." The archbishop of Canterbury was at that time abroad, and the new prelate crossed the Chamnel in quest of the rite of consecration, which he received at the hands of the bishop of Hereford in the church of Notre Dame at Paris on the the of January, 1265. ${ }^{p}$ 'The English barons were most unwilling that he should leare the country for that purpose, and phundered his manors when he went, an act which he requited on his retur'n by a sentence of excommunication." Giffard was at that time, and throughont his life, of a handsome presence, fond of gaicty and humour, but of a luxurions disposition. He had afterwards a tendency towards corpulency, which is said to have affected both his temper and his health. ${ }^{x}$

Whilst he was bishop of Bath and Wells Giffard experienced many marks of the royal favour. In 1265 he was raised to the honourable position of lord-chancellor of England, receiving an anmual pension of fire hundred marks. The resigned the office when he was translated to York. ${ }^{y}$ During the intestine troubles of the time the king made him the lieeper of Oxford castle, and gave him instructions to furnish it with stores and munitions of war. $z$ On the 15th of Octolser, 1266, the pope promoted Giffard to the see of York, which had been racant for more than a year. ${ }^{a}$ He was enthroned on the festival of All Saints, and obtained restitution of the temporalities on the 26th of December. ${ }^{b}$

sxcerpt. e Rot. Fin., ii., 243.

$t$ Honum. Francise., 257-8.

"Prymne's Coll, iii., 221. Anglia Sacra, i., 566. Le Neve, i., 159. There is a life of him, containirg nothing new, in Cassan's Lives of the Bishops of Bath and Wells, 139.

" Reg. Sacr., Angl., 41. In archbishop, Giffard's register at York his acts as bishop of Bath and Wells are recorded from 1261 to 1266. 'These are arranged under archdeaconries in the usual way.

w Wikes, apnd Gale, ii., 67.

$x$ Chron. Lanereost, 71,103 . "Folmosus et illustris clericus," or as Clancer says,

"Now certainly he was a fayre melat." y Fose's Judges, ii., 353.

z Reg. Gillard, 76b. On Ang. 12, 1266, IItenry IIJ. leatsed to him his manors of Pydingelon and Brehull, sulbject to an anmual payment of $\mathrm{E} 30$. (On Oot. 12, 1268, the kimer allowed him to add to the cromed beloming to his palace in lork a piece of crown land arlinent (ibil.) 56 Hen. III., licence to the archbishop of York, "kemellare domum suam de Garrode ad morhm catsir" ((al. Rot. l'at., 11).

a MSs. Cotton, Vitellius, $A$, ii, 111 b. Wikes, apul Gale, ii., 77. Chron. Lam., S1. Matt. Paris, Addit., 859. Knyeliten, col. 2161. 'Trivet, 228.

${ }^{b}$ Vitellins, ut supra. Wikes, 8 . Stuble, eol. 1726. 
(iiflard still continued to take a part in public affairs after he came into the North. Th the autumn of 1268, he had a (puanel with the arehbishop of Canterbury about the right of hraring his cross ereet, as on the listh of Oetober in that year Gillin'l's proctor, li. de $W^{+} \mathrm{ell}$, was at Lambeth, and in the prescurce of the aldehishop made an appeal in bchalf of his master to the pope. With Ehward I. Giftard was a great favourite. In Inonst, lo\%(), when that monareh, then the heir apparent, was starting on his crusale, he drew up his will, in which he ilpuinted the Northern primate one of the tutors of his sons. ${ }^{d}$ I1 $1: 271$, II tinchan and jerby, which his nephew Hugh de Babington superintended as his deputy " In the spring of 1272 I find that lie was constable of the tower of London; another of his nepphews, Sir J. Neville, arting in his room. $f$ On the 23rol of Novenuber in that year the archbishop was one of the persons who ammonuced to the prince his fatler's decease, and he was fresent at the coromation of the new king. ${ }^{h}$ For some time after that Giflard was busily employed in receiving the oaths of alleciance to his master, ${ }^{i}$ and in $12 \% 3$ he was acting in his behalf in the aflain's of St. Augustine's, Canterbury.j In 1275 he was one of those to whom the charge of the kingolom was entrusted lu'ing Edwatrd's alsence, ${ }^{k}$ and in 1277 he scnt his service against l. lewellyn prince of $W^{T}$ ates, according to his summons. ${ }^{b}$

The best account of archbishop, Giffard's official acts is to be watlered from lis register, which is preserved at York. It is full of nofel and curions information relating to the ecclesiastieal condition of the North of England. There are in it, among many other things, the carliost ordination lists that I am acquainted with; focmments which have never yet been brought to beall, as they ought, upon the history of the clergy, and the anmals of the chureh. 'lhe register gives us a very favourable idea of (iilland's attention to his dioeese. In every respect he seress to lave luecu a faithful pastor. Ile was a strict and fearl's reformer of abusce, in days when there were many offenders, and stantling deviations from discipline and order. Giffard made a regular risitation of his clergy, and shewed no mercy to

liene Crififurd.

Fuel., i., ist. Tet. Vreturt., 9. Salox, Hist. Exch., ii., 153 . IIe buth it till I-1 Erlw. I. ('l. Fulles"s

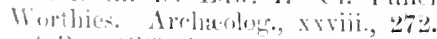

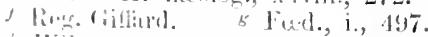
"Wike, apurl fale, ii., lo1. We arre cold that the ling would not alli,w

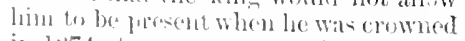

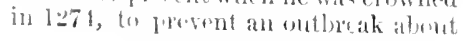

Hhe eross witl the archbishop of Canforlury (Aun. Waverl., apud Gale, ii., $227)$.

i Anulia Sucra, i., 499.

j P'ryme's Coll, iii., 124.

"Cal. Rot. Pat., 16. Godwin (n.e., 682), fuuting the Close Rolls, says that Gitlard was deputy in 1272 , and again allerwards.

l'ar. Writs, i., 195, 197. 
titled culprits. He reprehended William de Perey, eanon of York and a brother of Sir IIcnry de Perey, for wasting his time among courtiers, and in undignified pursuits. IIe also attempted to grapple with Bogro de Clare, a son of the great earl of Gloncester, an ecelesiastic who gave much troulsle to more than one archbishop of York. The history of this man is a most remarkable one. Itis noble blood, perhaps, made him spurn authority, and he paid no attention whatever to decency and discipline. At one and the same time he held as many as cighteen livings, in addition to the treasmrership at York and the deanery of Stafford. On one occasion when a royal official served a writ at his honse in London, Bogo's servant:s compelled the unhappy man to eat up the document, seals and all! Of eourse his parishes were grievously neglected, for Clare merely valued the income which they produced. 'The treasury at York was in such a state during his rule, that it was reported against him that the vestments and ornaments of the chureh were often used by women in childbed. In the ehureh of Simonburn in Northumberland, whilst he was the reetor, the chronieler of Lanereost observed in the place of the earving which ought to have been behind the altar some wieker work taken eridently from a stable, and still smeared with the dung of oxen. In striking and painful contrast to this parsimonious and guilty carelessness was the gift which Clare made to the queen of France, a coffer for her trinkets in the shape of a ear on wheels. The coffer itself was of irory, the wheels and all the exterior fittings, even to the smallest key, were of solid silver, whilst within everything was of gold or silk.

Arehbishop Giffard paid much attention to the religious houses within his diocese. They stood at that time in great need of supervision. More than a century had elapsed sinee most of them were founded, but during this period the defects of the system were seriously and alarmingly developed. 'The following extracts will be the best illustrations of the sulject. They are taken from the reports of the investigations which were made between 1274 and 1276 .

Bolton in Craven. The whole convent conspired against the predecessor of William de Danfield, the present prior. Nicholas de Broe, the sub-prior, is old and useless. Silence is not observed, and there is mueh chattering and noise. John de Pontefract, the present cellarer, is ineompetent. The eellarer and sub-cellarer are often absent from service and refections, and have their meals by themselves when the canous have left the refectory." The house is in debt to the amount of $324 l .5 \mathrm{~s} .7 \mathrm{~d}$.

n These canons and many other ec- clesiastics within the diocese of York 
Swrus. The prioress canmot kecp diseiphine. Sibilla de Bella and another mon ane rebellious, and Alice de Serutevile, Beatrix de St. Quintin, and Matilda Constable, abet them. 'The sick are neorlected. The nums have only a pair of shoes a vear, scarcely a tunic in three years, and a pallium in twenty, but what their parents or friends may give them, or they are able to beg. The prioress is full of suspicions, and is eredulous and hasty. The muns and sister's quarrel, the sisters pretending to be equal to the muns, and using black veils. There are two wholows broken, through which vietuals, etc., are earried out; and the nuns and eanons meet together in an unseemly way. The houschold of Sir Robert de Hilton wander about through the cloister and parlour, and takk suspicionsly with the nums. 'The nums have nothing for their fare but bread, eheese, and beer, and, on two days in the week, water instead of beer, whilst the (anons live luxurionsly.

Senzy. The chureh of St. Germanus in the town is a cliapel, and the rite of baption was administered in it until ehildren were curried to the momastery. The chapel and its altar are not dedicated, neither is the ecmetery, because the dead are interred in the burial ground of the abbey. The ehaplain was ordained in Irekand, but archbishop Gray allowed his orders. The abbat "mulierculas habet in maneriis suis et in villa de Selby,"

Tewriocur. 'The prior is too easy, and the superior too lot-trmpered. A camera has been necdlessly built at Thirsk. 'The cellarer trafties in horses like a dealer', and has a rough tomguc. 'The kecper of the fabrie is abroad at the cost of the house, and has not given in his account.

Fencri. Ralph, the prior, laid riolent hands on Ralph his brother-canon, and then took part in the service. He is old and infirm. Ile broke into the place where the common seal was kicyt, and took possession of it against the will of the monks. (He is deprived.) The eanons lead rery immoral lives.

Archlsishop (iiflard was hold cnongh to exereise his visitatorial power within the diocese of Durham, even within the walls of the potent monastery of St. Cuthbert. The see was at that tinc vacment, and, accorling to one of the Durham historians, the right of the arehbishop of York to act within the bishopric duriug the interresmun seems to have been eoneeded. The chronicle of Lancreost, howerel, tells us that Giffard's visit was not mattenderl by dissension. The prior of Durham .ndearomerd to besuile his potent guest at his residence in the "ominty with the dainty cates of which Gifiand was so fond, but the ardhishop did not forget the main olject of his coming; 
and a quarrel arose, which ended in Giffard's exchusion from the cathedral, and the excommmication of the prior and his rebellious brethren. We find also that Giffard was more or less mixed up in the controver'sy which preceded the election of bishop de Insula."

Archbishop Giffard must be reckoned anong the bencfactors of the church of York. He augmented the chancellorship with the living of Acklam, and appropriated the bencfices of Mappleton, Withernwick, Waghen, and Thustall, to the archdeaconry of the East Riding, the prebend of Holme, the chancellorship, and the suecentorship. ${ }^{\circ}$ He gare also to the minster a fair mitre, a gold ring with a balas, two small sancers of gold, and two precious phials of silver gilt, wrought with cumning workmanship, and decorated with valuable stones. $p^{p}$

Among the grave and formal documents with which the archbishop's register abounds, there are sereral pages which are devoted to an interesting subject, the private cxpenditure of Giffard. From it we may gain what is of great value, a pretty fair insight into that prelate's character and life. I need make no apology for giving a number of extracts. There is, unfortunately, a provoking absence of minute details which is much to be regretted. We have a glimpse, however, of the archbishop's kindness to his relations, and his charitics. The large sums which he gare for wine secm to shew that he was, as the Lanercost chronicler has described him, "socialis et dapsilis." The expenses incidental to his taking possession of his see were in all probability so heavy that he was obliged to have recourse to the Italian bankers, or usurers as he appropriately calls them, to borrow money, and it is doubtful whether he was erer thoroughly extricated from their elutehes. Many of their bonds, to which he was a party, have becn preserved, and he might well complain of the "whirlpool" into which he had been plunged.

In addition to the special charges for providing necessaries, we find the record of large sums which were laid ont for the expenses of the arehbishop's hospice. Under these would be inchuded the items of wages, provisions and travelling. For 1267 and 1268 the cost of the hospice amomenter to $1.50 \%$ per annum. In 1269 it was only 3207. In 1270 it was as high as $860 l$, or $8 \% 0 l$, whilst in $12 \% 1$, of which year we have only an imperfect account, it was above $600 l$. Ill this scems to joint to an extravagant scale of expenditure, if we take into account the relative value of money at that time and the present.

The chief cause of this outlay must muloubtedly have been

$n$ Hist. Dunelm. Ser. Tres, al. Sur. tees Soc., 56. Chron. Lamereost, 103.
"Ren. Giffard.

"York Fabric Rolls, 213, 214, 216. 
the great number of retainers that the arehbishop was obliged to sinport. He had his regular officers to preside over each departunent of his household, with fixed and by no means small stipends. In addition to these, at each of his numerous residences, some of his scrvants were constantly living to take chinge of the house, and at his various manors there were the fam-labourets and the bailifts, all of whom depended upon him for their subsistence. The archbishop would thus be put to a very considerable expense. This would be greatly increased by the migratory life which the prelates of that age delighted in. $\Lambda$ bishop, like his sovereign, was rarcly more than three days at a time in one place. He was always passing from residence to residcnce with all the pomp and ceremony of a great feudal baron. Hawks and hounds were frequently his companions on lis travels, and he would turn aside cvery now and then from the beaten causeway to flush the heron from its waterpool, or to chase the red deer through the woods. Behind the archbishop there rode a loug train of domesties, who earried with them the wardrobe and the plate, and a great part of the furniture of their master. With these cach of his manor-houses or castles was equipped, to be stripped again when the visitors deserted it. The bailiff' of the place had little more to do than to provide the kitchen from his lands and streams, and to pay over, when it was required, the balance of his account. A pretty accurate itinerary of several of the northern prelates might easily be constructed, and it would be most interesting and suggestive.

The following extracts will give my readers some idea of the private expenditure of arehbishop Gifiard.

126\%, Sept. 1\%. To Lurane Bom, eitizen and merchant of Florence, the deputy of Revner and Techarius, merchants of the simme city, 1000 marks. Sept. 21 . To Loeco Hugolini and (ircogory Sunclli, merehants of Sienna residing in London, 600 marks. Sipt. 2.2. 'To our valet R. de Ascoc', 64l. 3s., to buy rloth in the fair of Bloceelegh." On the MLonday after Michaelmas day, to master Ruffinus, arehicacon of Cleveland, 200 marks, in part payment of the debt that we owe to the merchants of l'aris, contracted for the business of our church and ourself in the court of Rome, and, also, an orter to N. de Wodeford to pay 3.5) marks for the same purpose. Nov. 3. To Sir Wm. d'Aubeny, knight, a robe of the value of 20 s., and another to Roger IIs.se.' Nor. 9. 'To IIngh Everard, our clerk, 310l. 10s. 4d.,

$q$ There is a valualile pajer on the hictory of these foreign merchants and their dealings with England in the Arcliserl, xxviii., $2017-326$.

Blockloy, co. Worcester. In the fifty-fourth of Henry III. bishop Gif- fard was allowed to have a fair there ('Thomas's Worcester, 136).

$s$ Ruflinus died this year.

t Henry Hoese was one of the barons who fotight against Henry III. He had lands in the counties of Wilts, 
towards the expenses of our hospice. Dec. 9. To Paulinus, the Roman jester, 5 marks of our gift. To dame Alice, ${ }^{n}$ our sister, 5 marks. Dee. 28. To Hugh de Cantilupe, ${ }^{r}$ our precentor at York, $60 l$.

1268, Feb. 10. To the merchants for 21 casks of wiue, bought at Hull, ${ }^{20}$ 50l. 6s. 8d. April 12. 'To our valet, Richard de Button ${ }^{x}$, for the expenses of our hospice, 80l. Apr. 27. 'To Ancherus, the eardinal,y 80 marks. May 6. To Henry le Walcys and Philip le Tailhur, 100l. for wine; to Stephen le Munden, 26l. 13s. 4d., for jewels $; z$ to Robert Neveracom, 73s. 4d. for wine; to Robert de Mumpaillars, 33s. 6d. for the debts of dame Sibilla Giffard our mother; to Anketill, the mercer, 10l. 8s. 4d. for cloth bought from him at Paris; to Edmund, the baker, at Loudon, 6l. 13s. 4d. for corn; to Simon de Insula, ${ }^{a} 40 \mathrm{~s}$. to repair our houses in London. June 7. 'To Philip, our constable at Oxford, for the expenses of Edmund de Mortimer, ${ }^{b} 20 l$; to my lord, the earl of Norfolk, for a palfrey and a saddle for his

Kent, etc. (Dugd. Bar., i., 623). In 1290 a Henry Hose was constable of Porchester castle (Rot. Parl., i., 25.)

${ }^{u}$ Alice de Mandeville, who is mentioned afterwards.

" A member of the noble family of Cantilupe. An executor of the will of Walter de Cantilupe, bishop of Hereford (Thomas's Worcester, 136), archdeacon of Gloucester 1256-12St (Le Neve, iii., 77), rector of Stewkley, Bucks, 1246-1271 (Lipscombe's Bucks, iii., 472. ISS. Harl., 6950, $80 \mathrm{~b}$ ). In 1285 Mr. Hugh de Cantilupe, a dignitary in Hereford eathedral, being dead, John de Clara, his executor, gave $\mathbf{2 2 0}$ ont of his effects for poor scholars at Oxford (Antiq. Univ. Oxon., i., 321).

My readers must understand that these notes do not contain a tithe of what I could say about many of the persons they commemorate.

${ }^{w}$ A great place for wine-merchants. The archbishop had the prisage there, which will be alluded to afterwards.

* A kinsman, no doubt, of ITilliam de Button, Giffard's predecessor and successor at Bath and Wells. He was precentor of Wells (Cassan's Lives, 134). Cf. Abbrev. Plac., 152. Giffard gave a stall at York to Thomas de Button, afterwards bishop of Exeter (Anglia Sacra, i., 565-6).

TViliam Button, the second, was nephew of his namesako and was Giffard's cousin (Cassan, 141). Giffard had the charge of the temporalities during the vacancr, and on Mareh 8, 1267, he wrote from London to order the bailills of the manors, etc., throughont the diocese of Bath and Wells to surrender them to Button, whose appointment had been confirmed (Reg. Gitfard, 81). On Jnly 7, Giffard sold to him for 600 maiks all the winter-corn on the manors belonging to that see, which he had of the king's gift, having sown it himself (ibicl.).

Bishop Button made lis will in June, 1275 , from which it appears that the arehbishop owed him mones. Thomas de Button and Roger de Crukes, provost of Wells, were the executors (ibid.).

y A Roman cardinal, to whom the pope gave the stall of Wetwang at York. He resigned it, and a pension of 80 , and subsequently 100, marks per annum was granted to him.

" Jocilia" may be more appropriately translated ornaments.

a In 1265 Simon de Insula was presented by Henry III. to the living of Thornfagan (lege. Githard, Bath and Trells).

${ }_{b}$ I do not know who this person was. Eilmund de Nortimer, a powerful baron, had a son Limund who was rector of IIodnet (1)iegd. Bar., i., 138). Edmuml, soll of Roger de Mortimer, was made treasurer of York iu 1265 (Forll., i., 158, and lieg. Gitlard). Oxford castle had been in Giffard's custody. 
fec at our translation, ${ }^{c} 5$ marks and a half; to Hugh de Balington to buy a robe "et pemulas" for the use of our mother, 11. 5s. al.; to James de Longeton to buy eoffers and eertain other necsisaries fol dame Nlice de Mandevill, 28s. 9d.; a release to our valet, IValter le Barber, of his aeeormt of 100 marks which he carrical for us to Paris when we were elected to the see of Bath and II clls.d July 20. To our beloved sister, dame Alice de Manderill,e 10 marks, and to dame Matilda de 'Tywe, ${ }^{f} \mathbf{1 0}$ marks. Ang. 16. To Gilbert, our steward at Norton, 55s. 5d., which he has expender at our crder for the staying of our dear sister, dame Matilda," at Norton from the feast of St. Dunstan to that of SS. Marecllimms and Peter. Oct. 1. To our valet, R. de Ascoe', 83l. at St. Botulph's fail. Oet. 31. 'To Philip le Taillur and Ileny le Waleys, citizens of London, $236 \%$.

1:269, March 2. 'To the friars preachers of Gloneester, two quaters of eorn, and one quarter to a woman at Gloucester. March 1. 'To the bailiff of Norton, 28s. as a gift, and for the pigs which we had of him at Wykham. Mareh 27. For the expenses of masters G. de Sancto Leofardo ${ }^{h}$ and H. de Brandeston and J. de Mulcford, chaplain, $9 l .10 \mathrm{~s}$; to the clerks officiating in the clnuch of Iork on Easter day in our presence, 18s. April :2. T'o Itugh de Babington, 100\%. to lay out for us at St. Ires' fair. April 9. To Simon, bailiff of Cawood, 10l. to buy stock. Apiil 20. To the dean of York, 120l., whieh we borrowed of him for the king's use.j Jume 1. To Hugh de

c The earl marshal reguired a palfrey calarisonel an his fee.

d Giffurl was consecrated at Notre Diture in leg6.

- In umoticed sister of the archhishop. In 1279 Edmmond de Mandeville resisnce the stall of Stanwiek at liipon (Rer. Wickwaine). In 1301 hishop Gillard left $10 \%$ to Erhn. de II, a friar minor (Thomas, 80). Cf. Duenl. Bar., i., 206,

$f$ Jolu and (iilbert de Tywe were canons of Tork in 1211. In 1225 Sir Jolm de Tywa, knight, presented Gilbert de 'Tywa to the living of Watltumstre, dioc. Lincoln (MSSS. Harl., $6950,137)$.

$g$ In 1301 bishop Gifrard left to the ch'treh of Wrorester a restment which liad bren given to him by his sister dame Mabel riffird, abbes of Shaftesbury, and he tare to her 20 "sentella " of silver and as milly "selsaria" fur the use of her momastery, a pot or litcher of silver for wine, and another for water, etc. (Thomis's Worcester, appendix, 78-9).

$h$ Otticial of the court of York (Reg. Giffard). On Oct. 22, 1274, Mr. G. de S. Leofardo had the archbishop's letters authorizing him to borrow 60 marks for the business of Mr. G. (ibid.). In 4th Elw. I., he, Thomas de Munkegate, oflicial of the court of York, and Mr. Simon de Clervaus, ete., were in tronble for hearing matters not relating to wills (Rot. Hundred., i., 108). He held many pieces of preferment, and was bishop of Chichester, 1288-1305.

$i$ Dean of Sarum, archdeacon of Dorset and bishop of Salisbury in 1287 (Prynne, iii., 359. Cassan, 197, etc.). 5 On Feb. 6, 5tth Henry III., the king acknowledges that the archbishop has lent him $£ 120$ in his great neel. The sum of $£ 20$ has been repaid out of the profits of our mint, and we promise to pay the rest soon (Reg. Giffard, $76 b)$. Giffard, it will be seen, was obliged to borrow the money of the dean. He was frequently employed in raising sulplies for the king. 
Babington, 553l. to pay oul debts. June 7. To Fr. Th. Thulus 20 marks for a palfiey ; to dame S. de IIeriz three oaks from our woods at Sherwood. ${ }^{l}$ June 25. An order to the bailift' of Chirehden to pay to Roger the miller of Oxford 20s. to provide neeessaries for our kinsman Willian de Grencfend" at Oxford, whilst he is studying there, beeanse it would be difficult for us to send money to him on aceonnt of the perils of the ways. July 23. 'To Richard de Button, our valet, $20 \%$. for the use of master William de Bolynton." Sept. 22. 'To Wm. le Escoe' and Wm. le Warcu', of Pontefract, 2\%l. 10. for 11 casks of wine. Sept. 24. To William de Burdeaus, 32l. 8s. 8d., to Peter le Gascomn, 72s., and to Galfrid de Maund, 1l. for wines bought of them. Nor. 25. To Gregory, prior of the friars of Mount Carmel at York, 30s. for certain things which we have ordered him to procure. Dec. 1. To Reyner, eitizen and merchant of Florence, 200 marks.

1270, Jan. 16. To R. de Ascoe' the monies which $\mathrm{Wm}$. Suwell has laid by, i.e., 52l. of the temporalities, and 30l. which Clement, our elerk, placed with him ont of the synodals, ete., for the expenses of our hospice. Feb. 10. An order to pay 200 marks to the merehants to expedite our affairs in the eourt of Rome "ut usurarum roraginem vitemus ad presens." Feb. 19. To Simon, bailiff of Sherburn, 200 marks towards the expenses of our hospice. Fels. 27. To Mr. W. le Rns, sub-dean of Wells, and the other executors of J., once sulj-dean of Wells, $20 l$. for goods belonging to the said J., bought for our use. April 1t. 'To Robert de Aseoe', 100s. from the goods of per'sons who have died intestate, for the use of our house. May 25 . 'To Reyner' de Luk, or 'Thomas his deputy, merehant of Lucea, 200 marks which we had of him at London for the expenses of our hospiec. July 11. To Baldwin de Frivil,,$^{\prime}$ our nephew, $60 \mathrm{~s}$; ; to two valets

$k$ In 1244 Jollan de Nerill paid 20 marks to the king for his leave to marry Sara, late wife of John IIeriz, who seems to have died in 1211 (Exc. e Rot. Fir., i., 363, 426. Dugd. Bar., i., 685). Sarah, daughter and heiress of Sir John de Heriz, married Sir Robert Pierpoint, temp. Edw. lI. (Coll. Top., riii., 316). Ab. Rot. Orie., i., 19.

$l$ There are sereral notices of sherwood in Giflird's register. Some one is excommmicated for taking a lawl's nest. The deer, however, were the chicf care on the scene of the adventures of Robin Hood and his eompanions. Cf. Pryme's Coll., iii., 291.

"They were outlaws, tis well known,

And men of a noble blond ;

And many a time was their valour shewn

In the forrest of merry shecrwomb."
" A very valuable entry. It refers, no doubt, to Williasn de Greenfield, a kinsman of Gitlard, ind afterwards archbishop of York. Giffard, it seems, educated his youthful relation at $O x-$ ford.

"The archbishop's proctor at Rome.

o On Oct. 20, I265, the subleanery of Wells was given to Mr. W. le Rins, the prebend of Bnckland, ibid., to Joln de Inolteby, the prebend of IIole. combe to Roser, seneschal of my lond of Exrter, but lie refinesl it, and then it was given "in crast. S. Clom." to Mr. Wh. areledearen S. Sereni in the ('hlurels of Querey (lien. Gillard, as lishop of bath and Wells at rork, $70 b)$.

"An account of this family in Durgl. 
of the carl of Warwick bringing deer to Scrooby ....; to the messeryer of niy lord of Worester, $2 \mathrm{~s}$; ; to J. Giflard, $60 l$; t to Stephen de Cormille for J. Giflard, ${ }^{r} 66 l$. 13s. 4d. ; to our cook, for his wages, $20 \mathrm{~s}$; to $\Lambda$. Giffurd, $20 \mathrm{~s}$.; to the valet of $\mathbf{R}$. de Montcforti" at Henby, by the hands of II. Pererel, 13s. 4d.; to the messenger of my lord Octobonms, ${ }^{t} 12 \mathrm{~d}$.; to repair our houses it Lonclon, 15l. 12s. 8d.; to the recluse at Doncaster, 6s. 8d.; to spirioc going to the IIoly Land, 12d.; to two rechuses at Blyth, 1:d.; to Bissop de Crancumb, 18d.; to a poor man at Wikham, 12d.; to R., our almoner, to buy shoes, 4s. 8d.; to friar William de Hothum, $20 \mathrm{~s}$. 8l.; to the friars minors of Nottingham, I0s.; to a lame clerk at Iveden, 2s. Oct. 5. To our beloved nephew, Robert de Escoc', 201 . to lay ont for us in the fair of St. Botnlph; to om nephew IIngh re Babington, ${ }^{\text {p }}$

Bar., ii., 103. Cf. 'Thomas's Torenter, appendix, 79-80. Exc. e Rot. Fin., i., 210, 227, 243, etc. Coll. Top., ir. 218.

"The arehlishop's brother. The earl of Tharick was William de Bean(hamp, who hat just succeeded to the titlo (1)nd. Bar., i., 227). In his will, made in lag6, ho left to his countess a rul) which the bishop of Worcester fave him ('T'est. Tet., 52).

$r$ Sir John Githurd of Brimmesfield, a kinsman of the archbishop, a soldier and statesman, of whom there is an account in Ihugel. Bar., i., 501. In 1271 he carried ofl and marrit a noble lady, Matildil lonerese, and paid a tine of 300 marks tor pstousing her (Ford., i., 485). He married, secondly, Alice Maltravers, and, thirdly, Margaret de Neville ( lorl., i., 663), by whom he had

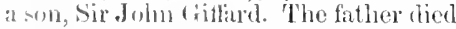
at lioyton, 27 th Edw. 1. On "die sabb. f. f. S. Mich.," 1271, Sir Poter de Mauley, kt., frays fo anchlsishoy, Githard $20 \%$, part of the doht he owed to Sir J. (Xiffirrl, who made it over to him (Reg. litiard, 72b). In 1301 bishop Giffard hitt to John fillind, his nephew, 10 marks; to dame Marsaret de Neville, monetime wite of Sir John Fillard, his niece, a 'mp, etc. ('Thonnas's Worcestel, apprendix, 79). Ab. Rot. Orig., i., 107. - A relation, probably, of the celeJurater earl.

\& I woll-known oficer of the paral "omet. Huring the contention lutween the kinter and his latrons he took refuge th the 'Tumb', and was resened by the andhishop of lisk and others. The date of this is lureertain (hist hton,
$2438,2155)$. In 1269 there is a letter from Ottobonus to the archbishop of York abont the disme granted by the king to the pope (IVilkins, ii., 21). There is mmeh mystery about the war with the batons. On Dec. 14, 1261, the archbishop of York was one of those apmointed by Henry III. (then a prisoner) to treat with Simon de Mont. fort (Furl., i., 449). When the rebellion was supluressed, Gitfard, then bishop of Bath and Wells, was one of those who arranged about the forfeited lards (Jugd. Bar., i., 759).

u Some account of this great man will be riven afterwards.

- In 1301 bishop Giffard left to Hugh de Escoce 10t. and armonr, and a legacy to Joan his wife (Thomas's Wor., 80),

" Or Burghley, co. York, and Rolleston, Notts. Constable of Nottingham castle and sheriff of Notts and Derbyslire in 1271 (Coll. Top., viii., 313. liot. Hlumbred., ii., 312), sheriff of lluntingdonshire, 23rd Edw. I. (Parl. Writs., i., 267), Inq. p. m. 25th Edw, I., dying seised of the manor of Burghley (Cal. Inq., p.m., i., 133), Richard de Babington being his son and lieir (Abbrev. liot. Orig., 95). In 1301 bishop Giffird left to Richard de Babington 10 marks and a horse (Thomas's Worcoster, 79). On 12th September, 1312, archbisho), Greenfield granted to Lucy, widow of Richard de Babington, who held of him the manor of Burghley by knight's service, the marriage of Hugh, son and heir of the said Richard (Reg. Greenticld). Cf. Coll. Top., viii., 31315. Rot. Humde., ii., 3]9. Thoroton's Notts. 
11l. 18s. 3d., to expedite our business at Nottingham castle. Nov. 4. 'To the prior of Shelford three oaks from our wood of Sherwood, for timber. Nov. 7. At Nottingham, to Stephen de Norwich, of our alms, 6l. 2s. 9d., of the surplus of his account for the year when he was our almoner; to R., our chaplain, 4. to amnounce our election ; to friar H. de Misterton, 13s. 4.l.; to our barber 2s. of our gift; to a certain clerk of Hedon to buy a shirt, 2s.; to the nuns of Wilberfosse and Brumnum (Nubuirlholme), 20s. each; to the friars preachers and minors ${ }^{x}$ on the day of the Nativity, B.M.V., 13s. 4.d. each; to friar William de Hotham at St. Oswald's, 2s.; to the recluse of Eland, 3s.; to the muns of Kirkeleye, 5s.; to the nuns of Thikkehened, 3s.; to the friars preachers of Donestaple, 2s.; to J. de Neville, 133l. 6s. 8d. for the marriage of his wife; to Simon de lusula, 28l. 6s. 8d. to repair our houses and quay at London ; to damePeverel 113s. 4d. from her son's ehureh; ; to William de Grenefeld 2s. for his expenses from London to Oxford; to Edward, the king's son, 66l. 13s. 4d. of our gift $;{ }^{*}$ to Lucas de Luk, $7 l .7 \mathrm{~s}$. for silks ; ${ }^{a}$ to J. de Weston, 40s. for a silken zone for $\mathrm{A}$. de Manndevill ; to master J., called Le Romeyn, ${ }^{b}$ 13l. 6s. 8d. of our debt at Paris; to the clerks officiating in the church of York at our mass on the festival of the Nativity, B.M.V., 18s.; to Agatha Giffard, 27s. 4d.; to two minstrels, 40s.; to master J. de Craucumb, c 40s. Nov. 14. To Roger Dousing, 8l., and to

$x$ Each of the four orders of friars had a monastery in York, and the Minorites an important one. The wardenship of York had within it seven honses, - York, Doncaster, Lincoln, Boston, Beverley, Scarborough, and Grimsby. Martin de Barton was the first custos of the Franciseans at York, Eustacius de Mere coming after him. Two ministers provincial of the order in Enggland, John Mardiston and John Tyssyngton, were buried at York (Mon. Francise, 27, 43, 561, 579, 321). In 1277 bishop Giffard was admitted to the suffrages of the friars minors (Thomas's Worcester, appendix, 35). Cf. Wilkins, i., 762.

$y$ I carnot find out to which branch of the Peverels this lady belongel.

= No doubt for the crusade on which Edward went, having previonsly appointed the archbishop one of the guardians of his sons. In $39 \mathrm{Hen}$. III. the friars minors were ordered to preach in favour of this expedition (MIon. Francise., 620). There is in Giffard's register a long and very curions list of the crucesignati within the diocese of
Tork. On oct., B. M. T. 1275, at Skefling, Sir S. dictus Constabularius, knight, confessed that he had committed adultery with Katherine, wife of Sir John Dentorp, knight, and he was fined $100 \%$. The archbishop, in consideration of his contrition, anve him the sign of the cross (Reg. Giffard). IVe find the culprit in another character on June 26, 1281, when the primate decides in favour of a marriare between him and Catherine, daunhter of Philip de Wynelesby (lieg. Wickwaine).

a "Pro sericis et sindon."

b Afterwards archbishop of Tork.

c A kinsman of the archbishop, and probably a son of Alice de Cormeille, sister of Sibilla, who married - Crancombe (Bugd. Bar., i., 502. II arre's Wiltes, ut supra, 201). IIe was a person of great consequence - archdeacon of the East lidimg, canon of Grendale, and incumbent of Feliskink, dioe. Bbor., and of Gousel (Goxhill), dioc, lineoh (MSS. 11ar., 6951, 19a), of Sutbraten in 1265 (Reg. Giflard, bishop of Bath and Wolls). IIe was 
Philip de Barton, 12l., which they lent us at the fair of St. (iiles at linohester.

l:z 1, April ?. T'o a ecrtain writer for each quire that he writes for my lord, 16id. Jume 2. To the friars preachers of Gloncester', a mark, and two logs of wood for their fire, and to a poor matron there half a quarter of eorn.

l:-7, July 13. 'To our eterk, E. de Well, $f$ 100t. to buy groods for us at St. Botulph's fair." August 11. We hear that the friars preachers are going to hold their gencral chapter at lork on the feast B.MI.V., an order to provide a banquet for them. Sept. :5. An order to the bailiff' at Bererley to buy 13 casks of wine. Nor. 3. To the friars Carmelites of York, two quarters of corn and $30 \mathrm{~s}$.

1:75, March $\%$. To Vtalter, our butler, 19l. to buy wine at IInll. 'T'o the marshal of our hor'ses, six colts from our stud at Berceler. An order to the bailiff of that place to edneate John Ancher" and his two companions, in the school of Beverley, providing them with erery necessary, and spending $30 \mathrm{~s}$. upon three rober for them.

Archlishop Giftard died at Tork on the 25 th of April, 1279, ${ }^{i}$ and was interred in the minster, probably in the ehoir. When that prortion of the eluurch was rebuilt, the remains of Giffard and of sereral other archbishops were removed by the pious

summoned to parliament on several oeasions, and in 26th of Edward L. liad the trmpotary charge of the great seal at Jork. In 1295 lie went to Romr in the kins's business, and is called "a clerke rode and wys" (Parl. Writ, rol. i. Cal. Rot. Pat., 59. Ford., i., 817. Lan oft, ii., 262). Me dicl in 130s, and there was a chantry at which he was commemorated in lork minster (Fabric liolls, 299).

d "Quilupus." ('f. clossiry to "The Priory of Finchale," 110.

r fitlind resider oceasionally at his manors, co. Ciloncester. In $1217 \mathrm{king}$ John gave archbishop, Gray timber to huild his houses at Eseott and Otinton (liut. Claus., 297).

$f$ bdwarl de Well, vicar of South Kirkly, ordained deacon at lork, in visilia I'astlie, 1268 (Reg. Giffard).

s" 'There is an alconnt of an extra. ordimary scene at this famons fair in 1.25, in Knyehton, col. 21.66, and in Trivent. 2696.

s liobrut le Arelier married Alice, sirere of Alice de Craucombe. In 1214 dlire le Areher fined to the kins for the curtody of the lands of her heirs.
In 1253 Archer's heir was a ward of Sibilla de Gitlard (Dugd. Bar., i., 502. Exe. e Rot. Fin., i., 329, 411, 419; ii., 165). In 1301 bishop Giffard leaves 40. 10 his niece, dame Margaret Ancher of Shafteshury, 10l. and armour to his nephew, Sir Henry Aucher, knight, and 10 marks and armont to his nephew, Richard Aucher (Thomas's Worcester, aphendix, 79). Abbrev. Rot. Orig., $\mathrm{i}, 3,5,6$.

On Nor. 28, 1315, archbishop Greenfielk, another kinsman, orders his receiver at Sonthwell to pay 20l. to dame Nargaret Auchier, a nun at Shaftesbury, elected abbess of that house, and directs him to pay her every possible attention if she stays at the manor of Sonthwell (Reg. Greenfield.)

i Uss. Cotton, Vitellius, A, ii., 111. The date is doubtful. Wikes (Gille, ii., 108) says that Giffard died on the Virril of St. Gresory soon after Easter. I'eter de Ickliam, on April 22 (Le Neve, iii., 103, and Reg. Sacr. Angl., 4.1). Stubbs, on April 29 (col. 1726). Int. p. m., 27 April (Godwin, n. e., 682. Le Neve, ii., 103). 
Thoresby to the presbytery immediately before the great east window, and placed under monuments which had becn prepared for them. It was there that Leland saw them when he came on his antiquarian tour into the North in the reim of IIcnry VIII. ${ }^{j}$ and they were there in the eighteenth century.

After Giffard's decease, on the 28th of A pril, the king committed the custody of the see, during the vacancy, to Thomas de Normanvill and Mr. Henry de Newark, who was afterwards arehbishop. Giffard was in debt to the king, but his property was not seized, as the bishop of Bath and Wells and Nicholas Wudeford pledged themselves that ererything should be paid. ${ }^{k}$ One of the exccutors of Giffard's will was his brother Godfrey, bishop of Worcester. On the 21st of July, 1280, archbishop Wickwaine made a general order to his bailiffs, directing them to assist the executors in gathering in the effects of his preclecessor. They were released from their trust on the 2nd of December, 1281..$^{l}$

Archbishop Giffard died seised of great estates. Ile possessed, in a public or private capacity, manors in the countics of Wilts (Boyton), Somerset, Hereford, Gloncester, Southants, Notts, Oxford, and York." Ilis brother, Godfrey Giffard, bishop of Worcester, was found to be his heir." 'The farour" which the archbishop shewed to this kinsman excited some little murmuring and ill feeling. In 1270 one Adam de Filliby complained at Rome of the conduct of the Northern primate in making his brother archdeacon of York when he was only in minor orders, and in giving him many benefices without a dispensation, when he was deficient not only in clerical rank but in learning. The arehdeaconry scems to have becn the only thing that Grodfrey Giffard held in Yorkshire, with the exception of the living of Adlingflete, to which he was presented by Jolm de Eville in 1267. $I$ find, however, that he had much preferment in the South.p Godfrey Giffard was a great man both in

$j$ Lel. Itin. The antiquary gives a rough note of the inscription, "Walter" Gisfart obiit vii Kal. Maii" -i.e., Apr. 25.

$k$ Jeg. Wiekwaine, 41. Pryme's Coll., iii., 221. Abbrev. Rot. Orin., i., 33. The bishop of Bath and Wclls was Robert Burnell, sometime arehdeacon of York. In 2end of Elw. I. letters of protection were granted to Mr. Nicholas de Wodeford, rector of Flatbury and Westbury (Prynne's C'oll., iii., 599).

'Res. Wiekwaine.

" Cal. Inq. p. m., i., 67. Ablsev. Rot. Orig., 33.
"Thoroton's Notts, 390. Dugd. Bar., i., 501.

- Reg. Gilfird.

p Coll. archdeaconry of Barum Gitı November, 1265, res. 1267 (Le Neve, i., 405), canon of Wells (Newcourt, i., 59), rector of the greater medicty of the church of Atleburgh (Blomeliekl's Norfolk, i., 523), April 28, 1267, collated to the areldeaconry of York (lieg. Giffard). Now. 1, 1266, installed to the living of Mells (lies. Ciiffird, as bishop of Bath and Wells, at York). A,ril 3, the arehbishop gives him leave to borrow 60 marks in the court of Rome (lege. Giflard). John Gillard 
chmoh and state. IIc was a justice itinerant, chancellor of the cxrleyucr, and lord high chancellor of England. He presided orer the see of Worcestel from 1268 to 1301, with many vicissitudes of fortunc. The will of the bishop is a remarkable docuncnt, and contains more than one allusion to his deceased brother.q II bequeaths to the church of Worcester his best mitre which archbishop (Giffard had given him, with amice, stole and maniple, en suite, all coreled with rery precions pearls. 'l'o the altar' of the holy cross in that cathedral he left a chasuble of red samite of his brother's gift.r To his brother, Sir William (Yiffarl, he gave the ring of his chapel, a gemmel with a ruby and an cmerald which the archbishop had left to him as an hoirloom, firc ancient and costly rings on a silk riband which belonged to his ancestors at Boyton, together with four bugle-horns at 13oyton which were used as drinking cups, one of which had a foot of silver." To his nephew, Mr. John de Elorovis (Erreus), the bequeathed a mitre coreled over with pearls, which had once belonged to his mele, the Northern pri-

was his nephew and heir (Abbrev. Rot. Urig., i., $12(1)$.

3 l'rinted in the valuable collection of records in the alpendix to the His. tory of Worcester, by Dr. Thomas,

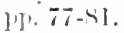

In the Anglia Sacra (i., 49.) it is stated that archbislon, (riffard bequeathed to Worcester "athedral, "insinnia rifellx preticsi."

- These striking and beantiful objerts were fromuently the title-deeds of estates. Such was the noble horn of Clhhus, which is still preserved at York. 'There are other: at T'usey and queen's colleze, Oxford. Dr. Whitaker gives an ancrating of one in the possesion of lord Ribbleslale (IIi-tore of ('raven, red. 1412, 36). In 1612 John Ireland, Ew. of the Hutt in Lancashire, begueaths to dilbert his brother and heir "my jate of silver and guilt, one chaine of andd, one sealinge ringe or sienct of armes that was my father's, teinther with the llorne of Crotonn", (liver. Test. apud Ebor.). Henry I. eave to the ehurch of Carlisle the tithes of a part of the forest of Inglewod "ot c"slesiam incle feothwit per quodcam cornu eburnemun ruod dedit ecele-

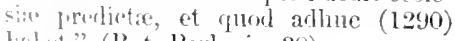
liathe " (liot. Parl., i., 3S).

t $1 \mathrm{son}$ of - Cijtirard, the archhiwhons sister, by William de Ebroicis, whro willed at the battle of Evesham. July 2i, 1256, licence to him to be absent from his stalls at Southwell and lipon, for three years, to study (Reg. Romanus). lle resigned the prebend of Studley at Ripon in 1297, in which year he was holding the stall of Oxton, part ii., at Sonthwell (Le Neve, iii., 419. Reg. Newark). Arehdeacon of Gloncester 1285-1295 (Le Neve, iii., 77). In 22nd of Edward I. he had letters of protection as arehdeacon, canon of Ripon and Southwell and rector of Kemp,sey (Prynne, iii., 598). On July 23, 1295, bishop Giffard gave lim the living of Tredington (Anglia Sacra, i., 517). Cf. Thomas's Worcester, 142, and appendix, 50. Angl. Sicer, ii., 509.

The family of Brun were conneeted with the archbishop by the marriage of Albreda, daughter and co-heiress of Walter de Cormeiles, with Richard le Brun (Dugd. Bar., i., 424). The primate gare the living of Schipwit (Skipwith) to $\mathrm{X}$. de Brun his kinsman, and the prebend of Osbaldwick to $\mathrm{R}$. de Brun his chaplain (Reg. Giffard). On Sept. 3, 1291. arehbishop Romanus gave a pension of 5 marks per annum to William, son of William le Brum, till he prorided him with a benefice (Reg. Romanus). In $1295 \mathrm{Mr}$. W. Brun was rector of Lake, dioc. Woreester (Angl. Sarr., i., 517). Archbishop Greenfield llade Edmund le Brun sucentor canonicorum at York. 
mate, in the hope, perhaps, that it might sometime rest upon his brow. To the arehbishop of Canterbury lie gave a ring with a lion graven on it set with emeralds, to deseend to his suceessors in the see. The testator then mentions, singularly enough, that he had received the sign of the cross in tokcin that he had devoted himself to the conquest of the Holy Land, and he now leares the sum of 50l. to equip) a knight who is to cross the seas in his stead on that advcnturous royage.

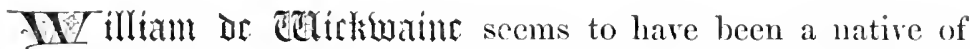
the Sonth, but of his parents and early history there is nothing known." He occurs to us for the first time on the 4th of February, 1262, when he was instituted by the bishop of Lincoln to the reetory of Ivinghoe, in Buckingliamshire. Ile was then chancellor of the ehmeh of York, and held both these picees of preferment till he became arehbishop. ${ }^{p}$ On St. Alban's day, the $22 n d$ of June, 1279, the elrapter of York met to ehoose a new diocesan $;^{w}$ eighteen of the votes were given to the chancellor, two to Thomas de Corbridge, who was afterwards archbishop, and one to Hugh de Evesham, a brother canon. ${ }^{x}$ This was the celebrated physician who obtained a place in the Sacred College in 1281. Wiekwaine was of course elected, and obtained the royal assent to his appointment on the 4th of July. ${ }^{y}$ IIe then went abroad to seek the pall. Nicholas III. referred the consideration of the matter to the cardinals of St. Mark and St. Mary in Porticu, and the decision of the ehapter was thrown over, not from any flaw in their nominee, but apparently from some defect in the mode of procedure which they had adopted. The pope, however, solved the difficulty by appointing Wickwaine to the arelıbishopric of his own authority, as he had the majority of votes, and that the see might be no longer vacant. He eonsecrated him at Viterbo on the 19th of September, 1279, and wrote a long letter on the same day to Edward $I$. acquainting him with what he had done..$^{-}$On the 28th of October the

"In 1282 Walter de Wykewone, cellarer of Winchcombe, became abhat of that house (Angl. Sacra, i., 506). There are several places called Wicken in the South of England.

$v$ MSs. Cotton, Clandius, B, iii., 89. Lipseombe's Bucks, iii., 393. Le Neve, iii., 163.

w MSS. Cotton, Vitellius, $A$, ii., $111 b$.
Sinbbs, col. 1727. Licence to elect an archbishop was granted May 7,1279 (1.e Neve, iii., 103).

$x$ P'ryme's Coll., iii., 225.

y Le Neve, iii., 103.

= Prynne, ut supra. Vitellius, ut supra. Reg. Wickwaine. Ann. Waverl., alud Gale, ii., 231 , where he is erroneously called treasurer. Wikes, 
king restored the temporalities of his see, and the new prelate was (nthroner at York at the festival of Christmas. ${ }^{a}$ A contomporary writer leprescnts him as stern in disposition, careful in lis habits, and cmaciated in his personal appearanee, yet a good and a most conscientions man. ${ }^{b}$ The records of WickWaine's life that are still preserved fully rerify this deseription. He was eridently a strict disciplinarian, and the heart of a monk beat muder the robes of an arehbishop. He is said also to have been a man of learning and efueation, and to have written a work ('alled the Nemoriale. ${ }^{c}$

As soon as Wickwaine arrived in England on his return from the papal court, he came into collision with the archbishop of Canterbury on the old question,- - the bearing of his cross erect. It was set up, according to ancient custom, when the travellers were in the middle of the sea and were in Enghish water's, and it was carried in the same position into the province of Canterbury. The missives of the Southern primate had anticipated his arrival. The services were stopped in every parish in whieh Wickwaine halted; if he had been a heretie he could not have been treated worse, and, wherever he went, he conld find no market, for the sentence of excommunication was hurled against any one who rentured to sell to him. But the worst las not yet been told. Adam de IIales, the official of the archbishop of Canterbury, and his party, made an assault upon Wickwaine and his friends. If the obnoxions symbol had not been hastily removed, it would have been broken into fragments. 'They abused and reviled the intruders to their hearts' content, affirming that they had their master's anthority for what they did, and that he would bear them out. A large number of armed men were meditating a more serious assanlt npon Wickwaine when he entered London, but the archbishop was forewaned, and reached the court by a different ronte, and he there obtained the temporalities of lork." The king called Peckliam, the Southern primate, to account for his violence, (o)liging him to recall his order's to his ofiicials, and charging lim to be more wary for the future. ${ }^{\circ}$

For the next fire years Wickwaine was most actively and usefully employed in the laborious eharge of his diocese. He seems to have deroted himself entirely to that work, for with the execption of his sending his service against the Welsh in $128: 2$, and his being required to demand and collect sereral

ibisl., 10s. Trivet, 251. Stubbs, col.

1727 . Amal. Sacria. i., 501. Walsinghan, apud Camden, 49.

a IISt. Cotton, Vitcllius, $A$, ii., 111 \%. Le Neve, ini., 103.

${ }_{b}$ Chron. Lanerenst. 102. c Bale, Script., cent. x., 42-3. Fuller's Cluturch Hist., book iii., 79.

d Reg. Wickwaine. Wilkins, ii., 43, 119. Wikes, apud Gale, ii., 108. Flores Hist., 409. Cottou's Cliron., 158.

e Prymne's Coll., 235-6. 
subsidies from the elergy of his provine for the use of the king, we never find his name alluded to in eonnection with the state. $f$ He stayed at home and worked diligently in his province. I find the bishops of Carlisle, Woreester, and Sens assisting him as suflragans on various oecasions, but in his eare for his flock he seems to have relied almost entirely upon his own exertions. He tried to do lis own duty, and expected every one clse to copy his example. As I have said before, he was a rigid disciplinarian, and he paid more attention, perhaps, than any other arehbishop of York to the monasteries within his diocese. He arranged and earried out a systematic visitation of all that he liad the power to reach. The reports of the eommissioners have in a few eases only been entered on the register, but that volume contains what is of great importanee,-the archbishop's injunetions to each house, based of course upon the result of the inquiries that had been made. These diselose a great laxity of diseipline and a considerable falling away from rule and order. I shall give my readers a portrait of the a!bat of Selby in December, 1278 .

Thomas de Qualle (Whalley), abbat of Selby, does not observe the Benedietine rule; he does not sing mass, nor preaeh, nor attend chapter, nor keep discipline. IIe seldom eats in the refectory, and never sleeps in the dormitory. He rarely enter's the ehoir, and searcely ever hears matins but in his bed. He does not visit the sick. IIe has his meals before laymen within and without his monastery, and is quarrelsome, hot-tempered, and altogether incorrigible. Ife has alienated some of the property of his house, and gives its lands to the eharge of grooms and ribalds. He is grossly incontinent. He is mider sentence of excommunication for not paying the disme to the pope, bnt, notwithstanding, he comes to the elmrel. He laid violent hands on brothers Robert of York and Thomas of Suaith, drawing blood from them, and he dragged with his own hands William de Stormeworth from the choir of his elureh. IIe cmployed Elias Fammell, a sorecrer, to seck the body of his brother when he was drowned in the Ouse, and gave lim a large sum of money. This valuable offieial was of course removed from lis post, but he was allowed to remain in the louse, probably as a simple monk. Many months had not elapsed before he broke out of the monastery at night, carrying many things away with him!

In the year 1280 Wiekwaine cndeavonred to carry his visitation into the North, and to examine into the state of the

$f$ Ibid., 275, 285-6, 289, 302. Parl. Writs., i., 11, 224, 228, 233 . Wilkins, ii., 41-2. Foed., i., 53s. In February,
1276, he is orlerer to exconmmicate Llewellyn (Foel., i., 511. Prynne's Coll., iii., 1212). Foel., i., 607, 625. 
priory of Durham. The prior and the monks most stremously resister him. I shall not attempt to lead my readers through the tedious unazes of the dispute, but shall content myself with some of the more salient points in the controversy. ${ }^{g}$ 'The prior was anxions to shelter himself under the wing of the bishop, but the bishop went abroad and left the prior to his fate. He proved himself to be an adept in the art of defence. Wickwaine came to Durham, but he was met at the north gate which led into the priory by the knights of the bishoprie, who would not suffer him to enter. Upon this he spoke to the ('rowd around, and excommunicated all the officials of the diocese. He then turned aside to Lanchester, appointing a day for his return. When the time arrived, the sub-dean of York and Robert de Pickering, who was afterwards dean, came to loold the risitation in the place of their master, but they were stopped upon Elvet bridge, and some partizans of the prior, "atching hold of the reins of their horses, would not suffer them to approach. The contest, after this, went on with varying success for the remainder of Wickwaine's life. Either party excommunicated the other. Commissioners were appointed by mutual consent, who did little or nothing. Appeals were made to Rome, but they were of little use. In 1283 the archbishop paid another visit to Durham in the hope of indueing the noncontents to sulbmit to him. The hope was a rain one. He went to the church of St. Nicholas, and after he had addressed the audience he was again on the point of excommunicating the prior and his adherents, when some young fellows of the city terrificd him so much by their demeanour that he was obfiged to desist. Ife fled from the church, descending the steps which still lead you towards the river, and, hastening across the Sands, nerer paused till he found a sanctuary in the neighbouring hospital of Kepier. The ear of his palfiey, oh profane act! was cut off, and its master would have been very roughly handled had not Guischard de Charron and Peter de Thoresby, two officers of the bishop's comrt, interceded in his behalf. After' this he wisely kept aray from Durham, and was never able to oblige the prior to sulmit to him. This resistance rankled in Ilickwainc's mind as long as he lived, and it was the wish, as a Durham chronicler tells us, to bring the papal power to bear upon the offenders that induced him to set ont in 1284 on that jomrney to Rome from which he never returned.

The following extracts from archbishop, Wickwaine's register will give some idea of his life. In spite of his repritation for

g IIist. Dunelm. Ser. Tres, ed. Surtees soriety, 58-69. Pronne's Coll., iii, 30y. Chron. Ianercost, 120. 'There are many documents relating to it in Hickwaine's register. 
abstinence and parsimony the charges for the maintenance of his household are large.

1279, Dec. 16. A bond to the exeeutors of William Langton, dean of York, for 200 marks, $2 \% l$, and $9 l$. for barley-malt sold to us. ${ }^{h}$ Dee. 27. A bond to 'Thomas Guydysion' and the merchants of Lueea for 316 marks. A pension of $20 l$. per antumu out of the stall of Knaresbro' to John de Metingham, ${ }^{i}$ one of the king's clerks, till he be provided by us with some prebend.

1280, Jan. 16. We are indebted to the excentors of Walter Giffard, our predecessor, in the sum of 95l. for hard eorn (bladum) and a stack (tussum) of old hay, riz., for the hard corn of Scrooby, 18l., for that of Askham, 43l., for a staek and the eorn at Southwell, $34 l$. Maich 17. A bond for :2()l. to the executors of dean Langton for twelve dishes, twelve sancers, and two large dishes of silver. On the feast of the Holy Trinity, another bond to them of 6 marks for kitchen utensils, 10l. for wax, 16l. 6s. 3l. for 7 easks of wine. May 24. The abbat of Furness repays the archbishop 50 marks ${ }^{j}$ Angust 23. A request to the prior of Birstall to provide for us in his lauds beyond the sea two dogs for the ehase (canes perdriarios seu culheros), and we will repay him for them. Nov. 14. A bond for 300 marks to Peter de Cestria. ${ }^{k}$ Nov. 29. An order to the bailifls of Otley and Ripon to find provisions for our huntsmen whilst they are within your bailywieks. Nov. 30. An order to the bailift' of Sonthwell to supply us with geese, hens and other birds against the festival of Christmas. Dee. 7. An order to the same officer to pay 100s. to Simon, our poulterer, for his use ; and the bailiff of Beverley

${ }^{h}$ Nov. 8, 1287, the executors of Tickwaine have paid to those of dean Langton 350l., which the archbishop owed them.

$i$ On Jan. 20, 1281, he was collated to the prebend of Bole at York, which he held till 1301, when he died (Reg. Wickwaine, ete.). On April 13, 1301, the stall of Weighton was offered to hin, but be declined it. Ile was born at Metingham in Suffolk (Fuller's Worthies, ii., 337), and held a prebend at Darlington in 1292 (Lonlostalle's D):rrlington, 191). He was a great and an upright lawyer, and was justice itinerant, and, in Eyre, a judse in the Comsmon Bench and of Pleas (Durd. Oris. Jurid., 26, 44. Parl. Writs, par. loc.). He and Elias de Beckinghan were the only two judges who, in a enrupt ase, had the courage to remain honest (Ferne's Lacie's Nobilitie, 120. Fuller, ii., 337). Atterbury, however, chares him with injustice to the clergy, and says, "Look through all our history, and you shall find that wherever the dereny have smarted under any great hardship, some of their own order have been still at the bottom of it " (Rirhts of Convocation, 358). There is nothing to shew that Metingham injured the clergy in any way.

$j$ the abbat was "solaris et discipulu: archiepiscopi" (Hist. D)unch. Sor. 'Tres, 6i2). C'f. Beck's Ann. Furnesienses, 22.5.

* Supposed to have been an illegitimate sinn of one of the Lacies, carls of Chester. Prebendary of Bustliorle at lork, prosost of lieverley, rector of Denford, Whalley and Slaidburn, ete. (Whitaker's Whalley, 50, 5!; IVhalley Concher Book, i., 91, ote.; Brikges's Northants, ii., 232. (otc.); a justice itinerant and a barm of the Exchequer (1)urd. Cluron., 2s. Marlox, IIist. Exchequer, ii., 322. Foss"s Judges, iii., 7.). In the 2end of Ed- 
is desired to release the man and dog that he has eaptured, as sir hoger (irrmet has explained the matter to us.

1:S8, April 7. At Homby in Lonsdale, a pension of 10 marks per innmm to Mr. Walter le Breton, the king's elerk, till we provicle him with a benefice. April 14. A bond for 200 marks to MIr. Robert de Scarthburg, mean of York. April 20. $A$ boul for $1: 2()$. to $M r$. H., arehdeacon of Richmond." We have taken, through our men, from the forest of Wervelmor, belongine to the lord Edmmer. the king's brother, three deer and five fawns. Jume 1. At Coverham; a bond for 100l. to Mr. Simon de clareralle, rector of Bulmer. July 8. To Mr. W. de bolington," our clerk, 100 marks for his expenses to court. July :27. An order to the bailiff of Chirehden to pay his son Heiry 5:s., which we have giren him as a mark of our affection. 'T' XI'. Thomas, chancellor of the church of York, money for his expenses to Rome on behalf of our ehmreh. 4 Oet. 16. We have reecised from $\mathrm{Mr}$. Roger de llolt a Bible which once belonged to Mr. Roger Peprnor Oet. 28th. An order to the hailift of Ripon to provide provisions for our huntsman whilst he is in rour distriet. Nov. 17. An order to $\mathrm{Wm}$. de Malton to make things ready for our eoiner's at lork as he had promised. Nor. 19. We have made Mr. P. and Mr. G. Guydon masters of (oul mint. ${ }^{\prime}$

198.2, Jan. 27. A pension of 10/. per annum ont of our chamber to our elerk Master Robert de Ros." Mareh 14. To ward I. lo hal letters of protection as provost of Beverley and reetor of Rudby and IThalley, anon of Lichifield aim Hiereford, rector of Arksey, Easinstun and slatidburn (Prome, iii., 5!) $9-4)$. No wouder that he could lent 11)(1)

I'The kins wrote to ask this favour, Fob, ofi, les1 (Res. Wickwaine). In 1 st he Edward I. Walter de Berton, clerk, was in the Tower on al charese of treason for counterfeitins the kines's seal (l'rynme's ('oll., iii., 110). In 21th Filivarl 1. Walter de Berton, rector of' Bredon, dioc. Worcester, oce. (Rot. T'trl., i., 22-7).

"n lighoept ['chitred, of Sicarborough, dean of Fork from 1279 to 1290 , a statesman and a great man. I shall not now describe his chequered life.

"Heury Nermark, afterwards archbiskep of lork.

I som of Robert de Claris Vallibus, ritizen of York, by Exa, daughter of William Fairfax (Lonestaffe's Darrlinstron). In loth Edward I. he, as oflicial of the archdeaconry of rleve.

land, was in trouble in the king's contsts (l'ryme's Coll., iii., 438). On 22nd April, 1301, he was allowed to be non-resident on the rectory of $\mathbf{L}$ the (which he had held for many years) on accomnt of ill-health (Reg. Corbridge).

$p$ He was subsequently rector of North Ferriby, near IInll.

"Thomas Corbridge, afterwards archbishop,

$r$ Sub-dean of York. He died in 1267.

- By a clause in the forest charter of 1297 foresters were forbidden to take oats, etc., for themselves (Statutes of the Realn, i., 120).

For an account of the York mint I must refer my readers to the able work of ny kind friend, Mr. Davies. Cf. Rot. Claus., 361. Plac. de Quo Warranto, 8-9th Edw. I., 198. There is a list of the oflicers of the York mint, 32nd of Henry III., in Chron. Joh. Oxenerles, 322. Hugh de Sampson was mint-master in the time of arehbislop (tray (Reg. Wickwaine).

u Prebendary of St. Pancras, London, a stemiarius of that church and arch- 
our treasurer, Walter de Gloncestre, ${ }^{r} 36 l$. 7s. 9d. for 15 easks of wine at Hull. March 30. To Walter, the goldsmith of York, 6 . $9 \mathrm{~s} .3 \mathrm{~d}$., the remnant due to him for 12 silver bowls, and for making them and the bowls of maser. April 16. 'To Sir Richard de Baunfeld, our seneschal, 20 marks for the expenses of ou adrocates (narratores) and servants in the next parliament at London, and for other matters of ours there. May 16. 'The bailiff of Ripon is ordered to pay 10l. to Walter, our elerk, to make provision against Pentecost. Oct. 7 . To Mr. Robert de Seartheburg, dean of York, 100 marks. Nor. 19. 'To the warden and brothers of the friars minors of Bererley, 10 marks. Nor. 23. To John Ronal, chaplain of the chapel of 'Thorp, $z(0 \mathrm{~s}$. for his stipend and for lights, for the term of St. Martin, 1981." Nov. 26. 'To the friars preachers of Bererley, and their prior', 10 marks. Dec. 11. To dan Wm. de Capella, 20l. to make purchases for us in Cleveland.

1283, Jan. 4. To Robert de Exon ${ }^{x}$ our brother, 17 marks and a half which are in arrear for his payment in Bristol. Jan. 8. To Elias Drury, valet of Hammondy Box,y merchant, 33l. 5s. 9d. for wine bought of him. Jan. 15. 'To dan Simon, our receiver at York, 6l. 13s. 4d. for "jocalia," which we have bought, and 39s. 8d. laid ont in "joealia," and presents made to my lord of Dublin, $z$ etc. Jan. 23. To William de Bolington, clerk, 100 marks to expedite our business in the court of home. Feb. 18. To Mr. H., arehdeacon of Richmond, 200l. for goods

deaeon of Londor, rector of Nuch Hadham (Newcourt, i., 60, 829-31). 22nd Edward I. he had letters of protection as rector of IIadham (Prynne, iii., 594).

"A great man. Canon of Beverley prebendary of Apesthorpe, archdeacon of York, and ineumbent of Normanton on Sore. He held the livings of Norton com. Oxon. and Woodston com. Hunts (MSS. Harl., 6950, 37, 78), and was dean of Chichester (Le Neve, i., 256), eschactor sonth of 'Trent, 1302-7 (P'arl. Writs., i., 132, 379. Chron. Thorn, col. 2006i), and frequently employed in state affairs. $\mathrm{He}$ was sometime archbishop Wickwaine's receiver. Cf. Foss's Judges, iii., 275.

w Cf. Prynne's Coll., iii., 67 I. IIe was appointed to Thorp on July 26 , 1280 (Reg. Wickwaine).

$x$ The only occasion on which this person is mentioned.

$y$ A merchant of Lowlon, and a member of an honourable family in the eity which was comnected at the same time with Hull. Hamumd Box was a sheriff of london in 1292 (Hon. Irancisc., 503). July 22, 1289, licence for two puiests to be chosen by IImmudus Box, eitizen of London, to do service in ons chapel at Hull for the soul of Robert de la Grave as long as the said] Hamund chooses (Reg. Romamus). Narclı 11, 1309, licence for John Boox, of Ilull, to have service vithin his manse there (Rer. (ircenfield).

z Joln de Darlington, a friar preacher, was the author of a coneordance, etc. (Chron. lan., 156). He was confessor to Henry III., and in 1277 he was marle colloctor of the disme in Fingland against the rule of his order (Walsincham, apun (amblen, 17). 1le was a friend of llickwaine, and is montioned in lis register. lle was consecrated archbishoy of Inblin at Walthim on Aner. 27, 1279, by the archbishom of cantorbury, and died near London in 128t. (Contin. lil. Wierorn., ii., 2202, 231). l'rrme's Coll., iii., 1230. Cotton's Fasti Fecl. Hib., ii., 12. 
bought of him. Feb. 27. 'To Walter, the goldsmith, 11ls. for' two silver elips bought of him at Christmas. Mareh 8. A pension of 50) marks per ammum from our chamber to Gerard de (irandison, ${ }^{a}$ nephew of Sir Otho de Grandison, counsellor of our lord the king. April 14. To Alexander de Kirketon, our seneschal, 100 marks to lay out for us at the fair of St. Ives. June 14. 'To Walter de Gloncester, on treasurer, $977.16 \mathrm{~s} .6 \frac{1}{2} \mathrm{~d}$. for wines. Jume 15. 'Twenty marks to him to huy silver pitehers. Jume 22. To Sir John de Eyvil, ${ }^{b}$ 100l. for his expenses in making our service in Wales. July 1. 'To Mr. H., arehdeacon of Richmond, 300 marks to adrance our business in the eourt of Rome. August 9. 'To Robert, rector' of Sutton-on-Derwent, 20 marks towards the reparation "pontis belli."

1281, Mareh 6. A mandate against the ribalds and beggars who wander about our dioeese, especially among the monasteries, sceking alms and pretending to be our messengers or kinsmen.c A pril 24. To Mr. John Clarell, ${ }^{d} 100 l$. to buy robes for us at the fitir of St. Ives. July 22. To Calmo, our baker, 180 marks to make purchases for us at the same place. Angust 11. To the prior of the friars preachers at York, 100s. of our gift. August :y.5. 'To Nicholas, of our ehamber, 20l. to spend at St. Botulph's fair. Sept. 10. To master William, the notary, 40l. for the expenses of our clepks at Warwick. Nov. 25. 'To Mr. W. de Bolington, om elerk, 200 marks to advance our business at Rome. Dec. 13. To Alexander, our seneschal, 12l. 6s. 6d. to buy sheep. Dec. 14. 'To master Bartholomew earrying 20l. for the use of our lord the cardinal.

a He becane prebendary of Apesthor,e in Norember, 1243. "His brother" ()tho was recommended for a stall at lork in 1301. It is imposible to give an accoment here of this noble and illustrious fintuly, and of the sreat services which several members of it rendered 10 the state and to letters. The rame of John de Grandison, lishop of Exeter, is quite enongh to make it famous.

${ }^{4}$ An aceonut of him and his fimily, which resided co. Notts, is in Dugd. Batr., i., 593. On 25th October, 13i2, an oratory was allowed to dame Matilda le Eyvill in the manor of Galmeton for iliree years (Reg. Greenfield). Sir John was a juticiar (Iryme's Coll., iii., 112). He seems to have taken the jart of the barons in the was with Henry III. (Abbrer. Plac., 227).

These questores or brevigeri were very troublesome, and the archbishops of Yurk frectuently denomiced then.

${ }^{d}$ Prebindary of Norwell Overhall at Southwell from 1256 till he died in 1293 (Le Nere, iii., 437). In 3rd Edward 1 , he and Henry le Vavasour were in trouble for making a park there (Rot. Itundred., ii., 311). In 1258-9 he was a messenger from the king to the jope about Sicilian affairs (Ford., i., 379). In June, 1275, Clarell, being the nope's chaplain, was made a proctor to represent the king of lingland in the French parliament (ibid., 521). On July 2, 1282, archbishop, Wickwaine made him and two others his representatives at Rome (keg. Wickwaine), and he was engaged in the dispute between that prelate and the prior of Durham (Hist. Dunelm. Scr. Tres, 61-2, 66). He occurs very frequently on the public records. The following notice of him is startling.

In 2end Edward $I$. he had ietters of protection as prebendary of Southwell, rector of the chapel of Tickhill castle, and of Peningston, Harewood, 
1285, Jan. 13. To Richard de Bannfelde seneschal of our house, to buy "jocalia," 14l. 7s. 4.. Feh. 17. To the steward at Wetwang, 100 s. for oats and peas, and $15 l$. to the excentors of Thomas de Ludham $f$ for sheep. April 18. 'To Walter, the bailift' of Cawood, and dan Thomas de Sutton, everything necessary for the construction of our quay at Thorp. April 24. To Cahmo, our chamberlain, 100 marks to spend for us at the fair of St. Ives, and 20l. more on Jume 4. Jume 4. To master Jolm, called the Roman, 100l. in part payment of $1000 l$. we onee received of him. June 9. 'To the prior" of Watton a loan of 200 marks.

On the 23rd of December, 1283, Wickwaine made a provision for which his suecessors had good reason to be grateful. He had himself experienced the want of money when he cane to York, and now he wiscly and generonsly made an arrangement which bound each archbishop for the future to leare a certain quantity of stock and gear upon cach of his manors for the benefit of the prelate that came after him. He marle a rule, which the king confirmed on the 6th of Octolser at Acton Burnell, that the amomit to be kept should be 602 oxen, $5 \mathrm{l}$. horses and 1000 sheep, to say nothing of the carts and other necessaries, and these were to be distributed orer twenty-three places. On the part of Wickwaine this was neither more nor less than a gift to his successors, aud he evidently regarded it himself in that light, for he says that he made it for the weal of his own soul, and for those of the king and (nucen, Walter Gray, sometime arehbishop of York, and William de Rotherfield, the late dean. ${ }^{g}$

We are told by Stublss that Wickwaine was a great builder of churches, and that the greater part of the places of worship within his diocese were consecrated during his archiepiscopate. ${ }^{h}$ He is also to be remembered for the part that he took in the translation of the remains of St. William in January, 1281. As I have already given a description of the ecremonial on that occasion, it is unnecessary to repeat it.

Wickwaine's life was now drawing towarls its close. On the 24th of August, 1281, Edward I. states that he had giren the archbishop leave to visit the papal court, ${ }^{i}$ a jommey which, as a Durham historian informs us, had for its object the expediting

Babbeword, Wheteley, Fstmarkam, Northwell, Walesby, Horeton, Edingeley, Briggeford, Ludham, IIenningeford, Staneford and Ouston. Prynue may well eall him "an execrable pluralist" (Coll., iii., 597). Cf. Ifunter's South Yorkshire, ii., 52. Clarell was the founder of the friary at Tickhill (Coll. Tol., iv., 73). e In 4th Edward I. Richard Banmfeld, the archbishop's bailiff at Otley, was in trouble for some malrersation about a robleer (Rot. IIundred., i. 106).

$f$ Canom of York, and brother of archbishop, Ludlam.

5 lier. Wickwilue, and Prymnes Coll., iii., 311. "Stubbs, col. 1727.

'Prynue's Coll., iii., 321 . 
of his suit with the great Northern priory. ${ }^{j}$ The opposition which he met with from the monks of that house seems to have been the chicf cross and trouble of his life. He would gladly lave subjected them to himself, as his predecessor Murdac had done more than a century hefore, for he was animated by the same encrectic and uneompromising spirit. To the latest hour of his life he regretted that he had consccrated Anthony Bek, bishop of Imham, ${ }^{k}$ for he rendered him no assistance in his elaim. Tnable to obtain himself what he deemed to be right, he sought for rerliess from Rome. Whether he ever reached that illustrions city and court it is difficult to say, but as he went or returned he halted at the Cistercian honse of Pontigny in Bursimdy, a place of great renown in the twelfth and thirteenth centuries.

"Est Pontigniacum pons exulis, hortus, asylum,

Hie graditur, slatiatur in hoe, requiescit in illo."

Becket had passed two years of his exile within those sacred walls; and more recently they had witnessed the death and the alleged miracles of St. Edmmin of Canterbury. Pontigny was now the destination of many hands of pilgrims and a place of repute." Tiekwaine, who had all the fechings and mueh of the atsterity of a monk, would gaze upon it with reverenee. We are toli, indeed, that he assumed the cowl in that monastery ; and he would have many incentives for doing so, for everything that he saw around him would reproach or attract him. Wearicd and prepilexed as he had often been, he would long for rest, and the time

\footnotetext{
"When the spirit stoops

To drink with gratitude the orsstal stream Of' unreprovel enjoyment; and is pleased

To muse, and be saluted by the air

Of much repentamee, waftiric wallfower seents

From ont the crumbling ruins of fallen pride

And chambers of trausgression, now forlorn.

O calm contented days and penceful nights!"
}

A deeper and a more lasting repose than the poct pictures was soon to be Wickwaine's lot. IIe was seized with a fever at Poutigny, and died there on the 26th of August, 1285. He wat interred within those walls which overshadowed the tombs of Edmund of Canterbury and many of his countrymen, far

j IIist. Dunelm. Scr. Tres, 69.

k Chron. Lanereost, 122 .

"Henrir., Phornix Reviviscens, 46.

m Wiekwaine himself trantel permiswion to Roger de Malton and Hugh He Wethley to make a pilgrimage to Pontigny, s.a. Malton was master of st. Lenuart's hospital, York.

"Martene, 'Thes. Nov. Ancedot, iii., 125t. Stubbs (col. 1727) says that he resigned the archbishopric and retired to Pontigny.

- Stubbs, col. 1727. MSS. Cotton Fitellius, A, ii., $111 \mathrm{~b}$, the 27 th of Angust. Wikes (apud Gale, ii., 108) about Pentecost. 'Trivet, 263. Chron. Lanereost, 122. Contin. Flor. Wigorn., ii., 236. Lel. Coll., i., 179. 
away from the harder skies of England, and his own eathedral beside the waters of the Onse. The holiness of his life has led Stubbs to speak of him as a saint, ${ }^{p}$ and he had that reputation among many people. His memory would be invested with additional renown by the fame of miricles said to lave been wrought at his tomb,q which seems to have acted as a febrifiger. If the church of York had been without a patron saint, the chapter in all probability would have tried to secure the canonization of Wiekwaine.

On the 15th of September, 1285, Edward I. committed the custody of the temporalities of the see of York during the vacancy to Sir Otho de Grandison, who made Malcolm de Harcla his deputy. The proeeeds, whieh amomited to the large sum of $1812 l$. $12 \mathrm{~s}$. $4 \mathrm{~d}$., were deroted to the construtetion of the royal castles in Wales.s

Wickwaine made a will, of which Walter de Gloncester, archdeacon of York, and Thomas de Wakefield, the sub-dlean, were the executors. On the 18th of Jume, 1286, Roger Suayn, canon of Ripon, was anthorized to sell the goods of the deceased prelate for the execution of his will. About Martinmas, 128\%, arehbishop Romamus acknowledged himself indebted to the executors in the sum of $1056 \%$. for cattle, coln, ete, and on Norember 9 he received from them 220 marks on the seore of dilapidations. On the 9th of $\mathrm{A}$ pril, 1293, he anthorized Thomas de Corbridge, canon of York, and William de Blida, sub)-dean, to make an enquiry about some of the chattels of his predeeessor, which, it was alleged, had been deposited in the elureh of York, and had been carried away. ${ }^{t}$

Fobn Zigmanth, or It Rioman, was the son of the treasurer of York who bore the same names, and who secms to have migrated from Italy to England." "The father died at an ad-

$p$ Stubbs, col. 1727 .

a Chron. Lanercost, 122. Stub!s, col. 1727. Fuller's Chureh History, book iii., 79. Acta Ss., Jume 8. The anthor of the notice of Si. William of Tork in that eollection, when at Pontigny at the end of the seventemth century, heard nothing of any worship of Wickwaine, and silposed that his reputation had been olsenred by that of St. Edmund. Liber de Melsa, inter MSS. Egerton, 1141, fol. 83.

r Chron. Lanereost, 12:. s Prynne's Coll., iii., 3 is, 133 . Abbrev. Rot. Orir., i. In 1293 Malcoln de IIncley was one of the king's eschactors (Rot. Parl., i., 92), and he was much employed in the service of the state.

theg. Romamus. In 12sti Itareley acknowledges the receipt of $100 \%$. in fart payment for corn sold to Romanis in the kins's name.

" "Lx qualiun pedissecua procreatus" (Kinyiltom, col. 2507). Stubbs, col. 172t. Prymne's Coll., iii., 512. Abbrev. Rot. Orig., i., 228. 
vancel age in 1:56, having held in snceession within the minster of lork the sub-deancry, the treasurership, and the arehdea(onty of Richmond. Matthew Pan's speaks in disparaging terms of his aralice and pecrish temper, but we must recollect, on the other hand, that the north transept and the central tower were crected by his munificence. The latter has been re-faced or destroyed, but the former still delights the eye with its rrare and beauty. The treastrer was a firiend of Grostête and archbishop Gray, and was a person of consequenee and reputation."

Ilis son, John Romanus, the archbishop, received his eduration at the miversity of Oxford, and was well versed in dialectics and theologr. $y$ An molated letter fiom Innocent IV. is in existence which may possibly refer to him. It is addressed to John, called Romanus, elerk, remembraneer of the papal

"Matt, Paris, 789, 792.

w Gray save Romantsis a pension of 20 mathis fer anum (Rot. Gray), and Gipentete was his correpondent Gratii Fareic, ii., 351. Grostete, Li\}., 65, 20:3). IIe wats a cumon of Jork as morly as 1228 , and was the first sulsdeain (MsS. Cotton, Claudius, B, iii., 16. Le Neve, iii., 127-8), in which fear the pope empoweresl him to superserle an alpointment to a stall at Sarmm (Wilkins, i., 563).

He finmded about the year 1210 a chantry at the altar of st. Andrew in Fork ininster, which stood against the north-west pillar of the lantern. It was for the souls of the domor, John and Mary lis prents, Cincins his priest, atul Richanl 1. (Fabric Rolls, 217). liomamu: alon (astabli-lsed an obit for himolf (1)onestay Brok, 82), and granted land in frombamgate, Kork, to) the ricars choral (Reg. Mlagn. MIlum, part iii., 11).

This is probably the same Cincins, a mumon of London, who was robbed, and carrien ot for fise weeks, near st. Allatu's in 12:31 (Natt. Paris, 313-16). Romanus was approinted to enyure into the matter (ibicl., 316). Ife may also br the ("inerius "vir disertiminus komamms," who is the author of a preface

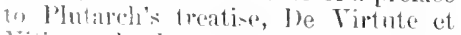
Vitio, and who wrote a letter to Tollun about the transtation of the lo fontemucula Alorteot'toorates. These fiecen are in the library of linet collece, Camblid (Smith's ('atalogue). The work amber to sontrates is of course the well-known Plixdo of Plato, whom Daniel Heinsins commends in his poem on the same great theme,--

' Xampue illi Graiorum omnis sapientia servit.'

Leland is quite wrong in saying that Joln Romanus the son was treastrer of York. The father held that powt at his death, and, afterwards, the surcession of treasurers can be regulirly traced. This is an important fact for deciling the date of the north transelut of York miuster, which was erected by John Romamus, the treasurer. Siubbs (col. 1727) makes the father the treasurer, and says that he built the north transept and the Iantern tower at his own cost, together with a great lapt of the hospital of $\mathrm{st}$. Leonard. Whe are not necessarily to infer that he built them whilst he was treasurer: slubbs merely calls him so to distingutish him from his son.

* In 1295 archbishop Romanuswrites in bchalf of the university, "Recolentes memoriter ac sincero animo recensentes, quod quasi a primis eunabulis scholastici stndii ubera apud vos suximus in continuatione diutina donec ad majorem solicitudinem Divina providentia nos vocaret" [Wilkins, ii., 2l1]. On St. Stephen's day, 1289, the archbishop and the chapter of York asigned the house in the close at York belonging to the stall of Drmnington for a schoul (Reg. Romanus).

y Chron. Lanercost, 126. Kinyghton, cril. 2507. Trivet, 263. Polydure VerEil, 325. 
penitentiary, and in it the pope desires him not to accept a bishopric without asking lis permission. ${ }^{z}$ It is quite possible that the person here alluded to was the young linglishman in whom the prescient eye of his master had already detected signs of future greatness. Many years, lowever, elapsed before it arrived. The first preferment that Joln Romanus secms to have enjoyed was in the eathedral of Lincoln. He became prebendary of North Kelsey in 1258, and resigned it for the stall of Nassington. In 1275 he was made chancellor,-a post which he gare up for the precentorship in 1279." On the 7 th of December in that year lie was collated by archbishop Wickwaine to the prebend of Warthill at York, ${ }^{b}$ the only picee of preferment in that church that he seems to have posscssed.

Archbishop Wickwaine died in Angust, 1:28.5, and on the 22nd of the following month the king anthorized the clatpter of York to proceed to a fresh election. On the 29 th of Octoler they chose Romamns, and on the 30th informed Edward 1. of what they had done. He gare his assent on the 15 th November, and Romamus went abroad to receire the pall and to be conseerated by the pope. 'The eeremony took place at Rome on the 10th of February, and the temporalities were restored to him on the 12th of April.c

When Romanus returned to England he was very nearly having a collision with archbishop Peckham about the bearing of his cross. On the 6th of April Peckliam wrote from Saltwood to the dean of the Arehes and Mr. William de Harepberg to inform them that he had heard that Romanus was to land on Palm Sunday following with his cross ereet, and directing them to check him. An order was also given to the rural dean of Dover forbidding any clerks to approach the intruder, and commanding the services to be stopped in every parish where he halted, if he made use of the obnoxions symbol of his anthority. The king had already heard that a quarrel was imminent, and had tried to prevent it, ordering that provisions and everything that Romanus and his snite required should be supplied to them on their joumey. On the 11 th of $A$ pril Peckhan again wrote to say that the archbishop, as he had heard, was in the priory of Bermondsey with his eross ereet, and he forbade erery onc

: Bahuzii Mise., ed. Mansi, i., 211.

a Le Neve, ii., 83, 92, 191, 196. Pryme, iii., 268. In his callacity as precentor of Lincoln, in 1255, Rominus came into collision with the kins for bringing a suit against the prior of Huntinsdon (Pryme, iii., 35 t). Jan. 1, 1288, quit claim to Jolun Tehanrl, chapter-clerk at Lincoln, of the nuo- nies received by Romanus on account of the choir boys at lincolu during his precentorship (Reg. Romanus).

${ }_{b}$ Rer. Wickwaine, $58 b$.

- Le Neve, iii., 104. Pryme's Coll., iii., 355. Stubbs, col. 1727. Trivet, 263. ("liron. lancreost, 121. Wikes, apul Cale, ii., 113. Mss. Cotton Vitellius, $A$, ii., $111 b$. 
to go near either the place or the prelate. ${ }^{d}$ We hear nothing nore of the (puarel at that time, but Romanus, in all probability, proceeded quietly into the North, the king interfering in his behalf to prevent any open dissension. The matter in disputc was afterwards the subject of some fruitless debate and negrotiation. ${ }^{e}$ The new arelibishop was enthroned at York on Trimity Sunday, the 9th of June, 1286..$^{f}$ His installation hanquet seems to have been on a magnificent seale. Several of the letters of invitation which Romanus sent have been prescrved, and from them we learn that among many others the carls of Cornwall and Warren, the bishops of London and Carliste, the dean of Lincoln, Sir R. Sutton and Sir William de Ros, knights, were asked to become his guests. ${ }^{g}$ The Latinity of the arehbishop was elegant and coneise, and his epistles seem to have been regarded as patterus of composition by his suecersors in the see. ${ }^{h}$

liomanus, like some of his predecessors, was in want of money on his accession to office, and was obliged to fill his empty coffers by borrowing large sums. The following are some of the persolls to whom he was indebted. My readers will observe how large a portion of the money-lenders were clerks, and they must draw their own inferenecs from the fact. The arehbishop would naturally turn to them for assistance rather than to the foreign merehants. He was obliged, however, to have recomrse to the latter.

1:86, May 18. The archbishop anthorizes Mr. William de Lincoln, elerk, to contract a loan of 500 marks for him in the contrt of Rome. Jume 10. A bond to Robert de Scartheburgh, dean of York, for 1000 marks. A bond to Roger de Saxton for 5o) ., and to Coppo de le Cotenne, citizen and merchant of Florence, of the company of the Frissinbaldi, and his fellows, for 200l. Junc 18. A bond to Mr. Thomas de Wakefeld, ${ }^{j}$ sub-

d Reg. Wickwaine. Prynue's Coll., iii., 355.

When Romanus was elected he endeavoured to get this point rettled at Rome (Reg. Romanus). In May, 1287, archlishop Peckham ordered the bishop of Worcester to prevent the Northern primate from raising his cross within lis clocese (Wilkins, ii., I2s), and Romanus was oblised to seek for letters of siffe enduct from the king (Thes. Rom:nuis). On Oet. 9, 1291, M1\%. H., dism of Tork, William, arehrleaeon of Nutts, and 'thomas de Corbridge were appwinted to treat with the archbishop of Canterlunry (ibid.). In 1295 there is a letter from arehbishop Winchilseat "wh the subject (Wifkins, ii., 216). On

Jnne 12, 1295, Bertrand and Simon, the cardinals, offer to act as mediators between the two primates, and their proposition was accepted by Romanus (Reg. Romanus).

$f$ USS.Cotton, Vitellius, $A$, ii., $111 b$.

$g$ Reg. Romanus.

$h$ Some of the letters of Romanus are inserted in the book which contains those of Thoresby. The epistles of these two prelates seem to have been resarded as models of orthography.

i Der. 29, 1286, Mr. Wr. de Lincoln was collated to a stall at Beverley. In 1290 he was at Rome in the archbishop's behalf (Reg. Romanus).

j Prebendary of Botevant, ehancellor and sub-tean of Tork, and canon of 
dean of York, exeentor of William our predecessor, for 961 . July 12. A bond to Richard de Horton and Philip de Werkesworth, executors of the will of John de Wydington, canon of Lincoln, ${ }^{k}$ for 100l. July 24. A bond for 200 marks to the merchants of Pystoria. July 2r. A bond to Peter de Cestria, provost of Beverley, for $200 l$.; to Adam de Patrington for 100l.; to Mr. Thomas de Dalton for $20 l$., and to Mr. Simon de Clarevall for 100 marks. July 31. A bond to William, dominus de Huks, ${ }^{l}$ for 200l. Sunday before the festival of All Saints, an order to Henry, archideacon of Richmond, to sell the archbishop's houses at Paris." Nov. 3. A bond for 300l. to $\mathrm{Mr}$. Thomas de Grimston," arehdeacon of Cleveland, Mr. William de Langton, rector of Croft, Walter his brother, ${ }^{\circ}$ and Henry de Mileford, executors of William de Rotherfend (Lanctons), latc dean of York. 1287, Jan. 3. Authority to R. de Bamfeld, canon of Sonthwell and rector of Stillingfleet, to borrow for the archbishop 110 marks from the merchants. Jan. 24. A bond for 16l. 16s. to the executors of Mr. Henry de Skipton, archdeacon of Notts, for silver plate bought of them.p March 3. Authority to Mr. William de Lincoln, eanon of Beverley, and Peter Durandi of Lincoln, to borrow 100 marks for the archbishop.q April 11. Bond for 200l. to Mr. Simon de Clarevall. May 10. Bond to Richard Guydicioniis for 200 marks. Nor. 24. Bond to Henry de Mileford, exccutor of dean Langton, for 100 marks. 1288, Trinity Sunday. A bond for 1000 marks to the dean of York. 1290, July 19. A bond for 200 marks to

Ripon. He was a favourite with the archbishop, who granted an indulgence of forty days to all who listence to his preaching. In giving Wakeficld the chancellorship the primate spoke of "persona tuæ nota probitas, meritorumque tuorum odorifera famositas."

$k$ Prebendary of Lafford (Le Neve, ii., 160). Horton was treasurer of the same church. Executors at that time seem frequently to have acted as trustees of the estate of their deceased friend, and to have made the most of lis effects by becoming money-lenders.

1 Ile occurs in the Rot. Scotix, and was sheriff of Yorkshire 1305-7 (1) rake's Eboracum, 351).

$m$ On May 9, 1286, Romanus informs bishop Bek that he had let his houses in Paris to the nephews of Matthew the cardinal. On Jan. 6, .1289, he desires his elerk, Robert de Themlby to sell them for him, and, on August 15, 1290, he orders Mr. William de Haxeby to sell them, and to examine the aeeounts of William de Sens, eitizen of Paris, who had had the charge of them.

Archdeacon Newark oceurs as a money-lender. On Dec. 27, 12s6, he lent the archbishop 20l. On March 16,1287 , he received from $\lim 100$ marks for first-fruits. On Angust I3 he lent the archbishop 47 marks, 6s. sil.

$n$ Archdeacon of Cleveland I2501289. Archbishop, Wickwaine speaks of him as "auratissimus et intimus filius noster."

"The well-known bishop of Lichfield and a creat statesman. He was a canom of York and master of St. Leonard's hospital.

" Harch 22, 1287-8, the archlbishop buys sheep of his executors for $10 \%$. April l, he buys of the executors of Mr. Thomas de Barneby, rector of 13armston, for 20 marks, the corn in the laith and in the eround.

7 'The money was lent by Durandi de Lincoln, the father of Peter. 
Richard de Horton, treasurer, and 'Thomas de Perar', canon of Lincoln, executors of $\mathrm{Mr}$. W. de Hancton, ${ }^{r}$ canon of that church. July 21. A houl for 40 marks to Sir John de Reygate, kt. ${ }^{s}$

Arelibishop Romamns took but little part in public affairs after he came into the North; indeed, at no period of his life can we regard him as a statesman. In 1288 he had some dissension with the king, for which he lost the temporalities of his see ; it was, howcrer, of short duration; for, between the months of Harch and August, ${ }^{t}$ he was in Gascony with Edward." In 1:90 he was present at the funeral of queen Eleanor, and at the king's request he ordered prayers to be offered up throughout his diocese for her soul. ${ }^{\circ}$ In 1291 he was required to render military scrvice against Scotland ;" and in the following year he was mixed up in the negotiations about that kingdom. ${ }^{x}$ On the 18th of Jume, 1:94, he was enjoined to require the suffrages of the people of his diocese for the success of the king and his anmy on their way to Gascony, and on the 19th of August he was summoned to a conncil at Westminster about that country. ${ }^{y}$ On two or three other oecasions he was called to parliament; but lis name is not connceted with any public office or with any important act in eomection with the state.

The whole of the time of archbishop Romanus seems to have been devoted to lis diocese. Henry, bishop of Whitherne, ${ }^{a}$ acted for some time as his snfliragan, and he was oecasionally assisted by one or two other prelates, but he seems to have relied for the most past npon his own exertions. The annals of his life are to be derived from his own official registers which are preserved at York, and they certainly shew that he was a zealous and eneretic archbishop. The acts of our early prelates have Iseen so little examined for biographical and historical purposes,

$r$ Neithor of these canons appears on the lineoln Fasti.

"A commisioner of array in lorkshire in 1300 (Parl. Writs., i., 345, etc.). On Tee. 10, 1290, John de Reyfrate was bailiff of Sherburn (Reg. Romanns). 'Pryme, iii., le93.

"leg. Romanus.

"Chron. Lanereost, 137.

"Ford., i., 753. Parl. Writs, i., 256.

$\checkmark$ Fud., i., 762. In 1292 Greerory IX. wrote to the archbishop of York and the bishop of Carlisle urying them to eshort the soottish king to keep the joar. (Chron. Lan., 116).

y Parl. Writs., i., 261. Foed., i., 802, $808-10,831$.

s larl. Writs., i., 25, 30-2. Fod., i., 822. In 1286 the king bess him and the archleacon of Richmond to procure a subsidy for him from the York clersy (Foed., i., 673).

"On Sept. 9, 1286, he made his profession of obedience to the arehbishop at Hexham, and had leave to go to Rome. He died Nov, 1, 1293 (Chron. La1., 155), being at that time erucesimuatus. He was at one time abbat of S. Crux. On Jan. 13, 1294, John king of Scotland wrote to Romanus about Thomas de Kirkcudbright, chaplain of Robert Bruce, who had been elected bishop by John, prior of Whitherne, and his convent. On May 30, 1294, the new prelate made his profession of obedience to Romanus, and the bishops of Carlisle and St. Asaph were asked to assist at his consecration, which took place at Gedling "die dom. in crast. B. Dionisii, 1294." 
that a short series of extracts from those of Romanus will be interesting and novel. In the first place 1 shall give a list of those persons to whom the arehbishop gave an ammual pension. These sums were frequently spontaneonsly granted, either from aftection or interest. Occasionally the king, in addition to the stalls and benefices which he filled up himself or becrged, requested the prelate to place some court favourite upon his list of pensioners, or some foreigner gave a hint that he would like to be upon it, as the price of his good offices at the papal court. These persons became occasionally a very serious burden upon the arehiepiscopal revenues.

1286, May 12. A pension of 20 marks per ammun to Benedict, cardinal of St. Nicholas in Carcere 'Tulliano, for his good offices towards us and our church. 1287, $\mathrm{Heb} .4 .4$ pension of 10l. per annmm to Ralph de Hengham, ${ }^{b}$ elerk. April 18. A pension of 10 marks per ammun to William de Burneton, ${ }^{c}$ and on May 10 one of 100 s. to William de Saham, ${ }^{d}$ elerk. Another of 5 marks to John de Ousthorp, elcrk, at the instance of friar William de Hothum, ${ }^{f}$ till we provide him with a benefice.

b Son of Sir Andrew de Herigham, of Hengham, in Norfolk. Chief justice, arehdeacon of Worcester, chancellor of Exeter, canon of IIerefold, Exeter, Lincoln and London. He oceurs frequently in state documents. Foss's Judges, iii., 261. Weever, Fun. Mon., 367.

c A justice itinerant in 1302 . Foss, iii., 68 .

dA justice of the King's Bench. Ibid., 146.

- He was a prebendary of IIowden (Reg. ii., Prior. and Conv. Dunehm., $69,81)$.

$f$ Prior-provincial of the friars preachers in England, and a person of very pleasing manners and of great piety and learning (Chron. Lan., 133-1. Fred, i., 766. Cotton's Fasti Eccl. Hib., ii., 12). The was elneated at Merton college, Oxford, and at Paris (IIist. Univ. Oxon., i., 324 ; iv., 14. Cotton ut supra). In February, 128?, he is mentioned in connection with the king's intended expedition to P'alestine (Fied., i., 703. l'ryme, iii., 42\$), and on May 8, seq., he had letter: of credence to the pope from the king (ibid., 708. Prynue, 389). In 1292 he was concerned in Scottish politics (ibid., 766). He was also intimately connected with Eleanor, the consort of Edward I., and had much to do in settling her affairs (Manners, ete, of lingland, 103, etc.). In l298 he was preferred to the archbishopric of Dnblin, and was consecrated abroad by bishop Bek. IIe died on Ang. 25, 1298, the year of his election, in the Dominien convent at 1)ijon in Bursundy. II is body was bronght to London, and was interred in the chureh of the bominieans. Cains says that he was an anthor (Chron. Lan., 133-4. Trivet, 306. Prynne, iii., 772-3. Cotton, ut supra).

And now for a romantic story to enliven a dull note. It connes from MSS. Harl., 912.

De Monte Chyviott. Dominus Johamnes de IIothom Elyensis episcojuls, andivit a fratre Willehno de llotlom, avumeulo suo, historiam qua sequitur. Retulit vero quod erat in trannmarinis jartibus quidan nobilis oni ommia sta dimiserat fropter amorem 1)ei, et dnxit vitam hereniticam in nemore. Jlic, ergo, andiens quod talis fratur de Anglia transiret fer patriam illam versiss eapitulum zenerale, misit ad cum rogans guod preventer ei lowueretur. Ad quem cum reniret (vemedat ivit si norit aliguen montem in Marchia Scoria qui rocaretur C'lyyriott? qui dixit quol seiret. Quare, igitur, yux o indicalo tibi. Fna, igitur, noete, andivi extra tignrium menm quasi masnus fopulus transiret, et, respiciens, 
Dec. 9. A pension of 5 marks to James Simbaldi, elerk, till we can provide lim with a benefice. 1288, Nov. 6. A pension of 10 marks per anmum to Mr. Robert de Ros, arehdeacon of London, and Mr. R. de Branndon, ${ }^{g}$ canon of London, till we can wrive cach of them a stall. 1290, May 13. A pension of $20 l$. per' annum to Peter de Sabaudia, ${ }^{k}$ elerk, on account of his noble birth and his relationship to the king, till we ean find him a prelend. Scpt. 23. A pension of 5 marks to Nicholas, son of Mitthew Rugepall, merehant of Lucca, till we give him a beneficr. 1:91, July 2. A pension of 10 marks per annum to $\mathrm{Mr}$. liicharel de Ilerteford, till, ete. 1293, May 8. A pension of 10()s. per anmm to John de Vere, son of the earl of Oxford, till we find him a stall at York. ${ }^{i}$ Mem. He died in the same year, and so the pension ceases. August 7 . A pension of $100 \mathrm{~s}$. to Thomas Brabazon, rector of Humgerton, dioc. Lincoln, on account of the affection which his brother, Sir Roger Brabazon, ${ }^{j}$ shews to us and our chuch, till we can give him a stall. 1295, May 13. A like sum to Hugh de Cressingham, ${ }^{k}$ clerk, till we find lim a prebend.

1 now give in chronological orter the following remarkable series of extracts from the register of the archbishop. Their

vidi perlites transire in maxima multitadine, deinque armigeros, deindeque milites, nltimo tres reses nobilitatis ville, unm a dextris et alium a sinistris epritunt es et luasi ducentes tertirm inter se. Lt crm omnes transissent dohui nimis geod non congnisivi fui asont. Wit cito pervenerunt tres minerj claudicantes a quibus eonquisivi qui rsscont illi precodentes. Qni responderunt yuod ommes erant domones exeepto nno, veilicet illo nltimo, in medio, qui fuerat rex Arraconix,-ductus ad nontem Chyvott, qui ost loens frigidus value, nt in lingiclo loco aftligeretur qui delectabatur in calidis cibis et potis.

Ol frivid and most impotent eonclusion! and yet it is an appalling fate for the disemborlied spirit

\section{"To reside}

In thrilling regions of thick ribued ice."

F Cauons of Lincoln and London. 2"2ul Ldward I. letters of protection to him as rector of Littlebury (Prymne's ('sll., iii., 591).

${ }^{h} 1 \mathrm{son}$ of 'Thomas prinee of Piedmont, and comin of Edwarl I. Prebemlixy of Newbald at Tork 1290 . 13(4), sean of Salisbmry and Lyons, and eanon ot Lincoln and Ilereford. He was made arehbishop of larons in becouber, 1308. ('f. Gall. Christ., iv.,
161, 205. Baluzii Misc., i., 221, ed. Mansi. L'Art de vérifier les Dates, 8vo ed., xvii., 168. Grichenon, Histoire Generale de la Maison de Savoie, ete.

i A son of Robert earl of Oxford, mnoticed by Dugdale (Bar., i., 191-2). He was prebendary of Scamlesby at Lincoln (Le Neve, ii., 202).

$j$ Sir Roger Brabazon was a justiciar and a person of eonsequence.

${ }^{k}$ A great man, justiciar and treasurer of Fingland. In 21st Edward I. archbislop Romanus allows him and his fellow-justiciars to hold assizes at Tork in the time of Septuagesima and Sexagesima (1'rynne, iii., 579). 22nd Edward I. letters of protection to him as canon of St. Panl's and rector of Enderby, Kingsclere, Hatfeld, Chalk, Berles, Barnton, Dodington, Cressingham and Peymerston, "an insatiable pluralist" (ibid., 597) Rector of Rudby, dioc. Ebor., in 1296.

'The record of his pension is caneelled, for he was killed in Scotland, and so sreat was the liatred that the Scots had for him, that they actually flayed his dead body and tanned his skin, and, cutting it in pieces, kept them as memorials of them foe. Cf. Kiyghton, eol. 2519. Walsingham, 73. C'Iron. Lancleost, 190. 
variety does not diminish from their interest. It would be difficult to find any historical notices of greater novelty and value.

1286, April 17. A letter from Edward I. to the arehbishop, requesting the prayers of the faithful for the soul of $\Lambda$ lexander, king of Scotland, who has recently died.l April 23. An indulgence for the brethren of the hospital of St. John Baptist and St. Thomas the martyr at the bridge of Stanford, for the repair of the said bridge, which has been destroyed by a flood, and for the perpetuating of the mass B.M.V. thereon." An indulgence to those who visit the ehurch of Mansficld at the dedieation of two altars therein, viz., that of B.M. and S. Katharine, and that of SS. William and Margaret, and another for those contributing to the chapel of S.M. at Staner, near Selby. An indulgence for the eathedral of Carliste, which has been destroyed by fire, and for the shrines of SS. C'nthbert and John at Durham and Beverley. An indulgence of 10 days for the soul of John dietus Venesun, whose body lies in the cemetery B. M. at Dover, on the north side. An indulgence of 40 days for the fabric of St. Savionr's ehurch, Bermondsey, and one for the fabric of the house of the Augustinian hermits at Huntingdon, which has been burned down. An indnlgence for the soul of Mr. William de Gyseley, who is buried in the monastery of Kirkstall, and for the liealth of Richard de 1lalton during his life and for his soul after his decease, together with the souls of Robert and Aliee, his parents, who lie before the altar B. M. V. in the ehureh of Inalton, Lincolnshire. April 27. An indulgence for the sonl of dame Christiana Ledet, ${ }^{n}$ mother of Sir Gerard de Furnivall, whose body lies buried before the high altar of the priory of Byssemede, and her heart in the church of the friars preachers at Cambridge; also for the soul of that noble lady dame Aliee de Ros, whose body is interred in the churel of the friars minors at Lincoln. April 29. An

1 Alexander was the king's brotherin-law, having married Marsaret, datighter of Henry III. He fell from his horse in a dark night, and broke his neck (Knygliton, col. 2168).

in A series of extracts of great importance and novelty. It is impossible to illustrate each as it deserves; indeed I do not profess to do it, although I have a superfluity of materials.

"Cf. Ingd. Bar., i., 7ะ6. Plac. de Quo. Warr., 396. II shire. Thoroton's Notts, 155. Bishop Kellawe's register at Durlam contains many entries of this matme. 1311, 15 Dec., ind. of forty days for the souls of Sir Walter Fancombrine and dame
Agnes his wife. 1312, $23 \mathrm{Aug}$, ind. of forty days for the health of II und de Everesdon, abbat of St. Allan's. 1312, Nov. 11, ind. of forty days to all who listen to the preaching of the monks of Durham. lece. 2s, ind. of forty days to those who visit the enureh of Bliburyh, co. Lincoln, dediented to St. Alkmund, and for the soul of Vialter, sometime rector there, who is buried in the churels. Ind. of forty days to those who visit the chapel of St. Leomard in Firksteal abbey. Ind. of forty days for the souls of 'Thomas de Kellawe, Arnes his wife, and Willian their son. 
indulgence of 10 days for the souls of Elias de Stapleford and Ilawis his wife, who are buried in the ehureh of Stapleford. ${ }^{\circ}$ May 1. An injunction to the people of the diocese of York to jray for the good estate of the $\operatorname{king}$ and queen and their

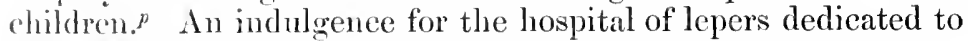
S.M. Magd., near Pontefraet, and another for the hospital of St. Nicholas, near Beverley. Letters addressed by the arehbishop to the bishops of Bath and Wells, and Durham, William de Luda and the archdeacon of Richmon $\mathrm{A}$, in behalf of John de Lithergrynes, " who is not at present in the king's service. Jume 15. $A$ royal mandate to the arehbishop to summon before the justices itincrant at York, Mr. William de Clifford, Mr. Thomas de Barneby, official of the bishop of Carlisle, and Mr. Henry Hay, rector of Aughton, his clerks, for a transgression in hunting. July 6 . An indulgence, to last for three years, for the brethren of the hospital S. Spiritus de Saxia, at Rome.s July 7. Administration of the effects of Sir 'Thomas de IIuks, kit., to Adam de Derlington and Ingh de Collum, his executors. ${ }^{t}$ Sept. 10. An indulgence of 40 days for the ehurch of Whitherne containing the relies of St. Ninian, which has been burned down. Dec. 5. A gift of two oaks from our park of Bererley to Mr. J. de Penningston." The following clerks, all having the first tonsure,

- Aug. 25, 1322, a elantry is foumled in the church of St. Ellen, at Staple. forl, for the souls of Itugh de Stapleford and Alire his wife (Reg. Melton). Cfi. Thonotomis Notts, 213.

$p$ Another order amo 3 , and another anno $y$.

" A person much employed in state affairs. A justice itinerat (Foss, iid., 121). 20 h litward I. he and Alice his wife founded a chatrel in their manor of Lascuby, in which prayers were to be said daily for the souls of Edward I. and bishoj, bek (Prynne, iii., 463). In the sane year the king authorized lim and the abbat S. M. Ebor. to ehoose a master for St. Nieholas's hospital, Sork (ibid, 170). Eicchactor north of 'T'rent zoth Edward I. (Parl. Writs., i., 2y6i). Ile was sheriff of lorkshire between 1280 and 1286 (Drake's Ebora(c1111, 351).

$r$ Some of the arehbishop's elerks are in trouble for hunting. 'They were of the same mind with Chancer's nonk-

"We yave not of the text a pulled hen,

"That saith, that hunters ben not holy men."

"This was the hospital to which the pope wished to appropriate the stall of Fenton at York. It will be again mentioned.

$t$ 'There are many of these valuable instruments in the early registers. 1287, Jan 24, administration of Sir Tobert Sutton, knight, to Stephen de Sutton, his brother and exeeutor. 1289, May 3 , commission to reeeive the aeconnt of the exeentors of Sir Robert de lios. Hay 10, commission to hear the acconnt of Sir John Huse, Robert de sherington, and Jordan de Stokes, exeeutors of Sir Henry de Newmareh. 1293, July 13, commission to hear the accoint of the exeentors of Sir Robert de Ros, knight. 1293, Dec. 5, the will of Isabella de Fortibus, conntess of themarle, is proved at Tottenham, and administration is granted to her executors, the priors of Brommore and 'I'wynham and Sir William de Knouill, knight. 1294, Mareh 1, commission to hear the aeeount of the exeeutors of ditme Amy de Percy.

" Canon of South Muskham at Sonthwell, and probably of Beverley. William Clifford, who has been recently mentioned, was also a canon of Southwell. 
are degraded this year; John de Horeden for stealing 3s. 6d. at York; Henry de Norocastro for breaking into a liouse at Hoton in Bulmershire and stealing a tabard; John de Fainfoss (Fangfoss) for stcaling 5 marks at Hoton-on-the-Wold; William de Baildon for stealing at York 4 silver spoons, and Robert de Karl' for stealing some decretals valued at 5 marks.

1287, Jan. 27. Laurence de Crepings, rector of Hoton, acknowledges that he owes the archbishop 20l. as a pumishment for incontinenee. $\mathrm{Feb}$. 16. Licence for the bretlinen of the hospital of St. Anthony, in the diocese of Vienne, to collect alms; another for the hospital B.M. withont Bishopsgate, London; and a third, of twenty days, for the repairs of the bridge of Gloucester and the hospital upon it. August 1\%. A commission to the bishop of Whitherne to dedicate the churches of Oswaldkirk and Edstone, and to the dean of Bulmer to act as the archbishop's deputy in dedicating the churches of 'Thormanby, Dalby, Bulmer and Ellington. There remain to be dedicated those of Scalton, Whenby, Foston, Helmsley and Wheldrake. The archbishop binds the rector' of Foston under a penalty of 5 marks to have his church built and ready for dedication within three years." Sept. 24. Licence to Sir Robert de Baliol to have an oratory in his manor of Redness. ${ }^{x}$ Dec. 27. An order to the bailiff of Sonthwell to give to the prior of the hospital at Jerusalem 10 wild animals, viz., deer, fawns, etc., as they come to the nets.

1289, Dec. 29. To Walter ke Maydeston," 400l. for the 30th, by order of the king.

1290, May 15. The archbishop grants the first-fruits of the arehdeaconry of Richmond to Sir Otho de Grandison to enable him to go to the Holy Land. $z$ June 11. A mandate of enquiry to the official of the archdeacon of York ex parte Sir Fulk Fitzwarren of Albebury, dioc. Hereford, kt. We have heard that Agnes Bacun, lady of Edlington, deceased, the late Fulk's sister, left him by will a precions stone ealled asimu', which Agnes, danghter of Robert le Gru of Northampton, the maid of the

$v$ These convictions of clerks are of painful frequency.

w Some valuable dates. It must not, however, be imagined that churches were always derlicated as soon as they were built. There are some valuable notices of this kind in the Iork Fabric Rolls, 235-242.

* An nnrecorder member of a rreat house. March 2:3, 1273, lieence fiom Gregory X. to Robert de bialiol to build a chapel in lis manor-homse at Redness on account of the inmolations, etc., which keep him from the larish chureh (lieg. Wickwaine). Baliol was knight of the shire for co. York 25 th and $29 t h$ Edward I. (I'arl. Writs., i., $58,91)$.

y Jan. 11, 1290, collated to a moiety of the chnich of kendal (Reg. Ri()manus). May 5, 1307, to have the next vaent stall at Fork by papal provision (Reg. (ireenfich). Bishop of Worceste. 1313-1317. He was a great policician.

z 'lhis creat man and his family have been atrearly mentioned. Cf. Dugd. Bar., ii., 17. 
sairl Agnes, has kept on the plea that there are two persons of the name of Fulk Fitzwaren; one the Jrother, and the other the nephew of her mistress." June 13. The archbishop writes to the bishop of Ely expressing his regret that he cannot be prescent at lis consecration. ${ }^{b}$ Sept. 18. Licenee to R., bishop of Bath and Wells, to hold a special ordination within the diocese of Tork to make J. de Langedon and Roger de Esserug, subdeacons.c Nor. 28. A letter from Edward I. to the archbishop, desiring the prayers of the faitlif:l for the soul of queen Alianor, our wife, from our elitlhood." Dec. 5. Purgation of dame ('hristiana, wife of Sir Nicholas de Micnil, kt., from the charges of having prepared poison to kill her husband, and of having committed andultery with Mr. Wr. de Grenefeud and Walter de Hamerton. ${ }^{e}$

A Pery curions story. On Jan. 12, 1290, administration of dame Agnes Baeun de Edlington, who died "in crastino festi S. Nicholai," and was buried on the sunday after, to William do Boserill and lichard de Rokeley, lier executers (Reg. Romanns). For an account of the noble house of Fitzwarren, cf. Thed. Bar., i., 4t5. The first Fulk in the funily was nearly killed by prince John, aftertwards kins, who broke his head with a chessboard.

b Willian de Luda (Louth), prebendary of Amulelord at lork. "Vir mantifens at eminentis scientiae" (Wikes, apul Gale, ii., 121). ('omecrated at Ely, in the chureli B.Al.V., ly John ar'hbishop of C'muterbury, with sreat soleminty, on Nor. 23, 12uc, having been ordained priest on ()ot. 1 (Contin. l'l. Wigortl, ii., 213). $A$ great statemsau. On Oct. $31,12 y 1$, on the marriage of a son of Sir John de Potihou to a daughter of Sir Gilbert de Luda, the atchbishol, ordered lis othicial to pay over the money he held belonging to the lady (Reer. Romanns). J 11 leyg IIenry Newark oecurs as one of the executors of Gilbert de Juela (lint. Parl., i, 86i). Nicholas de Luda was his son and heir (Abbrev. Plac., 307 . (rilbert de Linda was mayor of Tork in 128t. (1)rake, 360).

A great fincour. 'The bishop lad been canon of Grendale and architeacon of York. He was lord chameellor, and was a very reat man. J le left a will, of whel Mr. Willian Burnell, dean of IV ells, and William de Hamiltom, were tho executol's, and Philip de Burnetl was the festator"s nephew and heir
(Act. Capit. Ebor., 22). Asherngge was a jace in Bricks where Edmund, earl of Cornwall, fomded a college. Walter de Asherugge was chaplain of Edward 11. (Areliacol., xxvi., 310). Roger de Asherngge was a clerk of the chapel of Edward 1. (Lib. Garderobe, 311). Langton is, I presume, the same person who becane chancellor in $1293 . \mathrm{He}$ was jubendary of Friday thorp at York, and held many valuable preferments, the highest of which was the see of Chichester, to which he was raised in 1305.

$d$ The king say's she died "die Martis proxino ante l'estum S. Andrex apostoli" (Reg. Ronanus), Ob. 4 kal. Thee. (28 Nov.). (Acta Cayit. Ebor.). The chanter of York ordered a full leal to be rmog when they heard of her decease (Lib. Garderobe, 29), and on Jnly 10, 1291, Edward sent to the church from scotland, in memory of liis late wite, a chasuble, alb, and amice (Jalnic liolls, 154).

Romanns at once granted an indulgence of forty days for those who shonld pray lor the queen's som, and this was Pefraterl on Doe. 8, 1290. On June 7, 1.21, the archlbishop wrote to the king to say that his wishes had been attended to (Rer. Romanus). Cf. Pryme's Coll., iii., 448. Contin. Fl. Wigorn., ii., 214. Arehaol., xxix., 167, ete.

c A curions episole in the listory of this mhatply lamily. Greenfield afterwards becane archibishop of York. On Jan. 29, 1293, Romanus writes to the ling, who had ordered him to make an encuiry on the fart of Menyl against lis wife, and says that the husband 
1291, Feb. 7. Roger de Wychton is made the archbishop's proctor to enquire of Mr. Giffred de Vezano, canon of ('ambray and ehamberlain of the pope, about the will of II. the cardinal. April 4. Dispensation for 'Thomas rle Multon and Marsaret his wife. They have lived together, and a son has been bon to them, they not knowing that Isabel, the former wife of the said Thomas, and Margaret, were first cousins.g May 29. Licence for Roger de Malton to go on a pilgrimage to Pontigny.h July 20. An order to pray for the soul of the queen-mother. ${ }^{*}$ Sept. i. A commission to Mr. John Clarell, canon of Southwell, to preach in behalf of the crusade. ${ }^{j}$ Oct. 10. Licence to dame Margaret de Percy to reside for a year within the nummery of Appleton, provided that her attendants are not disorderly. ${ }^{k}$

1292, Dec. 13. Licence to the arehbishop of Dublin to use his pall within the diocese of York.?

1293, Jan. 12. Licence to William de Mortimer and Alice his wife to bave an oratory at their pleasure within their manor of Sibthorp. May 4. The archbishop requests the king to give up to him Nicholas de Menill, clerk, who liad becu aceused on the testimony of two felons, William Cokercl and Reginald le Hunter, of cansing the death of William de Mowbray, Matilda his wife, and William and Hilda their children, by firing their houses and those of the vicar of Rudby. We have acquitted him

had driven his wife from his house and refused to maintain her. His old age made him dislike her (Reg. Romanıs). He was ordered to provide alimony. On May 13, 1310, arehbishop Greenficld granted to dame Cliristiana de Menyl, relict of Sir Nicholas de Menyl, the marriage of Richard, son and heir of Robert de Furneaux, knight, the archlishop's tenant at Lutterington (Reg. Greenfield). Cf. Dugd. Bar., ii., 110.

$f$ Hugh de Evesham, among other preferments in the diocese of York, held the prebend of Bugthorpe and the livings of Spotforth and Hemmingburgh. He was a famous physician, and wrote several works on medicine and divinity. In 1281 he was male cardinal priest tit. S. Laur. in Lucina. He died of the plague in 1287. Cf. Knyghton, col. 2435. Ciacon., i., 773, etc.

g Cf. Dugd. Bar., i., 568. Nicolson and Burn's Cmml) d., ete., ii., 218.

${ }^{h} \mathrm{He}$ had been there before. $\mathrm{He}$ was master of St. Leonard's hospital, York, and of the hospital B.M. Magd. at Ripon. He resigned the latter in
1291. On May 30, 1276, the ehapter of York presented him to St. Leonard's hospital, Thomas, the former rector, having died on the Sunday after Ascension-day (MSS. Cotton, Claudius, B, iii., 18).

i Eleanor of Provence, widow of Jenry III, who died in the numncry at Ambresbury.

$j$ This person has been already mentioned. A list of the places at which Clarell was to preach is given in the register. In 1291 a provincial comeil was held at York abont the ILoly Lamel, and the proposed mion of the 'T'emplars and the IIospitallers (Chron. Lanereost, 143-1). William de Ifotham was a great alvocate of this arusade (P'ryune, iii., 128), which came to manght.

$k$ A privilere only granted to great ladies. Archbishop Irickwaine pernitted the wife of lioner de Howbray and her family to reside for awhile in the monimtery of Newhurgh.

'John de Sinnford or Stanford, arehbishop, from 1281 to 1291. He was a Franciscan, and a person of consequence (Cotion's Fisti Eecl. Hib., ii., 12). 
in our court. Jume 8. An order to use prayers for fine weather, that the great rains may be stayed." August 27. Henry de Brumpton, an inlablitant of Scarbrough, about thirty years ago makle a row to go to the shrine of St. James of Compostella. On accomnt of bodily infirmities he is mequal to the journey. $A n$ order to Lanrence de Wetwang, warden of the friars minors at Scarbrough, to release him from his row on the payment of 100s." Dec. 8. A general letter from the king. It has been signified to us that William, scn of Thomas de Lonesrlale, lost his right ear by the bite of a horse. This is not to be to his prejuclice. ${ }^{\circ}$

1:94, Jan. 30. A mandate to pray for the soul of Margaret, some time queen of France. ${ }^{p}$ March 1. A letter from the archbishop to the abbat of Fountains. We intend to pass a night within your monastery on our way to Otley, but this visit is.not to he rised as a precedent. ${ }^{q}$ June 16 . We have received from Robert de Perey 50 marks for the use of the hospital B.M. Magd. at Ripon. The said Robert is to reside in the hospital with one attendant, and to be maintained, and we give him a robe yearly. Dee. 20. Licence for the canons of Furness, Cartmell and Cockersand to be ordained by the bishop of Carlisle.

Archbishop Romanus surpassed all his predecessors in his hospitality and munificenee. ITe had a great number of knights among his retainers, and did everything in his power to advance the dignity and the fame of his eathedral. His name will always be remenbered in comection with the fabric. On the 6 th of April, 1291, he laid with his own hands the foundation-stone of the present maguificent nave. The dean and the canons were standing around him whilst he involied the blessing of the Spirit upon the work which was then begm.s The archbishop was at the south-eastern corner of the nave, hard by the transept of Walter Gray, and in front of him were the tower and the northern transept which his father had erected. How many memories of bygone years would rush into his mind, even amid

${ }^{n}$ On July 12 there was an awful fhunderstorin in the diocese of York (Chron. Ian., 154). "Transil annus iste multum frugifer nee fameliens" (Walingham, 59).

" Cf. Nommenta Francisc., 406.

Thus Piers Plonghnan kays,"l'ilerymos and nalmeros
I'lingliten bem toridere,
lor to seken sont Jame"

"It minht otherwise have been thoright that he was a folon.

"A similar order was made by the kims in Jamuary, 1296 (Pryme, iii., (5)1). F(1.1., i., 8365). $q$ These visits were very heavy burdens. In 1309 a statute was passed to prevent them (Statutes at Large, i., 153). The monastery of Fountains was at this time in a very bad state, and the visit was a matter of necessity.

Dee 10,1289 , licence to the bishop of Carlisle to ortain the monks of Furness, Cartmell, Comishead, and Hexliam, and a commendatory letter to the abbat of Furness, who is going to the general chapter of the Cistercian order. ff. Berk's Anmal. Furnesienses, 238.

- Stubbs, col. 1728. 
that concourse, when he looked and prayed! It was inded a high privilege for a father and a son to call into being so large a portion of that noble and beantiful eathedral.

Romanus was the founder of the prebend of Bilton at York, which he established in 1291. He contemplated also the division of the stall of Masham into three and that of Langtoft into two. The arrangements for the last step seem to have been nearly completed, and canons were actually appointed, but the proposed scheme after all seems to have fallen through, and it was never attempted afterwards. The king put his reto upon the project, and the life of Romanus was too short, and his influence at court too small, to enable him to obtain the consent of the sorereign. The archbishop was also a great benefactor to the ehurch of Southwell, and founded several stalls in that eathedral." One great point in the life of Romanus was the opposition that he offered to the encroachments of the papal power. Itis patience, which was never great, must have been considerably taxed by the system of provisions to which he was obliged too frequently to submit. Some of the best piees of preferment in lis chureh and diocese were given away by the pope to foreigners, regardless of the wishes and the cognizance of the arehbishop, who saw that if this state of things continued his diocese wonld soon run to waste. These favourites of the pope were of eourse nonresident, and that feeling of annoyance and discontent was already springing up which resulted, after a time, in the order that no cardiual should be beneficed in England. In 1289 an event took place which made a great stir throughout the eountry. The pope, Nicholas III., had given the stall of Fenton at York, and that of Nassington at Lincoln, to his nephew Mattlew Rubeus, eardinal deacon of S.M. in Via Lata, a man of great learning and distinction, and the protector of the order of the friars minors. ${ }^{n}$ The cardinal obtained the consent of lis mole to the appropriation of the prebend of Fenton to the hospital of the Holy Spirit at Rome, of which he was the hear. 'ilhis arrangement was so novel, and was fraught with so much danger to the English ehmeh and her independence, that a great uproar was at onee made. 'The king wrote a strong letter of remonstrance to the pope, in which he quictly hinted that what he proposed to do would not be tolerated. T'ine nobles of the lingdom sent another missive eonched in the same strain. But the

${ }^{t}$ Reg. Roman!s. Prynne, iii., 7S3. Each of the divided stalls of MInham was to be worth 50 marks per annum (Aet. Capit. Ebor., 15).

"Dugd. Mon., vi., 1311-15. To Neve, iii., 421, etc. Thoroton's Notts, 313-14. An examination of the archi- tecture of this chemerh will throw ereat light upon that of York, especially that of the tower and chaptor-lomse. I'he regrister of archbishop liomimus entains some documents relative to the firbric. ." Ciaconins, i., 721-2. The cardinal crowned five jopes. 
most striking doemment in the whole controversy is a letter addiessed by Romanus to the cardinal himself, in which, withont making a personal attack upon that dignitary, he reprehends in vigorous and remarkable language the wrongs which the church was suffering at the hands of the pope, who ought to have been her protector." The cxamples of Grostête and Borill, his own predlecessor, were no doubt in the archbishop's minul, and he expresses himself with honest zeal and eloquent indignation. I shall not apologize for placing the letter of Romanus before my readers in the language in which it was written, as a proof of the encryy of his character, and as a specimen of his seliolarship.

"Domino Matheo Rubecard pro prebenda de Fenton, eui in annexionem hospitalis Sancti Spiritus de Urbe in Saxia de illa dicitur esse provisun.

"Domino M., Dei gratia Sancte Mariæ in Via Lata diaeono cardinali, J., primas, ejusdem Ebor. archiepiscopus, etc., sahutem. Tarti sunns dolore cordis intrinsecus, et tedio nobis est, nee immerito, vita nostra, quum, ut ridemus, commissa nobis Ebor. ceclesia fircta est nostris temporibus, utinam non nostris demeritis! sub tributo; tributo quidem gravissimo quo domesticis snis ct notis contra cursum materni moris oceultantur ubera cjus plena, et ignotis ac alienigenis mutato caritatis ordine suggenda nulantur, sieque cogitur esurientibus propriis panem porrigere alienis rt lac siticntibus propriis extrancis propinare. Nee est ex ommibus rerera quos genuit qui occurrat; non utique qui sustentet ex omnibus filiis (fuos nutrivit, dum inde imponuntur oncra humeris cjus, unde velut ab arce refugii relevacionis dexteram implorare erediderat, inde gravamina venerunt unde profecto contra spiritum procelle Dei auxilia proventura sperabat. Nec solummodo collo ejus jugum lamentatur impositum, sed et omnibus membris suis cum doloris ingeminaeione deplorat. Eree etenim quod preter provisiones factas vobis et fratri domini Portnonsiis episcopi in eeclesia memorata, sanetissimus pater, (lominn noster summus pontifex, nune tercio in provisione cujusdam alterius candem gravarit ecclesiam, et collegiatis etiam ab ipsa veht a matre dependentibus non pepereit, sed provisiones certis fecisse personis de racaturis canonicatibus et prebendis ascritur singulis carumdem, per quod et eadem ceclesiæ divinis framlantur obsequiis, cum non sit ex talibus personis qui pro tympano psalmum reddant, et nobis prejudiciale nimis existat 'um collationes alique per nos factre personis idoncis per sedem ipostolicam jam anmullatie dicantur, et providendi nostris elerieis et aliis incligenis, qui personaliter residerent et divine hospitali- 
tatis exhibitione debita septies in die laudis cantica personarent, vel adempta potestas, rol saltem ad longa tempora sit dilata. Porro de provisione vestra in prefita eeclesia a principio quando illud andivimus gandebanus, sed nunc merito dolere possemms pracepto quod ad sustentationem hospitalis Saneti Spiritus de Upbe, cujus habetis custodiam, sicut fertur, facta volbis dicitur provisio memorata. Sic nostra prebenda, virtute provisionis hujus robis in ecclesia ipsa collata, reputatur alienata perpetno, cum verisimiliter presmmatur guod futuri post ros custodes hospitalis ejusdem sint eidem prebendie ad ipsius hospitalis supportanda onera quasi jure hereditario snceessuri. Ex quo provenit quod canonici valde perpanci ecclesie memoratie descrvinnt chm ejus peculium ad renotas nationes abducitur, et de ijsins spoliis alienis necessitatibus subrenitur. Fit quoque quod relut illa exigna corpore animalia, sed artis emuditione permaxima, gens apum, que non sibi sed aliis nectar mellem in thecis cereis thesaurisat, velut etiam qua sil)i non semper sed potius aliis vellera ferunt oves, non sibi quoque sed aliis juga boves.... propriam ecclesia prelibata, non sibi rel suis obsecuiiis, non proximis et ricinis, sed exterorum usibus et gentis ignotie profectibus conquisivit. Spoliatur hoe modo Eboraeensis ecclesia et Romanum hospitale vestitur; altare motur Elooracensis eeclesiae et certum amictitur Sancti Spiritus hospitalc. 'Tollitur' Anglicis lospitalitas et transwchitur ad Romanos. IIis demitur', illis augetur. Hi denique seminant, illi metunt. Hi laborant, illi vero manducant. Sic, sic, pater et domine reverende, Elsor'acensis tractatur ecclesia, sic patrimonimn ejus expenditur, sic proficit incrementis. Utinam sit qui adjuret at non totaliter desoletur! Terumtamen non fuit hoe pia intentio ac derota clare memorixe catholicorum regum Anglia et aliorum Christi fidelium, qui nedum prefatas nostras ecclesias, sed et totam ccelesiam Anglicanam ad dilatationem fidei orthodoxe fundantes, eas temporalium bonorum largitionibus dotaverunt amplissimis, et libertatum immunitatibus nmmicrunt, sed ca nimirnm consideratione constat sic eos cisdem eeclesiis fuisse mumificos 11 t, cum delictorum expiatione, consequerentmr per hoc salubre remedium animarum, coltus divini nominis angeretur, servaretur hospitalitas, elemosina darentur pauperibus, et per ministros idoneos ad guos pro tempore ex cisdem bonis coclesianticat stipendia devenirent, servire profatis ecelesiis personaliter tonerentur. Ad laee pietatis opera pictatis amici et miscriendiat scetatores in extruetione sanctarum adium lapides jactavere primarios, ad hece bona dotalicia concesserment, ad hae immmnitatem cirographa smut largiti. Non fuit cormm in talibus cogitatus guod ipsormm clemosine in ustes cederent exterormu, qui licet velhus evellere non tanen pecoris vultum agnoscmet, bala- 
tnm nescinnt, linguam ignorant, et postes sacros nedum terere pedibus sed videre neglignut iedium sacratarum, quamquam if:alum uberibus chucentur. Sauc mirari compellimur veheun'uter (quod vos salten, qui cidem ecelesia, presertim post vestrae promotionis eventum, jam eratis obnoxii, gravaminibus his subsccutis occurere non curâtis, cum, sicut firmiter credimus, illis resistere restrie circumspectionis industria potuisset, qua ad obstacula majora tollenda et faroris exhibenda potiora suffragia vires habet, ad que nihilominus suffragari spes preconeepta debucrat, quam a longe retroactis temporibus et reposuimus in gratiae restre simu et adhuc nodis indissolubilibus repositam retinemus; reverendie dominacioni vestrae devotissime supplicantes quod reconmendatam habentes in caritatis visceribus ecclesiam memolatam contra persecutionum incursus et turbines, eidem vos, si placet, defensionis chyeum apponatis, et indempnitati ejusdem Eboracensis ceclesice que canonicis residentibus orbatam se fore conqueritur super alienatione prefatre prebendx, quam perpetuitatem, occasione clausula pro sustentatione predicti hospitalis apostolieis insertie literis per quandam successionem quasi hericlitariam in successores vestros deputandos ad custodiam hospitalis predicti transfundendam, quod absit, non absyne gravi prejudicio ipsins ceclesiae comminatur, pro futuris post ros temporibus tam pie (puam misericorditer dignemini præcarcre; exhibentes ros, si placet, inter tot gravamina quibus premimur, procuratoribus nostris in curia favorabiles et benignos super promotione propitia petitionum nostrarum quas ipsi vobis nostro nomine dnxerint exponendas, ut qui gravamur in pluribus saltem per ros in aliquibus relevemur. Datum apud Jaceam, xij kalemdas Octobris."

The opposition of the archbishop and the king to this scheme of alimation was successful, as the project was abandoned. The sorercion indeed put his reto upon it, which was decisive. The carclinal sometime afterwards curdearoured in rain to induce hime to alter his deternination. ${ }^{x}$

We must not shut our eyes to the refects in the character of archbishop, Romanns. Persons with his energy and resolution ape very frequently in extremes. He was subject to an unhappy infirmity of temper, of which the Italian blood that was flowing in his reins must have been to a great extent the cause. He was nearly always involved in some quarrel or dissension which had its origin in the clashing of contending interests, or some petty jealousy or dislike. It is painful to trace the path of an archbishop throngh the darkness of the past by the light of commity atel discord.

"Prynne': roll., iii., 416-18, 625. 031. Kot. Parl., i., 33. Fonl., i., 740, 754. 
The relations between archbishop Romanus and his elapter were by no means of an amicable kind. Ile had a feud with the dean, apart from his brother-canons. 'The dean, Robert $\mathrm{I}^{\top} \mathrm{gh}$ tred of Searbrough, got into trouble, among other reasons, becanse he was a pluralist, holding, in addition to his office, the prebend of Husthwaite at lork, a stall at Beverley, and the living of Adlingflete. In September, 1287, the archbishop deprived him summarily of his deanery and his canonry at York, and ordered the chapter to elect a new superior. A compromise seems to have been effected, as in May, 1290, the dean consented to resign all his preferments, the archbishop giving him, at the instance of the king, an amnual pension of 109 marks for his life. He did not enjoy it long, as he died in the same year. At his decease he was in arrear to the archbishop, probally for some dne or fine for non-residence, and the executors of his will, Sir Robert Ughtred, knight, and John his brother, were put under a sentence of excommunication, which was remored in May, 1293.y

The archbishop's contention with the chapter was on the question of his right to hold a visitation of the minster, and when he mooted this claim, he found that he was treading on very delicate and dangerous ground. The controrersy secms to have been so warm that in 1:28\% the king anthorized Edmmul, earl of Cornwall, to act as mediator between the combatants. On the 20th of May, 1288, they arreed to submit the matter to arbitration, the bishop of Norwich acting for the archbishop, and William de Corner, the preeentor of York, for the dean. On the 24th of September the bishop of Chichester took the place of his brother of Norwich, who was prevented by ilhuess from attending. In consequence, probably, of their award, an arrangement was made on the 21st of Norember, 1?90, with reference to the power of visiting the chapter. It contains a great number of minute articles. The chief of them are as follows:-The dean was to pay the archbishop canonical obedienee withont infringing upon the privileges of the chapter. 'The archbishop might visit the minster onee in five years, if he chose, but not by deputy. IJe must intimate lis intention by letter to the ehapter, and they were to give the formal notice. 'The archbishop alone was to enter the chapter-honse, two member's of the cathedral body, who were to be sworn to secrecry, acting with him. Any canon might then make his complaints. If any fault were detected, the arehbishop was to allow the offender six months to anend it, and, in ease of defanlt or neglect, he was to award proper punishment in the chapter-house, with the

$y$ The account of these quarrels is taken chiefly from the archbishop's register.

"Foed., i., 679 . 
advice of the canons.-This is the sum and substance of the reculations about the visitation. Some arrangements were also made abont the hearing of canses, which are of little interest.

The greatest struggle that Romanus was engaged in, and that which cansed him most annoyance and anxiety, was that which he had with Anthony Bek, bishop of Durham. ${ }^{a}$ There hat been for a long time a sorcness between Durham and York on the question of supremaey and the right to hold visitations, which had gircu much trouble to archbishop Wickwaine. The fend was roming high when Romanus came to the see of Tork, but $b_{y}$ the kind interference of cardinal Hugh de Evesham an arrangement was made with the prior and convent of Durham, by which the arehbishop of York was allowed to have the control of the diocese during the vacancy of the see. ${ }^{b}$ This seems to have giren satisfaction, and the sentence of excommunication, in which Wickwaine had inrolved the monks of Durham, was now withdrawn. Romanus, howerer, was soon in the middle of another controversy with Bek, the wealthiest and most influential prelate of his day. It began, probably, about the gruestion of the subjection of the see of Durham to York, which bick was far too ligh-spirited to submit to. In 1290, when Romanns was at the funeral of queen Eleanor, the king in vain endcaromed to reconeile the two Northern prelates. On the 31st of July, 1291, when the archbishop was at Hexham, he sent his clenks, Ienry de Tymparon and William de Thorneton, to biskop lick to projose that the dispute should be referred to arbitration, but the offer was in all probability rejected. Romanus now resolved, if possible, to go abroad and plead his cause before the pope. The king, after much hesitation, allowed him to make the jommey, and he started on the lst of November, 1:91. Jle was honourably received at the papal court, and contimed there till the spring of 1292, but from the silence which exists abont his mission we may conclude that it was unsuceessful. In the beginning of the following year, 129:, matters at last came to a crisis. John de Amelia, a notary, and William de Wrelton, alias De Piks, two of the archbishop's clerks, no doubt under his directions, went to 1 morham to deliver to Bek or his servants a citation from their master. Bek was then in Scotland with the king, but his officials acted as their lord would have done if he harl been at home. John de Maydenstan treated the hostile mandate with contempt, and, seizing the hekless messengers,

"The anthorities are, Pryme's Coll., iii., 156;, 5l60-5, 1293; Rist. P'arl., i., 16:-5; Chron. Tamereost, 110-11, 137; kinghton, en. 2502,2507 ; Contin. Ih. II jorn., ii., 267 ; Jadox Bar.
Angl., 150-1 ; Fuller's Worthies, n.e., ii., 510 ; Irake's Eboracum, 430.

${ }^{b}$ Ilist. Hunelin. Ser. Tres, 73, and ajpendix, 93, etc. 
shut them up in the dungeons of Durham eastle, of which he was the constable. Romanns was abroad when this adrenture took place, but he wrote from Viterbo, where lie was probably with the pope, on the 6th of April, 1292, to his oflicial at York, commanding him to denounee the bishop of Durham as excommmicated. He sent also a request to Bogo de Clare, who, he probably thought, was bold chongh to do anythine, desiring him to beard the lion in his den by proclaiming the sentence in the priory of Durham, at the same time giving lim a quiet hint that it would be well for him to say nothing at all about his being treasurer of lork. Bogo would know Bek well, and would do nothing of the kind. The thonght that he wonld refuse to act seems to have oceurred to the archbishop, as on the 19th of April, a few days afterwards, he issned a like conjmission to the prior of Bolton, who published the sentence of excommmication. Like a wise man, with the fear of imprrisonment before his eres, he kept within sight of lorkshire, for he performed the duty which was assigned to him at Northallerton and Darlington. Bek had been thrice warned, but he eared not a whit for the ban; he kept the two mufortmate officials in captivity, and set at nanght their master.

In the following year the dispute came under the cognizance of parliament. It was laid before the king, in all probability, by Bek, and Edward took the matter up with relemence. it appears that when the bishop of Durham was excommunicated, he was with the king in Scotland, and the monarch regarded the denmeiation of his favomite prelate, whilst he was thus ocenpied, as a personal insult to himself. To obtain the release of his clerks Romanus ought to lave proceeded against Bck in the king's cont. The injury to the royal prerogative was assessed by the officers of the crown at the large sum of $: 20,00(0)$. The arehbishop pleaded his own cause, and tried to justify his conduct. It had never entered into his head, he said, to offer any slight to the king. The bishop of Durham was his suffragan; after repeated warnings he had been disobedient, and the archbishop in exeommunicating him had merely acted in aceordance with ceclesiastical law. In answer to this the roval adrocate stated that Bek was a temporal as well as a spiritual dignitary ; that he was prince palatine as well as bishop of Durham, and that a sentence of excommunication, which was an ecclesiastical rentsure only, would injure him in his secular chanacter. Bek had a right to order the men to prison in his character of prince palatine, with which the archbishop had nothing whaterer to do. The decision of the parliament was manimous against Romanus, and he was committed to the 'Tower for his offener. The nobles, howerer, intereeded for him, and he placed himself 
at the king's merey. He was restored to the royal favour, but only after submitting to a fine of 1000 marks.

"This was not the only reverse which Romanus experienced in the sane parliament. Some time before this the king had expelled the Jews from England, and had appropriated their possessions. Among the sufferers was a person of the name of Bonamy, who had lived at Tork. When Romanus was on his way home from the papal court he halted at Paris, where he met Bonamy. The Jew told hin, that he had lent the prior and ronrent of Bridlington the sum of $300 \%$, which was still owing to him, and begged him to recover it for him. It was afterwards insinnated that the archbishop bought the debt; but this he donied, and it is only fair to believe lim. When Romanus rame back to England he made an official visitation of the priory of Bridlington, and the existence of the debt being proved the archbishop compelled the prior to pay the $300 l$. to one of his officers. It was an obligation, he told him, whieh the convent conld not conscientiously disown. Quite true, my lord archbishop, but the money ought to have gone, not to yourself, but to the Jew or the king. Romanus, by receiving it, put himself at the merey of the prior, who lost no time in complaining of his diocesan for concealing money which belonged properly to the crown. The case was of eourse decided against the arehlishop, but we are not told to what penalty he was subjected. II is conduct, to say the least, was suspicions in the extreme; and most persons will be inelined to think that it was highly reprehensible.

The catalogue of mischief and eontention is not yet exhansted. In 1294. Romanus quarrelled with the prior and sub-prior of the monastery of the Holy Trinity at York, and excommunicated them, taking possession of their goods, although they were exempt from his jurisdiction." He had also a keen figlit witl Bogo de Clare, a well-known delinquent, and the notorious pluralist who has been already mentioned.e 'The archbishop was clearly a hot-headed and a most indiscreet person. Kuyghtom tells us that coretousness was lis chief infirmity, and lis conduct in the case of the Jew would certainly seem to shew that he had inherited that grovelling vice which is said to have (characterized his sire. The contests in which Romanus was perpetually involved bear a melancholy testimony to the way-

'Prynne's Coll., iii., 565-6. Rot. P’arl., i., 99, 100, 120. d Hlicl., 610. c lieg. limmanus. Pryme, iii., 1281, atc. In 1:293 he had sutits with Thomas de Neville and Nicholas de Segrave (Rot. Parl., i., 93). Ite had also a serions aftray with boniface de Salueiis
(Rer. Romanus. Rot. Pat., i., 138).

$f$ Col. 2507. The words which Erasmus nses in his colloguy on "Opulentia sordicla" are anplicable to him, "Illi in hujusumbli sordibus educato preter lucrum nilnil erat dulce" (Collor., ed. $1650,195)$. 
wardness of his temper, his impatience of control, and his unwillingness to brook even the idea of a riral,

"Nee quemrnam jam ferre potest Casarve priorem

Ponpeitusve pareun."

The archbishop died suddenly at Burton, near Bererley, where he had a residence, on the 1Ith of March, 1296. IIis remains were brought to York, and were honourably interred in the minster on the Saturday following.g It is not known where he was first laid ; but when archbishop 'Thoreshy began the rebuilding of the ehoir, he removed the bones of Romamus, and deposited them in the preshytery, placing orer then a marble stone whieh was decorated with brass. ${ }^{h}$

Romanns died in the king's debt, and sccurity was obliged to be taken that payment should be made as far as his eflects extended. ${ }^{i}$ Knyghton tells us that the archbishop's execntors, of whom John de Leke was one, ${ }^{j}$ refused to act, and that the eharges of his funeral were borne by strangers, whilst no grifts for pious nses were made on the day of his interment, and not a prayer was offered up for the repose of his soul. ${ }^{k}$ 'The charge of the temporalities of the see during the vacaney was entrusted to Jolm de Lithegreynes. ${ }^{l}$

After the decease of Romanus his executor's gave into the king's wardrobe a cup of white silver and a ring with a sapphire, which had belonged to him.."

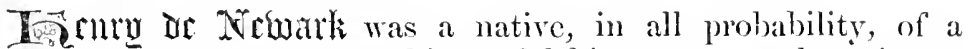 little town in Nottinghamshire. Of his parentage there is no- thing known, but he seems to have been a kinsman of William de Newark, who was a canon of Southwell and archdeacon of Huntingrlon."}

5 MsS. Cotton, Titellius, $\Lambda$, ii., 111 b. Stubbs, col. 1728. I'rymine's Coll., iii., 612. Knyghton (col. 2507) speaks of a mean funeral. In the Chron. Lanereost it is said that the archbishop died abrond (170).

h See Thoresby's Life.

i Regr. Melton, 18, 31. C1. Kuyghton, col. 2502 .

$j$ Reg. Newark. In 3 lith of Eilw. I. John de Leke was the king's ahmoner (Prynne, iii., 1166). Chaplain of prince Edward, 28th Edward I. (Lib. Garderobac, 31). There are letters to the pope in his behalf from Edward 1. and
II. in Ford., i., 987, 1005, 1009, 1016 ; ii., 10, 46. IIe was bishop elect of Dunkeld in 1309 (Foed., ii., 86), and in 1311 the poje elected him arehbishop of Dublin (ibid., 132). Tle diad in 1313, and was buried in Westuninster (ibbey (Cotton's Fasti, ii, 1.1).

${ }^{k}$ kityghton, col. 2507.

1 pryutes coll., iii., 67t.

"m Wardrobe Acesunts, $315 . \quad 1$ erift of his to the king is mentioned, ibid., 3 is.

" Ile was archdeacon of IIuntingdon in 1281 and $12 \times 2$, and died in the lat ter end of 1286 (Le Nere, ii., 19). He 
Newark appears to have risen in importance through his state scrvices and his conncetion with the court. He was one of the derks and chaplains of Edward I., and in that capacity he was sent by the king to the pope on the 12th of December, li:s 6 , to anmonnce the part which he intended to take in the proposed crusade, and in the following year he was acting as the king's proctor at the papal court, and was busily engaged in making preparations for that experition. ${ }^{\circ}$ In 1281 he was appointed to quict the disturbances between the English and the Hollanders, $p$ and in Jannary, 1283, he was one of those who were ordered to collect the subsidy for the expedition into Wiles within the bishopric of Durham. ${ }^{9}$ On the lst of Febriary, in the same year, he was selected to arrange the amount of scrvice that was due to the king from the knights to the north of the Trent.r In the summer of 1290 Newark was sent as an ambassador to Scotland to contract an alliance between the heir to the English throne, and Margaret, daughter of Eric king of Norway, queen of Scotiand.s 'The year 1291 saw him with Edward I. at Norham, and he was deeply involved in the intricacies of Scottish polities. ${ }^{t}$ In 1.292 the king granted him letters of protection." On the 1st of January, 1296, he was one of the commissioners who were deputed to make a truce with France, and treaties with Guelders and Flanders. ${ }^{v}$ Indeed, he seems to have taken a very prominent part in public affairs during the reign of Edward I., and to have been a thorough man of business and a skilfnl and actire statesman. ${ }^{2}$

Thilnt Newark was thus engaged in the service of his country he was in the possession of numerous and important ceclesiastical preferments. In $12 \% 1$ and $1275 \mathrm{I}$ find that he

was also prebentiluy of Farreudon at tincoln (Reg. Romanus). On July 11 , 1257 , archbishop Romanus denounced those who had abstraeted a charter which testified to Thomas de Lineoln, rerk, being the leir of Mr. William de Newark. On Feb. 11, 1288, the sime lrelate ordered Mr. Henry de Newark, arehdeacon of Richmond, to convert to its intended purpose the 100\%. which Mr. William de Newark, archdeacon of Huntingdon, gave in lis' will to hire a chaplain to sing for his soll. 1289, Mareh 21, the sim of 10 marks, which had been wiven to IIatilda Arletyn, of Newark, deceased, is 1)ticl oree io the arehbishop by $\mathrm{MI}$. W. de lielmu and the other executors of Willian de Newark; 6 marks of it are ordared to be paid by the arehdeacon of ficlunond to the danghters of John de Egliston; and the other 4 to the nums of Molseby by Mr. W. de Blida (Reg. Romanus). Cf. Thoroton's Notts, 197 .

On June 18, 1298, archbishop Newark collated his chaplain, William de Newark, to the stall of North Muskham at Southwell, which he had himself racated. He seems to have held it nutil 1310 (Le Neve, iii., 428-9).

"Pryune's Coll., iii., 193, 197. Foed., i., 537, $512 . \quad$ "Fœed., i., 597.

" Pryme's Coll., iii., 303.

$r$ Foed., i., 625.

\& Hbid., i., 731-6. Prynne, iii., 395, $398-9$.

t Foed., i., 767, ete. Prynne, iii., 501 , etc. " Pryme, iii., 683.

"Ibid., 7.18. Foed., i., 834-5.

w Kuyghton (col. 2528) calls him " magnus elericus." 
was prebendary of Brownswood in St. Panl's eathedral, $x^{*}$ and in Jamnary, 1293, he occurs as a canon of the church of "Irells." In 1296 he racated the living of Basingham, in the diocese of Lincoln. $z$ But it was with the province of lork that he was principally eomected. On the 30th of March, 1:2ro, he was presented to the living of Barnby, which lie resigned in the same year, ${ }^{a}$ and on the death of archbishop Giflard in 1:279 the king marle him and Thomas de Normanvill the keepers of the temporalities of the see of York. With archbishop Wickwane Newark seems to have been a great favourite. Soon after he became primate he made Nerark archdeacon of Richmond, and on the 20th of December, 1280, he was collated to the stall of Holme, which he resigned for that of Strensal on the 9th of Norember, 1283.c In that year the archdeacon secms to have been adrancing his master's interests in the court of Rome, and they were associated together in more than one pecuniary transaction. ${ }^{l}$ Soon after arehbishop Romamus came to the see re find Newark lending him money, and the arehdeacon fonnd a patron in that prelate, who gave him the stall of Great Muskham at Sonthwell on the 4 th of June, 128\%, and appointed him his vicar-general on the 12th of Narch, 1288, durme his absence with the king in Gascony ${ }^{f}$ In the spring of 1:290 Newark was eleeted dean of York. The arehbishop ordered the ehapter to install him on the 12th of May, and that ecremony took place on the 10th of June. ${ }^{g}$ Newark then resigned the archdeaconry of Richmond, but he held the stall of Weighton with the deanery till he was advaneed to the primacy. ${ }^{h}$ In his position as dean he had a collision with archbishop Romanns, who endearoured to extort from him a profession of obedience, and an acknowledgment of his right to visit the cathedral. ${ }^{i}$ I have already stated how this dispute was arranged, and it is umnecessary to refer to it again. Newark was prescnt on the 6th of April, 1291, when Romanus laid the foundation-stone of the new nave of the minster, ${ }^{j}$ and in the progress of that work he conld not fail to be deeply interested. 365.

$x$ Newcourt, i., 120. Le Neve, ii.,

y Prvnne, iii., 577.

= Miss. Harl., 6951, 32 b.

a Res. Giffarl.

$b$ Prymne, iii., 224. Nommanille was a justiciar and excliactor beyond Trent (Rot. Parl., i., 38).

c Reg. Wickwaine, 3, 11 1. 'Torre says that he was made archrleacon of Richmond on Nov. 12, 1281.

d Res. Wickwainc. In 1286 Newark farmed the prebend of Ulleskelf, ancl

rebuilt the homses belonging to it near the minster (lier. liomanns, $69 a$ ).

e 'The stall was burdened with an ammual persion of so marks to Adenulphus, a carbinal, by an old arrangement. Newark was one of the sureties of liomanus for the galynent of his fine to the king (1)ake's Eboractm, li30). lieg. liominus, Tob.

$f$ Reg. Romanms.

5 Ile was arlmitted on May gO (Let. (apiit.). "Le Neve, iii., 1:37.

i Acta Capit. j Stubls, col. 17:8. 
Archbishop Romanus died in Mareh, 1296, and when on the 26th of that month the ling gave his permission to the chapter to choose a new primate, they responded by electing their own dean on the 7 th of May. ${ }^{k}$ The appointment appears to have satisficd the king, who gave his assent to what had been done, on the 5 th of $J$ me. Edward also wrote to the pope, begging him to shew farour to Newark, and to give him the pall. He told him that he had made him a guardian of the kingdom during his owu absence in Flanders. ${ }^{\text {I }}$ For some reason or other, with which we are maequainted, nearly two years passed away before Newark was consecrated. That eeremony at length took place in York minster on the 15th of Jume, 1298, Anthony Bek, bishop of Durham, officiating, with the assistance of the bishops of Iichfield, St. Asaph, and Cork. ${ }^{m}$ The temporalities had been restored to him on the 2.2nd of June in the preceding year. ${ }^{\text {It }}$ was by the special permission of the pope that Newark was consecrated at York. He professed his inability to risit the papal cont on acconnt of the wars which were then raging abroad. ${ }^{\circ}$

Archbishop Newark has left rery little at York by which he can be remembered. II is life, after his aecession to offiee, was so short that he had no opportmity of distinguishing himself in his new sphere of duty. In 1297 he was a member of the conncil of Edward the king's son, ${ }^{p}$ and in that year and 1299 le was summoned to the pariiament at London. ${ }^{2} \mathrm{He}$ is also mentioned in comnection with the gathering-in of the taxes within his diocese, ${ }^{r}$ and once or twice he eame into collision with the royal prerogative in judieial matters; the eases, however, were of slight moment.s One pious act of the arehbishop has been handed down. He covered with buildings a pieee of waste ground at Hull, and with the rents he endowed a chaplain for cach of the manors appertaining to his see, at Cawood, Burton, and Wilton, and a chantry priest, who was to perform service at the altar of St. William, in York minster, for the souls of the kings and queens of England, and the primates of the Northern provinee. ${ }^{t}$

Archbishop, Newark died on the feast of the Assmmption of the Bilessed Virgin, 1299, and was interred at York." He left

\footnotetext{
s Thid. MSs. Cotton, Vitellius, A, ii., 1116 .

1 Reg. Newark. Pronne, iii., 675.

"Rer. Newark. Stubbs (col. 1728) makes the day June 21 , and MSS. Cotton, Vitellins, 1 , ii., $111 \mathrm{~b}$, the 25 th. "Prynne, iii., 767. In Act. Capit. Ebor., $8 b$, is a list of some stock betongitus to the treasury which the archbishop had whon he was first elected.

"Ilid., 612. Kinyghton, col. 2507.
}

p Parl. Writs., i., 61.

7 Ibid., i., 55, 78.

r Prynne, iii., 671, 692, 740-1, 789.

Tilkins, ii., 235.

- Prynne, iii., 779, 793-4.

$t$ Ibid., 862-3. Cf. Fabric Rolls, 236, where some work of his at Newark is perhaps alluded to.

" MSS. Cotton, Vitellius, A, ii., $111 \mathrm{~b}$. Stubbs, col. 1728. 'Trivet, 316 -cirea. 
a will, of which two distinguished brothers, Willian and Robert de Pickering, both of them deans of York, were the exccutors. On the 18th of July, 1306, arehbishop Grecnficld appointed some commissioners to receive the account of their administration. The task of the executors secms to have been a thankless and a laborious one. They did not obtain their release till the 29th of Mareh, 1311, and it was then found that they had receired 5592/. 16s. $9 \frac{1}{2} \mathrm{~d} .{ }^{n}$ and paid 6010/. 2s. $0 \frac{1}{2} \mathrm{l} .$, so that they were actually losers by their executorship.

\section{Nhomas ar conturiogr was born within the provinee of} York, and was a native, in all probability, of the little village of Corbridge in Northumberland, which is sitnated on the 'Tyne." It was formerly a place of so much importance that it sent mombers to parliament; but its incipient greatness was soon

" Reg. Greenfield. On "die Sabbati p. f. Assump. B.V." Newark's executors proved his will before the chapter. On "die Martis p. f. S. Gregorii," at the request of Peter de Ros and $R$. de la Ford, canons of York, the goods of Newark were sequestered on account of something due to the church. They were deposited in the house of the friars minors at York, and on the next day, G., the chamberlain, and H. de Newark, friars minors, bronght nine large and four small chests to the chapter (Act. Capit., 9 b). On Nov. 21, 1301, a commission was appointed to receive the aceounts of Newark's executors (leg. Corbridge).

* Reg. Romanus. Several other persons of the name of Corbrilge, who were probably related to the arclbishop, occur in the registers of York.

H. Corbridge was a clerk of archbishop Giffard.

Thomas de Corbridge las licence to be ordained, beins then an accolite, April 9, 1301. Sept. 25, 1301, Mr. Thomas de Corbridge, dictus de Malton, to the church of Brumum. Sept. 26 , licence to him to be non-resident for seven years to study. Sepit. 29 , he, being the archbishop's clerk, was collated to a stall at Ripon, which, after all, he did not obtain (Reg. Corbridge). 1313, Oct. 4, licence to Mr. 'Tliomis: de Corbrig, rector of $\mathrm{Ki}$ lask (Kippax), to be non-resilent for thrce years (Reg. Greenficld). Fcb. 28, 1318, a similar permission (Reg. Melton), and on Sept. 7,1327 , he was made collector of the money to be raised for the university of Oxford (ibid.). In 1318, Thomas de Corbridge, S.T.P., became canon of Thorngate, at lineoln, and he wasburied there. Ilis arms, on a cross fitche five escallops, were on his tomb (Le Neve, ii., 222). Prynne's Coll, iii., 903. Rot. Parl., i., 39\%. In 1313, Thomas de Corbridge was ordered to go abroad with the king (Fod., ii., 212).

Robert de Corbrilge, instituted on Sept. 25, 1301, to the living of lioos on the presentation of Kirlham prinry. Sept. 26, licence of non-resilence for seven years "ald scolis." On Auril 9, he had letters dimissory. He made his will on the Saturday after the feast of the Cirenuncixisn, 1317, being then rector of kons. To he buried at the east end of the churchyarl. 100s. for" his funemal expenses, and 15 marks ind his best portiphor noted to Peter de la Watrobe to celcluate for him for two years. 'To the church a missal and his better vesiment. My sister Alice and Stephen and Andrew her children, and Peter, son of my brother Richard, called Mareachill (P'r. Fob. 1, 1348). 
absorbed in the wealth and influenee of the neighbouring town of Newcastle. Hexham, with its stately monastery, was in the immediate vieinity, and young Corbridge would thus be bronght into conncetion with the officers of the see of York, and their lord and master. He reeeived an university edueation, and was a master in theology and a person of reputation and learning. ${ }^{x}$ Stubbs eommends his erudition in the highest terms, and speaks of him as a kind of admirable Criehton. ${ }^{y}$

The first piece of preferment that Corbridge held at York was the stall of Osbaldwick, but it is not known when he was first promoted to it. ${ }^{z}$ This he gave up in 1279 , when he was adranced to the chancellorship on the elevation of Wickwaine to the archiepiscopate. ${ }^{a}$ On the 16th of January, 1280, he and Henry de Newark, archdeacon of Richmond, were appointed to enquire into the recent election of Robert de Scarborough to the deanery. ${ }^{b}$ On the 25 th of Jume he was eollated to the prebendary of Stillington, ${ }^{c}$ and in 1281 he was at Rome on some business connected with the minster, and arehbishop Wickwaine defrayed the charges of his jomrney. On the 16th of Jume, 1290, he was made sacrist of the chapel of St. Sepulchre at Iork, and he resigned the ehancellorship. ${ }^{d}$ This office, which was an honourable and luerative one, involved its oceupant in no little difficulty and annoyanee. It had beeome racant by the death of Pereival de Lavannia or Lavagna, an Italian of rank and wealth, and at his decease Nieholas IV. gave arehbishop Romamis permission to bestow it upon an Enghishman. Romanus offered it to Corbliclge, who aceepted it on the condition that he should have it without suit or annovance of any kind. On these terms he gave up the ehancellorship, to which Thomas de Wakeficld, the sub-dean, was appointed, William de Blida sueceeding lim in that office. Corbridge, however, on taking possession of the manors of the sacristry, found that there was trouble and litigation enough, e and, availing himself of the eondition that he had made, he again entered into his stall as chaneellor. He ought really to have known what the eondition of the sacristry was before he accepted it; by his present conduct he threw the ehapter of Tork into confusion, disloeated

s 'Trivet, 316. Knymhton, col. 2528.

"Stubbs, col. 1728. "Sacræ theologire doctor egregilis, et non solum theologix, immo quod raro uni nortalium accidit, omninm artium liberalium professor extitit incomparabilis."

2Reg. Wickwaine, 59. Cf. Le Neve, iii., 206.

a Let Neve, iii., 163.

${ }^{b}$ Reg. Wickwaine, 58 b. Dec. 17 . 1279 , licence to the chanrellor and $\mathrm{Mr}$.
Ifugh de Evesham to examine clerks (ibid.).

c Reg. Wickwaine, 59.

d For the account of this controversy cf. Acta Capit., i., 2. Reg. Romanus. Stubbs, col. 1729 .

- The church of Calverley, the revenues of which John Scot claimed against Corbridge. On July 6, 1290 , Romanus ordered James de Langtoft, his sequestrator, to seize them. 
the arrangements which had been recently effected, and male Wakefield and Blyth his enemies. When his conduct, which was justifiable enough, came to the cars of the archbishop, he regarded him as an intruder and threatened to proceed anainst him. Blyth now claimed to be installed as sub-clean, but the chapter civilly declined, and the choir was watched lest the archbishop should come and bring about the installation. The precaution was a wise one, for Romanus came to the minster, and the door into the choir was not opened to armit him till he had promised to do nothing about Blyth until the dean, Henry Newark, had returned from Scotland. When the dean eame back he visited the archbishop at Ripon, and the primate begged him to recal Corbridge who had started for Rome, and to get the dispute quietly arranged. Newark assented; but when he reached lork and called the chapter together, he would be astonished when he saw Blyth present a citation from the archbishop, ordering the dean and canons to appear before him. This looked rery like double dealing on the part of Romanus. The chapter now despatched Philip de Alnwick, their anditor, and Andrew de Tang, a notary, to the archbishop who was still at Ripon, to expostulate and to express their dislike of controrersies and quarrels. The primate exhibited his usual infirnity of temper and spoke very angrily and indiscreetly, and the two emissaries of the chapter were thrown into prison. The dean and his brethren were now summoned to appear before Romanus at Cawood, but they were too cautions to pay any attention to his bidding. Corbridge in the meanwhile was pushing his case at Rome, but he was unsuecessful, and, refusing to cede his point, he was excommunicated on the 2rth of July, 1290, and the sentence continued in force till the 21 th of March in the following year.

On the 5th of September, 1299, Edward I. gave the ehapter of York permission to elect a new archbishop in the room of Henry de Newark. $f$ They met on the 12th of Norember, and John de Metingham, John de Cadamo and Robert de l'ickering were appointed to scrutinize the votes. The majority fixed upon Corbridge, ${ }^{g}$ and on the 16 th the king assented to their choice. ${ }^{h}$ He went to Rome and was consecrated by Boniface VIII., on the 27th of February, receiving at the same time the pall. The pope, howerer, obliged him to resign his right of election into his hands and afterwards gave him the archbishopric of his own anthority. On the 30th of April Edward I. ordered the temporalities of the see of lork to be restored to him. They 
had been in the custody of Geoffrey Russell and Lambert de Trykingham. ${ }^{i}$

When Corbridge beeame archbishop of York he of course resigned the sacristry of the chapel of St. Sepulchre and the stall of Stillington. They were given by Boniface to his greatnephew Francis, son of Peter Gatano, a noble Italian.j In 130). Gactano scems to have resigned the sacristry, and Corbridge, at the request of the pope, gave it to Gilbert de Segrave, a person of great learning and ability, who was afterwards bishop of London. ${ }^{k}$ Edward I., however, was most wishful that one of his orn clerks, John de Bush, should have not only that office, but the prebend of Stillington, considering that it was his right to give them away as they had become racant by the archbishop's accession to the primacy. Corbridge was now in a difficulty ; he refinsed to adnit the king's right, and pleaded in his defence the wishes and claims of the pope. On the 6 th of June, 1301, Bush came to the archbishop at Selby, bringing a letter from the king who was then in Scotland, in which he remonstrated with the primate for his disobedience. The arehbishop replied that he was ready to appoint a commission to enquire into the merits of the ease. Bush murmured at this, and denicd the neeessity of the proceeding, upon which Corbridge quietly obserred, that the king, when he presented him, would of coinse do nothing contrary to the law. Bush now tried a legal remedy, and he was successful. The archbishop was bronght before the king's conrts and lost his cause, being deprived, as a pmishment, of the temporalities of his see, which remained in the king's hands till his decease. Bush recovered the prebend of Stillington, for which he had been a petitioner. The sacristry came into his hands at a later period. $\Lambda$ s soon as Corluidge died, the ehapter of York acted very ungenerously, and dirl an act of gross injustice. They removed Gilbert de Segrave from the control of the chapel of St. Sepulchre, and cntrusted it to Bush.? 'The appointment, as the result sliewed, was a most unsatisfactory one, for the new sacrist paid no attention to his cluties.

i MSS. Cotton, Vitellins, A, ii., 112. Stuble, col. 1729. Pryme's Coll., iii., 860. Buring this tine the king and areen ocerified the residences of the archbishop at their plensure. We find them at Lomton ant Cawood (Lib. (iarlerobit, 51, 93, 105).

i For :m alcenut of this controverst, see Prymus, s6o, 1111, 1132. Feril., i. 1600; ii., $21-21$. Stubbs, col.1729, where there are serral statements which are not verified by historieal evi- denee. Abbrev. Plac., 251-2.

k On Sept. 13, 1309, archbishop Greenfiek empowered the abbat of St. Mary's, York, and Robert de Riplingham, the chancellor, to enquire into a clain for 40 marks which Gilbert de Serrave, arehdeacon of Oxford, made on the executors of Corbridge (Reg. Grecufield).

'A elerk of the king 28th Edward I. (Wardrobe Accounts, 314); rector of Beckenham, Kent, in 1306 (Hasted, 
This was not the only eollision that Corbridge had with the king. There was a great deal of angry fecling between them about the chureh of Beverley. The archbishop gave great offence by his conduct whilst Edward was in that town, and, as a mark of his displeasure, the liberties of the place were taken possession of by the crown. They were restored on the l.1.th of June, 1301." In 1304 Aymon de Carto, the provost of Beverley, and Corbridge, had a very serions quarel on the subject of the visitation of the ehureh, to which the king was made a party. The provost was anxions that the matter in dispute should be decided, not at Rome, but before the national courts, and Corbridge was as eager to prevent this. The archbishop had many charges against Carto for neglect of duties, extortion, ete., and besides all this, he was a phuralist, as he held, in addition to the superintendence of the church of Beverley, the precentorship of Lyons, the provostship of Lansanne, and the ehimeh of 1)uncarnayn in the diocese of Lismore. In June, 1301, Carto was excommunicated for his contmmacy, and Robert de Alberwick was made provost of Beverley in his room. He was afterwards raised to the episcopal bench abroad."

The debated point of the right of the Northern primate to earry his cross erect was not lost sight of whilst Corbridge was at York. On the 25th of April, 1300, the archbishop of Canterbury wrote to the bishop of London to say that his brother in the North had been following the obnoxious precedent which his predecessors had set, and he ordered that no one should stoop to receive his blessing. On the 25th of Jamnary, in the following year, he sent a deprecatory letter on the same subject to his suffragan the bishop of Lincoln. ${ }^{\circ}$

The name of arehbishop Corbridge occurs very rarely among the state papers of the day. In 129t he had the royal letters of protection.p In 1300 I find him attesting the exemplification of the bull of pope Boniface for the extension of the truce between France and England.4 In 1301 he was smmmoned to the meeting of the parliament at Lineoh, and to those at Westminster and London in 1302. In 1303 he was recprested to send his contingent to serve against the Scots.r 'The great Northern war was now raging, and the names of Wallace, Brus and Donglas wonld be ringing throngh the whole of Yorkshine. The eity of lork would thus become the great rendezrous of

- 88); canon of St. Dirvid's in 1307 (Parl. Writs, i., 185); a public notary (Pell Records, 105); a trier of petitions in parliament, and much occulyed in parliamentary work (Fol., i., 973. Rot. Parl., i., 182. Parl. Writs, var. locis, etc.). Stubbs, col. 1729. m Prymne's ('oll., iii., s6i.

"Rrug. Corbrilige, 9s-100. Rot. Parl., i., 162.

- Wilkins, ii., 255, 261.

p l'ronue, iii., 59s. o lbid., 872

r Tirl. Writs, i., S9, 112, 11\%, 116, 367,370 . 
the English armies and a place of unusual importance. In 1298 the courts were removed to it from London, and thes continued there for seren years.s The king and his family were frequently in the neighboiuhood. ${ }^{t}$ The following extracts from the archbishop's register will throw some light upon the history of the time as well as upon the proceedings of Corbridge within his own diocese.

1301, May 31. The archbishop receives from William de Newark, canou of Southwell, a missal of the York use, which we promise to restore to him when it is required. Jume 14. The will and codicil of dame Eva rle Tibtoft" are proved before the primate in the honse of the friars mimors at Doncaster, and administration is granted to Roger de Wordham, rector of Arksey, and Adam de Radegrare, rector of Little Blakham in the diocese of Norwich. Jume 1\%. An indulgence of 40 dars for the ehmeh of Ripon in which the relies of that glorious confessor, St. Wilfrid, are prescrved. ${ }^{r}$ Jume 19. The archbishop writes to Henry de Lacy, earl of Lineoln, allowing Michael de Nerton and Reginald de Kington, friars minors, who are going with him to the wars of Scotland, to act as confessors for natives of the diocese of York. Sept. 24 . A dispensation of non-residence to Mr. Ralph de Xevill, rector of Middleham, ${ }^{x}$ to enable him to study for two years. Oct. 3. A commission to Patrick de Braferton and Richard de Stowe to enquire for those who have deserted from the army in Scotland, having received their mages." Nor. 2. John de Care and Ralph, our bailiff at Beverley, appointed justices within that liberty to see into the use of had noney. Dec. 1\%. Edward de Clement gives to the trea-

Pot. Parl. i., 113.

t See the Wartrobe Acconnts. Walsinghan, 7t. Kuychton (col. 2521) mentions the subsidy granted by the acchbishn and the clergy tomards the war.

" Dauchater of Pain de Chaworth (D)igd. Hon., ii., 38). On Oct. 10, 12!s. the adninisiration of the efferts of Sir liobert re Tipetoft, knimht, was sranted to dame Era, lis widow, Sir baldwin de Hanmers, knight, and linger de Wrtham, priest (Reg. Newark). Sir Robert was with Edward I. in the Holy 1 and ('Test. Vetust., 8).

" (p. Fabric Roll- of York, erl. Surlees suricty, 235. Walbran's Ripon, ڤ6)

v () July 15, 1300, William Namy loring the earl's will to 'Thorp with his ealc anumderl, and relivers letters

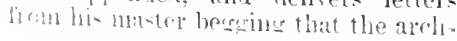

bishop s seal might be put to it, which was lone. For the acts and deeds of this prince-like noble, - the greatest man in the North of England, see Dugd. Bar., i., 105, etc.

: On Sejt. 19, 1306, licence to $\mathrm{Mr}$. Robert de Teville, rector of Well, and deacon, to study for two years (Reg. Greenfield). These were, no doubt, members of the barorial house of $\mathrm{Ne}$ ville. On Jume S, 1311, a confirniation of two chantries in the chapel of 'Thorakleby par. Arsgarth, made by the kins, the earl of Richmond, and Mary de Feville, lady of Middleham (ibid.).

y In 31st Edward I. the sanctuarrmen at Beverley and many thonsands of thieres and outlaws had been allowed to enlist. This accounts for the character of the army (Pryme, iii., 1010). Cal. Rot. Pat., 60.

- In 1299 a statute was rased against 
surer and chancellor two piles and three ordinary trussels for the archbishop's mint. ${ }^{a}$

1301, July 19. The will of the comntess of Warwick is proved at Sprotburgh before Reginald de St. Albans and Willian de Beverley, the archbishop's elerks, John de Wolfington, dioe. Worcester, representing two of the executors, (iny, carl of Warwick and Sir John de Hastings, and John de Schukeberewe appearing for Robert, prior of Kenilworth, and Mr. 'Thurstan de Keswiek, co-execntors. ${ }^{b}$ Sept. 15. A general letter against those who have broken into Beverler park. ${ }^{c}$ Oct. 2. Licence for George, rector of Dimnington in MIorthen, to be absent from his living for a year at the request of Sir Brian Fitzalan.d Dec. 20. Sir William de Ros, jum, of Ingmanthorp, does homage to the archbishop in the chapel of Scrooby for the manor of Muskliam.e Dec, 25. Licence to John de Drokenesford, $f$ canon of York, to have a private confessor.

1302, Mareh. Licence for Roger de Bhida, rector of a moiety of the chureh of Rotherham, to be alssent for a year in the service of the earl of Warren. ${ }^{g}$ Nor. 29. A licence for Humphrey, son of Walter de Beauchamp, rector of Harewood, to be nonresident for a year to enable him to study. ${ }^{h}$

false money, pollards, ete. (Statutes, i., 131). In 1301 the use of foreign money was prohibited. Walsingham, 77 . Food., i., 919. Wikes, apud Gale, ii., 127. Statutes of the Realm, i., 218.

a In 1300 liberatio cuneorum. Pontius de Couwers and Simon de Senis the archbishop's moneyer's (Reg. Corbridge).

${ }_{b}^{b}$ Mande Fitz Geoffrey, widow of William de Beanchamp, earl of Warwiek, died in May or June, leg8 (I) Iigd. Bar., i., 229). Cf. Test. Tetusta, 52-4.

c A statute was passed about breaking into parksin 1293 (Statutes, i., 111). The parks at Beverley gave the archbishops of York much tronble.

d For the splendid services of this great man see Duscl. Bar., i., 53. Wis monument in Bedale church is one of the finest sepulchral memorials in England.

e Ingmangthory is near Wetherhy. On Oet. 11, l29s, the archbishop received at York the homage of Nir William de Ros, jun., of that place, for the manor of Muskham, which he held by knight's service, and his brother, Thomas de Ros, did homage for the manor of Douseby, co. Iincoln, which he held by the same tenure. There is a good deal of information abont this family in Thoroton's Notts, $3.16,374$. In 1300 'Thomas de Ros, sm of Sir William de Ros, of Insmangthorp, did lomage in the presence of 'Sir William de hos, his brother, for the manor of Donselyy.

$f$ He never actually obtained a stall at York. A very great man, a conrtier, and a statesman. Camon of Northwell, at Sonthwell, 1301-9 (Le Neve, iii., $440)$; rector of 1)alston, Cumberland, 1292 (Rep. Romanus) ; rector of Childwall, 1307 (Res. Langton, at lichfield); camon of Lichfield, IT chls, and lincoln (Le Neve, i., 595, 635; ii., 191); kerper of the king's wardrobe, 1301-5 (Parl, Writs, i., 105 , ete. Mugel. ('brom., 31); limutemant, trensurer, and rhancellor of the exrhequer (Cil. Rot. l'at., fis. l'ell Recorls, 116. Matox, ii., 165, 305); cf. Parl. Writs and Foul., in many places; chanlatin to the polpe; bishop of Bath and If ells, 1304-1329.

5 I very great man, and the zeneraliseimo of the army in the North. 'livet, 299, Kuyghtoi, col, 252t, hot. Seot., linel., and Parl. Writs, passim. ('l'. Dunel. Bar., i., 80, cte., Hunter's South forkshire, and the llistory of the Monse of Warren by Matson.

h $1 V$ altop re Beanchimp of Alcoster was a brother of William earl of War- 
1303, Jan. 11. An indulgence of forty days to all praying for the king and gucen and their ehildren, the peace of the kingdom and the good estate of the clmreh. ${ }^{i}$ Feb. 15. A mandite to the vicar of Thorp against those who have broken into the treasury at 'Thorp, and carried away, among other things, charter's and mumiments relating to onr ehureh. April 13. An orrler to pray for the king and queen, his son and the army grome against the Scots. May 2\%. Licence to Sir William de Vavasour to choose a confessol whilst he is absent in the wars in Scotland.j August 4. We have received by the hands of Robelard, our valet, from Wralter de Aileshury, executor of the will of Eilnmund, late earl of Cornwall, ${ }^{k}$ a ring of gold which was bequeathed to us in his will.

130 H, Feb. 28. Wandate to the chapter of Bererley to prerent tomprinents and duels in Lent. ${ }^{l}$ Mareh 30 . Licence to Sir Cieoffrey de IIotham, liniglit, to have an oratory for life within his manor at Cranswick." March 30. Commission to conscerate the cemetery of the Carmelites who have lately taken up their abode within the bomdaries of the parish of St. Saviour, lork. Jume 11. An indulgence of forty days for the fabrie of Lork minster. ${ }^{n}$

Archbishop Corbridge dicd at Laneham, Notts, on the 22nd of Scptemler, 130t. His remains were removed to Sonthwell, and were interred in the collegiate chmreh on the 29th. ${ }^{\circ}$ His

wick (Datd. Bar., i., 229). Cf. Rot. Parl., i. 199. IIe was seneschal of the kine's lospire (lib. (tarteruba, 13, ete.)

i l'rynue, iii., 1153. The papacy was nowin trouble (Walsingham, 87-8). Nlar. 26, 33rd betwel I., an order to the krepers of the spiritualities of York for prayers to be ollered up for the sonl of Blanche duchess of Austria, sister of Mlarsaret yneen of England (Prynne, iii., $1107-8$. Ford., i., 972).

j Of I Iaslewool, which lie had leave torpenellate, 1sth bilward 1. (Cal. Rot. Pat., 53), rastos eiv. Ebor, 5th Elward 11. (ilid., 7:3), and a creat soldier. Cf. bued.13ar., ii , 19. Itis will is in the Ihurhann Wills, ii., 13, ete. 'The chureh of Jink will fomg treasure his name. Jan. 1, 130m, liobert le Tasasour, strbleacon, shll of Sir William le Tavasonr, to the rimpols of lireston (Res. Corloridese). II alter le bavasour was son and heir of Sir Willian. On J)er. 19, 1315, bishop, Kellawe errants the narriage of Alicmer, lis widow, "ratione numerii de Cokefithl," to Nicholas, som of William de IHultely (Ro... Kellawe, $262 a$ ).

${ }^{k}$ I combin of the king. He died at Asherugge, Bucks, where he had foumled a college, on Oct. 1, 1300, s.p., and was buried with great ceremony at Westminster abbey (Walsingham, 78). 'This ring was for the arehbishop for the time being (Fabrie Rolls, 214). On sSth Angust, 130t, the archbishop cranted in influlgenee of forty days for the repose of lis soul (Reg. Corbridge). Food., i., 930. Lib. Gard., 32-3.

$l$ 'These jousts, etc., generally marked the presence of the court or army. They were sometimes put down with a liigli hand. Dee. 30, 1299, mandate to the sherifl of Yorkshire to prohibit tomnaments (Foed., i., 917).

${ }_{n}$ Not mentioned by Dugdale or in any peligree of the family. He was wie of the collectors of the quindisme in Yorkshire in 29th of Edward I. (Rot. Parl., i., 242). Abbrev. P'lac., 279. Abbrev. Rot. Orig., i., 249. Parl. Writs, rar. loc. He was a partizan of thomas of Lincanter (Fod., ii., 230). In 1330 he fonnded a louse of Anstin friars at Hull (CoH. Top., ir., 132).

"Printerl in the Wabric Rolls, 151-5. MLs. Cotton, Vitellius, A, ii., 111. 
resting-place is beneath a large blue marble slab close to the pulpit. It was originally covered with a brazen effigy of the prelate which has been destroyed, but the inseription which ran around it might recently be deciphered. $p$

'The arehbishop left a will, of which Lambert de Trykingham, Mr. John de Nassington, senior, and William de Jafford were the executors. ${ }^{q}$ On the 5th of Jannary, 1311, archbishop Greenfield appointed William de Estden ${ }^{r}$ and other's to reecive the account of their administration, and on the 21 th they were released from their responsibility. The eare of the temporalities of the see during the vacancy was placed in the hands of Lambert de Trykingham and John de Byrons.s The dean and chapter, as usual, attended to the spiritualities.

TW illiam de Grenfeud, or Grenfitid, was the next arehbishop of York. Ife was in crery respect a most distingnished man, being a wise and active prelate and an illustrious and useful statesman. The presidents of the sce of York during the fourteenth century oceupied a high position among the great men whom it was the policy of the Elwards to gather around them, and their good deeds will be long remembered in the North of England.

The birthplace and parentage of Greenfield have not been diseovered, but we know that he was comected with several families of antiquity and distinction. ${ }^{l}$ IIe was perhaps a native

Stubbs, col. 1729. Ols. Se1t. 30 (Chron. Lan., 202).

${ }^{p}$ IIistory of Sonthwell, 277.

q Lambert de Trykingham. A justiciar and a baron of the excheruer (Dngd. Orig., 36, 39, 41, etc.); rector of Harby, co. Leicester, 1275 (Nichols's Leicestershire, ii., 213); the king's tallager, 33\%d Edward I. (Malox Ex., i., 74.1); canon of IIallonghton, at Southwell, 1310 (Le Nere, iii., 423); master of Sherburn hospital, Durham, 1313 (keg. Kellawe, 238). Cl'. M'arl. Writs, vai. loc. Foss's Judges, iii., 533.

Joln de Nussington. A canon of York. It is imposible to sleak here of this great man and the serviees and distinctions of his family.

Hilliam de Iafford was rector of Croft, to which he wats institıted Nov. 2, 1300 (Res. Corbridge); a canon in
St. Sepulchre's chapel at York. On 22nd Angust, 1312, Nicholas, vicar of Topeliffe, and John de Eseby, the executors of his will, were relcased (Rer. Greenficld).

$r$ June 2, 1308, commission to confer the next vacant stall at beverley on our clerk, William de Witden. İ 1310 lo was holling the prebend which once belonged to Mr. Peter Ermerici. On Jan. 11, 1310, William de Esflen, eanon of Beverler, Mr. Nicholas de Calvetom, Robert de Bluntesdon, and Nicholas de Molondinis, were ortered to receive the aceounts of the excentors of Corbrillue (Res. (ireentield). In woth bilward I. he was treasurer of the exchequer at Dublin (Cal. Rot. Pat., 5i).

- P'runce's Coll., iii., 108.5-7, 111 1-15.

- Mentioned in l Iist. Co. Limouln, ii., 149. In Carow's survey of Corn- 
of a little hamlet, which bears his name, in Lincolnshire, and he was related to the ancient houses of Giffard, Babington, and lireville. The mirersity of Oxford was his alma mater, and the charges of his elucation were defrayed by his kinsman archbishop Giffard. Little did that prelate think that the youthful consin whom he befriended would at a future time repay his pious are by governing the same see whieh he himself moderated, and surpass him in his zeal for the interests of his church and in his brilliant services to his eountry and his king. (ircenfield was a student at Oxford in 1269 and 1270, and became a doctor of civil and eanon law." He was a courtier also as well as a scholar, and Stowe happily describes him as "an clopuent man and pithie in eounsell."

Greenfield obtained preferment in the elumeh at an early age. On St. 'Thomas's day, 1:69, whilst he was still at Oxford, his kinsman archbishop (iiffard collated him to the stall of Ilalloughton at Southwell, which he resigned in the summer of $1: 27: 2$, having been promoted on the 29th of July to a prebend at Ripon. In the month of August, 1287, he oceurs as canon of Laughton in the church of York. ${ }^{y}$ He was also prebendary of IIolborn in St. Paul's eathedral, and dean of Chichester in 1:299 and 1303.z I also find that he was incumbent of Blockley in Worcestershire between 1.291 and 1294, ${ }^{a}$ and in the latter year, on the 2:nd of September, he obtained the rectory of "Stratford-on-Avon, which he held till he became archbishop. ${ }^{b}$ IIe was also the temporal chaneellor of the dioeese of Durham.c

We must now turn to Greenfield's services to the state, which were numerous and valuable. He was one of the clerks of Litward 1., probably in connection with the ehancery. On

wall (el. 1602, p. 59) it is said that he wals a Coruish man. Fuller (IVorthies, i., 212) makes the same assertion, pobably confounding the name of Greenficll with Grenville. It mast be remembred, however, that Richard do Grenville, the foumder of that fimily, came into Bnesland at the Conquest with Walter Gitfard, earl of Bucks, whose lanthter he marricd. C'f. Puat. liev., (iii., "97; Wright's Esays, i., 131.

"Trivet, 339. Tanner, Bibl., 311.

" Innals, exl. 1615, p. 209. Fuller's Wortlier, i., 212. "Vir elofuentia, consilin et rurialitate preclarus" (Stubbs, col. $17: 29)$.

" Res. Giffard. Le Neve, iii., t23.

$r$ Coll. p. m. dom. Wrm. le Vavacur. (Rere. (itfard). The stall is not mentirnforl, but it seems to have been that of Monkton. which was sequestered on account of Greenfield's non-residence. The sequestration was relaxed May 10 , 1303 (Reg. Corbridge). In the taxation of poje Nicholas he is called canon of studley, and, in the Nova Taxatio, of sikelton. 'The inaccuracy of these taxations is well known.

$y$ Reg. Romanus. He held it till he became archbishop.

z Newcourt, i., 156. Le Neve, i., 256.

a Nash's Norcestershire, i., $10 \%$.

b Dugdale's IVarwickshire, n.e., 479. Greenficld had letters of protection in 1296 as canon of York and Ripon and parson of Stretford suyer Avenam (l'rynne, iii., 682).

c MSS. Surtees. Hutchinson's Durham, i., 256. 
the 3rd of February, 1290, he was one of the three persons whom the king sent to Rome about the subsidy for the crusade. This was the adventure in which the eelchrated friar, William de Hotham, took so great an interest, and (ireenfield, possibly, was indebted to him for his introduction to the notice of the king. In 1291 Greenfield was engaged in treating with the kings of Arragon, Sicily, and France. ${ }^{e}$ In the following year he was with Edward at Norham when he was busy with the affairs of Scotland, $f$ and he and J. de Lascy were appointed to pay the debts which the king had incmred since his coronation. ${ }^{g}$ In 1295 he received a summons to the parliament at W'estminster, and he was called to the meetings of that body and of the council in $1297,1298,1299,1301$, and 1302 , in his capacity as elerk of the comneil. ${ }^{h}$ On the lst of Jannary, $1: 96$, he and others were sent to make a truce with France and treaties with Guelders and Flanders. ${ }^{i}$ On the 25th of April, 130:2, he was made one of the king's proctor's to carry on negotiations with France, and on the 15th of August he was empowered to treat for peace with that comntry. ${ }^{j}$ On the 30 th of September he was advanced to the honourable position of lord chancellor of England, ${ }^{k}$ having been previonsly a elerk in the chancery. IIe held that office with eredit and distinction for three years.

On the 19th of October, 1301, the king authorized the chapter of York to elect another archbishop, in and on the 1.th of December their choice fell upon Greenfield, who was at that time dean of Chichester and ehancellor of England." He reeeived the royal assent on the 21th. ${ }^{\circ}$ He told the king in the presence of his coumeil at Lincoln that it would be necessary for him to go to the papal court, and on the 31 st of December Edward wrote to the pope and cardinals in his behalf, spealing of his merits and services in terms of high praise.p "The pontifieal chair was at that time racant through the decease of Benedict $\mathrm{X}$., and, as some time elapsed before his snecessor was appointed, the stay of Greenficld at Rome was necessarily prolonged. Edward urged npon the new pope and the eardinals the necessity for haste, and on the 2nd of October, 1305, lie granted Ietters of protection to (ireenfield, which were to remain in foree until the following Christmas." On the 30th of January,

\footnotetext{
¿ Foedera, i., 726, 71.1. l'ryme, 1ii., 429. e Ford., i., 7.1-5.

$f$ Ibid., i., 767. Prymne, iii., 506.

$s$ Rot. P'ar\}., i., 85.

" Parl. Writs, i., 29, 35, 65, 79, 91,

103. Fod., i., 889. Prrme, iii., 881.

i Foed., i., 831-5. Pryme, iii., 7.15.

j Foed., i., 910, 912, 915. Cf. Lib. Garderobex, 90.

k Cal. Rot. Pat., 63.
}

' Prynue, iii., 1010.

m Is Nere, iii., 105 .

" Uss. Cotton, Vitellins, 1 , ii., 112. Stubbs, col. 1729.

- Le Neve, iii., 105.

p Fiest., i., !68. l'ryme, iii., 1073-t.

q Prrme, iii., 1112. In Find., j., 1008 , is a letter from the kine to the cardinils, dated on the eath of Jinnary, 1306 , urging the consecration. 
1306, the archbishop-eleet was at length consecrated by Clement $\mathrm{V}$. at Lyous.r On the 10th of February the king gave him a lctter of safe conduct, with which he returned to England, and he received the temporalities of his see on the 3lst of March. ${ }^{t}$

The cost of Greenfield's residence at Rome, and the sums which he was obliged to disburse to hasten his eonsecration, were cnormons." He came back to England literally a beggar. On the 30th of Hay he required of the dean and chapter the profits which they had derived from their administration of the spiritualities of the see during the vacaney. He was obliged also to borrow money on a very large scale, and his resources were thus crippled for several years. On the 21st of November, 1306, he wrote to William, cardinal priest of St. Potentiana, professing his entire inability to pay the money which he owed at home, and begging the pope to respite him till Christmas. He had not, he states, reeeived any of the revennes of the arehbishopric for the current year, as they had been assigned to a certain nobleman, ${ }^{*}$ and he conld neither pay the disme imposed by the pope nor the troisdisme for the expedition to Wales, to say nothing of the costly exnipment of ten knights which he was required to provide. On the 15th of February Greenfield wrote to another cardinal to entreat for a little longer time, and pleading as his cxcuse the great straits he was in and his poverty. ${ }^{x}$ On the 26 th of Jume, 1307, Francis Rodolossi, and the company of the Bellardi at Lucca, of which he was a member, entered into an olsigation to pay for the archbishop to the chamberlains of the pope and the college of cardinals the large sum of four thousand florins.y This sum, probably, would release Greenfield from his debts at Rome, but the borrowed money was to be raised and repaid, and to do this he was obliged to throw himself upou the kindness of his friends. On the 26th of December, 1306, the abbat of Selby lent him 207. On the 29th he asked for the following loms, which he promised to repay in two months. Mr. Thomas Eadberbury, z canon of York, lent

$r$ MSS. Cotton, Vitellius, A., ii., 112. Stublu, eol. 1729.

"Cal. Rot. P'at., 66. Pryme, iii., 1116 . 105.

Prynne, iii., 1115-6. Le Xeve, iii.,

"Fuller (Worthies, i., 212) says that Greenfield spent nine thonsand five huniked marks, on what authority I do not know. He aloosays that Groenficls rereived two benevolences from lis rlerey in one year.

- lis cireenticild.
" John de Britaxnia, earl of Richmond.

* On Jall. 25, 34th and 35th of Edward $I .$, the king wrote to J., cardinal of SS. Marcellin and Peter, in behalf of Greenfield (Prynne, iii., 1159).

y The archbishop might say with Piers Ploughman-

"And witl Lumbardes letters I ladde gold to Rome."

z Canon, sncessively, of Osbaldwick and II etwang, and archideacon of Cleve- 
him 100 marks, and the prior of Kirkham the same sum; the abbats of Meaux and Whithy, the priors of Bridlington, (iisburgh, and Nostell, each 40 marks ; the priors of Malton and Newburgh cach 20l.; the prior of Watton and Mr. W. de Lincoln, canon of Beverley, each 40l, ; the priors of Pontefiact and Drax and Mr. H. de Carleton, canon of Bererley, 20 marks each, and Mr. J. de Markenfield 60 marks. On the 5th of March the archbishop was borrowing again; he obtained from Walter de Gloncester, canon of Beverley, 100 marks and 1.0\%.; from the priors of Bolton, Worksop, and 'Thurgarton, from each $20 l$, from the prior of Lenton 40 marks, for three months, and from Walter de Langton, hishop of Lichificld and Coventry, the large sum of 500 marks. On the 31 st of May John de Drokenesford lent him 100 marks. He receired 10\%. from Stephen de Bella Aqua, his valet, on the 5th of Jume, and at Michaclmas, 1308, he borrowed 100l. from Walter de Bedwinde. ${ }^{a}$ I have reason to believe that these were only a few of the anchbishop's creditors who aided him in extricating himself from his difliculties. It will be observed that all the money-lenders were ecelesiastics. The Jews had disappeared some years before, and the greater part of the treasure of the comntry was now stored away in the ehests of some wealthy elerk or in the cofiers of the monastery.

The city of York at this time must have becn a place in which any prelate would be glad to take np lis abode, cren though it cost lim the ransom of an emperor before he could sit down in the chair of Panlinus. We should be much struck with the appearance of the capital of the North at the becinning of the fourteenth century. In the arrangement and building of its streets we should observe perlaps no difference between it and any other medieval town. They resembled the close narrow wynds which may still be seen in Scotland, and the population, too large in proportion to the space that it ocenpied, as well for protection as from choice, was crowded within the walls. The houses would be principally of lath and plaster, jointed together by beams of wood turned and twisted in fan-

land. He was also precentor of Licl1field (Le Neve, i., 579), viear-eneneral and prebendary of Wrollinstoll, ibil. (Shaw's Staflordshire, i., 299). Hedied 35th Edward I., seised of manor's, etc., in Oxfordshire and Berks (Cal. Ine. P. M., i., 216), and he left a will in which he bequeathed a cup of the value of twenty marks to arehbishop Greenfield.

a Reg. Greenficld. Walter de Bedwin, rector of Catton and Augliton, co. Tork, trea urer of York, prebenlary of Baruby at llowden, insumbent of Fingle (Nish's IVoreestershire, ii., 299). In 13:3 he exchanged baruby for a stall at croditon, and in 1329 ho crave ul, the treasury at York for the living of Nouth lecriby (Res. ii., I'r.

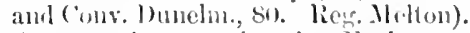
A remembrancere in the Exelespler (Vidox, ii., 267), and au assistant of the conncil to the parliament, 1310 (Parl. Writs, ii., lart i., 12), ete. 
ciful devices, and there would be much picturesqueness in the quaint gables and windows and buttresses that were around you. A residence of stone, from the difficulty of procuring it, inust have been a great rarity. Here and there you would eme upon the abode of some person of consequence, whose inn or hospice stood by itsclf in an enclosed court. The Jews had till rery lately been the moneyed class within the city, but their recent banishment had directed the stream of wealth into other clanmels, and the class of ricin merchants was springing up which mate lork so famons. The number of trades that existed there in medireval times is indeed remarkable, and there was considerable traffic upon the river. But whilst the coffers of the citizens were being filled by honest exertion, art and religion were advancing with equal strides. The four orders of mendicant friars had recently established themselves in the city, and were begging their way, as fast as they could, to riches. Most of the churches werc in existence which even at this day startle the traveller by their frequency, and they were being filled with chantries and other memorials of the living and of the dead. 'The number of the windows that they contain, and their leight in the walls, shew how difficult it was to obtain light in the crowded localities in which they were erected. On the Northern side of the city you will see many signs of the progress that religion had made and of the wealth that had been lavished on lier. Without the walls was the monastery of St. Mary encircled by the haia and fossa, the petty cause of too much bitterness and contention, and its stately church was now rising from the ground in all its glorious beauty. Within the fortifications, but in too close proximity to its neighbour, was the spacions hospital of St. Leonard, which had its origin in the mmificence of $A$ thelstan, and had recently been almost entirely rebuilt by John Romanus, the treasurer of the minster. Farther up the strcet you entered into the close containing the resilences of the canons and their dean, and archbishop Roger's palace. In the centre of this space there was nothing now but bustle and confusion. The magnificent nave of the cathedral was rising inch by inch, and casting into the shade every edifice aromind it, and you could hear on ercry side the creaking of the wains as they rolled slowly up the narrow causeway from the liver to the minster, with the voices of the masons and the chipping of the stone.

One great reason for this accession of wealth and influence to lork was the political importance with which it had been invested. The wars with Scotland had converted it into a military position, and it became for a time, as it were, the capital of England. In 1298 Erward J. held a parliament in the city, 
and the arehbishop and the clergy granted him a sulsidy of a fifth. $^{b}$ 'The courts of justice were also removed thither' firm London, and they did not return for seven years. In lygy a large army assembled at York under the command of John de Warren, earl of Surrey, for service in Scotland.c 'There were two more parliaments there in 1299 and 1300 in the presence of the king, $d$ and Edward spent some time in the city in 1306. The position of the archbishop as a great potentate in the North would neessarily involve him in negotiations with Scotland and in the wars that too frequently interrupted them. He was olsliged, at a great cost, to find a contingent for the anmy, and the presence of the court so near his own residence, although it enhanced his dignity, would add greatly to his anxicties and expenses. He would frequently be ealled upon to play the lost to the distinguished men who were passing to and fro, and his assistance would be often sought for and required in the comeils of the nation. Arehbishop Greenfield was summoned to the parliament at Westminster in $1306,{ }^{e}$ and on the ?nd of July in that year he and the bishop of Lichfield were made the guardians of the kingdom. $f^{\prime}$ In $130 \%$ he was ealled to Edward's last parliament at Carlisle, and there he proclaimed the peace between France and England. ${ }^{\prime}$ After the death of that intrepid monarch, whieh oecurred shortly afterwards, his sceptre fell into very feeble hands. Greenficld, however, was elosely connected with English polities dhring the rcign of Elward II. On the 26th of Angust, 1307, the new king summoned him to the parliament at Northampton to deliberate, among other matters, about his coronation, and on the 18th of Jamuary he was invited to that eeremonial, which was to take place at Westminster. ${ }^{h}$ In consequence of the suspension of archbishop Winehelsea the pope had desired Greenfield to officiate on that occasion, but a reconciliation was subsequently efïeeted between the king and the Southern primate, who wais thus enabled to maintain and exereise his privilege. ${ }^{i}$ 'The reign of the new king was anything but a haply one. Groatness was always within his reach, for he was by no means destitute of ability, but he forgot it among the fops and fools who surromuded him. II is partiality for Gaveston and the Despensers aroused the anger of his barons, and Yorkshire spoke ont against his folly through the mouth of her farourite, Thomas carl of Lancaster. 'These 74

${ }^{b}$ Knyghton, col. 2528. Walsingham,

c Flores Hist., 431. Kuygliton, col. 2530. Walsingham, 89. Rot. Parl., i., 35. $\quad d$ Walsingham, 77 .

- Parl. Writs, i., 164.

$f$ Foed., i., 989. Cal kot. Pat., 66.
8 Parl. Writs, i., 182-3. Chrom. Lanereost, 206.

h Furl., ii., 4, 27.

i Wilkins, ii., 295. Somner's Canterbury, ii., 62. In Flores Hist., 158, it is said that Greenfield and Bek conserrated Fiward. 
tronbles and dissensions and the easy temperament of the king aroused the hopes of the Scots, who were eager to avenge their wrongs and vindicate their nationality. The war between the two countries broke out with redoubled fury, urged on by all the fiery energy of Robert de Brus. The weapons of the chmeh were thrown into the seale against him, and the murder of Cunyn and his brother in the friary at Dumfries had brought upon him the sentenee of excommunication which had been lumled against him by the pope. It is not probable, however, that "Carriek's outlawed chief" eared mueh either for his curses or his blessings. On the 12th of August, 1309, the hishops of Durham and Whitherne were desired to denounce the euprit, and when they did so they would hear around them the note of preparation and the elash of arms. On the 5th of August the king requested the archbishop to raise one hundred men on his manor of Hexham for Scottish service, ${ }^{j}$ and about the same time Gilhert de Clare, earl of Gloucester, Edward's nephew, who afterwards fell at Bannockburn,

$$
\text { "___ Indignus quem sors tam sæva moneret," }
$$

was Greenfield's guest at Bishopthorp, and his unele, who was then at York, assured the primate that the risit should not be regarded as a preecrlent to the injury of his suceessors or himself. $^{k}$ In 1311 the archbishop was again asked to supply men for Seotland.' The Christmas of that year was spent by Edward in Iork, and he then ordered the walls of the eity to be strengthened, and to be made ready for defence. He was now joined by Piers de Gareston and his friends, whom his father had wisely removed from his soeicty, and the old favourite was welcomed with open arms." Among the frivolities of that eourt cren the careless observel would deteet angry looks and open murmurings. The nobles and the commons were watehing their monarch in dismay. The clisasters which soon fell upon the country would be regarded as a rightcous punishment of weakness and evil-pule. The sword of the Seot beeame the avenger of the national wrongs of his foemen. The summer of 1314 witnessed the ealamitous defeat at Bannockburn, when the pride of Edward was laid low.

"And the best names that England knew

Clain'd in the death-prayer dismal due."

j Fred., ii. 83. Rot. Scotix, i., 70.

" Ibid., 95.

1 Riot. Sert., i., 101.

"n Walsingliam, 99, 101. Trokelowe, Anu. Edward II., 10, 117. Carte's Gascon, etc., Rolls, i., - . Stowe's Chron., ed. 1615, 215. On May 1, 1313, the archbishop was peremptorily ordered to come to the king before he started for France (Foed., ii., 210). Walter de langton, bishop of Lichfield, was thrown into prison at York, for having been the meass of driving Gaveston into exile (Adam Murimuth, 13). 
It was with great difficulty that the English sovereign made his eseape from that field, and he seems never to have panserl in his flight till he formd himself at York. He had there a large meeting of his comeil to discuss the affair's of the nation, and, on the Thursday before Michaelmas, Edward, in his own chamber within the palace of the archbishop, made John de Sandal, archdeacon of Richmond, lord chancellor of England." (irecnfield, like a loyal patriot, conld not fail to be troubled at the reverse which his country had sustained, and he took an active part in the attempts to resene her from her misfortmes. On the 4th of January, 1315, he and the bishop of Durliam were excused from their attendance at parliament, as they were then busily engaged in protecting the marches of England against the Scots. ${ }^{\circ}$

Whilst this interneeine warfare was raging in the North of England, a great, and I may eall it an unhappy, novement was taking place within the church. The famons society of the Knights of the Temple was being destroyed. The leaders of Christ's flock manifested a strange ingratitude when they struck a fatal blow at that illustrious order. A period, comprising only two centuries, witnessed its creation and its ruin. It arosc when the swords of the conquering Moslems were already gleaming over Europe, and it mitcd against the bold invader's the soul of the ehivalry of the West. The pilgrims who eame ont of the beloved but distant liast had many a tale to toll of their sufferings and their wrongs, how the infidel trod upon the shrines which a glorions presence once emmobled, and the praises of Mahmoud were heard where Christ once walked and spoke.p A shiver ran through the whole Christian world when it heard the news. Uninvited and umaided a little band of knights devoted themselves to the dangerous tissk of protecting the travellers to Jerusalem, and they took their name from the holy temple, which was its chief ormament. 'T'le zeal for (iod's eause and the spirit of adventure soon increased their mumbers, and they formed themselves into the sacred order of the 'l'emplars. The union in them of valour and derotion added sereatly to their popularity. The chivalrons daring of the knights, theil' heroism in the field and in the eloister, the fascinating charm of the enterprize that they took up, the stirring praises of St. Bernard, soon won for them a position such as no religious borly

$n$ Fred., ii., 255. Ftward held a parliament at York in 1313 (Murimuth, 20).

Ibid., 260. Rot. Scot., i., 137. Walsingham, 107 .

$p$ Their feelings are easily imasined.
"Al gran piacer, cle quella prima vista

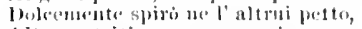
Alta contritin sucesso, mista lin timoroso, averente aftettu. () samo à pena d'inalzar la vista Fer la C'itti, di c'lurista nllergo eletts.

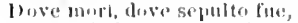
Dove put rivesti le membia sue," 
has sinee occupied. The heart of the whole of Christendom was yearning towards the East. The Templars were delighted to croke this feeling, and to join in the energetic action that it prompted. They took the lead in every crusade, they were the first to carry the standard of the cross into the Moslem vansular' :-

\author{
"Chieftains, lead on! our hearts beat high, \\ Lead on to Salem's towers! \\ Who would not deenı it bliss to die \\ Slain in a cause like ours? \\ The brave who sleep in soil of thine \\ Die not intombed, but shrin'd, O Palestine!"
}

The most dashing cxploits were theirs; they could exhibit the most patient endurance. There were few places of note in Palestine and the East with which the Templars were not associated for some adventurous feat or some reverse heroically borne. We think of the holy city so often lost by them and retaken, we think of Antioch and Damasens, of the shores of Acre which have witnessed in a later day our own triumphs, and of that host of noble warriors who fell among the hills which orcrlook Gennesaret.

The close of the thirteenth century saw the last crusade, and the Moslems, against whose progress the Templars had so long been a successful harrier, were now numolested in their advance. The Red Cross Knights were now unoccupied, and they flocked homewards to settle down upon their estates in Europe which had been given to them in bygone years by kings and nobles. They busied themselves with local politics, and amassed great stores of wealth. 'The more interest they took in secular affairs the more mpopular did they becone. Men began to think, and with some reason, that they were not in their proper sphere, without remembering that it was not through the Templars' fault that the passage to the East was closed. The enthusiasm for the rescue of the holy places disappeared, and the exploits of those who had shed their hlood to win and keep them from the infidel were forgotten. Avaricious monarchs heard with bated and then quickening breath of the hoards of money which the Templars had amassed, and Edward I. seized upon the treasure in their house in London; but, nummindful of the wrong, the leaders of the noble brotherhood fonght and fell by his side at Falkirk. In $130 \%$ a deliberate assault was made upon the body in Franee, where Philip le Bel was their opponent. The new pope, himself a 'renchman, was on the king's side. The commission of incredible crimes was laid to the 'Templars' chargethe most atrocions offences against decency and morality, and hideous blasphemy. Was it likely that a society which had 
especially deroted itself to the service of the cross, and had surrendered fortune and life for the sacred cause which it had adopted-was it likely that its members would belie their glorious traditions and their practice and their rows? It was impossible. Doubtless there were among the Templars many Bois Guilberts, half priests half soldiers, with too great a sliare of the spirit of the latter, but the conduct of the great mass of the order seems to have been irreproachable. It was doomed, howerer, to destruction, and the first blow was given in France with frightful vehemence. Evidence, which a modern court of justice would reject in derision, was listened to against the society, and noble gentlemen were led to the stake and the torture rather than confess themsclves gnilty of offences which they had never perpetrated. $q$

In the autumn of 1307 varions attempts were made by foreign potentates to prevail upon Edward II. to enter into the league against the Templars. He discredited the stories which were narrated to him, and withstood for a time the importumities of those who besought his co-operation. At the request of the pope, however, he changed his policy, and acted with such secresy and vigour that in January, 1308, the greater part of the Templars, resident in England, and their property, were taken possession of by the royal officers. Clement $V$. was now eager for their punishment, and we must see how they fared in the North of England. On the 12th of August, 1309, the pope sent two bulls to the archbishop of York; the one was a general denunciation of the culprits, and especially of those within the province of York; the other was a mandate for the institution of an official enquiry. He also nominated the commissioners who were to act in that behalf. They were the archbishop himself, the bishops of Durham, Lincoln, Chichester, and Orleans, the abbats of Lagny and St. Germain des Champs in France, M. Sicard de Vaur, canon of Narbonne, chaplain to the pope and auditor of the causes of his palace, and Ciny de Vichy, rector of Hesh (sic) in the diocese of London. 'The exhortations the pope were backed by a letter from the king of liance, in which he earnestly requested the archbishop's co-operation.' Greenfield evidently dich not like the duty which he was called upon to discharge. On the 26th of Scjtember he positively dechined to take any part against the Templars within the province of Canterbury. He told the pope that the bishops of Lincohn and Chichester conld mot act in the aftains of the pro-

$q$ There is an interesting account of this persecution in a volume entitled, "The Knights Templars, by C. ( $\dot{*}$. Addison, Esq. Svo. London: 1812."
"The original letter is in Greenfiedl's resister. From that repository my account of the Templars is drawn, unless sone other anthoritr is siven. 
rince of Fork, and his peculiar relations with the Southem primate would not allow him to go into their dioceses. He cxpressed his readiness, howerer, to do what he could, and wrote to the bishop of Lincoln to suggest a friendly meeting at Laneham, Notts, on the 2nd of July, 1310, when the matter might be eonsidered. The abbat of Lagny and Sicard de Vaur were in England, and for two years the elergy of the diocese of lork were taxed for their support. They were, no doubt, the means of expecliting the persecution. On the 11th of March (irecnficld wrote from London to summon a provincial council to enquire into the allegations against the Templars. It was to be held at York on the 20th of May. Before it assembled, the culprits, who were confined in York eastle, were examined. 'They were twenty-four in number, and eame from Yorkshire and scren adjacent comties. They had been in the castle since the autumn of 1309, although they had been in restraint for a much longer period. 'The names of the sufferers must be perpetuated. They were William de Grafton, senior, preceptor of Ribstan, Ralph de Roston, Thomas de Stannford, Henry de Kereby, Thomas de Belleby, of Penhil, Robert de Langton, William de la Fenne, preceptor of Faxflete, Richard de Kesewyk, Stephen de Radenhalgh, priest of Westerdale, Michael de Sowrelyy, priest of Sorenty (?), in the dioeese of Durham, Ciodfrey de Arches, preceptor of Newsham, John de Walpole, Iro de Etton, Henry de Craven, Roger de Hugyndon, Henry de Ronclyf, Galfivil de Wylton, Walter de Gaddesby, Richard ale Ripon, Thomas de Thresk, Richard de Shefeld,s John de Whreston, William de Midelton, and Walter de Clifton. To these a twenty-fifth may be added, 'Thomas Streche. The examination of the prisoners lasted from the 28th of April to the th th of May, but it produced no fruits. The knights had nothing to confess; they denied the charges of blasphemy, ete., which were brought against them, and asserted the orthodoxy of their faith. ${ }^{t}$ They told but little of their own history. Grafton said that he had been admitted into the order at London, more than thinty-two year's before, by Robert de Torvile, then grand preceptor in England. William de la Fenne took the oaths at Chaplay, in the diocese of Chichester, some fifteen years previonsly from (iuy de Foresta, at that time grand prereptor. Stamiford had been a brother for thirty years, having been mitiated in Cypus by William de Beaujen. Roston had been a member of the order for twenty-three years, and entered

" Ile is called Roser in another list. in IIa 17, 1311, the king wrote on helatf of John de Eberston, who had apostatized from the order through fear of death.

tChron. Tanereost, 215. 
it at Lentini in Sicily." What stirring adrentures and how much rongh life such men must have secu!

The conncil met at lork on the 20th of May, and most of the ecelesiasties of the North were there, with the exerption of Anthony Bek, bishop of Durham, who was then seriously ill. Nothing, howerer, was done, as the eximnination of the knights themselves had been musatisfactory, and farther cridence was required. The meeting, therefore, was adjoumed to a finture day. In the meantime the archbishop was not idle. On the 25th of May he, in conjunction with the abbat of Lagny and Sicard de Vaur, eited the knighits, who were still at large, to appear before them at Lancham on the and of July. Only eight are mentioned, so it is evident that the excrtions of the Northern sheriffs had becn cminently sucessful. They were William de Grafton, jmo, Joln de Esflet, Edmmed de Laitiner, otherwise called de Ciarvyle, John de Poynton, Richard Engayne, Ralph de Bulcford, Stephen de Stapelbrigg," and $\mathrm{V}_{\text {alter }}$ le Rebel. On the 1st of June the archlishop commissioned Henry de Botelesford, his penaneer, and John de Hemmingburgh, dean of the Christianity of York, to hear the confessions of the Templars in York castle, if anything farther could be extracted from them. ${ }^{x}$ Erery attempt was also male to sceure fresh evidence. On the 20th of June (Brecnficld appointed several of the elergy to examine the servants and retainers of the Templars who had been with them at their houses or manors of Ribstan, Wrtherby, Newshan, and Templehmst in the Wrest Riding of Yorkshire, Faxeflete and Wythele in the East Riding, and Foukebrioge, Wosterdate, Penhili, and Cowton in the Nortly. What this cuquiry produced we are not informed, but it is not probalsle that it bronght to light anything of importance. The archbishop was at Lancham on the 2nd of July, and the bishop of Lincoln was with him by appointment. The 'Templars who were smmmened nerer made their appearance, and they were excommunicated.

Before there was another meeting of the provineial conneil at lork some cridene was taken in London relating to the proceedings of the 'Templats in the Nortlem porince, which may be comsidered a fair sample of that whole was ucuerally produced against that body. It was more hearsay of the nuost

u Wilkins, ii., 37]. It is the said that this examination was taken in llay, 1311.

"Bek seeme to have beem a frient of the Templars. On May $21,1308.11 \mathrm{~m}$. de la More, the English ermul master, was placed in his charese (Fud., ii., 15).
"Stapelbriger wate canght at Silisbury in 1:311, and male a ronfission, after which hewas recoldeded (Ahlison).

s (O11 July s, 1:311, a similar (an1-

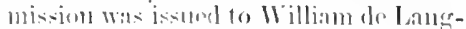
wolt amel Vhe Plitip de Bonltom (Rege. (ireenlichl). 
contemptible kind. Mr. John de Nassington, ${ }^{4}$ the official of the archlishop of York, deposed that he was told by Sir Miles de Stapleton and Sir Adam de Ereringham, that when they were once the gucsts of the grand preceptor at a banquet at 'l'emplelurst, they were informed that many of the knights had come there to pay worship to a calf! Sir John Eure, sheriff of lorkshire, said that he had once asked William de la Fenne, the preceptor of Westerdale, to dine with him, and after dinner the preceptor took out of his bosom a book which he gave to Lady Eure to read, and she found a paper in it full of blasphemy against Christ. Like a prudent woman she shewed it to her hishand, who spoke about it to his guest, and he laughed the matter off, and nothing more was said about it for six years. De la Feme, in answer, said that he recollected the irook, but knew nothing of the paper which it contained. William de la Forde, rector of Crofton, deposed that William de Reynbur, an Augustinian friar lately deceased, informed him that he heard the death-bed confession of Patrick de Rippon, 'Templar, son of William de Gloncester. He told him that on his entrance to the order he was stripped to the shirt, and taken to a secret chamber, where he was ordered to spit upon the crucifix and dishonour it in a more gross way, and, finally, to kiss and wor'ship the image of a calf, which he did. The testimony of this witness was somewhat shaken when he acknowledged that he had only heard of this story after the institution of the proceedings against the knights. We find also that several of the Minorites eame forward to give evidence which was of the most contemptible description. Robert de Oteringham asserted that he was once at Ribstan, and when grace was saicl after a meal, the chaplain tumed round to the brethren, and made an observation which will read most appropriately in Latin, Diabolus ros uret! 'ihe same friar had a marvellous tale of something that he saw at Wetherby at midnight through a keyhole in the chapel, when he thought that he had surprised the inmates at their orgies. Another Minorite had heard that a 'Templar had been seen ruming abont a field in a demented state, and erying out that he had sold himself to the evil one. ${ }^{*}$ These creatures had a purpose to fulfil, and like their ancestor's in baseness whom the Roman amalist denounces, "Sic delatores, genus hominum publico exitio repertum, et pœuis quidem numquam satis coërcitum, per præmia eliciebantur."

y On Aug. 19, 13i1, Roberi de Pickcring, vicar-seneral, made lim penancer for the Templars. (Reg. Greenfield). On Ans. 18, the king ordered the sheriff of York hire to place the Templars in Pickering's hands during the archbishop's absence (Fued., ii., 167). Pickering probably sent them to the monasteries.

$z$ Wilkins, ii., 358-9. 
Greenfield, however he might dislike screrity, was obliged to proceed against the acensed 'Templars. On the 21st of Feb., 1311, he summoned another provincial councila to consider what was to be done. It was to meet at York on the : Ith of May. All the prelates and dignitaries of the North were invited to it, together with several members of the mondicant orders, who took an especial interest in the crusade against the knights. They were Mr. John Gower, S.T.D., Mr. Thomas de Chifford, William de Okam, S.T.D., friar Thomas de Middleton, S.T.1)., Friars Preachers, Richard de Wetwang, an Angustinian at York, and Adam de Lincoln, a Minorite from the same city. The council had eleven sittings, the last being on the 30th of July. The proceedings commenced with the celebration of the mass of the Holy Spirit, followed by a sermon from the archlishop, who stood at the high altar. When this was over the primate explained the object of the meeting, and the members then went to their work. The result was, on the whole, a proof of the good sense of the Northern clergy. The punishment of death was not awarded, as in other countries, and there was no crnelty nor torturing. 'The Templars, twenty-four in number, were brought from the castle, and were persuaded to submit themselves to the commeil. It was then ordered that cach of them should be sent to a religions house within the province of York to do penance for his errors. ${ }^{b}$ This decision yare some umbrage to the monasteries, ${ }^{c}$ but the Templars, as a rule, appear to have conducted themselves with propriety, and before a year had expired the archbishop had released nearly the whole of them from the sentence of excommunication." "A due provision for their wants was agreed upon and was granted by the

a March 13, 1311, an onder to the sheriff of Yorkshire to bring the Templars before him (Reg. Greenfield).

${ }^{b}$ Eperston was sent to Salley, Craven to Pontefract, Keswick to Kirkham, Langton to Bridlingion, Gaddesby to Jervanx, Stannford to Fountains, Wilton to Whitby, Sheffield to Kirkstall, Kerby to Rievinx, Walpole to Byland, Radenachs to Worksop, Clifton to Shedford, Hnghendon to Gisisurn, Streche to Nostch, and Graftoli to Selby. Stubbs (col. 1730) ascribes this arrangement to the kinduess of Greenfied, but it did not, J think, originate with him.

$c$ On March 1, 1312, a letter to the abbat and convent of Rievint for refusing to supply food to IIenry de Kierreby. They are ordered to do so. At the same time there is a letter from the vicar-general against the ablont and convent of Kirkstall for allowing, throush their neglimence, lioger de Shefeld to leave their mollistery. Stannford ane some tronble at Fomintains by using violent language and refusing to eomply with rules, but a sharp reproof bronght him to his senses.

d Ill were releated in 1312 (Rer. Greenfield). They were kimbly treited.

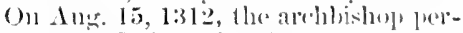
mitted Willian de Grafton, senn, to leave selby abhey tor a month, on alecommt of business in the dioneres of Fork, Linouhn, and Jemeloni (kies. (imenfield). In the the of Edward III. William de ciraften was abotred from lis sows, ambl was allowed to turm to a secular jursuit (Cal. Lint. Pat., 10!)). 
king, anounting to a considerable sum, out of their sequestered estates. Year's passed away, and on the 31st of August, 1319, the pope made an order that any 'Templar, if he chose, might take the rows required by the monastery in which he was residing, lut two only seem to have availed themselves of his permission within the diocese of York. $f$

Within a fortnight after the termination of the gathering at rouk archlishop Grecuficld took his journey towards the South. Clenent $\mathrm{V}$. had convoked a general comeil, which was to meet in the month of Oetober at Vienne in Dauphiny, and on the Ist of Jume Edward II. desired the Northern primate to come to London, as he was anxious that he should go abroad to be present at the great assembly in France, to which he had been smmmoned. On the 26th of July he directed him to remain at home, and to come to the parliament at London. Greenfield, howerer, after all, went to Vicme, the king giving him letters of credence and safe conduct on the 10th of October.g The archlishop was weleoned by the pope, and oceupied an honourable position at the council, sitting next after the cardinals and the archlishop of 'Treves. ${ }^{h}$ The aftairs of the Templars and their ollenees were fully discussed. The meeting was prorogued till the month of April, 1312, and then, in the presence of (irecufield, the ancient order of the Temple was finally dissolved. On the 15th of Angust in that year the archbishop directed his official at lork to make the ammouncement that it lad ceased to cxist.

A considerable light will be thrown upon Greenficld's arehicpiscopal carece by the following extracts from his register. "ilhey not only illustrate his public and his private life, but give

c On Sent. 30, 1312, William de firafton refeives from the archlishop the sim of yot. As. for the siluenrls of himself and his twenty-thee brethron within the diorase at lork from the siunday . . the feast of St. Nichulas to the simday before the least of St. Peter al Viunula next ensumer. On bee. 6. 1311, the king ordered Alexamler te ('ave and Robert de Amecotes, kappers of the linuts, ete.. of the 'T'emplass in the (ntinty of Tork, to pray the wages above montioner, whinl were asced

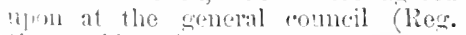
fresuftold). The 'Templar's lingered for is lone time in the monasteries. () April 2, 1335, un order was made (1) laty to Thomas de Streche, who was at Nostell, the arrars of his lension of five mark per ammum (lieg. Melton).
Romclyf, Streche, and Gaddesby had an anmual pension of six marks (The Kuiphts Hospitallers in England, ed. Caurlen Soc., 209). June 6, 1321, a repuest to the prior of St. John at Jerusilem to pay to Ralph de Roston, formerly a Templar, the stipend assinned to him by the goneral council (Res. Melton).

$f$ Der. 18, 1319, an order to the prior ans convent of Gisburgh to allow Robert de Lanceton, once a Templar, to enter their honse, and on Sejt. 29, 1320, a similar direction to the abbat of Selby in behalf of II enry de Kerby.

r Frel., ii., 135, 141, 145. Cal. Rot. Pat., 73.

"Stublss, col. 1730. Labbe, Conc., xi., 1557. Nrlam Mnrimuth, 15. Baronii Anu., Raynaldi, xxiii, 533. 
us some curious glimpses of the state of mamers and morals in the North of England.

1307, Marcl 25. A commission addressed from liose castle to the bishop of Lichfield and Corentry authorizing him to consecrate the bishop of Bangor at Carlisle. April 9, at Beaurepayr, the arehbishop certifies to a marriage having takcu place between John, son of Sir John de Fglesclif, knight, and Juliana, daughter of William de Eglesclif. 'Ther were married in the church of St. Sariour in the Marsh in Tork on the 1th of Jume, 1294, by Stephen the rector. ${ }^{j}$ A letter to the pope recommending the translation of St. Robert of Lincoln. ${ }^{k}$ April 28. An order to cite Sir Nicholas de Mernell and Lucial, danghter of Sir Robert de 'Tweng, to answer to a cliarge of adultery? May 23. A commission to liberate from prison Sir Willian Sampson, knight, who has been excommmicated for divers oflences, amongst others, for incest with Isold and Clemence his own daughters. He is ordered to do penance at Nottingham, Newark, and Southwell. Junc 5. Licence to the official at York to sprinkle with holy water the ehurchyard of St. Martin in Micklegate, which has been polluted. Two boys were fighting in it, and the nose of one of them bled. Angust 7 . An indulgence of forty days for the soul of Edward I. "Mareuit ct aruit flos militia.",

1308, Jan. 9. An oratory to Sir John de Gray, knight, in the manor of Farewath. Jan. 21. An indulgence for the fabrie

i The bishop, Griflin ap Torweth, was conseerated on the following day by Walter de Laniston, bishop of Lich. field. The court was then at Carlisle.

$j$ When parish registers were $\ldots 1$ known, ages, marriages, ete., could only be proved by some such doemment as this. The arehbishop was at Beurepaire, near Durham, the eountry-house of the prior, of which some ruins still remain.

${ }_{k}$ Bishop Grostête. Arehbishop Romanus wrote a strong letter to the pupe in favour of his canonization (lies. Romanus). On May 6, 1307 , the king made the same reunest (Furl., i., 1016. Pryme, iii., 1185)), but in rain. (irostête was not a person whom the pajal court would be likely to canonize.

'A very sinemlar story. Nov. 2, 1305 , the chapter of York anmounce that William de Latimer hats been excommunieated at the instance of dame Lney, daughter of Sir liobert re 'Tweng. Sept. 4, 1309, commission to rereive the purgation of dame Lucy de 'Tweng, wife of Sir Willian de Lat ymer, knight, for alultery and incest with Sil Nicholats de Meynyl. On the Friday alter the Epiphany, 1309, Mernyl and the lady enter into a bond to pay sol. each to dan Henry de Botelford, the lieerer of the fabric at York. On July 8, previously, Meynyl as a puni-hinent had been tinet 10\% by the arehbishop (Res. Greentield).

The fraily of Huer de Trens cast a doubt "Inom the lenitimany of hor lusband's sond, hut on July 1, 132-s, it was fomml ont, mon a formal encuiry, that Sir William, the reputed son of Sir William de Latsmer, Was nol illesitimate, but the som of latiner and

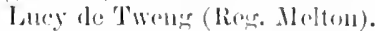

"t The kins dien at linenh on the Saluds, not tat from carliste, on the The of July (firel., i., lols). On (Bet. ws the archbishol, was dexired to pay for the unw kint (ibir,, ii., !), "The thoure of Cristemdam" (P'cter Lailigtolt, n. e., 311). 
of the church of St. Andrew at Bordeaux." April 9. To Sir Golffey de Melsa, knight, a gift of two or three deer.out of our park at Bererley. ${ }^{\circ}$ April 11. The archbishop writes to Stephen de Manley, archdeacon of Cleveland, begging to see the deeds relating to the privileges of the prior and convent of Durham in IIowdenshire and Allertonshire, about which he has spoken to him.p Nay 3. Commission to the bishop of Whitherne to dedicate the elureh of the Friars Preachers at Yarm which has been kately built. June 13. At Meaux, William de Rolleston of Beverley, Adam his servant, John Golding of Bererley, and John de Esingwald laying their hands on the archbishop's cross, promise that they will not again break into the park of Beverley." July 17. An order to Robert de Bardelby, canon of York, and William de Threntoft, rector of Knesale, to fine to the king for fire knights' fees, for which we are bound to find service in Scotland.r August 23. A mandate to the chapter of lipon not to hold markets in the minster. Sept 10. A lieenec for the consecration of the altar B.M.V. in the ehureh of the Carmelites at Nottingham.s Oet 6 . An ora-

"A place of ereat consequence and value to England. There was more than one comnection between it and lork. In September, 1308, Bertrand de Fargis, a canon of Bordeanx, was matle archdacon of the East Riding. In 3 th Fdwath I. Richard de Haverinss, a canon of lork, was constable of that town (Prynne, ini., 1091). 'This is the freron who was elceted arehlishop, of Dublin, but he never went there. for a very stmenge reason. He was so often previnted by stomy weather form nuaing the passase to Irelant, that he save it un, thinking that T'rovidence wits ageinst him. The story reminds us of the famons De Courcy and Jis arlventure.

"The most important of all the archbishou's manks. De Molisa was the loat of a rood Holderness family. In sili Ehward IT. Nilliam de iIelton inid thee hundred marks to the king fur llow custory of smme of the lands of Gocifrey de Viela (Abbrev. Rot. Orige, i., 190). ('f. Rot. I'arl., i., 326.

p Hanley was a great man and a member of the rorkshire house. A cousin of bishop Bek (Mise. Doe. treas. burlism, 195), prebentary of Busthorpe, arehduan of Cleveland, rector of Bayton and IIemminbursh, co. Tork. IIe lad the livine of Onston, er. Lincoln (1Ss. Harl., 6y51, 32), the deanery of Anckland, and the rectories of Honghion and Hanghtor, co. Durham (Res. Kellawe, 22, 29). Seneschal of Jurham castle, and vicar-general (MSS. Surtees), dean of Wimborne, and archdeacon of Lichfield (Intchins' Dorset, ii., 53k). He had much to do with the translation of St. William. He died on the Friday after the feast of St. Lamence, 1317, and was buried in York minster,-but see Prymne, iii., 1213. Abbrev. Plac., 258.

I'or the dispute abont Howdenshire, etc., see Hist. Dunelm. Scr. Tres, 105.

$q$ In 1323 a special commission was issued to try those who had broken into Beverley park (Parl. Writs, ii., part ii., 208 )

- This service was a great burden to the arclibishop. Bardelby was a clerk in the ehancery. I shall speak of him aftelwards.

s Nov. 23, 1310, licence to the Friars Winors of Sottingham to have their chmel and its altars consecrated. May 17, 1311, licence to the Carmelites of Hull to have their chmrch consecrated (Rer. Greenfield). Sept. 17, 1311, licence to the bishop of Enachdune to dedicate an altar newly erected in the honse of the Friars Ifinors at Tork (ibikl.). John bate was the chief ornament of the last-mentioned house (Lel. de Script. Brit., 431). 
tory to Anora de Pirpomnt in the manors of IIolm, Wodehouse, and Weston. ${ }^{t}$

1309, Jan. 15. The archbishop grants to Thomas, son of Robert de Grenefeld, and Joan, daughter of John Attewell, and their heirs, two mesuages, four bovates, and eight acres of arable land, and six and a half aeres of meadow in Sherburn." May 21. Bull of Clement V. excommunicating Robert le Brus for many enormities, and for killing with his sword Johm and Robert de Comyn, of the diocese of Glasgow, knights, for refusing to join him in his proceedings against the king, one in the cloister and the other in the chureh of the Friars Minors at Dumfries, near the high altar. ${ }^{p}$ Nor. 9. We have corrected, on her own confession, dame Joan de Corewenne, reliet of Sir Thomas de Corewenne, knight, for adultery with Sir Simon Ward, knight. ${ }^{20}$

Among these friars there were many distinguished men who were natives of Yorkshire and of the North of England. Among the Carmelites were Jolin de Eboraco, Galfrid Alievanti, Walter Kellaw, John Chelmerton, and Jobn Goldston-all of them Yorkshiremen. Stephan de Patrington was the confessor of Henry $V$. Robert Baston was a brother of Philip Baston, prior of the house at Scarbro', and was born at York. He wrote several works on Scottish polities. Bishop Scrope is well known (Bibliotheea Carmelitana, i., coll. 531, 581, 809, 836, 853; ii., 149 , $686,761,829,971-2)$.

Among the Preachers were Robert of York, Joln de Derlington, Thomas Stubbs, John de Heglescliff, and Holcot (Quétif, Scriptores Ord. Predic., i., prefat., xxv, 395, 625, 631, 671). Nor must archbishop Hotham, who has been already mentioned, be forgotten (ibid., i., 459-60). "Huomo da comparare con i più rari soggetti del suo tempo, nella dottrina et bontì della vita" (Pio, Ifnomini illustri di S. Domenico. Bologna, 1607. Part ii., 107). Cf. Ware's History of Ireland, ell. 176t, ii., 326. Touron, Histoire des II Iommes Illustres de l'ordre de Saint Dominique, i., 603-s, ed. Paris, 1713. Tammer, Bibl. Brit., 114.

' Annora, daughter and heiress of John Manners, married Sir ILenry P'ierpoint (Coll. Top., viii., 315 ). Abbrev. Plac., 2.2.2.

uA settlement on their marriage. On Jan. 7, 1311, Thomas, son of Robert de Grenefeld, was made kecper of the woods and warren at Sherburn and $\mathrm{Ca}$ wood. On Tuesday, the teast of the Puritication B.V., Robert de Greneteld and William his son were made gnisdians of the lands of Godfrey de Melsa at Hodeleston on acconnt of the minority of John his son and heir (lierr. Greenfield), Robert de Grenefeld is mentioned in Abbrev. 1'lac., 250 .

"A document, hitherto tunknown, of much historical importance.

\section{"The church of God saw Comyn fall."}

The murler itself is deseribed with painful minuteness. "In ejus refrigerare sanguinem ealentem gladio mom contentus, nisi sanuinem ipsum cinsque cercbrum, arulsum de capite, sinper dictum altare feritate diffunderet bestiali." Cr. Chron. Lan., 203. Frerl., i., 982, 987. Prymne, iir., 1021. On Jin. 14,1315 , an order to denomice as excommunicated Bris and his aceomplices (lieg. Greentield).

t On 21 st September Ward promises that he will torfeit $20 l$, if it neress asain (Reg. Greentield). On June 17, 12ys, sir simon $1 \mathrm{Wam}$ did lommere at lipon for lands in Gruiseley, Geviletale, and Kirkby Wharf, held by knipht. service, and for Newby, held for the service of the fourth part of a knishly's fee (lieg. Newark). On Nov. 21, 1306; Sir Simon le Warde, knight, jun., son of Sir simon le Wird, decensed, did homage for Giniseley, etc. In Iuly, 1309, he was a justice of assize for the

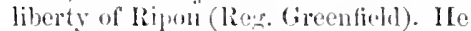
will beeur arain. ILe was sherifl of Yorkshire 1315-1321 (Drake, 351). 
1310, April 5. Liecnce for William de Ayketon, rector of Berewrk, to be absent from his living for a year in the service of Mlevia de Lascy, countess of Lincohn. ${ }^{x}$ Jume 8 . To John le Wirner, of Ripon, at the oversight of Sir Robert de Conyers, knight, two oaks from our wood at Thornton, one for our house at Ripon kately belonging to John Trenys, and the other to mend the bridge at Killingdall. Jnne 9. A letter to William, bishop of St. Andrew's, in behalf of Beatrix de Hodsak, late a mmu it collstream, which place she left on account of the war. She is now living at a house of anchorites near Doncaster, and the archlishop asks for her to be allowed to return. ${ }^{y}$ Jume 22. Commission to receive the probate of the will of Beatrix, late wife of Geoflier, son of Robert le Staumton, co. Notts. ${ }^{z}$ July 3.. A deer from our park at Inecksgrave to Sir John Lysours, knight, and another to William de Dogmerfield, our seneschal of Sherwood forest. August 24. Robert de Hendeley, Adam lis brother, and Ithell his groom, have beat and wounded William 'Tyas, esquire of the conntess of Tancaster, in the church of Pickering: a commission to the chapter to encuire and to exact satisfiction. Angust 28. Licence to John de Rolleston, one of the seven clerks in the chureh of Beverley, and chaplain of the chantry of the fraternity of St. Nicholas, to carry the standard of St. Joln of Bererley to the wars in Scotland, by the kine's order." Sept. 15. Licence to Margery, sister of the late Sir Brian Fitzalan, to have an oratory for three years in the manor of Baynton. ${ }^{b}$ Oct. $1 \%$. The archbishop gives sixteen shillings from his tenement near Otley which the lepers hold of him, to repair the bridge of Otley. Dee. 31. An order to the bailiff of lipon to provide the necessary materials for the construction of a chapel in our manor at Ripon. ${ }^{c}$ The archbishop writes to the bishop) of Norwich to say that Walter de Boynton,

* The wife of ILenry the last carl.

y In l:96, when Edward I. was in Scentland, he made his hearlyuartors in the mumery of Coldstrem (Trivet, 289). These wandering mus are mentioned in Walvingham, 79.

z A soon old fimily, on. Notts.

"Oet. 13, leg6, an order to John de Wirren, earl of 'surres, and intardian of Seotland, to prefter to the next racant benefice of the value of 207 . or marks Giblhert de rirymmesby, for bringing the banner of St. Jolim of beverley and staying with it in scotland during the wir (Fonl., i., 818. l'ryme, iii., 667. Lit). Gatrderobe, 51, 331 ). The butucer was returned 29 th Eilward $\mathrm{I}$. (l'ryme, 910). The ensign was deemed to he the harbinger of victory, like that of 'st. Cnthbert of Durham.

\section{"Aul thus with girdle round his waist, Wherem the banner-staff might rest It needl, he stool, advancing high 'The glittering floating pageantry."}

Elward $I$. went to Beverley in 1289 to visit si. Johm's shrine (V alsingham, 75). Ile was frequently there, and Beverley was sometimes put in antagonimn with Tork. The battle of Asincon't was fonght on St. Jolm's day. (f. Lib. Garderob., 27, ete. John di. Rolleston was master of the hospital of Newton in IIolterness, 5th Edward II. (Ab)rev. Rot. Orig., i., 195).

${ }_{b}$ Not mentioned in Dug. Bar.

c Oet. 15,131 , ordination of a jer- 
rector of Ersham, in his diocese, a native of the East Riding, has broken with his servants into our park at Bererley, to hunt. The bishop is requested to correct him.

1311, Jan. 18. Joln Tankard, of Pontefinct, layman, has struck and drawn blood from IIenry, vicar of Aldbro'. Ho is to go to Rome for penance. Jan. 19. Letters dimissory, for minor orders, to John de Wyelyve, reetor of Wyclyve." March 30. Licence for Sir Ralph de Bulmer, knight, to choose a confessor. April 5. A relaxation of the sentence of excommunieation purnounced against Mrr. Robert de Baldoek and Roger de Walthin for impeding the arehbishop's risitation of the diocese of 1) nuham. Nay 16. Proving of the will of Henry de Lacy, earl of Lincoln, and administration sranted to Nicholas de Reding, Robert de Silkeston, Jolm de Sandale, the king's treasurer, and Sir Henry le Serop, knight, executorse Jume 1. A gift to the prebendary of Wistow of ten loads of thorns and other brushwood to enclose his placea at Wistow. Jume 19. We have given to master Peter de Insula four or five bueks, now fat, in Cawrood park, and three oaks there, and licence to Sir John de Insulat, or some one in the name of the said Peter, to take and hunt the wild beasts within our liberty of Hexham. $f^{f}$

1312, Feb. 24. Licence to the parishioners of Newark to

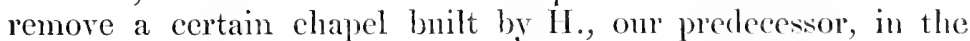
churchyard. It is useless, and the room is wanted: the mate-

letual chantry in the chapel built within the arehbishop's manor of Ripon, and William Swayny appointed the priest (Reg. Greenfield, and Acta Capit., 1313-1365, 50). The eliantry was well endowed. Cal. Rot. Pat., $7 s$. Abbrev. Rot. Orig., i., 212.

${ }^{d}$ A famous name.

$e$ The great earl died in 1312 (Dngrl. Bar., i., 105). On Sept. 27 Henry de Pluckele and Thomas de Folearideby were approinted "coadjutores" of Joan, countess of Lincoln, a minor, for the diocese and city of York. She married Thomas, earl of Lancaster. On Dec. 22, 1313, she had leare to choose a confessor (Rer. Greenfick). $1 \mathrm{er}$ shrift would be a long one.

$f$ Peter de Insula was canon of Bole and sub-dean of York. ITe was probably born at Bywell in Northumberland, and, on that aceomst, arelubishop Corbridge, the native of an adjicent villace, calls him "carissimus." Insula was archdeacon of Carlisle, Wells, Exeter, and Coventry, and dean of Wells. IIe died in 1311.

Sir John de Insula, his brother, was a baron of the exchentuer and a grent man. The piblie records contain much information about him. On March 19, 1323, Eudo de Crosuat, rector of Fyugale, Ralph de balton, of IThaltom, and Richard tle Kinagestom, cxecutors of the will of Sir John de Insula, knisht, are eited to say why they have not administerel to his eifeets.

On Nox. 20, 1298, arelibislop Nowark gave Robert, son of Sir fohn do Insula, a stall in st. Sepulehre's chapel, Fork (Rer. Newark). Richard de husula, another som, wiss preecentor of beverley ant rector of llotham. In 1306 and 1308 be hat permision to be non-resident (twice) fin lwo gears at the regrest of lis lither (Res. (irecuficld). On Feb. 2, 1311, he wats make promeer tor the diocese of Burloim (Rer. Kreblawe). On()et.21, 1:317, he save up ILotliam ame the precentorship for the liviur of hong Xewton, dioc. Durliam (Regr. Mloton). ln 1:31:3 Richarel te Rusula, rector of Stuckton, was ordered to go aloroad with the king (Fued., ii., 212). 
rials are to be used in the churel. Feb. 26. A commission to Robert de Pykering, eanon of York, to receive the vow of chastity of Nice, willow of Sir Richard de Bingham, knight. Angnst 2. A general letter against those who detain the relies and muniments belonging to the hospital of St. John at Nottingham. Sept. 4. A mandate to the bishops of Durham, Carlisle, and Whitherne to pray for the king and queen and the peace of the kingrlom. Sept. 13. Licence to J. de Amcotes, one of the seven clerks of the belfrey at Beverley, to be absent for a year in the service of Stephen de Mauley, archdeacon of ('leveland.g Oct. 24. A commission against Sir Richard lc Waleys, knight, and Paulina, wife of Sir John de Graas, who is with him in his house, living in adultery. ${ }^{k}$ Nov. 12. Licence for Cristiana, danghter of Nieholas de Cayli, to reside in the nummery of Clementhorp till she is nine years old, at the request of her father and friends. ${ }^{i}$ Nor. 13. A monition to the parishioners of Worksop to repair the north-west tower of their church, which is in decar. ${ }^{j}$ Dec. 27. Purgation of Sir Gerard Salvayn, knight, and Margaret, wife of Sir Robert de Percy, knight, who were eharged with adnltery. ${ }^{k}$ An order to the bailiff' of Bererley to take twenty-four deer in our park there and give them to our friends in those parts, as we shall tell you viva rore. Dee. 31. Licence to the prior and convent of Hexham to sell a corrody to Sir John de Swinburn, for a lady a cousin of lis. ${ }^{l}$

1313, Fels. 17. Citation of Mr. Francis de Luco, vicarsceneral of Francis Gaytani, arehdeacon of Richmond, for extortions from the clergy, etc. He travels about with fifteen and

5 April 13, 1313, licence for John le Porter, one of the seven clerks at Beverley, to be absent in the service of Sir ilenry de Perey, knight (Reg. Greenfield).

$h$ John le Graas, of Studley Royal, was sheriff of Yorkshire in 1369 . On Narch 14, 1331, an order to pay the cost of an enquiry in a case of bastardy of Isabel, dauchter and heiress of Joln le Graas (lieg. Melton). See IV albran's accomint of the lords of Studley. Aug. 22,1313 , a commission aqainst dame Juliana, wile of Sir Roger de Grimston, knight, and, on June 8, another asainst Marsaret, widow of Sir John de Grey, knight (Rer. Greenfield). Adultery, ete., were too frequent.

Mareh 24, 1312, the ablat and morks of selby are prohibited from visiting Clementhorp or spronding the nicht there. Nox. 13, 1314, licence to Acnes, dambhter of Sir William de
Colville, to stay at Swyne till she is twelve. Oot. 27, 1315, licence to Margaret, sister of Sir Nicholas de Meynil, sheriff of Yorkshire, to stay for a year at Clementlorpe (Reg. Greenfield).

$j$ A valuable architectural notice. Another monition was given or Jan. 5, 131\%. On May 7, 1314, the prior and convent of Worksop had the archbishop's permission to fell, for the use of their house, two hundred oaks in their wood of Roumwode (Reg. Greenfield).

$k$ Salvin was high sheriff of Yorkshire in 1310, 1312, and 1313. Cf. Surtees's Durham, iv., 117. He was a hot-tempered man, and was frequently in trouble. Eschaetor ultra Trentam 1st Edward II. (Abbrev. Rot. Oric., i., 156), a soldier and statesmar.

1 Not mentioned in the pectigree of Swinburn in Hodgson's Northumberland, vol. i., part ii., 231, etc. 
sometimes with twenty-four horsemen, cach aceompanied by a dog, for hunting. It is a great burlen to the clergy to be obliged to entertain them." $\Lambda$ pril 9. The archbishop prohibits any adoration of an image of the Virgin lately set ny in the church of Foston. There is a great flocking of simple people to it, as if there were any more virtue in it than in any other image." April 16. At Burton, the archbishop absolves Sir Peter de Mauley, knight, for incest with Alyna, daughter of Sir Thomas de Furnivall, his wife's sister, on the condition that he pays one hundred marks to the fabric of Jork minster. ${ }^{\circ}$.June 27. Nandate to Peter de Dene to summon Sir Rannlph de Neryll, Anastasia, his daughter', Alexander and Sir Rolocrt de Neryll, knight, sons of the sairl Sir Ramlph, Maria their sister, and Christian de Sutton, to reply to eertain articles." Junc 28. Commission to enjoin penance on dane Nianor, wife of Sir Walter le Varasou', knight, for divers exeesses.4 July 14. To Sir Robert Hastang, knight, of our special favour, ciolht oaks from our wood of 'Thornton, fit for timber. Sept. 19. The archbishop requests the abbat of St. Mary's, York, to give an anmual pension to his clerk, Robert de Grenefield, on account of his confirmation.r Dee. 31. Licence to G., bishop of Enachdune, to ordain Robert de Holden, a domestie chaplain of the earl of Laneaster. Dee. 31. Licence to John de Stapelton to have service, for two years, performed by a competent person in a chapel of old foundation in the churehyard of Melsanby. ${ }^{s}$

\section{${ }^{\prime}$ An official gets into tronble :-}

" _ـ_ He was a prickasoure a right: Greihoundes he hadde as swift as foul of flight: Of pricking and of hunting for the hare

Was all his lust, for no cost wolde lie spare."

Luco afterwards became canon of Laughton at York. Francis Gaetano, arehdeacon of Richmond, was cardinal deacon of S.M. in Cosmedin. He was nephew of Boniface VIII.

$n$ A very remarkable entry (Wilkins, ii., 423). On Feb. 20, 1314, sentence against those who worship an image of the Virgin in the monastery of Bridlington (Reg. Greenfield). 'This reminds us of the words of bishop l'ecok. The Lollards in after years raised the same cry against images (Walsingham, 363).

o A tilled culprit, who will be mentioned again. Fines of this kind were frequently devoted to the fabric.

$p$ Bishop Kellawe is said to have made Sir Ramulph Neville do penance for incest with his own danghter (Lel. Coll., ii, 33i). These are frightful revelations. On Sept. 13, 1312, dame
Petronilla de Nevill had leave to liave service performed in her manor of Rudham. She was old and could not go to Dambywisk (Reg. Greenfield).

There is a long accomnt of l'eter de Dene, his romantic life and his stringe fortumes, in the Journal of the Archioslogical Institute.

$q$ This lady and her lunsband have been already mentioned. The early wills of the Vavasors disclose a mirious state of morality. In 13 h bilward II. liobert le Vavasour gives liunds iu 'Thorpunderwool and Elnewyk to Foumtains abbey for the sonls of $11 \mathrm{~m}$. le Vavasour, his father, and Walter, lis buother (Abbrev. Plac., 335). In my extracts from the registers and other books of records I have preserved the suclling of the names and places as I foumd then.

'A customary claim. The king asked Greenfield to do the same thing for loblert de Cottinglam on his own accession to the see (l'ryme, iii., 1153).

- A chantry was founded in the churel of Melsanby for the souls of 
1314, March 25. Commission to Henry de Wilton, official, and John de Wodehouse, rector of Sutton-on-Derwent, to denomee in the ehureh of York the insult done to us by some one on the part of Pandulph de Sabellia, throwing in eertain plapers at the gates of our manor of Cawood. ${ }^{t}$ April 3. Commission to absolve Sir Ralph de Neville from excommunication for striking Alan de Morton, eanon of Marton in Galtres, and for a matter relating to tithes. May 2. Licence to the prior and conrent of Newburch to reecive into their house, as an aet of charity, among the poor of Christ, a ehaplain broken down with age, Stephen de Sandale, who officiated for a long time in the chapel of Sandbeck ncar Maltby. May 16. The archbishop pardons his tenants at Hexham $59 \%$. 14. $6 \mathrm{~d}$. on aceount of the lorses they have sustained from the Scots by plundering and fire." August 1. A mandate from the archbishop to Mr. J. de Nassington, junr., Mr. Philip de Nassington, and Mr. William de Stanes, proctors in the court of York, ordering them to plead the cause of Joan, daughter of the late comte de Bar, against John de Warren, earl of Surrey, in a suit for divoree. ${ }^{v}$ Sept. 8. Citation of Joan countess of Surrey. John, earl of Surrey, tells us that when he was a minor and a ward of Edward I. he was obliged by eertain noble men and women of England to marry her through fear, although related to her in the third and fourth degrees. 'The citation is to be made at the castles of Conisbro' and Sandal, and she is to be summoned to appear before the archbishop. Sept. 15. An oratory to John, carl of Surrey, at Clifton, near York, during the continuance of the present parliament, movided that Walter, arehbishop of Canterbury, does not go there with his eross erect.w Oet. 18. Licenee to Sir IIenry de Perey to have service in his chapel at the Friars P'reachers, York. ${ }^{x}$ Dec. 10. Sir Nicholas de Menyl has sum-

Alan and Henry de Nelsanby (Reg. Cart. Mon. de Eaby). Alan be Helsanby and dram ani ILenry his brothers are enshrined in the Liber Vita of I)urham, P. 96.

tsoms libellous papers. Sasclli, an Italian, harl a contest with Richard de Cormulia for the stall of North Newhald, which was lecided at Rome in fasour of the former. Great violence was usel, and armed men were enployed (Reg. Greenticld and Melton. Firl., ii, 112, 202). Savelli was notary of pope Johm XXII., and died in 1320.

"There is an account of these destructive raids in the ("hron. of Lanercost.

"An obsenre and extraordinary in- cident, upon which these extracts throw murh light. The lady was a daughter of Ilenry, comte de Barr, and a grancdaughter of Edward I. The marriage was an unlappy one, but no divorce conld be procured. 'The two, however, lived apreat (I Imnter's Sonth Yorkshire, ii., 10s, and Watson's History of the honse of Warren, ii., 8, etc. Coll. Top. and (ieneal., vii., 133).

w A cantions provision. York was now filled with persons of distinction, in attendance upon the court and parliament. The king gave the archbishop leave to erect his cross in the city (Ford., ii., 253).

* The family of Percy had an "inn" in Walmgate. On Dee. 27,1313 , the archbishop aprointed a commissioner 
moned divers rectors, vicars, etc., to come to him at Easingwold with horses and arms for service in Scothand. We forlsid them to go.y Dec. 19. Lieence for Richard, bishop of 1)ultam, to dedicate an altar transferred from one place to another in his chapel at Welhalle. ${ }^{z}$ Dec. 25. Lieence for Albreda, danghter of Sir Robert de Perey, knight, to have an oratory in her manor of Sutton-upon-Derwent, where slie resides."

1315, Jan. 9. Mandate to pray for the soul of Philip, late king of France, at the request of Edward II., who says of him that he has on all occasions been a well-wisher and a friend of us and our kingdom. ${ }^{b}$ Jan. 14. A commission to MLr. John Gower, S.T.P., rector of Wheldrake, to preach at Northallerton on Monday, the feast of S.S. Fabian and Sebastian, before the army on its way to Seotland, and the Friars are desired to preach against the Scots. ${ }^{c}$ Jan. 1\%. A letter to the abbat S.M., York, enjoining lim not to exact 2d. in each mark from the dignities and stalls at York for the Scottish war. ${ }^{d}$ Jan. 29. A mandiate to the executors of Sir John de Barton, of Oswaldkirk, knight, who has been killed in Scotland, to prove lis will.e March -. A commission to eorrect offenees and misconduet in our household at Cawood. Mareh 11. A commission to the parish priest of Birkin to hear the confession which a parishioner of his, Sir William de Holand, knight, is most anxious to make. $f$ Angust 6. A general denunciation of those who with an armed force have taken possession of the church and manse at Egmanton. The corpse of Roger de Bergh, the late rector, is in

to hear the confession of Sir Henry do Percy (Reg. Greenfield). I sliall not attempt to describe his greatness and his magnificent services.

$y$ Menyl was high sheriff of Torkshire. An array was being made to protect the Marches and to avenge Bannockburn.

* Bishop Kellawe built this manorhouse near Tork (Hist. Dunelm. Sor. Tres, 97). Every trace of it has disappeared, but I have a portion of a minnte survey of the place made in the reign of Elizalieth, when many of the residences of the bishop were allowed to fall into decay.

a Sir Rubert, who is clsewhere mentioned, was the owner of Bolton Perey and Siston-on-Derwent and a great benefactor to York minster (Abbrev. Plac., 210). In 21st Elward 1. The had licence to crenellate his residences at Sutton and Bolton (Cal. Rot. P'at., 56).

${ }_{b}$ The buther-in-law of lidward 11.
The praise he bestows was excessive (Valsingham, 77). April 13, 333 Edward I., an order to pray for the soul of Joan, queen of France (I'ryme, iii., 1107). Foed., ii., 258.

c 'The Friars were the great preathers of the day. Gower wats probably an orator,-

"An specially aboven every thing

Excited he the peple in his prechyng."

d Jan. 17, 1315, licence to the rean and chapter to take 2l. from each mark "contra Scotos" (lieg. Gircenfield).

e lle was smmmoned to serve in Seofland on June 30, 1311 (Lot. Scot., i., 115$)$.

f A getlant soldier, who oecurs as a partizan of the carl of lanraster in 1316; (Kurghton, 2533). In 7th of litward 1I. the king padoned him for his share in the tleath of Giveston (P'arl. Mrits, ii., 66). 
the house and it camnot be interred, nor can service be performed.

It is through sueh materials as these that the past comes back to us witl the lights and shadows with which it was once elicquered. Great men who have long since mouldered into dust are again alive. We hear of the wars at which their hearts once beat. We sce them in their homes,-their joys and sorrows are laid open; we know rhat they did and gave; we ean critieize their rirtues and their crimes, and we forget for awhile that these men lived and died more than five centuries ago.

It is rery pleasing to have so many witnesses of archbishop Greenfield's piety and zeal. His register, a stont folio in two parts, speaks to us with many tongues. The primate was a most exeellent and pains-taking diocesan. The details of monastic life which his acts exhibit are most remarkable. Greenfield tightened the cords of discipline around his monasteries in a way that none of them would like. He was constantly visiting them and correcting offenees even of the most minute kind. IIe was very strict also with his clergy on the question of nonresidence, but he must have been much thwarted and annoyed by the number of foreigners who were sent over to him for preferment. It would be most mortifying to him to find that when he had collated one of his own clerks to a benefice, some stranger arrived with a provision from the pope which he could not venture to oppose, and that, oeeasionally, a third claimant would spring up for it in the person of the king. When this was the case, as it not unfrequently was, how could the archbishop reward the men who descrved his farour? He was dragged into the courts of justice or before the papal consistory, angry and disgraceful brawls took place in the churehes themselves, and much scandal and biekering ensued. Greenfield, however, did his best to attend to the interests of his flock, and he laboured, for the most part, with success. It was almost impossible for lim to do everything himself. I find therefore, withont surprise, the bishops of Thitherne and Enachdune ${ }^{g}$ acting as his suffragans, and he now and then was aided by his brethren at Carlisle and Durham.

'The relations between Greenfield and the ecelesiastics within the diocese of Durham, although not entirely satisfactory, were generally amicable. The arrangement that had been made between Bek and Corbridge scems to have been adhered to. Grcenfield and Bek had but little intereourse. We find them associated together in the enquiry about the Templars, to whom

g In 1306 and 1313 Thomas, bisbop of Whitherne, was acting as sulfiazan. April 11,1314 , a commission to him to that effect. In $1314 \mathrm{G}$., bishop of Euachdune, was acting (Reg. Greenfield). 
both were farourable. Bek died in the spring of 1311, and Greenfield then went into his dioeese and ruled it dming the vacancy of the sec. He removed the sentence of suspension which the deceased prelate had laid upon some of the monks of Durham for their opposition to him during his visitation, but on the 26th of March he himself excommunicated William the prior, ${ }^{h}$ Henry de Stannford the sub-prior, the sacrist, and $\lambda$ dam de Boyvill, one of the monks of Durham, together with Robert de Baldock ${ }^{i}$ and Roger de Waltham, ${ }^{j}$ two of the elergy of the county, for endeavouring to impede lim in his work. With the exception of Boyvill, they were forgiven soon afterwards. ${ }^{k}$ During his stay in Durham Greenfield visited the archdeacomries,

${ }^{h}$ Hist. Dunelm. Ser. Tres, 96, 98. Stannford became prior of Finchale.

i A great but unfortunate man. His preferments were numerous. In the North he was rector of Bradford (Reg. Melton) and Welton (Reg. ii., Prior. and Conv. Dumehm., 67), rector of Whickham and canon of Chester (ibid., $22-3)$. He had a pension of 100s. from the priory of Durham, which he gave up on the 4th of May, 1314, for one of 10 marks (ibid., 26). Richard de Baldock, prebendary of Weighton at York, was his brother. Robert de Baldock became lord chancellor of Eugland. The chroniclers give an aceonnt of his unhappy fortunes and his end.

$j$ Of this person some account may be accentable. He was a native of $\mathrm{W}$ altham (Fuller's Waltham Abbey, 20). Rector of Arksey 1294-1319 (?) (IIunter's South Yorkshire, i., 327). Mar. 31, 1304, Benedict XI. grants him a dispensation to bold the rectories of Long Newton and Egglescliffe, aurl canonries at London, Darlington, Auekland, and Chester, and bishop Kellawe confirmed it 23rd March, 1314 (Reg. Kellawe, 118). April 5, 1306, Clement $V$. allowed him, being then bishop Bek's private chaplain, to hold benefices of the value of 200 marks per ann. (ibid., 119). He was temporal chancellor of Durham (IISS. Surtees and Prynne, iii., 996), and a pensioner of the monastery there (Misc. loc. I'r. and Conv. Dunelm., 3 139, 4562). He was prebendary of Cadington Minor at London, and a royal chaplain (Newcourt, i., 130), and on wunc 28, 132:2, the king made him archdeacon of Bucks (Le Neve, ii., 68). In 1334 he hart licence of non-residence on his rectory of Hatfield (Reg. Melton). IIe was keeper of the king's wardrobe at the time of his death, which took place in 1342 (Reg. ii., Prior. and Conv. Dnnehn., and Reg. Kellawe, 317). IIe gave some mesrages, etc., in London to keep two priests to pray in the chapel of St. John Baptist for his soul, those of his parents, and bishop Bek, and gave it costly vestments, some of which were set with precious stones. He also founded an oratory on the south side of the choir, with a glorions tabernacle, splendidly 'arved and coloured (Dugdale's St. Paul's, n.e., 21-2).

Waltham wrote a book called the "Compendium Morale," which was very popular in the middle ages. It is somewhat in the style of Talerius Maximus, and is pleasantly drawn 11 . There is a fine cony at Durham (B, iii., $24)$ in the library of the dean and chapter, which ends thus :-

"Explicit Compendium Morale de quibusdam dictis et factis, exemplaribus antiquorum, per Rogerum de IV altham canonicum London. compilatum, qui simplici opere sno his concludens, em Ovidio, libro de l'onto, ait

\footnotetext{
Leta quidem letus cecini, cano tristia tristis,
}

Conveniens olexi tempus ntrumque sto.'

Sic Domino et Beatic Maria Virgini se commendaus. Amen."

I can trace six other (o) book. Fuller says that Watham wrote other works, espectally one ealled "ImaginesOratormu." His account als keejer of the cireat Iradrobe was anoug the Stowe Miss., and is now in the possession of lord Ashburnhan. Cf. Leel. Commo de. script. Brit., 261, anı bile, rent. iv., 302 .

${ }^{k}$ Regr. fircenfictd. 
and the call-roll of the elergy and the proceedings of the visitor are prescried at York. This is the carlicst list that we possess of the incmmbents of any district in the North. The archbishop took some interest in the clection of Richard de Kellawe to the vacant see, the whole process of which he entered in his register. Ile conscerated him at York on Whit Sunday, 1311, receiving from his new suffragan the profession of obedience, which he always carcfully observed.

ir e must not expect to find that the old fend about the cross between the two primates had been given mp. It broke ont several times while Greenfield presided orer the Northern province, but with no great violence. When the archbishop-elect went abroad after his election, the king wrote a letter to the pope begrging that he might be allowed to carry his cross erect on lis return." In Felmrnary, 1306, when Greenfield came back to England, Edward sent an order to the arehbishop of Canterbury that no violence should be offered to him, although it had been intended.n On his route the Northern primate paid a visit to the abbat of St. Augustine's, Canterbury, but he took especial care that his presence should entail no amoyance upon his host. ${ }^{\circ}$ In the spring of 1312, when Greenfield was on his way to the council at Viemne he met with such rough nsage at the hauds of the scrvants of the archbishop of Canterbury that the king again stepped in to protect him as he retumed.p When he arrived in lork, on the 1st of December, Greenfield cmpowcred Adam de Osgodby, Robert de Bardelby, John de Markingfeld, William de Melton, and Mr. John de Franceys, eanous of York, to state his position in the controversy to one of the cardinals. In the autumn of 1314, when the court was at lork, there was a great risk of a collision. The arehbishop of Canterbury was on his way to that city, and it was not likely that he would eede a single point to his rival in the North. On the 31st of Augnst Greenfield ordered his official and the dean and chapter of York to resist him if he asserted the offensire privilege, and directed the services to be suspended at every place and chureh at which he halted, muless it were the royal chapel. Instructions were also griven to the arehdeacon of Nottincham to check the Southern primate on his entrance into the diocese.? The king, howerer, put an end to the danger by ordering Greenfield to allow his brother to carry his cross erect diung his stay in lork.r He would submit most unwillingly.

I llist. Hunelm. Scr. Tres, 92. In 1:311 Greenfielrl granted an indulgence of forty days to those visiting the shrine at Dorliam (Raine's st. Cuthber, 103).

${ }^{m}$ liond., i., !69.

"Willizis, ii., 2s.
- Chrou. W. Thorne, col. 2005. Pryme's Coll., iii., 1146.

$\dot{p}$ Ford., ii., 167.

" Reg. Greenfield.

'Fuil., ii., 253. Trokelowe Ann., 
On the 12th of June in the following rear, when there was a chance of Greenfield going into the dioeese of Worcester, a strict injunction was given to the bishop by his superior that he should not permit the saered symbol to be raised. ${ }^{s}$

The clergy of Torkshire were indebted to archlishop (ireenfield for some useful constitutions whieh were promulgated at a synod held at Ripon on the 30th of September, 1306. 'They are identieal, as Wilkins observes, with those drawn up in 1289) by Gillbert, bishop of Chichester, one of Greenfield's oldest friends, and a kind patron to him. Some special injunetions were added to the effeet that no apneal or obedience should be paid to Canterbury. The archbishop had another meeting of his elergy at Laneham in 1311, and he there gave them another set of constitutions. ${ }^{t}$

'Tum we now from offieial duties and state employments to the private life of the archbishop. Let us look at him in his palace and home, and not in the eomeil-chamber or on his throne. The following graphic details, which require little comment or illustration, give us an interesting picture of his everyday life.

1307, May 14. An order to pay to Thomas Dodington and John de Marcadel 34l. 14s. 9cl. for wines. May 26. For 180 sheep bought of Thomas de Marston, 12/. 15s. June t. 'To Mr. Robert de Rampton and the execntors of Walter Oliver, 36l. for 300 sheep and 180 ewes reckoned by the greater hmmdred. August 13. To the abbat of St. Mary's, York, the eollector of the disme for the relief of the Iroly Land, 100/. Dec. 29. We have received of John de Ripon, bailifl' of Sherbuun, 20l. in part payment of 100 marks for oaks sold out of Outwode.

1308, April 11. To William de Grenfeld," our nephew, 1:20 marks for eloth bought at Stamford fair. May 12. 'To Richard de Polew 55l. for 15 ealsks of wine bought of lim. June 1. 'To John le Warmner, of Nunketon, money to pay for 10 oxen and 80 sheep purehased for our larder. Jume $1 \dot{\gamma}$. To Nicholis de Molendinis 20l. for certain lusiness of ours which he has to transact at London. Oct. 21. To Mr. John de Nassingrton,

- Reg. Greenfield.

t Wilkins, ii., 285, 409-15.

" The money was never need for that purpose. The abbats of St. Mary's, York, were frecurently collectors for the polve. On Dec. 5, 1307, there was another payment of 100 mark; to lim for the Holy Land. On May 2, 1308, Greenfield faid him 100 marks on account of the "decima biennialis" which was due to the king, and or
Ance 1 the abbat and convent recoived 100 marks from hine as a subsidy to tho ahureh of Rome (Rer. Greenfield).

"On Nov. 1, 131s, William de Gireenfichld, one of the allierents of the earl of lanmster, hats a someral pardon (l'arl. Writs, ii., part ii., 131).

"One of the le la Poles of lIull, a family afterwarils emobled. Ife was kilinhted, and died in 1315. Cf'. 'l'est. Elor., i., 7 . 
Mr. J. de Cranembe, and dan Adim de Sheffeud, executors of Nr. John de Crancumbe, arehdeacon of the East Riding, 311. 13. 2d. for shcep, lambs, and hay. Oet. 24. To Giles le Morton, onr scriant at Thorpe and at the granges at York, 127. for' corn for' seed.

1309, Jan. 25. To Giles le Morton, servant at our granges at lork, the money necessary for making a foss in the Old Baily, $x$ for proeuring plants to put in the said foss, and for repairing the road to the mills. Feb. 5. For six casks of wine, 18\%. Feb. 18. 'To Eudo de Assarto, our ehambcrlain, 100l. for the expenses of our hospiee. March 10. To John le Graas, sheriff of Yorkshre, four oaks for timber in our wood at 'Thornton. March 24. To Clement, slipman of the abbat of St. Mary's, York, 5s. which he spent whilst carrying timber to ou manor at Patrington. July 21. To Richard de Wystowe 10l. to buy animals to give to on lord the king if he chances to journey to Scotland this way. July 27 . To Lambert de Trikingham, seneschal of our lands, 20\%. in part payment of his fee (which was 10 marks). Augnst 7 . Nattlew, reetor of Little Sandal, pays to Eudo, our chamberlain, 40s. for the reconeiling of the chnirehyard of Little Sandal.y August 9. To Toetus, Drother of Frysotus de Monte Clare, 61\%, in which John de Britamia, earl of Richmond, $z$ says that he is bound to him for corn during the racancy of the see. The letter was dictated by the archilishop.

1310, March 21. To Giles le Morton, keeper of our granges at York, 66s. for hay bought of John de Pelham," keeper of the king's oats. The said John has intimated to ns that he has oats for horses to sell at York at 4 s. a quarter, and that he ean sell as much as we want. April 11. To Thomas, bishop of Whitheme, ${ }^{b}$ 100s. as a gift, and an honest hospice at York against the time of our general comeil. May 2. To Giles le Morton, keeper of our granges at York, money suffieient for the repairs of our manor at 'Thorp and our palace at York.

x. The Old Bailey is in York on the Mirklegate side of the Ouse, in the direction of Clementhorje. It will be azain mentioned (Drake's Eboracum, $265.5)$.

${ }^{4} \mathrm{~A}$ slip of marchment inserter in Cirecufield's register tells us that the following churches, ctc., were reconriled during the year 1309 . June 30 , the eluurch of Wiest Retford; July 8, the churchyard of Little Sandal; Anfrust 3, the chapel of Laxton Morhous; ().t. 10, the churehyarel of Dunham; Sele 21, the churehyarl of Branliam; Nor. 1, the churchyard of Bandesey;
Nov. 5, the churchyard of Harewood. 1310, April 16, the churchyard of S.M. at the gate of York castle. The shedding of blood was the canse of the follution. The cost of reconeiling a churchyard was, it appears, $40 \mathrm{~s}$.

= Cit. l) kgd. Bar., i., 51 .

a He is mentioned once or twice in the Parl. Writs.

${ }_{b}$ He made his profession of obedience at Scrooby on the $261 \mathrm{~h}$ of Jime, 1306 (Rer. Greenfield). On 20th September, 1314, the king gave Thomas, bishop of Whitherne, leave to visit his diocese (Rot. Seot., i., 131). 
May 19. To Nicholas de Molendinis 5\%l. to make provision for us in the fair of St. Ires. May 24. To repair our mills at Ripon 17 oaks, under the superrision of Sir Robert de ('orgners ${ }^{c}$ and the bailiff' of Ripon. Jume 1. 'To William, son of Robert de Grenfeld our kinsman, 20/. for the repairs of the honses of the manor of the elmurch of Bolton Perey. July 4. To John de Wynton our butler, 71l. Fs. 11d. for wines bonght at llull. August 25. To Sir Thomas de Colville, knight, lord of Cokewold, 100l. for the serviee duc from us to the king in the Scottish war. Oct. 14. 'To Sir Robert de Coyners, knight, 50l. for a horse sold by him to us at Ripon fair for the nse of John Giffard. ${ }^{d}$

1311, March 4. An order to pay the expenses incurred by our messengers holding a prorincial eouncil at Durham. July 4 . 'To the bishop of Whitherne 20l., for' acting as our suffragan during our absence. July 8. An order to pay the money for building our study in our camera at Cawood, and for repairing the front of our ehapel at Burton.

1312, August 21. 'To William de Langtoft, keeper of the fabric of the church of York, 100/., which we have promised and gracionsly conceled for the said fabrice Scpt. 12. To H. de Wodhouses, servant of our manor of Cawood, money sufficient to carry on our work there to its completion. Nor. 13. For wines bought at 11 ull, $8 \frac{1}{2}$ marks. Nor. 15. An order to Henry de Henney, canon of Ripon and our receiver there, to pay 10l. to the keeper of the fabric of two bridges near Ripon which have been broken down. Nor. 23. 'To Roger de 'Thornton, our receiver at York, 24s. 11d. for repairing our old crozicr. for

r Probably of Ripon. On June 15, 130 t, he and Adam de Middleton, clerk, were made justices of assize for the liberty of Ripon. On Ang. 30, 1310, he, Adam de Middleton, rector of Amcliffe, and Thomas de Fyssheburne, had a similar commission, and Convers had another on Jan. 18, 131.1. On Nov. 11 , 1309, he was appointed to enguire into a dispute between the archbishop and the abbat of Fourtains about the boundaries of the moor or pasture near the vill of Colhou (Reg. Corbridge and Greenficld).

June 7, 1313, dom. Thomas le Conyers occurs as the sequestrator of the archbishop within the archdeaconries of Notts, Cleveland, and the Last Riding (Reir. Greenfield).

On Angust 11, 1336, a loan of 10 marks to Sir Robert Coinliers, kuinht. Jume 25, 1338, another of $20 \%$. to his executors. Aurtst 3, another of $25 l$. to Robert Coigners (Reg. Melton). This is, I presume, the person whose marriage archbishop Melton bousht in 1333 for Joan his niece for the stm of 60 marks. He is a witness in the Scrope and Groswenor Roll (ibill., ii., 317 ).

d Probably Sir Joln Githard of Brimmesticld, the archbishop's kinsmin, or one of the Gifliteds of Westom. On Feb. 10, 1309, Grecnfiehl gives an acquittance to dame Margaret Githerd for 50 marks, part of a debt of $100 \%$. in which she was boumd to us for sir John Gilfard of Weaton (Rer. (ireentield).

e On May 21, 1306, cirecentielel cranted an indulgence of forty diss in behalf of the misster. In the prefice to the Fabric Rolls, p. xi, I have stated erroneousty that he save a domation of 500 marks to the fabric. The real donor wa his sucersior Melton.

$f$ 'The pareels are, "In cruce domini 
making a new one, 40s. For furs to set upon onr mantle bought by Thomesrne, 12s. For the York fairs on the feast of St. P'eter ad Vineula, 26s. 8d. Dee. 16. A loan of $40 \mathrm{l}$. to the prior of Watton in his great necessity. Dec. 21. To Peter de Baddefosse 16 marks for four casks of wine.

131:3, Jan. 5. To the Friars Preachers at York 40s., to the Friars Minors 2 marks, to the Augustinians 20s., and to the Carmelites 20s., to cnable them to keep the festival to-morrow. ${ }^{g}$ Jan. 11. To Adam Munketon, goldsmith of York, for making our new crozier, 20s., and 16t. for testing the silver used thereon; for quieksilver 6d., and for three gold florins bought for gilding the said crozier, 12s. 10d. For a saddle bought for John l'auconberge, ${ }^{h}$ 5s. Gol. Jan. 29. To Walter de Brikynhale, 5s. Fd. for the cost and apraratus of our Bible. Feb. 11. To Nicholas de Molendinis $40 \%$ for certain matters which we told lim to do. Feb. 13. To the goldsmith for making the cover of our eup, 1.2s.; for one florin bought to grild it, $4 \mathrm{~s}$, and for making it, 3s. March 5. 'lo a wine merchant $9 \frac{1}{2}$ marks for two cakks of new wine. March 29. To Adam de Munketon, goldswith, 11\%. $5 \mathrm{~s} .9 \mathrm{~d}$. for the making and the metal (pondere) of seren salvers (scutellarum) and six cups of silver. April 27. To Gaylard de Laden, 107. 16s. 8d. for fonr casks of wine bought for our use at Hull, and to Arnald de Leulk, $40 l$. for 16 casks of wine bought there. June $\boldsymbol{\sigma}$. To Margery de Wyghton for straw (iiteria) bought for our use, 10 marks.' June 13. To William de Crrenefeld, our nephew, to marks on our business. June 19. "To John de Sandwich 10 marks to make prorision for us at London. July 26. We have pardoned Robert de Mering, of sonthwell, 10s. in eonsideration of a colt we have bought of him. ruly 15. T'o Robert de Bhuntesdon, 200l. to make prorisim for "ns at the next fail at St. Botulph's. Sept. 3. To Mr. John de Weston, the king's chamberlain in Scotland, or to

farcienda; in pondere primo, 7s. 31. In dimimutione operis, 8d.: in vivo ar fouto enuto pro earlem, 4h.: in factura ejuclem crucis, 6s. 8d.: in ij florinis et di. anri emptis, 9.."

In the Wardrole Aceoment of Edwrit I. (H, ete.) similar gifts oecur. 'The Friar were not infornet of sood livins if l'iers Plowman, Chancer, and Ibuchintan are to be believel. Their unicratory life was one of their ehief 1halanteristic: that they would justify in the words of Lrasmin, "Tales erronce erant apostoli; tialis erat et Domims olest:" and for their finstins, (n'.:, the lines of the poet minht be their warrant:-

\begin{abstract}
"Our Lork . Tesu, as holy writ deviseth, lare us ensample of fasting and praieres. Therfore we mendicants, we sely freres, Ben wedded to poverte and continence."
\end{abstract}

Their life, soou after their introduction inte Englaud, must have been anything but pleasant, as Eeeleston speaks of their crowding together for warmth "like a litter of pies."

$h$ A soln of Walter de Fauconberce and a ward of the archbishop of York. He will be arain mentioned.

Lib. Garderobe Edward T., 33.

l'aymaster at Berwick 1299, 1300 (Lib. Garderobe, 115). An eschaetor and much concerned in soottish affairs (lied., ii., 193. Rot. S'cotice, i., 61 
Peter Bonarieta, merchant, of the eompany of the Bardi, 100 marks. Oet. 25. 'To the abbat of St. Mlary's lork, $10 \%$. which we are compelled to pay in these days in behalf of our predecessor J. Romayn for a certain disme imposed in his time. Nor, li. A loan of 120 marks to Mr. P. de Denek which he has borrowed from us in the time of his great need. Dee. 23. "Fo the woldsmith at York for the metal and the making of six silver cups, 4l. 18s. 7d. To Peter de Barlefos, 15\% for five easks of́ wine which he sent to Carood.

1314, Jan. 25. An order to pay the money required for' making a new gate in our manor of Hexham and for other works there. Feb. 11. A loan of 10l. to the prior and convent of Hexham on aceount of the frequent incursions of the soots. Feb. 20. To John de Sandwich money sufficient to buy half a web of eloth of the suit of our winter livery, and a thick variegated fur for dan William de Melton. "T'o the Wriars Preachers and Ninors of York, 40s. each, and to the Aronstinians and Carmelites, 20s. each, of our alms, and let cach convent be asked to permit every priest in their houses to say a mass for the soul of Robert de Grenefeld, our brother, lately deceased. March 22. To John the goldsmith at York, and others, \%l. 7 s. 6d. for certain small things. May 12. To Thomas Frere, William Curtays and Roger de Upton of Doneaster 20 marks for the repairs of the causeway between Doncaster bridge and a bridge ontside the town ealled Wylghebrigg. May :60. To the kecpers of the fabric of the chureh of St. Peter, York, 50 marks, of our speeial farour. May 28. To William de Tasconia, wine merehant, 25\%. 2d. for 8 easks of red wine bought of him, and to Peter de Badefosse, $333 / .16 \mathrm{~s}$. 1d. for 10 casks of red, and 1 pipe of white wine bought of him. May 31. To the repairs of 2 bridges at Ripon, 10\%. June 18. To John de Merkingfeld 100\%. as a loan to restore his fortunes, with cool's help, for we are much concerned at his unhaply case." July 18. To John

etc.). Constable of the Towor of Tondon (The French Chron. of Lonton, 55). Constable of Bordeaux, lst of Edward III. (Cal. Rot. Pat., 99).

${ }^{k}$ Prebendary of Grendale at York, which he gave up in 1322, when he took the cowl in the monastery of st. Angnstine, at Canterbury. Lle made a will in farour of that house, but tiring of his profession, ran away. Thorne gives an amming aceount of his recaptiure.

'Afterwards archbishop.

" Prebendary of Warthill at Tork and Studley at lipon, and rector of Escrick. In the 5th and 6th of Ed- ward II. he was ehanection of the Exchefuer (Halox, ii., 326), liaving been a]printed to the oflice two sein's before, when he had the royal premistom to crenellate his house at Mankenfiedr, near Ripon, which still remains (citl. liot. Pat., 70). JIe was orempledel neensionally in state matters (liot. Siot., i., 71). liot. Parl., i., 119. Pull., ii., 219, $4(0)$ ), and lent mones fo the monatery of Burlam (Rer. Kellawe. 7I). lle was exemtor of IVilliam de llanilton, dean of Tork and lord chansollor of England, with whom he had been long connecterl. He sot into tromble and was excommunicated on aceomit of his 
de Okhanl, "the king's cofferer, 100 marks for our service in the Scottish war in 1313. July 22. T'o Nicholas de Molendinis, 10\%. I (is. 81. for cloth and furs for our use, and to Peter de Badefosse, 40\%. (is. 8d. for a pipe of wine. July 12. To Henry de Carod, our poulterer (poletario), 17l. 3s. 5d. to buy oxen, sheep, and pies for gifts to the king and queen. ${ }^{\circ}$ August 6 . To Nicholas de Molendinis, $200 l$. to provide for us at St. Botulph's fair. Lugust 14. To John de Sandale, lientenant of the treasury, $10 \%$. which we have granted to the king for the wages of forty footmen who are to be sent to Berwick to guard that town in its great need.p Angust 19. To a goldsmith at York, 69s. 2d. for the metal and the making of four silver cups. To a certain baker at York for consecrated bread (panis Dominicus) lately sent to Sir Hugh le Despenser, and Ralph de Mehermer.q Scpt. 2:2, To Sir Joln de Wylmerton, knt., 200 marks which we have ar'minted to our kinsman Sir John Giffard of Brymmesfield to help towards the payment of his ransom in Scotland. To Sir Hen'y de Wylmerton, knight, 100 marks which we have giren to Sir Baldwin de l'ryvill, knight, ou kinsman, towards his ransom in Scotland. Oct. 3. To Sir Simon Warde, knight, $20 l$. for the same purpose.r Sept. 21. 'To John de Sulle,s 10l. which we have lent him in his great need. Nor. 6. To William de Ponteburei, our bailiff at Sherburn, money to pay for fifty furs bonght at Pontefract for oni winter livery. Nor. 21. To the Friars Preachers of Beverley three quarters of corn. Dec. 9. 'To the bailift' of Sherburn money to pay the wages of John Lousing our carpenter. Dee. 10. 'To Peter de Badfos 50 marks

matuduninistation of that trust, and this, problatly, is the "niseria" to which Greenfield alludes. Markenfield's will was made in 1321, and is in the registry of the dean and chapter of Tork.

"A baron of the Exeheuper.

o IValsinglam, 101.

r (f. Chron. Lanercost, 221, ete. Firll., ii., 218.

" England was roused-on erery side (courter and post and herald hied, To smmmon prince and peer,

At larwick hounds to met their liege l'repared t" raise fiar stirling's siege

With buckler, brand, and spear."

? It is imposibible to speak here of these ureat men. The panis may be thus explained, "Quorue aplellata

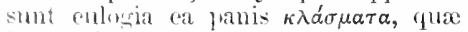
in reteri exceseia ard alias prarecias, ant

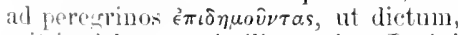
mitti solebant. Similiter etiam Latini enturias dixere frusta panis benedicti quiten, sed non in usum eucharistie, quæe et absentibus et catechumenis, jus sumendie encharistixe non habentibus mittelantur, ut ipsis essent vice sacramenti. Fractio panis dicebatur eulogiarum benedictio, qux a presbyteris vel episcopis fiebant ante cibi sumptioncm seu prandium; quas eulogias anticis vel convivis in communionis srmbolum distribuebant." See also Irucanse sub roce Eulogia.

r The consequences of the defeat of Bannockburn. We see from this how the ransoms of the prisoners were raised. Wylmerton had been a captive himself, and Ward is, erroneously, said to have been killed on that fatal field. II ylmerton is probably the same person that was executed for treason at Bristol in 1322 (Murimuth, 37). Miracles are said to have attested his excellency.

" Clamberlain of Edward I. in 1306 (Foril., i., 998). Abbrev. Rot. Orig., i., 36 . 
for red restments of " siklatum," which belonged to Sir IIenry de Perey, with parures, stole, and maniple, embroidererl.

1315̃, Jan. 14. To Hugh Saunterre, our valet, and Giles de Morton, "domicello nostro," money to buy for each of them the following arms, "one aketun, one liaubergeon, and one bacinet," and gauntlets and a lance. Jan. 27. To Gaillard Cessime, wine merchant of Gaseony, 20 marks 13s. for 4 casks of wine. Feb. 13. To Stephen de Bella Arua, hailiff of Southwark, 7 ts. 8d. which he paid for stone and flint bought for making a certain chamber in our manor of Scrooby. To John de Moubray and Peter de Manley 50 marks each, as captains of these parts, appointed by us and our clergy for the defence of this provinee against the Scots. ${ }^{0}$ Mareh 30 . Mandate to the reecivers at Chinchedon to buy 3 casks of good wine, as we inteud to come there this summer. April 8 . To the bailiff of Sherburn for 55 lambs' furs, bought for our use at Pontefract, the necessary money. April 18. To $\mathrm{Wm}$. de Grenefield, our nephew, 50 marks for certain business of onrs. April 26. To William de Thorp, our baker (pancturio), 20l. to buy horses for our use at Ripon fair. May 5. To Sir Robert Coigners, 20\%. which we have lent to him. May 6. To Peter de Badefos, 49l. I4s. $2 \mathrm{~d}$. for 15 casks of wine at Hull. May 17. To the keeper of the bridges at Ripon, ${ }^{x}$ 20l. To our steward at Scroby, money to buy certain things required to build a chamber in our manor there. May 28. 'To the keeper of the fabric of the ehureh of York, 50 marks for the more expeditious progress of the work this summer, August 11. A loan of 50 marks to Sir Ralph Fitzwilliam.y August 23. A loan of 20/. to Henry de Kuaresburgh minister of the house of' St. Robert of 'Knaresburgh and his convent on account of their great need. August 31 .

${ }^{t}$ In 1295 the cope of John Mansel "de parno aureo qui vocatur cielatona" was in the treasury of St. Pan's (1) ngdale's St. Paul's, n.e., 1318). Other instances occur in Ducange under the word cyclas. Cf. Kuyghton, col.2740.

u Walsingham, 107. There was a great levy about this time in Yorkshire (Rot. Scot., i., 165).

"He was bailiff of Ripon in 1307 . The family belonged to Nottinghamshire. Cf. 'Thoroton's Notts, 321. John de Bella Aqua (Bellew) married Laderina, one of the daughters and co-heirs of Peter de Brus (Madox, Bar. 51). On " die Dom. in crast. Omn. Simet.," 1309, Isabella de Bella Arrua granted to William, son and heir of sir John de Bella Aqua, her son, his own marriage which she bought of Sir William le
Vavasour for 200 marks (lkeg. Greenfield). Plac. de quo Warrauto, 18s, $193,212$.

w On 16th March 200 marks more were griven to four eaptains, and a like sum on the 26th (Reg. Greenticid).

$x$ On 26th Angust another sum of 10l. for them to William le Littenter, burgess of Ripon (ibicl.).

$y$ In 2 lth of Sedward 1 . he ocenrs as brother and heir of Geoffrey litiwilliam (Abbrev. Rot. Orig., i., 96). Ie was custos of Newcastle and ('irlisle in 1315 (Rot. Scot., i., 1.40), and was much employed in the service of the state. For an aceomt of him and his princely fortumes, see Hodssom?s Northumberland, vol. ii., prart ii., 274. Foss's Judges, iii., 89. 
To the prioress and convent of Clementhorpe, $40 \mathrm{~s}$. of our alms. and to a poor man, who made a ditch in the garden of our palace to carry off the superfluous water, 2s. Sept. 5. To the prior of St. Mary's York, $20 \%$. for the eovering of our houses at Westminster. Sept. 10. To Stephen de Bella Aqua money to buy 50,000 or 60,000 turves, and 6 marks for making a certain mill of ours at Laneham. Nov. 18. To the Friars Preachers and Ninors of York, each 5 marks, and to the Angustinians and Camelites 10s. each, on aceount of the excessive dearness at the present time.

Archbishop Greenfield died at his manor house at Cawood on the festival of St. Nicholas, Saturday, December 6, 1315, ${ }^{a}$ and was interred within the minster of York to which he was a generons benefactor. He lies in the north transept on the eastern side, in the corner adjacent to the choir aisle. The momument which commemorates him, although much mutilated and injured, is a very striking one. The marble slab that covers his remains has been plated with brass, of which nothing is in existence save a portion of the figure of the archbishop which time and neglect hare almost entirely obliterated. He wears his mitre, and is clad in full canonicals, and his hand is raised in the act of beneliction. ${ }^{b}$ Above the figure there towers a lofty orerarching canopy of rich decorated work surmounted by a statuette of Greenfield who is seated in his ehair. ${ }^{c}$ This is a valuable memorial of the skill of a recent master mason of the cathedial. Between the tomb and the wall there onee stood the altar of St. Nicholas, for, as the decease of the archbishop occurred on the festival of that saint, this plaee, most happily and appropriately, was selected for his interment. At the time of Greenfield's death two chartries were in existence at that altar, and on the 28th of April, 1316, Richard de Cestria, canon of York, added a thirl at which the soul of the arehbishop was expecially commemorated. ${ }^{l}$

Abont 1 135 the tomb was opened and a fine gold ring with a mby was taken from the dead man's ninger. It is now deposited among the treasures in the restry. The lines of Hugo Grotius may be applied to it:-

\footnotetext{
= Linyshton (col. 2532) spenks of the "caristia tritici" in 1307 , but he does not allule to this year. Murimuth, lonvever, nentions it (i, 21), and says that a culurter of wheat was worth 30 . and mire. ('f. Sprotti Chron., 77, and I'onelowe, 34. The corn conld not ripen in conserpence of the wet weathei. a IISS. Cotim, Vitellins, A, ii., 112. Stublin, col. 1730.
}

s Engraved in Waller's Sepulchral Brasces, and in Drake, 432.

c It wats behind this tomb that the wretclied fanatic Jonathan Martin secreted himself in 1829 when he set fire to the minster. In 1434 the archbishop's tomb was enclosed (Fabric Rolls, 53).

d labric Rolls, 299. Domesday book penes Dec., and Cap. Ebor., $52 \dot{b}$. 
"Anmule, qui thecam poteras habuisse sepulchrum, Hac, natalis erit nune tibi, theea, locus."

I find also that Greenfield bequeathed another ring to the dean and chapter to decorate the feretory of St. William. 'This came into their possession on the oth of Jannary, $1316 .^{e}$

Goodwin tells us, withont stating his anthority, that the arehbishop bequeathed his library to the monastery of St. Alban's, ${ }^{f}$ which at that time was in very high repute. "His will has not occurred to me. 'Thomas de St. Albans', canon of Sonthwell, and William, son of Robert de Greenfield, the testator's nephew, were the cxcentors. They were released from the responsibility of their charge on the i6th of Lugust, 13:2.."

DV illiam ac faltom, the forty-second archbishop of York, was a person of whom all contemporaly writcrs speak with respect and admiration, and he must be regarded as one of the greatest prelates that erer presided orer the Northern prorince. He was of humble origin, but he raised himself to distinction by his natural abilities and his unflagging cncrgy, and becanc one of the most conspicnous and nsefin statesmen of the age in which he lived. Nor were his scrviees to the ehureh less remarkable from his connection with the court. ${ }^{i}$ It is, indeed, difficult to do full jnstice in a narrow space to so illustrions a man.

He was a native of a little hamlet, ealled Melton, in the parish of Welton near Howden, ${ }^{j}$ which is sitnated about five miles from North Cave, and nine from Bererley and IInll. 'The district in which he was born was uuder the control of the see of Durham from very carly times, and the prior and consent of that renowned monastery were the patrons of the church in

e Fabric Rolls, ed. Surtees Socicty, 21.4. There was in the treasury, by the sift of Greenfieth, a yontifical rim with an emerald in the mirlde surrounded by four rubies and four large pearls (ibid.).

$f$ De Presulibus, n.e., 685. IIe probably derived his information from the famous Golden Book of St. Albans' which is in the Cottonian library.

$g$ Drake's Eboracum, 132.

$h$ March t, 1319, commision to Mr. Dennis Avenel, canon of Deverley, and Thomas de Cave to receive the accounts of the excentors. Oct. 10, 1321, the king orders Mr. Thomas de St. Albans to he summoned to frity the stmm of 193/. 17. $5 \frac{1}{2} \mathrm{l}$. to archibishop Velton (Rese. Meltomi).

i "Licet de curia regis esset asimup11s, religiosam tamen vitam habuit et lonestam" (lanerost Chron., 233).

$j$ Mr. Nichols milkes lim a native of Melton Mowbray (IListory of Leicesfer-hire, ii., 25is). There are pedierees of the funily in Baker's Northants, i., 6iziz; l'onleon's IIoldemens, ii., 199; ILuter's Suth Jorkshre, ii., 162. 
which Melton would worship in his boyhood. They befriended him in his struggles with the world, brit it was in all probability to bishop bek and archbishop Grecnfield that he was mainly indebted for his rapid progress in the court and church. 'The neighbourhood from which he sprang produced another great man abont the same time, John de Hotham, lord chancellor of England and bishop of Ely.

In 1300 Melton oecurs as one of the ostiarii of the wardrobe of Edward I., and he was comptroller of the same department at the accession of his son, an office which he was holding in $1315{ }^{k}$ In the spring of 1308 he went abroad with Edward II., being at that time the sccretary of that monarch, in the charge of the temporary seal. ${ }^{l}$ On the 20th of April, 1310, the king sent a eommendatory letter in his favour to the pope, praising him highly, and saying that he had been in his service from his boyhood. 'This seems to shew that there was then some prospect of Melton's rising to greatness, and this is the more probable from the fact that lidward wrote in the same strain to the pope and cardinals on the 12th of November, 1312."n On the 1:2th of August, in the same year, he went as a commissioner from the king to the harons and probi homines of the Cinque ports, ${ }^{n}$ and he was sent abroad on May 3, 1313, with letters of protection, on the king's business, and the constable of Dover was ordered to make arrangements for the passage of Melton and his companions. ${ }^{\circ}$ On the lst of August, in the same year, Melton was one of the commissioners who were to look to the protection of the marelies of England against the Scots, and on the 12th of Jme, 1314, he and others had letters of credence to archbishop Greenfield, as the representatives of the king, in the convocation of the elergy that was to meet at York to consider the subject of the experlition into Scotland which ended in the disastrons defeat at Bannockburn. ${ }^{p}$

Whilst Melton was thus cmployed, he was a pluralist of the first water. He seems, indeed, to have been beneficed in every part of England, but it must not be inferred that he held all his pieces of preferment at the same time. In 1299 he was presented to the rectory of Refham, in the diocese of Lincoln, which he was holling in the following year. ${ }^{q}$ On the 10th of

' liber Garderobe, 45, 87, 95, 166, 181, 332. Madox, IIist. Excl., i., 7.1. Rot. Scotia, i., 113. Pell Records, 118. Parl. Writs, rol. ii., Jart ii., 10.

1 Foed., ii., 29. Parl. Writs, vol. ii., part ii., 11, 43. In 13 t3 he gave the great seal to the keepers thereof by the king's order.

n Forl., ii.. 107, 187.

n I'arl. Writs, vol. ii., part ii., 4.
"Foed., ii., 211.

$p$ Ibid., 219. Rot. Scotiæ, i., 113. Parl. Writs, vol. ii., part i., 421; part ii., 77. On August 13, 1313, he was sent to various prelates within the province of York to ask for loans against the Scots (ibid., vol. ii., part ii., 65).

$q$ MSS. Harl., 6951, 33. Cal. Iriq. Post. Mort., i., 165. 
July, 1301, he was instituted, at the presentation of the abluat and convent of St. Mary's York, to the rectory of Hornsea in Holderness." On the 2nd of January, 1305, he olstained the first part of the prebend of Oxton cum Crophill at the church of Southwell, ${ }^{s}$ and on the 13th of March, 1308, he was institnted to the rectory of Lythe, at the presentation of Sir Peter de Mauley, and he made a diligent enquiry into the dilapidations of his living. ${ }^{t}$ On the 27 th of August, 1308, he was made dean of the college of St. Martin-le-grand," and archdeacon of Barnstaple, in the church of Exeter on the 13th of October. ${ }^{v}$ In 1309 he became prebendary of Lonth at Lincohn.w On the 3rd of May, in that year, he gave up his stall in the collecriate churech of Westbury, in the diocese of Worcester, to Mr. Willian de Lincoln for his prebend at the altar of St. Michael at Beverley, to which he was collated. On the ?nd of Jume he was presented by Edward II. to the stall of South Cave at York, but it was found upon enquiry that Neapolio, a Roman cardinal was in possession of it in virtue of a papal provision, and Melton did not obtain it. ${ }^{x}$ On the 30 th of July he was collated by archbishop Greenfield to the prebend of Northwell at Southwell which John de Drokenesford had held, and on the 6th of October he was preferred, by the same prelate, to the provostship of Beverley. ${ }^{y}$ In the same year he was presented by the king to the rectory of Thorpland in Norfolk. $z$ On the 23rd of Mareh, 1310, he was collated to the stall of Driffield at York, exchanging for it, with John de Cadomo, his prebend in the collegiate chureh of Darlington, and he was installed by the chapter on the 15th of August. ${ }^{a}$ On the 4th of August lie was instituted to the rectory of Spofforth at the presentation of Sir Henry de Percy. ${ }^{b}$ In 1312, on the th of July, Richard Kellawe, bishop of Durham, granted him an anmul pension of 20l. for the good service he had rendered him, ${ }^{c}$ and Melton was in the receipt of a similar gift of ten marks per anmum from Walter de Langton, bishop of Corentry and Litehificld, which he gave up on the 12th of November, 1318, when he no longer needed it. ${ }^{d}$ On the 8th of April, 1312, the prior and convent

$r$ Reg. Corbridge, $33 b$. Reg. Greenfield, part i. Instituted again May 7.

s Le Neve, iii., 1.17.

¿ Reg. Greenfield.

u Newcourt, i., 426. Kempe's St. Martin-le-Grand, 102. Mon. Francise., 506. Plac. de quo Warranto, 52 . Cal. Rot. Chart., 140. "Le Neve, i., 406.

$w$ Ibid., ii., 180.

* Reg. Greenfield, part i., 12.13.

$y$ Ibid., part i., 46 b. IIe was collated to it previously on Oct. 22, 1308.
Oliver's Beverley, 390. Cal. Rot. Chart., 1.1, 1.7. I'lac. de quo Warranto, 636 .

z Blomelield's Norfolk, vii., 98.

a Reg. Greenfield. Acta Capit., $16 b$. In August, 1311, when Robert de Pickering was elected dean, Melton receiver the vote of Robert de Riplplingham, the chancellor.

$\checkmark$ lieg. Greenfield, part i., $80 a$.

r Rer. Kellawe, $4 b$.

" Reg. Melton. IIe had also a pen- 
of Durham gave him the rectory of Wclton, his native parish, lut he resigned it on the 1.th of September following, $e$ and on the 13th of Jamuary he is said to have been preferred to a stall in the ehurch of Howden $f$ On the 21st of November, 1314, he received the living of Castre, Northants, which he gave up in 1316,9 and in September, 131\%, he resigned that of Brigham, in Cumberland, upon his promotion to the arehbishoprie of York. ${ }^{k}$

The death of archbishop Greenfield in December, 1315, vileated the see of York, and on the 13th of that month the king gave the chipter leare to proceed to a new election. On the :Ist of Jamnary they fixed upon Melton at the king's request, and on the 5th of Ecbruary Edward assented to their choice. On the Sth the king wrote in Mielton's behalf to the pope and wave him letters of safe conduct to cnable him to leare the kingdom. On his arrival at the papal court he was subjected to a lengthy and tedions dclay oceasioned, no doubt, to a great cxtent by the death of Clement $\mathrm{V}$. His wishes, however, were thwarted by sone attaches of the papal court, among whom may be mentioned Pandulyh de Savelli, George de Poregia, and Francis Gactano, all of whom were beneficed in Yorkshire and had some grudge, in all probability, against the archbishop-elect. On many occasions the king wrote to the pope and cardinals in Melton's favour, at one time protesting against the delay, and expressing the mischief which it might oceasion in eonsequence of the ineursions of the Scots, at another time remonstrating with the opponents of the confirmation and imploring that it might at once be made.j Smooth words, howerer, as well as rough were impotent, and the eonsecration was actually delayed until the 25th of September, 131\%, when it took place at Arignon. ${ }^{k}$ On

sion from the frior and convent of coventry. There is a singnlar letter from prince Elward relating to it in 33rd Ellwarl I., which certainly shews that Helton was fond of money (Ninth Report of the Deputy Keeper of Public Records, aplendix, ii., 217-8).

c lieg. ii. Prior. and Conv. Dunelm., i., $111 b$. When Melton was elected arelbishop he wrote a kind letter to the frior asking him to be present at his enthronization. He also lent the conrent 100 marks (Hise. Doementspenes Lee. and (apit. Dunelm., 4603, 4967).

$f$ HsS. 'l'urre. Hutchinson's Dur. lram, iis., 151.

g IISS. IIurl., 6951, 5ъ そ. Bridges' Northats, ii, 501.

${ }^{h}$ lieg. Miforot. II le resigned at the same tinc the rectory of Ifornsen, valued at 50 mark jer annum; the prebend of Driffield, taxed at $100 l$. per annum; the stall of St. Michael at Beverley, worth $17 l$.; and the provostship worth $40 \mathrm{l}$.

i Stubbs, col. 1730. Le Neve, iii., 106. Fud., ii., 285. Cal. Rot. Pat., 79. On 19 kal., Jan., 1315, the chapter asked the king's leave to proeeed to a new eleetion (Reg. Dec. and Cap., sete rac.).

$j$ Fird., ii., 297-8, 300, 305-7, 310, 312-15, 318-19, 327, 332-3, 341. Edward calls Melton "predilectus elerieus et fimiliaris noster." On April 20, 1317 , the pope wrote to the king to say that he had ordered a eardinalbishop to hear the matter (Foed., ii., 3ำ). Carte's Gaseon, ete., Rolls., ii., $6-9$.

${ }_{k}$ Stubbs, col. 1730. MSS. Cotton, Fitellins, A, ii., 112. 
the 8th of October Edward restored to Melton the temporalities of his see. ${ }^{l}$ The new primate was at Beverley during the eelebration of the next Advent, and on the 14th of February he was solemnly enthroned at York, the festivities on that occasion lasting for three days."

When Melton returned into the North he was phumged into the rortex of Scottish polities which occupied his attention for the remainder of his life. The peace of the Borders was being continually broken, and it was neeessary for the English soldiers and statesmen to be always on the alert. On the 27th of January, 1318, the archbishop was summoned to a meeting of the parliament at Lincoln, ${ }^{n}$ and on the 18th of March he was one of the commissioners appointed to make a truce with Scotland. ${ }^{\circ}$ Negotiations, however, were thrown aside, and on the 8th of June the proposed meeting at Lincoln was deferred in consequence of the news that the Scots were at that time in England. 'The restless marauders broke into Yorkshire in the month of May, plundering and burning what they could as they passed along. The towns of Northallerton, Boroughbridge, Knaresbrough and Skipton in Craven were destroyed, and Ripon was only saved from ruin by the tenants paying down to the invaders the large sum of $1000 .^{p}$ On the 5 th of Jume the arehbishop excommunicated the Scots for the mischief they had eaused at Ripon and Otley. They had done very serions injury, besides, to a large portion of his diocese. The value of eluurch property in Yorkshire was depreciated by that raid to the large amount of 1000 marks, and as many as sixty benefices were injured. The church of Tadcaster was destroyed, and that of Pammal burned, as the invaders had tarried at that village. The tower of the church of Knaresbrough still bears the marks of the fire that was kindled around it in the vain hope of bringing it to the ground and destroying the fugitives whom it sheltered. The abbey of Fountains was for some time the head-quarters of the Scots, and, as may be expected, the substance of that noble house was entirely wasted or taken away. $q$ Corpses and smoking villages marked the path of the retreating foe. 'The utmost vigilance was required to prevent the recurrence of the injoad. The archbishop was made one of the keepers of the marches,

' Fod., ii., 314.

" Stubbs, col. 1731. The bishops, abbats, justiciars, etc., were invited to the entlironization (Reg. Melton).

$n$ Parl. Writs, vol. ii., part i., 173, 175,178 . 179.

Fod., ii., 358. Rot. Scotia, i.,

$p$ Chron. Lanercost, 235. Parl. Writs, vol. ii., part i., 181. Foed., ii.,
137. Reg. Melton, where there is a list of the places injured. On Jam. 1, 1319, the archbishop ordered his own tenants at likinon to gas their yuota. In Leland (Coll., i., 250) it is said that the scots killed matry of the clergy, etc., at Ripon. Tlus information is in Murimuth, 38.

$q$ Res Melton. Cal. Rot. Pat., 83.

r Cal. Rot. Pat., 83. 
and on the 10th of June and the 25th of Angust he was ordered to array his servants and send them against the Scots.s On the :(0th of October he was summoned to the parliament at York, and, on the 16th of December and the 13th of January following, he was again desired to prepare his tenants for service across the Tweed.t

The year 1319 found Edward II. keeping his Christmas at Bererley, as he was eager to punish the Scots for their recent foray into England. The attempt of Edward Brus upon Ireland hatl ended in a signal faihure, and his brother Robert had been formally excommunicated by the pope. On the 6th of May the archbishop was summoned to a parhiament to be held at York." The king was gathering together for his expedition all the forces that he conld collect, when he was distressed to hear that the goremor of Berwick had treacherously surrendered that town to the enemy, and he hastened northwards to recover it. On the 21st of July archbishop Melton wrote to the bishop of Durham, the dean and chapter, and the official, of York, soliciting the prayers of the faithful on behalf of the expedition, and granting an indulgence of forty days to those who offered them. On the 4th of September the primate wrote to the abbat of St. Mary's and other dignituries requesting them to meet him on the ensuing Friday at the church of the Holy Trinity in Micklegate, York, and to join in a solemm procession, with its customary litany of supplications, for the success of the royal forces. $v$ On the same clay a very different order was issued by the king, and it came to York - the herald of alarming news. It told the archbishop that whilst the English monarch and his chivalry were at Berwick, Randolf, earl of Moray, and the famous Donglas were making a raid into the kingdom in another direction, and Melton and the chancellor, John de Hotham, bishop of Ely, were ordered to array and lead against them the posse comitatus. ${ }^{20}$ The erozier scems to have been thrown aside for a more potent weapon, and the warrior-bishops seem to have taken all the precautions that civilians could adopt. ${ }^{x}$ The soldiers were absent

- Parl. Writs, vol. ii., part i., 502, $505,511,512$.

'Ibid., 182, 511-12. Fæd., ii., 352. Rot Scotice, i., 190. Wilkins, ii., 485.

" Tarl. Writs, ii., part i., 197.

"Reg. Melton. On March 10, 1318, Melton enjoined the people of his diocese to pray for peace, there being at that time dissensions between the king and his barons (ibid.). On the 2otly of July the kin: asked for their prayers (Focl., ii., 402), and, on October 3rd, Itelton granted an indulgence of forty days to those who complied (Reg. Melton). What a contrast to the spirit and the temper of the present age! In 1321 Ielton granted another indulgence of forty days to all who prayed for the king, and another in July, 1319 (Hist. Dunelm. Ser. Tres, appendix, 123).

"Parl. Writs, ii., part i., 525. Rot. Scotix, i., 202.

The think of the archbishops of Orange and Poggio in the Gierusalemue Liberata :- 
in the North, but the exhortations of their diocesan wonld bring the clergy into active service with as many of their parishionces as they could persuade to accompany them. A motley crew of 10,000 men is said to have been collected, many of whom were better acquainted with the breviary than the sworl, and all seem to have been completely ignorant of discipline and military array. ${ }^{y}$ Parsons, vicars, friars of divers orders and hues, citizcns of York who left unwillingly their merchandize, grooms and ribalds were sent into the field. The invaders had made a daring but unsuceessful attempt to seize the queen in the neighbonrhood of York; they had actually destroyed the suburbs of that city, and were now lying about twelve miles off' on the promontory between the Swale and the Onse, near the little village of Myton where the two streams unite. On the 12th of Oetober the English 10,000 came up to them in disorderly array and shewing a front that any enemy would rejoice to encounter. The Scottish forces must have watehed them with eager satisfaction till they crossed the river by which their retreat was intercepted. Several haystacks were now fired, and the smoke drifting into the eyes of the Englishmen blinded and bewildered them. In the middle of the confusion and right through the smoke, the Seots came down upon them, and they turned and fled to the right hand and the left. They were thrust into the river to be drowned, or perished by the sword upon its banks. Great numbers were killed, whilst others were carried away into captivity, amongst whom was William de Armin who was subsequently bishop of Norwich. Nicholas de Fleming, the mayor of York, was one of those who fell, and the fugitives seem to have been rescued from complete destruetion only by the night. The maranders now made their way homewards and escaped from the English army, carrying with them an immense booty. 'The Scots, in memory of the profession of a great number of their opponents, gave to that contest, if sueh it may be ealled, the title of the white battle; and the English soldiers, in bitter ridicule of the prowess of the clerieal warriors, called that mecting and its debate "the chapter of Myton." *

"Poi duo pastor de' popoli spiegaro Le squadre Ior, Guglielmo ed Ademaro.

L'uno, e l'ultro di lor, ele ne' divini

Uffici gia trat tò pio ministero,

Sotto l'elmo premendo i lnnghi erini,

Essereita de l'arme lior l'uso fero."

$y$ There is an account of the battle in Chron. Lanereost, 239. Lel. Coll., ii., 462-474. Buchanan, Revum Ścot. Hist., 8vo, Francofurti, 263. Murimuth, 30. Walsingham, 112. Trokelowe, 45 .

= Rot. Scot., i., 201. In Barbour's
The Brus, ed. 1856, p. 401-5, the following lines oceur :-

\footnotetext{
"The archlishop of York tha mul Thar capitane, and till consale

Ilas tume that tha in plane battile Wald assale the Neottismen,

That fer fewar then tha war then. Fhan lan displait his baner, Aud other bischopis that thar wer.

of tha yliet thre hundreth war lestis that deit intill that daat Thatore that lorrgane eallit was 'The chiptour of $\mathrm{Hy}$ toun, for thar Slane sil mony prestis war."
} 
If arehbishop Melton was present at this disastrous adventure, it was the first and the last time that he tried his fortunes in the field. How the English soldiers would laugh at his puny and nnsuccessful efforts when the army came back from Berwick! Edward returned to York with all speed as soon as he heard the news. On the 15th of September Melton and several other commissioner's were sent to Carlisle to propose an armistice, to which the Scots, who had secured everything that they desired, rery readily assented." In the following month the conrts of justice were remored from London to York, and remained in that city for half a year. The hopes of England scemed now to centre in the metropolis of the North. The king was there, full of indignation at the recent mishap and yet fearful for the future. He was dealing with a subtle and potent chemy, and time was necessary to bring together another army. On the 15th of Jannary, 1322, Melton was ordered to explain Edward's intentions by causing his deelaration to be read in the churches, ${ }^{b}$ and on the 19 th he was anthorized to treat with Robert de Brus. ${ }^{c}$ On the 7 th of February, and on two other occasions in the same year, he was directed to supply men or money for the Scottish war and to provide his enstomary service. ${ }^{d}$ II is diplomaey, therefore, had been unsneeessful. In the antumn of 1322 there was another inroad of the Scots into Yorkshire. They swept over much of the same ground whieh they had devastated in 1319. The king sent John de Britannia, earl of Richmond, with a hody of soldiers to wateh their movements, but he ineautiously allowed himself to be surprised among the hills between Byland and Rievanx. The invaders, who were at home among the rocks, made prisoners of the English eommander and a number of his men. Edward, never dreaming that danger was so near, was all the while in the monastery of Rievaux. IIe fled in haste, two of the monks serving as his suides, leaving all his plate and treasure behind him, of which the encmy possessed themiselves. After seouring the eountry towards the east and south as far as the Wolds, and receiving a large sum of money from the inhabitants of Beverley for sparing

In IIardyng's Chronicle, n. e., 309, there is the following description of the liattie :-

"To Borourhbrydge by East and West he brent,

And home agayne with nany a prysomer,

Witlout harne or lette of his entent,

With mykell gord, but in Myton medowe, nere

To Swale water, laye then with great jower Wialter Wareyn anong the hay kockes
bushed,

Ijon (the byslon) srikenly with fouttes yssimid.
And xr hundreth Englyshe there he slewe, And home lie went with kyng Edward full glad,

With prysoners many, mo then men knewe, The bysliop fled tro the felde full woo bestad, With his clerkes tlat then were full mad."

a Fod., ii., 434. Parl. Writs, ii., part i., 230.

${ }^{b}$ Parl. Writs, ii., part ii., 17.

- Foed., ii., 141.

d Parl. Writs, ii., part i., 544, 558,

568,620 . Wilkius, ii., 514. 
their town, they returned leisurely into Seotland.e They carricd off with them the earl of Richmond, and several years passed away before he could be ransomed. He had already become acquainted with the troubles of eaptivity, as he had becn taken prisoncr in lis youth in the wars in France.

A very distinguished man comes prominently forward abont this time in the history of the North of England, and plays a conspicuous part in the ammals of the nation. It was long before Yorkshire forgot one of the greatest of her favourites, 'Tliomas, earl of Lancaster. Royal blood was flowing in his reins, for he was a grandson of IIenry III., and he had a spirit far more fitted to control an empire than that which animated his fechle-minded consin who now sat upon the throne. An alliance with the heiress of the Lacies gave him umbonnded inflnence and a princely fortune. He was far too powerful to look with indifference upon the busy world of politics around him, and too honest to countenance the follies of the monarch and his courtiers. When the hireling Gaveston was in the flush of his ambitious career, Lancaster was one of the nobles who drove him into exile and set themselves to work to correct the abuses in the administration of the kingdom; and when that liaughty minion subsequently returned, the stout earl was one of those who took him prisoner and sentenced him to death. After this event there was a turn in the tide of the fortumes of Lancaster. The king regarded him with the most bitter hatred; but domestic affliction was the thorn which rankled in his side. His wife dishonoured her ancient name by her disloyalty to her husband, and the monarch rejoicing at his trouble, contemptnously rejected his demand for redress. The indignant noble, when he looked around him, found that other peers were as discontented as himself. He rushed into rebellion, for he was a man with a vast number of friends and retainers and a fearless spirit. He raised a large army to vindicate his rights, but a little subtle diplomacy on the part of Edward earsed it to be disbanded. In 1321 the ridienlous partiality of the king for the Despensers again aroused the anger of the nobles, and there was a meeting at Sherburn in Elmet where a confederary was organized which resulted in the banishment of the faromites. Untoward cireunstances, however, produced the dismemberment of the league,

e Walsingham, apud Canden, 113. Chron. Petrib., 163. Chron. Lanercost, 247. In Leland (Coll., i., 250) it is said that the burgesses of Beverley paid down the sum of 400 . Buchanam, Rerum Scot. IList., 8vo, Francofurti, 265. Fordun, Scotichronicon, ii., 279. Barbour's The Brus, ed. 1856, 431.
"Sclip Johne of IBrotane tluar was tane And richt fele of his folk war slane."

The Buik of the Croniclis of Sieotland, iii., 256. Murimutl, 3๙. Walsinglam, 113. Galfr. le Baker, 66. Otterbourne, i., 6*, 110, "apud Bydland bankes." 'Trokelume, 61. 
and in the following year Edward had the opportunity presented to him, which he had so long coveted, of effecting the ruin of Isincaster. The earl and his followers eame into eollision with the royal forces at Boroughbridge and were compelled to submit to them. The eaptors led him in triumph to Pontefract with every mark of ignominy, and there, on the 22nd of March, he was put to death in the sight of his own castle. $f$ The circumstances attending the execution were calculated to impress the scene upon the beholders, and encircled the memory of the dead with fond and affeetionate regrets. The vietim had always been a favourite, and when he died, as the people thought, in his country's cause, their sympathy was exlibited in a remarkable way. The same sufferings which led the people of the North to desire the canonization of arehbishop Serope, and Henry VI., induced them to regard Thomas of Lancaster as a saint. His mutilated body was interred in the parish church of Pontefract, and, on the rth of October, 1322, archbishop Melton issued a mandate forbidding any one to approach his tomb for the purposes of derotion. He found it necessary to repeat his injunction on the 21th of Angust in the following year. On the 24th of February, 1327, when the tide was turned in favour of the friends of Lancaster, lie adopted a very different tone. The concourse of worshippers to Pontefraet had not slackened, and the country was ringing with the report of miracles which had attested the sanctity of the deceased earl, when Melton wrote a letter to the pope to mention what had oceurred, and to request the appointment of a commission to enquire into the circumstances of the case. Nothing in all probability was done, but the fame of the great nobleman was not soon extinet. On the 30th of October, 1343, archlishop Zouche, at the earnest entreaty of Henry, earl of Derby, set at nought the prohibition of Melton, and permitted service to be done by a monk in a chapel on the hill at Pontefract, ${ }^{h}$ and on the 21 st of May, 1354, archloishop 'Thoresby made a similar concession. ${ }^{i}$ The ehapel

$f$ Tel. Coll., ii., 461-5. Chron. Lanercost, 211, etc. Trokelowe, 10, 5363. Mon. Malmesb., Vita Edward II., 121, 178, 220. Knythton, col. 253941. Froisart, ed. Juhnes, i., 4, etc. Srak Chron., 148-9. Foed., ii., 478, fte. Walsingham, 116. Galfr. le Baker, 6.5. IIardyng (n.e., 310) says,-

"Ther" he was headed anone upon the hyll, Aind buryed was there in a chapell fuyre."

E Reg. Melton. I veland says that lord chaucellor Baldock "caussid xiiij fiacoynes well armid to wateh the hille a certen tyme" on account of reported miracles (Coll., ii., 466). The beads of the earl were treasured in the monastery of Durham (Raine's St. Cirthbert, 122).

" Reg. Zonche. On Dec. 15, 1327, a royal order was issued prohibiting any unauthorized person collecting money for the chapel on the hill where the earl was beheaded (Foed., ii., 726 . Cf. ibid., 707). On 7th Mareh, 1330, and April 3, 1331, the king wrote to the prope requesting that he might be canonized (ibid., 782, 814). Cal. Rot. Pat., 100.

i Reg. 'Thoresby. On 21th of May, 
was on the place of the earl's execution, and was perched on an eminence adjacent to the town.

I have just alluded to archbishop Melton's attempt to check the expression of the feelings of the people of the North towards their favourite. He had previously done what he conld to assist him, having induced his clergy to make a grant of 2000 marks to Lancaster. On the 9th of April, 1322, the king eensmred him for his conduct and desired him to express his contrition by making a similar gift to himself. ${ }^{j}$ Later in the same year Melton was ordered to array his tenants beyond the Trent, and was summoned to the parliament at York, which was to have met in the first instance at Ripon. ${ }^{k}$ It was on this oceasion that all the enactments against the Despensers were ammlled. 'The monarch and his court spent their Christmas at Tork, and preparations were being made for the renewal of the campaign against the Scots. On the 5th of April, 1323, the arehbishop desired the people of his diocese to put up their prayers in behalf of the proposed expedition.' There seems, howerer, to have been little cordiality between Melton and the king. Edward would not forget how the primate had aided Laneaster, and he would see that he looked with disgust ipon his follies and misgovernment. The feeling of the monareh towards Melton was shewn in the tone in which he addressed him. On the 21st of May the archbishop was peremptorily summonerl to attend a comeil at York carly on the morning of the 23rd, and on the 30th he was at a similar meeting at Bishopthorpe, when the subject of a truce with Seotland was mooted and considered. ${ }^{m}$ It was on this oceasion that Hemry de Beaumont was guilty of rudeness to the king, for which he was sent to prison." On the 18th of June, 1323, Melton was made a justiciar for the county of Notts, to try the eommissioners of array who had been gnilty of malversation and oppression. ${ }^{\circ}$ On the 2nd of February, 1324, he had letters of protection to earry him to the parliament at London. ${ }^{p}$ On the 6th of Angust he was requested to give his aid in arraying soldiers within the comnty of York, and on the

1361, the archbishop confirms the ordination of a chantry made by simon Symeon on the hill near Pontefract, in the chapel where 'Thomas, earl of Lancaster, was beheaded (169). 20th Nov., 1361, ordinatio nova vicarise de Pontefract et cantarixe pro anima Thomse quondam comitis hanc. (ibid., 109). Cf. Test. Ebor., i., 281.

; Parl. Writs, ii., part i., 566. On the 28th of February Melton had been ordered to raise soldiers to olyose the eart (ibid., i, 550).
${ }^{k}$ Foed., ii., 496. Parl. Writs, ii., part i., 567. Between 1317 and 1325 Melton was frequently summoned to parliament (ibid., ii., part i., 173, 175, $178,182,197,215,219,231,215,261$, $290,317-18,329,331,350)$.

' Reg. Melton.

n Parl. Writs, ii., part i., 286. Hurimuth, 37.

"Foel., ii., 520. Abbrer. Plac., 312.

- Parl. Writs, ii., part i., 63.1.

p Ibicl., part ii., 268. 
8th of Norember he was desired, with others, to treat with the representatives of Robert le Brus. ${ }^{q}$ On the 21st of December he was summoned to send his service into Gascony, and on the 30 th he was called to the council at Winchester. ${ }^{*}$ Melton seems now to have recovered altogether the good opinion of the king, for on the 3rd of Jume, 1325, he received the honourable appointment of lord treasurer of England. $s$ There are some letters in his register relating to the fortifying and the victualling of the castles of Dorer and Rockingham, ${ }^{t}$ which shew that his office was no sinecure, but it does not appear that he held it long.

A decp mystery is hanging over the history of the period, and we know but little of the latter days of Edward II. and of the intrigues which placed his youthful son upon the throne. Upon the imprisonment of his old master, Melton seems to have looked with great displeasure. The archbishop owed everything to Edward's kindness, and he did not forget him in his adversity. He refused to be present at the coronation of the new sovereign, ${ }^{n}$ and although he did not desert the court, he would regard its proceedings with vexation and distrust. On the 12th of May, 1326, he was ordered to prepare himself and his retainers to defend his king and comtry, and in the following year on the 15th of April, he had letters of safe-conduct to enable him to join the court at Stamford." At Christmas he was at Wallingford with the young monarch and his mother, ${ }^{x}$ and he was one of Edward's guardians.y Soon after this the archlishop was implicated, to all appearances, in a very dangerous intrigue, an attempt to upset the govermment of the new king. Edmund, earl of Kent, was the leader, and he is said to have been abetted by several prelates, of whom Melton was one. 'The archbishop, according to the confession of one of the delinquents, entered with heart and sonl into the enterprizc, and promised to supply the carl with men and money. Ile was arrested, and obliged to answer for his share in the conspiracy. The verdict was one of acquittal, and Nelton brought an action against his accusers, assessing the damages for the wrong which had been done to

7 l'oed., ii., $565,578$.

Parl. Writs, ii., lart i, 326, 681 . He was also ordered to send his service into (iavenny on Maf 17 and Angust 2 , 1:305 (ibid., 697, 711).

Ibid., fit. ii., 272. Dusedale (Chron. 38) says that he was electel on July 30. Cal. Rot. Pat., 96-9. Ile lad a lieutenant in that oflice (Madox, Hist. Exch., ii., 11). "Eboracensis ille, Willelmus nomine, olim curialis, in omni commisso fidelis extitit, et quamvis inter curiales diu conversitus, mores tamen a convictu non traxit, set, obviatus Anglorum eupiditati, per Dei graciam impolutu: semper permansit" (Mon. Jalmesb., Vita Edward II., 237).

Reg. Melton.

"Anglia Saera, i., 367.

" Parl. Writs, ii., part i., 749.

w Foerl., ii., 703.

$x$ Walsingham, 126.

y Barnes's Edward III., 4. 
him at $1000 l^{*}$ This is seareely reconcilealle with the statement of the author of the Peterbro' ehroniele, that the arehbishop fearlessly acknowledged his partieipation in the seheme, and said boldly that for the good of the state he would emperil his own life and everything that he possessed."

In the spring of 1327 the young monareh and his court were at York making ready for an expedition into Scotland. He and the queen-mother were residing in the monastery of the Greyfriars, and around them were all the luxury and pomp which that rich century could produce. ${ }^{b}$ The eity was filled with soldiers and their eaptains, eager to avenge the reverses of past years, and among them were the men at arms from Hainanlt under the guidanee of their gallant count. Every village, also, in the neighbourhood was thronged with fighting men, many of whom, as if in mockery of their profession, "were cloathed all in eotes and hoods embrodered with floures and branches verie seemelic, and used to nomish their beards," a practice which tempted a Seottish wag to fasten the following "rime" to one of the church doors in the eity,

"Longbeards hartlesse, painted hoods witlesse,

Gaie cotes gracelesse, make England thriftlesse."

I shall not detail the quarrels of that army in the eamp, or its adventures in the field among the forests and moors in the wilds of Durham. The mareh was full of pieturesque incidents, sudden alarms,

"When those behind cried forward, And those before eried back ;"

the startled deer leaping in and out among the spears and ensigns, and the bold and gallant Douglas charging among the English tents in the silence of the night. ${ }^{c}$ Whilst these things were going on in the North, the queen-mother and her younger children were the guests of arehbishop Melton in his palace at York, and the eity was strietly guarded, the primate aiding the mayor and eitizens in rearing and manning the fortifications. ${ }^{t}$ On the 23rd of November, after the return of the army,

" Walsingham, 129. Chron. Lanercost, 265. Fnyghton, col. 2555. Froissart, i., 83. Lot. Parl., ii., 31-2, 5 t.

II rimuth gives the evirlence against Melton from the lips of the informer. "Ly dit, qe le ercevesque de Everwik. ly manda per $m$ chapelyn, Sir Aleyn, une lettre de erelence, et fut la credence ticle: f'il ly aidroyt a la deliverance soun frere de $\mathrm{v}$ mille li et ontre quant q'il aveit, e quant r'il pareit rendre." " C'hron. Petrib., 165. b Lel. Coll., ii., 307-475. Froissart, i., $39-45$.

c Froissart, i., 62, etc. Chron. Ianercost, 260. Kunghton, col. 255\%. Scala Chron., 154. Jel. Coll., ii., 475. Barbour's The Brus, el. 1856, 156-7. Murimuth, 51. IIardyng's Chronicle, n. e., 316.

d Foed., ii., 709-11. There was some controversy between the archlishop and the corporation about the wall. (Reg. IIclton). Stubbs, col. 1731. 
Mclton was empowered by the king to treat for a peace with Scotland, and he and the bishop of Lincoln were authorized to grant letters of safe conduet to the ambassadors from that country. $^{e}$ On the 10th of December the archbishop was summoned to a parliament which was to meet in York. $f$ Soon after this that fair eity witnessed a more brilliant speetacle than the sight of an army eager for the field or the assembling of the conncil of the nation. This was the marriage of the youthful monareh to Phillippa of Hainault which was solemnized in the minster at the end of January 1328. Archbishop Melton and John de IIotham, bishop of Ely, officiated at the ceremony, and the whole country was wild with joy and excitement. ${ }^{g}$ Of this alliance an illustrious offspring was the fruit. There flowed from it the noble chivalry of the Black prince, the generous greatness of the progenitor of the royal house of York, and the sage and cantious wisdom of "time-honoured Lancaster."

In 1330 the conspiracy of the earl of Kent occurred which has been already alluded to. Melton's assumed participation in that rash attempt must have exposed him to no little danger and must have lost him the favour of the king. Edward, however, was too generous to be malieious or revengeful, and he was too well aware of the merits and services of Melton to allow him to continue in disgrace. On the 16th of February, 1331, the archbishop was made a conservator of the peace between England and Scotland, $h$ and on the 28th of November he was again advanced to the post of ford-treasurer of England which he leeld till the month of April in the following year. ${ }^{i}$ On the 26th of June, 1332, the king asked him for an aid towards the marriage of his sister to the duke of Guelders, and, in the antumn, Melton seems to have been present at the parliament at Westminster. ${ }^{j}$ On the lst of December he, Robert de Stratford and Geofliey le Scrope, or any two of them, were empowered to open the council of the nation at its meeting in York. ${ }^{k}$ The parliament seems to have been summoned again to York in the spring of 1334,' and on the 12th of June in that year Melton was desired to ask the clergy of his diocese to give their assistance agrainst the Scots who had recently been signally worsted at Halidon Hill. After this Melton appears to have taken but

\footnotetext{
'Foed., ii., 723-4. Rot. Scotix, i., 223.

f Knyghton, eol. 2552. Fod., ii., 725. On two oceasions, on 18th Aug. and $23 \mathrm{rd}$ Sept., orders were given for the removal of the treasury to York (Foerl., ii., 7]3).

5 Inifferent dates are assigned to this ceremeny. Kuyghton, col.2552. Cliron. Lanercost, 260. Lel. Coll., ii., 476.
}

${ }^{h}$ Foed., ii., 809.

- Dugdale, Chron. Jurid., 40. Cal. Rot. Pat., 109. $j$ Knyghton, 2560. Foed., ii., 810, 811.

${ }_{k}$ Foed., ii., 818. Kinyghton, col. 2562. Chron, Lanereost, 270. Jan. 4, 1333 , breve regium pro parl. apud Ebor. (Wilkins, ii., 570). Rot. Parl., ii., 67. Walsingham, 133.

'Barnes's Edward III., 83. 
little interest in public affairs. We find him now and then engaged in the collection of subsidies and aids for the king," and in 1339 he was on sereral occasions made a commissoner of array to gather men together for the wars in Scotland."

The great variety of Melton's avocations in connection with the state did not cause any delay or neglect in the administration of his diocese. He secms to have been a man who did with all his might whatever he took in hand, and this, no doubt, was the main canse of his success in life. His archiepiscopal register, which extends to more than 1200 pages, shews that he was an energetic prelate, prompt in action, zealous in the suppression of vice and irregularity, and a good shepherd of his flock. He lived in an eventful period and witnessed changes around him such as no arehbishop of York perhaps has ever beheld. Two monarehs died whilst he was connected with the court, the one surrounded by the warriors who were to fight their country's battles, the other terminating an unhappy existence by a still more unhappy end. Melton saw the rise and the fall of Lancaster; that drama so rich in incident and misfortune was acted before his rery eyes. He wonld hear with joy or grief of the exploits on the Borders, of the fatal rout at Bannockburn and of the triumpl at Halidon Hill, of the chivalrous daring of Brus and Donglas, Fitzalan, Bohnm, Percy and D'Argentine. The story of their gallant deeds would be frequently recounted in the halls of Bishopthorpe and York, and many a mass would be said and many a prayer would be offered up for the champions and the cause of England. The archbishop, however, had anxictics of his own in Iorkshire. He would grieve bitterly over those oft-recurring incursions of the Scots which turned his diocese into a wilderness. IIc was obliged to welcome within the walls of York the troops who werc continually streaming towards the North bent on eonruest or revenge, and the eity presented, far too frequently, all the pomp and bustle of a camp. Their presence portended, as he was wcll aware, a long succession of subsidies from his aftlicted

m Foed., ii., 858. On Oct. 23, 133 t, and onl July 5, 1335, Melton was desired to have prayers offered up for the king (Reg. Melton, and Foed., ii., 896). On 26 th March, 1336, he was requested to procure a subsidy from his clersy in the convocation at York argainst the Scots (Fœd., ii., 935). On Airg. 21 and 28,1337 , he and others were inade commissioners to raise money in Yorkshire for the French war (ibid., 991, 991). On Nov. 1 the king asked him and his clergy for a loan for that pur- pose (ibid., 1005). On Feb. 8, 1338-9, a mindate to him to eall upon the clergy for a subsidy (1069), and acrain, 10 th Oet. sect. $(1092)$.

$n$ On Feb. 16, May 4, and Oet. 10 (Foed., ii., 1070 . Rot. Scotise, i., 56 \%, 573). In 1338 Melton gave the king five hundred guarters of wheat towarhs provisioning the Scottish army (Rot. Scotix, i., 554). Wilkins enmmerates the meetings of the chergy at York during Melton's archiepiscopate, ii., 519-20, $516,583,623,629,673,711,727,735$. 
clergy. The court also was very often in York, for it followed after the army, and Melton had kings and queens under his roof. He had been an attendant upon royalty from his youth, and had long since discovered with Sejamus that

\section{"The way to rise is to obey and please,"}

but still when he became a courtier lie did not forget to be a patriot. The wish to advance the interests of his country led him to support the canse of Laneaster, and, perhaps, all but wrecked his prospects and position in the conspiracy of Edmund carl of Kent.

Archbishop Melton had a good deal of trouble with his brethren of Canterbury abont the bearing of the cross. I do not find that there was ever any actual outbreak, but eare was always necessary to prevent it. It is needless to enumerate the many occasions on which precantionary measures were adopted; suffiee it to say that neither primate ever left his province unaccompanied by some order from the king to direct that no riolence should be used towards him during his progress. ${ }^{\circ}$ But this was not the only contention which Melton was involved in on behalf of the privileges of his see. In 1327 he had a quarrel with the dean and ehapter of York about the visitation of the ehurch, which was of so violent a character that the king wrote to the pope to beg him to interfere. In the following rear the dispute was amieably settled through the intervention of John YXII., and the visitor was not impeded in the performance of his duties. ${ }^{p}$ In 1328 and 1329 Melton had a fierce controversy with Lonis de Beaumont, bishop of Durham, abont his rights in the peculiar jurisdiction of Allertonshire. The men of the Bishopric and the borderers from Northumberland and Tynedale were arrayed on the side of their diocesan, and were ready, if necessary, to take the life of the intruding primate, who laid them under a sentence of excommunication,

- Fort., ii., 499, 511, 574, 601, 716, 739, 766, 8ti, 888, 901. Parl. Writs, ii., part i., 263, 291, 318-19, 352. Ibid., jart ii., 274-5. Cal. Rot. Pat., 115. Aus. 7, 1318, a letter to the archileacon of Fotts to desire the archbishop of Canterbury "ne crucem deferat in prox. Ebor." Jume 3, "1334, litera r.lliciali Ebor. ad tractandum cum arch. Cint. pro bajulatione erucis." July 4, 3335, "relaxatio seifuestrationis intermositie in erresiis Ebor. pro bajulacione crucis Cantuar" (Reg. Melton). Wilkins, ii., 525, 526. There is a curious story about Melton and archbishop Resinald in the Anglia Sacra, i., 365.
Mon. Malmesb., Vita Edward II., 237. Carte's Gascon, etc., Rolls, ii., 8.

p Stubbs, col. 1731. Foed., ii., 725. Wilkins, ii., 547 . In 1327 , "visitatio thesauraria Ebor." The chapter resist. Nov. 25, a letter to the king "ad amovendum vim laicalem ab ecel. Ebor." 1332, "compositio inter Dec., et Cap. super forman visitationis" (Reg. Melton). 1333, Feb. 3, letter to the pope from the king asking him to take away his sentence of suspension from the church of York, on account of the quarrel between "P. S. Stephani in Cxlio Monte Card.," and Mr. William de la Mare (Foed., ii., 819). 
for which they cared not. The ehurch of Leek secms to have been the centre of the attack, and it was regularly garrisoned; but at length the king stepped in to prevent the shedding of blood, and the controversy was stayed.q On the death of Beanmont, Melton was for some time in disgrace with the sovereign for adrocating the elaims of Robert de Graystanes, the historian, to be his suecessor, and for eonscerating him at York. 'The appointment, howerer, was subsequently set aside, and nono can regret it who know that the great scholar Richard de Bury was the prelate who was selected. Arehbishop Melton had also a long controversy about the dues in the port of Hull.s

The following brief notes of some of the morc remarkable documents in archbishop Melton's register will give some idea, at all events, of the variety of his official duties. I have taken no pains to extract the ordinations of livings, the foundations of chantries, etc., which that noble volume contains. There is no lack of materials for history and biography; their very multiplicity obliges me unwillingly to pause. ${ }^{t}$

1318, Jan. 21. Licenee to John de Hotham, bishop of Ely, to have service performed in a fair ehapel recently built at 'Threhouses, his birth-place." May 1. We have received from the executors of our predecessor, 100l., in part payment of the sum

$q$ Hist. Dunelm. Ser. Tres, 101-6. On Oct. 29, 1329, the king interfered (Foed., ii., 774-5). Melton had excommunicated the bishop (Reg. Melton, 491). Cal. Rot. Pat., 106.

r Hist. Dunelm. Scr. Trcs, 120. Chron. Lanercost, 276. Anonym. Hist. Edward II., apud Hemingford, ed. Hearne, ii., 401. Foed., ii., 88\%. Cf. Murimuth, 74, where it is said that peace was made between the king and Melton at the intervention of Bury and the nobles.

- Foel., ii., 697, 710, 850. Rot. Parl., i., 431-2; ii., 39, etc. Rer. Melton, 420 , etc. Frost's Port of Hull, 120. 'Tickell's IIull, 73, ete. Cal. Rot. Pat., 108.

${ }^{t}$ I well remember placins this noble volume some years ago in the hands of my kind friend the late historian of South Yorkshire. His words and looks of astonishment are not forsotten. "I have ventured," he said, "to write a work on Yorkshire topography without eonsulting this book, which I never saw before. It would take me six montlss to examine it properly."

"A very ureat man. Yorkshireman by birth. of his parents were Alan and Maude, and his uncle was archbishop of 1)ublin. He was canon of Dublin, rector of Rowley and Cottingham in Yorkshire, and prebendary of Stillington. In 1316 he became bishop of Ely, and ho lield that post for twenty years. Ilis offices in the state were numerous and his services considerable. He was successively chancellor of the Irish and the English exchequer, lord treasurer and iord chancellor of England. It is impossible to enumerate his acts in this place. Cf. Foed. var. loc. Cal. Rot. Pat., 69, 71, etc. Rot. Scot., i., 113, ete. Anslia Sacra, i., 617. Fasti Ecel. IIib., ii., 193. 'Thoroton's Notts, 419, 452. Bentham's Ely, 156-7. Newcome's St. Alban's, 412. Rer. Kellawe at 1)uham, 115. Reg. Langton at Iich field. Foss's Judges, iii., $265,414$. Cinte's Gascon, ete, Rolls, i., 70.

On Dec. 7, 1318, archbishop Melton authorized him to dedicate the chureh of North Cave "de novo constructa." It hatd probably been built by Hotham himself: On 21th September, 131t, bishop Kellawe, of Durham, whilst at Naburn, granted an induligence of forty day's in behalf of the ehinel B.M.V. 
of 200 marks due to us for oxen and horses appertaining to the stock of the archbishoprie, which is deficient. ${ }^{0}$ July 26. Letters testimonial in behalf of Aveline, daughter of Peter de la Twyere, who has been unjustly defamed. ${ }^{w}$ August 24. A pension of 40 s. per amuum to Wm. le Cossale. ${ }^{x}$ August 31. A commission to dedicate the ehureh of the Angustinians at Hull. Oct. 11. Licence to the abbat and convent of Selby to have the chapel of Armyn consecrated. Nov. 3. Permission to Sir John de Scgrare, knight,y and Christiana his wife to have as their confessor William de Drayton, a Friar Preacher. Nov. 8. An indulgenee for the cathedral of Carlisle which has been burned hy the Seots. Dee. 7. To John de Fontibus, the queen's clerk, four marks for his amnual pension.z Dee. 16. Leave to J., bishop of Glasgow, and J., bishop of Ely, to hold an ordination within the diocese of York.

1319, Fcb. 12. Bond from Walter de Fauconberge, son and heir of Sir John de Faueonberge, knight, deceased, to keep the arehbishop and the excentors of his predeeessor harmless. Dame Eila de Faneonberge, his mother, is dead, and he promises to divide her substanee with John and William Fauconberge, his brothers, and Arnebrongh and Joan his sisters, of whom the archbishop is the guardian. ${ }^{a}$ Mareh 18. An indulgence of 30 days to all who hear the mass of Robert de Bardelby, ${ }^{b}$ canon of

in the church of Sonth Cave, for the cood cstate of Alexander de Cave and Joan his wife, and for the sonls of Peter and Elen de Cave, his parents, who are buried in the church of All Saints at Sonth Cave (lieg. Kellawe, 133).

"Soon afterwards the archbishop buys a number of sheep. 190 wethers and 33 ewes are bought at Wilton, 8 wethers and 19 ewes at Patrington, the price of each being $2 \mathrm{~s} .1 \mathrm{~d},-,-28 l .2 \mathrm{~s} .6 \mathrm{~d}$. 41 lambs at Patrington and 172 lambs at Wilton, the price of each 20d.; sum 19l. 8s. 4d. On the death of Greenfield, Melton, then keeper of the king's wardrobe, Walter de Norwich, the treasurer, and John de Insula, bought the corn and wine belonging to the deceased primate (Abbrev. Rot. Orig., i., 223).

w A Holderness lady. On 28th Nov., 1318, the king writes to the archbishop and complains that some malicious citations and charges for adultery, etc., have been made in his diocese. He rerpests they may be stopped (Foed., ii., 379). Cf. the Frere's 'T'ale in Cliancer.

* A native of Cossale, Notts, and a baron of the Exchequer. Cf. 'Thoro- ton's Notts, 228. Foss's Judges, iii., 418.

y A great warrior. Custos Scotixe (Trivet, 340. Kuyghton, col. 2530), where he shewed great valour ( $W$ alsingham, 87). He was taken prisoner at Bannockburn.

z Elsewhere called John de Fonteneio. John de Fontenay, the king's clerk, luad a controversy about the living of Utford, in the diocese of Iincoln (Foed., ii., 449). A John de Fontibus, the physician of queen Margaret, was advanced to a stall at Rouen in 31th of Edward I. (Prynne, iii., 1159).

a Cf. Thoroton's Notts, 448-9. Coll. Top. and Genealog., iv., 262.

$b$ Prebendaryat Dunnington at York, which he exchanged in 1323 with Gilbert de la Bruere for a stall at Chichester ; canon of St. Sepulchre's chapel, and incumbent of Moor Monkton (Reg. Melton. Cal. Rot. Pat., 86). IIe was a clerk in the Chancery, and was much employed in parliamentary work (Parl. Writs, Foed., Madox, Cal. Rot. Pat., etc.). In 1316 he founded a chantry at the altar of St. Michael in 
York and the king's elerk, on Easter day, and pray for the good estate of the said Robert and his father and mother. $\Lambda$ mil 26 . Sir Wm. le Constable is allowed to have an oratory in his manors of Holm and Flayneburgh during the archibishop's pleasure. May 26. The arehbishop grants time to dame Margaret, relict of Sir Geoffrey Maneorenant, to enable lier to rebuild the chancel of the church of Esington, in "Wytbistrande." July 26. An order to pray for fine weather, on accomt of the excessive rains. Oct. 1. Licence for Martin de Alnewick, ${ }^{d}$ S.P.P., a Friar Minor, to hear the confessions of Sir IIenry Fit $\%$ hungh and Sir Robert de Hastang, knights, Garnins de Vieston, Nicholas de Ask, Lady de Charmues and Sara her domicella in the parts of Richmond and IIexham. Oct. 22. Elen, widlow of Nicholas Flemyng, mayor of York, takes the vow of eontinence before the arehbishop in his chapel at Bishopthorp. ${ }^{e}$

1320, Jan. 29. An order to the bailift of Chirehdon to give three oaks for timber to Mr. William, the queen's chandler. $f^{\prime}$ Feb. 1. Letters testimonial in behalf of John, bishop of Glasgow, who ean receive nothing from his see on account of the war with Scotland. Mareh 1. Licence for Roger de la MLore, rector of the moiety of the ehureh of Ketilwell, to be absent from his living in the scrvice of Sir Henry le Serop, knight, justiciar of the king. May 16. A dispensation, "super defectu natalium," to William, son of Henry le Scrop, knight. May 19. An order" to prevent tournaments and jousts near the eity of York. ${ }^{g}$ June 17. The abbat and convent of Rufford enter into an obligation to entertain for a day and a night each arehbishop of York on his first coming into his diocese. July 24. John de Piekering, chaplain, is absolved from the sentenee of greater excommunieation for breaking into the elose of the manor of $\mathrm{Mr}$. Demis Avenel, canon of Beverley. ${ }^{h}$ August 18. An indulgence for the conventual church of Pontefract. Sept. 9. An anmual pension of 40 florins to Oldred de Laude, and another of 20 florins to Mr. John de Rocea, adrocates in the Roman eourt. Sept. 10. Licence of non-residence to John de Mauley, rector of

the church of St. Dunstan in the West (Newcourt, i., 336), Cf. Foss's Judges, iii., 50, 226. $\quad$ Sir Geoffrey is mentioned in the Rot. Scotix.

${ }^{d}$ Alnwick was divinity reader at Oxford among the Friars Minors (Mon. Francisc., 553), and an author (Bale, cent. v., 401).

$e$ Fleming was mayor of York, and was killed at the battle of Myton. Aug. 22, 1320, an indulgence of forty days for the soul of Nicholas de Fleming, whose body is buried in the church of St. Wilfrid at York (Rers. Melton). 'This elmrch, which is now destroyed, was in Lendal. A chantry was founded for Fleming in it (Drake 337).

$f A_{1}$ ril 24, 1318, to William do la Mare two oaks for timber from our wood of Ontwode, and, on May 1st, timber to mend the chnreh of Cirwoot. $g$ the usual accompaniments of an arniy.

${ }_{h}^{h} A$ venel was archdeacon of the East Riding, an oflice to which he was preferred in 1322. 
Baynton, that he may make a pilgrimage abroad. ${ }^{i}$ Sept. 26. The archbishop announces the canonization of Thomas, late bishop of Hercford. ${ }^{j}$ The 10th of October is the day appointed for his commemoration.

13:1, Jan. 2. An order that no toll or custom be taken from the citizens of York whien they come to Beverley. Jan. 8. Bull of Pope Jolm XXII. for the safe conduct of Robert de Brins and the Scottish bishops to the papal conrt. ${ }^{k}$ Jan. 12. A letter of safe conduct to our valet, John de Mar, to go to Newcastle to provide hay, fuel, oats, ete., for us, and a missive to Richard de Emeldon, the mayor, in his behalf. Jan. 23. An indulgence for the fabric of the church of York. ${ }^{l}$ March 24. Leave to the Carmelites of Scardeburgh to erect a chapel and set up a tower with a bell in it in their house. ${ }^{m}$ May 28. An indulgence of 20 days in behalf of the church of St. Patrick at Lameley in the diocese of Durham, which has been destroyed by the Scots." July 2. Licence to Margaret Malbys, a young girl, sister of Sir W'm. Malbys, knight, to stay in the numery of Swyne till she be ready for the reil. Sept. 3. An order to break the seal of Peter de Wyverthorp, prior of Bridlington, who has resigned his office. ${ }^{\circ}$ Dec. 21. Absolution of John de Whiteby, clerk, for using necromancy. ${ }^{p}$

- He is mentioned as seised of the manors of Doneaster and Mulgrave in the Ninth Report of the Deputy Keeper of the Public Records, p. 76. What was the motive that led Mauley across the seas?

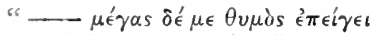

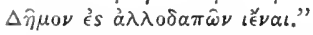

$j$ 'The archbishop grants an indulgence to those who risit his tomb. The bull of canonization is given in Melton's Register. The king was very alixious for the camonization (Fod., ii., 355, $363,385,413)$. 'The bishol', of course, was Thomas de Cantilupe. Cf. Wilkins, ii., 651. The canonization was solemnized in 1318 in great state (Banes's Edward IJ I., 420-1).

${ }_{k}$ Brus was arixious that the sentence of excommunication that had been jassed on him should be recalled. For this object he sent TRandolph, earl of Murray, to Avignon in 1323. In Foed., ii., 413, is a bull of John XXII. excommunicating Brus. In the Buik of the Cronicles of Scotland, iii., 258, are these lines:-

"Quhen all this thing es brocht to sic an end, Ambassadouris this ilk king liobert send, Greit wen of gude wer greitlie till advance, Ane to the pail and uther minto r'rance."
? Another was granted on Jan. 6, 1324-5. On Feb. 12 there was a letter for the quxstores. Cf. Fabric Rolls of Tork, $\%$. 159-60.

"n Richard I. gave the church of Scarbro' to the abbey of Citeaux. The Cistercians at Scarbro' were very jealous of the Friars (Beck's Furness, 88), and there was some contention between them. 'The rector of Scarbro' seems hitherto to have been desirous that the Carmelites should worship

\section{"Withouten noise or clatering of belles."}

$n$ A little numnery in the upper part of Tyuedale. It was destroyed by the Seots in 1296 (Chron. Lariercost, 174), and the marauders seem to have penetrated again into that wild and romantic neighbourhood.

- The seal was broken, especially on the decease of a dignitary. There is much information on this point among the mumiments at Durham.

$p$ What halst been at, sir clerk? at what forbidden arts

\footnotetext{
"The time when scritch-owls cry, and ban-dogs howl,

And spirits walk, and ghosts break up their giares?"
} 
1322, Feb. 7. Licence to Joan de Tacy, comtess of Lineoln, to have John, chaplain of Meleheluuri, for her confessor. Mareh 22. Thomas de Brounctofte, a monk of Blyth, is sent to the court of Rome to be absolved for consccrating ('hrist's body twice over.q Mareh 25. A commission to absolve IIumphrey de Bohnn, earl of Hereford, from the sentence of excommunication. ${ }^{r}$ July 5. Sir $\mathrm{I}^{\top} \mathrm{m}$. de Brus, knight, is absolved from the charge of drawing blood from Michacl de Harcla. 1]c denies it.s July 8. Licence to 'Thomas de $\mathrm{W}$ ake, lord of Lydel, to build a monastery of Angustinians in his vill of Cottinghan, by the leave of the pope. ${ }^{t}$ July 16. Administration of the effects of Sir Nicholas de Menill, knight, to Nicholas de Menill and John de Menill, brother of the deceased." A general scntence against those who have concealed the deeds of Sir IIenry le Vavasour.

1323, Feb. 4. Sir Geoffrey de Upsale, ${ }^{r}$ knight, is ordered to maintain his wife. April 4 . An order to receive the purgation of Sir Peter de Mauley, knight, who is charged with having committed adultery with Alice Deyvill. April 21. A commission to dedicate the altars in the monastery of Thurgarton, which has been constructed de novo.w Juire 23. A general sentence against those who have dragged Philip de Deen from

q A very heinous offence. The culprit said that he did it ignorantly. On June 8, 1323, the archbishop ordered Bruntoft to be expelled from Blyth for rebellion and insolence. There seems to have been a great lack of diseipline in Blyth abbey.

r He was killed on the 16th of March, 1321, at Boroughbridge, whilst he was arrayed on the side of Thomas, earl of Lancaster. He died in a very jeculiar. way (Dngd. Bar., i., 181. Coll. Top. and Geneal., iv., 76). He was buried in the ehurch of the Friars Preachers at Fork. Knyshton, col. 2510. Galf. le Baker, 65. De la Moor, 596.

"Sir William Brus founded a chantry in the church of Pickering for the souls of himself and Matilda his wife, Idam and Matilda, his parents, Mr. William and Mr. Robert de Pykering, his ancestors ard heirs, his nncles and annts, and William and Alexander de Bergh (Domesday Book, apud Ebor., 152). The Pickerings were consins of the founder. "In Pykering chirch I saw two or three tumbes of the Bruses, wherof one with his wife lay in a chapel on the south syde of the quier, and he lad a garland about his helmet. Ther was another of the bruses biried in : chapel under an arch of the north side of the body of the ruier, and there is a cantuarie bering his name" (Lel. Coll., i., 6. Lel. Itin., i., 65, ed. 1769).

t The public records are filled with notices of this great baron. See Dugd. 13ar. 'The establishment at Cottinirliam was soon transferred to Ilautenprize. The pedigree of the Wakes recently published by the Arehitectural societies is by no means a correct une. See liut. Parl., ii., 191, ete.

"On August 23rd the viear of Ormesby was made the cralljutor of Nicholas Menyl, who was a numor.

"A commisinner of allray N.R.Y. in 1318 (Rot. Scotia, i., 185). lle lad a pardon given to him for his share in the death of Gaveston, being a retainc. of the earl of Lilncister (Foed., ii., 230).

w A monustery co. Notts, which was erected in the twelftl century by Ralph Deyucourt. Its foundation ousht to have been mentioned among the rood deeds of archbishop 'Thurstan (Thoroton's Nots, :302). 
the elurch of the Augustinians at York, where he had taken sanctuary, and remored him to the marshal's prison. ${ }^{x}$

1324, Jan. 22. Dame Beatrix, widlow of Sir Robert de Percy, lord of Sutton-on-Derwent, took the row of chastity before the archbishop at Cawood. June 24. Commission to the archbishop of Armagh to confer the first tonsure, and to confirm children within the diocese of York. ${ }^{y}$

13:5, Sept. 3. Absolution of Roger de Mora for saying mass in the presence of the Scots who are exeommmieated.z

1326, March 3. Licence to Thomas Wake, lord of Lydell, to transfer his monastery from Cottingham to a place called Ifantenprise." March 1\%. An order to Robert, servant at the Grange at Iork, to give to John de Waltham, the king's messenger, a quarter of wheat, of our special favour. April 1. The king writes to the pope to say that thieves have broken by night into the archbishop's chapel, and have carried off his pall and other ornaments. He begs for another pall for him. ${ }^{b}$ April 18. An order to our bailiff at Beverley to give to Thomas Whiteheade, our servant at Kynalton, two strong but not valuable colts, and nine three-year-old colts, to work at Kynalton in plonghing and waining, and the bailiff at Southwell is directed to give him timber to repair the chancel of our church at Kynalton. Jume 12. Certificate of the baptism and conversion of a Jew, viz., Nalter de Notyngham, in the church of St. Mary, Nottingham, on Monday after the Octave S. Trin., 1325. Sir Walter de Goushill and Richard de Whatton, knights, and

* In 33rd of Edward I. Willian, son of Richard de Whitgift, fled for protection to the churchyard and altar of the church of Whitgift, and was dragged away. The king ordered him to be released (Prynne's Coll., iii., 1105).

$y$ The following suffragans of arehbishop Melton have occurved to me. April 28, 1318, commission to David "Reereensis eplise.," to reconcile the ehurchyard of Masham. He had been acting for two years (Reg. Sacr. Angl., 1.13). On Nov. 19, 1326, Rowland, late archbishoy of Amagh, was commissioned to celebrate order's. On 27 th (Actober, 1332, the bishop of Carliste was made sulfragan. In 1335 the bishops of Lineoln and Norwich assisted the archbishop. March 28, 1310, the bishop of Corbaria was licensed to act.

* Some tale himgs ujon this entry, but what was it: More received a licenee of non-residence in 1320 to join the stite of Sir IIenry le Scrope.
Every orthodox churchman would now regard Brus with the utmost detestation ;-

"- A wretch beneath the ban

of pore and church for murder done

Even on the sacred altar-stone!

Well mayst thou wonder we should know

Such miscreant here, nor lay him low,

Or lleam of greeting, peace or truce

With excommunicated Bruce."

"Removed thither from Cottingham. John XXII. sanctioned the change on Jan. 1, 1327. On Oct. 31, 1327, the archbishop granted a licence for the performance of service at Hantenprize. The fomnder nominated Thomas de Overton, a monk of Brome abbey, dioc. Lincoln, as the first prior (Reg. Melton). In the 15th of Edward IJ. Thomas Wake, the king's cousin, had leave to found a religions house at Newton (Cal. Rot. Pat., 90), and to crenellate his manor-house at Cottingham in 1st of Edward III. (ibid., 99).

"Fued., ii., 621. 
Orframnia, wife of Robert Ingram of Nottingham, were his sponsors. ${ }^{c}$

1327, Jan. 28. Licenee from the abbat of Westminster for the bishop elect of Whithern to be consecrated in a ehapel in that abbey. ${ }^{d}$ Feb. 24. Leave for dame Joan Luterel, lady of Gameleston, on account of old age, to eat whatever kind of pulse and stuffed meats she pleases. May 5. An agreement between the arehbishop and Robert le Constable of Flaynburg. Constable is to perform the arehbishop's service in Scotland, receiving for it 100l. May 26. An indulgence of 40 days to those who hear the preaching of the monks of Durhame

1328, Jan. 4. Penance enjoined by the archbishop to Sir Peter de Mauley, knight, for adultery with Sara de London. On every Friday in Lent, the Ember days and Adrent, for seven years, he is to fast on bread and small becr, and on Good Friday and the vigil of the festival of All Saints, to use only bread and water. He is to make a pilgrimage to the shrines of S. William of York, S. Thomas of Hereford, B.M. at Southwell, S. John of Beverley, and S. Wilfid of Ripon, and is to be "fustigated" seven times before a procession in the ehureh of York "in sola basna, capucio deposito." $f$ Jnly 29. An indulgenee of 40 days for the fabrie of the chureh of Ripon. Sept. 1. Licence for Sir Wm. de Malbys, knight, to remove the bones of his father and mother, Sir John and dame Agnes de Malbys fiom the ehureh of Acaster Malbys to Rievanx abbey, where the remains of his ancestors are interred. ${ }^{g}$ Oct. 11. In indulgence for the dedication of the altar in the house of the Friaus Carmelites at York. The arehbishop dedicated it on Tuesday, Oet. 5. Oet. 24. Lieence for $\mathrm{Wm}$. de Boyton, reetor of Lockington, to take the body of $\mathrm{Wm}$. Danyel from the ehurehyard into the church.

c On Mareh 21, 1334, the archbishop eertified that Walter Conversis, formerly called Hagyn in the Hebrew tongne, was baptized at Nottingham on June $30,1325$.

d Commission to John, bishop of Carlisle, to conseerate bim, which he did "die Dominica in vigilia purif. B.M.V.," the new prelate naking lis profession of obedicnce to York. In 1323 the arehbishop wrote letter's against his being consecrated at Rome.

e There is a mandate from bishop? Hatfield in the same behalf issued in 1346 (Hist. Dunelm. Scr. 'Tres, appendix, 135). In 133t archlishop Melton granted an indulgence of forty days to those visiting St. Cuthbert's slinine
(Raine's St. Cuthbert, 103).

$f$ A salutary example. Manley was an old offeuder, and the archlishop, probably, was glad to eatch him. In the 9 th of Elward II. the king ordered an encuiry to be made into an affair in which lie, Manley, and others were concerned. They hat orened and carried ofl' a car containing as many as seven nums from Watton abbey! (Cal. Rot. l'at., 80).

$s$ 'The little ehurch of Acaster still remains, and would, probably, have sheltered at the present diy the monuments of the Malbis. The abbey of Rievanx is in runs, and there are no memorials of the dead to be espied within its walls. 
1329, May 30. Licence for Sir Robert de Eceleshale, knight, to citer a religious order with the consent of dame Matilda de Codenoure, his wife. ${ }^{h}$ Angust 10. The arehbishop dedieated and consecrated the ehurch of Wakefield, the great altar in honour of All Saints, and that of B.M.V. on the south side, the altar of St. Nicholas on the north, and that of St. Peter in the middle of the chureh. ${ }^{i}$

1330, March 8. Appropriation of the church of Stretford to Eggleston abbey, the ammual revenues of which before the war used to be taxed at seven marks, but now, in consequence of the war, they camnot be taxed at all.j Sept. 24. Licence of nonresidence to $\mathrm{Mr}$. Robert Baldock, rector of Bradford.

1331, May 3. A loan of 100 marks to Wm. de Cusance. ${ }^{k}$ August 21. A letter in behalf of John Akerman of Bruges, who has taken sanctuary at Norwich for killing Sir John Nele, knight, at Courtrey.

1332, Sept. 19. Acquittance from Cardinal Neapolio ${ }^{m}$ for his pension of 80 florins. Dee. An acquittance to the abbat and convent of Whitby for a pension of $100 \mathrm{~s}$. to Wm., son of Henry de Melton. ${ }^{n}$

1333, Feb. 12. A loan of 50 marks to dan Richard de Bury,o

"On Jan. 30, 1469, in the clunrel of Manfield, Joan, wife of Tilliam Coke, of that village, gave formal permission to ber husbancl to take orders (Orin. penes 'Tho. Witham, cler., de Larting(on).

- A raluable architectural date.

$j$ This house was at all times borne down with poverty. The remains of the abbey exhibit the plainest workmanship. Their ehief charm is derived from the glorions combination of scenery, the hill and wood and water that are around them.

* Canon of Thorp at Rifor 13111338, when he exchanged it with Vin. de Dalton for a prebend at Auckland and another in the chapel of liridgenorth. T'rebendary of' Lincoln and Iondon, arehdeacon of Cornwall, ote. (Le Nere, i., 398; ii., 161, 414). He was also keeper of the king's wardrobe 15th Edward IIT. (Pell Renords, 149), and treasurer of the exchenuer, and was much employed in state aflairs.

$l$ some interesting adventure of which we know nothing. The lists of those who took sanetuary at Durham and Beverley have been fublishod by the Surtees Society.

$n$ Nearolio Trsinus, cardinal of $\mathbf{S}$. Iladrian in Tribus Foris, a Roman by birth, was one of the leaders of the Sacred College, in which he had a seat for nearly sixty years. He died at Avignon in 1317 (Ciaconiıs, j., 904, etc.). He was canon of South Cave at York and Sutton at Lincolu. Cf. Foed., ii., 577, etc. He had many benefices in Eng. land.

n 'The archbishop's nephew and brother, who will soon ocenr again.

" The illustrious bibliomaniac, and the gem and grace of the North of Ensland in the forrteenth century. Statesman, bishop, scholar, "nihil tetirit guod non ormavit." How few in that age would throw aside the cares of oflice, for Bury had been chaneellor and treasurer of England, and solace themselves in the untrodden paths of literature and taste. What a delight it must have been to the bishop to find himself at Allckland with sucl companions as Bradwardin, Fitz-Ralph, Burley, and IIolcot, and refreshing himself among the many tomes which he had colleoted,

"Ducere sollicitæe jucunda oblivia vitæe."

"Prélat pieıx et charitable, politique fin ct habile, bibliophile savant et spirituel, il sut se faire aimer par ses contemporains, non pour ses dignités, ni pour sa fortune, mais your les pre- 
eanon of York. Feb. 24. A loan of 200 marks to John, bishop: of Winchester.p Oct. 19. A dispensation from John XXII. to Sir Geoffrey Luterell, kniglit, and Agnes, damghter of Sir Riehard Sutton, knight, who have marricd, not knowing that they are related in the third and fouth degrees. Dec. 3. A lieence to baptize, bury, etc., in the ehapel and chapel-yard B.M. at Hull.

1334, Feb. 23. A licence of non-residence to Robert de Creyk, reetor of Aekworth, as long as he officiates in the chapel of queen Philippa. April 9. A commission to the abbats of Fountains and Kirkstall to absolve the body of Sir Simon WVard, knight, late deceased, from eertain sins which he had committed.? Angust 5. An order forbidding any one to listen to the teaching of friar Henry de Staunton, hermit. Oct. 7. A licence to beg for the fabrie of Whitby abbey. Oct. 23. A similar liecnec in behalf of the house of St. Sepulchre, at Jerusalem. ${ }^{r}$ Oet. 21. A loan of 1000 marks to the king.

1335, June 6. To Robert de Malton, domestic chaplain of

cieuses qualités qui le distinguaient à la fois, comme homme de Dieu, comme homme d'Etat et comme homme de science" (Philobiblion yar Richard de Bury, ed. Paris, 1856. Notice Biographique, xvi).

$p$ A very great man and a native of Yorkshire (Hunter's South Yorkshire, i., 5t. Cal. Rot. Pat., 72). Archdeacon of Richmond, prebendary of Gevendalo and Riccal, canon of Beverley and Southwell, incumbent of Stillingfleet and Lockinuton, in Yorkshire, and Radeliffe-on-Sore, co. Notts, canon of Lineoln and London, and treasurer of Lichfield (Le Neve, ii., 417 ; ii., 1.10 ; i., 581). Prebendary at Howden (Reg. ii., Pr. and Conv. Dinelm., 10). Rector of Simondburne. Northumberland, 6th Edward II. (Reg. Kellawe, 177 b). Rector of North Mimms, Heris, 1312 (IISS. Harl., 6951, 73. Chutterbnck's Herts, i., 460). Chancellor of the exchequer, treasurer and lord chancellor of England, chamberlain of Seotland, and much employed on state business (Foed., Cal. Rot. Pat., Parl. Writs, and Rot. Scotice, var. loc. Dugd. Cluron, 34, 36. Madox, Hist. Exeh., ii., 53, ete. Liber Garderobe, 5. Rot. Parl., i., 266-7. Introd., Pell Recorils, +1.th Fdward III., xxiv., ete. Foss's Judges, iii., 296).

$q$ Jate sheriff of Yorkshire and a man of importance. On 12th August,
1336, the archbishop sirys that Sir Simon de Ward, late deceased, owed him 22l., and lesires that the smm slould be raised out of his effects at $t$ he oversight of Sir John le Wrard. Melton was very careful in looking after his debts. On April 7, 1337, he ordered the coods of Sir John Manleverer, deceased, to be sequestered, to recorer 20l. which he owed to him. This system of noney-lending would sive the arehbishop extraordinary influence. Stubbs, indeed, says as mitch.

Monsienr Johan Wade is one of the witnesses in the Serope and Grosvenor controversy. "Ft dit anxi qil ad une chambre en un manoir q'homme appelle Gyvendale one lez armez de Serol, sont mys et depeyntez or la pareye (2il quelle chambre sount les amez dis sr de Neryll, les armez da $\mathbf{S}^{\mathbf{r}}$ de Percy, les armez du $\mathrm{S}^{\mathrm{r}}$ de Clitlorel" (i., 115). An interesting pricture of an old sumur.

$r$ On Sept. 16, 1336, Melton uranted a licence for besring to the representattives of the hospitals of the Holy syirit at Rome and St. Anthony at Vienne, and, on Nov. 20, anotler was given to the master and brethren of the hospital of Nit. Thomas the Martyr at listbridge near Cantromry. The whole conintry seems to lave been overmu by these preripatetic nendicants, amones whom, necessarily, were many impostors. 
John, earl of Cornwall, the king's brother, 200 marks as a loan for the use of the said earl. Oct. 15. Licence for John de Bampton, rector of Foxholes, to be non-resident. He is a tutor in the family of Sir Geoffrey le Scrop, the king's justiciar.

1337, March 11. Licence to remove the ancient and disused chapel of St. Peter, in the churchyard of Dewsbury, employing the materials on the fabric of the parish church.

1338, April 10. A mandate to the bishop of Carlisle to pray for the king.s

1340, March 18. Licence to enclose Isold de Knesall in a house contignous to the wall of the church of Knesall. ${ }^{t}$

In the time of archbishop Melton ecclesiastical architecture was at its full perfection, and great works were going on in all the cathedral churches within the province of York, to which the primate must have been more or less a patron. No one should surink from rendering his homage to the age which produced these masterpieces of Christian art.

\section{" - tibi res antiquæ laudis et artis \\ Ingredior, sanctos ausus recludere fontes :"}

Piety, surely, could not be dead, when she bore such fruits as these. It was to no momentary impulse or capricious influence that our cathedrals owed their origin. They were the offerings of men full of devotion and self-sacrifice, who, if they gave largely in the cause of God, never thought that they gave too much. What they did was well done, and they built for their spiritual descendants rather than for themselves. Arch-

s Foed., ii., 1026. William de Hatfield, one of the younger children of Edward III., died ibout this time, and was interred in Fork minster. He was born in 1336. The monument aseribed to him is in the north aisle of the choir. The marble etrigy of the youthful prince is wrought with wonderful skill and beauty. It las been said that the niche in the wall in which it is laid was not made for it; this is an error, as the canopy above and behind the figure is powilerer, as I discovered, with the plaztagenista. The efligy, however, had been removed to amother part of the church, and was restored to its present position about eichly years ago by the poet Mason when he was precentor (Corr. of Mason and Gray, ed. Mitford). The fact that one of her children was intered in the minster probably accounted for the gift of the ricluly embroidered bed of queen Philipra which was male to the cliapter
(Fabric Rolls, 125).

$t$ During the latter years of each archbishop the documents in his register generally hecome less numerons. 'The reason is an obvious one. The documents were not transcribed when they were drawn up, but were kept till a certain number had been collected. At the death of any arehbishop many of these would be frequently lost, and some would be necessarily regarded with less interest, especially such as related to private matters. The various parts which constitute a register were not bound together till aiter the decease of the arehbishop, and then, occasionally, original doemments which had been missed were inserted between the leaves. Eren in those years with which most eare has been taken omissions may sometimes be detected, when a comparison is made with some contemjorancous register. 
bishop Melton gave at one time to the fabric of the chureh of York a sum which, in the money of the present time, is equivalent to many thousands of pounds." He restored the tomb of St. William. He finished the westem portion of the nave of the minster, ${ }^{v}$ and on the exterior, in the most conspicuous position, on that glorious façade, his munificence is strikingly commemorated. He sits above the central doorway, graven in stone, in his archiepiscopal attire, with his hand still raised in the attitude of benediction. Orer his head is the finest Gothic window in the world, built in all probability by himself, and still beaming with the glowing colours with which he adorned it. On either hand is an effigy of a benefactor of the church, the heads of the noble houses of Vavasor and Perey, bearing in their arms the wood and stone which they onee gave. Any one might be proud of a momument like that! But this is not the only architectural memorial which arehbishop Melton has left behind him. His name is traditionally connected with the erection of the noble church of Patrington in Holdemess. He helped to raise the glorious minster, of which Beverley may still be proud, and at Ripon ${ }^{w}$ and Southwell he is not yet forgotten. Great indeed was he in the offices which he filled and in the gifts that were prompted by his munificence; but, with the tme spirit of the age in which he lived, he did not forget the little hamlet in which he was born and the humble parents from whom he sprang. He built and endowed a chapel in the village of Melton, in which father and mother and son were to be commemorated. The worshipper in that tiny shrine would muse with no little pride upon the noble fortunes and the piety of his compatriot.

Many pleasing traits in the character and disposition of Melton have been handed down to us, and the historian Stubhss speaks of the archbishop in a manner which shews that he was well acquainted with the prelate whom he commends. IIe made great alditions to the dignity and the revenues of the archiepiscopate, without trespassing in any way upon the patrimony of the needy. His poor tenants had no oppression to complain of. The fines imposed by Melton's scheschals were not exacted, rents were lowered, and debts and arrears were frequently forgiven. Affluence and plenty were around him, and the servant was revelling in abundance whilst the master

"When arehbishop Zouche visited the chapter in 1313 this stm of 500 marks was still unpaid (Acta Capit. Ebor.).

"Tumbam Sancti Willehni smmptibus $x x$ librarum renovabat. Occi- dentalem partem navis ecrlesia beati Petri' Bbor., we libris argenti apyositis consummabat (Nubbs, col. 1731).

" In 1333 Noltom made statutes for the churel of Rijon (1)ngd. IIon., vi., 1368). 
was as frugal as a hermit. Courtier although he was, Melton would fist and pray so often that his chaplains and officers were worn ont when they tried to copy him. Matins he never missed, and the mendicant never appealed in vain to his charitable heart. His diocese was most sedulously attended to. For many years he held in person or by deputy as many as five ordinations. He frequently confirmed and risited the sick. It was not munsual for him to absolve the bodies of the deat, and he would leave his chariot, and, taking his stole and book, release them from the guilt of the offenees of their past lives. ${ }^{x}$ When the chronicler mentions this circumstance, our thoughts wander unconsciously to the scene of the disaster at Myton. We see the archbishop, full of grief at the mishap, passing hastily and anxionsly among the dying and the dead, speaking words of peace to those on whom the light of life was still resting, and pardoning or trying to pardon those who had gone into that land of silence where earthly defeats as well as victories are forgotten.

There is no eridence to shew that Melton was a person of any literary distinction. He was too sagacious, however, and too good not to pay due respect to the scholar and his work. Bred as he had been in the service of his country, he conld value well the peace which the student covets and creates. Melton was a kind friend to the university of Oxford. On the 5th of Nareh, 132!, when that illustrions abode of learning was at a low ebh from distmbances within its own walls, the archbishop took it under his protection, and, on the rth of September, $13: 27$, he authorized the making of a collection throughout his rliocese for its relief. ${ }^{y}$ On the 7 th of March, 1331, he appropriated the elumeh of Aberford to University College. It is

r Stublus, coll. 1731 .

y Res. Melon. On Nor. 11, 1316, Amandus de Irawyk, clerk, proctor for the nuster and scholars of University liall, Oxford, receiver from the charter of Iork the sum of 207 . in mat layment of a bequest in the will of Mr. Rolvert de Riplingham, late chancellor of York (Acta Capit., Ebor.).

Riplingham by his will, dated Jar. 11, 1331-2, left 1002 . to secure the prayers of several priests for the souls of himself, Walter de Merton, bishop of $\mathrm{R}$ ichester, archbishop Newark, and others. 'To the scholars of Merton college he cave his silver spoons, a cup and a groblet, his books of Concordance, his book of Sentences, the Summa of master Ilemry de Mandario, and all his other book: save those which belonged to John de Hesele. He left the mmuificent sum of $300 l$. to purchase advowsuns or lands to maintain perpetual scholars or masters of arts in the miversity of Oxford, or in whatever place the university slionld be transferred to (Rer. 'Test. Mbor.).

Riplingham was a fellow of Merton collegre, which had been founded abont sixty years before by the bishop of Rochester. Merton collerre was first established at Maldon, in Surrey, and it was from thence removed to Oxford. The troubles which had recently assailed the university suggested to Riplingham's mind the possibility of its removal to some other place. The legacy above mentioned seens to have been lest (Wool's Intiq., Univ. Oxon., iv., 13. Smith's Annals of Univ., Coll., 99). 
pleasing also to know that a member of that illustrious seminary, the learned author of the Philobiblion, held a stall at York during Melton's arehiepiscopate, and to see that the great scholar found a patron in his cliocesan. A halo rests around the memory of Richard de Bury, the scholar-bishop of Durham, who first kintdled the lamp of learning within the classic walls of Anckland, where a Tunstall, a Norton and a Butler hare since worked and thought. The annals of his life, his wanderings in quest of books, the aridity with which he deromed them, the number of his literary friends and his intimacy with Petrareh, form a bright spot in the history of the North. What a contrast to the unlettered pride of Lonis de Beanmont his predecessor in the Palatinate, who, althongh he was allicd to kings and princes, was ignorant, strange to say, of the Latin language. On the day of his consccration, when he was making his profession of obedience to the archbishop of York, he stmmbled, witl a readiness which a refractory suffragan might enry, at the word metropolitice, and passed it over with the convenient words, Seyt pur dit. On another oceasion, whilst he was officiating at an ordination, he faltered at the words in cenigmate, and confessing himself to be a Davus when he ought to have been : CEdipus, he astonished the listening clerks by the observation, Par Seynt Lowis, it ne fu pas curtays, qui c'est parole icy escrit.z

In spite of the disasters of the nation and of the warfare which reduced many of the elergy in the North to begurary, arehbishop Melton was a very wealthy man. He was a cantions and prudent person, and was very fougal and sparing in his tastes and requirements. His register presents him to us as one of the great money-lenders of the day. Searcely a year seems to have elapsed without some thousands of marks passing through his hands in the way of loans. The archbishop hat debtors in every class of society. The monareh himself refuired money, and he found it in Melton's coffers. The barons and knights stood in need of it to provide their equipment for the wars, or, perehance, to pay their ransom, if they were unfortunate enough to be captured, and they got it from the northern primate, oceasionally learing hohind them as a pledge for its repayment some of the plate which formed almost the sole orinament of their eastles and halls. 'The poor abbat, or prior, whose granges had been destroyed by the marauding Scots, received a loan from his diocesan which cuabled him to provide subsistence for his distressed brethren. 'The ability to supply the wants of so many petitioners, shews that Melton was a man of great wealth and substance. It would make hin courted and treated 
with respect by all, and would add very greatly to his influence. ${ }^{a}$ It is quite possible that the possession of these riches would dull some of the finer lines in Melton's character,

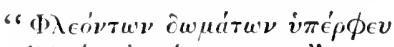

$$
\begin{aligned}
& \text { "Yте́ }
\end{aligned}
$$

It enabled him, horever, to befriend his kinsmen, whom he was, perhaps, too fond of advancing and providing for. The archbishop was desirous of "making a family," and he made it. The greater part of his wealth seems to have come to the children of his brother Heury. He was fond of purchasing and trafficking in land for their use; and the knightly house of Melton of Aston, which was fostered and upreared by his munificence, took its place soon after its founder's dccease among the greatest families in Yorkshire.

Archbishop Melton maintained his household and lived in a style which befitted his high position. The number of his retainers was very considerable, and there was no want of hospitality or munificence in his palaces. The following extracts will give a more graphie picture of the requirements of the times in which he lived and of the domestic economy of his household, than any remarks or observations of mine.

1318, Jan. 22. To Simon Rose, our attorney, 100s., if necessary, to provide comnsel for the archbishop. Nov. 4. To John de Ecelesclif, bishop of Glasgow, 5 marks towards his expences. ${ }^{b}$

1319, March 10. To Thomas Deyvill, our bailiff at Ripon, 40 s. for the use of our tenants in the bailywick of Ripon, who are coming to York to go with the king into the North for the defence of the kingdom, and 20s. for a standard of silk for the said tenants. ${ }^{c}$ July 30. To Walter, the elerk, of Beverley, 79/. 16s. 8d. for eloth bought of him. Nov. 11. To Henry de Melton, our brother, 20l. as a gift.

13:0, Jan. 7. An order to the park-keepers at Beverley to gire to Mr. Richard de Mclton, rector of Brandesburton, a deer. Angust 5. To Mr. Richard de Melton, ${ }^{d}$ rector of Lythe, 200 . to make provision for us at St. Botulph's fair.

13:21, July 25. To William Lumbard, 112s.3d. for our summer

a Stubbs, col. 1731.

$t$ There is no bishop of this name in Keith's Fasti of the Scottish ehurch. The bishop of Glasgow at this time was a person of the name of Joln Wiseheart. IIe was probably acting as a sufragan for Melton like the Irish prelate who is mentioner below. Ecclescliff has been mentioned before. He was a Friar l'reacher, and was successively bishop of Bethlehem, Comnor, and Llandaff
(Quètif. Scriptores Ord. Predic., i., pref., $x \times \mathrm{v})$.

$c$ It was in this year that the Scots ravaged the Ripon country.

${ }^{d} \mathrm{He}$ occurs, also, as rector of Gilling and seneschal of the archbishop's hospice. On Jan. 19, 1327, Richard de IIelton, rector of Brandesburton, was collatef to a stall in St. Sepulchre's chajel at Tork. 
liverey. August 8. To the Friars Preachers in their general chapter at Pontefract assembled, 100s. August 20. An order to repair the kitchen of the manor of Otley at the orersight of John, vicar of Otley.

1322, Jan. 23. To John, bishop of Clonfurt, 20s. as a gift. May 22. To Gregory de Thornton, knight, $f: 0$ marks in part payment of 100 marks due to him for our service to be rendered in Scotland to the king, which he is to do. May 23. Sir 'Thomas Ughtred, knight, releases the arehbishop from the payment of his wages due for the same service. ${ }^{g}$

1323, June 1. To Thomas de Escrik and Richard de Warwick, our houschold servants, for the use of the king and queen and their servants, 94. 6s. 8d., and for the use of Sir Hugh le Despenser, jun., the best silver cup in our ehest, of which we send you the key, and a smaller eup to Eleanor his wife. ${ }^{h}$

1324, July 12. To Henry de Melton, our brother, two stots. July 24. To Robert Valeyns, ${ }^{i}$ canon of York, two deer for his feast during his residence.

1326, Feb. 2. To IIenry de Melton, our brother, a gift of ten marks. June 18. To Richard de Gretford, our' bailiff' at Hull, the money for ten casks of wine. July 19. An order to pay ten marks for the expenses of the arehbishop's horses in London. Oct. 20. To Mr. Robert de Dufton and Mr. William de Carleton, 40s. for their expenses in going to Scotland in our behalf. An order to give to William de Ayton, brother of Ralph, late perpetual vicar of Sherluurn, $4 \frac{1}{2}$ marks of silver, a silver piece, a cup de murro, a portiphor of the Sarum use, and a pix covered with pearls, and he to enter into a bond to answer to us about the dilapidations of the vicarage. Oct. 21. An order to Roger de Somervill, sheriff of Yorkshire, to pay for the arehbishop forty marks for the wages of Sir Henry Fitzhngh, knight, who is going to the aid of the king in the train of Joln, carl of

e In Stubbs (col. 1731) it is said that Melton gave out his liverey twice a year.

$f$ A farther sum of $60 \%$. was paid to him on July 4, 1322.

$g$ The agreement between him and the arehbishop was made Sept. $9,1318$. Ughtred was to serve with " $\mathrm{x}$ hommes d'armes od $x$ chevaux covertz." 'There is an account of several members of the house of Ughtred of Kexby in Dngel. Bar., ii., 11., and in the public records. Sir 'Thomas was summoned to parliament 18-3Sth Elward III. He died in 1365, and was buried at Catton, his son Thomas administering to him on the 4.th of July.

${ }^{h}$ The archbishop is playing the contier to a roval favourite.

i Robert de $\mathrm{I}^{\text {taloinnes, precentor of }}$ Fork 1317-1320, in which year he oxchanged it with Thomas de Berton fin" the rectory of Clive in the dioesse of Worester. In 13:3 he became canom of Warthill, which he held for twouty years. Tle died in 1313, and was buried in the climed of the church of Northfleet, of which he was rector. He was probably a residentiary of York. In 131.3, when andhishop /onehe visited the minster, it was reported to him flit there were "dissensiones et diseorlize detestabiles" between Valoimes and John de (iilard, a brother canon (Acta (apit. Ebor.). 
Surrey, and, on the same day, a loan of 200 marks to Sir Willian de Ros, lord of Hamelake.

132\%, June 30. To dan Nicholas de Hugate, ${ }^{j} 100 l$. to give to the king and queen. July 2. To Robert de Wodehous, ${ }^{k}$ keeper of the king's wardrobe, for the ling's use, 500 marks in money and gold fiorins "de agno, eathedra et mace," to the ralue of 300 marks, as a loan. Nor. 9. The arehbishop desires Mr. Alan de Conyugesburgh, his proetor at the court of Rome, to make a present for him of 1000 florins to the pope. Nov. 25. To Mr. John de Thoresby going to the court of Rome, $20 \mathrm{l}^{\mathrm{m}}$

1328, August 12. To the king fifty marks to buy him a palfrey. Angust 29. To Plilip de Redmere, our valet, 20l. for certain works of ours at IIull.

1330, April 9. An order to pay to Mr. Robert de Bridlington for the nse of William, ${ }^{n}$ son of Henry de Melton, 1000l.,

j Provost of Eeverley 1315-1338. Probend of Barnby at York 1317. Arelideacon of Gloucester 1317 (he Neve, iii., 77). Canon of Ifowlen and Sat lmarsl at Howden (Reer. ii., Pr. and Conv. Dinelm, 107). Master of St. Nicholas's hospital at York (1)ucrd. Mon., vi., 710). Inemmbent of Lythe and Welwick. In 17 th Edward II. he oceurs as receiver of monies to be spent in Aquitaine (Pell Reenrk, 136. Abbrev. Rot, Orig., i., 276). In 2nd of Wilward III. he was appointed to smperintend the reparation of the apartments in the palace of the archbishop of York for the celeluation of the kine's marriage (Pell Reeorts, 1 10). He was anon of Ascrarby at Lincoln (Le Neve, ii., 101), and his will was proved on the 12th of July, 1338 (MSS. IIarl., 6951 , $556)$. A chantry was founded for his soul in York minster in 1357 at the altar of SS. James and Katherine (Fabrie Rolls, 286).

$k$ A younger son of Sir Bertram de Wodeliouse, of Kinberley, by the lieiress of the Feltons (Blomefield's Norfolk, ii., 513). Chaplain to Edward II., clerk of the wardrobe, chancellor and baron of the exchequer and lord treasurer of Cngland (Foed., ii., 395, 419, 787 , 1010. Cal. Rot. Pat., 105-6, 109, 132. Rot. Scot., i., 139. Rot. Parl., ii., 79. Madox, Hist. Exch., ii., 327. Dugd. Chron., 39-12. Lib. Garderobx, 73. Foss's .Judges, iii., 314, 539). Prebend of Knaresbro' and arehdeacon of Richmond, canon of Hereford, Lineoln, Southwell, and Lichfield, incumbent of
Boney and Tyverington. In his will, which was made in 1345 (Test. Ebor., i., 13), he desires to be buried in the chureh of the Austin canons at Stamford. The author of the metrical pedigree of the family of Wodehouse tells us, whilst speaking of the nephew of the treasurer, -

\section{"His unele Robert, being Iligh Treasurer Of England, one who hall sometime before Bin Richmond's dean and chaplain to the king, \\ So pious and discreet his life had bin."}

lA most raluable description of these coins, which, in the absence of gold at home, English bankers, etc., were most anxious to procure. I believe that coins of all these three types are not now in existence. Peter de Dene in his will made in 1322 mentions Florins "deagno et mas" (Chron. W. Thorn, col. 2037).

" Afterwads archbishop. He arose into importance throngh his skilful diplomaey at liome. A farther sum of 30/. was given to him by Melton on Dec. 2 nl at Newcastle. In 1326 he occurs as receiver of Melton's chamber and his private chaplain.

"Afterwards Sir William de Melton, knight, of Aston, the archbishop's nephew and heir, ret. 23 in 1310. He died in 1362, leaving a son and heir, Sir William, at. 23, whose mother was Joan, sister and co-heir in her issue of 'Thomas lord Lucy, who died July 4, 1369 (Baker's Northants, i., 673. Hunter's South Yorkshire, ii., 16\%). I make some additions to the pedigree.

The will of Sir William Melton, the 
and for the use of Thomas, John and Joan the brothers and sister of the said William, 100/. each. April 21. An order to Simon de Swanlond to buy 10,500 small florins of Florence to prosecute our cause in the papal court against the bishop of Durham. ${ }^{\circ}$ Jume 1. To dan. John de Elghton, chaplain, celebrating at Melton for the sonls of our parents, a wage after the rate of five marks per anmum. Jume 8. Thomas Fox, the receirer at Hexham, is ordered to construct a good and a stent gaol at that place.

1331, May 17. An order to the receiver at York to have made for the archbishop a silver enp of the price of $40 \mathrm{~s}$, and another of $2 \frac{1}{2}$ marks or $30 \mathrm{~s}$. May 21 . 'To Adam Coppendale of Bercrley, 100l. 4s. for cloth bonghit of him for our summer liverey. May 24. To Walter de Kelstern, 185l. 8s. 1d. for plates of white silver, and to IIenry de Belton, ${ }^{p} 32 \pi / .18 \mathrm{~s}$. 9d. for plates of white silver received from him through the hands of Mr. Robert de Bridlington and John de Nottingham.q

second, is printed in Test. Ebor., i., 216. He died in 1398, having been a witness for the Scropes in 1386 (Scrope and Grosvenor Roll, ii., 301), and his widow, shortly afterwards, took the vows before archbishop Scrope in the following manner :-

"In the nome of Jhes! Crist, Amen. Y Katerine de Melton de Aston, of the erchebisshopricke of Iork, by for you lier, worsshepful fader in God and lord Richard by the grace of God erchebysshop of York, primat of Engelond and legat of ye court of lome, in the wyrsship of Gode and hys moder Scinte Marie maiden and al seintz of heven, in your holy handes make arowe and byhot that $y$ shal kepe my body henforword in chastitee, and in token of this arowe $y$ make this seyne of the holy cros whith my owne lionde +."

A Mr. William de Melton was sometime the archbishop's receiver at IIexham. Possibly he was the issue of the following marriage which is entered in archbishop Melton's resister. Jan. 13, 1307, Clement $Y$. grants a di:pensation to William, son of Nicholas de Melton, and Christian his wife, who had married although they were related, and had had four children. The consanguinity was thus shewu. A person called "Anketinus diaconus," had two children, Thomas and Agnes. Ralph "dictus clericus" was the son of this 'thomrs. Ralph had a son Rathl, the father of Maud, mother of Wrilliam de Ilelton.
Agnes, danghter of Anketinus above named, was the mother of Alexander Paslewe, who was the father of Geoffrey, the sire of Christian. I scarcely think that this document relates to the parents of the archbishop.

On Oct. 4, anno 22, archbishop Melton writes to the bishop of Durbam to enquire about an exchange of bencfices as proposed by William Melton, rector of Alston, and John de Bridlington, rector of a moiety of the church of Roxby in the diocese of Lincoln (Regr. Bury, 311). June 22, 1370, ind. Mr. William de Melton in vie.de Withornse, having exchanged for it his rectory of Brandesburton with Thomas de S. Martino (Reg. Thoresby). Mr. Milliam de Melton was ordained priest at York on the Saturday after St. Incy's dity, 1358, William de Ferriby giviug him a title (ibid.).

o The contest between Melton and ly. Beamont is clsewhere alluded to.

${ }^{p}$ Mayor of York 1334-7 (Irake, 360-1). On July 2, 1336, the prior and convent of jurham allowed him and the other parishoners of All Saints, Onserate (l'arement), to build lonses in the churchyard, where the dearl were not interred, to support a chaplain in lonour B.M.T. in the sail church (Rer. ii., P'r. and Conv. J)melna., 108b). beloul tomeded a chantry there on - ith of July, 1317 (Drake, 291).

"A Joln de Nottinghan was dean of Lincoln in 1340 (Le Neve, ii., 32). 
Angnst 9. To Riehard de la Marer and Thomas de Ergom their expenses, ete., in taking the fattest of the deer in our parks, co. Notts. Augnst 20. To Mr. Richard de Snoweshull and Richard de Grimeston of York, goldsmith, 100lb. of silver plate. $^{s}$ August 31. 'To Willliam de Cliff, the money neeessary for himself and men, his horses and dogs, whilst taking the fere in our park at Beverley, and salt for salting what he takes. ${ }^{t}$ Sept. 2:. 'T'o William de Melton, son of Henry de Melton deceased, our brother, 1000/. as a mark of our affection. Nov. 22. 'To Mr. Riehard de Eryom, ${ }^{u}$ eanon of York, 100 marks to ex-

A consin of the archbishop. I shall notice several other members of the family.

$s$ The York nint was in full play during this archiepiscopate, and I shall give some new and valuable notices of its progress. A great quantity of mom ney seems to have been struck at York, but there are few peculiar mint-marks, such as are observed on the coins of the bishops of Durham. Their alsence may be easily accounted for by the fact that Tork was not a palatinate like Inrham; such a privilege, therefore, as the use of mint-marks conld not properly bo assumed.

Mr. Richard de Snoweshill was Melton's mint-master. Nelton made him his receiver, and he beeame rector of Huntington near lork. He made his will on the 27th of August, 1349, in which he desired to be buried in the choir of the chureh of All Saints at II untington, near the vestry-wall, if he dies in the diocese of York. II gives a legend to the church, and leaves 10 s. to buy a stone coftin in which his body is to be laid. Pr. 7th August, 1319 (Rers. Zouche).

The following extracts relate to the operations of the York mint at this time. August 7, 1331, an order to Mr. John de Notyngham, the archbishop's receiver at York, to give to Mr. Richard, the goldsmith, of Grimesby, whom we have appointed our magister cuneorum, all our silver plate in your keeping. August 8, Mr. Richard Snoweshill appointed custos cambii, and on the same day, Nottingham, the receiver, is directed to give him $200 \mathrm{lb}$. of silver to hand over to Richard, the goldsmith, to coin into money. Aug. 28,1331 , the receiver is ordered to pay Snow eshill 100l. for the use of the nint, and on August 31 the same oflicer is ordered to place in his hands the arehbishop's silver plate. Dec.28, 1331, to Mr. R. de Snoweshill, our receiver at York, the money he has spent "circa missionem euneorum nostrorum apud London et pro ipsis cumeis ibidem fabricandis," and for bringing them to York, and, also, for making a chasuble for our chantry in York minster. March 13, 1333-4, acq. of the accompt of Snoweshill as keeper of the mint, 3110 . lib. arg. 4 s. 11 d. remaining in his hands. The accounts run from August 8, 1331, to Nichaelmas, 1333, and are passed. Jan. 12, 1337-8, an order to the receiver at York to buy silver plate for our use.

t August 5, 1334, an order to pay to William de Cliff and his companions the money they require for hunting for us at Ripon.

"Prebendary of Ulleskelf, which he held from 1322 to 1338 , when he died. His history is a remarkable one. He made his own way in the world, as in June, 1301, he is mentioned in arehbishop Corbridge's register as " Richard de Eryum super Tees, pauper clericus." He soon rose in to importance, Kellawe, bishop of Durham, having taken him by the laand. In 1313 he was prebendary of Lanchester, and in receipt of an annual pension of $66 \mathrm{~s}$. 8d. from the convent of Durham (Reg. ii., Pr. and Conv. Dunelm., 35, 61. Hist. Dunelm. Ser. Tres., appendix, 107). On Dec. 3,1315 , the dean and chapter of York ask Kellawe to ordain Mr. Richard de Erium, rector of St. Nicholas's, Durham (Reg. Kellawe, 155 乙). In November, 1316, he was made canon of Saltmarsh at Howden (Reg. ii., ut supra, 79b). He is very frequently mentioned among the acts of bishop Kellawe. In June, 1322, he exchanged his stall at Howden with Richard de 
pedite the business of ourself and our clureh at Rome. Nor. 28. 'To Mr. John de Barneby, our domestic chaplain, 1500 florins for our affairs in the court of Rome. Nor, 29. An order to the receiver at Howden to give to John de Haytefeld as many hens "de lak" at this time, and whenever he comes to you, as the sumpter horses of our poultry store, ean carry to is at York, and the wheat and barley "de doddes," which are due to us from Howdenshire, to be brought to our manor of Cawood. ${ }^{v}$

1332, Jan. 18. To Mr. Jolm de Notingham, the expenses of his journey to and from St. Oswald's, Gloucester. Jan. 19. 'To Mr. Thomas Sampson, ${ }^{w}$ official of our eourt at York, two deer from our park at Beverley. Feb. 21. An orler to pay loos. for building a grange at Boulton. April 5. To John le Waryner, money to repair our camera at Ripon. May 14. An order to Mr. Robert de Bridclington, ${ }^{x}$ seneschal of our lands, to pay 1000 marks of the money of our cousin which is in your hands to David earl of Athol.y May 25. 'To dame Margery de Mel-

Osyodby for the prebend of Ulleskelf. In April, 1323, he was presented to the living of Brompton in Pickering Lyth, which he held till he died (Reg. Nelton). On July 8, 1324, he was one of the persons appointed to settle the disputes between France and England "ratione castri de Monte Pessato" (Foed., ii., 558). He died in 1338. See Hist. Dunelm. Scr. 'Tres, 104.

" Some curious customary rents. In Best's Farming Book, which has been published for the Surtees Society, there is the following explanation of "doddes." "Many have alledged $y^{t}$ white wheate is ye best to mingle and sowe with rye and $y^{t}$ it will bee ye soonest ripe, but wee finde experimentally $y^{t}$ Kentish wheate is ye best or $y^{t}$ which (hereabouts) is called dodde reade, and besides it is a larger corne, and a wheate $y^{\imath}$ will sell as well amongst rye as ye other."

* A distinguished man. Ile was son, I believe, of John Sampson, who was knight of the shire for l'orkshire in 1298, and was elosely connected with the families of Sutton and Malbys. He lield at vitrious times the livings of Acaster Malbys, Halmby, and Mlisterton, and was warden of the chriuel of Sutton in Holderness, canon of llolme at York, and a residentiary and prebendary of Beverley. In 1312 the canons of York elected him their dean, but the appointment was set aside by the pope after a long and angry controversy. Sampison was employed in state affairs (Foed., ii., 791, 870,917 ; iii., 116. Rot. Scot., i., 590-1. Rot. l'ml., ii., 105). 'There are letters from hin in existence describing the victory at Neville's cross (MSS. Bodl., 2086, 18), and he was very useful in ardvancing the bnilding of Tork minster. He died in 1319, having made a noble will which is still mutublished. His wealth was enormous.

2. Private chaptain of Melton. In February, 1320, he exchanged his stall in the church of All saints, Derby, for that of Welton at Lineolu (MSS. II arl., $6951,77 \mathrm{~b})$. He was canon of Nunwick at Ripon, Woodburgh at Southwell, and Soutl Newbald at Iork, the last of which he obtained in 1330 in exchange for the stall of Parva Cestria at Derby. He held, also, the livings of North Ferriby, Claworth, and ELneley. Ile died in 1332. On Dee. 29, 1331, the custody of the marriage of Richard, son and heir of Richard de Fornens, was entrusted to Brillington. kohert and William F., his brothers, are mentioned (Res. Melton).

$y$ This was for the manor of Gainsborongh. 'The barrain was eancelled. On March 15, 1333-1, the arehbishop desired the noney shonld be received lack from the earl, together with the decds. 
ton, our kinswoman, three quarters of wheat and five of malt. June 16. To Richard de Danport, tanner of Pontefract, 107s. for thirty-one hoods and twenty-one super-tunics furred with budge, and forty-four lambs' furs for our summer liverey. June 24. 'To Mr. Iro, the mason, five marks for stone bought at Tadeaster for' our work at York. August 1. 'To the Augustinians at Lincoln, in their general chapter there, two marks. Angust :4. To dan Richard de Melton, seneschal of our hospice, 200 marks to make provision for us at St. Botulph's. Sept. 29. 'To Mr. Robert, our cook, money enough to buy 2000 stockfish in the next fair of St. Botulph's, with his expenses. Nov. 12. To John de Dyoek, the money necessary to hire a ship to bring "plastre ston" from Gainsbro' to Sontliwell.

1333, Nay 4. To William de Fereby,, our domestic clerk, 100/. for the expenses of our hospice. Oet. 18. An order to Mr. Richard de Snoweshull, our receiver at York, to repair and make a glass window in our chapel, the east window of our chamber, a new window in our study, and a new partition (particula) in the west end of the great hall of our palace, and to pay 40s. for a silver gilt cup. Oct. 21. An order to pay 100 s. for a pontifical ring. Oet. 23. To Adam de Coppendale of Bevcrley, 39l. $17 \mathrm{~s}$. for spices. Nov. 1. To Simon, master of the schools at Newark, for the expenses of our kinsmen William and 'Thomas de Nelton and their tutor as long as they are there, 2s. 5d. per week. Nor. 2. To John de Esk, 24l. for two borates of land bought for the use of our beloved kinsman Thomas, son of Henry de Melton."

* A kinsman of the archbishop, and a member of a great clerical family which held many preferments in Yorkshire. Ferriby is near the archbishop's birthilace at Melton. It wonlu be terlions to enmerate minutely the preferments of William de Ferriby. Suffice it to say that at one time or other lie held the archdeaconry of Cleveland, the chancellorship and the stalls of Bilton, Holme, and Dunnington at Tork, where he was a residentiary. IIe was also eanon of Ripon, Southwell, and Salisbury, dean of IIereford, chancel'or of Beverley, and prebendary at Chester and Osmmiderley. He held the livings of Bromptori, Clawortl, Stokesley, North Ferriby, Hugate, Carleton in Lindrick, Kijpax, Acaster Nalbys, the mastership of Bawtry hosrital, and the rectory of Watford, Nortliants. Ile was exeeutor of arch. bishops Melton and Zouche, and dying in 1379 was lumier in Tork minster.
His will is in Test. Ebor., i., 103. Cf. Fabric Rolls, 123, 286, etc. Ferriby leaves to the fabric of York minster 20 marks, and all the books which formerly belonged to archbishop Melton.

a A very interesting notice of the education of the archbishop's nephews. The eldest lias been already mentioned. IIis unele seems to have allowed him 100s. a year after he left school.

On iIay 30, 1332, Mr. William le Burton, viear of Kirkby Moorside, reeeived the charre of Thomas, son of Henry de Melton, a boy. On May 14, 1335, the eare of Thomas and John, sons of Henry de Melton, was entrusted to $\mathrm{Mr}$. William de Yafford, parson at the altar B.H. Magd. in York minster. On Dec. 5, 1335, William de Ferriby, the air hbishop's domestie ehaplain, was made their curator (Reg. Melton). On Mareh 30, 1351, there was a commiseion to ordain Mr. Thomas de Melton, rector of Hotham (Reg. 
1334, Jan. 15. To Rogrer de Monketon, jeweller of York, 52s. 11d. for a eup and two pieces of silver. April 1:. 'To Arlam de Coppandale of Beverley, 10\%.21d. for two clls of cinviss. May 10. An order to reward Robert Parvyer, Itillian Basset, Jolin de Trevanyon, William Seot and John de Anlayghby, arlvoeates, of York, for their advice and assistance in our business. May 19. To William de Popelton, seneschal of our hosprice, fifty marks as a gift to our lady Philippa the queen, and nnoncy to buy two eareases of oxcn, three of pigs, and six of sheep to give to the king. ${ }^{b} \mathrm{Jmme}$ 3. 'To Mr. Thomas Sampson, official of our court at York, sufficient moner for our cause against the archbishop of Canterbury.c July 10. To Richard Lme, steward at Otley, 20l. for building and repairing our houses in the manor there. August 1. 'I'o Johm Levenyng, ${ }^{l}$ our valet, the money required for hunting for us, and storing what he takes, at Sonthwell and Serooby. August 10. An order to pay the moncy for the silver chain of our seal, and for a case to it. Mrgust 13. To Robert the plumber, money for lead nails used in our chapel and oriole at York. August 21. An order to Nicholis de Siglesthorn, our receiver at Beverley, to pay ten marks to the keeper of the fabrie, towards the fabric of the high altar there, and twenty marks towards the fabric of the nave. August 31. To John de Worne, 100 marks for the charges at the eustomhouse and the expenses comnected with our wool which has been exchanged in Flanders. Oct. 31. To Thomas de Ougtered, knight, who is about to go to Scotland, tol., and he requires for the present the nse of some part of his silver vases. His request is granted. $f$

1335, Feb. 19. Release of the aceompt of Richard de Snoweshill, our receiver at York. IIe has in hand belonging to us, 1712l. 14s. 6d., thirty-six "florinos regales," forty-nine "de agno," and forty-six "de Florentia," with a silver cup gilt and enamelled, an ewer gilt and cnamelled, pledged by Sir Jolm Cromwellg for twenty marks, and two "inpele," plediged by sir

Zonche). In 1358, on the Saturday after St. Matthen's day, he was made deacon at York, his title being a chantry to which he was appointed by Willian de Ferriby. He was ordained subdeacon on the vigil of the feast of 'Trinity preceding (leg. 'Thoresby).

${ }^{b}$ In this year Edward III. won his great victory at ITalidon hill.

- No doubt arising from the bajulalio crucis.

${ }^{d} A$ cousin of the archbishop. In 1336 a Richard de Cardoyl is mentioned as standing in the same relationship to that prebate.

- A very valuable date. Abont the year 1321 there was a panal indulgence issued in behalt of the church of licverley. Cf. Cal. Rot. Pat., 101.

$f$ Sir 'Thomas Vinhtred hat borrowed money of AIelton, leaving his plate as a pledire for its rejayment.

g A pr. 11, ammo jont. 16, a loan of 20 marks to Sir lohn Cromwell, who gives as a pledge a cul and ewer of silver. 
Fulk Fitzwarren, for 20l. April 2]. To William de Wirkesworth, 200 marks and more for our summer livery.

1336, A pril 5. 'To the prior' of Wartre, 100l. at the oversight of John de Melton, to the use of the said John and Margery his wife our kinswoman. July 13. An order to Mr. Richard de Snoweshill to give out fourteen ells of silk for our summer livery. Dec. 11. We have received from our receiver at York, 842\%. 1 ls. 10d. of our new money. ${ }^{h}$

1337, Jan. 8. To Thomas Fox, our receiver at Hexham, 23s. 41. for making our mill at Alwenton. ${ }^{i}$ April 27. To Sir William de Erghom, knight, ninety marks for a mesuage, a bovate of arable land and the advowson of the church of Aston, which we have bought of him. ${ }^{j}$ May 8 . To Roger de Middleton, 100 marks for the manor of North Milford bonght of him.

1338, June 7. To Mr. Thomas Sampson and dan Nicholas de Hugate, canons of York, 500 marks to the use of the fabric of the church. ${ }^{k}$ Sept. 21. To dan Richard de Melton, rector of Brandesburton, 30\%. for the making of the work of our chapel at Melton, together with the sum of 20l. due from the excentors of Nicholas de Hugate.

1339, Feb. 4. To Mr. Thomas Sampson or Thomas de Ludham, kecper of the fabric of the church of York, 100 marks for the glazing of the window newly constructed at the west end of the eathedral. ${ }^{l}$ May 14. An order to Mr. Giles de Reddmere ${ }^{m}$ to provide for us some good parchment at Lincoln, paying for

$h$ Was this the produce of the York nint or Florins, ete, which lad been chtained in the way of exchange?

i Ang. 21, 1351, Thomas Fox, rector of Gilling in Ridale, and John Luk, rector of Haltwhistle exchange (Reg. Konche).

$j$ 'Tlie manor of Aston, IT.R.Y., rame into Nelton's hands in 1332, when Thomas de Anuby prssed it over to him (IImter's Soutl Yorkshire, ii., 162). "Aston's secret shade" was in subserfuent years the patrimony of the family of Darey, and, in still later days, sheltered the joet Mason, who became precentor of the minster of York.

In 1331. Nelton granted letters of attorney to Thomas de Lelom, his valet, to take possession in his name of the manor of Killom from Peter, archbishop of' Rounen, and his chayter. The archhishop knew in what peril the property of aliens in England was placed, and le was wisely selling bis lands in that conntry (Reg. Melton). In 8th Edward 1II. Holton was entertied by the arch- bislop of the manors of Ottery St. Mary, co. Deron, Kingsclere, and Buntworth, Hants, and Killom, co. York (Cal. Inı. P. M., ii., 62).

${ }_{k}$ Stubbs (col. 1731) says that Melton gave 700 marks, and there is no reason to doubt his accuracy, although the whole amount is not accounted for in the register. No one can suppose that all the items of the primate's exnenditure are entered in that book.

$l$ The beantiful west window, the glass of which is still perfect.

" A kinsman of the archbishop. Canon of Hungate at Lincoln (Le Neve, ii., 99). He nuade his will on the Wednesday before the feast of St. Baruabas, 1317 , in which he desired to be buried in Lincoln cathedral, before the great cross in the nave, near the tomb of Sir William de Bolorn. 'To the fabric he gave 40s. To Juliana, his sister, a nun at Irford, 2 marks. To Thomas de Geynesburgh, chaplain, vicar in the catherlial, 20s., and his portiphor of the Lincoln use, and to him and $\mathrm{Wm}$. 
it 40s. or 50s. July 25. To dan Richard de Melton, 25l. for our chapel at Melton.

1340, Jan. 7. We have received from Sir Antony de Lucy, knight, 200l. in part payment of 400 l. due to us for the marriage of William de Melton our kinsman, and this money the archbishop gives on the 13th, as a special faronr, to his cousin Richard de la Mar. ${ }^{\circ}$

Archbishop Melton died at Cawoor on the 4th or 5th of April, 1340, and was interred in the north aisle of the nave of York minster, near the font. ${ }^{p}$ Mr. Drake, the historian, thus describes the opening of his tomb in 173 . "On the laying the new pavement of the ehurch the stone which covered the grave of this prelate was taken up. It was of bhe marble, very large, but quarterly cloren, and had been plated with brass on the borders, and all orer the middle part of it. Upon trial for a vault the workmen came, at abont two yards depth, to six large unhewn stones, which laid cross and eross, as a drain is covered. Upon removing two or three of them we discovered a curious walled grave of ashler stone, in which the archbishop was laid. He had been put in a lead coffin, and afterwards in a mighty strong oaken one; but both were so decayed that it was easy to get to his bones. On the top of the uppermost coffin, near his breast, stood a silver chalice and paten which had been gilt. On the foot of the chaliee was stampt a erucifix of no mean workmanship, and on the inside of the paten a hand

de Redmer, his brother, all his books which are not set apart for the Friars Preachers at Lincoln. Pr. 20th Jume, 1347 (Reg. Zouche).

Philip de Redmer " consanguineus $\operatorname{arch}^{\mathbf{i}}$ " is mentioned in Melton's register. Philip, son of John de Redmer, occurs in Abbrev. Rot. Oris., i., 156.

$n$ A great warrior and statesman. Melton married his nephew to Lucy's daugliter.

- The family of De la Mare were connected with the archbishop, and were preferred by him. The name is a suggestive one.

William de la Mare "consanguineus noster," once called W. de la Mare de Melton, held many offices. At various times he was canon of South and North Newbald and Ulleskelf and tressurer at York, prebendary in St. Sepulchre's chapel, All Saints Derby, provost of Beverley, incumbent of North Ferriby, Wath, and Waltham. On.Jan. 1, 1319, he was made seneschal of all the archbishop's manors and lands. IIe died 25th Norember, 1365, and was buried in York minster.

Thomas de la Mare, brother of William, also called "consanguineus" by the archbishop, was saerist of St. Sepulchre's chapel. In 1338 he became canon of Weighton, exchanging for it his rectory of Stratford, dioc. Lincoln. He died at Clareburyh, Notts, on 6th of Oetober, 1358, and was buried there. His will is in Test. Ebor., i., 63. It is a valuable document, and several of the Meltons are mentioned in it.

$p$ His obit was observed on the $1 t^{t h}$ (Res. Marn. Album, part iii., 112). It is said that he died on the 5th in Stubbs, col. 1731. MSS. Cotton, Vitellins, $\Lambda$, ii., 112 . On $\Lambda$ pril 6,1310 , the dean and chapter of York semi Villiam de la Vare and two others to the king to tell him that the arelibishop died on the 5th, and to ask leave to choose a successor (Aet. ('apit.). Bur. "in crast. s. Geor" (cii" (lron. Lan.). Mr. Baker (IIist. Northants) is wrong in saying that Jelton died on April 1 i. r. $1: 2$ 
giring the benediction. We could not find that he had been buricd in his robes; his pastoral staff laid on his left side, but no ling conld be met with. His bones, as they laid together, measured six foot, which argues him to have been a very tall man. His grey hairs were pretty fresh; after we had taken a short survey of the exucice of this once famous man, the grave was closed ip in the mamer it was before; but the chalice and paten were carried to the restrv.",

Archbishop Melton left a will, of which William de la Mare, canon of York and provost of Beverley, William de Ferriby, canon of York and rector of Stokesley, and William de Wyrkesworth, rector of Slaidburn and prebendary in the ehapel of St. Sepulchre, were the executors, and they had their release on the 6th of Norember, 1315. It appears that with all his wealth the arehbishop had not paid proper attention to the buildings, cte., belonging to his see, as on the 14th of November, 1342, the executors bound themselves to pay to his successor the large sum of 4000 marks on the score of dilapidations. ${ }^{r}$ Melton, howerer, left great wealth behind him, of which perhaps he was a little too fond, and his nephew William de Melton of Aston was found to be his heir, being at that time twenty-three years of age.s The archbishop died seised of the manors of Kingsclere and Buntworth, co. Southants, Killam, Aston and Towton, within the honour of Pontefract, North Milford, Kirkbywharf, Abholme and Sherburne in Yorkshire, and Upston, eo. Notts. ${ }^{t}$ All these estates came into the possession of his nephews, whose descendants were among the highest kuightly families in Yorkshire.

On the 1st of February, 1355, William de Ferriby, an executor of the deceased prelate, and probably in accordance with his wishes, established two chantries to commemorate his benefactor and kinsman. The condowment consisted of twenty-six marks per ammum ont of lands in Hotham, Northeare, Melton, Ferriby, Swanland and Elveley. The first of these chantries was in the chapel of St. James at Melton, which the primate limself had erected. The other was at the altar of the IIoly Imuccents in York minster. Two pricsts officiated there and marle special mention of the soul of the archbishop and that of Ecward of Camarron, king of England, throngh whose means he had risen to greatness. Each of these ehaplains reeeived the sum of fire marks per anumm."

? Trake's Eboracun, 433.

- Reg. \%ouche.

" Baker's Northants, i., 673.

' Cal. Tur. P'. Ml., ii.,91. The names of the keepers of the temporalities after Nelton's death are given in Abbrev.
Rot. Oris., i., 224.

" Res. Thoresly. Domesday book, penes Dec. et Cap. Ebor., 55-7. Fabric Rolls of York minster, 286. Hutchinson's Durham, iii., 477. 
On the 20tl of January, 1359-60 Elias de Walkington, the sub-chantor of the viears choral, made an arrangenent with Ferriby and De la Mare, by which the obit of the archbishop, was to be annually observed on the th of $A$ pril.o

MTilliam la Zanthe is said to have been a youmger son of William, lord la Zonche of Haringworth, Northants, by Mande danghter of John lord Lovel, and to have been born at lis father's seat." But whether these were his parcuts or not, his very name bears witness to his illustrious birth. The lords of Haringworth were famous for their hospitality, and in Kemet's time the proverb, "to go a Zoucling, was commonly applied to an unbidden but welcome guest.".

Zouche was probably engaged in the serviee of the king in early life, as we find hin acting as a clerk of the wardrobe in 1332.y On the 8th of May, 1329, he was sont to France to make provision for the king against lis arrival; and on the 6th

$v$ Reg. Magnum Album, pt. iii., 112. MSS. Cotton, Clandius, 13, iii., 297.

w Bridges' Northants, ii., 318. 'Tliere are pedigrees of the family of Zonche in Dugdale's Baronage, i., 688, ete. ; -Warwickshire, 42 ; Nichols's Leicestershire, ii., 372 , but the archbishop is not mentioned in any of them. The name Zouche is of French origin "de stirpite sicco," as Camden says (liemaines, ed. 1674, p. 191), the "durmm ex stirpe genus" of Virgil, and the primate fully verified the derivation by his prowess in the field.

On the th of November, 1314 , archbishop Zonche made his brother, sir Roser la Zouche, knight, his soneschal at Ifexham (Rer.). In Feloruary, 1316, he was retained by him, with six others, to defend the IIarches of Scotland, and on that account he was excused from going abroad with the king (Fedl., iii., 69). On the lth of July, 13 15, Sir Roser, who is deseribed as belonsing to Leicestershire, had orders to cross the seas with the sovereign (ibid., $52)$, and on 12th of January, 1359, he and three others were desires to raise an hundred archers for service (ibid, $416,411)$.

Henry la Zouche, perhaps a brother of the archbishop, was presented in
1316-7 by Sir William la \%onche, of llaringworth, to the rectory of Barby, Northants (Baker, i., 26i). ln the year 1350 he was male prebendary of Somth Cave at Tork, which he exchanged for the stall of Ampleford with Ilenry de Ingleby on the 12th of Ang., 1351. He died holding it in Mareh, 1361-2, being at that time archdenous of sudbury, having been appointerl in Jamuary, 1351 (Reg. Zouche. Le Neve, ii., 4:11).

.T Kemnet's Par. Ant.,ii., 4.7-3. The following testimony is borne to the hospitality of the llerberts: "It was an ordinary saying in the conutrey (Montsomeryslire) at that tince, when they saw any fowl rise, "Fly where thou will thon wilt light at Blitek-hall " (Life ol Eclward ford 11 erbert ol ('herbur erl. 1770, p. 5). 'The inseription, which was formerly engraved ujw the village cross at sirotborough, was an homour to the Fitzwilliams (Ilunter's Sonth Yorkshire, i., :31i).

\footnotetext{
Who so is humgry and list well ante

let him conse tis Sprothurgh to his meate, And for a night and tor a day

flis lurse shall have buth come and hay,

And nomatue shall aske lim where le goith aw:ay."

y Pell Records, 112.
} 
of June, 1335, he was present in the eamera of the Friars Minors at York, when the great seal was given to the archbislop of Canterbury. Before this time, however, he had obtained church preferment. On the 10th of December, 1329, he was collated to the archdeaconry ${ }^{z}$ of Barnstable in the church of Wxeter, which he must have given up on the 12th of July, 1330, when he was adraneed to the archdeaconry of Exeter. ${ }^{a} \mathrm{He}$ exchanged this office with Thomas de Nassington for the rectory of Jakclee on the 10th of June, 1331. ${ }^{b}$ On the 9th of March, 1334, he was admitted by archbishop Melton, on the provision of the pope, to the next vacant prebend at Sonthwell, but it does not appear that he ever actually enjoyed one. On the 11th of February, 1336, he was promoted in a similar way to a stall at York. In 1336 the canons of that cathedral elected him their dean, and he was installed on the 12th of Norember. On the 29th of June, 1338, Zonche made his obedience to archbishop. Melton in the chapel of the palace at York in the presence of a goodly company of ecelesiastics. ${ }^{c}$ He was collated to the prebend of Ufton at Lichfield, of which he had only a brief tenure, on the 9th of April, $1310 .^{d}$

The deanery of York was an honourable and an arduous office, but Zonche had still time to spend in the service of his comntry. The post which he held had been already occupied by sereral distinguished statesmen, for the deans of York had rare facilities for making themselves useful in the controversies and the wars with Scotland. Zouche, in this respect, was no exception to his predecessors, and he rose in early life to greatness. In 1337 he was made lord treasurer of England, and he scems to have held the office in the 15th Edward III. ${ }^{e}$ On the 23rd of April, 1337, he was one of the persons who were to arrange about the wages of the soldicrs who were on their way to Scotlaud, and, on the 26th of June, he and others were directed to summon the army to York. ${ }^{f}$ On the 28th of the same month he was ordered to be present at York to state the king's intentions about his turbulent neighbours in the North. On the 28th of Angust he was one of the commissioners who wcre appointed to raise money in Northants for the French war, ${ }^{g}$ and on the 6th of Oetolser he was requested to act upon the Borders, in fortifying the towns, treating with the Marchmen

* Foed., ii., 762, 909.

" Le Neve, i., 393, 406.

$b$ IISS. IIarl, 6951, $101 b$. Nassington was canon of South Newbald at York, and died in 1316.

- Reg. Melion.

d Le Neve, i., 633. e Cal. Rot. Pat., 128, 131. In 1339

Zouche, as treasurer, was abroad in the king's behalf (ibid., 134). Dugd. Chron., 42. Avesbury's Edward III., 46. Fed., ii., 961, 1094.

$f$ Rot. Scot., i., 489, 494 .

8 Fued., ii., 979, 99.t. 
and other necessary business. ${ }^{h}$ On the 19th of Jamnary, 1310 , Zouche, in lis eapacity of treasurer of England, together with several others, was deputed to open the parliament at Westminster in the absence of the king. ${ }^{i}$

Archbishop Melton died in the spring of 1310, and, on the 13th of April, the king issued his eongè d'elire to the authorities at York. On the 2nd of May, the chapter assembled, and two candidates were proposed, the dean and William de Kildeslyy, Edward the Third's seeretary and favourite, who was a notorions pluralist. The wishes of the sovereign seem to have been openly expressed in Kildesloy's behalf, but they were disregarded ; as out of eighteen voters who were present, Zonche obtained the suffrages of all but five. The archlishop-elect and his friends seem to have suspeeted that some controversy would ensue, and Zouche took the singular but wise preeaution of being installed on the day of his election. ${ }^{j}$ A rehement contention now broke out; Kildesby leaving no stone unturned to earry his point, and the king vigorously assisting him. ${ }^{k}$ On the 1.th of Nareh, 13t1, Edward wrote to the pope entreating him to support his favourite against Zonche. ${ }^{l}$ 'The puarrel had the effect of delaying the settlement of the question for more than two years, bit it ended in the defeat of Kildesby, as Zouche was consecrated by Clement VI. at Avignon, on Simday the 7 th of July, 1312. On the 8th of September the king granted him letters of safe conduct to enable him to retum home, and, on the 19th, the temporalities were restored to him." On Sunday the 8th of December, the festival of the Conception of the Virgin, the new archbishop was solemnly enthroned in his cathedral, and there was a banquet in the palaee for which great preparations were

${ }^{h}$ Ibid., 1100. Rot. Scot., i., 503.

i Foed., ii., 1106. Rot. Parl., ii., 107.

j Stubbs, col. 1731. MSS. Cotton, Vitellins, A, ii., 112. Le Neve, iii., 106.

${ }^{k}$ Stubbs, col. 1732 .

'Foed., ii., 1118.

${ }^{m}$ Stubbs, col.1732. MSS. Vitellins, ut supra. After a long delay, for the pope "electos Eboracensem et Lincolniensem tenuit in curia languentes, et nullatenusexpeditos" (Murimuth,115). The same writer says that Clement VI. appointed Zouche to York on June 26, whose election had been hindered on account of an alleged resignation ( $\mathrm{P}$. 133).

$n$ Foed., ii., 1210-11. William de Kildesby was a great man. On Dee. 2 , 1340 , he was made master of the rolls (Foed., ii., 11.13), and between that year and 1342 he was keeper of the privy seal (ibid., 1129. Rot. Parl., ji., 132. Rot. Scot., i., 625. Cal. liot. Pat., 138). He was canon of Wetwans and treasurer at York, warden of the chapel in 'Tickhill castle (IImuter's South Yorkshire, i., 236), prebendiry of Darlington 2oth October, 1311 (Rers. Bury, 317 ), rector of Worfich, dioc. Lichifield (Willis, i., 175), (anon of Southwell, Bath and Wells, Ilowden, Lineolı, Iondon, ete. In 1313, after his disappointment at York, he had the king's permision to make a pilgrimage to Jerusilem, and was allowed to retain all his preferments (Ford., ii., 1220-2). Ile died at Cacn on the 20th of July, 1317 , after an active life. Robert de Killesby, canom of Sontl Cave at York, was his brother. ( $f$. Angl. siacr., i., 22, 10. Carte's Gaseon, ete., Rolls, i., 111. 
viade. One incident in the programme of that great day was the presence of IIngh, the abbat of Jorcvaux, to render his submission to his diocesan. ${ }^{\circ}$

l'or two or three years after archbishop Zonche's arrival in the North he seems to have deroted himself entirely to the requirements of his diocese, and it is probable enough that his collision with the king on the question of his appointment was the canse of his being temporarily mnocenpied in the service of his eonntry. Before long, however, he had an opportunity of disploying in a pre-eminent degree his patriotism and his valour, There began to be some measiness on the Border's, and all eyes were turned towards their troublesome and restless neighbours. In the antumu of 1345 a Scottish army broke into Cumberland and did much mischief, but this foray was only the prelude to a more serions campaign. In the begimning of the following ycar, when the danger became imminent, the king shewed that he had forgiven the archbishop by making him one of the wardens of the Marches, and Zouche, in his new capacity, was most actively employed." In the month of July Edward went abroad and began his career of victory in France, and, about the same time, Harid king of Scotland made another raid into Cumberland, but it was not of a grave character. The news of the giorious trimph at Cressy came across the seas to England, $q$ but the conqueror's mind was ill at ease when he heard of the attitude which the Seots were assuming. On the and of Jnly the archbishop was ordered to go to the Marches with all his power, $r$ and, on the 25 th, the king sent his clerk, Richard de Saham, to bring him some news from the Borders. On the 20th of August Edward desired the mayor of York and others to lery men at the orersight of Zonche, Ifenry lord Perey and Ralph lord Nevill whom he had made commissioners of array.s All these precautions were salutary and wise. In the month of October the Scots broke into England with a large army bent upon something more than plmder. They rolled down Tynedale, scattering the inmates of Lanereost and Hexham, and wasting the comntry as they came. They passed from thence into the bishoprick of Durham, and drew themselves up upon the green hills which overlook the Wear from the west, and within riew of the stately tores which still adom the capital of the palatinate. The news of their arrival had rum through York-

- Iiss. Cotion, Vitellius, A, ii., 112. lier. Zomche.

phot. Srot., i., 683, 670. Zouche lat wiren the king erreat offence, and, as beneea says in his Hedea, "(ipavis ira ream est sempei."
7 The king wrote to Zouche arnouncing the rictory. The letter is printed in the Retrospective Review, n.s., i., 120 .

' Ibill, 672.

- Fued., iii., 87, 89. 
shire, and the arehbishop, nothing damted by the peril of the undertaking, immediately took the field. Queen P'hilippa remained behind at York whilst the primate wont forth to the battle,

"Infula cui sacra redimibat tempora vitta,

Totus collnceus veste atque insignibus armis."

The heads of the great honses of Perey, Mowbray, Neville, Scrope and Rokeby went with lim, and an army was soon collected. It rested for awhile at Richmond, and then entered the Bishopric at Barnard castle, under the command of the archbishop. On the night of the 16th of October they were in Anckland park, the troops being divided into tluree bodies, one of which was led by Zouche. ${ }^{t}$ Early on the morning of the 1 th he had a sharp skirmish with Sir William Donglas and a troop, of horsemen in which the Scots were worsted. On the morlow, the 18th of October, the two armies met on the hills to the west of Durham which look down upon the eity. It must have been a striking sight to see the warrior-prelate going among his men, cheering and encouraging them and giving them his benediction. His prayers were heard; for before that day was over the royal invader was a prisoner, and the Hower of the chivalry of Seotland was torn and dead. That was a victory which the monks of Durham never afterwards forgot. The elronicler of that noble house has told us a romantie story of what then oecurred to them." A rision is said to have warned the prior and his brethren to be present at the fight, but they were not in warlike guise, with spear and panoply and sword. They elevated on a spear one of their most precions relics, the colporax cloth of St. Cuthbert, and, fearless of injury or wrong, they went to pray for their countrymen in the middle of the battle.

\section{"-The prior of Durham with holy hand \\ Raised, as the vision gave commantl, \\ Saint Cnthbert's relic-far and near \\ Kenned on the point of a lofty spear."}

Some sacred influence seemed to hover around the suppliants, for the foemen touched them not. They would hear the ringing shouts around them, the cries of the ranciuisher and the wounded. 'They could see, when they looked up, the chb and the flow of the fight, until at length the enemy was pushed off the green rounded hills, among which they stood, and driven in

$t$ For an account of tlie battle, ete., see Chron. Tan., 316, ete.; Knyshton, col. 2590 ; Stubbs, col. 1732; Lel. Coll., ii., 470. Mnrimuth (177) and the Monk of Malmesbury (250) say that the battle was chielly won by the York clergy. Walsingliain, 167. Minot's
Poems, 39-11. Arch. Riliana, $n . s$. Hardyng's Chron., n.e., 32-25. Galf. le Baker, 172. Avesbmy, 15. Fordun, ii., 311 .

"Rites of Durham, ed. Surtees Soc., 20-5, 50. Hist. Dunclu. Scr. 'Tres, appendix, 131-5. Iurham Wills, 2y-30. 
wild confusion towards the North. With what joy and gratitude would the delighted monks weleome the conquerors when they returned to them! They would lead them down the narrow pass which opencl out into the eity, and there before the sacred shrine the knees of the wearied soldier were bent in thankful acknowledgment of his trimmph. It was probably the first time that archbishop Zouche entered that stately temple. When he visited it again he would see the trophines of the battle which he had done so much to win, the famous black rood of Scotland, and the bamners of the slain or captured nobles waving over St. Cuthbert's shrine.

The disgrace of archbishop Melton's defeat at Myton was now wiped out, and Zouche had won for himself not only commentation for his energy and patriotism, but the reputation of a successful general. He sent his valet, William de Hugate, to the king with the news of the victory,$^{v}$ and Edward was profise in his thanks and praises. He begs the archbishop to continue his hitherto successful care in guarding the Marches. The monarch speaks, in a spirit characteristic of that noble age, of the mercies that had been vonchsafed to him, how thankful he was for Gol's goodness, of which he was unworthy. ${ }^{w}$ 'The cloud which had humg between Edward and Zouche seems now to have been remored. On the 10th of December the king requested the archlishop and several of the great men in the North to give him their presence and their advice at Westminster, where the war might be discussed,,$^{x}$ and, on the 18th of Norember, 1350, he shewed his especial favour to the Northern primate by condoning all his past shortcomings on arcount of his great services, particularly in the battle of Durhann.y This concession is partly, no doubt, of a general character, but it also has reference to the offence which Zouche harl given to Edward when he was elected to the sce of York.

'The archiepiscopal career of Zouche was not a long one, but it was signalized by activity and a painstaking attention to his duties. Il is was essentially a reigin of peace, and no controversy seems to have disturibed it. $z$ Ife received a subsidy from his

" On Dec. 11 the king orders him a reward of 10l. (Foed., iii., 98). Some two or three prisoners who had been captured in the battle foll to the archbishop's share, and there is sme correspondence about them in Foed., iii., 95, 105 ; Rot. Ścot., i., 687. 675.

${ }^{w}$ Fued., iii., 91-2. Riot. Scot., i.,

${ }^{x}$ Fæd., iii., 97. Rot. Scot., i., 679. On Selt. 5, 1318, the king desired Zouche "procurationes curdiualium collicere" (Fœd., iii., 170), and on March 1, 1351, he was asked to conroke his clergy, and obtain from them a subsidy in aid of the French war (ibid., 211). 210.

$y$ Cal. Rot. Pat., 160. Fæd., iii.,

z Feb. 18, 1313, commission to Mr. Thomas Sampson, jur. civ. prof. and oflicial, John de Aton, canon of Lincoln, and Robert de Askeby, our dowestic chaplain and rector of Washing- 
clergy on his accession to office, and, at the same time, he requested the heads of the various religions houses within his diocese to give a benefice to some poor clerk. 'The rexister of the see during this period mentions the establishment of a laree number of chantries and the appropriation of many livings. It also contains the following entries.

1342. On the Sunday after All Saint's day, the archbishop, at the request of the king, grants a pension of $100 \mathrm{~s}$. per ammun to Reginald de Donynton, ${ }^{a}$ elerk, till he can provide him with a benefice. Nov. 17. An order to the receirer at York to pay, at the oversight of William de Popelton, the money recpuired to repair our houses at lork to be ready for our installation banquet. $^{b}$

1343, June 15. To the nine canons in residence at York two oaks each and their fagots, from our woor of Langwath. August 4. Bull of Clement VI. denouncing Isouis, dluke of Bararia, as an enemy of God and an excommmicaterl heretic." August 27. An order to pray for fine weather. ${ }^{l}$

1344, July 18. Rahph, bishop of Lethlyn, ${ }^{e}$ appointed suffragan. Oet 21. Licence to John de Stafrord, rector of St. Michael's, Ousebridge, York, to be ahsent for a year in the service of the earl of Derby. Nov. 10. To Thomas Wadilove, the runner of our treasurer at York, a stipend of a penny a day.

1345, Jan. 21. To Mr. Robert de Askeby and Joln de Sutton, clerk, our domestic chaplains, their expenses whilst absent on the business of our mint. Jume 23. A mandate to pray for the king and his army.

1346, April 17. Licence to the abbat of St. Mary's, York, to hear the confessions of his monks. Jume 26. $\mathrm{A}$ general sentence against those who have entered $A$ berford ehureh and killed Jolm de Byngham, clerk, whilst he was on his knees

ton in the diocese of Durham, to treat with the archbishop of Canterbury "super bajulatione crueis." In Zouche's Register, 253-4, are some statutes made at a synod at York.

a In 1347 the king presented him to the stall of Barnby at York, and he died holding it in 1319 . CF. Foed., ii., 988, 1060. In 1325 Rerinald de Donington was sheriff of Lineolushire (Parl. Writs, ii., part i., 339).

$b$ On the 9 th of February the receiver, Mr. William de Wirkesworth, was desired to pay for the provision that had been made for the baurpuet, at the oversight of Joln de Thorp "dilecti clerici nostri." c Cf. Chron. Lanereost, 253, 301, ete. Kiny ghton, col. 2553, 2565. Murimuth, 60. 'The duke was mixed up with the athairs of the anti-pope and was made emperor. Barnes's Belwarl III., 410. Cf́. Baronii Amn., laynaldi, xxiv.

' On Oet. 21, 1315, the chapter of York gramt an inlulgence of forty days to those who pray for the removal of the "aëris intemperies" (Acta Capit., Ebor.).

c Another commision to him on Sept. 10. The archbishop gives him a pension of 10 marks per anmum and the fees. Jan. 20, $131.1-5,10$ marks to him for his salary. 
praying. August 9. An order to pray for the king and his arniy going to France. $f$

134 $\%$, Nay 3. To Mr. Thomas Sampson, official of the court of York, 50l. for his fee. October 5. Licence for Simon de Stowe, rector of a moiety of the ehurch of S.M. Castlegate, York, to be absent in the service of dame Joan Fitzwauter, lady of Egremont.

1348, Feb. 21. Commission to John de Coniston, a Carmelite friar, to hear the confessions of Sir John de Haryngton, knight, and his wife. ${ }^{k}$ Mareh 5. Hugh, arehbishop of Damascus, is appointed suffragan with a pension of 40 marks per annum and the fees. ${ }^{i}$ April 11. Letters testimonial to a mairiage between Robert de Swylington and Arora, danghter of Sir Stephen Waleys, knight, deceased. They were contracted on the Monday before the feast of St. Thomas the Apostle, 1347, in the homse of 'Thomas Basy in Nicklegate, York, and were afterwards publicly married. May 11. Sentenee against those who have hindered the procession at Southwell on the feast of Pentecost, coning up to the high altar with swords, clubs, ete. June 11. The feast of St. Bartholomew: the provost and scholars of Queen's college, Oxford, put themselves under the protection of the arehbishop and his suceessors.j July 28. An order to pray for the removal of the mortality and infection of the air. ${ }^{k}$

1319, leb. 1. A conmission to the official of the archdeacon of York to hear confessions, on account of the mortality and pestilenee in varions parts of on dioeese. 1pril 28. Mandate to the hishops of Carlisle, Durham, Whitheme, ete., to piblish the letters of the pope about the indulgence on behalf of the mortality. June :6. Commission to Hugh, archbishop of Damascis, to dedicate the cemeteries of the chapels of Egton and St. Thomas near licrerley. July 10. To dedicate in haste, on aecomt of the pestilence, the chapel and cemetery of St. Oswalt at Fulfort. Jnly 15. The emetery and chapel of

$f$ The year of the famous lattle of Cressy.

s Feb. 13, 1350, a sinilar sum to the oficial, Mr. Gribert de Welton, dretor of laws.

h 'There are many other licences for' the friars to hear confessions and preach. On Nov. 16, 1315, Hugh de Wamesby, a Friar Minor of boneaster, was authorized to act as confeseror to dame Margery de llastinges and her family for a rear.

i There are other commissions to him datol on Jane 5, 1319, Jan. 27, $1319-$ 50, and Jareh 4th, 1351-2. March 6, $13+7-8$, a payment of 10 marks to him in part payment of his salary. On Augurt 27, 131., Simon, bishop of Whitherne, mate his obedience to the archbishop at Cawood. There is an interestimg notice of archbishop Hugh in the Fod., iii., 229.

$j$ 'This college will be mentioned afterwarts.

${ }^{k}$ There is a dreadful account of this pestilence in Kinyshton, col. 2598, etc.; Ilurimnth, 178; Walsingham, 168; Fued., tii., 198, where it is said that a great part of the people, especially the operatives and servants, died of the plague. 
Clescby par. Staynwegges. July 17. 'The ecmetery at Wilton. July 23. The chapel and cemetery of Semer par. Rundby, and the chapel of Brotton par. Skelton. August 1. The ennetery of the chapel of Barton par. Gilling, to be nsed diuning the pestilcnee, and, on August $\tau$, the chapel of Eschy par. Stokesley?

1350, Feb. 20. To John de Acome, canon of St. Sepulchire's chapel, York, 20l. for our business in the court of Rome. Fel. 27. To Sir Henry Perey, sen., 50 marks for his fee. 1 pril 9. 'To Sir Thomas de Rokeloy, knight, late sheriff' of Yorkshire, 20l. July 24. Licence of non-residence for a year to William Nenport, rector of Arnelifi," in the service of lord Perey.

1351, Jan. 7. A letter to the chapter of York enjoining them to make Roger de Ledes, a vicar-choral, do penance for drawing blood from a clerk of the cathedral in the minster. Feb. 5 . Licence for John de Chesterficld, ${ }^{\circ}$ rector of Foston, to be absent from his benefice for 2 years in the scrvice of Sir William la Pole, knight. June $\tau$. 'To Jolm de Flete of York 11. marks of

I Stubbs (col. 1732) tells us that the phague began at Michaelmas. In 1319 there was a great mortality in the rity of York, which contimued till st. James's day. Aresbury (257) says,

"Mors prima communis Mc ter L minus uno."

The scourge, it will be seen, cxtended to the most remote and the healthiest villages in the county of York. These orders for the consecration of cemeteries tell a sad tale. Cf. Galf. le Baker, 189. Fordun, ii., 317 . The clergy sutfered very severely (Statutes of the Reahm, i.,.378).

${ }^{m}$ Sir Thomas Rokeby of Rokeby, sheriff of Yorkshire 1337, 1313-50 (Drake, 352), a great soldier, and one of the leaders at Neville's cross. For an acconnt of him see Scrope and frosvenor Roll, ii., 308-9. In 1327 he brought Edward III. in sight of the Scots at Stanhope park (Foed., ii., 717. Barnes's Elward III., 12. (Economia Rokebeiortim).

$n$ A retainer of the noble house of Perey. Rector of Arne?iffe 1319, which he gave up for Spoffortl. This he exchanged in 1359 for the rectory of Bishopwearmouth, co. Durham. In 1362 he again ascruired the living of Spolforth, and was allowed to hold that of Bishopwearmonth with it. In 1365 he gave up Srofforth for the prebend of Ulleskelf at York (Reg. Youche and Thoresby. Reg. Hatfield, at Durham,
43, 52, 58). Nemport diml in 1366, and his will is in 'lest. Ebor., i., so. $A$ chantry was fommder for hin at the altar of St. Gremory in Tork minster (Fabric Rolls, 251).

The love of non-re-idence was increasing. The work of Piers Plomehman may appropriately be cited :-

\footnotetext{
"Parsons anl parisshe preestes

pleynell hem to the bisshope,

That hire parisslats weren poutere

Sith the pestilence tyme,

To have a licenes and leve

At Loudon to dwelle.

Some serven tho kyng,

And his silver tellen

In cheker and in elnanedrie,

Chalangen hise dettes

lif warles and of wardenotes,

Woyve's and streyves.

And somme serven as sorvantz

Lurls and ladies.

And in stede of stywardes

Siltell and dermen

IIire mess: and hire matyms

And many of hise homres

Am doon un-devont lieke."
}

- The kines chaplain. Canon of Grendale at Fork. Ordained acoolite, sulb-rleacon and deateon in 1319 , lowing then restor of I'leslay and Foston (lieg. touche). Ile had leave to be nonresident at Foston in 1352, 1353, and 1361. Chesterlield was probentary of St. Stephen's, Westminster, 1318 -5s (Newenurt, i., 7 17 ), and canon of ('halk at Wiltom, dioc. Samm (l'billips's Wiltshive Incumbents, 40). 
silver for wines bought of him. Sept. 6. The archbishop orders the use of a new service in honour of the Virgin, and others for the translation of St. Thomas of Hereford and St. Ambrose. ${ }^{p}$ Oct. 4. A letter against the begging friars, ordering them not to seek alms in the churehes "libris apertis more quæstus." Dec. 11. Commission to William, bishop of Sodor and Man, to celebrate orders.

1352, Feb. 1. A mandate to pray for Henry, duke of Lancaster, who is going abroad against the enemies of the faith and cross $q$ Mareh 9. General letter against those who have dragged William de Echardeby from sanctuary at Wetheral. April 11. Licence to the dean of Pontefract to exhume the bodies of three men interred in the churchyard of All Saints, Pontefract, who were condemmed by the justices, and to inter them " in loeo de Sancto Victore," near the town, which is said to be dedicated, where it has been the eustom to bury criminals who have been hung. May 6. Commission to William de Bokenham, prior of the Carmelites at Coventry, to wash away with holy water a stain of bloor in Beverley minster. May 7. Licence for Thomas de Percy, ${ }^{r}$ rector of Catton, to be non-resident for two years to study. May 14. An acquittance to William de Newport, rector of Arncliffe, an executor of the will of Sir Henry de Perey, sen., knight, for a horse ealled Lyarde de Patrington, in onr hands at the time of our decease, as a mortnary on account of the church of Catton, and also for a gold ring with a stone called an emerande; ${ }^{s}$ and, on the same day, the executors release the archbishop from the pension of 100 marks granted by him to the said Henry, the archbishop paying 100/. for all arrears.

For some time before his deatl arehbishop Zouche was afflicter with a rery serious bodily infirmity, and it was the

"Both to be with Novem Lectiones, and the liymn Salvator, mundi domine, to be said on each double festival instead of that $T e$ lucis ante terminum. On Feb. 11, 1343-1, the arehbishop makes some alterations in the services for the feast of the Conception B.II.V. Good Friday, and the feast of St. Martha. They are to be specially kept.

" Zonche calls him "regni Angliæ membrum nobile et columpma una." Whilst on his way to Palestine, he was arrested at Cologne by the emissaries of Otho, duke of Brunswick. This orisinated a dnel, which will soon be allided to (Barnes's Edward III., 465). The was ealled the grood duke of Lancaster, and was a famons warrior.

r Marcl 31, 1352, inst. in rect. do
Catton, "ad pres. regis, eustodis terrarum patris tui dom. Henriei de Percy." On J time 17, the pope allowed him to hold a stall at Chester-le-street, he being then but 19, in respect for Edward III. and Isabella his mother, Perey being their cousin (Reg. Zouche). Percy was bishop of Norwich from 1355 to 1369 (Le Neve, ii., 464-5. Test. Vet., i., 8.t).

s In his will made in Sept., 1349, Henry, lord Perey, leaves the archbishop 100 marks, which he owes him, and " unum annulum pontifiealem cum ameraude" ('Test. Ebor., i., 61), and he bequeaths to Sir Ralph Neville "duos bacinos quos dominus archiepiseopus milıi dedit." 
consciousness of its presence and the recollection of the perils from which he had escaped, that induced him, we may believe, to make the last disposition of his worldly substance anil commit himself into the hands of his God. His will is dated at Kipon on the 28th of June, 1319, and seems from internal evidence to have been drawn up in one of those blessed intervals of health which sick persons are occasionally permitted to enjoy. 'There is little in the document to interest my readers, indleed it seems to have been prepared for the special purpose of securing the foundation of a chantry. The testator simply directs his remains to be interred within his cathedral, and leaves the snm of 300 marks for the establishment of a perpetual chantry in York minster, which is to be served by two chaplains who are to do service for his soul, and it is to be dedieated to God, his mother the Blessed Virgin, All Saints, and especially to SS. Mary Magdalene and Martha. 'The remainder' of his estate is left to the disposition of his executors, Ralph lord Neville of Raby, Sir Roger Zouche, knight, his brother, Sir Marmaduke Constable, Sir William de Place and Sir Christopher Mallory, knights, Mr. Gilbert de Welton, William de Ferriby and Roger de Sticullyy, clerks, and Anketil Mallory, esq., the two last being placed in the most responsible position, as nothing is to be done by the executors withont their cognizance. There is an allusion in the will to the archlishop's parents, which shews that they were then alive. ${ }^{t}$

The erection of this chantry, although mentioned in the archlishop's will, was not altogether left to the care of his executors. The founder began the building of it himself. IIe wished it to be contiguous to the south wall of the choir, withont detracting in any way from the beauty of that part of the fabric, and he was desirous, as the best means of carrying this into effect, that the master-mason at the minster should have the management of the work. It is pleasing to observe the affectionate way in which the consent of the chapter of York was sought for' and granted. 'They speak to cach other witl the kind and touching sympatly of old friends, and in those words, few although they are, the melancholy conviction scems to be expressed that their intereourse in this workl woukd ere long be at an end."

The erection of the chapel seems to have been begmm in $1350,{ }^{v}$ and it was the fomnder's intention to have been laid in it, $5-78$.

$t$ Printed at length in Test. Ebor., i.,

" York Fabric Rolls, ed. Surtecs Society, 168-9.

" Nov. 16, 1350, Roberto de Swet- month, rectori alt. S. Laurencii in ecrl. catl. Ebor., 40l. pro diversis expensis eirca constructionem capcllie nostra ibidem. April 25,1351 , a sinilar sum for the same purpose, to John de Acone, 
but before it was completed he was called away to his account. He died at Cawood on the 19th of July, 1352, and on the 8th of Augnot he was interred before the altar of St. Edward, in the nare, hard by the remains of his predecessor archbishop Melton. ${ }^{w}$ When Stubbs wrote his chronicle, no monument had been erected to commemorate him ; "a proof," as the historian sarcastically observes, "of the noble disposition of his parents and of those whom he had benefitted exceedingly." But he needs no memorial of that kind, when you gaze upon that glorions nave with its trimmphs of sculpture and of art, which the prelate, who is now sleeping beneath your feet, once assisted in creating!

The chapel which archbishop Zouche began was probably completed after his death; but its subsequent history is involved in mystery and donbt. Within eight years after his deeease the reluilding of the castern portion of the eathedral commenced; and as the Norman choir was grathally removed, the chapel which was appended to it conld not ocempy the same position. The new choir was wider than its predecessor, and the archbishop's chapel, therefore, must have been taken down. After that time no trace whaterer of the ehantry has oceuried to me. There might possibly be some diffienlty about the rebuilding, and the chapter may have appropriated the endowment to that purpose; perhaps the exccutor's of Zonche's will were as careless of their trust as they were of creeting a memorial over their benefactor's grave, and the endowment was negleeted. The present office of the chapter elerk, which was at one time the vestry of the cathedral, is supposed to be Zouche's chapel; at all events it cammot be fur from the position which that building originally occupied. It the east end there are still traces of an altar and its aceompaniments, but their presence in this place prores but little, as we know that the service was transferred for awhile from the minster to the restry in 1394. The room is now the depository of the records of the dean and chapter, which remind me of the comrteous attention that laid them open to me, and of the many long hours that have been spent upon their pages. The labours of past years, which have filled these volumes, rise

canun in the chapel of the B.V.MI. and the Holy Angels. Nov. 1S, 1351, another sum of $40 l$. to Swetmonth and Acome. On May 10, 1352, the account of the two is passed. They are called "custodes nove fabrice capielle nostra juxta latus australe ecclesice nostrie cathedralis Ibor. noviter inchoate." The account runs from April 23, 1350, to April 28, 1352, and they have speut 25l. 9s. 7d. more than they received.

* Stubbs, col. 1732. Acta Capit. Ebor. His end is thus described in the metrical chronicle of the archbishoys of York in MSS. Cotton, Cleopatra, C, iv. :-

\footnotetext{
"Ilic Willelmus pontifex anno suo nono Quierit a laboribus suis fine bono, Apud villam propriam Cawod vocitatam, Eboracus habuit glebam tumulatam."
} 
vividly before the writer when he aceidentally finds himself on this seene of his exertions,

"And as a have whom hounds and horns pursue,

Pants to the place from whence at first he flew."

On the 2nd of April, 1353, arehbishop Thoresby emporered Mr. William de la Mare and Joln de Wodehouse, eanons of York, Joln de Crakhall, doctor' of decrees, and Adam de 'T'wysilton, commissary general, to encquire into the dilapidations of the houses and woods belonging to the see, and into the dannages done by the exeentors of his predecessor. This strengthens the inference that there was some negleet of duty on the part of those officials.

Tahn de Thorestry was one of those great and good men who were the glory of the fourteenth eentury. That was indeed, in every respeet, an illustrions age. Whilst the ehivalry of England was winning renown in the wars in Franee, every liberal art was being fostered and cherished at home, and John de Thoresby stood in the front rank of that band of worthies who signalized themselves by their taste and learning. It is with a feeling almost akin to reneration that I look back upon his many services to his country, his pious zeal and his open-handed munificence.

We are indebted to a scion of the family of Thoresby, in a later age, for an account of his ancient house of which he was so prond. The name of honest Ralph Thoresby, the Lecds antiquary, would be a eredit to any pedigree in Yorkshire. There is a little lamlet of the name of Thoresby hard by the well-known castle of Middleham in Wensleydale, and there, in all probability, it was that the arehbishop of rork was born. His father, Hugh de Thoresby, was the owner of the plaee, and his mother was Isabel, daughter of Sir Thomas Grose of Suffolk.

x Thoresby's Vicaria Leodiensis, 185, etc., where there is a life of the arch* bishop. Ducatus Leodiensis, ed. Whitaker, 69. Diary, i., 225, 366. 'Thoresby gives an engraving of a figure of the archbishop taken from a window in the minster. He is holding a ehurch in his right hand.

The following persons were, no doubt, related to the arehbishop, but in what degree $I$ cannot say.
Richard de Thoresty, incmubent of Busbrooke, Northants, 1318-9, and rector of Oundle 1352 (Bridges's Nortliants, i., 1S7; ii., to8). May 16,1355, coll. preb. at st. Andrew's altar, Beverley, exclanging for it with 'Thomas do lielwell, his prebend of llatherdon in the chapel at Folverlampiton (lieg. 'Thoresly'). June 25, 1355, collated by the ardihishop to the free chanel of Ferrybridge, which, on July and, ho (i) $\mathrm{G}$ 
Far be it from me to question a genealogy of which a lierald of some note has said, "In my opinion, I never saw any descent so well travelled, nor so truly set dowm." It would ill become me to differ from the deeision of my compater, ${ }^{y}$ and the illustrious authorities by whith he is supported.

John de Thoresby was prohably induced to take up the profession which he adopted, by the good fortune of his umcle Peter, who held several important offices in the bishoprick of

exchanged witl Joln de Honyngton for the stall of sharow at Rinon (ibid.). There is a letter extant from the archbishop in behalf of his comsin, Richard de Thoresby, canon of Beverley, "super travis sibi debitis," in MSS. Cotton, Galba, E, x., 80. On May 12, 1350 , there is an order from the king to Richard de Thoreshy, keeper of the hanaper of the chancery, to pray for him certain monies (Foed., iii., 106).

John de Thoresby, doctor of laws, instituted on Oet. 21, 1353, to the rectory of Lilford (Bridues's Northants, ii., 242), which he resigned in 1373 for the jiromstship of Beverley (MSS. IIarl, 6952, 6). On 1)ec. 7, 1367, he was admitted on the anthority of the lwe to the stall of Grondale at Kork, and on 19th of Decomber, 1369, he exchanged his stall of Oflley at Lichfiekd with Mr. John Turke for the lrebend of Nunwick at Ripon (Regr. Thoreshy). ()11 Anroust 20, 1360, he and others wore appointed to treat with l)avid Brus (Fued, iii., 506). The archbishop, wrote to the bishop of Lincohn asking him to grant a licence of non-residence to his kinsman, John de Thoresby, rector of Lilleford, "ad scolas" (Miss. Cotton, Galba, E, x., 85). He was one of the archbishop's executors ('Fest. Elour., i., 90).

Elias le Thoresty, on Nov. 7, 1361, exchanged the hospital of Bawtry with John de Grantlam for a stall in st. S'pulchre's ehalpel at Fork. On May 26, 1362 , he exehanged his reetory of Forthcoles, dioc. Lincoln, with the same person for the rectory of $S$. Trin., Goodramgate, York. On Fob.9, 1362,3, he exhanged the last-nentioned living lor that of St. Demnis in Wamgnte, which, on July 10, 1367, he exchanged for the rectory of Gamelston, Notts. 'This he again exchanged on Nov. 27 for the rectory of Weston. On Aing. 2,1371 , he was collaterl to a stall in st.
Sepulchre's chapel, York (Reg. Thoresby). On December 16, 1391, Elias de 'Fhoresby, rector of W'eston, makes his will, desiring to be buried in the chureh of Weston. He leaves 7 marks to be given to the poor on the day of lis burial, and 10 marks for the expenses of the funeral and the entertainment for his neighbours, besides the corn and malt ard everything that can be provided at the rectory. To the fabric of the chinrch of York he leaves 20s., and be leaves $40 z$. to three chaplains who are to celebrate for him at Weston. To William Thoreshy he gives 40s. 'To the fabric of the bell-tower of Weston chureh, 20:. To John, rector of Wilford, a silver cup with a cover. 'To the frion of Bridlington, two silver cups. To the prisoners at Lincoln, 40s. IIe appoints as executors, John, rector of Wilford, John, vicar of Wheatley, John Golias, chaplain, and Robert de Thoresby. The will is dated at Stretton, and was proved at Fork on Jan. 14, seq., Thoresby, one of the executors, renomicing (Res. Artmdel).

William de Thoresby, rector of a moiety of the church of Cotgrave, male his will on Friday, the feast of S.s. Vitus and Modestus, 1347. To be buried in the cemetery of the church of 1 ll Saints at Cotgrave. 'Fo Juliana, his sister, 5 marks. To Isold, his sister, 10 marks. 'To Joln, son of Beatrix de Thoresby, 40s. and 10 ewes. To his brother .John, 20s. To his brother Allam, a lowe, etc, at Thoresby. Pr. June 21, 1317 (Reg. Zouche).

In 1344 Joln de Thoresby, a friar preacher, was ordained priest at Newark (Reg. Zouche). On July 20, 1349, John, son of Cecily de Thoresby, was collated, at the presentation of the king, to the livmer of Aldwalby, and died in 1355 (MSS. Harl., 6951, 110 b.)

$y$ Mr. Surtees, in his History of I) 
Durham, in addition to the reetory of Aysgarth in his native vale. ${ }^{z}$ The young Yorkshireman went to Oxford, where he beeame a seholar of repute and a great lawycr." llis learning and his energy soon made for him a pathway through the world. He beeame beneficed in Yorkshire, being instituted whilst he was merely an aecolite, on the 15th of Octobcr, 1320, to the living of Bramwith on the presentation of "Thomas, earl of Laneaster. We know not to what extent the youthful elerk was interested in the fortmes of that ill-fated nobleman, but we soon find him eonnected with arehbishop Melton, and he was made one of the members of that prelate's household who were in elose attendanee upon his person. In 1326 he was receiver of the arehbishop's ehamber and a domestic chaplain, an office which he filled in the autumn of 1328. In 1327 he went in his master's behalf to the court of Rome, and, in 1331, he is deseribed as his attorney, being evidently a person wise in eounsel and learned in the law. ${ }^{b}$ Ile became a great ecclesiastieal adrocate and a proetor to the papal court, an employment to whieh he was indebted for his reputation and his adrancement.

Thoresby soon beeame possessed of high elerical preferment, and arehbishop Melton was not his only patron. A clerer and an aetive lawyer would gain many friends. Between 1325 and 1335 he was incumbent of Honington in Warwicksluire. ${ }^{c}$ On the 17 th of June, 1327, he was admitted by archbishop Melton, on the provision of the pope, to the next racant prebend at Southwell, whieh seems to have been that of Norwell Overhall, which he was holding in 1329. ${ }^{d}$ In Angust, 1335, he resignied his stall in the eliapel of St. Sepulchre at York. ${ }^{e}$ In March 1338-9 he oecurs as arehdeaeon of London. $f$ On the the of January, 1339-40, I find him, as reetor of Elwick in the diocese of Durham, making a grant of a messuage near his church to the priory of Tynemouth, and in the spling of the following year he resigned the mastership of the hospital of St. Edmmid at Gateshead. $g$ On the 22nd of May, 1340, the king appointed

* Rector of Aysgarth, a son of IIugh de Thoresby, and the archbishop's uncle (Ducatus Leodiensis, 69). 'Temporal chancellor of Durham in 1289, and constable of Durham castle (MSs.' Surtees, ined.). Master of Kepier hospital iu 1311 (Reg. Kellawe). Cf. Abbrev. Rot. Origr., i., 38).

a Vicaria Lcodiensis, 189. A dirige was performed for him at Oxford on penult. Feb. (Avesbury, 30z). Bale, cent. vi., 493. Godwin (687) says that Thoresby was a great benefactur of the
University of Cambridge. He must mean Oxford.

$b$ Rerg. Melion.

c Durdale's Warwickshire, n.e., $4: 27$. IIe appropriated this living on Feb. 25, 1350-1, to the priory of Coventry (Thomins's Worcester, 180).

d Reg. Melton. Le Nere, iii., 137. Plac. de Quo Wirr., 618.

r Reg. II elton.

$f$ Le Neve, ii., 320. 1)id he ever enjoy it?

8 Reg. Bury at Durham, $321 b$, (i) $(2$ 
him to the stall of South Muskham at Southwell, ${ }^{h}$ and he is said to lave held that of $\mathrm{W}$ arthill at York in $1343,{ }^{i}$ but I have seen no documentary evilence of the fuct. On the $29 \mathrm{th}$ of September, 134.3 , he was instituted to the rectory of Oundle, Northants, which he held till $134 \%^{j}$ In 1313 lie resigned the living of Sibbeston in the same comnty ${ }^{k}$ He was prebendary of (Thorngate at) Lincoln in July, 135, when the pope wrote to inform him that he had adranced Thomas Lisle to the see of Ely. ${ }^{l}$

'i'horcsby, it will be observed, was indebted to Edward III. for more than one piece of preferment. We know not when he was first introrluced to that monareh's notice, but it is probable that lis abilities as a lawyer were the cause of his rapid advance in honours and position. He seems to have been the king's proctor in the conrt of Rome, and to have won the good opinion of all with whom he was conmeeter by his diplomatic skill and his integrity. On the 7 th of March, 1330, Edward sent a letter by Thoresby to the pope and cardinals, begging for the canonization of his father's foe, Thomas, earl of Lancaster, ${ }^{n}$ who had given the ambassador his first liring. In 1336 'Thoresby's friendly relations with the pope were imperilled by a singular adrenture. A summons to appear before the pope on some question of appeal was served upon him in open court in England ; the papal messengers were at once thrown into prison as guilty of a contempt, and were only set free when queen Philippa interceded in their behalf." "This seems to have done Thoreshy no permanent injury, as on the 16th of Mareh, 1340, he went again to the papal court to procure a dlispensation for a marriage which was to take place between Hugh le Despenser and a daughter of the earl of Salisbury. ${ }^{\circ}$ In the same year he was a trier of the petitions which were presented to the parliament from England and Flanders, ${ }^{p}$ and he is said to have gone as one of the royal enroys to Rome on the question of a peace with France. ${ }^{9}$ On the 21 st of February in the following year he was appointed master of the rolls, and he held that office till the month of July, 1316.r In 1313 and 1345 he had the temporary cliarge of the great seal of England.s In 13\%4 he was

310 b. On March 1, 1310-1, Mr. Walter Fancomberg was presented to the hospital of St. Edmund at Gateshearl, then vacant by the resicnation of Mr. Jolin de Thoreshy, Mr. Gibsen, in his Tymemouth Priory, gives a different date to this grant to that honse (i., 149). $\quad{ }^{h}$ Le Neve, iii., 431.

i Ibir., iii., 220.

j IfSS. Ilarl., 6951, 103 b. Bridges's Northants, ii., 408.

k IISS. Ilarl., ut supra.
? Foed., iii., 55. He was canon of Lincoln in 1347 (Le Neve, ii., 222).

${ }^{m}$ Foed., ii., 782.

" Foss's Judges, iii., 523.

- Foed., ii., 1119.

p Rot. Parl., ii., 112.

$q$ Barnes's Edward III., 207.

r Dugd. Chron., 45. Newcourt, i., 339. Fod., ii., 1151. Le Neve, i., 294.

Cal. Rot. Pat., 146. Fod., ii., 1231 ; iii., 53. Carte's Gascon, etc., 
sent to the pope to tell him how the truee with France had been broken. ${ }^{t}$ In 1345 he was present when John, duke of Brittany,

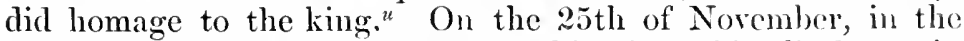
same year, Clement VI. addressed him in a friendly letter in which he besought him to assist with all his energies the two cardinals who were coming to England in the vain hope of preserving the peace between that comtry and France. ${ }^{x}$ In 1315 and 1346 Thoreshy had the charge of the priry seal," and in the latter year he was variously employed. I find that he was one of the collectors of the quindisme, and on the Sth of September he was one of those who were desired to announce the king's wishes to the parliament. On the 2.2nd of October he was made one of the commissioners who were appointed to treat with France at the instance of the pope and cardinals, and Clement wrote to him a letter full of gratiturle for his serviees in the cause of peace. ${ }^{x}$ They had been attended hitherto by little suceess. The erowning victory at Cressy, which had just been won, seattered the pride and the hopes of the chivalry of France, and was a bitter mortification to the chicf pontiff and the conrt of which he was the centre. Ten years after this, after the defeat at Poictiers, which the cardinal of Périgord had done his utmost to arert, some wag wrote the following verses in which he treated with derision the paitizanship of the pope:-

\footnotetext{
"Ore est le pape devenu Franceys

E Jesu derenu Engleys,

Ore serra veou ge fra plus,

Ly pape ou Jestus.",y
}

In 1347 Clement VI. shewed his regard for Thoresby hy appointing him lishop of St. David's. The king gave him the temporalities on the 14th of July, and he was consecrated on the 23rd of September. ${ }^{z}$ There is nothing known of what he did in his Welch bishoprick, but we hear of 'Thoresby in another character and in a more conspienous position. In the year in which he was elevated to the epriscopal bench he was in attendance upon the king at Calais with ninety-nine persons in his retinue, ${ }^{a}$ and he, no doubt, took part in the stiming incidents of that romantie siege. On the 16th of June, 1319), Thorenhy had a still loftier step, for he was raised to the woolsack as lord chanecllor of England. ${ }^{b}$ On the the september in that year

Rolls., i., 114. Kalendars and Inv, of the Exchequer, i., 158, 160.

t Barnes' Edward III., 313. Foss's

Judures, iii., 523 .

u Fœd., iii., 39.

$v$ Ibid., 61.

* Ibid., iii., 53, 86 . $s$ Foed., iii., 89, 92, Rot. Parl., ii. 160 .

y kuyghton, col. 2015.

Le Yere, i., eg). Jomes and Freman's IIistory of it. lavidls, 303.

a Yiraria Leodiensis, 189.

b Le Neve, i., 291. 
a papal bull translated him from St. David's to Worcester, and the temporalities were restored to him on the I0th of January, and the spiritualities on the 11 th. ${ }^{c}$ The duties of his office in the state delayed his enthronization until the 12th of September, 1351," and 'Thoresby's connection with Worcester must have been brief and unsatisfactory. He was destined to fill a higher and a more hononrable position. The Northern primacy was vacant in 1352 by the decease of arehbishop Zouche, and on the 25th of July the king desired the chapter to proceed to the clection of his successor. With one voice they fixed upon Thoresby, and sent Gilbert de Welton to aequaint him with their decision and to urge him to assent to their postulation which had been forwarded to the pope. He gave them his reply from London on the 6th of September, and his letter is coucher in that graceful and flowing Latinity which Thoresby had always at his command. He expresses his extreme surprise at the intimation which he has received, and wonders that the clectors have passed over better men among their own body. Without giving them a decisive reply, he is profuse in his expressions of gratitude and longs for an opportunity to shew his kindly feeling towards his benefactors and their church. At the same time Thoresby seems to have despatched another letter to his patron Clement iI., desiring his advice. He thanks him for his past goodness to him in raising him to two sees in suceession, and, mentioning what has occurred, he refers the matter to the pope's judgment. He will abide altogether by his decision, relying upon that kindness which has so often been shewn to him. "The letter was one with which Clement wonld be pleased, and no one could better appreciate the merits of the writer. The wishes of the chapter of York were accerled to. The pope, however, appointed 'Thoresby of his own right, and not as the person postulated by the electors. Clement wrote from Arigion on the 22nd of October, 1352, $f$ and the temporalities were restored by the king on the 8th of February. 'Thoreshy, it will be remembered, was at this time chancellor of England, and was unable to disengage himself from the official rlaims upon his time. On this plea he made William de la Mare his vicar-general in the diocese of York, on the 20th of Janury, 1352-3. Like many of his predecessors, Thoresby was in want of money at his accession to his new dignity, and

c Ibirl., iii., 57-S.

d Thomas's Worcester, 150. Anglia Sacra, i., 531-5.

- On July 20 the chapter write to the king to say that Zouche died on the $19 t h$, and to a.k for leave to choose his suecesor. I meeting for that purpose was held on August 16 (Acta Capit. Ebor.).

$f$ Printed in the appendix to Thomas's History of Worcester, 116-19. The bull is in Foed., iii., 249. Reg. Thoresby.

g Fœd., iii., 251-2. Le Neve, iii., 107. 
he complained of his necessities to the pope. The clergy, however, assembled in synod on the 8th of May, and granted their diocesan a very liberal subsidy, the seenlars giving him sol. and the religious ligd. in each mark. The new primate was all the while engaged in the South, and from an order which the kiner made on the 1st of April that he should bear his cross erect without being molested, ${ }^{i}$ we ean see that the old quarrel with Canterbury had not yet died ont. A few montlis after this Thoresby turned his face towards the North. On the 8th of September he was solemnly enthroned at York, and the ceremony was witnessed by a great coneonrse. 'The arehbislop then laid upon the high altar as an offering a small gilt crucitix of great value, containing, among other relies, a portion of the true cross. This was returned to him on the loth of October, that he might have the use of it for the remainder of his life, an engagement having been made that it should be restored after his decease under a penalty of $1001 .{ }^{k}$

Thoresby, like a faithful pastor, devoted for the future the greater part of his time to the chuties of lis diocese, and gradually disentangled himself from all state cmployments. It was some time, however, before he conld releasc himself, and even after his resignation of office his services were still occasionally required. Men were loath to lose him, for he was one of the most able and most popular statesmen of the day. He was one of the sponsors of Philippa the infant daughter of Lionel duke of Clarence, ${ }^{l}$ and Edward III., whom he very faithfully served, held him in high estecm. In 1355 Thoresty was one of the wardens of the einque ports, and on the 1st of July, when the king was starting on his French campaign, he was male one of the regents of the kingdon during the absence of the sorercign.". On the 27th of Norember, 1356, the arehbishop resigned the eharge of the great seal, which the king receired with many expressions of affection and regret." On the I6th of Angust, 1357, Thoreshy was one of the commissioncrs appointed to treat with the Seots for the ransom of their king who had been a prisoner since the disister at Neville's cross in 131.6, and the prinate was engaged on several oceasions in after years in the same tedious negotiations. ${ }^{\circ}$ On the a(1) of July, 3359), the

h Reg. Thoresby.

i Foed., iii., 257. This date ought, perlings, to be 1353 .

j Stubb:, col. 17:32.

${ }^{k}$ Fabric Rolls, ed. Surtens suciety, 186-7. The treasury of York poxessed also of Thoresby's gift, "I Tra mitra cum appendicis bene ponderans: (ibid., 213).

'Hardyng's Chron., n.e., 333.
"'Fod., iii., 305. (al. Rot. Pint., 16is.

"Foul., iii., 31t. In this vear Thoresby begins to bold his ordinations at rork limeelf. It is probahle, threefore, that bufore this be was cenerally

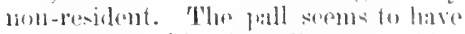
beroll sent to lim from liome (stub), (col. 17:39).

"1hid., 365, 367-8, 37\%, 342, 506, 6.59. liot. secotion, i., sog, sol. 
king, as a compliment to Thoresby, released his tenants in Hexhamshire from the payment of tenths and other state dues in consequence of the good service which their lord had rendered to his king and country. ${ }^{p}$ There is something very touching in the mamer in which Edward speaks of his faithful and affectiomate subject. He mentions his loyalty and goodness, and the prayers which the trusty prelate had offered up in his behalf to One who is mightier than man. He is now on the brink of old age, and is eager for contemplation and repose, and the good wishes and the blessings of his grateful sovereign are with him in his retirement.q

That retirement was merely a new ficld of duty, holier indeed and more peaceful than that which he had deserted. A good man like Thoresby will find work for himself to do, wherever he may be placed. Great and noble as were his services to the state, we find the striking features of his eharacter still more pleasingly and usefully developed in his attention to his diocese. He was truly great in everything that he attempted. He possessed a very practical mind, a thorongh aptitude for business, much cnergy and zeal, and a very kind and considerate heart. These are qualifications which in any age are almost sure to command sucecss. Honest excrtion, aided and set off with habits of personal piety, and modulated by Christian charity, is a noble gift. It was conspicuous in everything that Thoresby did, and gare him an influence orer others of which he could scarcely be unconscions. Whenever money and labour were rechuired for other's, he was always ready to bestow both without any regard to his own ease or comfort, for he was thoroughly unselfish. It is not often that we find a great statesman and scholar surendering lis country for his fiock, and making his intellect subservient to the interests and welfare of his diocese. I shall point out, one by one, the good decds of the archbishop, and shew with what suceess he moderated the great Northern province. I shall first regard him in the light of a peacemaker

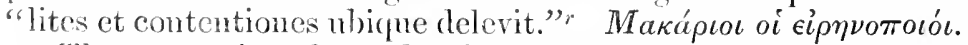

The contention about the right to bear the eross erect had been for several centuries a fertile and a painful source of controversy hetween the Northern and the Southern primates. This Thoieshy very happily brought to an end. On the 20th of A pril, 1352, a meeting took place, at the intervention of the king, in the palace of Westminster, between arehbishops'Thoresby

" Foerl., iii., 136. On June 8, 1355, the arelibistog was commissionerl to arriy Hexhamshire (Rot. Seot., i., 777).

" inere is a letter extant from Thoptshy th the king's secrotary, in which be asks him to present for him to the king "chariotam cum attilio et sex equis de melioriluns quos habemus, et duobus valectis et duobus gareionibis:" he sent them by $R$ (ichard) de R(avener) (Rer. Nerille, part ii., 20). r stubis, col. 1733 . 
and Islip, and the following arrangement was effected. Each primate was to be allowed to carry his cross erect in the provinee of the other, but, as an acknowledgement for this concession, Thoreshy, within the space of two montlis, and each of his successors within the same period after his election, was to send a knight or a doctor of laws to offer in his name at the shrine of St. Thomas of Canterbury an image of gold of the value of $40 /$, in the fashion of an arehbishop holding a cross or some other jewcl. At parliaments and councils the Southern primate, as the tenant of the most aneient and dignified see, was to sit on the right hand of the sovereign on the higher seat with his cross erect, the arehbishop of York being on the left. 'The bearers of that insigne, when they met in the open street, were to walk abreast, but in a gateway or a narrow passage the eross of Canterbury was to have the preeedence. ${ }^{s}$ The pope, also, had his share in the arrangement, and, as Fuller says, "to end old dirisions, made a new distinetion, primate of all England and primate of England, giving the former to Canterbury, the latter to York. Thus, when two children ery for the same apple, the indulgent father divides it betwixt them, yet so, that he giveth the bigger and better part to the ehilde that is his daring." It seems rather to me, pace Master Thomas Fuller, to be a distinction without a difference. The papal confirmation was marle in 1354," and the king, who must liave been delighted at the result, shewed in the same year how highly he was gratified by Thoresby's aequiescenee. There is an order for the payment of 7l. 8s. 5d. to Richard de Grymeshy, goldsmith, for certain images made in honour of St. Thomas of Canterbury, and delivered to John archbishop of York, of the king's gift, for his oblation at Canterbury. ${ }^{p}$

The good offices of arehbishop Thoresby were also employed in effecting a reconciliation between the mayor and citizens of York and the abbat and monks of St. Mary's abbey. 'There had been many disputes between them on the question of boundaries. As early as 1262 there was an athay in which some of the servants of the abbey were killed, and in 1315 and 131 ; there was an active and violent renewal of the quarrel. It broke out again soon after Thoresby became archbishof, and a suit was begun in the king's comrts. 'Tlie primate was fortunate enough to allay it, and an agreement was dram up to prevent any recurrence of the disturbances."

- Reg. Laur. Booth, 77 a. Printed in the Anglia Sacra, i., 13, 75. The year 1353 is also given as the date of: this artangement. Stubbs, col. 1732. Wilkins, iii., 31,51 . t Chureli IIistory, hook iii., 39.

"On Feb. 22 (Ninclia Sacra, i., 77).

" Pell Recordis, 161.

w Stubhe, (on]. 1733. Drake's Eboracum, 581, 597. 
I shall now gather some flowers from the archbishop's official acts.

135.2. An order to the official at Worcester to solicit the prayers of the faithful in behalf of Henry duke of Lancaster, who is to be at Paris on the 4th of December to prove his innocence and the justice of his canse in a single combat with the duke of Brunswick. ${ }^{x}$

1353, April 11. A licence of non-residence for three years to Stephen Manlyon, $y^{y}$ rector of Sandal, in the suite of the queen. May 4. Licence to Sir John Meaux, knight, to have the bones of Codfrey Meanx his great-grandfather, John Meanx his grandfather, Codfrer Meaux his father, and Scolastica and Joan his sister's removed from the church of Aldbrongh to the priory of IIantemprise in consequence of the encroachments of the sea: they are to be buried in a place, in which, as we understand, Sir John himself intends to be interred. $\tilde{~ A n g u s t ~ 16 . ~ S e n t e n c e ~}$ of excommnnication at the instance of John de Clone, ${ }^{a}$ our domestic chaplain, custos of the free chapel at Ferrybridge, against those who have plundered the said chapel of its books and ornaments. Sept. 12. A commission to Gilbert, bishop of Carlisle, ${ }^{b}$ to bless chalices, ete. Oct. 21. A commission to William, bishop of Sodor, to confer orders, etc.

Lancaster eharcel the duke with havins arrested him whilst he was at Cologne on his way to Palestine, and challenged him to mortal combat. Cf. Kuyghton, col. 2603. Barmes's Fatw. II [., 145-7. Froisiart. Wilkins, iii., 27,52

y A Fleming, rector of Sandal and canon of Wetwang. [11 $134: 3$ he was archleacon of Winchester (Le Neve, iii., 25). In 1337 he was dean S. Gancherii, and, afterwards, in 136\%, of Cambray (tallia Cluristiana, iii., 71).

z A valuable entry in more respects than one. It combletely overthrows the pedigree of the family of Meanx which is given in Ponlson's Ifolderness. It also shews us the date of the present clnureh of Aldborough, as Sir John Weanx, to whom the present licence was granted, was buried in it and not at lautemprise, in 1:37\%. A rich altar tomb, which bears his effixy, commemorates him, and the chureh in which it stands is at the distance of a mile from the still encroaching sea. Alilbro' church, therefore, was built between 1353 and 1377. Sir John de Heaux in his will ('l'est. Ebor., i., 100) desires to be buried in the aisle of B.H.V. in the churel of St. Bartholomew at Ald. broush, and orders his corpse to be dresied for the grave in the garb of a Friar Minor, he having become a brother of that order.

a Claplain and executor of archbishou, 'Thoresby. On July 5, 1371, he was instituted to the rectory of Kirkby Ravenswath, exchanging for it his living of Birkin with John de Middleton (MSS. ILarl., 6978), 4b). On Feb. 5, 1379-80, he exchanged Ravenswath with Robert de Wycliffe for the rectory of st. Crux in York (Reg. Hatfield at Durham, $169 b$ ), and on the 26 th of the same month he was instituted to the stall of West Witton at Auckland, a part of the above-mentioned exchange (ibicl., 170 b). On April 30 he was admittel to a prebend in St. Sepulchre's chapel at York (Reg. Neville). A John de Clone was the king's attorney 1339 , 1310 (1)mgd. Chron., 43).

${ }^{b}$ Gilbert de Welton exchanges in 1313 his rectory of Wistow, dioe. Lincoln, with Thomas de Ripplingham for the stall of Eton at Sonthwell and the rectory of Claworth. In 1317 he was made camon of Osbaldwick at York, and in 1318 he gave up Claworth to he 
1354, Jan. 25. An indulgenee of 40 days in behalf of the monastery of Helagh park, which is in greait decay.c May 1 (f. Licence for Alan de Corbrigg, reetor of St. Peter the Little, York, to be absent for two years from his benefice, to visit the sepulchre of our Lord and the limina of S.S. Peter, Panl, and James.

1355, Feb. 7. A bull of pope Imnocent VI. granting an indulgence of a year and forty days in behalf of the monastery of St. Angustine, Canterbury, and another, ordaining that the feast of St. Angustine be observed as a double festival throngh the whole of England. ${ }^{d}$

1356, Mareh 19. Lieence of non-residenee to Thomas de Langetoft, rector of St. Helen's in Stonegate, at the request of the prinee of Wales in whose suit he is. August 11. An order to pray for the prince of Wales and Henry duke of Lancaster.e August 28. Commission of enquiry to Mr. John de Craksall, doctor of decrees and canon of Ripon. Hugh Knyght, pricst, informs us that he was attacked at Wath by eertain armed laymen, and that he killed one of them in self-defence.

1357, Jan 11. Licence to Sir Ifenry le Serop, ${ }^{f}$ knight, to have scrvice in an oratory in his manors, and a commission to consecrate the area, ete., for the conventual elumeh, ete., of the Carmelites at Northallerton. Feb. 18. Indenture between the archbishop and Lanrence de Florence about the making of sterlings in the palace at York. ${ }^{g}$ Dec. 20. Dispensation for Mr. William de Carleton, canon of St. Sepulchre's chapel, York, to

the chantry priest in the archbishop's manor of lipon. In 1319 he obtained the prebend of North Leverton at Southwell, and was appointed an executor in archbishop Zouche's will. He was bishop of Carlisle from 1353 to 1363. Cf. Reg. Zonche. MSS. IIarl., 6951, 103b. Test. Ebor., i., 56. Foed., iii., 116. Le Nere, iii., 236. Nicolson and Burn's Cumberland and Westmerland, ii., 266, ete.

On Feb. 28, 1353-1, bishop Welton was empowered to celebrate orders, and, on the 28th, to consecrate the olemm and chrisma.

On Jan. 17, 1358, the king gave leave to Miehael, bishop of Whitherne, suffragan of the archbishop of York, to come to England on business reliting to his chureh and himself (Foed., iii. 387 ). In the same year a strange prelate, Thomas, bishop of Chrysopolis, was attacked at Kexby, near York. IIe charged the bishop of Durham with the assault, but he was aequitted (ibid., 389 ). c A monastery at a short distance from York, of which some remains are still in existence. It seems to have been rebuilt abont this time.

${ }^{d}$ Cf. Chron. W. Thorn, col. 2120. Labbe, Cone., xi., 1930. Wilkins, iii., 33.

e The year of the battle of Poictier:s. Thoresby was desired by the king to order thanks sivings thronghont his diocese for the victory (Barnes's biw. III., 517). In IISs. 13odl., C, iv., 2080, are letters from him reeiting the order of the king for the thanksoriving (Sinith's Catalogise).

$f$ First lord Scrope of Masham amel father of lichard scrope, archbishop of York. IIe died in 1391, set. 76 (Scrone and (irosvenot Rolt, i., 134).

g On May 2, 1353, the king allowed Thoresby "duos enneos monetales" at York (Foed., iii., 258). On July 18 there is a valuable order from the king about the Tork mint (ibid., 261. Dikries's York Mint, 33-1). 
be absent from canonical hours on account of illness, still reeeiving his distributions as a residentiary.

1358, Feb. 21. Absolution of William de Roston and Joln his son. They were going through the fields at Esterton to their work when John Pie, ehaplain, lept upon them, being armed. William Roston ran away, but a great dog belonging to Pie pursued and eaught him, and his master gave him a gricrons blow on the arm with a weapon ealled a gisham. Upon this, the wounded man, to save his life, struek Pie on the head cum blado, and his son wounded him with an arrow. Sept. 6 . A mandate to pray for the soul of Isabella the queen-mother. ${ }^{h}$ Sept. 17. Permission to Sir Robert de Hilton, knight, to remove the bodies of Matilda and Margery his daughters, who have becu dead for some time, from the lower part of the poreh or aisle of the Holy Trinity in the ehurch of Swyne to a higher place in the same porel, where the said Sir Robert intends to be interred with others of his kin. ${ }^{i}$

1359, July 3. A commission to Geoffrey arehbishop of Damaseus $\mathrm{s}^{j}$ to aet as suffiagan. Oet. 20. To William de Burton, citizen and merchant of York, 8\%. 6s. 8d. for a long woollen eloth bonght of him for our use.

1360, Jan. 15. To our kinsman, Robert de Thoresby, $10 l$. for different works in our manor of Thorp. Sept. 14. To William de Hormgham, goldsmith of York, 10l. in part payment of the price of a silver dish which we bought of him to lay alms in at our table. Nor. 3. To Richard de Leven, eitizen and tamner of York, 20 marks in part payment for furs for our livery. ${ }^{k}$

1361, June 9. Mandate to the prioress and eonvent of Molseby to re-admit to their honse Elizabeth de Neville some time an apostate. July 12. An order to pray for the removal of

$h$ She diert at Risings, near London, on 22nd of August, 1358, and was buried at the Grey Friars (Barnes's Edward 111., 550-1). From April 30 to May 14, 1358, she was residing in London at the house of the arehbishop (Archarologia, xxxv., 453). Murimuth, 191. Coll. 'Top' and Geneal., v., 278.

i Extensive alteration were being made in this curions old church. In January, 1361-2, there is a monition to the parishioners of Swine to contribute to the new work of the nave and tower of their church (Reg. Thoresby). The monmments of the Hiltons are a conspicuous feature in the Trinity aisle.

On April 21, 1317, a chantry was founded in the church of Wr thestede by Sir liobert de llilton, for the souts of himself, Nargaret his wife, his an- cestors, and Sir Ralph de Grerstock (Reg. Helton). Curiously enough, the manor of Swine afterwards came into the possession of the Meltons with the heiress of Hilton (Poulson's Holderness, ii., 19S).

${ }^{j}$ On Angust 10, 1359, Thomas, bishop, of Norwich, was authorized to confirm for the archbishop. He was a Percy, and was, therefore, connected with the North. Some suffragans of the archbishop will be mentioned afterwards.

${ }^{k}$ June 10, 1361, 20l. more to him for our livery against Christmas. Oct. 3 , to Richard de Wateby, citizen of Jork, 40l. to provide our liverey, and, on Feb. 4, 33l. 6s. 10d. to him for the same purpose. 1362, April 18, to livehard Wardrober, $10 l$. for our liverey. 
wars, pestilences, and other troubles of the lingdom.' July 21 . To the Friars Minors and Augustinians of York 5 marks each for their general chapter to be celebrated at York. Oct. 1. 'To Elias de 'Thoresby, receiver of our chamber, 1000/. for the expenses of our hospice. Oet. 3. To Mr. Walter de Skirlawe, ${ }^{n}$ our beloved clerk, 21l. 15s., for our expenses in the court of Rome.

1362, Feb. 1. Licence to the inhabitants of Staynburn, par. Kirkby Overblows, to have scrvice in the cemetery of their ehapel there during the eontimuance of the pestilence." ${ }^{n}$ Feb. 26. Commission to absolve Sir Adam de Everingham, knight, who las been excommunicated for laying violent hands on Richard de Halghton, rector of a moiety of the eluureh of Derfeld. May 6. To Johm Boys, 5\%7. 16s. 9d. for 567 shcep bought at Ripon.

1363, April 18. An order to pray for the prince of Wales and his army, they being detained by eontrary winds. July 20. An order to pray for fine weather on accomt of the harvest. Oct. 2. William Strother, canon of Kirkham, is absolved from the sentence of greater excommmication for giving the encharist to Robert Corbet, chaplain, without the leave of his eurate. The relaxation is to last till Nichachmas, 1364, on condition that he goes to Rome for absolution. ${ }^{p}$

1364, Jume 29. To Robert de Thoresby, our esquire, 100s. for the building of a new chamber in our manor of 'Thorp. ${ }^{\text {? }}$ An

$l$ There was a great pestilence this year which carried off three bishops and Henry, duke of Lancaster (Murimuth, 195). In Hardyng's Chron., 330 , it is said, -

"In that same yere was on Sainct Maury's, day,

The greate winde and earthquake mervelous,

That greately gav the people all attray,

So dredfull was it then and perelous,

Specially the wind was so hoistous

The stone walles, steples, houses and trees,

Were blow downe in diverse ferre countrees."

" The great and good bisliop of Durham. He was a Yorkshireman by birth, and was a great benefactor to his native county. IIe gave largely to the choir and central tower of York minster, and a chantry was foumded for him at the altar of St. Cuthbert. He was one of the greatest builders of his day, and was a man of prince-like munificence. My collections for his life are far too numerous cren to abbreviate here. I saw him about fifteen years ago at Durliam, when his tonib was disturbed, swathed in lead, through which the ontline of his erozier could easily be traced. Ile row lies in the north aisle of the choir, between the organ and the wall, before the stonc seat which he erected for the aged men who were to sit thereon and ofler "11' their prayers for his soul. A gorgeons brass, filteen feet iu lengtl, once corered his remains. The matrix is now laid before the altar-steps, and is erroneously ascribed to bishop Beammont.

" Valsingham (179) says of this year, " Moriebantur plures morbo litargia, multa infortumia prophetantes: mulieres insuper decessere per fluxum, et erat communis pestis bestiarmm." Great winds also previled.

- 28th Edward I. Prob. act. Ada de Gveriugham til. et laxer. Roberti do Everingham (Abbrev. Plac., $21: 2$ ).

\section{$p$ "To wash this blood from off my guilty hat11."}

9 1361-5, 10/. nuore for it on Fib. 13. (On Mireh 22, 10l. more. ()n May 2, 10/. more. On June 10, 100s., and $100 \mathrm{~s}$. on July 15. 
indulgence of 40 days to those who relieve two brethren of Armenia whose monastery has been destroyed by the Saracens. 1365, March 14. Lease of the archbishop's mint, for two vears, to Andrew de Florencia, at a rent of 20 marks per aninum. April 27. Absolution of Johm de Gaytford, Gervase de Pecco, etc., for cutting off the head of John de Wynteworth, chaplain, till they can go to Rome for absolution. July 2. Excommunication of those who have broken into the monastery at Pontefract and carried away piate, jewels, and a pix before the altar of St. Leouard. August 5. Licence of non-residence for two ycars to William Wyclyf, rector of Wyclyf, to enable him to study. Sept. 9. An order to the parishioners of Worksop to

- In interesting extract. In 1361 a William de Wycliffe was one of the fellows of Balliol whilst John de Wycliffe, the reformer, was master of that college (Faseic. Zizan., prefat., xi). This licence of non-residence was, in all prolability, to allow him to return to Oxford. He is probably identical with William de Wycliffe, who was insti. tuted on the Tth of August, 1363, on the presentation of John de Wyeliffe, to the rectory of Wyeliffe in Torkshire (MSS. Harl., 6978, 1, 2, extracts from a resister of the archdeacons of Richmond which is now lost), and with Mr. William de $\mathrm{W}^{\mathrm{r}} \mathrm{y}$ clitfe, rector of $\mathrm{Wy}_{\mathrm{y}}$ cliffe, who was ordained accolite at York on the Saturday after St. Matthew's day, 1363 (Rerg. Thoresby). After this we hear nothing of him.

In 1368 another William de Wycliffe was ordained accolite, sub-deacon, deacon, and priest at York, Easby abbey griving him a title (Reg. 'Thoresby).

We now come to two greater personaces, who accompanyeach other through life, as they began it, in the most perlexing propinquity. One of them is the celebrated reformer.

On Saturday before St. Mark's day, 1350 , John de Whytecliff was made an accolite in the honse of the Friars Minors at York, and Joln de Wycliffe an accolite at the Friars Preachers in the same city on the Saturday after St. Lucy's day in the same year. In 1350-1, also, Joln, son of Villiam de Wykliti, and John, son of Symon de Wycliff (the names of the fathers being fortunately given to distinguish the two), were ordained sub-deacons at the Friars Preachers, deacons at Pentecost, 1351, in St. Mary's abbey, and priests in York minster on the Saturday after St. Matthew's day, 1351, the officiating prelate being Hugh, archbishop of Damascus (Reg. Zonche). This information is entirely new.

Mr. Shirley has spoken about these two jersons in a note to the Fascie. Zizan. I agree with him that an argumeut ean be drawn with diffieulty from the spelling of an old name. It is still remarkable that one of the two John Wycliffes, $i . e$., the prebendary of Chichester, was ealled John Whytcliff in his will and before it. One of the aecolites at York is also "Whytecliff," but only in that instance; and as Wyklif is much more akin in sound to Whyteliff than Wycliff (the name of the village is always pronounced hard), the presumption is that in John, son of Symon de Wycliff, we have the master of Balliol and the reformer. I do not, lowever, set much value upon this inference.

It may, I think, be safely assumed that the reformer is one of these two. Both of them had their title from Eggleston abbey, which is within three miles of the little village of $\mathbf{W}$ ycliffe. They were both, therefore, Yorkshiremen. The genealogy of the Wyeliffes at this early period is beset with difficulties, and I shall not now weary my readers with a long piece of genealogical criticism. The little church of Wycliffe, with the sparkling 'Tees rushing by it, will well repay a visit. It contains some interesting sepulehral memorials of the family, including one to an only son, the last hope of that ancient house, which was ereeted by lis father, who reared it, as he observes witl much feeling, " non sine summo 
desist from wrestling, archery, indecent dances and singing, in their churchyard.s

1366, Jan. 16. 'To John de Bererley, tailor', for a long cloth, “de tanneto," 11l.4s. April 20. Scritence against those who have laid violent hands on the dean of Pontefract, and killerl Jolm de Whitthened, his servant. July 7 . To Joln de II chwill, ${ }^{t}$ camon residentiary of York, two oaks in our wood of Langwath, and their faggots, our accustomed gift at this time. Oct. 9. A commission to absolve Adam de Wordelworth, chaplain, for killing Jolm de Staynton, at Berneslay, in self defence. Nor. 17. An order to pray for the prince, who is going abroad to help the ling of Spain.

1367, April 13. Licence of non-resiclence for two years to John de Ledcombe, rector of Castleford, to be in the king's service, and, on May 5, a similar lieence to Elias Brithewell, rector of Bramwith, in the service of John, duke of Lancaster. Dec. 6. An order stopping markets being held on Sundays in the porch and churchyard of Whitgift, and prohibiting catings and drinkings there.

1368, Oct. 26. An order to pray for the removal of the pestilence.

1369, March 3. John, son of W'illiam Chapman, of Great Drifficld, aged 8, was giving hay on the feast of St. Edmund the king, 1363, to a certain horse belonging to William lchon, of Cranncewyk. The horse being mbroken, bit off the greater part of the boy's right ear. A certificate to that effcet. Hay 8.

rerum humanarum fastidio." As Waller says of the only son of lord Andover,-

"Tis not a single corpse alone does lie

Under this stone, but a whole family;

Il is parents' pious care, their name, their joy,

And all their hope, lies buried with this boy."

My father was born within a mile of the village of $\mathbf{W y e l i f f e}$, and I have often heard him say that at the begiming of the present century the dialeet of the neighbourhood was so identical with the language of the reformer's version of the New Testament that he wonld undertake to read any chapter of it to an old person, and it wonld be nulerstood thoroughly, with the exeeption perhaps of a word or two.

- A practice which liad arrested the attention of Giraldus Cambrensis in the twelfth eentury. He speaks, in terms of reprobation, arainst the saltationes and eantilena then prevalent in churches (Gemma Ecolesiastiea, 119). t Canon residentiary of Tork and prebendary of barnby from 1319 to 1387. He was also rector of Misterton and Rowley. 13y his will, dated on the 3rd of Mareh, 1386-7, he desired to be interred in York minster, and gave the sim of 100 s. to the fabric.

"The famons expedition into Spain in behalf of king l'edro,

"For whiche the prince with all his hole power liode into spain to heIpe hym to conquer."

The great battle of Najara and the exploits of sir John Chandos and his illustrious leader are matters of listory. 'There is a long aceount of the fisht in "l'he lilack P'rince," edited for the Roxburghe Club, 250, etc. 'Jlue layer of the rietor is a striking one:-

\footnotetext{
"Que je ne sui pas ey venuz Fors pur droit estre sustenuz Et proesce et pur franchise Q qu num coer semonte et atlise be confuestre vie de lonamr Je vous supplie qen cesti jonr" Voillez garder moy et mat gent."
} 
An order to pray for the king, queen, and prince, and for the remoral of the pestilence. ${ }^{x}$ May 20 . To Mr. J. de Waltham, ${ }^{w}$ for his expenses in going to London, to the parliament to be held at T'estminster on the octares of the fostival of the Trinity. June 5. An order to repair the nave of St. Peter the Little, lork. July 7 . To Mr. Robert de Patrington, master-mason, 1.t marks for repairing the windows in the chapel of our manor at Cawood, and to Henry de Miryman as much as is due to him for the eustody of our manor of 'Thorp.

13\%0, May 31 . A commission to receive the row of chastity of Beatrix wife of Andrew Gow $r^{x} .^{x}$

13\%2, Feb. 18. Licence to Nicholas de Swanland, rector of St. Cuthbert's, York, to pull down some houses at the east end of his church, built at his own cost, and to use the materials in enlarging and repairing the choir. Nor. 9. Licence to Isabel de Fancomberge, widow of Walter de Faucomberge, knight, to remore his body from before the image of the Holy Cross in the church of Gisburgh to that part of the church in which his ancestors are interred. ${ }^{y}$

1373, Nov. 5. A grant of the wardship and marriage of John son and heir of John de Langton of York to William Gray, citizen of York, and Robert de Wyclif, $z$ rector of St. Crux, lork.

" There was a great pestilence, and the corn was much injured by floods (Walsingham, 181).

* A fierson who had many preferments in the clutureh. Canon of Lichfiekl, York, Southwell, and Bromyard, sacrist of St. Sepulchre's, York, official of the cont of York, master of the hospitals at Bawtry and Beck, Norfulk, canon of Lanchester, incumbent of If ummanby, Cortenale, Saxby, SteepleLangforl, Towcester, and Heversham (Reg. Thoresby. Nichols's Leicestershire, ii., 312. Blomefield's Norfolk, viii., 190. USS. Harl, 6952, 4, 10; ilid., 6978. Le Nere, i., 603. Misc. Hoc., penes dec. and cap. Dimelm., 4196). He was an executor of archbishop, Thoresby in 1373 ('T'est. Ebor., i., 90), and was his kinsman (MSS. Cotton, Galba, E, x., 85).

He was probably the uncle of John de Waitham, archdeacon of Richmond and bishop of Salishurs, one of the fuvourites of Richard II., "who harde pleased the king so greatly that (though many murmured at it) he commanded him to bee buryed at Westminster among the kings." His brazen efligy is still gleaming over his resting-place on that sacred platform.

${ }_{x}$ A name to which the poet Gower has given a great interest. Would that his origin conld be safely traced to the county of York! On Dec. 17, 1342, archbishop Miclton allowed Alice, widow of John Gower, of Cold Ingleby, to have an oratory for three years in her manor there (Reg. Melton). The question of the origin of the poet has been disensised by Sir Harris Nicholas in the Retrospective Review, second series, ii., 111, and by Dr. Reinhold Pauli in his introduction to the Confessio Amantis. Their researches prove that the poet lived in the South, and had estates in Suffolk, but nothing more. ITe might still have been a native of Torkshire, as Leland says he was. One of the persons mentioned in the transfer of the Suffolk estates, Guy de Rocliffe, who was also interested in then, was a Yorkshireman, and it must not be forgotten that Gower had a lease of the manor of Southwell, co. Notts.

$y$ some notices of this family have already occurred.

${ }_{x}$ 'The Langtons and the Grays were 
The following horrible crime was eommitted at Beverley in November, 1372. A shoemaker of the name of Willian de Watton, who had been for some time deranged, eame into the chureh of St. Mary in that town. The poor ereature observerl a priest of the nanie of Peter de Aldegat, and went up to him, as if to make his confession, with his hands folded after the guise of a penitent. "Woe is me that ever I was born," he said : "by God's heart I will go and drown myself." "Far be this from thee," said the priest, "for then thou wouldst be lost both in body and soul." The lumatic then eried out, as if some surden idca had flashed across his mind, "He wanted to kill me unless I would be friends with Adam de Coppandale. 1 will kill myself." Aldgate replied, "Away with the thought. Hope in God and pray here, and I will soon make Adam de Coppandale and all his people thy friends." He then went away, and told the master and the kinsmen of the madman to come and take him away, saying that he was insane. On his return, Watton, who no douljt had

two wealthy and distinguished families in York.

Of Robert de Wyeliffe, who was very probably a near relation of the reformer, perhaps a nephew, some account may appropriately be given. He was a man of wealth and influence. On the 2nd of Ausnst, 1362, he was instituted to the rectory of Wyelife on the presentation of Katherine, widow of Roger Wycliffe. He held it only for a year (MISS. Harl., 6978, 1 a). In 1368 he was ordained sub-deacon at York, being rector of St. Crux in that eity (Reg. Thoresby). On May 14, 1375 , he was collated to a prebend at Auckland (West Witton), vacant by the death of David, son of Sir Thomas de Ingilby, knight (Reg. Hatfield, 79a). On Feb. 5, 1379-80, he exchanged the rectory of St. Crux, York, for that of Kirkby Ravenswath with Joln de Clune, and on the 26th of February Clmne was inducted into Wyclitre's stall at Anckland, which was jart of the exchange (ibid., 169, 170). From 1377 to 1423 he was rector of Rullyy, having been aplointed by Phili], lord Darcy (Graves's ('levelanil, 165), and on Jan. 17, 1382.3, he was instituted, at the king's presentation, to the rectory of Romaldkirk, which he lield till he died (MSS. Harl., 6978, $10 \mathrm{~b}$ ), having obtained it in the way of exchange with Richard de Mildleham for the living of Ravenswath.

He was closely connected with bishop
Skirlangh. From 1399 to 1402 he was constable of Durham castle. On Feb. $3,1390-1$, he occurs as temporal chancellor of Durlam, and he continired so till Skiplangh's death. He was also his receiver-general (MSS. Surtees, and Hutchinson's Durlam, i., 324), and one of his executors (Test. Ebor., i., 311). Wyclitie dierl at Kejier lospital, near Durhiam, of which he was master, in 1123 (Surtees's Durham, iv., 65).

Wyelifie was connected as execuitor or trustee with several sreat personages. He was an exentor of Mlargery, wirlow of Sir Irilliam de Aldeburgh, in 1391 ('Test. Ebor., i., 152), of Plilip, lord I arcy, in 1399 (ibid., 255), and of Sir John Depreden, in 1102 (ibid., 299). IIis own will and sehedule of bernests, full of interesting and valuable watter, are in Durham Wills, i., 66, and 'l'est. Ebor., i., 40:3.

From notices of the Wydilles which have been given befure it will be seen that they were a great clerical family. I can searcely idcutify the following person with the ecclesiastic of whom i late been speaking. On March 28 , 133s, liobert de If yeliff was ordained priest in the priory of Durham ly

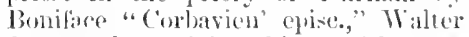
de stapelton rriting lim a title of 5 matks (Reg. Bury, \$nz a). On the vigil of the feast of the 'Trinity, 1:36is, Nicholas, son of Joln de "ir verliti, was ordained priest at lork (liers. 'Thoresby). 
suspected his errand, stabbed him in the breast with his knife, and the priest died of the wound. The bailiffs, who were in the church hearing mass, at once seized the murderer, but his victim adjured them by Christ's body to do him no harm as he did not know what he was doing, and he forgave him before God. The prisoner was shut up in the honse of Thomas de Waghen and went raging about during the night with a drawn knife, saying that he heard and saw his enemies devising his death. It was discovered that on one occasion he had cut off his mother's hair. She submitted in fear and trembling to the operation, and the maniac afterwards thanked God that he had not choked her. This is a fearful pieture. It is dreadful to think of the times when there were no reecptacles for lunatics; who were permitted to wander abont at their will among their friends and kinsmen.

It will be seen from the extracts which have just been given, that several violent assaults ryon ecclesiasties are mentioned. They are a very fair criterion of the spirit of the times. Those are indeed evil days when the garb of a elergyman cannot protect him from insult and wrong. But, as a general rule, when such is the case, the fault is to a great extent to be ascribed to the chureh itself. The cords of discipline have becn slackened till it becomes perilons to draw them tighter. An evil example has been set by those who profess to teach, ${ }^{a}$ and, as Dryden tells us,

"If they be foul on whom the people trust, Well may the baser brass contract a rust."

The trumpet has been giving an uncertain sound. And so it was in the middle of the fourtcenth century. There was, in many respects, a great decline in morals and in devotion. We find laymen and elerks killing and wounding one another, churches descerated, the privileges of sanctuary abused, and all the grades of society distorted and confused. ${ }^{b}$ The church scems to have been powerless to correct or regenerate. Internal weakness and eorruption made her voice very weak, if it could be heard at all. It is a very grand sight to see a man like Thoresby push himself boldly forward in such a crisis into the fore-front of the battle, with the skill to originate, the energy to earry ont his plans, and the honesty to scourge offenders whether

a Gower is not complimentary when he is speaking of the pastors of his day in the prologue to his Confessio Amantis. After many severe words he says,-

"Lo, thus to-broke is Criste's folde Wherof the floek withoute guide Devoured is on every sides
In lacke of hem, that ben unware Sheplerdes, which here wit heware Upon the worlde in other halve. The sharpe pricke instede of salve They usen now, wherof the hele They hurte of that they shulden hele. And what sheep, that is full of wulle Upon his baeke, they toose and pulle."

$b$ For an account of several cases of sacrilege, see Knyghton, col. 2628 . 
they were friends or foes. The archbishop of Canterluny made bitter complaints to him about the wretehed state of the ehureh of England; how the high and mighty gave her no support, and how her influence had departed. ${ }^{c}$ Thoresby spoke to his brother primate some strong and earnest words of comfort, and prepared himsclf for the battle. His cagle eye saw at once that this was the time for action, and his zeal for God's cause induced him to withdraw himself from the clash of party warfare in which he had honourably achieved so many brilliant successes, that he might strive to win a bolder victory, the reformation of the church. There is nothing to prove the assertion which has been made, that he was dissatisfied with his ereed; he merely culleavoured to purify and not to overthrow what was before him ; and yet there are many points in his charaeter that remind us of Wyeliffe, and it would be curious to know if there were any connection between the primate and his compatriot. Both were natives of the North Riding of Yorkshire, and it is possible enough that they were kinsmen. Both were animated, in matters of discipline at least, by the same earnest and fearless spirit, but Wyeliffe stepped out of his way to do what Thoresby attempted to effect through the ordinary paths which the church snggested to him. It was indeed a time for energetic action, and Thoresby knew it. 'The country around him had been desolated by the plague and the wars, and the spirit of irreligion had erept in and estahlished itself too securely. The people were in a state of gross ignorance, and many of the clergy, if they were disposed to work at all, were not fit to teach. Some were wandering away from their parishes in the trains of knights and nobles, or haunting, in quest of secular preferment, the purlieus of the court. Many livings were held at the same time by one man, whilst others, through the system of papal provisions, were possessed by foreigners. ${ }^{d}$ A ficree fight was raging on this point betwech the king and pope, in which the ecclesiastical sorercign and his party were ultimately worsted. At the close of the reign of Edward III. the power of the cardinals in this comntry cance to an end.e It had been dominant for many years in the church

c Reg. Al. Neville, part ii. Among Thoresby's letters.

d'The poet Occleve gives strong evidence (De Resimine P'rincipum, ed. Roxburghe Club, 1860 ; p. 51):-

"A dayes now, my sone, as men may see,

$O$ chirche to o man may nat suflise;

But algate he mote have plinmlitce,

Elles he han not lyve in no wise.

Ententyfly he kepethe bis servise

In court, ther his labour shall wot moule,

But to his cure loketh he full foule.
"Thonghe that his chauncolle roof be alle to turnes,

Anl ou the liye antere ruye or smewe.

Ile rokketlue init, the cost may he furbune

('ristes house to reparia or make newe;

And thoughe ther be fulle many a vicious hewe

Indir lis cure, ho taketle of it mo kejm:

1le rekkethe never how rusty ben his shepe."

e In the sime recister there is a strong letter from Edward III. to one of the carlinals reprehending him for calling him a fool! It was probably $1111:$ 
of York to its exceeding detriment. Since the commencement of the fourteenth century, more than thirty of these dignitaries had held the highest offices in the minster whilst they were of conrse non-resident. Between 1313 and 1385 the deanery was in their hands. The first of the three who occupied it, I élie Talleyrand, $f^{f}$ cardinal-bishop of Alba, the fruitless intercessor" at Poictiers, might have been the "lucidum ecclesia sidus," as his friend Petrarch called him in Italy, but he never shone at York. He was far better acquainted with the intrigues of the sacred college at Arignon, the vineyards of his ancient honse at Périgord, and his college at Tonlouse. His successor at York and in the cardinalate, Anglicus Grimaldi, adopted the cause of the anti-pope, and was ejeeted from the deanery which he never once saw. The wisdom and the learning of Adam de Eston could not preserve him from the same fate, although they sared him from the vengeance of Urban VI., when five of his brother-cardinals, who had joined him in a conspiracy against the pope, were fastened up in sacks and thrown into the sea. When the heads of the eathedral at York were thus non-resident, it was not to be expected that there would be much order or discipline observed in the church that they neglected. It was not in the power of 'Thoresby to check the system of provisions; he was indeed too elosely bound to the papal court by the strongest ties of gratitude to attempt to do so even if he had possessed the power; and there was a continnous influx of carchinals into his diocese whilst it was under his care. ${ }^{g} \mathrm{He}$ did, however, what he conld to see that the chureh of York was properly attended to. On the 1.2th of May, 1362, he visited the chapter, and there he reprehended the system of non-residence, of which archbishop Melton had formerly complained to him. ${ }^{h}$ 'The dean, of course, was not there, and the forty poor

addressed to one of those dignitaries who luad a stall at York.

$f$ "Consanguineo di presso ehe tutti i Prineipi della Francia, nomo di gransenuo e valore pe' snvi tempi, e assai lodato dagli Scrittori di 'inell' età, e sonra gli altri dal Petrarca, e da altri molti, per la dottrina e prudenza" (Cardella, Memorie Storielie de' Cardinali, ii., 133).

$g$ In the letter and common place book which is called the second part of archbishop Neville's register, fol. $6 b$, is the following sentence whieh would express Thoresby's feelings about the cardinals, and it is probably from his pen :-

"Hen michi quia ineolatus mens prolongatus est ad extraneos et alienigenas, qui velut surdi et muti suorum ovium balatum non intelligunt, de morsibus luporum non eurant, sed relut mereenarii videntes lupum renientem fugiunt, auferunt vellera lae et lanam, linera eaptantes, semper dorsa ab oneribus divertentes, prout dolor ymmo immensus dolor, sed utinam ejus doloris auferatur oceaeio potentia Salvatoris."

$h$ 'The letter is in Neville's register, part ii., $16 b$. The archbishop speaks of the non-residence of the canons at York, and wishes to have the poor stalls angmented with the rich. It is possible that Zouche was the writer, and not Helton. 
persons, to whom he was bound to supply food, were forgotten. The sub-dean, also, was non-resident, and his house in the close was in decay. Branktre, the treasurer, had never becn in York since he was appointed, and the sacristans and relcks of the vestry had received from him no wages. 'The vicars experieneed a more than eommon share of hlame. Nany of then had had roices, and those who could sing sang wrong. When ther left the Beddern and went into the city they were dressed after the fashion of squires, in very unelerical attire, with knives sticking in their girdles, and basclards dangling between their legs. ${ }^{i}$

Thoresby was not a man to be daunted by difliculties and obstructions. Ignoranee was one of the great vices of the age, and he resolved to assail it. Ile eaused to be dram up, in the form of a eatechism, a brief statement of what he deemed to be necessary for salvation, comprising the articles of belicf, the ten commandments, the seven sacraments, the scren decds of bodily and ghostly mercy, the seren virtnes and the seren deadly sins, and in them we see the first faint shadowings of an Finglish ritual. These were prepared in a trofold fom, and were issucd from Cawood on the 25th of Norember, 1357. The first was in Latin, and was apparently to be perused by the cleroy, to the neglect and ignorance of whom the alchbishop boldly and sliarply ascribes the existence of the evils of the times. ${ }^{j}$ "The

i Acta Capit. Ebor. Fab. Rolls, 242.

$j$ The preamble runs as follows:"Joluannes, etc.; dileeto filio archidiacono nostro, ete. Quia nomnulli Christi fideles, quibus, licet immeriti, prosidemus, non sunt, quod dolenter gerimus, saltem in grossis et neeessariis Christiane legis observantiis instructi, quod tam ex nostra, quam ex rectorum, vicariorum et sacerdotum parochialinm, qui ipsos juxta suseeptre curae debitum haberemus instruere, incuria, ne dicamus irnorantia, dicitur evenire, per quod, quod Dens arertat, de facili via patere potest erroribus et gravibus periculis auinarmm. Nos volentes, ut tenemur, super hoc remedium apponere salutare, sacro approbante eleri nostrarmm diocesios et provincix consilio, super hoe sie duximus ordinandum, ut guilibet rector, vicarius, eapellanus parochialis et enratus alius, saltem diebus Dominicis, sine expruisita verbormm subtilitate exponant, seu exponere faeiant, populo in vulsari, articulos fidei, prxeepta tam Novi chlam Veteris Testamenti, opera misericordic, virtutes prineipales, gratia saeramenta et pecrata mortalia, cum sua sernela; et guod rice nostra injungant paroehiauis suis, viris et mulieribus, ynod ipsi et eormm singuli manissa ommia dilisenter audiant et addiscant, et fuom hece parvulos suos, filios et filias, clare doceant, et ijsos ad hiec adkiscenda compellant : et gued saltem in singulis puadrageimis dieti curnti parochimos suos, an hece sie dislisectint et sciverint et sie liberos suos instruxe. rint, examinent; exquisite injumetites nou parentibus in hac parte frouitentiam salutarem, quam fro tempre, front eorum rernirit inoliedientia, stndeant agravare. Et ne guis super hiis per itrnorantian se valeat excusire labe sub rembis planis et incultis, nt sic: levius in publieam deducantur notitian, fecimus annotare."

IVe grather from this that the Encrlish of the document that will be shomly. given was of the plainest and rudest kind.

'lhere are copies of this mamlate, the ereal, ete., slightly varving from the abone, amone the Mss. at lannbethe, 108, 575 (Tamner, Bibl. Brit., 711). C'f. Whatou's note ad Ilict. Dormatir., Arehiep. Ussher, ed. logo, 
other was in English verse, which is so uncouth that it is difficult to distinguish it from prose. This was translated from the Latin by John de Taystek ('Tavistock or Garrick?), a monk of St. Mary's abbey, and it is entered on the register of archbishop 'Thoresby's official acts. Mr. Halliwell has printed it in his Yorkshire Antiology, and it is also to be found in the Vicaria Leorliensis of Ralph Thoresby, who did not know, however, that it was in verse. ${ }^{k}$ The English version was intended for the benefit of the laity, and, that it should be properly understood and appreciated, the archbishop gave it as wide a circulation as he possibly could. Copics were multiplied and dispersed in varions forms, and the primate "sent them in small pagyantes to the common people to lerne it and to knowe it; of whiche yet manye a copye be in England." ${ }^{\prime}$ So wrote some one in the fiftecnth century. The word "pagyantes" opens out a very interesting field of speculation. It is the name applied to the miracle plays which were once so popular and so common. IV as the North of England indebted to Thoresby for the introduction of these instructive, yet somewhat profane, representations? It is very probable indeed that he would press them into his service to arrest the attention of the wayfarers in the streets, and please the cyes and ears of the unlettered crowd. The Crede or Belief play was one that was once acted and recited in York. ${ }^{m}$ It will,

P. 430-1. See also Harmer's Specimon of Error's in Burnet's IIistory of the Reformation, lart i., 56.7 .

h Iorklire 1nthulory, 297-314. Viearia lesdiensis, 21:35. Mr. IIalliwell derived lis eory from ISS. Harl, 1022, 71-80. At the end of the poem in this IIS. is the following account of its aluthorship:-

"Transmupta crat ista fuedicacio a linsua Iatina in nostram maternam linfum de nuanelato domini Johaunis de Thoreshy, Ebor'. Archiep., per venerabilem el discretun virum Johamem de Taystek, monallum monasterii beatie IIiric Ebor., ann: Domini millesimo trescentesimo puiurpagesimo septimo."

$l$ "Sir William 'Thorsby, arehebishop" of Torke, did do drawe a treatise in Englyslue by a worshypful clenke whose mame was Garryk. In the whiche were eonteyned the artycles of beicfe, the vij ledly sines, the vij workes of marcy, the $x$ comaunlements; and sent them in small paryantes to the common veople to lerne it and to knowe it, of whiche yet manye a copye be in England" (Wibrlin's Typogr. Ant, iii., 257). Faccic. Zizan., mefat., xiii. Foxe's
Book of Martyrs, i., -

"' By will, dated Angust 2, 1446, William Revetour, of Iork, chaplain, leaves "fraternitati Corporis Christi in Eboraco quemdam librum vocatum le Crede play, cum libris et vexillis eidem pertinentibus" ('lest. Ebor., ii., 117). lavistock's verse would certainly require all the paraphernalia of the banners, etc., to render it attractive.

For an account and specimen of these plays at York, see Mr. Davies's volume of Iork Records of the Fifteenth Century; Drake's Eboracum, appendix, 2932 ; (Croft's) Excerpta Antiqua, 10510; Camden Niscellany, iv., No. 3. The mamseript collection of the old lork miracle plays, which was formerly in the possession of the corporation of York, is now in the library of the earl of Ashburnliam. Among the many treasures from Stowe which that nobleman has gathered together is the following work :-

"A poem on the Trinity by William of Nassyngton, a proctor or advocate in the ecelesiastical court of York. 4 to. A curious MS. of 610 pages, partly on vellum and partly on paper, written 
I think be some day discorered that this is the poem by John de Tavistock.

The poem, if such it can be called, is, with a few exceptions, without rhymes. It was drawn up, as the archbishop tells us, with studied plaimness, and it is very uneonth and quaint. Is it has been printed twice before, although by no means aecurately, I shall only give on the present occasion the preamble and the Ten Commandments. The document is a valuable one, not only for philologieal purposes, but also as the creed of the inhabitants of Yorkshire in the fourtecnth century. The writings of Buonaventure and St. Thomas Aquinas, the Seraphie and the Angelic doetors, and those of that now almost forgotten scholar, from whom they derived so much, Peter Lombard, the Master of the Sentences, hare supplied the anthor with many of his materials, another rerifieation of the works of the earliest of our English poets,

"Out of olde fieldes, as men saithe,

Cometh all this new corne from yere to yere;

And out of olde bookes, in good faithe,

Cometh all this new scicnce that men lere."

My reader must tax his own ingenuity and pationce to ('xplain the many curious worls that are presented to him.

Aus that a gret clerk ${ }^{n}$ shewes in his bokes, ef est secundo Sentenciarum, distinctione prima, of all the creatures that Gool made in heven and in erthe, in water, or in ayre, or in onght elles, the soveraigne eanse and ye skill whi that he maide thaime wis his owen gode will and his godenesse, thurgh whilk godenesse, als he is all gode, he wold $y^{t}$ som ereatures of thas that he made were commmners of that blisse that evermore lastes. And for no ereature might come to that ilk blisse withouten linawyng of God, als that clerk techis, uli supra, he made skilwise creatures angels and man of witt and of wistone to knawe God al myghten, and thurgh yaire knawyng love him and serve him, and so come to that blisse that thai were made to. This maner of kmawyng had our forme fadirs in ye state of innoeentz that thiti were made in, and so shuld we have had if yai had noglit symmed noght so mikell als hali sanles has now in heren, bot mikel mare than man has now in erthe; for our forme faclirs synned, sais the prophet, and we bore ye wickednesse of thaire misclede.

Treñ ultimo. For ye knawyng that thai had of Cood Almighten, thai had it of Goddes gift at thaire begynnyng with outen travaile or trey or passyng of tyme, and all ye knawyge yat we have in $y$ is

about the year 1480." I should eonjecture that the date is a century earlier, and Nassington, in all probability, assisted Thoresby in his religions work.

n Petri Lombarli Scntentice, fol. Lovanii, 1566. Lih. ii., distinctio prima, 157-161. Peter Lombard owed many obligations to the works of the fimons Abelard, for there were other things thought of besides love

"Near l'araclete's white walls and silver
springs."

This preamble is in metre, but I print it, as a curiosity, in prose. It is written so. 
world of him is of heryng and leryng and techyng of othir of the lawe and the lare yat langes till hali kirk, ye whilke al creatures that loves God Almighten awe to knawe and to kun and lede yaire lyve afit, and so com to yat blisse yat never more blynnes. And forthi that mikell folke now in yis world ne is noght wele ynogh lered to knawe God Almighten, ne love him, ne serve him als thai suld do, ats thair dedis oft sithe openly shewes, in grete peril of thaime to lyce and to sanle, and peraventure ye defante in thaime that has thatire saules to kepe, and suld teche thaime, as prelates, persons, vikers and prestes that er balden be deit for to lere thaime, oure fidiu ve erce bissshop, yat God Almighten save, that als Saint Paule sais of 'Jhesu C'rist (Paulus ad 'Thimo ${ }^{\mathrm{m}}$, secundo capitulo), will that al men be saufe and knawe God Almighten: and namely thas undirlontes that to him langes has treted and ordayned for commune profet thurgh the consaile of his clergie, yat ilkane that undir him has kepyng of saules, openly on Inglis opon Sononndaies teche and preche tham, that thai have cure of, the lawe and the lore to knawe God al mighten, yat principali mai be shewed in yis sex thinges. In the fourctene poyntes that falles to ye trouthe. In ye ten comandementez that God has gyven is. In ye seven sacrementez that er in lali kyrk. In seven dedis of merci iutil our even Cristen. In ye seren vertues that ilk man sal use, and in ye seren dedely simnes that man sal refuse. And he comandes and biddes in al that he may, that all that haves kepynge or cure undir him enjoygne thair parochiens ant thair sugettes that thai here and lere this ilk sex thinges, and of sithes reherce tham til that thai kun thaime, and sithen teche them thair childer, if thai any have, what tyme so thai er of eld to lere tham. And that persoms and vikers and all paroche prestes enquere diligently of thaire sugettes in the Lentyn tyme, when thai come to shrit, whethir thai kun this sex thinges, and if it be funden that thai kun tham noght, that thai enjoygne than opon his behalve and of paryne of penanne for to kun them. And forthi that nane sal excuse tham thum molsmalechyog for to km them, our fadir the ercebissshop of his gorlenesse has ordayned and bidden that thai be shewed openly on lnglis omanges the tolk.

'The secund thyng of the sex to knowe God Mimighten,

Is the Ten Comandementz that he has gyven us.

" See Petri Lmmbardi Sent., lib. iii., disilict. xxxvii. We decem preceptis quomodo continearter in duobus mandatis charitatis. Cf. Opp. S. Bonarenture, ed. 1609, v., 411-27. Opp. S. Thomse Arninatis, vi., 142, ete, ed. 1591.

In the library of the dean and chapter of York, xvi., L, 12, is a curious MS. in English written soon after Thoresby's jeriod, and no doubt with the same object that was so dear to his heart. A brief summary of the contents may he given. "Here bigrnneth ye ten comanndementis. Of feitl, hope and charite. The Paternoster. The Ave Marie. The Crede. The werkis of bodili mercy. The werkis of wostli mercy." An account of the creation, baptism, etc., follows.

In a copy of the York Breviary, printed at Paris by Francis Regnault, some one had written the following complet, the meaning of which is ob. vious :-

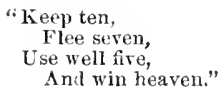


Of the whilk ten, the ilure that er first

Angh us haly to hald onentes oure God,

And the seven that er aftir onentes our even Cristen.

The first comandement charges us and techis

That we leve ne loute nane false godles:

And in this comandement is forboden $\mathrm{us}$

Alkyns mysbeleres and al mawnetries,

All fals enchamntementez and all sorceries,

Al fals charmes and al witchecraftes,

All fals conjurisons and all wicked craftes

'I'hat men of mysbyleve traistes opon,

Or hopes ony help in withouten God Amighten.

The secund comandement biddes us noght take

In ydelship ne in rayne the name of oure God:

So that we trow nouht in his name, bot that is stedefast,

That we swere noght be his name but bihovely,

And that we neren noght his name but worshipfully.

The third is that we sal hald and halowe our lalliday,

The Sonomday and all othir that falles to the yliere,

That er ordayned to halowe thurgh halikirk.

In whilk daies all folk lered and lawed,

Awe to gyf tham godely to Goddes service

To here it and say it aftir thair state is,

In worship of God Almighten and of his gode lalowes;

Noght than for to tent to tary with the world,

Ne lyve in lykyng ne list that the flesh yernes,

Bot gladly to serve God in clennesse of lyfe.

The ferth biddes us do worship to fadir and to modir,

Noght anely to fleshli fadir and modir

That getes and fosters us forthe in this world,

Bot til our gastely fadirs that has here of us,

And teches us how to lif til hele of onre simles,

And til our gastely modir that is halikirk,

To be buxom tharto and save the right of it,

For it is modir til all that Cristenly lyfes,

And als swa til ilk man that worshipfull is,

For to do worship aftir that it is.

The fift biddes us that we sla naman,

That is at say bodily ne gastely nouthir,

For als mony we sla in that at we mai

Als we sklandir or bacbite or falsly defames,

Or fandes for to confound tham that noght serves,

Or withdrawes lyvelade frat tham that nede haves,

If we be of haveyng for to help than.

The sext comandement forbedes us to syn,

Or for to foly fleshli with any woman,

Onthir sib or fremmed, wedded or nuwededed,

Or any fleshly knawyng or deid half with any

Othir than the sacrement of matermoyne excuse,

And the lawe and the lare of halikirke teches.

The sevent comandement bidiles us noght stele.

In whilk is forboden robbyng and revgner,

Al wrangwise takyng or withlaldying, 
Or hiding or helying of othir men godes,

Ogayne thaire wit and thaire will that has right to tham.

The anghtand biddes us we sal bere

No fals wittenes ogayne our even Cristen :

In whilk is forboden al maner of lesyng,

Fals conspiraeie and forswerying:

Whare thurgh our even Cristen mai lese thair catell,

Faith, favour or fame, or any thyng elles

Whethir it be in gasteli or bodili godes.

The neynd is that we noght yerne oure neghtebure house.

In whilk is forboden al wrangwise covatise,

Of land or of lithe or of onglit elles

That mai noght be lifted ne raised fro the ground,

Als thing that is stedefast and that mai not be stirred.

The tend and the last is that we yerne noght

The wife of our neghtebure, ne of our even Cristen,

Ne his maiden re his knave, his ox nor his asse.

In whilk is forboden us to yerne or to take

Ony thing that may be stirred of othir men godes,

Als robes or richesse, or othir eatell,

That we have no gode title, ne no right to:

For what thing so we gete, or tas in othir mise,

We mai not be assojled of the trespas:

Bot if we make assethe in that at we may,

To tham that we harmed withaldand thaire godes.

$\Lambda$ nul in cas that we have thurgh false athes,

Als in assises or othir enquestes,

Wittandly and wilfulli gert oure even Cristen

Lese thaire patermoyne or thaire heritase,

Or falsly be deseved of land or of lithe,

Or fals dirorce be made, or ony man damponed,

Of al we do that we may unto the party,

Jit may we moght be assoiled of oure fals atle,

Bot of our lisshop or him that has his powere,

For swilk eas is rively reserved til him selven.

This ten comandementz that I have nowe rekend

Lr umbilonked in twa of the godspell (Luce $\left.\mathrm{x}^{\circ} c a^{\prime}\right)$

T'he tane is that we love Gorl over al thinges,

The tothir that we love oure even Cristen als we do oure selven;

For God angh us to love halye with hert,

With al oure might, with al oure thought, with word and with deid.

Onre even Cristen alswa angh us to love

Un to that ilk gode that we love us selren:

That is that thai welefare in bodi and in sanle,

And cum to that ilk blisse that we think to,

Who so dos this twa fulfilles all the othire.

There is no evidence to shew what reception the remarkable formulary met with, of which a specimen has been given, or what effect it had upon the religious belief of the North of England. But when the people looked at their archbishop, they conld see that he was in earnest. His practice was as pure and simple as his precepts. He could be seen going about his diocese exhorting and correcting, neglecting no portion of his 
varied and extensive duties. His private life secms to have been one continned round of work and devotion ; the day began with the celcbration of matins, and the services for the hour's were regularly observed. The arehbishop and his almost $\mathrm{cx}$ liansted elerks were present at them all.p The elergy and the primate frequently met for deliberation in synork and comncils," and many wise enactments were then made. On the lsth of April, 1364, Thoresby promulgated a set of constitutions which met some of the error's of the times. ${ }^{r}$ One of them was to prevent the holding of markets, wrestling matches and archery meetings, etc., in churches and ehurchyards. Another forbarle games and sports at wakes. Mother's and nurses were ordered to keep their ehildren out of their own beds for fear of overlay ing them. Pricsts and clerks were to be attired in a secmily dress. All fraudulent assignments of property were reprobated, and some minute directions were given about tithes, the stipends of chaplains and others, and clandestine marriages.

It was of course Thoresby's great desire to improve the tone and character of his clergy. Whilst archbishop Zouche presided over the see, some thousands were admitted into orders, but a great number of them were in all probability laid low by the pestilence in 1349. A visitation of this sererity is gencrally followed by a great deterioration of morals and manners. When Thoresby, therefore, came to York in 1352 he wouk find not only a paucity of elergy, but much ignorance and inattention to their duties among the ecclesiasties of Yorkshire. One of his chief endeavours was to add to their number's and increase their efficiency. His ordination lists, which have been preserverl, shew us how he laboured. He very rarely permitted any one to assist him in this part of his episcopal duties, ${ }^{s}$ and the care whieh he bestowed upon it would soon bear its fruits. To give some idea of the extent of his work, the proceclings of a single year may serve as a specimen. In the year 1369 the arehbishop held three special and four general ordinations, at which he officiated himself. At these, as many as 306 became accolites, 187 sub-deacons, 163 deacons, and 161 priests. They were to officiate in Yorkshire, a part of Nottinghamshire, and in those portions of Lancashire and Westmerland whieh were comprised in the arelideaconry of Richmond. When we contrast such numbers as these with the scanty lists sent forth by the prelates

$p$ Stubbs, col. 1733.

ฯ Wilkins, iii., 39, 85, 91, 96 . 68.

r Reg. Thoresby, 14t. Wilkins, iii.,

From 1356 to 1361 Thoresby officiated himself. In 1361-1, "fr. Galf. cpisc. Milien" acted once in cach ycar.
Iu 1365 "Thomas epise. Magnassien", ofliciated thrice, and "Robert epise. Lambren" "twice in 1366. From 1370 to the end of 'Thoreshy's life the labour of the ordinations fell cutirely on "Ric. Sermen' epise." 
at the present day, we may well be startled at the difference. But we must not forget the reasons which, in the middle ages, made so many throng into orders. Canons, and monks, and chantry-priests, in addition to the regular paroehial elergy, come then before ns. The light is now quenehed in the ehapel and the oratory, and the monastery, which onee perhaps had a hondred inmates, is now untenanted by one.

These ordination lists are a perfect study for the thoughtful and enquiring mind. 'There are four' or five of them in each year of Thoresby's archiepiseopate, and the ceremonial usually took place in York, at the minster, Bishopthorpe, St. Mary's abbey, one of the houses of the friars, or, perhaps, now and then, elsewhere. We have no means of knowing to what examinations the eandidates were subjected; but the test, in all probalbility, was a slight one, and eonsidering the humble origin and the almost necessary iguorance of many of those who submitted to it, it could seareely be otherwise. If a man was desirous of a degree in an university, he frequently obtained the permission of his diocesan to desert his living for a year or two in after life. Comparatively few, it will be observed, beeame either deaeons or priests: the duties of a eantarist could be performed by persons of an inferior grade, and, possibly, the two higher steps neeessitated a stricter examination, from which the majority would shrink. A benefice, indeed, eould be held by a person who was in no orders whatever, although of course he eould take but little part in the sacred duties that devolved upon him. A mediaval ordination list is a suggestive pieture of clerical life which very few have looked upon. The youth eomes before his diocesan frequently withont a patronymie, and finding for the first time in his life that he stands in need of a surname, he adopts the title of his birthplace. Richard the son of William the baxter would convey a perfect notion of identity in Ravenser, but not beyond it; and, when he assumed the higher orders, he called himself Richard de Ravenser, by which appellation he was long honourably known. William or John Thomas's son, was not deemed euphonious or distinguishable by the world in which he wisher to rise. The patronymie, also, was oceasionally discarded for the name of the birthplace. Henry Daniel of Wakefield beeame Henry de Wakefield bishop of Worcester and lord treasurer of England. The prefix dominus, Ian or Sir, which so frequently meets your cye, is applied more frequently, I think, to the possessor of a benefiee than to a graduate who eomes before you with the word magister. Here is a rector or a viear from another diocese with letters dimissory from his bishop, and next to him, perhaps, is a graduate of Icrton or of Baliol with his fellowship for his title. The ques- 
tion of what constituted a title to orders is full of interest. No one required one till he wished to become a sub-deacon; and then a canon, or a monk, or a beneficed elergyman had enough when he mentioned his monastery or his living. No difficulty was raised when the candidate had some means of his own or was in receipt of a stipend of five marks, abont $80 /$. yer anmm of our money, from his father or a friend. Any one who did not come under the above eategory sought a title from some religious house, for it had the privilege of giving one. We sometimes see a little monastery containing, perhaps, ten or a dozen monks, giving fire or six titles in a year. In all probability they conld be bought. Some indeed might say that the recipient had been subjected to some preliminary course of training within its walls. This, no donbt, was in many instances the ease, but it could scarcely be so when the religions honse was a nunnery.

Another way in which it was in the power of Thoresby to improve the tone of his diocese was by the eneomagement of learning and by promoting persons of eminence and reputation. He was himself a man of no mean or ordinary attainments. Ile received his education at Oxford, where he was well acquainted with Divinity and the canon law. ${ }^{t}$ The ease and happiness of his Latin eorrespondence are great. His letters wege regarded as masterpicees of eomposition by his eontemporaries, ${ }^{u}$ and if a selection from them were published in the present day, they would be read with pleasure even by those who have derived their style from the purest morkels of classical antiquity. $\Lambda$ few specimens of them will excite the interest and curiosity of $\mathrm{my}$ readers.

I. Archiepiscopus significat abbati Ebor. qualiter monachus suus jam redit ad monasterium.

Salutem, ete. Venit ad nos, ${ }^{v}$ quasi columba suam rediens ad fenestram, confrater vester frater J. de G., commensalis noster carissimus, qui jam in preterito festo Nativitatis Doniniex nelum Divini verbi pabulo sed gestus houesti modestia tam salubriter cuam laudabiliter nos refeeit, quem nostri consideratione habere velitis propensius commendatum. Sibi fraterux earitatis dulcedinem ot spiritualioris communionis habundantiam petimus, impendentes per yuod nos ad rotiva vestra iureniri volumus pro tempore promptiores. Et quia quidam, ut dicitur, murmurant contra enun, fingentes eum yuadam sinistra nobis contra restrum aliquos pradicasse et correctiones in

t Bale, cent. vi., 493.

"There is a large collection of them in that farrago of curious matter, the second part of the Register of archbishop Alexander Neville. There are many of them, also, in MSS. Cotton, Galba, li, $x$.

"This, probably, was the monk, Garrick, or Taristock, who was busy with the ereed, ete. 
eapitulo restro fieri procurasse, ipsum ab impositis hujusmodi sub verbo veritatis plenins excusamms, quia revera super hoc totaliter est immunis, et ideo nullus restrum sibi improperet ex hac causa. Circa rero principim quadragesimse ipsum libenter haberemus, nobis ad nalgnum nostrum solatimm assistentem, quem ad hoc licenciare velitis cum scripserimus pro eodem. Feliciter in Domino raleatis. ${ }^{*}$

I1. Archiepiscopus cleganter scribit cardinali.

Beneficiorm aflluentia multiplicimm qua nobis, licet inmeritis, tam liberaliter impendidit vestra dominatio gratiosa eidem dominationi suprat vires nos efficit obligatos. Sed cum non habeamus quicquam tomporale condigmum quod robis digne possimus rependere pro receptis, Ille, qursumus, robis tribuat, qui supra meritum præmiat unirersos. Quoddam tamen memorale, licet modicum, affectionis, et obsequï debiti verum signum, unam ridelicet capam, vobis transmittimus per dilectum clericum nostrum W. de S(kirlaugh), presentim portatorem, cui in dicendis ex parte nostra relitis credulam, si vlacuerit, dare fidem.

III. Archiepiscopus eleganter significat alteri episcopo qualiter cura ccclesice divisa est pluribus pastoribus in partem solicitudinis vicarii Christi scilicct pape, ut sic quisque agnoscat gregem suam.

Convalescente dudum statu sancta matris ecclesia, cooperante semine verbi Dei, tilles sibi cultores allexit, sicque propagante sobole distinctæ fuerant per sanctos patres in ecelesia prelaturæ, ut sub plurium pastorum vigilis qui in partem solicitudinis capitis ecclesiæ vicarii, videlicet Jhesu Christi, sunt rocati, gregi melius provideretur Dominico, et dum simm quisqne pastorem agnosceret, salus proximior euilibet pararetur. Sed revera admirationem nobis jugiter multiplicem (sic) quod restra circumspectio fines sic distinctos excedens, in alienam segetem falcem mittit, non contenta terminis quos posuerunt patres nostri. Nostis enim quod talis prioratus nobis et non alii proter Romanam ecclesiam insolidum est subjectus, tamen, ut dicitur, voluntarie minis opprimitis, subtrahendo, etc.

IV. Archiepiscopus eleganter commendat magistrum Thomam de Nevill ${ }^{x}$ iturum ad curiam Romanam cardinali Petragoricensi et rogat corditer pro eo.

Reverendissimo in Christo patri et domino domino Taillere Dei gratia episcopo Albanensi Eboracensis ecclesiæque decano, Johannes ejusdem ecclesiæ archiepiscopus, Anglia primas, cum rotiva sua recommendatione reverentiam ommimodam et honorem. Generis claritas et morum graritas ordinata quibus filins in Christo carissimus magister T. de Nevill, natus nobilis et priepotentis baronis domini Radulphi de Nevill, canoniens Ebor. et magister in artibus, qui etiam

« Erasmus in his book, "De conseribendis Epistolis," would searcely coincile with 'Thoresby in his liking for short letters, "Illic mihi blatero quiciliam arropta censoria virgula, Solonis lerres dictabit, clamabitque delendam esse epistolam quæ non intra duodecim rersiculos constiterit." It will be remembered how Pliny discusses this point with his friend Tacitus. Of course lie is against brevity, and covets the ingens copia rerborum.

$x$ Of Thomas de Neville something will soon be said. The cardinal to whom the letter was addressed was dean of Tork. He died in 1364. 
in jure civili laute studuit et profecit eminenter, noseitur insignitus, digne proveniente intuitu attolli laudibus, et fidelis testimonii sufliragio propalari. Sane cum idem nuagister Thomas saterosinctan Romanam euriam ex certis de causis, per Dei gratiam adire disponat, ipsum quem ex familiari notitia sic fore scimus genere, moribus, et seienciat conspicuum, dominationi vestrat revereuda, qua ex mirata vobis nobilitatis et bonitatis exuberantia libenter intelligitur super dignos, votiviori quo possumus recommendamus aflectu: corditer supplicantes quatinus ipsum nostri consideratione habere relitis, si pliteet, propensius commendatum et gratiosoribus prosequi consiliis et anxiliis in agendo paternitatem vestram.

The following letters shew that the arehbishop was not deroid of humour.

T. Litera testimonialis missa per archiepiseopm alteri episcopo quod talis clericus est superstes, et letus, et non mortuns, pront fama laborat.

Rererendo in Christo patri et amico nostro carissimo domino $A$. de B., Dei gratia Exon. episcopo, J. eadem permissione, etc., saluten et semper excrescentia traterna fodera caritatis. Quia locorun distantia et relatorum levitas inconsulta plerumene veritatem obnubilant, et vias aperiunt ad errores, pium et meritorium fore credimus fidum veritati testimonium perhibere. Cum igitur, ut audivimus, quorumdam in partibus restris habeat assertio socium nostrum carissimum renerabilem rirum magistrum $\mathrm{W}$. de $\mathrm{Ex}(011 .)^{y}$ canonicum ecelesire nostra Ebor. diem sum clatusisse extremum, scine relit vestra sinceritas pro constanti quod die datre prosentium iclem magister IV. ad nos renit apud manerium nostrum de Cawode, sanus, hillaris, et jocundus, et pro nobis, qui quandam discrasiam habemus, aptam ordinavit sui gratia medicinam, et pro certo eum a magno tempore non vidimus ita letum; quod robis sub verbo veritatis fideliter contestamur. Incolumitatem vestram diu conservet, ete.

VI. Arehiepiscopus eongrutulatur cuidam semi per verba jocosa, et regratiatur sibi de literis sibi missis, et rogat ut habeat eum in precibus suis.

Seni senex salutem, et in senectute bowa diutine prosperare. Tenit nobis in suavitatem odoris recensita memoria specialis amicitia, ac gratw liberalisque familiaritatis, quas semper in robis pre coteris invenimus, et valde cedenter rotis nostris presentialiter ros videre ut mutuis possemus colloquiis, et solatiis conforeli. Sed com luo locorum distantia commode non permittat, suppleat, quasumus, defectum corporalis præsentiæ mentalis prasentia plenitudo, qua latius se diffundit; nam sicut seribitur" non ubi animat est anima, quin verius ubi amat." Unde consideratione amoris antiqui, quem inter nos non antiquatum esse credimus, velitis in devotionibus restris memores esse nostri, requirentes vos semper eum fiducia, si qua volu-

y William de Exonia, master in theology, arts, and medicine, became prebendary of Riceal in 1336. He held stalls at Lincoln and Exeter. He died about 1360. Cr. Fed., ii., 1101. Fuller's Worthies, ii., 305. Fad., iii., 8*. Queen Philipla presented him in 1339 to the rectory of Castleford. 
critis nos facturos, ad quorum placabile complementum invenietis ex animo nos paratos. Sit diu robis retas valida, quæ, licet pruinosa insenescat in capite, virtuosa tamen insenescat incremento.

V1]. Arehiepiscopus recommendat se magistris de cancellaria regis. ${ }^{z}$

Soeii ct amici carissimi, cederet nobis ad augmentum latitia de prosperitate vestra andire placentia, et quia de nobis similia libenter, ut confidimus, audiretis, dilectioni vestræ arridentem jam nobis, laudetur Deus, sanitatem corpoream nuntiamus, gerentes in votis vobis et restrum singulis facere quxe sciverimus fore grata. Et quidem jam rem novam aggredimur, nune laboribus, nune solatiis, indulgentiis, plus quandoque vacantes in visitatione nostra venationi Teneris quam ferarum. Et sic caveat dominus W. de L., ne commissa sua præterita jam in lncem elumpant; quod si forsan contigerit, propter reliquias antique familiaritatis agemus mitius cum eodem. Alia non occurrunt jam scribenda, sed agenda nostra penes nos, cum emerserint, habere relitis affectione solita, si placuerit, commendata, nos semper in rotivis fiducialiter requirentes.

VIII. Aichippiscopus seribit cuidam veteri amico suo, jocando, et rogat eum visitare eam et habebit bonum rinum.

Venerunt ad nos in exultatione spiritus dilectionis vestræ literæ pluries nobis nisse, quix, licet de veteri dicamus, imnecata procedant pharetra, cum juvenem at latum animum representant, dum in eis apta connexione jocosa sapidis ministretis. Et quidem merito dici debet placabilis hae mixtura per quam avida mens scientia instruitur et hillaritas prorocatur, sed cum hillaritas floridam producat xtatem debet potissime senibus esse grata. Et quia bonum rinum eor exhillarat, ut alludamus potatorum proverbio, vinum subtile facit in sene cor jucenile, ipsius usum moderatum jocundo vobis consilio sancimus; ut cum ad partes veneritis nos personaliter visitetis, ut de antiquis possimus communicare praludiis, et de vino nostro cum appendiciis ad recreationem vel renovationem juventutis mutuæ vobis participabinus lieta manu.

We acquire from these letters a very pleasing impression of 'Thoresby's powers of composition, and they shew us, also, that their benevolent writer was neither a bigot nor a fanatic. A man who could use his pen with so mueh facility and in so pleasing a manner, conld speak no doubt with the same ease and readliness. There must have been in lim the voice and the bearing of a courtier. The skill which he had manifested in diplomacy must have aided him in his diocese, and there would

* An amusines and familiar letter, written probalily soon after Thoresby became permanently settled in the North, to his old friends in the chancery oflice. Sereral of them held preferments at Tork. David de Wooller, master of the rolls, whom 'Thoresby speaks of as "socius noster "arissimms," was prebendary of Fridaythorp from
1352 to 1370 . Henry de Ingleby held, in succession, the stalls of Ampleforth and South Cave. Richard de Ravenser was a canon of York and provost of Beverley. The list might be increased. Who the delinquent was to whom Thoresby humorously alludes I know not. 
be many even there to ahmire the learning which harl attracted the attention of Edward III. and Clement VI. John Baconthorp inscribed to the arehbishop his commentary on the Ethics of Aristotle, ${ }^{a}$ and Thoresby himsclf was not miknown in the world of letters. He is said to have entercel into the lists with the Mendicant Friars, ${ }^{b}$ who had been bold cuough to preach that mortnaries ought not to be rendered to the priest. A gainst them, as Bale informs us, Thoresby wrote "Processum ruenulam" in one book, commeneing with the words "Pridem sunctissimus in Christo pater." 'The second part of archbishop Nerille's register contains several pieces which may perhaps be ascribed to his predecessor. They consist of a series of extracts from the Vulgate and the Patristic writings, some fragments of letters, and a portion of a Catholicon, or dietionary of difficult terms. ${ }^{\circ}$ It does not go beyond the first letter of the alphabet.

Among the great men who became bencficed in York minster during Thoresby's arehiepiscopate, it is cnongh to mention the names of Alexander de Neville, his suecessor in the sce, Robert Braybrook, bishop of London, Henry de Wakefich, bishop of Worcester and treasurer of England, cardinal Simon de Langham, archbishop of Canterbury, William de Courtncy, of whom it is unnecessary to speak, and John de Waltham, bishop of Salisbury. But there are two others with whom 'Thoresby was intimately connected at York who must not be forgotten, "Walter de Skirlaugh, bishop of Durham, his private chaplain and

a Vicaria Leod, and Bale. Cf. Bibl. Carmelitana, i., col. 750. It is there said erroneously, that Thoresby died in 1474, and Bacon in 1316.

${ }^{6}$ In Antiq. Univ. Oxon., i., 475, John Toresbie is mentioned as an opponent of the begging friars, who by their meddling had become an intolerable nuisance. Wycliffe, Fitzralph, and others, took the same side. Cf. Walsingham, 173. I do not suppose that 'Thoresby's encounter with the friars was an angry or a serious one. II is will is enough to shew that there was no ill-feeling towards them remaining in his mind. See the prefaces to the Fascic. Zizan., and the Monum. Francisc., by Messrs. Shirley and Brewer. Bale says the friars were " ad id invitati ac concitati a quibusdam primoribus, qui talia solvere jure debebant."

"This account of 'Thoresby's works is taken from Bale, cent. vi., 493. Vicaria Leodiensis, 189. 'Tanner Bibl. Brit., 711.

"Incipit tractus, catholicon dictus, abreviatus, in quo reperies omnes diffienltates sacrae seripturac, quie consueverunt legi et recitari conmuniter in ecclesiis, expositus, quantum ad intellectum literalem ac noralem, secundum ordinem alphabeticum." 'Tliere are $t$ wo or three leaves of $i t$.

d In MSS. Cotton, Galba, E, x., 71, is a letter from Skirlangh to the arehbishop excusing, for many reasons, his long stay at Rome. Thoresby writes, and says that skirlaugh has fold lim that Peter, cardinal bishop of Praneste, archdeacon of York, has left by will 100 florins to the church of York; and lie desires that measures be taken for sccuring it for the fabric (ibid., 82).

In 135.k and 1356 skirlaugh was Thoresby's domestic elaplain. In 135s he was ordained accolite, deacon, and subdearon at York, by Jetters dimissory, his title being the rectory of Preston Bisset, co. Bucks. In 136 i he was mide arohdeacon of the East Riding (lies. 'Thoresby).

Skirlaugh's connection with Thoreshy 
correspondent, and the well-known William of Wykeham. ${ }^{e}$ From these two distinguished ecclesiasties, so renowned for their arehitectural taste, Thoresby, in all probability, derived many hints for the work that he effected in his own cathedral, and it is likely enongh that the beantiful strueture which Skirlaugh and Wykeham would gaze upon as it arose from the ground at York, would awaken that zeal in the same cause which led them to imitate the example of their patron at Vineliester and Durham.

This brings before us the glorious choir which Thoresby commenced at York, and which was far superior in beanty to that which Conrad once raised in the sister-ehurch of Canterbury. Year's had passed away since archbishop Melton eompleted the western façade, uncrowned still by its two stately towers, and glazed the noble window which is its ehief grace, whilst, towards the east, the choir of arehbishop Roger, insignificant as it must have been in size and decoration, was still

and with York made him take great interest in the rebuilding of the choir. His arms, six osiers, in cross, interlaced, are cut in stone in the north rhoir transept, which, perhaps, he helped to build.

'They also oecur in the lanter'n tower, "magnam partem campanilis, vulgo lantern, minsterii Eboracensis construxit, in medio cujus operis ama sua posuit" (Hist. Bunclu. Scriptores Tres, 114). This, however, was done after his death. In his will, dated in 1403 , Skirlangh beineathed 100 marks to the fabric of the minster ('Test. Elor., i., 309). In addition to this sum, I supjose, his executors paid to the keeper of the fabrie in 1415 the sum of $52 \%$. for the wases of six masons for a year (Fabrie Rolls, 32). The lantern, probably, was being built in this year.

I look, I must confess, with mueh distrust upon the inferences drawn from the appearance of shields of arms in churches, and other heraldic derices. They were frequently earved, I believe, as is the case in the present day, long after the part of the building which they ornament was completed. The person to whom they carry us, was a benefactor to the ehurch, and probably to that part of it, but the inference as to the exact date is musafe. These shields, I believe, were often left blank till the building was finished, and for a good reason. A work, for example, extends orer twenty years. If during the first five all the stone shields were covered with the bearings of those who had contributed up to that time, there would be no room left to commemorate, perhaps, some far greater benefactor at a later period, or towards the elose of the work. When everything was done, a proper and a fair selection could be made. Mneh cantion also should be used in inferring dates from stained glass.

$e$ 'This great man was prebendary of Laughton at York, when he was arranced to the see of Winehester. He had also been a eanon at Beverley and Sonthwell. Thoresby wrote to congratulate him when he beeame a bishop (Reg. Neville, part ii., 26a); and between him and Wykeham there was much intimacy and friendship.

In 1357 Wykeham was custos of the royal works at Windsor castle, and at the same time he was actually the keeper of the king's dogs at that place! Eleven years after this he was bishop of Winchester. The story of his life is part of the history of England, "neither do I doubt," says Stowe the elmonicler, "but he that thus lived is now with God, whom I beseech to raise up many like bishops in England." Had not his birth-place been ascertained, I should have tried to fix it in Yorkshire, and yet Fuller says, "How can his cradle be certainly fixed in any place, when it is equally roekt betwixt twenty villages of the same denomination." 
untonched. The contrast would be deemed a painful one, and would excite many a remark. On Trinity Sunday, 1318, Thomas Sampson, a wealthy eanon who had had somewhat to do with the ereetion of the nave, left the sum of $20 \%$. to the new choir, if the work was begun within a year after his decease, thus fulfilling a promise which he had frequently made to Thomas de Ludham and Thomas de Patenham the keepers of the fabric. $f$ The time passed away and the legacy was unclitimed, and it is probable enough that the French war's, the pestilence, and the long continued illness of archbishop Zouche were a great bar to the commeneement of the building. When Thoresby came to the see in 1352, he found the minster overburdened with debt, ${ }^{g}$ another reason for delay, but he was not a man to be long: satisfied with inactivity, and, as soon as he could disengage himself from his state employments, he threw himself with heart and soul into his work at York. The mmfinished and neglected condition of the eathedral caused him mueh grief. ${ }^{h}$ On the 25th of January, 1354, he granted an indulgenee of 40 days to those who contributed to the fabrie, and on the 19th of Jamuary, 1356, the chapter wrote to ask him to give them timber to complete the ceiling of the nave. ${ }^{i}$ In 1359 and 1360 the archbishop gave several sums of money to the fabrie fund of the eluureh. ${ }^{j}$ The chapter and the primate had now made up their minds to begin the erection of a new ehoir, the old one being removed by degrees as it conld be dispensed with. On the 20th of July, 1361, Thoresby aided the good work by ordering his manorhouse at Sherburn to be pulled down, that the stone, a searce and valuable artiele, might be made use of in the minster. ${ }^{k}$ 'Ten days after this, he laid the foundation-stone of the new ehoir, accompanying the aet by a gift of 100 marks towards the under-

$f$ Test. Ebor., i., 54 .

$g$ MSS. Cotton, Gaiba, E, x., 61

${ }^{h}$ Among the observations in Neville's register, part ii., is the following which I refer to Thoresby and his church. He is using the Vulgate. " $N o^{n}$ ecclesia Ebor. (in margine). Capud meum doleo, conturbatus est in ira oculus meus, anima mea, et venter mens, quia corona capitis fere deciditur, fere deficit in doloribus vita mea. Nam ubi in primaria fundatione fueram in reverentia, sicut domina gentium, princeps provinciarum, libertatibus et privilegiis radiata et dotata, facta sum opprobrium gentium serviens sub tributo; facies mea qua aliquando fuerat formosa præ singultuosis suspiriis et nimium effusis lacrimis supra carbones denigratur, dium dispersi sunt lapides sanctuarii in capite omnimm platearum. Et qua olim fueram formosa corruo tristis et anxia, ete." (6 $b)$.

i Most of these docmuents, and others connected with the fabric about this period, nay be found in the York Fabric Rolls, published by the Surtees Society.

j 1359, April 20. 'To Joln de Corlyngham, master of the fabric of the Church of York, 20l. for the more rapid completion of the said fabric. 1360, Nov. 2t. An order to pay the like sim to him. The same on Jan. 7 ,

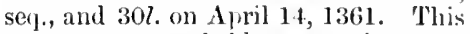
money was probably spent in conpleting what was wanting in the nave, or in making preparations for the commencement of the choir.

${ }^{h}$ Fabric Rolls, 17.1-5. 
taking. In addition to this sum, he prompted and stimulated the munificence of other's by indulgences granted by himself and olstained flom the chief pontifl, and during the remainder of his life he gave ycarly to the fabric fund the generous benefaction of $200 l .^{m}$ I cammot estimate the amount of 'Thoresby's gifts to the choir only, in the money of the present day, at a lower sim than $3 \%, 000 \%$, and this, in all probability, is considerably under the mark. When, in addition to this, we take into consideration the money which must have been derived from other soulces, it is impossible to doubt the accuracy of the historian when he tells us that the Lady-chapel or presbytery was finished in the arehbishop's lifetime."

In confirmation of the accuracy of the chronicler, we have

1 The order to gray it is dated on Aug. 1 (Rer. Thoresby). "In primi positione lapidis centum marcis de suo proprio dotavit" (Stubbs, col. 1733).

"n "Postea anmatim, dum vixit, fabrice pradicte ducentas libras persolvebat" (Stubbs). The following extracts from Thoresby's register shew the regularity of his payments, and the acenracy of the chromicler. 1361. Oet. 3, 50l. 1362. April 13, 100l.; Ang. 9, 100l. 1363. Ap,ril 16, 100l.; Nov. 3, 100l. 1364. July 6, 100l ; Dec. 4, 1007. 1365. June 13, 100l.; Oct. 16, 100l. 1366. June 24, 100l; Nov. 5, 100l. 1367. May 7, 100l.; Oct. 23, 100l. 1368. Al ril 20, 100l.; Nov. 14, 100l. 1369. Aug. 15, $100 l$. 1370. Jan. 28, 1002.; July 28, 100t.; Nov. 25, 100l. 1371. Jume 15, 100l.; Nov. 1, 100l. 1372. March 10, forty marks in full payment of $100 l$.; 25 -, 1007. 1373. Feb. 11, 1007.; July 24, 100l. The keepers of the fabric during this period were John de Codyngham (Cottingham), John de Sandale, Adam de Henedlay (Henley), John de Laghton or Leghiton, and John de Ferriby.

The sim total of the above gifts is no less than $2,376 l .13 \mathrm{~s}$. 4d., which was bestowed entirely upon the choir; in addition to which there is the following sift: April 5, 1362, To Robert de Rithre, lord of Rithre, $20 l$. for twentyforr oaks which we have bought of him for the fabric of our church at Iork. To bring this larie sum to the money of the present day we camnot multiply it by less than fifteen, and this prochces nearly $36,000 \mathrm{l}$.

" "Et ut operi predicto subrenire denolionem fidelium ardentius sxcitaret, omnilus ejusdem fabrica benefactoribus indulgentias largissimas a sanctissimis patribus apostolicis concessas, sua petitione impetravit, et ad remedium animarum suorum subjectorum et aliorum quosumcunque manum adjutricem prebentium, cum propriis indulgentiis et benedictione miro affectu illas participavit" (Stubbs). "This is borne out by the Fabric Rolls, 175-6, and other places. Everything was done that conld swell the fabric funds. The brevigeri were sent about even into the diocese of Lincoln to beg (Fabric Rolls, 178 ; Lit. quest. pro fabrica Ebor., 21 Oct., 1356, etc.). In 1360-1 the chapter made a tax of a twentieth, to last for three years. On Oct. 12, 1365, the dean of the Christianity of York was ordered to levy the recent subsidy to the fabric of $4 \mathrm{~d}$. in each mark from the clergy of his deanery; and on the 20 th a commission was issued to collect 21. in every mark from all spiritual and temproral benefices in the diocese, towards the fabric fund. In the eighth of Richard II. the value of the church property alone within the province of York was taken at 40,000 marks per annum (Chron. Thorn., 2164). By these means large sums would be gathered together, and I cannot think that the fabric fund would in any year in Thoresby's lifetime, after the choir was begm, be under $600 l$., and this is a low estimate when we recollect that a third of it was contributed by the archbishop. With such a sum as this wielded by active hands the presbytery could tasily be finished in less than twelve years. 
decisive evidenee that the presbytery was in use within a short period after the decease of its alleged builder. On the 1\%th of August, 1381, John de Waltham, sub-dean of York and Thoresby's kinsman, in a codicil to his will which was made at Newbald near York, left the sum of $20 \%$. to two chaplains who were to perform service in the new work of the church of lork, for the souls of his master, archbishop Thoresby, Henry de Ingelby and others. The new work was the ehoir, as is shewn by many documents and wills, and here we have an intimation that a portion of it, which was of course the presbytery, was so far complete that services could be done in it which were to extend over two years. It may be inferred from the mention of this period of time that the work was finished, as the chaplains could not, nor would they, be asked to $\operatorname{sing}$ for two years contimnously in a place where they might be interrupted by carpenters and masons, and stone and wood. It is well known that these masses, for obvions reasons, were performed immediately after the decease of the testator. If the presbytery had not been ready to allow the priests to officiate in it, or if there was likely to be any delay in carrying out the wishes of Waltham, the subdean, of all people, would have known that, and wonld have expressed himself differently. The conclusion, therefore, is irresistible that the presbytery was finished in $138 \%$. Where could Thoresby be more appropriately commemorated than at the altar which he had founded in that place? Otherwise, some different altar must have been in use in the same part of the cathedral at that time, and why should it not? In my memoir of archbishop Arundel I shall give some new and decisive evidence as to the date of the western portion of the choir.

One of the main wishes of Thoresby in all this labour and expense was to provide a place where the mass of the Blessed Virgin might be daily celebrated. ${ }^{\circ}$ Accordingly the work began

- "In ecelesia Ebor. non fuerat aliquis loeus congruus ubi missagloriosie Dei genetricis et Vircinis Mariae cotidie in ipsa ecelesia celebranda decenter poterat celebrari" (Fabric Rolls, 17.t. Thoresby's words). 'This document has reference to the choir only, and Stubbs gives us the result when he says, "Idem archiepiscopus, ut verus amato" Virginis capellam ejusdem Dei genetricis et Tirginis Maria-peregit" (Stubbs). The only portion of the chureh which is or has been ealled the Lady chapel is that at the east end, where there was : 11 altiar of St. Mary; and in 1557 Sir Leonird Beckwith desired to be buried "in our"
Lady queare wher they singe messe behynde the highe aulter;" and he wats buried at the east end of the ehureli, as is said in his wife's will. 'This proves where the Laty ehapel was and is: most certainly it was not the chapel, once arljacent to the north wall of the nave, of the foundation of arehlisiop Roger. That was always called the chapel of St. Mary and the Iloly Angels, or that of st. Sepulche, anil never at any time the Lady chatpel. What Thoresby of Leeds and Gent of Fork say on this point is of no ralue, and no argument can be drawn from the fict that some richly sculptured stones have been discovered in honses 
at the extreme east and proeeeded westward, and there he constructed a Lady chapel or presbytery, full of rich seulpture and painting, in the centre of whieh the altar to the Virgin was set up. This chapel occupies four bays of the choir towards the west, and the mumificent founder, as Stubbs informs us, had the privilege of seeing it thoroughly eompleted in his lifetime. ${ }^{p}$ Before that altar of the Virgin he eaused six marble stones to be laid to eommemorate six of his predeecssors who had been interred in the old ehoir, which was farther westwards. $\mathrm{He}$ was well aware that in eourse of time, as the old building that was around them was removed, their remains would be disturbed. He therefore took up their bones and plaeed them in the Lady ehapel under the six stones which were wrought for him by the master-mason of the eathedral. $q$ When Leland was making his

at a little distance from the site of $\mathrm{St}$. Sefulelire's ehapel. In the first place, no one can say that they belonged to it, or to the minster at all, and, if they did, they eannot be brought forward to shew that archbishop Thoresby built it, for they are not of Thoresby's time. 'They prove nothing. Stubbs las deseribed minutely the foundation of st. Sepulchre's chapel by archbishop Roger, and its re-formation by Sewal de Bovill in a way that leaves no doubt as to its ideutity. Would he not lave been equally clear and precise in telling us about 'Thorestyy's alterations in it, if he had made them?

$p$ "Item vero archiepiscopus, ut verus amator Tirginis, capellan ejusdem Dei genetricis et Tirginis Maria miraliti artis sculplura, atque notabili pictura peregit" (Stubbs). Nothing can be more decisive than this. Thoresby began a Lady chapel and he finished it. If, therefore, this Lady rhapel is the easternmost part of the church, or the presbytery, and it ean be no other llace, that part of the minster was altogetler built by Thoresby, and, putting aside the eorroborative docmmentary proofs of this which are given in the Surtees Fabric Rolls, the architecture itself tells the same tale.

It has been said that the life of Thoresby by stubbs is not to be relied upon, beeause it does not appear in every MS. of that clironicler, and because tlere are blunders in it.

If criticism is of any value, internal evilence will shew that the hand that wrote the lives, for instance, of $\mathrm{COr}^{-}$ brilge, Gieenficld, and IIclton, the authentieity of which has not been questioned, wrote that of Thoresby al:o. The circumstance of Thoresby's life not being in every MS., whieh is easily aecounted for, would be regarded by many as a proof of its authentieity. There could be no possible reason for aseribing it falsely to Stubbs, and not a doubt was thrown upon it till the controversy about the choir began. Even if Stubbs was not the author of it, it is taken from a MS. of undoubted antiquity, and it would possess, therefore, an independent value of its own.

With regard to the alleged errors in the life, they remain to be proved. There is no chronicle, I believe, whieh will bear in every place the searehing test of eollateral information, and minute points are often discarded. I will say this, however, for Stubbs: no one could have submitted the work of an historian to a more searching examination than I lave that of his, and, though oceasiomally inexaet, he is on the whole wonderfully eorreet, and his life of Thoresby is perhaps more eorrect, as it is also more interesting, than any other. I have given my readers an opportunity in these notes of seeing this for themselves. It eould not lave been written by any one who was unaequainted with the person that he speaks of, as is the case with the life of Melton also, and there is strong corroborative evidence of almost every faet that he narrates. With regard to the building of the ehoir Stubbs is very decisive, and his testimony is ineontrovertible.

$q$ "Idem archiepiscopus - capellam Tinginis Maric - peregit. IBrQUE 
tour in the begimning of the sixteenth century he observed the stones where Thoresby placed them, ${ }^{r}$ and they still oecupied the same position at the close of the seventeenth century when they

plurimorum renerabilium pontificum, pradecessorum suorum, corpora, a choro superius translata, propriis expensis fecit tumulari" (Stubbs).

It has been shewn where this chapel was. We are now told that Thoresby interred in it the remains of six of his predecessors. The following evidence and that in the snceeding notes will again shew the exactness of the chronicler, and fix decisively the position of that chapel and the tombs in it even at the beginning of theeighteentli century.

1369, Feb. 18, an order from archbishop Thoresby to pay to master Robert de Patrinuton, master mason of the fabric of the new choir of our church at York, for the making of six marble stones for the tombs of our predecessors, for which we have entered into an agreement with him, 10l. Aug. $23,1369,10$ marks more to him for the same purpose, in part payment of 40l. 1373, June 12, 100s. more to him (Reg. Thoresby).

In the Fabric Roll for 1131. (ed. Surtees Society, 54), among the smaller expenses, there is an entry which shews that the stones had been laid down before the altar of the Virgin, and that the brazen imasery was then fixed in them or re-set. " $I$ n vadio $j$ hominis firmantis ymagines episcopormm in petra coram altare B.M., 6s. Sd." Petri clearly refers to the stones in front of the altar. Petra never means a pier, and, besides, there is no pier before the altar of the Virgin in which they could be placed, supposing them to be statnes or images, nor are there traces of any fixings in the lateral piers.

r In Leland's Itinerary, viii., 14, ed. $\mathbf{1 7 6 9}$, is the following jassage :-

"Sepul. Archiepiscopormu in orient. parte ecclesia.

1277. Walterus Gisfart obiit 7 Cal. Maii, anno Dom. 1277.

1153. Henry Murdak obiit amno Dom. 1153.

1108. Gerardus obiit 12 Cal. dın. anno Dom. 1108.

Defuit inscriytio

1373. Johames de Thoresby, quondam Menevensis, postea Wigorn. et
Ebor archiepiscopus, yni fabricam ... ob obit 6 die Novembris anno Dom, 1373.

1113. Thomas junior obiit anno Dom. 1113, 5 ldus Mart.

1295. Johan. Romanus obiit anno Dom. 1295."

We thus see that in the reign of IIenry VIII. Leland saw at the east end of York minster the tombs of seren archbishops, of whom Thoreshy was one. The allar of St. Mlary is in that part of the elumeh, and nowhere else were there the tombs of six primates together. The position of 'Thoresby in the middle shews clcarly that the place of his interment was marked before these stones were lail down, for, ats Torre draws then, they were continnous to each other, and as Throesy tells us himself in his will that he had fixed inon the place in which he was to be laid (in loco alias ordinato), it seems naturally to follow that the tombstones of his predecessors, and perhaps his own, were then in their proper position.

The evidence of Leland is strongly confirmatory of what has been said already. But an atiempt has been made to throw diseredit upon his tesimony. The grounds taken for this are the confused state of the MIs. where this frassage occurs; the fact that the passige oceurs, not in Leland's own MLS., but in a copy of it made by stowe the intiquary. It is also asserted that from the nature of the information itsell, it was not taken by Leland firom personil observation, but from a 11.5 . of lord Serope's. 1. It is well known that tho omisions and misplacements in leland's MSs., which are very mumerous, were cansed not throunh leland's carelessness, for he was very accurate as lar as he profesised to so, but from the neglect of those who arranced and bound his $1 \mathrm{~s}$ s. after his deceise. P'roper allowance should be male for this. 2. Even if it was copjed by stowe, it was copied from heland's Mss.s., and it is therefore trustworthy, for slowe was a carcful and learned man, and would cony faithfully as lim as possible 
were sketched and described by James Torre, the well-known and laborious antiquary.

At that altar of the Virgin in the new choir, before which the remains of Thoresby himself were laid among those of his predecessors which he had so honourably entombed, a cantarist, who bore the same rank as the personce of the minster, offered up prayers for the archbishop's soul. Stubljs tells us that he derived his income from houses and lands of the primate's own procuring, but the history of this altar is a somewhat remarkable one. ${ }^{t}$ Henry lord Percy, who died in 1351, expressed a strong wish to his cxecutors that chantries should be founded by them

what was before him. 3. Supposing, for the sake of argument, that it was copied, as is said, from a book belon:ing to lord scrope, no family would be better able to know what was in this part of York minster, as it was their burial-place. But Leland was in York hinself, as his Itinerary several times shews, and it was unnecessary, therefore, for him to take from others what he conld see himself, for if Torre saw these monuments in 1700 , much more conld Leland almost two centuries before. The notes are rollohly taken, after his faskion, and they must not be criticized as if their writer intented to give a ful] and aecurate account of what he saw. The objection proves too much. If these notes are not Leland's making, the whole of his work, nay, his works, I may say, are an imposture. They are Lelard all over. Many passages might be civen very similar to this about Fork, for brevity and meagreness of description are his failing, althoush he was a shrewd and close observer. Take the following notice of IIereford catheiral (Itin., viii., 55):-

"In austrili parte chori.

1198. Gul. de Vere enisropus Hereforden: prefuit 12 annis. Obiit 9 call. Jannarii anno Don. 1198. Dominus Robertus Foliot episcolns Hereforden.

1117. Robertus de Melum sedit annis ...tempore Henrici 2 filii... Hic fuit in omni cenere literarum insigniter eruditus. Obiit anno Dom. 11. 17 .

Dominus Robertus Betune episcopss IIereforten.

1) omints Reinelmus ejiscopus Itereforlen.
1516. Dominus Richard Maiew episcopus Hereforden., doctor theologiæ, rector turbæ Magdalenensis, archedecon of Oxford, shanselar of Oxforde, elemosinarius Henri the 7, præfuit Hereforden. escl. 11 annis et amplins. Obiit 8 die April. anno Dom. 1516."

- Torre measured the stones, marked their ylaces in his map of the pavement of the minster, and sketched them in pen and ink. There were mitres upon them, and other signs of archbishops, formerly in brass, as he tells us, and they were laid right in front of the old altar of St. Mary, before the great east window. An engraving of his drawings and his verbal description of them is given in the preface to my Fabric Rolls, $\mathrm{x}$ viii. It will be seen therefore, by an irrefragable chain of evidence, where the altar of St. Mary and the chapel and the tombs were of which Stubbs speaks, and thus we know what part of the church it was that Thoresby completed before his death (perfecit-Stubbs). Leland also tells us the same thing when he says that Thoresby "de novo struxit chorum," and "perfecit navim" (Lel. Coll., i., 45, 121).

t "Itidem (i.e., at St. Mary's altar) pro anima sua et aninabus omnium fidelium defunctorum capellanum pro suo perpetuo celebratarum constituit. Quem quidem capellanum suosque successores habitum personalem in ecclesia cathedrali prodicta gestaturum, ad perpetuam ejus memoriam composuit, domos et possessiones de suo proprio acquisitas, perpetuam eleemosynam pradicto presbytero et successoribus suis mo suo perpetuo contulit duraturas" (Stubles). 
for the weal of his soul, but it was not apparently until 1362 that his son, Sir Henry Perey, and two of his exccutors, William Newport, reetor of Spoflorth and Sir Richard Tempest, knight, carried his desire into effect. On the 10th of December in that year the archbishop, in a very interesting and carcfilly constructed document, gave his eonsent to the establishment of four ehantries and laid down rules for their managencut. 'Three were to be at Alnwiek eastle and one in the minster of rork, and they were all to be endowed with the profits of the ehureh of Kirkby Overblowers, which were ceded for that purpose by Sir Henry Perey. Between the ehantries at York and Alnwick there is a marked and peenliar distinction. The three ehaplains at Alnwick were to pray for Henry lord Perey who was interred in Alnwick abbey, Mary lady Perey, etc., and they were to be presented by the exeeutors to the arehbishop, and he was to admit them. The cantarist at York, on the other hand, was to be nominated by the arehbishop and his sucecssors, and presented by the exeeutors. He was to pray for the good estate of Thoresby and the eanons during their lives, and for his soul after his decease, together with the sonls of his predecessors and suecessors, and for those of lord Percy, ete., and others of his family. There is no record here, it will be observed, of any endowment in the shape of lands or houses by Thoresby himsclf, but still the peculiar and prominent manner in which his name is conneeted with the York ehantry, makes it plain to me that he must have been in some way or other peemniarily interested in its foundation." The faet, which we learn from Stubbs, that he built and ornamented the place in which the chantry was erceted, is sufficient to aecount for this. Thoresby gave the executor's a position for the ehantry chapel to which it was neeessary to add nothing in the way of decoration and appendages. Hence it was that it was ealled the Thoresby-Perey chantry, and sometimes that of Thoresby only. ${ }^{v}$ It is impossible to suppose that the arehbishop would be allowed to take the lead in a chantis in which he had no right and elaim. 'The family of Perey wonkil not have tolerated sueh eonduct. He could not be doing a wrong or an injustice when the king, the chapter and Sir II enry Perey sanctioned his proecedings, whilst the executors of the deceased noble gladly accepted the arrangement, "seicnter et gratanter voto unanimi cum ommibus suis articulis acceptârunt,

"That this cireumstance was not publicly declared is no proof against its existence, and other feelings than those of shame might casily prompt its concealment, as Pliny says to his friend Saturninus, "Si qui bencfacta sua verhis adornant, non ideo pradicare quia fecerint, sed ut prxdicarcut, feeisse ereduntur. Sie quod masnificum referente alio fuisset, ipso qui gesserat recensente, ranescil."

" York Fabric Rolls, 295, etc. 
applanserunt et emologârunt."'w This looks as if the archbishop had heen doing them a farour instead of receiving one.

The shades of evening may be for a long time delayed, but they must come at last: the sun must at length set. ${ }^{x}$ And yet we may apply to the pious and now aged man the words in which Beza addressed Tiraquellus, when in his friendly warmth he spoke of him as the Varro of his time,

"Fortunate senex! te nulla oblivio mortis,

Te nunquam totum tollet avara dies."

The good arehhishop, who must have been more that seventy years of age, fell into his last sickness in the autumn of 13\%3, at his palace at Bishopthorpe. On the 12tl of September, a notary was summoned into the sick prelate's bedchamber to draw up his will. The sentences are evidently written down as they fell from Thoresby's lips. There is no display, and nothing can be more matter of fact and concise. There are in the will as many as forty-four legacies, all, with the exception of five, in money, the lighest sum bequeathed being that of 40 marks. The following legacies are probably to relations. 'To Agnes and Margaret de 'Thoresby, 80 marks. To John de Thoresby, 40 marks. To Robert Thoresby, 20 marks. To Elias de Thoresby, 10\%. Robert de Hackthorpe, notary, the writer of the will, Henry de Greymsby, John de Cloune, Elias de Thoresby and Thomas de Midelton, are each rewarded with a silver cup with a cover. The domestics of the dying prelate, the butler, harber, brewer, the keeper of the pantry and the larder, and the page of the chamber are all of them rememberecl. Two friars, John de Thoresby and William de Haynton, were to have five marks apiece, and Idonea de Brunnom, a nun at Hampole, 100s. To each house of begging friars in York a bequest of five marks was made. The following persons were then appointed executor's, Sir Richard le Scrop, ${ }^{y}$ knight,

* Domesday book penes Dec. et Cap. Ebor., $62 a$, ete. This contains the elaborate formdation of the chantries from which the information in this naragraph has been mainly derived. 'Thoresby was very anxious, as he tells ns, about these chantries, "desideranter" cupimus, quantum com Deo possimus, quod cantariis hujusmodi de cetero licudabiliter deserviatur." The place, time and manner of celebrating the service at York were left to his discretion, and we can easily imagine, therefore, why the altar of St. Mary in the presbytery was selected.

$x$ 'The beautiful lines of Waller suggest themselves:-
"The seas are quiet, when the winds give o'er. So, ealm are we, when passions are no more. For then we know how vain it was to boast Of fleeting things, so certain to be lost. Clouds of affection from our younger eyes Conceal that emptiness which age deseries. The sonl's dark cottage, batter'd and decay'd, Lets in new light, through chinks that time has inade:

Stronger by weakness, wiser men become, As they draw near to their eternal home:

Leaving the old, both worlds at once they view

That stand upon the threshold of the new."

y First lord Scrope, of Bolton. A great soldier, and lord treasurer and lord chancellor of England. He died in 1403 , xt. 75 , and in his noble will made in 1400 he left $10 l$. to the new 
Mr. John de Waltham, $z$ and Mr. John de Thoresby and dan Henry de Barton, ${ }^{a}$ canons of York, and Mr. Henry de (rrevmshy, and, as a last request, they were desired to make a further acknowledgment of the services of the servants of the testator, if his estate should permit of it. There is nothing to shew that Thoresby was a wealthy man, or that he had a large and expensive household. He had probably laid his treasure up where alone it can be found.

John de Cloune and Elias de Thoresby were standing by whilst the notary took down these words, and on the 31 st of October the three were summoned into the arehibishop's presence to listen to a codicil which he wished to make. He had but little to say and add. If it happened that he went the way of all flesh by reason of the infirmity which afflieted him, he desired that his body should be interred within four days after his decease in the place which he had otherwise arranged. To John de Cloune, who was standing by, he gave one of his better cups of silver, and he begged his executors to reward with his silver plate those clerks belonging to his household who had small benefices. He forgave Robert de Thoresby 10l. which he owed him. To Agnes and Margaret de Thoresby, daughters of the late Galfrid de Thoresby, ${ }^{b}$ he gave 100l. due to him from Henry de Barton. To the vicar of the elnureh of Leeds he left a robe which he had worn. ${ }^{c}$ The sick man said nothing more, and this is our last glimpse of arehbishop Thoresby. On Sunday the 6th of November, ${ }^{d}$ being St. Leonard's day, he passed away, and his good deeds went with him.

They laid his remains before the altar of the Virgin, for whom he had a profound veneration, in the lady-chapel at lork, the "novum opus chori" which he had himself constructed.c

work at York minster (Test. Ebor., i., 275. Scrope and Grosvenor Roll, i., 59).

z The archbishop's kinsman. Thoresby asked the bishop of Lincoln to allow John de Waltham, rector of Cortenhale, bachelor of laws, to be non-resident, that he might go to the schools (MSS. Cotton, Galba, E, x., 85). Mr. John de Waltham, rector of Cortenlale, was ordained sub-deacon by Thoresby at Westminster, by letters dimissory, on April 23, 1356, at a special ordination, deacon on the vigil of S. Trin., 1361, having the sacristry of St. Sepulchre's chapel at York as his title, and priest on Saturday after the fenst Exalt. S. Crucis, 1361 (Reg. Thoresby).

"Thoresby's domestic chaplain in 1360. Treasurer of York, prebendary, in succession, of Riceal and Osbaldwick, and rector of Bolton Percy. Master of the hospital of St. Mary Miret., near Southwell, and caunon of Lincolı.

${ }^{b}$ In 1350 Geoffrey de Thoresby received the dilipidations due to bishop Thoresbr at Worcester ('Thomas's Worcester, 179). In the 11th of Elward III. he was made "assaiator moncta regix" (Cal. Rot. Pat., 130).

${ }^{c}$ 'The will and codieil ate in Test. Ehor., i., 88, etc.

d Acta Capit. Ebor. On the 7 th the chapter order Robert de Newtom, their chamberlaiı, and John de Feriby, to sequestre Thoresby's effects. stibbs, col. $173 \mathrm{l}$. There is a short notice of 'Thoresby in Stowe's Chron., ed. 1611 , 270.

" Sepultus est corain altari beata 
II is predecessors in the see, whose bones he had honourably placed there, were sleeping on either side. It was a noble scpulchre for a noble-hearted man. The brazen imagery that once decorated his tomb, way the stone itself, has disappeared ; but his mood deeds, so numerous and so apparent, will perpetuate his memory better than either brass or marble.

Marice Tirginis in novo opere chori, die Jovis, in vigilia Sancti Martini" (Stubbs). He was thus connected in reath with that altar which he had constructed and honoured during his life. This makes the chain of eridence about the choir complete. Speaking of his place of sepulture in his will, Thoresby merely desires to be interred ' in loco per ipsum patrem alias ordinato." There was no reason for him to say more, as the place wonld be well known, and the blank stone or space among the graves of his six predecessors would shew to all for whom it was intended.

That Thoresby was laid there is evident from the statement of the metrical chronicler of York (MSS. Cotton, Cleopatra, C, iv.). This writer mentions some facts which are not in Stubbs or any oflier writer, and he has therefore an independent autlority of his own. The work seens to be in two parts, the first stopping with archbishop Scrope, the other, in a rather ditferent style, coming down to the time of arehbishop Willian Booth. A person who lived in the time of archlisiop, scrope is a viluble witnoss as to what haypened thirty years before.

The poct thms describes Thoresby's burial-place and death:-

\section{"Apud Thorp defuncitur mundanis exutus Ebrraci punitur scenosis indutus,

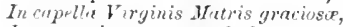 Inter coepiscopes presul yloriose (1)os de jun lis operis ferit hic levari Et sic honorifice ibi trimulari."}

Leland describes the position of the archbishop's tomb even more minutely. 'Torre, Thoresby (Tic. Leod., 193), Drake (Elooracrim, 435), anil Godwin $(697)$, give it the same position.

It has been suggested that a tomb on the nortl side of the nave of the minster commemurates Thoreby. From the strongest and the most indisputable evidence it has been shew that he was puried at the east end and not in the nave. It has been said however (for
Stubbs's statement lras now been admitted to this extent) that the Lady chapel in which he was interred was that of St. Mary and the Holy Angels, or that of St. Sepulchre, appended to the nave. In answer to this I assert that this chapel was never known as the Lady chapel, and that the tomb, now ascribed to Thoresby, is on the outside of that chapel and not within it, so that the words of Stubbs do not apply to it at all.

It may be said that the remains may have been irside the chapel of St. Sepulchre, but that they have been remored out of it. When could that have been done? Clearly not before the Reformation, for the chapel was then in existerice. Who, I should like to know, ever heard of the reforming iconoclasts preserving or translating a mau's bones that were in their way? Nor could the removal have taken place in queen Mary's days, because then there would have been no wish to destroy the chapel in which they were phaced. If 'Thoresby's remains were removed at all from St. Sepulchre's chapel, the change must have been made at the Reformation, and then either anew monmment must have been construeted for them, or a portion of the old one set up in a new place. If this were the case, the date of the stone-work of the present monument would be either 1373, the year of Thoresby's death, or at the period of the Reformation. Both these hypotheses are completely overthrown by the fact that the architestural features of this sepulchral memorial prove it to have been erected between 1480 and 1510 , and they shew that it is not a portion of an old tomb, but a new one specially construeted for the position that it occupies. Some years after 1510 Leland saw Thoresby's gravestone, with its inseription, in the presbytery at the east end.

In December, 1862, this monument, which had been injured, was completely 
There seems to have been some little controrersy between the executors of Thoreshy and archbishop Neville on the question of dilapidations. On the 4 th of Oetober, 1374 , those officials met the arehbishop in a chamber in his palaee, called Pountenysyn, and there, in the presence of his brother Joln, lord Neville, they submitted themselves to his deeree. On the 13th of April in the following year, the exceutors W I altham, 'Thoreshy and Barton, paid to the primate 2350 marks on the score of dilapidations, and 612 marks to supply the deficicneies in the stoek which was to remain on the archiepiscopal manors. $f$ 'The safest and wisest course, perhaps, that any prelate eould arlopt was to leave the adjustment of these claims to his suceessor and his executors.

It has been said that Thoresby was raised to the eardinalate by Urban V. Bale is the first person who makes this statement, and he gires him the title of St. Sabina.g Torre goes farther than this, and gives a rough drawing of his seal with this inscription, S. Johis tt Sci P. ad Vincula presbyteri cardinalis. ${ }^{h}$ There is no doeumentary evidence whaterer of Thoresby's ever having been a cardinal, and Ciaconius and the other biographers

restored, and the restoration has been such as to give it a much earlier date than belongs to it. Some liberties also have been taken with the seulpture, as, for instance, two birds holding scrolls, on either side of the central figure of the Virgin, have been metamorphosed into eagles with ears of wheat in their mouths. I cannot say a word, however, against the skill displayed by the masons, but no ancient monument, in my opinion, ought to be restored.

When the tomb was examined, a long box, more than six feet in length, was found containing bones and fragments of vestments. It was too narrow to admit of the reception of a body, so that these bones must have been gathered together and translated to this place at the latter end of the fifteenth century. Tradition, for the last century and a half, has ascriberl chis tomb to arehbishop Roger. It, no doubt, contains the bones of some cclesiastic, perhaps an archbishop, those grave was disturbed, and as re was no stone elsewhere ascribed Roger, who was buried originally in choir, it may perhaps be lis. The point cannot at present be settled, for even the fragments of lobes, if their date could be ascertained, conld prove nothing. Adhur sub judice lis est.

\section{$f$ Reg. Neville.}

g Cent. vi., 493. Thoresby, Godwin, and Tanuer quote Torre. Godwin, however (n.e., 687), questions the anthority of Bale.

${ }^{h}$ Through the kindness of my friend, Mr. C. Sykes, I have been allowed to examine the drawing made by Torre, which is in the library at sledmere. The seal is a large oral one. In the centre are the Viryin and child, under rich canopies. 'To the right is a figure of St. Peter witl his keys, and below him the letters S. Petrus. To the left is a figure of pope Urban, with $V_{r}$. banus under his feet. Below the Virgin is a kneeling figure of a cardinal holding a crozier, and on either side is a shield of arms. The charge on both is the same, viz., two stags, one above the other. The inscription in the text ocenpies the usual position. Different arms are assigned to Anglicus by Ciaconius (ed. 1677, ii., col. 561). The one bearing is probably that of his see, the other that of his family. "Che fu Decano della Metropolitana di York, nato, o ameno oriundo dall'Inghilterra per parte del padre, o sia dell'aro" (Cardella, Memorie Storiche de' Carlinali, ii., 208). Cf. Gallia Christiana, i., 823, etc. 
of the members of the Sacred College never mention his name. The person to whom the seal refers was not Thoresby at all, but John Anglicus Grimaldi, who was created cardinal-priest of St. Peter ad Vincula, in September, 1366, by his brother, Urban V. In the month of November, in the same year, he was made dean of York, an office of which he was deprived in 1381. The archiepiscopal seal of Thoresby, of which there is a fine impression in the British Museum, and at least a dozen at Durham, is a glorious specimen of sigillary art, and is very much richer than that of his contemporary the dean. 


\section{ADDENDA ET CORRIGENDA.}

pp. 13-15, etc. The Culdees. This peculiar name cannot be tracell, I bolieve, earlier than the ninth century, and the Christians of Iona, etc., slould, perhals, be ealled Columbites. As far as the ereed and the practice of the Culdees ancl Columbites can be ascertained, I find no substantial diflerence between the two, and I have used the word Culdees as a generic term, the followers of Augnstine and Wilfrid being of course exchuded from it. It is a very remarkable fact that the eanons of York were called Culdees in the reign of Henly I., another reason why I should use that word.

p. 37, note $j$. Bromton. The surname of the chronicler ought to be Brompton. This error runs through the volume.

p. 44, line 22, and note. Akebargh. "I never could think that Aykburgh or Ayksburghe was the place allnded to by Bede, and called after Jimes the Deacon. If it is Jakesburgh, what are we to say to Aykesearth, Aykeseourh, Aikby, and Aikton? and conld the same process transmute Jakeswell into llawkswell? Why should not Hackford, near Hawkswell, have not been changed? In Gale's map, Aikburgh is placed between Hawkswell and Tunstall, near Catterick, but in reality, Aikber, as it is now called, is near Fingall, a farmbouse by the side of Fingall beck. As to Hawkswell, I think I have seen the Saxon personal name of Havoe in Domesday book, at all events it is called Havocswell there. I exirmined the cross at Hawkswell most minutely on the 17th of November, 1831, and several times within four years afterwards, and I am willing to make an allidavit that there was no inscription upon it then."-J. R. W.

p. 63, note $y$. For clearly, read perhaps.

p. 67, note $i$. For Chron. Petrob., read Chron. Petrib.

p. 72, line 4 from foot of page. For Etla, read Oftfor.

p. 77, note $i$. For Canob., read Conob. So also in the note on the next lage, in note $g$, p. 125, note $i$, p. 133, and note $l$, p. 134 .

p. 78, bis. For Medhamstead, read Medeshamstead.

p. 80, line 5 from foot of page. For Grey, read Gray.

pp. 91-2, notes. For Fadera, read Fadera; also p. 240, notev, and p. 251 , notes $v$ and $y$.

p. 96, note $t$, and p. 97, line 1. For panitentiale, rear panitentiale.

p. 97, note d. For Alcuini $O_{p}$., read Opp. : this also ocenrs at 1'1. 98, 101-8, 106-11, 121.

p. 99, line 9 from foot of page. For Ceonwulf, read Coenuulf.

p. 106. The hexameter line at the foot of the page slould be,

"I tamen, i pro me, tu, cui licet, aspice Romam."

p. 109 and note $u$. Aclete is very probably Auckland, co. Durham. Sochiasburg is either Sockburn or Sadberge in the same county. W. II. D. I.

p.118, note $g$. For Servatus, read Senatus. The same correction may le made at $11.117,121,127,128$. 
p. 134. One of the pins found in Wulstan's grave is in the collection S. A., London.

p. 162 , line 19 from top. For two, read four.

p. 203. Ralph Deincourt founded the monastery of Thurgarton, Notts, by the advice and at the entreaty of 'Thurstan ('Thorotou's Notts, 302).

1. 209, line 6 of the poem on Thurstan. For inde finita, read indefinita.

1). 214. Fountains was the mother of eight religious houses, and not of seven.

p. 220, line 7 from foot. There is a different accourt of the parentage of St. William in Coll. Top. and Genealog., i., 219. It is there said that his mother was Adela, daughter of Sir Robert Corhet, a concubine of Henry I.

p. 227, line 6 from foot. Honorius III. decreed the canonization of St. Willian by bull daterl 15 Kal. Apr. anno x. (Addit. MSS., Br. Mus., 15351, fol. 311). The tramslation took llace as $\mathbf{I}$ have stated, and this may be regarded as the final act of the caronization.

p. 230. In the treasury of Iork, circa 1500, there was "umum feretrum de berill" adorned with silver gilt, and precions stones, containing part of $\mathrm{St}$. Villiam's hair (Fabric Rolls, 221). By will, dated April 24, 1506, Margaret Nurton, of Bilbrough, widow, left to Chr. Norton, "unam cathedram qua fuit Sancti Willehni Ebor. archiepiscopi " (Reg. 'Test. Ebor.).

1. 211, line 21 from top. For unhappy, read impious.

p. 215, line 25 from top. For thew, read threw.

p. 291, note $i$. On "die Sabbati, rua cantatur Scicientes, 1221, apud Blidam," the archbishop ordained Richard de Popeleswurch, priest, the master and brethren of the Temple giving him a title, "arl celebrandum in capella Novi Templi, Londoll., pro anima Johamis quondam regis Anglia illustris" (Rot. Gray).

p. 292, line 12 from top. In Gray's roll I find these most important notices: "Anno 19, 9 Kal. Dec. Indulgentia pro fabria ecclesiæ Southwell. On 5 Kal. 1ec., pro ecclesia Ripon. On $17 \mathrm{Kal}$. Aug. 17, pro ecclesia Beverlacensi 'miserabili ruina enormiter deformata." "

P. 295, note $v$, last line. For king, read pope.

1. 313, note $a$. Read sindon'.

1. 321. Canes perdriarios-(?) pointers or setters.

P. 328, note $w$. Archbishop Gray instituted Chinchius, Romanus clericus, to the living of Elveley.

p. 391, line 16 from top. In $1306 \mathrm{Sir}$ Jolm Giffard made over to his kinsman the archbishop the manor of Boyton, co. Wilts. He was to stay with the archbishol and to be maintained by lim, together with two esquires, six horses, and six sarciones. 


